\title{
UICN
}

\section{Diretrizes para a geoconservação em áreas protegidas}

Crofts, R., Gordon, J.E., Brilha, J., Gray, M., Gunn, J., Larwood, J., Santucci, V.L., Tormey, D., e Worboys, G.L.

Craig Groves, editor da série

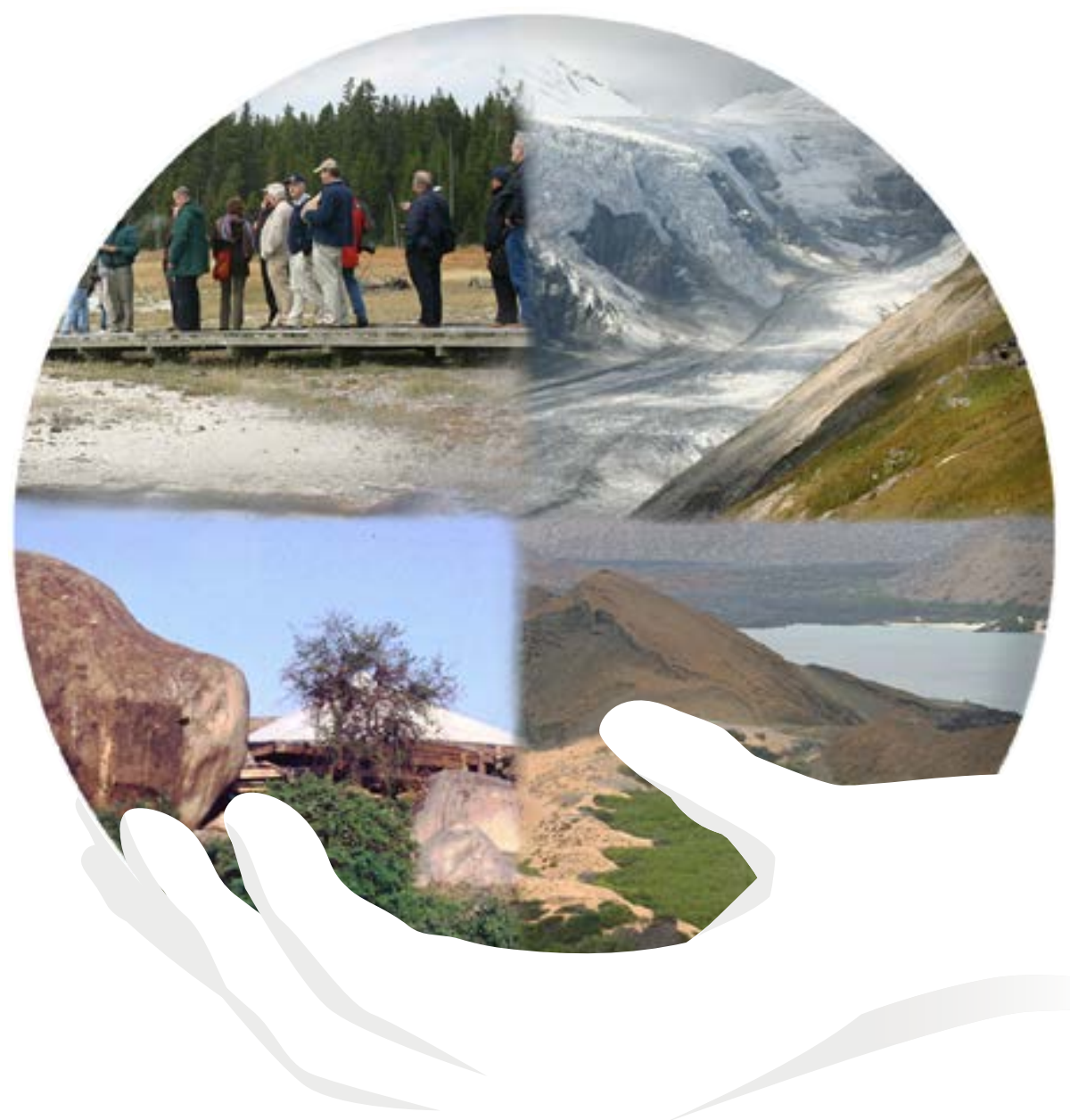

Desenvolvendo capacidades para proteger o planeta 


\section{SÉRIE DIRETRIZES DA WCPA-UICN DE BOAS PRÁTICAS EM ÁREAS PROTEGIDAS}

A Série Diretrizes de Boas Práticas em Áreas Protegidas da WCPA-UICN é um recurso de referência utilizado em nível mundial para gestores de áreas protegidas. Envolvendo a colaboração de especialistas, estas Diretrizes são o resultado das orientações e da longa experiência da UICN na capacitação institucional e individual para a gestão eficaz, equitativa e sustentável de sistemas de áreas protegidas, para fazer frente aos numerosos desafios. Estas orientações ajudam também governos nacionais, agências responsáveis por áreas protegidas, organizações não governamentais, comunidades e parceiros do setor privado a cumprir os seus compromissos e objetivos, principalmente o Programa de Trabalho em Áreas Protegidas da Convenção sobre a Diversidade Biológica.

A coleção completa de Diretrizes está disponível em: www.iucn.org/pa guidelines

Recursos complementares estão disponíveis em: www.cbd.int/protected/tools/

Contribua para a capacitação para um Planeta Protegido em: www.protectedplanet.net/

\section{DEFINIÇÃO DE ÁREA PROTEGIDA, CATEGORIAS DE GESTÃO E TIPOS DE GOVERNANÇA DA UICN}

A definição abrange seis categorias de gestão (uma delas com uma subdivisão) que são aqui resumidas. Um espaço geográfico claramente definido, bem identificado, com objetivos específicos e gerido por meios eficazes, sejam jurídicos ou de outra natureza, para alcançar a conservação da natureza a longo prazo, com serviços ecossistêmicos e valores culturais associados.

la Reserva natural estrita: Áreas estritamente protegidas em termos de biodiversidade, podendo incluir também aspectos geológicos/geomorfológicos, onde a visitação, o uso e os impactos humanos são limitados e controlados para garantir a proteção dos valores de conservação.

Ib Área silvestre: Áreas normalmente grandes, não modificadas ou ligeiramente modificadas, que mantêm o seu caráter e influência naturais, sem população humana permanente ou significativa, protegidas e geridas para preservar as suas características naturais.

II Parque nacional: Grandes áreas naturais ou quase naturais que protegem processos ecológicos de grande porte, com espécies e ecossistemas característicos. Também oferecem possibilidades espirituais, científicas, educacionais, recreativas e de visitação, ambiental e culturalmente compatíveis.

III Monumento ou aspecto natural: Áreas reservadas para proteger um monumento natural específico, que podem ser uma forma de relevo, uma montanha submarina, uma cavidade marinha, um aspecto geológico, como uma caverna ou um aspecto vivo como, por exemplo, uma floresta ancestral.

IV Área de gestão de habitat/espécies: Áreas para proteger determinadas espécies ou habitats, onde a gestão reflete essa prioridade. Muitas destas áreas necessitam de intervenções regulares e ativas para atender às necessidades de determinadas espécies ou habitats, mas este não é um requisito desta categoria.

V Paisagem terrestre ou marinha protegida: Onde a interação entre pessoas e natureza ao longo do tempo produziu um caráter distinto com significativo valor ecológico, biológico, cultural e estético, e onde salvaguardar a integridade dessa interação é vital para proteger e sustentar a área e seus valores associados de conservação da natureza e outros.

VI Áreas protegidas com uso sustentável dos recursos naturais: Áreas com ecossistemas conservados, juntamente com valores culturais associados e sistemas tradicionais de gestão de recursos naturais. São áreas geralmente grandes, principalmente em boas condições naturais, com uma parte sob gestão sustentável de recursos naturais, e onde o baixo nível de uso de recursos naturais não industriais, compatível com a conservação da natureza, é considerado um dos principais objetivos.

O tipo de categoria deve ser baseado nos objetivos principais de planejamento, que se devem aplicar a, pelo menos, três quartos da área protegida - a regra dos $75 \%$.

As categorias são associadas a um tipo da governança, considerando quem detém autoridade e responsabilidade sobre a área protegida. A UICN define quatro tipos de governança:

Tipo A - Governança pelos governos: Responsabilidade de um ministério/órgão federal, nacional ou subnacional responsável e gestão delegada pelo governo (por exemplo, a uma ONG).

Tipo B - Governança compartilhada: Gestão transfronteiriça (acordos formais ou informais entre dois ou mais países), governança colaborativa (em que diversos atores e organizações trabalham em conjunto) ou governança em conjunto (gestão formada por representantes das várias partes).

Tipo C - Governança privada: Áreas criadas e geridas por privados, organizações sem fins lucrativos (ONGs, universidades, cooperativas) e por organizações com fins lucrativos (indivíduos ou empresas).

Tipo D - Governança por povos indígenas e comunidades locais: áreas e territórios de povos indígenas, estabelecidas e geridas por populações indígenas ou por comunidades locais.

Para mais informações sobre a definição, categorias e tipos de governança da UICN, consulte Dudley (2008) Guidelines for applying protected area management categories disponível em: www.iucn.org/pa_categories.

Para mais informações sobre os tipos de governança, consulte Borrini-Feyerabend et al. (2013) Governance of Protected Areas: from understanding to action, disponível em https://portals.iucn.org/library/node/29138. 
Diretrizes para a geoconservação em áreas protegidas 


\section{UICN}

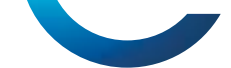

União Internacional para a Conservação da Natureza (UICN) A UICN é uma união de membros, composta exclusivamente por organizações governamentais e da sociedade civil. Fornece a organizações públicas, privadas e não governamentais os conhecimentos e as ferramentas que permitem o progresso humano, o desenvolvimento econômico e a conservação da natureza.

Criada em 1948, a UICN é hoje a maior e mais diversificada rede ambiental do mundo, com mais de 1400 membros e mais de 15.000 especialistas. É uma organização líder fornecedora de dados, avaliações e análises sobre conservação. O número elevado de membros permite que a UICN desempenhe o papel de repositório confiável de boas práticas, ferramentas e normas internacionais.

A UICN proporciona um espaço neutro no qual diversos intervenientes, incluindo governos, ONGs, cientistas, empresas, comunidades locais, organizações de povos indígenas e outros podem trabalhar em conjunto para delinear e implementar soluções para combater desafios ambientais e alcançar o desenvolvimento sustentável.

Por trabalhar com muitos parceiros e apoiadores, a UICN implementa um vasto e diversificado conjunto de projetos de conservação em todo o mundo. Combinando a ciência mais atual com o conhecimento tradicional das comunidades locais, estes projetos visam inverter a perda de habitat, a restauração de ecossistemas e melhorar o bem-estar das pessoas.

www.iucn.org

twitter.com/IUCN

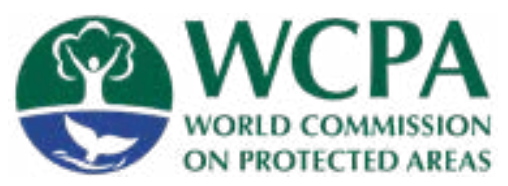

Comissão Mundial de Áreas Protegidas (WCPA) da UICN

A WCPA (acrônimo em inglês) da UICN é a principal rede de especialização em áreas protegidas do mundo. É administrada pelo Programa da UICN para Áreas Protegidas e tem mais de 2500 membros em 140 países. A WCPA é uma das seis Comissões da UICN constituídas por voluntários, sendo a sua missão a de promover o estabelecimento e a gestão efetiva de uma rede mundial representativa de áreas protegidas terrestres e marinhas, como contribuição para a missão da UICN.

A WCPA trabalha ajudando governos e outros atores a planejar áreas protegidas e a integrá-las em todos os setores, fornecendo assessoria estratégica a formuladores de políticas, fortalecendo a capacidade e o investimento em áreas protegidas e reunindo um público diversificado de interessados diretos em áreas protegidas para tratar de questões desafiadoras. A UICN e a WCPA têm estado na vanguarda da ação global sobre áreas protegidas há mais de 60 anos.

www.iucn.org/wcpa

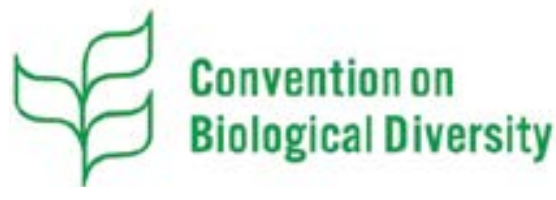

Convenção sobre Diversidade Biológica (CBD)

Esta Convenção foi criada na Cúpula da Terra do Rio em 1992 e entrou em vigor em Dezembro de 1993. É um tratado internacional para a conservação da biodiversidade, o uso sustentável dos componentes da biodiversidade e a partilha equitativa dos benefícios obtidos do uso dos recursos genéticos. Com 196 países envolvidos, a Convenção tem a participação de quase a totalidade dos países. www.cbd.int

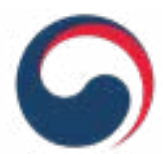

\section{Cultural Heritage}

Administration

\section{Administração do Patrimônio Cultural da República da Coreia}

A Administração do Patrimônio Cultural foi criada para salvaguardar a integridade das tradições culturais da Coreia e reforçar a vida cultural do povo coreano, por meio da preservação e promoção do uso do patrimônio cultural. Funciona sob a égide do Ministério da Cultura e Turismo. O seu papel é o de contribuir para o progresso da cultura nacional por meio da conservação e da criação de valores a partir do patrimônio cultural e promover a Coreia como um dos líderes mundiais em patrimônio cultural. Financia pesquisa em institutos, prepara candidaturas para apresentação à UNESCO e cuida de bens incluídos na Lista de Patrimônio Mundial na Coreia. Também fornece fundos para permitir a divulgação internacional do conhecimento, incluindo o financiamento para a publicação das Diretrizes para a geoconservação em áreas protegidas da WCPA-UICN.

english.cha.go.kr/cop/bbs/selectBoardList. do?bbsld=BBSMSTR 1205\&mn=EN 03 01\&ctgryLrcls=CTGRY209

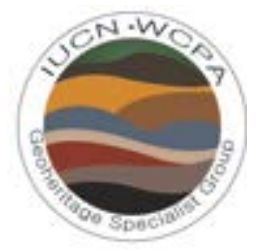

Grupo de Especialistas em Geopatrimônio da WCPA-UICN O Grupo de Especialistas em Geopatrimônio (GSG) foi criado na sequência da ampliação da definição de área protegida pela UICN, tendo passado a incluir todos os elementos da natureza, de modo que geodiversidade e geopatrimônio passassem a ser incluídos nas necessidades de conservação. Os membros do GSG possuem experiência e conhecimento em geociências, assim como em planejamento e gestão de áreas protegidas. O grupo tem mais de 100 membros e presta aconselhamento especializado em todos os aspectos da geodiversidade em relação a áreas protegidas e à sua gestão, incluindo cavernas e ambientes cársticos.

www.iucn.org/commissions/world-commission-protected-areas/ our-work/geoheritage 


\section{Diretrizes para a geoconservação em áreas protegidas}

Crofts, R., Gordon, J.E., Brilha, J., Gray, M., Gunn, J., Larwood, J., Santucci, V.L., Tormey, D., e Worboys, G.L.

Craig Groves, editor da série 
A designação de entidades geográficas neste livro e a apresentação dos conteúdos não implicam a expressão de qualquer opinião por parte da UICN ou de outras organizações participantes sobre a situação jurídica de qualquer país, território ou região ou de suas autoridades, nem sobre a delimitação de suas fronteiras ou limites.

As opiniões expressas nesta publicação não refletem necessariamente as da UICN ou de outras organizações participantes.

A UICN agradece o apoio financeiro prestado pelos seus parceiros: Ministry for Foreign Affairs da Finlândia; Governo de França e a French Development Agency (AFD); Ministry of Environment, República da Coreia; Norwegian Agency for Development Cooperation (Norad), Noruega; Swedish International Development Cooperation Agency (Sida), Suécia; Swiss Agency for Development and Cooperation (SDC), Suiça e United States Department of State (Estados Unidos da América).

Esta publicação foi parcialmente possível graças ao financiamento concedido pela Administração do Patrimônio Cultural da República da Coreia.

A UICN não tem responsabilidade por erros ou omissões que possam ocorrer nesta tradução ou desvios ao idioma da versão original desta publicação. No caso de discrepâncias, consulte a edição original. Título da edição original: Guidelines for geoconservation in protected and conserved areas. (2020). Best Practice Protected Area Guidelines Series No. 31 (2020). Gland, Suíça: UICN.

DOI: https://doi.org/10.2305/IUCN.CH.2020.PAG.31.en

Publicado por:

UICN, Gland, Suíça

Direitos autorais:

(C) 2020 UICN, União Internacional para a Conservação da Natureza e Recursos Naturais

(C) 2022 UICN, para a tradução em língua portuguesa

A reprodução desta publicação para fins educativos ou outros fins não comerciais é autorizada sem necessidade de permissão prévia por escrito do detentor dos direitos autorais, desde que a fonte receba os devidos créditos. A reprodução desta publicação para revenda ou outros fins comerciais é proibida sem a permissão prévia por escrito do detentor dos direitos autorais.

Citação: $\quad$ Crofts, R. $\quad$ 츤, Gordon, J.E., Brilha, J., Gray, M., Gunn, J., Larwood, J., Santucci, V. L., Tormey, D., e Worboys, G.L. (2022). Diretrizes para a geoconservação em áreas protegidas. Série Diretrizes para melhores Práticas para Áreas Protegidas N. ${ }^{\circ}$ 31. Gland, Suíça: UICN.

*Autor correspondente roger.dodin@btinternet.com

ISBN:

978-2-8317-2185-9 (PDF)

DOI: https://doi.org/10.2305/IUCN.CH.2020.PAG.31.pt

Tradução para

língua portuguesa:
José Brilha, Maria da Glória Garcia, Paulo Pereira e Ricardo G. Fraga de A. Pereira

\section{Nota dos tradutores}

A versão portuguesa destas Diretrizes segue a norma brasileira do português. Alguns termos técnicos do texto original em inglês não têm uma tradução direta para o português e, nestes casos, optou-se por manter o termo em inglês. O conceito de "conserved area" foi considerado como integrado na definição de "área protegida". Por vezes, os termos usados são distintos entre os vários países de língua oficial portuguesa. É o caso, por exemplo, dos sinônimos: "intemperismo" / "meteorização"; "biotita" / "biotite”; "carso" / "carste"; "Devoniano" / "Devónico"; "planos de manejo" / "planos de ordenamento". O termo "geopatrimônio", tal como em inglês ("geoheritage"), é sinônimo de "patrimônio geológico" ("geological heritage").

Fotos da capa:

sentido horário, a partir do canto superior esquerdo: plataforma para observação de gêiseres no Parque Nacional Yellowstone (Wyoming, EUA); Montanha Grossglockner e glaciar Franz Josef evidenciando efeitos de degelo provocados pelas mudanças climáticas no Parque Nacional Hohe Tauern (Carinthia, Áustria); vegetação em geoformas vulcânicas em San Bartolomé, Parque Nacional Galápagos (Equador); hotel construído cuidadosamente em torno de uma geoforma granítica no Parque Nacional Serengeti (República Unida da Tanzânia).

Fotos () Roger Crofts

Fotos da contracapa:

Exemplos de geoconservação em áreas protegidas, sentido horário, a partir do canto superior esquerdo: Folhelhos de Burgess, explosão de vida Cambriana no Parque Nacional Yoho, (Canadá) @ Parks Canada, Ryan Creary; Parque Nacional Triglav (Eslovênia) representado na bandeira nacional como um símbolo cultural do país; parte da escarpa do sítio do Patrimônio Mundial de Drakensberg e do Parque Peace transfronteiriço no Parque Nacional Royal Natal (KwaZulu-Natal, África do Sul); Parque Nacional Jiuzhaigou (Sichuan, China), muito popular entre os turistas chineses devido aos seus lagos coloridos em rochas calcárias. Últimas três fotos @ R Roger Crofts

Design:

Niall O'Laoghaire, Guilder Design

Disponível em:

UICN (União Internacional para a Conservação da Natureza)

Programa Global de Áreas Protegidas

Tel +41229990000

Fax +41229990002

wcpa@iucn.org

www.iucn.org/resources/publications 


\section{Índice}

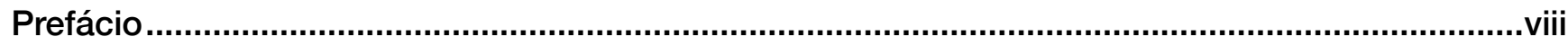

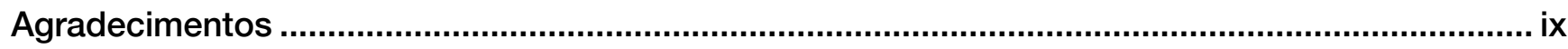

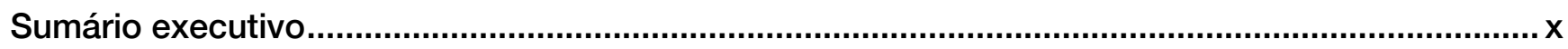

Seção 1. Objetivos, conteúdos e utilização destas Diretrizes ............................................................1

Seção 2. Geoconservação em áreas protegidas: conceitos e definições principais ...................... 5

Seção 3: Aplicação dos princípios gerais de geoconservação em áreas protegidas ....................... 13

Seção 4. Criação de áreas protegidas destinadas à geoconservação ............................................. 21

Seção 5. Gestão de patrimônio geológico em áreas protegidas................................................... 39

Seção 6. Enfrentando as ameaças ao geopatrimônio em áreas protegidas..................................... 63

Seção 7. Gestão da geoconservação em casos selecionados ........................................................... 88

Seção 8. Educação e comunicação para a geoconservação ...........................................................111

Seção 9. Visão geral ............................................................................................................121

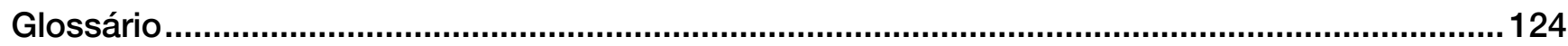

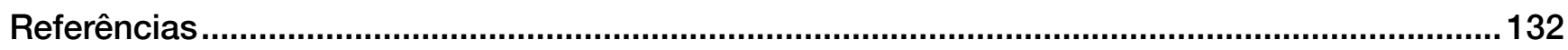

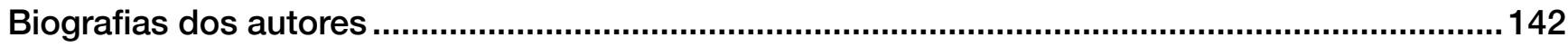




\section{Caixas}

Caixa 2.1: A Declaração de Digne

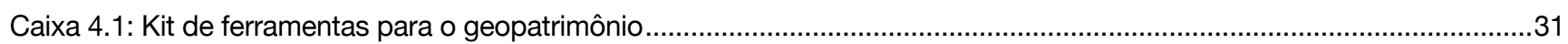

Caixa 4.2: Gestão comunitária de geoconservação em Gunung Sewu Geoparque Mundial da UNESCO, Indonésia................33

Caixa 4.3: Sítio de Especial Interesse Científico da Floresta Petrificada de Brymbo, Wrexham, Reino Unido ............................34

Caixa 5.1: Relatórios de caracterização dos geossítios e planos de manejo.......................................................................40

Caixa 5.2: O geoarqueossítio da Necrópole Etrusca de San Giuliano, Itália .......................................................................57

Caixa 5.3: Geoconservação e estratégias de gestão: Componentes para o sucesso de dois Geoparques Mundiais

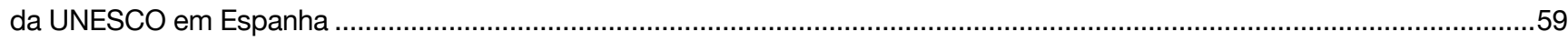

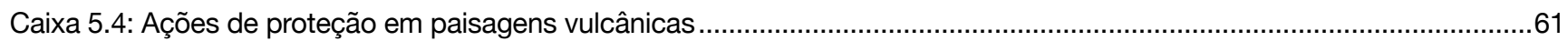

Caixa 5.5: Jenolan Karst Conservation Reserve, Nova Gales do Sul, Austrália ....................................................................61

Caixa 6.1: Pedreira Horn Park, Sítio de Especial Interesse Científico (SSSI) e Reserva Natural Nacional, Reino Unido ............68

Caixa 6.2: Melhoria da qualidade da água do rio Reka, Parque Regional Sekocjanske jame, Eslovênia .................................75

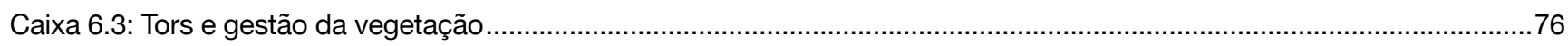

Caixa 6.4: Restauração após a erupção do Monte Santa Helena, EUA..........................................................................83

Caixa 6.5: Restauração do geossítio Alto Vez, Serra da Peneda, Portugal .........................................................................83

Caixa 7.1: Estudo de caso de restauro: SSSI da Pedreira de Pitstone, Buckinghamshire, Reino Unido ..................................98

Caixa 7.2: Estudo de caso de geossítios paleontológicos nos Parques Nacionais dos EUA................................................105

Caixa 8.1 Falésias fossilíferas de Joggins, Canadá.............................................................................................117

Caixa 8.2 Promover a educação e a formação: Um curso on-line sobre geoparques globais ...............................................118

\section{Tabelas}

Tabela 1.1. Estrutura e assuntos principais das Diretrizes .................................................................................... 3

Tabela 2.1. Exemplos de bens e serviços fornecidos pela geodiversidade no litoral do Estado de São Paulo, Brasil.......... 12

Tabela 3.1. Principais princípios orientadores para a geoconservação na gestão de áreas protegidas .............................. 14

Tabela 4.1. Principais interesses do geopatrimônio a serem considerados para a geoconservação

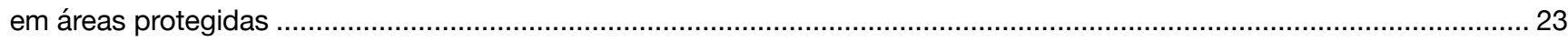

Tabela 4.2. Breves considerações sobre a capacitação de pessoal de áreas protegidas .............................................. 33

Tabela 5.1. Classificação dos tipos de sítios geológicos, ameaças e objetivos de conservação habituais

(Prosser et al., 2018 reproduzido com permissão) .................................................................................................. 41

Tabela 5.2. Atributos recomendados para monitoramento de sítios e metas gerais (adaptado de Ellis, 2004;

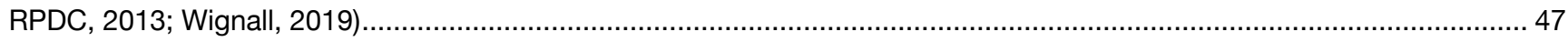

Tabela 5.3. Ações em áreas protegidas que se beneficiam da existência de especialistas em geociências ...................... 49

Tabela 5.4. Geopatrimônio e as categorias de gestão de áreas protegidas da UICN .................................................. 51

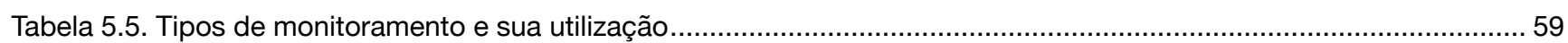

Tabela 5.6. Exemplos de monitoramento, avaliação e relatórios do geopatrimônio ...........................................................60

Tabela 5.7. Segurança dos visitantes em zonas vulcânicas ................................................................................ 62

Tabela 6.1. A escala de 10 pontos de geosensibilidade da Tasmânia (modificada de Kiernan,1996; Sharples, 2002) ......... 64

Tabela 6.2. Principais ameaças induzidas pelo homem ao patrimônio geológico em áreas protegidas

(adaptado de Gordon \& Barron, 2011; Brooks, 2013; Gray, 2013; Crofts \& Gordon, 2015) ........................................... 65

Tabela 6.3. Impactos das mudanças climáticas nos geossítios ................................................................................ 81

Tabela 6.4. Exemplos de relações entre geodiversidade e biodiversidade .................................................................... 85

Tabela 7.1. Considerações essenciais de geoconservação em cavernas e áreas cársticas...............................................93

Tabela 7.2. Principais ameaças e orientações de gestão da conservação para diferentes categorias

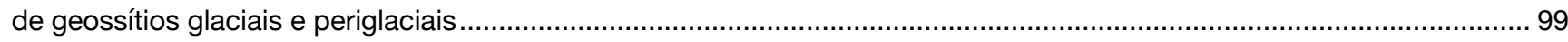

Tabela 7.3. Proteção contra ameaças em geossítios paleontológicos .......................................................................103

Tabela 7.4. Princípios práticos de conservação de geossítios paleontológicos e mineralógicos ..................................... 103

Tabela 7.5. Aspectos de gestão de risco a serem considerados em áreas vulcânicas.................................................... 109

Tabela 8.1. Alguns princípios gerais para interpretação e educação em geopatrimônio ................................................ 120 


\section{Figuras}

Figura 1.1. Etapas principais na criação e gestão de áreas protegidas destinadas à geoconservação e os assuntos principais abordados nestas Diretrizes..... 4

Figura 2.1. Serviços de ecossistemas sob a perspectiva da geodiversidade. Fonte: Gray, 2018. ................................ 11

Figura 4.1 Inventário e gestão do patrimônio geológico em áreas protegidas..................................................................25

Figura 4.2. Representação dos níveis de significância aplicáveis a feições do patrimônio geológico .................................. 30

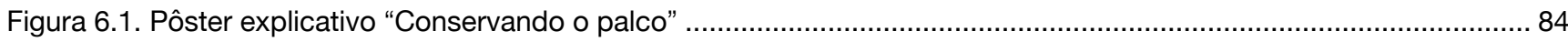




\section{Prefácio}

A Comissão Mundial de Áreas Protegidas (WCPA, por seu acrônimo em inglês) da UICN tem publicado Diretrizes de Boas Práticas há muitos anos, com vistas a ajudar todos os envolvidos nas atividades de áreas protegidas em todo o mundo a ter acesso à informação mais atualizada e a boas práticas desenvolvidas por especialistas.

Com a mudança na definição de área protegida da UICN há mais de uma década, de forma a incorporar a geoconservação ao lado e em complemento à conservação da biodiversidade, e com os mandatos aprovados por três Congressos Mundiais de Conservação da UICN em 2008, 2012 e 2016, há uma necessidade óbvia de diretrizes sobre geoconservação.

As áreas protegidas e outros mecanismos de conservação estão incluídos nestas diretrizes, em reconhecimento à importância destes outros meios na proteção do geopatrimônio. Dois destes mecanismos são de particular importância na geoconservação: Sítios do Patrimônio Mundial e Geoparques, estes últimos constituindo uma rede mundial em expansão, sob a égide da UNESCO.

Há a opinião generalizada de que o patrimônio geológico é robusto e pode tomar conta de si próprio. Como estas Diretrizes mostram, não é bem o caso. Muitos dos aspectos geológicos são frágeis e podem ser facilmente danificados pelo uso excessivo ou pela exploração de rochas e minerais. Mitigar estas ameaças é um desafio constante para os gestores de sítios geológicos. 0 aumento dos efeitos das mudanças climáticas significa que é ainda mais importante assegurar que a geoconservação seja eficaz na ajuda à compreensão de como a natureza respondeu no passado às mudanças climáticas naturais e da melhor forma de nos prepararmos, agora e no futuro. Uma abordagem dinâmica e flexível na identificação e na gestão dos sítios é, portanto, a mais aconselhada.

A geoconservação concentra-se na proteção e conservação dos melhores exemplos de determinados fósseis, formações rochosas e minerais e de certas formas de relevo que representam os diferentes regimes climáticos ao longo da história da Terra. Procura também assegurar que os atuais processos naturais, não biológicos, sejam devidamente conservados e geridos.

Existe uma relação vital entre a conservação da biodiversidade e da geodiversidade. À medida que o conhecimento sobre esta interação aumenta, o mesmo acontece com a necessidade de assegurar que todo o ecossistema e todas as suas partes funcionais sejam tratadas como uma entidade.

Os técnicos e gestores de áreas protegidas deparam-se, frequentemente, com dificuldades com a terminologia das ciências da terra. Os autores destas Diretrizes esperam contribuir para a eliminação desta barreira ao disponibilizar um glossário de termos de fácil compreensão. O mais importante é que as áreas protegidas consigam informar ao público sobre geopatrimônio, de uma forma fácil de compreender, que seja inspiradora e desperte interesse e entusiasmo.

Estas Diretrizes são o resultado de uma cooperação internacional dentro do Grupo de Especialistas em Geopatrimônio da WCPA, recentemente formado. Este grupo está em constante crescimento e possui conhecimentos e experiência em todos os aspectos do patrimônio geológico e sua conservação. Os seus membros estão dispostos a ajudar todos os colegas que trabalham em áreas protegidas.

Recomendo estas Diretrizes sobre patrimônio geológico a todos os envolvidos na criação e gestão de áreas protegidas e de outros mecanismos de conservação, para assegurar que protejamos o patrimônio associado à nossa geodiversidade, bem como à biodiversidade.

\section{Dr Kathy MacKinnon}

Presidente

Comissão Mundial de Áreas Protegidas da UICN 


\section{Agradecimentos}

O texto se beneficiou com contribuições recebidas de todo o mundo. Roger Crofts, na qualidade de coordenador destas Diretrizes, agradece em especial às seguintes contribuições na redação e edição: John Gordon, Murray Gray, Dan Tormey e Graeme L. Worboys. Gostaria ainda de agradecer outras contribuições de textos e de estudos de caso dados por: Tim Badman, José Brilha, Margaret Brocx, Thais de Siqueira Canesin, Rosana Cerkvenik, Nigel Dudley, Christof Ellger, John Gunn, Eko Haryono, Renato Henriques, Maria da Glória Garcia, Jonathan Larwood, Josep-Maria Mallarach, Dario Mancinella, Colin McFadyen, Anne Musser, Piotr Migoń, Diamantino Pereira, Paulo Pereira, Raymond Roberts, Vincent Santucci e Kyung-Sik Woo. Agradeço também as contribuições recebidas de Eleanor Brown, Enrique Diaz-Martinez e Shane Orchard.

As contribuições dos revisores independentes Judy Fisher e David Welch são muito apreciadas. Agradecimentos igualmente para Kathy MacKinnon, Trevor Sandwith e Craig Groves que disponibilizaram comentários que em muito beneficiaram o documento. Reconhecimento a Dave Harmon pela edição, importantes comentários e conselhos e a Niall O'Laoghaire da Guilder Design pelo design e layout.

Esta publicação não teria sido possível sem o generoso apoio financeiro da Administração do Patrimônio Cultural da República da Coreia.

Estas Diretrizes são dedicadas ao Dr. Graeme L. Worboys, que deu uma enorme contribuição para a sua concretização, tendo falecido antes da sua publicação.

Finalmente, agradeço ao incentivo dos meus colegas do Grupo de Especialistas em Geopatrimônio da WCPA-UICN, a Tim Badman, gestor do orçamento e à minha mulher Lindsay pela sua resistência e tolerância. 


\section{Sumário executivo}

Estas Diretrizes destinam-se a ajudar todos os envolvidos na criação e gestão de áreas protegidas ou de outros mecanismos de conservação a compreender e a promover a conservação do patrimônio geológico (denominado geoconservação ao longo destas diretrizes). O quadro da Seção 1 guia o leitor para as seções que são de maior relevância para a sua área de atuação.

No resumo de cada seção apresentam-se ainda exemplos de Boas Práticas.

\section{Seção 1. Objetivos, conteúdos e utilização destas Diretrizes}

Esta seção descreve o objetivo e o público-alvo das Diretrizes, descreve o contexto da geoconservação, fornece uma tabela e um diagrama para orientar o leitor ao longo do documento e apresenta as principais fontes adicionais de informação.

\section{Seção 2. Geoconservação em áreas protegidas: conceitos e definições principais}

Esta seção apresenta as definições de geopatrimônio, geodiversidade e geoconservação, descreve os cinco valores chave para o geopatrimônio e a geodiversidade e explica a relevância da geoconservação para a UICN e para as áreas protegidas. Também fornece recomendações sobre o uso destas Diretrizes a "Outros Mecanismos de Conservação Eficazes" e "áreas conservadas".

Recomendamos que todos os utilizadores leiam esta seção, pois fornece o enquadramento essencial para todo o volume.

Boa Prática n 1: Para evitar mal-entendidos, usar adequadamente os conceitos de geopatrimônio, geodiversidade, geoconservação, áreas protegidas destinadas à geoconservação e geossítios.

Boa Prática $n^{\circ}$ 2: Estas diretrizes devem ser aplicadas a áreas protegidas e também a "Outras Medidas Efetivas de Conservação baseadas em área".

\section{Seção 3: Aplicação dos princípios gerais de geoconservação em áreas protegidas}

Esta seção descreve nove princípios gerais como bases para estabelecer e gerir a geoconservação em áreas protegidas. Recomendamos a todos a leitura desta seção, uma vez que ela também fornece um enquadramento essencial para a aplicação das Diretrizes.

Boa Prática № 3: Utilize os nove princípios de geoconservação no inventário, no planejamento, no estabelecimento de objetivos, na gestão e no monitoramento dos elementos e processos do geopatrimônio.

\section{Seção 4. Criação de áreas protegidas destinadas à geoconservação}

Esta seção descreve as etapas necessárias para a criação de novas áreas protegidas destinadas à geoconservação ou para a proteção de elementos e processos geológicos e geomorfológicos em áreas protegidas já existentes: definição do objetivo, escala de operação (nacional, regional ou local), inventário do geopatrimônio e critérios de avaliação. São apresentados exemplos. A seção descreve a importância de incorporar a geoconservação no planejamento nacional, regional e local. É descrita a relevância de diferentes tipos de mecanismos de proteção, governança e regimes de propriedade. São discutidos os requisitos de conhecimentos especializados relevantes. É também brevemente discutida a importância das abordagens internacionais, tais como Patrimônio Mundial, Geoparques Mundiais, bem como Reservas da Biosfera e Sítios Ramsar.

Boa Prática ${ }^{\circ}$ 4: Usar os oito temas do geopatrimônio (Tabela 4.1) para ajudar a definir os objetivos de uma área protegida destinada à geoconservação ou de uma rede de geossítios.

Boa Prática ${ }^{\circ}$ 5: Fazer um inventário de geossítios usando a abordagem indicada no fluxograma da Figura 4.1.

Boa Prática n 6: Garantir que sejam utilizados critérios claros de avaliação de geossítios, contemplando os usos científico, educacional, geoturístico e recreativo.

Boa Prática nº 7: Incentivar o desenvolvimento de planos de ação em escala nacional, regional e local para garantir que a geoconservação seja incluída nos principais instrumentos de decisão.

Boa Prática n 8: Aplicar as diretrizes da WCPA sobre áreas protegidas e "outras medidas efetivas de conservação baseadas em áreas" para garantir o mecanismo de proteção mais eficaz para os geossítios.

Boa Prática n 9: Usar especialistas para garantir a contribuição técnica ao planejamento, gestão e comunicação da geoconservação. 
Boa Prática ${ }^{\circ}$ 10: Verificar se a área protegida e o geopatrimônio existente poderiam atender aos critérios para o reconhecimento pela UNESCO, sob a Convenção do Patrimônio Mundial e/ou pela Rede Mundial de Geoparques.

Boa Prática $\mathrm{n}^{\circ}$ 11: Verificar como a geodiversidade e o geopatrimônio em Reservas da Biosfera e sítios Ramsar podem ser gerenciados para alcançar a conservação da biodiversidade e das áreas úmidas, respectivamente, juntamente com o geopatrimônio.

\section{Seção 5. Gestão de patrimônio geológico em áreas protegidas}

Esta seção fornece orientação detalhada sobre todos os aspectos da gestão de geossítios em áreas protegidas, incluindo planejamento, aspectos operacionais, aplicação das Categorias de Gestão da UICN, incorporação de valores espirituais e culturais e sistemas de monitoramento e avaliação. Conclui com exemplos de gestão da geoconservação.

Boa Prática $\mathrm{n}^{\circ}$ 12: Seguir a estrutura genérica das duas etapas na análise das necessidades de conservação e do planejamento e execução da conservação, para incorporar a geoconservação nos planos de manejo de áreas protegidas.

Boa Prática n 13: Utilizar uma abordagem sistemática para orientar as operações de gestão, incluindo a adequação de materiais para trilhas e edifícios, as questões de segurança relacionadas com os principais perigos e os efeitos das mudanças climáticas.

Boa Prática ${ }^{\circ}$ 14: Avaliar a relevância de cada uma das categorias de gestão de áreas protegidas da UICN no estabelecimento de novas áreas protegidas para geoconservação ou na melhoria da gestão das existentes, de modo a incluir a geoconservação.

Boa Prática ${ }^{\circ}$ 15: Incluir valores culturais e espirituais nos objetivos de gestão de áreas protegidas e, quando apropriado, incluir o geopatrimônio em áreas protegidas criadas devido a valores espirituais e culturais.

Boa Prática $\mathrm{n}^{\circ}$ 16: Desenvolver planos de monitoramento para avaliar feições críticas e processos naturais, e ajustar os planos (em uma estrutura de gerenciamento adaptável) para garantir que as metas de geoconservação sejam atingidas.

\section{Seção 6. Enfrentando as ameaças ao geopatrimônio em áreas protegidas}

Esta seção centra-se nas ameaças ao patrimônio geológico e na forma de mitigá-las. São definidos os conceitos de risco de degradação e vulnerabilidade como bases para a tomada de decisões de gestão. São descritas as principais ameaças ao geopatrimônio em áreas protegidas e são apresentadas orientações sobre a avaliação dos riscos e impactos. São sugeridas orientações genéricas de gestão de sítios para nove tipos particulares de ameaças. Finalmente, discute-se a interação entre a geodiversidade e a conservação da biodiversidade e identificam-se as principais questões sobre esta relação.

Boa Prática N. ${ }^{\circ}$ 17: Utilizar os conceitos de sensibilidade e vulnerabilidade para orientar as avaliações das ameaças e dos seus potenciais impactos nos elementos que compõem o patrimônio geológico.

Boa Prática N. 18: Adotar uma estratégia em várias etapas para enfrentar as ameaças ao patrimônio geológico, incluindo identificação do tipo de ameaça, sensibilidade do local à ameaça, avaliação de riscos e priorização de ações de gestão.

Boa Prática N. ${ }^{\circ}$ 19: Reconhecer as inter-relações positivas e negativas entre biodiversidade e conservação da geodiversidade para obter a melhor solução possível para a conservação da natureza.

\section{Seção 7. Gestão da geoconservação em casos selecionados}

São apresentadas recomendações detalhadas sobre formas de relevo, processos e aspectos geológicos, ameaças e princípios de gestão para quatro situações diferentes: grutas e relevos cársticos, zonas glaciais e periglaciais, minerais e fósseis, e zonas vulcânicas. É sugerida a análise de estudos de caso por meio de links para páginas web na seção de referências.

\section{Seção 8. Educação e comunicação para a geoconservação}

Esta seção estabelece os princípios e práticas gerais de interpretação, educação e divulgação pública para a geoconservação. Trata da forma como tanto os novos meios de comunicação, como os tradicionais, podem ser utilizados eficazmente.

Boa Prática n²0: Determinar a natureza e as características do público alvo na concepção de uma divulgação eficaz em geoconservação.

Boa Prática $n^{\circ}$ 21: Incluir planejamento interpretativo, programas de educação ambiental em ambientes externos e interpretação com base na internet ou em aplicativos para dispositivos móveis em áreas protegidas destinadas à geoconservação, a fim de atrair visitantes e melhorar a compreensão da geoconservação e a experiência do visitante.

Boa Prática n 22: Utilizar várias mídias convencionais para informar o público sobre geoconservação.

\section{Seção 9. Visão geral}

São descritos pontos-chave para os leitores, salientando a importante interação e interdependência entre a geoconservação e a conservação da biodiversidade, e a necessidade de uma gestão ativa do patrimônio geológico e também de uma boa comunicação. 


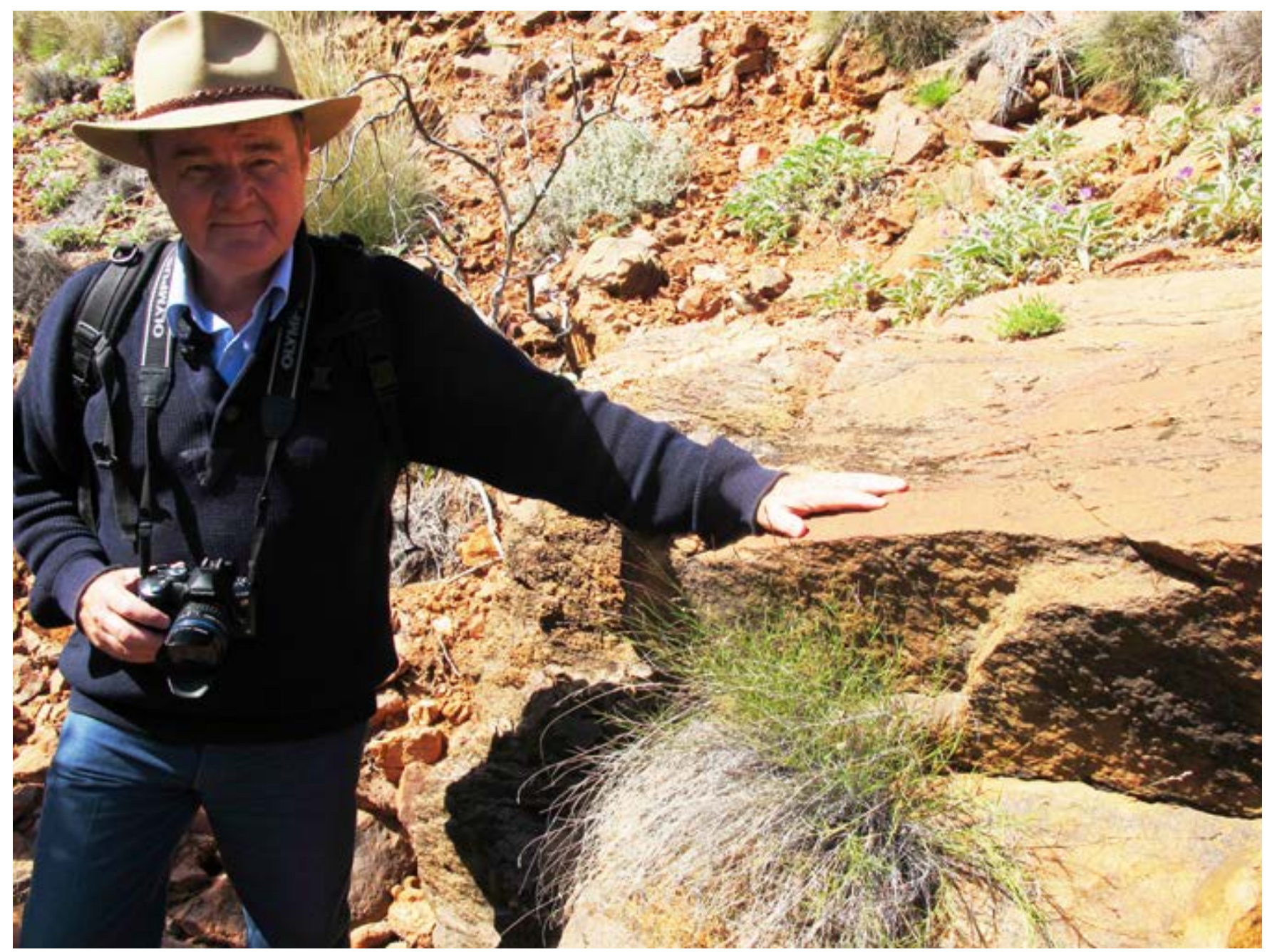

(C) Penelope Figgis

Estas Diretrizes são dedicadas ao Dr. Graeme L. Worboys, AM (1950-2020), um colega inspirador, um líder na geoconservação e um conservacionista combativo. 


\section{Objetivos, conteúdos e utilização destas Diretrizes}

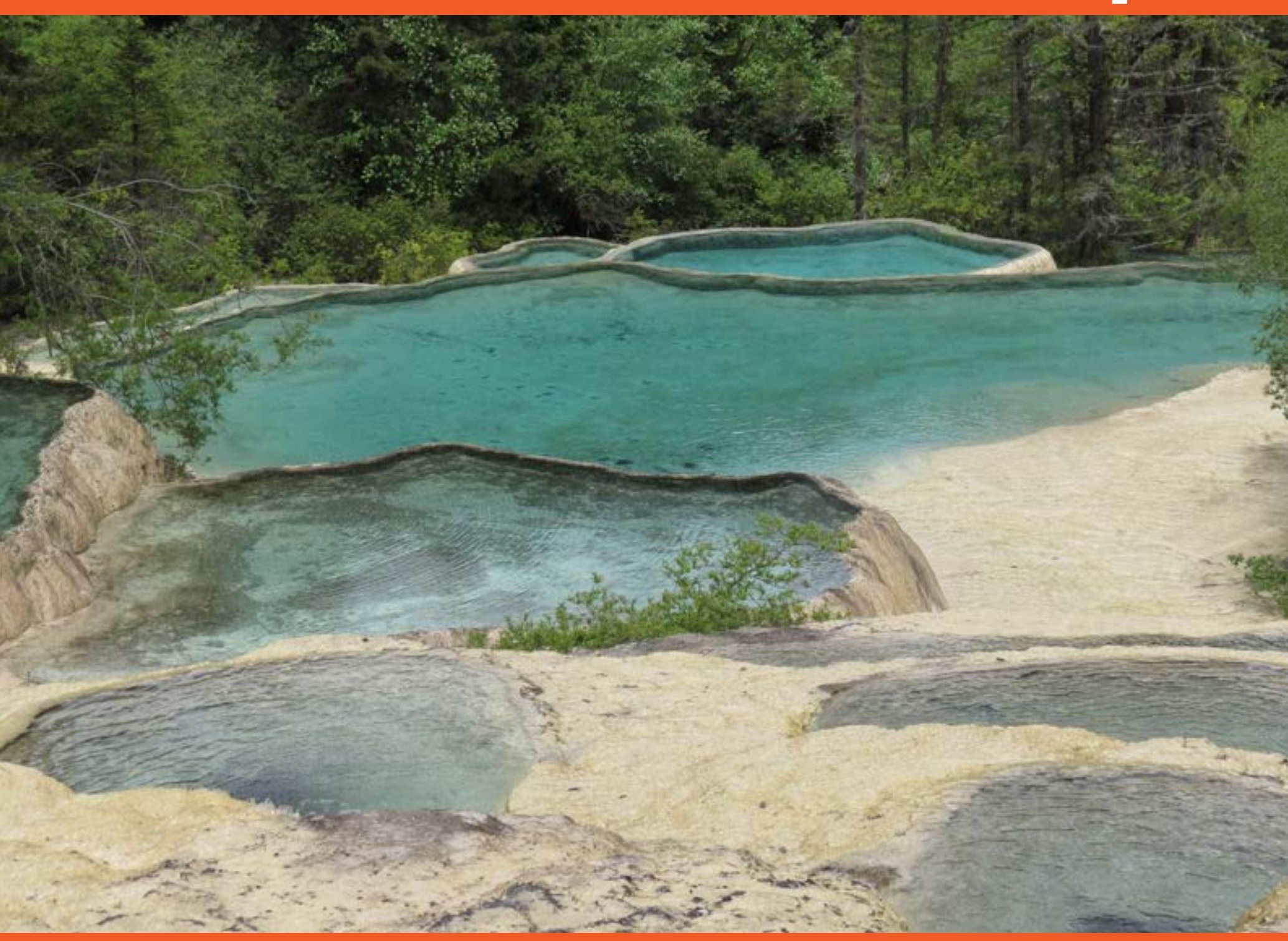




\section{Esta seção apresenta:}

Um sumário dos objetivos e conteúdos destas Diretrizes (1.1)

Instruções simples para a sua utilização (1.2)

Fontes adicionais de informação (1.3)

\subsection{Objetivos destas Diretrizes}

Estas Diretrizes destinam-se a ajudar os profissionais que trabalham em áreas protegidas e em outros mecanismos de conservação a incorporar a conservação e gestão do patrimônio geológico e a geodiversidade em suas atividades, em todas as escalas, desde o nível nacional ao do sítio. Recomendamos a utilização da seguinte definição simples de geoconservação: "conservação da geodiversidade devido aos seus valores intrínseco e ecológico e conservação do patrimônio geológico" (Sharples, 2002).

Estas Diretrizes enquadram-se nos temas específicos abordados na série Diretrizes de Boas Práticas publicadas pela Comissão Mundial de Áreas Protegidas (WCPA) e apresenta estudos de caso que ilustram as melhores práticas de geoconservação em todo o mundo.

Muitos dos profissionais que trabalham com áreas protegidas não são geocientistas e podem considerar a linguagem e os conceitos das Ciências da Terra difíceis de compreender e de incorporar no seu trabalho. Isto é compreensível, uma vez que a terminologia é frequentemente complexa, os conceitos são bastante diferentes dos relacionados com a conservação da biodiversidade (para a qual muitas áreas protegidas foram criadas) e existe a ideia frequente de que as características geológicas são relativamente estáticas e necessitam de muito pouca atenção (Crofts 2014). Por estas razões, o patrimônio geológico e a geodiversidade (como definido na seção 2.2) são frequentemente negligenciados na conservação e gestão de áreas protegidas. Porém, estes aspectos podem ter um elevado valor como parte integrante da natureza e precisam ser compreendidos e cuidados. Além disso, a saúde funcional de muitas áreas protegidas depende do conhecimento dos processos não vivos que ocorreram no passado, dos que funcionam no presente e que podem vir influenciar o futuro. Além disso, numa área protegida podem existir aspectos geológicos significativos de interesse para os visitantes e que podem representar riscos naturais (como a atividade vulcânica) que devem ser devidamente abordados pelos gestores.

Estas Diretrizes destinam-se a ajudar a melhorar a conservação e gestão do patrimônio geológico e da geodiversidade em áreas protegidas e a promover o reconhecimento das inter-relações e interações com aspectos e processos biológicos. Não se trata de um livro sobre práticas de gestão de geoconservação, mas antes uma apresentação dos antecedentes, contexto e princípios essenciais. Resume o conhecimento mais relevante para torná-lo mais facilmente acessível aos leitores e sugere literatura relevante e fontes adicionais de informação com orientações práticas detalhadas. Os exemplos de boas práticas de todo o mundo oferecem aos leitores uma confiança renovada no tratamento do patrimônio geológico e na relação da geoconservação com a conservação da biodiversidade.

\subsection{Utilização destas Diretrizes}

É improvável que a maioria dos leitores leia estas Diretrizes do princípio ao fim, mas certamente irá utilizá-las como fonte de referência para as suas necessidades e circunstâncias particulares relativas à geoconservação na criação e gestão de áreas protegidas.

As Diretrizes estão organizadas em nove seções (Quadro 1.1). Após as duas seções contextuais iniciais, aborda-se a criação de um sistema de áreas protegidas dedicadas à geoconservação, quer em escala nacional ou regional, a criação de áreas protegidas especificamente por motivos de geoconservação, a inclusão de medidas de geoconservação em áreas protegidas já existentes, terminando com a gestão, monitoramento, divulgação e interpretação dirigida ao grande público (Figura 1.1). Os gestores de áreas protegidas podem ir diretamente para a seção 5. No entanto, recomendamos fortemente que todos leiam as seções 2 e 3, uma vez que fornecem informação conceitual essencial para compreender o que é a geoconservação. A Tabela 1.1 e a Figura 1.1 fornecem uma orientação rápida para a localização de assuntos específicos que se encontram ao longo destas Diretrizes.

\subsection{Fontes adicionais de informação}

Algumas fontes adicionais de informação dão uma boa perspetiva sobre geoconservação em áreas protegidas. Crofts \& Gordon (2014, 2015), de acesso livre, apresentam uma introdução aos conceitos, terminologia e relação entre a geoconservação e a conservação da biodiversidade. Considerações mais abrangentes sobre geodiversidade e avaliação, proteção e gestão do patrimônio geológico estão disponíveis em Gray (2013) e Reynard \& Brilha (2018). A revista científica Geoheritage é a principal fonte internacional de artigos sobre todos os aspectos do patrimônio geológico. Muitos artigos estão disponíveis com acesso livre ou podem ser acessados por meio de plataformas como a Researchgate. 
Tabela 1.1. Estrutura e assuntos principais das Diretrizes.

\begin{tabular}{|c|c|c|c|}
\hline No. & Seções & Assuntos principais (sub-seções) & Páginas \\
\hline \multirow[t]{3}{*}{1} & \multirow{3}{*}{$\begin{array}{l}\text { Objetivos, conteúdos e utilização } \\
\text { destas Diretrizes }\end{array}$} & - Objetivos (1.1) & 2 \\
\hline & & [ Breves sugestões para a utilização destas Diretrizes (1.2) & 2 \\
\hline & & - Fontes adicionais de informação (1.3) & 2 \\
\hline \multirow[t]{5}{*}{2} & \multirow{5}{*}{$\begin{array}{l}\text { Geoconservação em áreas } \\
\text { protegidas: conceitos e } \\
\text { definições principais }\end{array}$} & - Por que é necessária a geoconservação (2.1) & 6 \\
\hline & & Definição de termos-chave (2.2) & 6 \\
\hline & & V Valores da geodiversidade e do patrimônio geológico (2.3) & 8 \\
\hline & & - O papel da UICN na geoconservação (2.4) & 10 \\
\hline & & - A geoconservação no conceito de área protegida da UICN (2.5) & 11 \\
\hline 3 & $\begin{array}{l}\text { Aplicação dos princípios da } \\
\text { geoconservação na gestão de } \\
\text { áreas protegidas }\end{array}$ & Diretrizes para a geoconservação (3.1) & 14 \\
\hline \multirow[t]{9}{*}{4} & \multirow{9}{*}{$\begin{array}{l}\text { Criação de áreas protegidas } \\
\text { destinadas à geoconservação }\end{array}$} & - Definição do objetivo e escala operacional (4.1) & 22 \\
\hline & & - Inventariação (4.2) & 24 \\
\hline & & - Critérios para a avaliação de sítios (4.3) & 27 \\
\hline & & Exemplos de inventários e de avaliação de sítios geológicos (4.4) & 29 \\
\hline & & $\begin{array}{l}\text { Integração do patrimônio geológico em planos de ação } \\
\text { nacionais, regionais e locais (4.5) }\end{array}$ & 29 \\
\hline & & Mecanismos de proteção (4.6) & 32 \\
\hline & & - Tipos de governança (4.7) & 32 \\
\hline & & Requisitos para especialistas (4.8) & 32 \\
\hline & & A geoconservação em nível internacional (4.9) & 37 \\
\hline \multirow[t]{6}{*}{5} & \multirow{6}{*}{$\begin{array}{l}\text { Gestão de patrimônio geológico } \\
\text { em áreas protegidas }\end{array}$} & - Planejamento da gestão (5.1) & 40 \\
\hline & & - Geoconservação e ações em áreas protegidas (5.2) & 50 \\
\hline & & $\begin{array}{l}\text { As categorias de áreas protegidas da UICN e a geoconservação } \\
\text { (5.3) }\end{array}$ & 52 \\
\hline & & - Os valores espirituais e culturais do patrimônio geológico (5.4) & 52 \\
\hline & & Monitoramento e avaliação de geossítios (5.5) & 58 \\
\hline & & Exemplos de ações de geoconservação (5.6) & 62 \\
\hline \multirow[t]{5}{*}{6} & \multirow{5}{*}{$\begin{array}{l}\text { Enfrentando as ameaças } \\
\text { ao geopatrimônio em áreas } \\
\text { protegidas }\end{array}$} & - Conceitos de risco de degradação e vulnerabilidade (6.1) & 64 \\
\hline & & Tipos de ameaças (6.2) & 66 \\
\hline & & - Avaliação do risco de ameaça e impactos (6.3) & 66 \\
\hline & & - Boas práticas na mitigação de ameaças (6.4) & 66 \\
\hline & & $\begin{array}{l}\text { Relação entre a conservação da geodiversidade e da } \\
\text { biodiversidade (6.5) }\end{array}$ & 86 \\
\hline \multirow[t]{4}{*}{7} & \multirow{4}{*}{$\begin{array}{l}\text { Gestão da geoconservação em } \\
\text { casos selecionados }\end{array}$} & Áreas protegidas em zonas cársticas (7.1) & 89 \\
\hline & & - Áreas protegidas em zonas glaciais e periglaciais (7.2) & 92 \\
\hline & & — Sítios paleontológicos e mineralógicos (7.3) & 102 \\
\hline & & E Áreas protegidas em zonas vulcânicas (7.4) & 107 \\
\hline \multirow[t]{5}{*}{8} & \multirow{5}{*}{$\begin{array}{l}\text { Educação e comunicação para a } \\
\text { geoconservação }\end{array}$} & - Interpretação (8.1) & 112 \\
\hline & & Educação (8.2) & 115 \\
\hline & & - Divulgação (8.3) & 115 \\
\hline & & - Novas soluções digitais de comunicação (8.4) & 118 \\
\hline & & • Comunicação na mídia convencional (8.5) & 120 \\
\hline 9 & Visão geral & Resumos dos pontos mais importantes & 122 \\
\hline
\end{tabular}


Figura 1.1. Etapas principais na criação e gestão de áreas protegidas destinadas à geoconservação e os assuntos principais abordados nestas Diretrizes.

Conceitos de geoconservação, definições e princípios (seções 2 e 3)
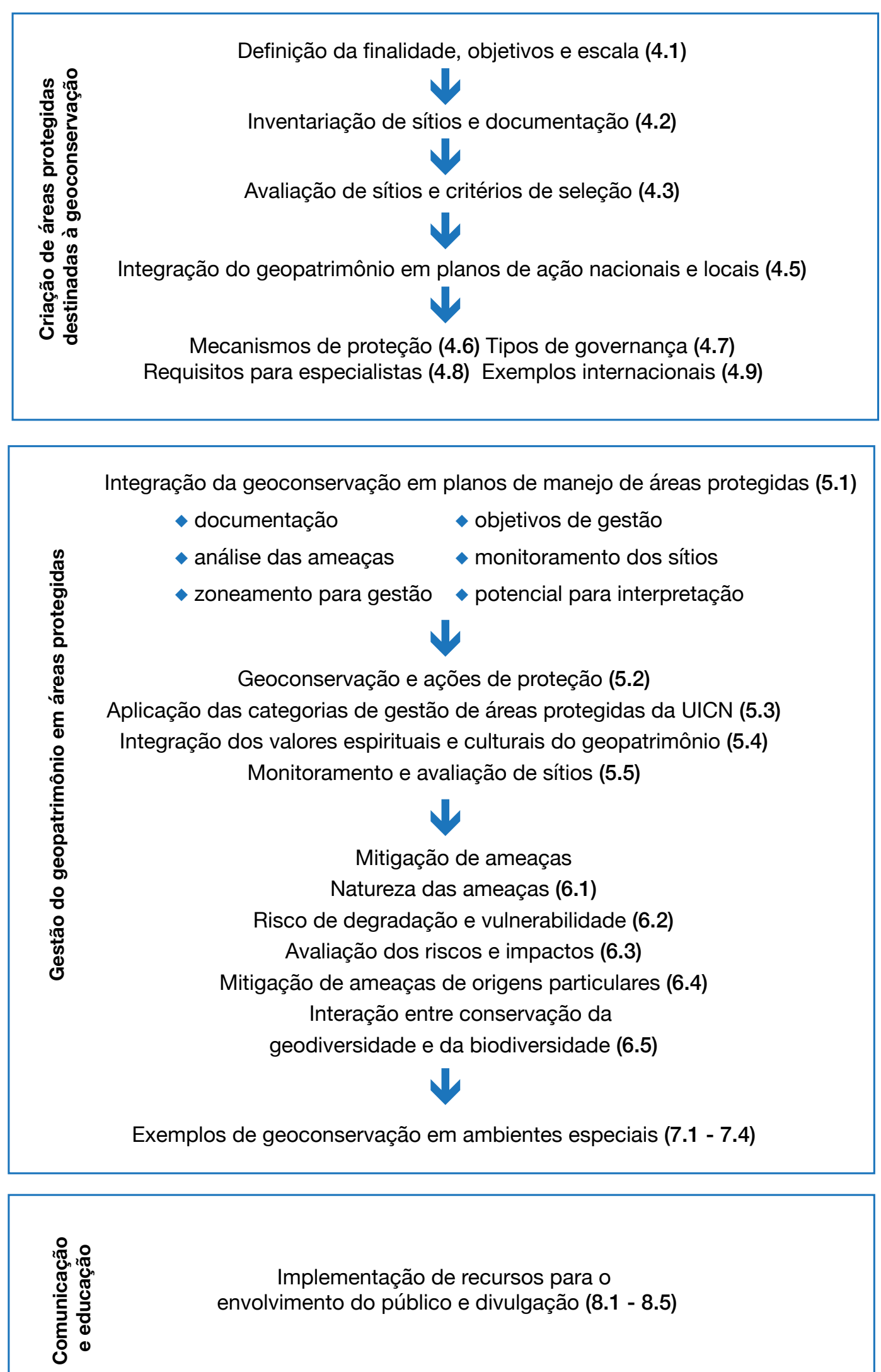

Implementação de recursos para o

envolvimento do público e divulgação (8.1 - 8.5) 


\section{Geoconservação em áreas protegidas: conceitos e definições principais}

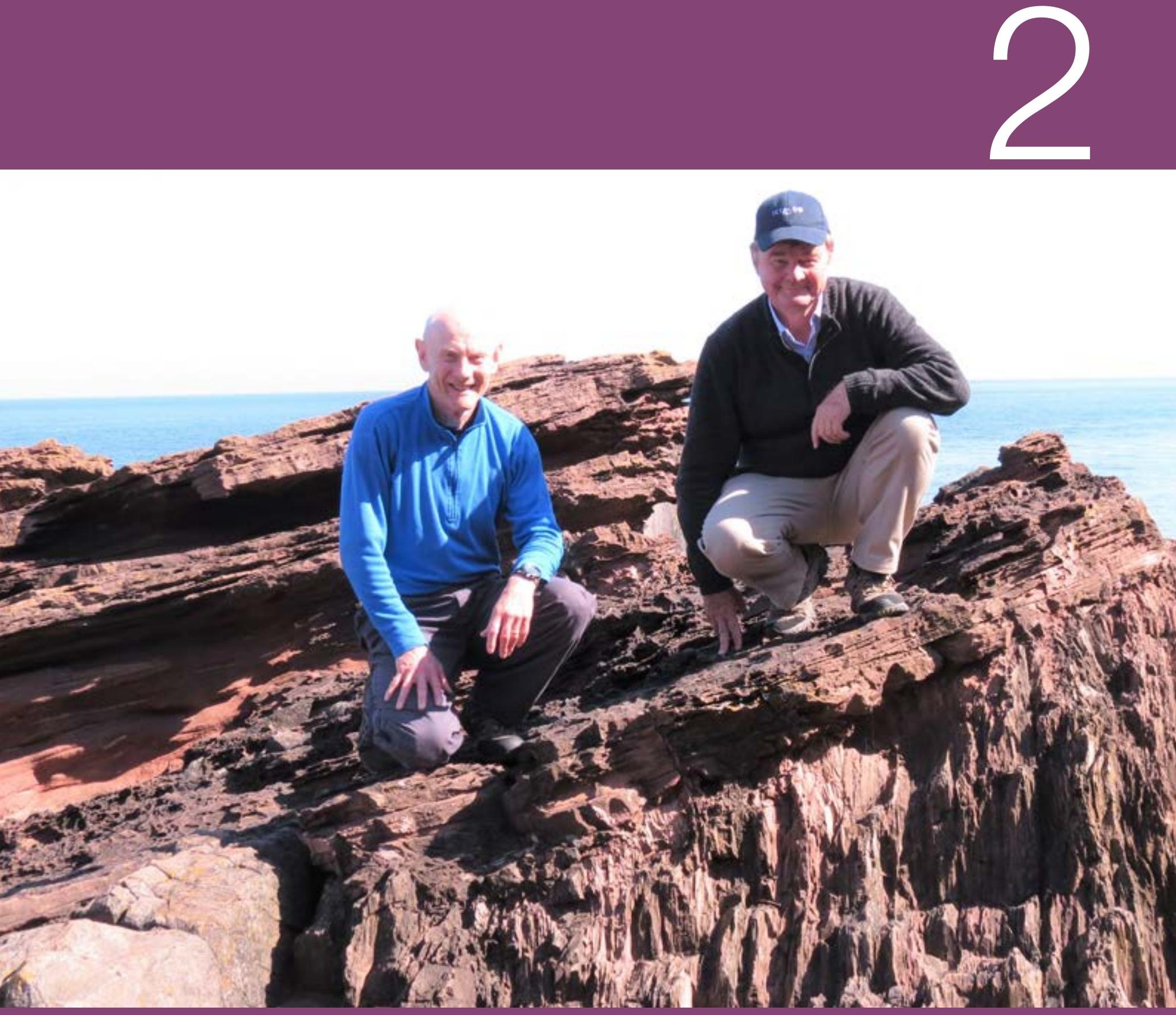

Siccar Point, na Escócia, é um lugar emblemático para a ciência que estuda a formação da Terra. Este Sítio de Especial Interesse Científico (SSSI) é protegido devido às formações rochosas que James Hutton descobriu em 1788 e relatou no seu tratado Teoria da Terra, de 1795. O contato entre as camadas muito inclinadas de rochas mais antigas e as rochas, mais recentes, que se sobrepõem, representa uma grande lacuna no registo rochoso, que inclui muitos ciclos de erosão e deposição, denotando a imensidão do tempo geológico. Na foto: Graeme L. Worboys (direita) e John Gordon (esquerda), ambos co-autores destas Diretrizes. @ Roger Crofts 


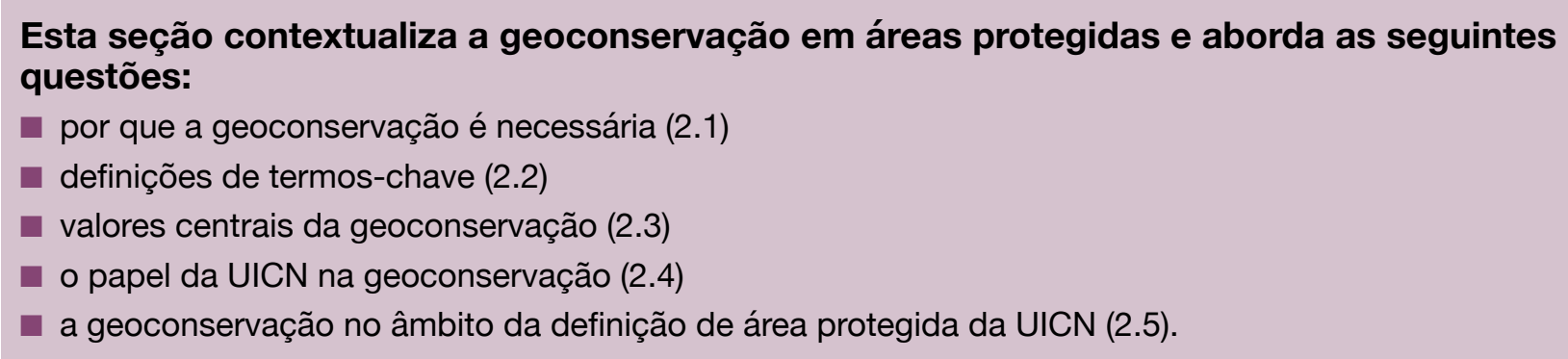

\subsection{Por que é necessária a geoconservação?}

Há a opinião generalizada de que as rochas e as formas de relevo são razoavelmente robustos, não sendo suscetíveis a sofrer alterações ou danos devido a atividades humanas e, por conseguinte, não necessitam de medidas especiais para a sua conservação. Esta ideia é incorreta uma vez que, na verdade, as rochas e as formas de relevo estão sujeitas a ameaças naturais e humanas. A geodiversidade e o patrimônio geológico fazem indubitavelmente parte do patrimônio natural da Terra mas, em comparação com a biodiversidade, sua conservação e gestão só recentemente começou a ser considerada de uma forma mais estruturada. Há várias razões para explicar este desequilíbrio (Crofts, 2014, 2018). Não existe o equivalente da Convenção da Diversidade Biológica para a geoconservação ou para a geodiversidade, embora existam vários acordos ou convenções internacionais, tais como a Convenção do Patrimônio Mundial da UNESCO e o Programa de Geoparques Mundiais da UNESCO, que incluem a geoconservação. Há pouca consciência na sociedade do quão importante é proteger aspectos e processos geológicos e geomorfológicos particulares devido aos seus valores patrimoniais e sobre o papel da geodiversidade no apoio à biodiversidade e às funções e serviços dos ecossistemas.

\subsection{Definições de geodiversidade, patrimônio geológico e geoconservação}

À medida que a prática da geoconservação tem evoluído, vários termos e definições têm sido introduzidos. Por razões de clareza, consistência e simplicidade e para facilitar a comunicação, recomenda-se a seguinte terminologia (Crofts \& Gordon, 2014, 2015).

A geodiversidade é a variedade de rochas, minerais, fósseis, formas de relevo, sedimentos e solos, assim como os processos naturais que os formam e alteram. Inclui feições e processos geológicos e geomorfológicos passados e presentes que registram a história da Terra e a evolução das formas de vida, tal como representadas no registo geológico, incluindo plantas e animais e os seus habitats. Os elementos da geodiversidade fornecem a base para a vida na Terra e contribuem para o capital natural e para os serviços de ecossistemas.

\section{O patrimônio geológico ou geopatrimônio compreende} os elementos e feições da geodiversidade, isoladamente ou combinados, que são considerados como tendo um valor significativo por razões intrínsecas, científicas, educacionais, culturais, espirituais, estéticas, ecológicas ou ecossistêmicas e que, portanto, merecem ser conservados. O geopatrimônio constitui um legado do passado a ser mantido no presente e transmitido para o benefício das gerações futuras. Registra a história cumulativa da Terra preservada nas suas rochas e formas de relevo, como nas páginas de um livro, embora fragmentada e com páginas faltantes. É representado em locais especiais (geossítios; ver definição abaixo) e objetos (espécimes in situ e em coleções de museus) que são fundamentais para o nosso conhecimento sobre a história da Terra e a evolução da vida. A base filosófica sobre a qual se apoia está estabelecida na Declaração de Digne sobre os Direitos da Memória da Terra (Caixa 2.1), que apresenta uma abordagem baseada nos direitos do geopatrimônio e é um dos fundamentos dos Geoparques Mundiais da UNESCO.

É importante conhecer a variedade de aspectos que compõem o geopatrimônio in situ, que inclui:

afloramentos rochosos únicos ou representativos de processos geológicos particulares ou de etapas fundamentais da evolução da Terra, quer globalmente quer em regiões específicas;

- formas de relevo que sejam únicas, típicas ou representativas de processos particulares, atuais ou passados (por exemplo, glaciação);

n sistemas ativos (por exemplo, rios, desertos, glaciares e solos); ou

- conjuntos de todos estes componentes.

O patrimônio geológico em áreas protegidas pode, assim, existir através de um contínuo de escalas, desde aspectos individuais muito circunscritos, tais como afloramentos rochosos ou blocos transportados por glaciares ao longo de longas distâncias (por exemplo, o Pierre á Dzo, Monthey, Suíça), a vastas paisagens, tais como sistemas montanhosos constituídos por conjuntos de rochas, formas de relevos e solos (e.g. Parque Nacional Los Glaciares, Argentina) ou sistemas vulcânicos que acolhem microhabitats extremamente diversos (por exemplo, Yellowstone Caldera, EUA, e o ecossistema associado Greater Yellowstone Ecosystem, incluindo megafauna carismática e espécies que habitam as fontes quentes). A definição da dimensão do sítio é apenas estabelecida pela entidade de gestão e respectivo plano de gestão.

É fácil ficar confuso sobre o que é uma área protegida destinada à geoconservação. Ela pode corresponder apenas a um único aspecto ou representação de um processo natural passado ou atual, sem existir toda uma diversidade de aspectos ou formas. Por exemplo, uma sequência espessa de calcários formados em águas profundas, aparentemente monótonos e relativamente 


\section{Caixa 2.1}

\section{A Declaração de Digne}

Declaração Internacional dos Direitos à Memória da Terra (1991)

1. Assim como cada vida humana é considerada única, chegou o momento de reconhecer, também, o caráter único da Terra.

2. É a Terra que nos suporta. Estamos todos ligados à Terra e ela é a ligação entre todos nós.

3. A Terra, com 4500 milhões de anos de idade, é o berço da vida, da renovação e das metamorfoses dos seres vivos. A sua longa evolução e a sua lenta maturação deram forma ao ambiente em que vivemos.

4. A nossa história e a história da Terra estão intimamente ligadas. As suas origens são as nossas origens. A sua história é a nossa história e o seu futuro será o nosso futuro.

5. A superfície da Terra é o nosso ambiente. Este ambiente é diferente do de ontem e será diferente do de amanhã. Não somos mais que um dos momentos da Terra; não somos finalidade, mas sim passagem.

6. Assim como uma árvore guarda a memória do seu crescimento e da sua vida no seu tronco, também a Terra conserva a memória do seu passado, registrada em profundidade ou na superfície, nas rochas, nos fósseis e nas paisagens, registro esse que pode ser lido e traduzido.

7. Os homens sempre tiveram a preocupação em proteger o memorial do seu passado, ou seja, o seu patrimônio cultural. Só há pouco tempo se começou a proteger o ambiente imediato, o nosso patrimônio natural. O passado da Terra não é menos importante que o passado dos seres humanos. Chegou o momento de aprendermos a protegê-lo e, protegendo-o, aprenderemos a conhecer o passado da terra, esse livro escrito antes do nosso advento e que é o patrimônio geológico.

8. Nós e a Terra compartilhamos uma herança comum. Cada homem, cada governo não é mais do que o depositário desse patrimônio. Cada um de nós deve compreender que qualquer depredação é uma mutilação, uma destruição, uma perda irremediável. Todas as formas de desenvolvimento devem, assim, ter em conta o valor e a singularidade desse patrimônio.

9. Os participantes do $1^{\circ}$ Simpósio Internacional sobre Proteção do Patrimônio Geológico, que incluiu mais de uma centena de especialistas de 30 países, pedem a todas as autoridades nacionais e internacionais que considerem e que protejam o patrimônio geológico, por meio de todas as medidas legais, financeiras e organizacionais necessárias.

Fonte: http://www.progeo.ngo/downloads/Digne Declaration.pdf

Versão Portuguesa de Miguel Magalhães Ramalho (Comunicações dos Serviços Geológicos de Portugal, 1991, t. 77, 147-148)

uniformes, pode representar uma parte importante da evolução geológica de uma determinada região ou da evolução da vida. Da mesma forma, uma camada particular de rochas pode esconder uma rica diversidade de formas de vida fósseis que não é facilmente evidente a olho nu, mas pode ser uma característica crucial de uma seção-tipo importante internacionalmente ou um local de referência para uma fase ou mudança evolutiva particular. Uma área protegida pode incluir geopatrimônio, mas a sua classificação nada teve a ver com geoconservação. Por outro lado, uma área protegida pode ter uma grande variedade de aspectos, formas e processos com relevância para a geoconservação. Todas estas variações são válidas e, portanto, é essencial assegurar que os critérios para a seleção de uma área protegida para efeitos de geoconservação ou a gestão de geopatrimônio em áreas protegidas sejam explícitos. Os princípios orientadores são fornecidos na seção 3 e orientações mais detalhadas sobre os critérios de seleção são dadas na seção 4.

É importante enfatizar que o patrimônio geológico deve ter um especial valor geológico ou geomorfológico (seção 2.3). Todavia, haverá outros casos onde as características geológicas ou geomorfológicas não são excepcionais em si mesmas, mas são importantes para o patrimônio cultural ou arqueológico (por exemplo, uma caverna com pinturas ou com fósseis de hominídeos).

Podemos encontrar locais ou áreas com patrimônio geológico de elevada relevância em toda a gama de Categorias de
Áreas Protegidas da UICN, seja como interesses primários ou como componentes dentro de um conjunto mais amplo de características naturais (ver seção 5.4).

A geoconservação tem sido definida como "a conservação da geodiversidade devido aos seus valores intrínsecos, ecológicos e (geo)patrimoniais" (Sharples, 2002). Essencialmente, a geoconservação em áreas protegidas compreende as ações que promovem a conservação, valorização e promoção da geodiversidade e do geopatrimônio. A geoconservação relaciona-se, portanto, principalmente com a conservação de características e/ou elementos que tenham valor geológico ou geomorfológico especial. A geoconservação pode ajudar a manter a biodiversidade e o funcionamento de ecossistemas saudáveis, assim como a conservação do patrimônio geológico.

O termo geossítio é usado para referir qualquer local que tenha ou uma única feição ou uma variedade de elementos geológicos ou geomorfológicos e processos dignos de proteção devido ao seu elevado valor científico (Brilha, 2018a). A palavra "geossítio" é a versão abreviada de sítio geológico ou sítio geomorfológico.

Em resumo, esta é a hierarquia dos termos utilizados nestas Diretrizes: Geodiversidade é a totalidade da natureza abiótica, da qual alguns elementos têm valor significativo e requerem conservação, designados por patrimônio geológico, que por sua vez é gerido em geossítios, que podem ser, ou não, áreas 
protegidas formalmente estabelecidas, sob o rótulo genérico de geoconservação.

\section{O propósito primordial da Geoconservação em áreas} protegidas e em outros mecanismos de conservação é conservar o geopatrimônio e a geodiversidade que ocorre em geossítios. A ação de geoconservação deve ser implementada em áreas protegidas especialmente constituídas para o efeito, ou como um componente da gestão de áreas protegidas estabelecidas com outros propósitos.

\section{Boa Prática n 1: Para evitar mal-entendidos, usar} adequadamente os conceitos de geopatrimônio, geodiversidade, geoconservação, áreas protegidas destinadas à geoconservação e geossítios.

\subsection{Valores do patrimônio geológico e da geodiversidade}

O geopatrimônio e a geodiversidade não são apenas conceitos tangíveis; eles são também sustentados por valores importantes. Serão descritos cinco valores básicos de geoconservação para garantir que todas as suas facetas sejam compreendidas e reconhecidas.

Em primeiro lugar, o geopatrimônio é importante por razões éticas, aquilo que é geralmente referido como valor intrínseco. No passado recente, e com demasiada frequência, o foco tem sido exclusivamente a utilidade da diversidade para a sociedade. Todavia, existe uma ampla justificativa ética para proteger o nosso geopatrimônio apenas por existir: pelo seu próprio valor. Esta razão é congruente com a responsabilidade da sociedade de conservar a natureza, a base da Declaração de Digne.
Em segundo lugar, é importante proteger o patrimônio geológico como um recurso científico e educativo que contribui para o conhecimento sobre a evolução da Terra. Por exemplo, a discordância angular de Hutton em Siccar Point (Berwickshire, Escócia) é um dos locais-chave onde James Hutton, "o fundador da geologia moderna", sustentou a sua teoria da Terra resumida na sua frase intemporal de que "não vemos o vestígio de um começo, nem nenhuma perspectiva de um fim" (ver foto de frontispício). Da mesma forma, os fósseis do Folhelhos de Burgess nos parques nacionais de Yoho e Kootenay (Canadá), fornecem informação excepcional sobre a evolução de formas de vida complexas na Terra há mais de 500 milhões de anos.

Em terceiro lugar, o geopatrimônio em áreas protegidas pode ser importante pelos seus valores estéticos, culturais e espirituais (Verschuuren et al., no prelo). Isto pode incluir comunidades que se identificam plenamente com seu patrimônio geológico local, como a montanha Triglav, no Parque Nacional homônimo, na Eslovênia e que está representada na bandeira nacional, ou o Monte Fuji, um ícone cultural do Japão. Alguns locais com características geológicas importantes, como os parques nacionais de Yosemite e Yellowstone nos EUA, têm uma importância cultural e educacional devido ao seu papel no desenvolvimento do pensamento e ação em áreas protegidas, enquanto muitos outros têm valor significativo por razões estéticas e para permitir atividades recreativas e turísticas. Da mesma forma, existem muitos locais sagrados, como os mosteiros cristãos de Meteora (Grécia) e muitos locais de história cultural, como as cavernas com pinturas antigas em KwaZuluNatal (África do Sul), que demonstram a estreita ligação entre o patrimônio geológico e a herança cultural e espiritual.

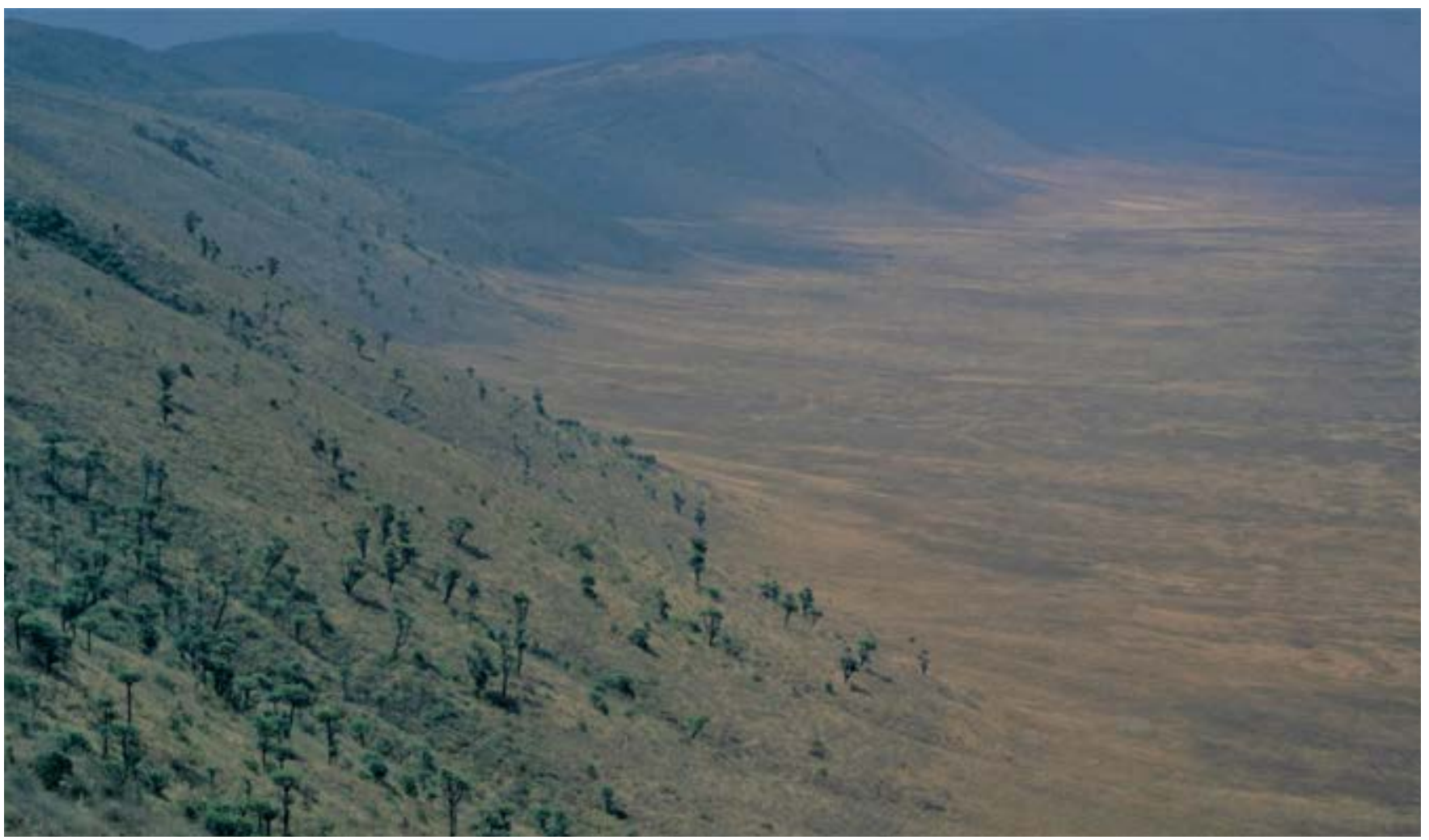

Foto 2.1. A cratera de Ngorongoro é um exemplo de valor intrínseco (Área de Conservação de Ngorongoro, Tanzânia). Trata-se de uma grande cratera de um vulcão extinto e também o lar de muitas espécies da fauna nativa. @ Roger Crofts 


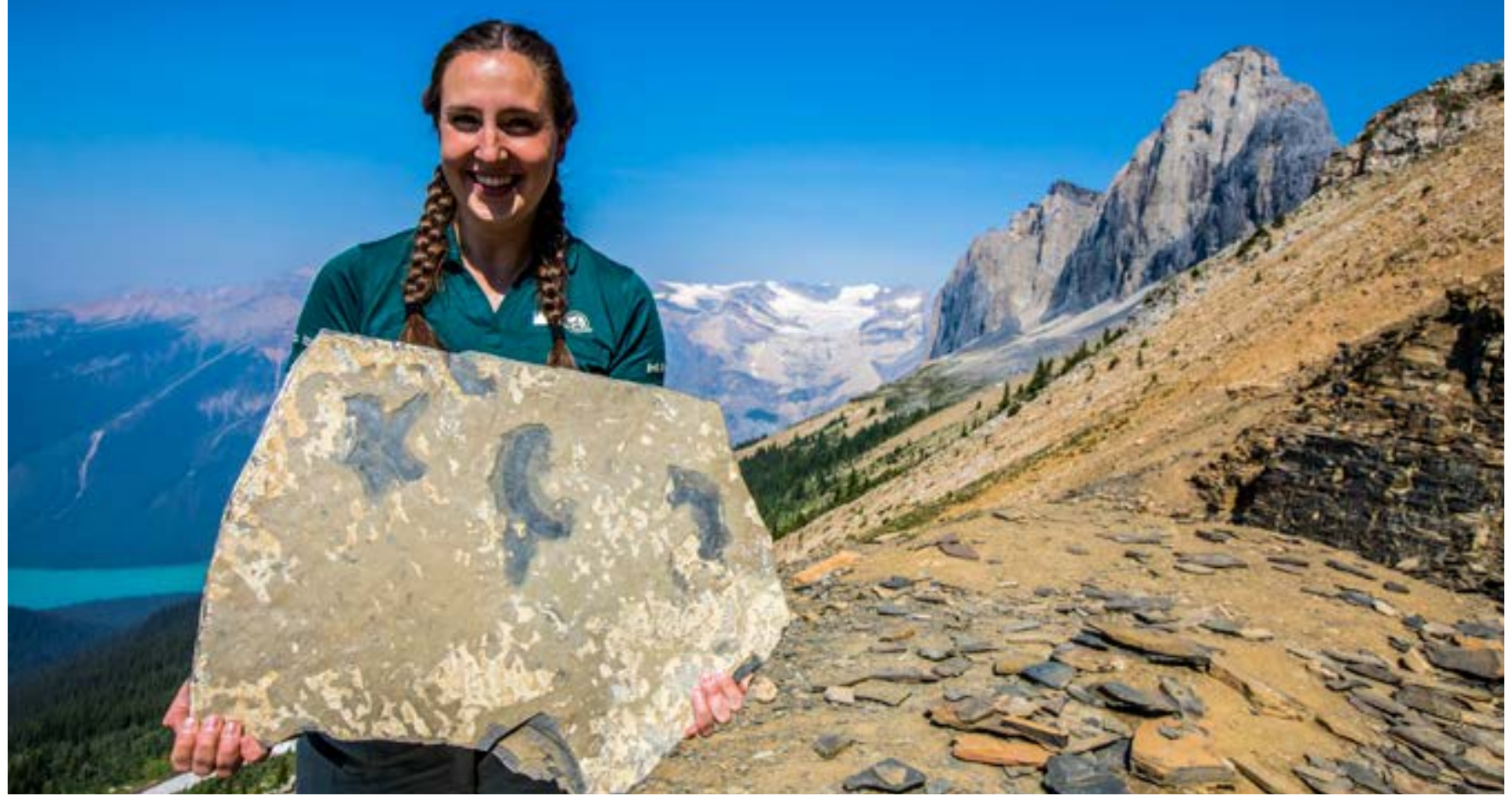

Foto 2.2. O xisto de Burgess (Parque Nacional Yoho, Columbia Britânica, Canadá) é um exemplo de um local onde a pesquisa permitiu o desenvolvimento de novo conhecimento sobre a evolução da vida na Terra há cerca de 500 milhões de anos, durante a época da "Explosão Cambriana". Uma monitora ambiental do Parks Canada exibe uma grande amostra contendo fósseis da Pedreira Walcott, Parque Nacional Yoho, Canadá. @ Parks Canada Ryan Creary

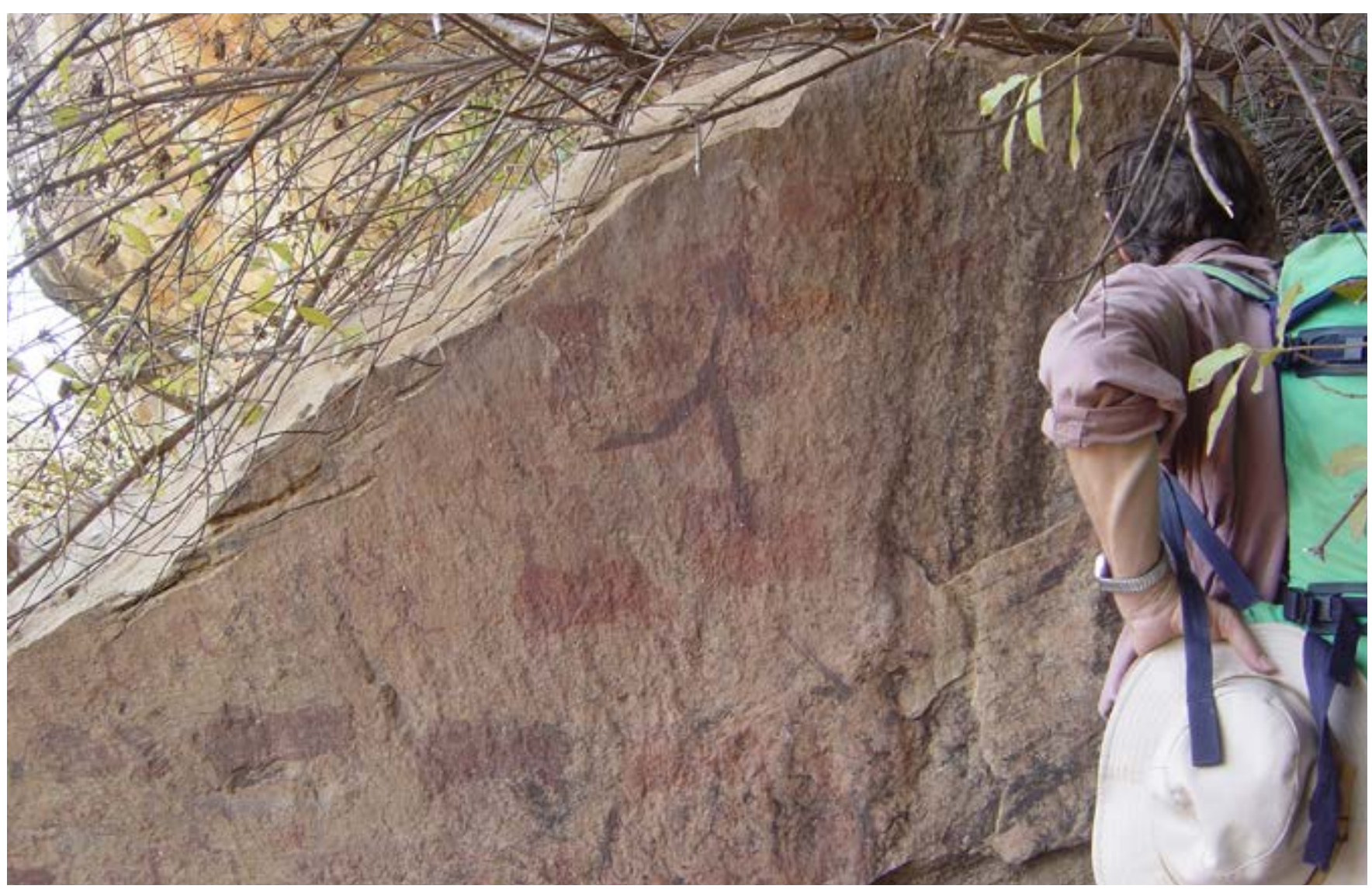

Foto 2.3. Arte rupestre do Parque Nacional Royal Natal (KwaZulu-Natal, África do Sul) ilustrando o uso de locais naturais abrigados para a comunicação simbólica do passado. @ Sue Stolton 


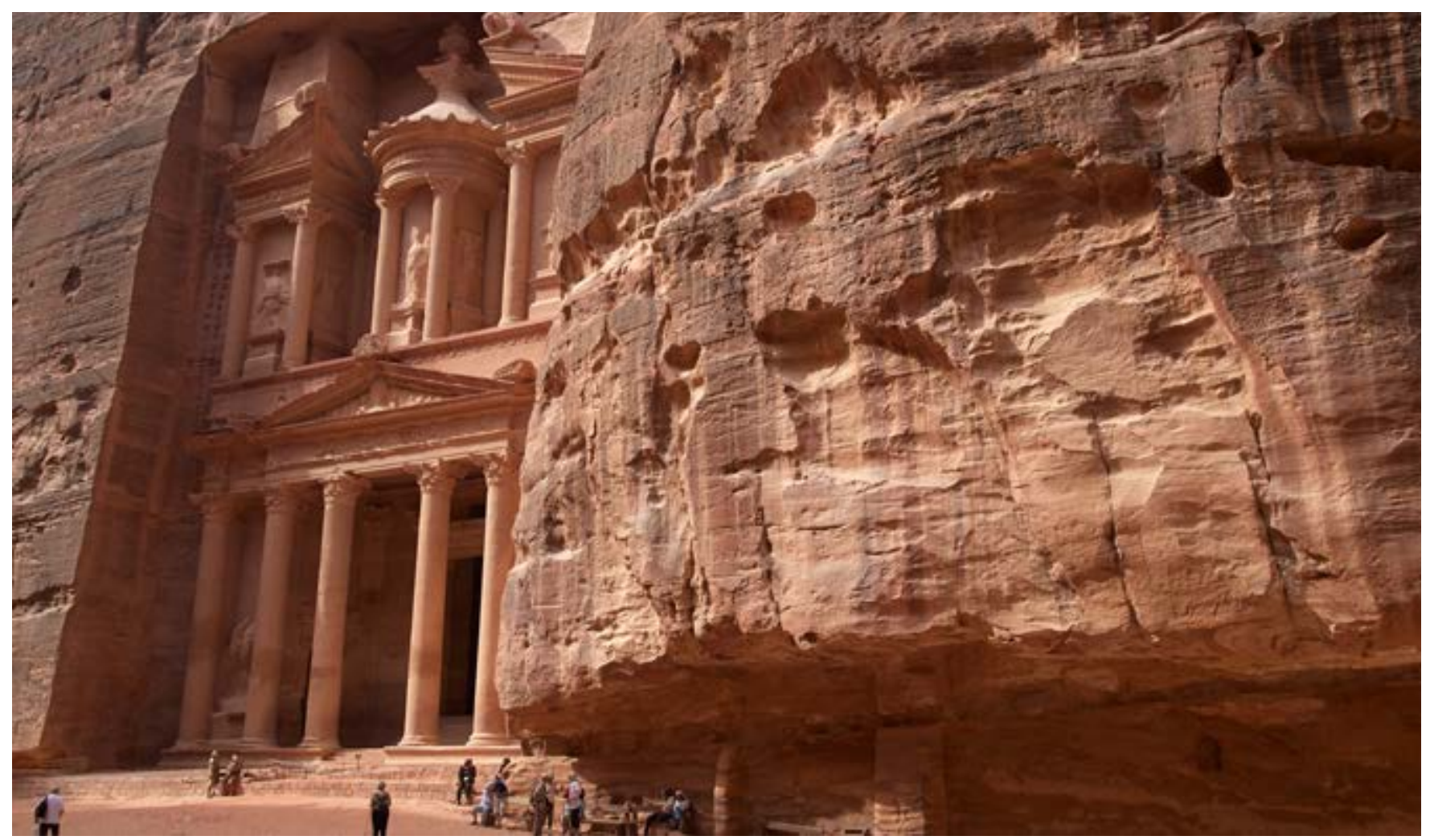

Foto 2.4. O uso de materiais naturais in situ é aqui exemplificado no Parque Arqueológico de Petra, integrado na Lista do Patrimônio Mundial da UNESCO (Jordânia). As rochas areníticas multicoloridas foram esculpidas como muitos tipos de edifícios (especialmente templos, túmulos e edifícios públicos) pelos povos nabateu e helênico ao longo dos séculos. @ José Brilha

Os patrimônios geológico e cultural podem ainda estar ligados de muitas outras formas; por exemplo, formações rochosas pouco consolidadas constituem os cenários de "cidades escavadas" nos sítios classificados como Patrimônio Mundial da UNESCO em Petra (Jordânia) e Vardzia (Geórgia).

Em quarto lugar, a geodiversidade tem um importante valor ecológico no apoio à biodiversidade e ao funcionamento dos ecossistemas. A diversidade de substratos, geoformas e solos, juntamente com processos como a circulação de água e a disponibilização, erosão e deposição de sedimentos, fornece as bases para habitats e espécies e para o funcionamento dos ecossistemas. Em muitos ambientes, os complexos padrões topográficos de micro e macro escalas, processos geomorfológicos e pedológicos e regimes de perturbação proporcionam condições para uma alta riqueza de espécies e diversidade de habitats.

A relação entre os elementos da geo e biodiversidade é essencial para o conceito de ecossistema. O termo recentemente criado "conservação do palco da natureza" baseia-se no fato de que a flora e a fauna são os "atores", tendo a geodiversidade como o "palco" no qual eles prosperam. Assim, a conservação da biodiversidade é mais efetiva quando se conserva todo o enquadramento, particularmente em tempos de mudança climática quando uma série de habitats podem ter de ser realocados para garantir a sobrevivência de plantas e animais (Anderson \& Ferree, 2010; Gross et al., 2016).

Finalmente, em quinto lugar, a geodiversidade é um componente crítico dos ecossistemas, e concretamente fornece muitos bens ambientais e serviços ecossistêmicos, que são os benefícios diretos e indiretos que os seres humanos recebem do ambiente natural e dos ecossistemas saudáveis (Figura 2.1; Tabela 2.1). Para apoiar a prestação destes serviços, os gestores devem trabalhar com a natureza, e não contra ela, e procurar manter os sistemas e processos naturais, como um objetivo fundamental das áreas protegidas. Isto também significa que todos os elementos dos ecossistemas devem ser vistos como um todo, em vez de, por exemplo, considerar apenas a biodiversidade ou apenas a geodiversidade. Em outras palavras, devemos pensar nos serviços da natureza ou na contribuição da natureza para as pessoas (Díaz et al., 2018). Não há dúvidas sobre a abordagem integrada dos ecossistemas, como definido no artigo $2^{\circ}$ da Convenção sobre Diversidade Biológica: "Ecossistema significa um complexo dinâmico de comunidades vegetais, animais e microorganismos e seu ambiente não vivo interagindo como uma unidade funcional." Neugarten et al. (2018) apresentam uma útil compilação sobre este tema.

\subsection{O papel da UICN na geoconservação}

A UICN tem desempenhado, ao longo das últimas décadas, um papel de liderança na geoconservação, em especial como órgão consultivo para o patrimônio natural no Comitê do Patrimônio Mundial da UNESCO. A Convenção do Patrimônio Mundial reconhece o geopatrimônio como um componente integral do Valor Universal Excepcional dos Sítios de Patrimônio Mundial, notadamente por meio do critério (viii) que está explicitamente relacionado com patrimônio geológico (ver seção 4.8 (i)).

Nos últimos anos, a atuação da UICN na geoconservação tem sido exercida de dois modos. Em primeiro lugar, as 
Figura 2.1. Serviços de ecossistemas sob a perspectiva da geodiversidade.

\begin{tabular}{|l|l|}
\hline $\begin{array}{l}\text { Regulação } \\
\text { 1. Processos atmosféricos e oceânicos (p.e. circulação dinâmica; } \\
\text { química da atmosfera; qualidade do ar e regulação climática; } \\
\text { ciclo hidrológico). }\end{array}$ \\
2. $\begin{array}{l}\text { Processos terrestres (p.e. ciclo das rochas; ciclo do carbono e } \\
\text { outros ciclos biogeoquímicos; sequestro de carbono e regu- } \\
\text { lação climática; processos geomorfológicos e regulação de } \\
\text { desastres naturais; controle da erosão). }\end{array}$ \\
3. Controle de inundações (p.e. infiltração, ilhas-barreira, diques \\
fluviais, dunas, planícies de inundação). \\
4. Regulação da qualidade da água (p.e. solo, sedimentos e \\
rochas como filtros naturais).
\end{tabular}

\begin{tabular}{|c|c|}
\hline & uporte \\
\hline & $\begin{array}{l}\text { Processos pedológicos (p.e. intemperismo; evolução do perfil } \\
\text { de solo) e solo como meio de crescimento. }\end{array}$ \\
\hline & $\begin{array}{l}\text { Disponibilização de habitat (p.e. habitats dinâmicos, cavernas, } \\
\text { falésias, salinas). }\end{array}$ \\
\hline & $\begin{array}{l}\text { Terra e água como plataforma para a atividade humana (p.e. } \\
\text { terreno para construção; navegação; surfe). }\end{array}$ \\
\hline & $\begin{array}{l}\text { Enterramento e armazenamento (p.e. sepultamento de pessoas } \\
\text { e animais; aterros municipais; armazenamento de resíduos } \\
\text { radioativos; reservatórios de petróleo e gás; captura e arma- } \\
\text { zenamento de carbono; armazenamento de água em aquíferos, } \\
\text { lagos, glaciares, reservatórios). }\end{array}$ \\
\hline & rovisad \\
\hline & $\begin{array}{l}\text { Alimentação (p.e. água doce; água mineral; sal; produção } \\
\text { cerveja e de whisky). }\end{array}$ \\
\hline & . Nutrientes e minerais para um crescimento saudável. \\
\hline & $\begin{array}{l}\text { 1. Energia (p.e. carvão, gás, petróleo, urânio; energia geotérmica, } \\
\text { hidrelétrica, marés, ondas e eólica). }\end{array}$ \\
\hline & $\begin{array}{l}\text { 2. Materiais de construção (p.e. pedra, tijolos, agregados, aço, } \\
\text { cimento, betão, betume, vidro). }\end{array}$ \\
\hline & $\begin{array}{l}\text { 3. Minerais para a indústria (p.e. metais; ligas; produtos } \\
\text { farmacêuticos; fertilizantes). }\end{array}$ \\
\hline & $\begin{array}{l}\text { 4. Produtos ornamentais (p.e. gemas; metais preciosos e semi- } \\
\text { preciosos). }\end{array}$ \\
\hline & 5. Fósseis para venda. \\
\hline
\end{tabular}

Fonte: Gray, 2018.

Diretrizes da Comissão Mundial de Áreas Protegidas da UICN para a Gestão de Áreas Protegidas estabelecem claramente que todas as áreas protegidas devem, quando apropriado, "conservar características significativas da paisagem, geomorfologia e geologia" (Dudley, 2008). Em segundo lugar, as resoluções aprovadas em três Congressos Mundiais de Conservação da UICN colocaram a geoconservação no programa da União (IUCN, 2008, 2012, 2016a). As resoluções 4.040 de 2008 e 5.048 de 2012 afirmam que a geodiversidade é parte da diversidade natural e o geopatrimônio parte do patrimônio natural. A Resolução 6.083 de 2016 promove iniciativas nacionais e internacionais voltadas para a conservação e o uso sustentável do geopatrimônio móvel (por exemplo, fósseis, meteoritos e bombas vulcânicas). Estas resoluções constituem uma referência no reconhecimento do papel integrador e na relevância do geopatrimônio e da geodiversidade, que também devem ser considerados na criação, governança e gestão de áreas protegidas.

\subsection{Geoconservação e a definição da UICN de área protegida}

A UICN define área protegida como:

Um espaço geográfico bem definido, reconhecido, dedicado e gerido através de legislação apropriada ou de outros meios eficazes, para alcançar a conservação da natureza a longo prazo e respectivos serviços ecossistêmicos e valores culturais (Dudley, 2008).
Os aspectos essenciais na geoconservação são:

- "Conservação da natureza a longo prazo", incluindo a geoconservação;

- As rochas e minerais, assim como o relevo, estão incluídos;

- A gestão pode, na prática, significar não fazer nada de modo a manter o desenvolvimento dos processos naturais;

- Os gestores devem garantir que o patrimônio geológico não seja danificado e que os processos a ele associados não sejam perturbados; e

- Os gestores devem promover, em conjunto, a geoconservação e a conservação da biodiversidade.

A UICN também reconhece a existência de "áreas conservadas", ou seja, espaços que não são áreas protegidas, e que podem não ter a conservação como objetivo principal, mas que, no entanto, conservam a natureza a longo prazo (UICN-WCPA Task Force on OECMs, 2019). A Convenção sobre Diversidade Biológica também define "Outras Medidas Efetivas de Conservação baseadas em áreas" ou OMECs (em inglês: OECM "Other Effective area-based Conservation Measures") como: Uma área geograficamente definida que não seja uma área protegida, gerida de forma a alcançar resultados positivos e sustentáveis a longo prazo para a conservação in situ da biodiversidade, com funções e serviços ecossistêmicos associados e, quando aplicável, culturais, espirituais, socioeconômicos e outros valores localmente relevantes" (Decisão 14/8 da CDB). 
Destaca-se que a maioria das OMECs ainda não foram identificadas e incluídas em bancos de dados nacionais ou internacionais. Além disso, como as OMECs são definidas no contexto da CDB, também podem existir áreas conservadas geridas por autoridades de governança autônomas (comunidades locais, povos indígenas, etc.) que não desejam ser reconhecidas sob a definição da CDB, e alguns Estados que podem não lhes conceder esse reconhecimento. Essas áreas conservadas, contudo, contribuem para resultados de longo prazo para a conservação in situ da biodiversidade (Borrini-Feyerabend e Hill, 2015) e devem ser enquadradas nos objetivos destas Diretrizes.
Estas Diretrizes podem, portanto, ser aplicadas em relação a áreas protegidas e OMECs, já que muitos sítios geológicos podem ocorrer nestas diferentes formas de governança da natureza. De fato, muitos territórios e áreas conservadas por povos indígenas e comunidades locais podem estar baseadas em patrimônio geológico com valor cultural e espiritual.

Boa Prática $n^{\circ}$ 2: Estas diretrizes devem ser aplicadas a áreas protegidas e também a "Outras Medidas Efetivas de Conservação baseadas em área".

Tabela 2.1. Exemplos de bens e serviços fornecidos pela geodiversidade no litoral do Estado de São Paulo, Brasil.

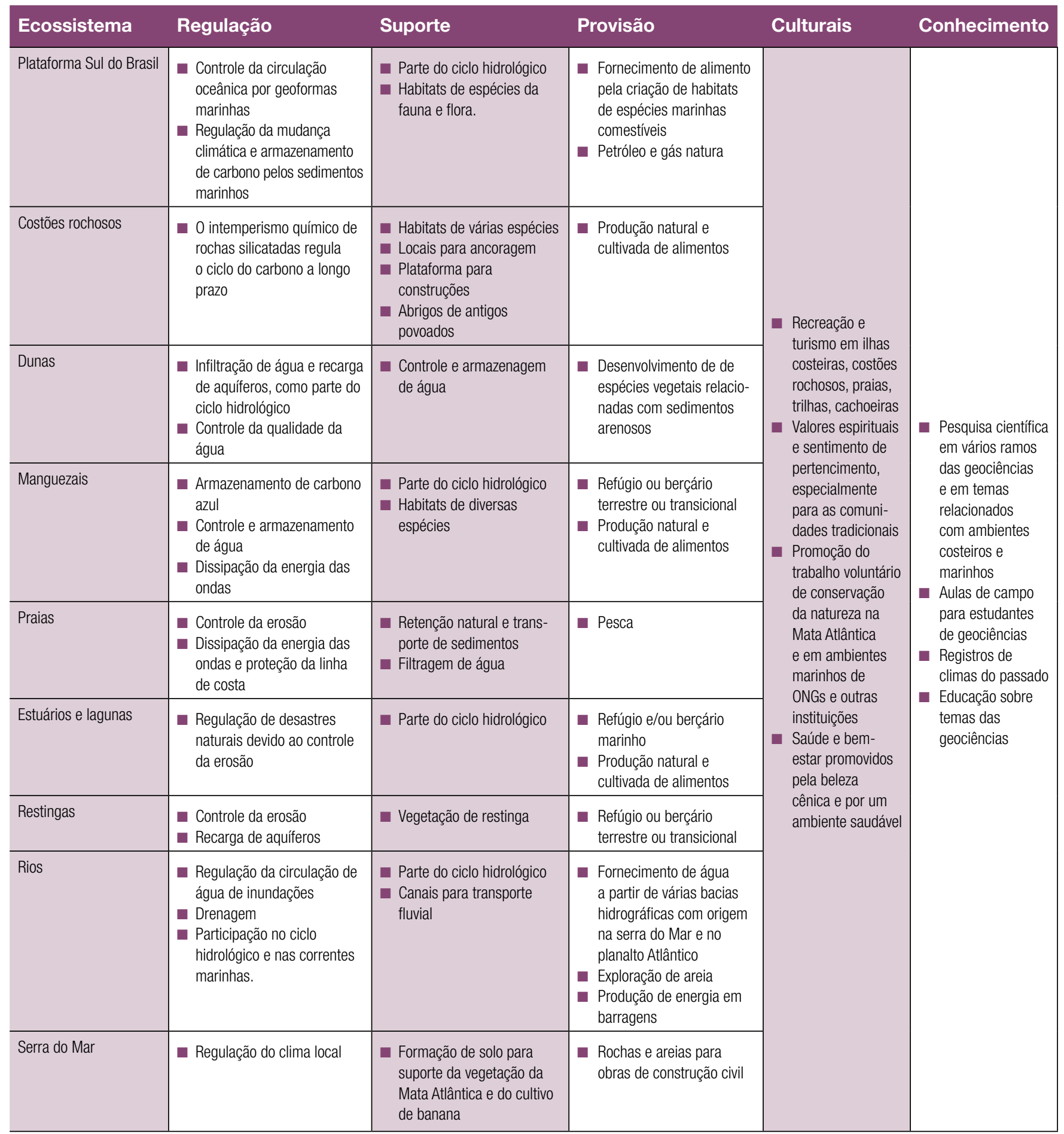

Fonte: Modificado de Garcia (2019). 


\section{Aplicação dos princípios gerais de geoconservação em áreas protegidas}
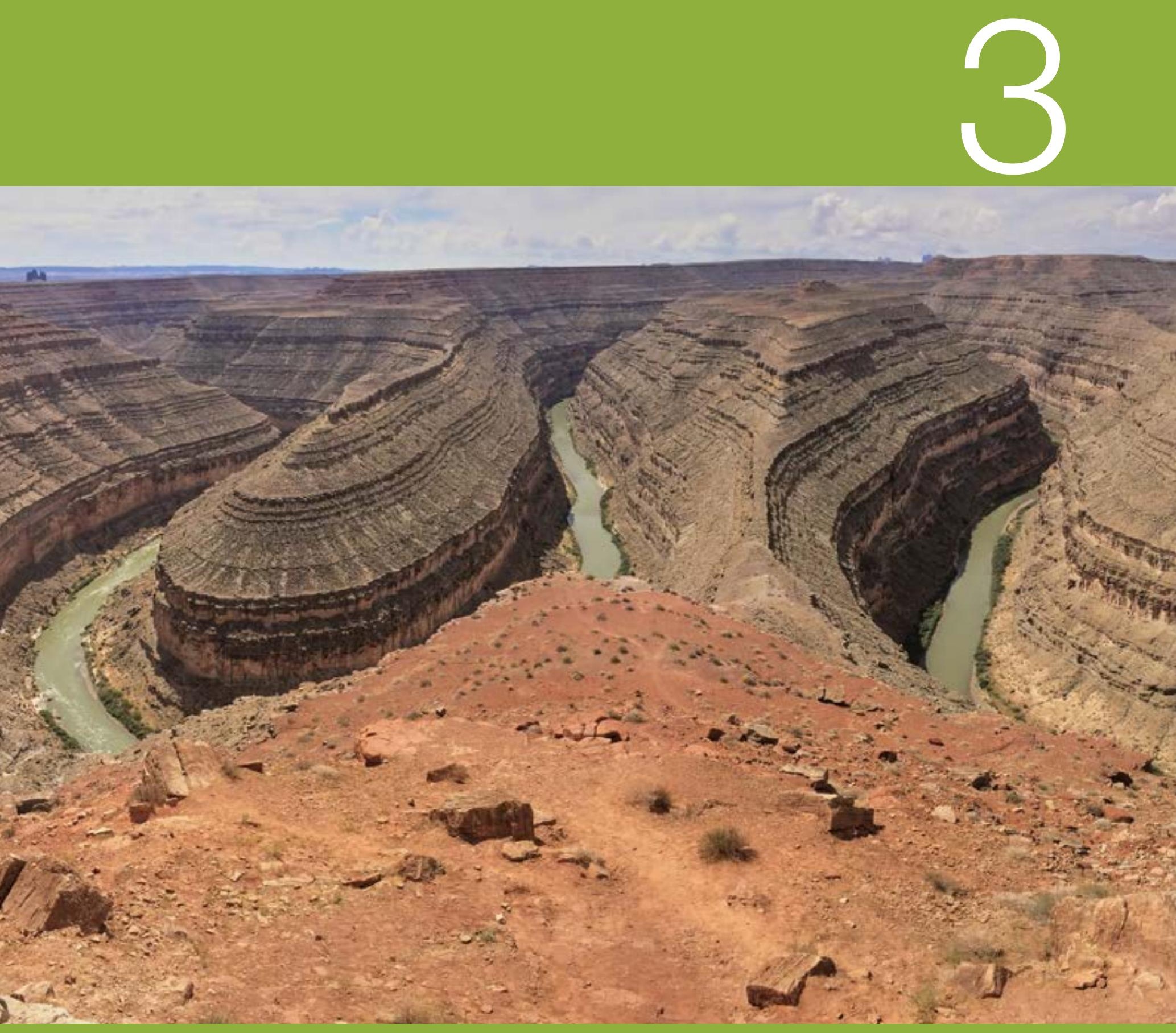

Meandros incisos, no Parque Estadual do Rio San Juan, Utah, EUA. ๑ José Brilha 
Esta seção descreve nove princípios gerais de geoconservação que devem sustentar tanto o estabelecimento de novas áreas protegidas e classificadas quanto a gestão das já existentes.

Os princípios se aplicam à proteção da geodiversidade e do geopatrimônio em todas as Categorias de Gestão de Áreas Protegidas da IUCN, incluindo aquelas áreas nas quais o geopatrimônio não é a principal razão para a sua designação.

\subsection{Princípios gerais}

Uma série de princípios gerais de geoconservação deve sustentar toda a gestão de áreas protegidas (Tabela 3.1). Esses princípios devem ser incorporados a planos de ação da geodiversidade nacionais, regionais e locais, onde existirem, e em sistemas de áreas protegidas e planos de gestão em geral. Aplicações específicas nos planos de gestão de áreas protegidas com fins de geoconservação devem corresponder às condições locais, à legislação e aos sistemas de gestão. Os princípios também se aplicam à gestão de áreas protegidas em todas as categorias de gestão de áreas protegidas da IUCN, mesmo quando o geopatrimônio não é a principal razão para a designação. A geoconservação deve ser parte integrante do plano de gestão (Seções 5.1, 5.2 e 5.3).

\section{Princípio 1. Os múltiplos valores do geopatrimônio e da geodiversidade devem ser reconhecidos.}

A conservação de todos os valores da geodiversidade e do geopatrimônio identificados na seção 2.3 deve ser parte integrante da gestão de áreas protegidas.

\section{Princípio 2. A geoconservação eficaz requer uma abordagem rigorosa e sistemática de todos os aspectos de identificação, avaliação, gestão e monitoramento do local.}

São necessários inventários dos interesses do geopatrimônio e uma avaliação de seus valores, seguidos de uma efetiva gestão da conservação, monitoramento e, quando apropriado, uso de interpretação e divulgação para aumentar a conscientização e a educação. Os objetivos de gestão devem ser adaptados adequadamente para diferentes categorias de áreas protegidas com fins de geoconservação, reconhecendo as diferentes características de geossítios do tipo extenso, vulneráveis e limitados (Seção 5.2). A proteção dos interesses do geopatrimônio será normalmente o objetivo principal, mas objetivos complementares, como geoturismo e conservação da biodiversidade, podem ser incluídos quando não entram em conflito. O monitoramento periódico da condição das áreas protegidas com fins de geoconservação é essencial para estabelecer a condição e o estado das características mais importantes; se estas estão mudando e, se sim, como; e se as metas de conservação estão sendo atingidas (Seção 5.5).

\section{Princípio 3. A gestão de sistemas naturais deve "ser feita naturalmente", permitindo que os processos naturais ocorram em toda a sua gama de variabilidade.}

Há um foco crescente no valor das Soluções Baseadas na Natureza e na promoção pela UICN e outros do papel de ecossistemas saudáveis na abordagem dos desafios globais atuais, tais como mudanças climáticas, redução do risco de desastres, segurança alimentar e da água, e saúde e bemestar humano (Cohen-Shacham et al., 2016; Griscom et al., 2017; UICN, 2020). Na medida do possível, os sistemas e processos naturais (por exemplo, regimes de fluxo em cursos de água) devem poder manter taxas e magnitudes naturais de mudança e sua capacidade de evoluir ininterruptamente na maior parte ou em toda sua gama de variabilidade. Se a intervenção for inevitável, soluções que funcionam em sintonia com os processos naturais são mais sustentáveis ambientalmente e mais eficazes do que soluções engenhosas que buscam controlar ou interromper processos naturais. Por exemplo, ao longo da costa, a construção de estruturas fixas para conter a perda de

Tabela 3.1. Principais princípios orientadores para a geoconservação na gestão de áreas protegidas.

1. Os múltiplos valores da geodiversidade e do geopatrimônio devem ser reconhecidos.

2. Uma geoconservação eficaz requer uma abordagem rigorosa e sistemática de todos os aspectos de identificação, avaliação, gestão e monitoramento do local.

3. A gestão de sistemas naturais deve "ser feita naturalmente", permitindo que os processos naturais ocorram em toda a sua gama de variabilidade.

4. Os sistemas e processos naturais devem ser entendidos cientificamente e geridos de forma espacialmente integrada.

5. As estratégias de geoconservação devem incluir a avaliação de vulnerabilidade e de risco.

6. A inevitabilidade da mudança natural deve ser reconhecida.

7. Os efeitos da mudança climática global devem ser avaliados e geridos na medida do possível.

8. Os sistemas naturais devem ser geridos dentro dos limites de sua capacidade de absorver as mudanças.

9. A interação e a interdependência da geodiversidade, da biodiversidade e do patrimônio cultural devem ser reconhecidas.

Fonte: adaptado de Crofts e Gordon $(2014,2015)$. 


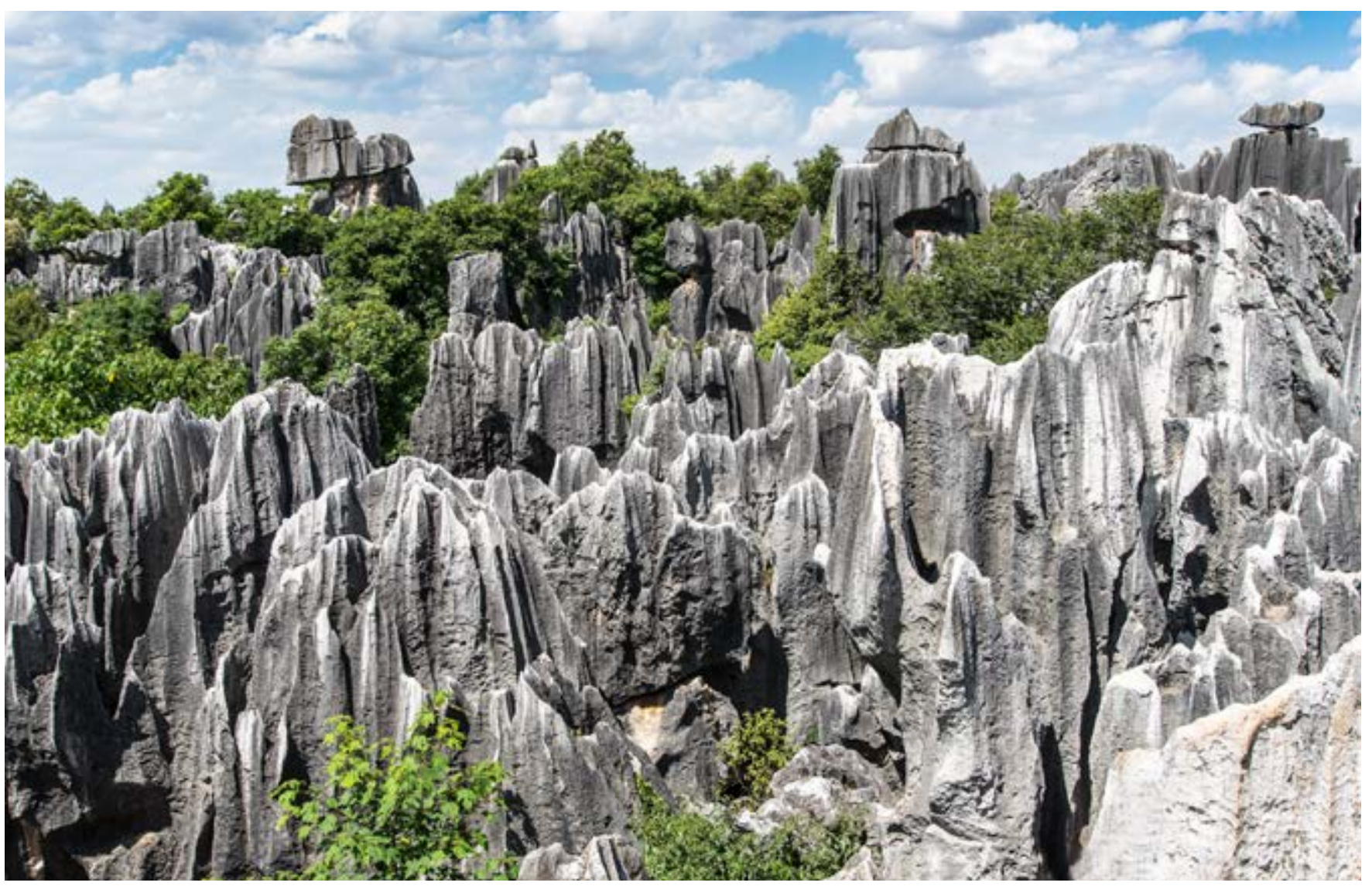

Foto 3.1. A Floresta de Pedra Shilin, na província de Yunnan, faz parte do Sítio do Patrimônio Mundial Karst do Sul da China e é um Geopark Global da UNESCO. As notáveis formas de relevo cárstico possuem importantes valores estético e cultural, celebrados em poesia, pintura, folclore e costumes locais e representam um suporte significativo para o geoturismo. @ John Gordon

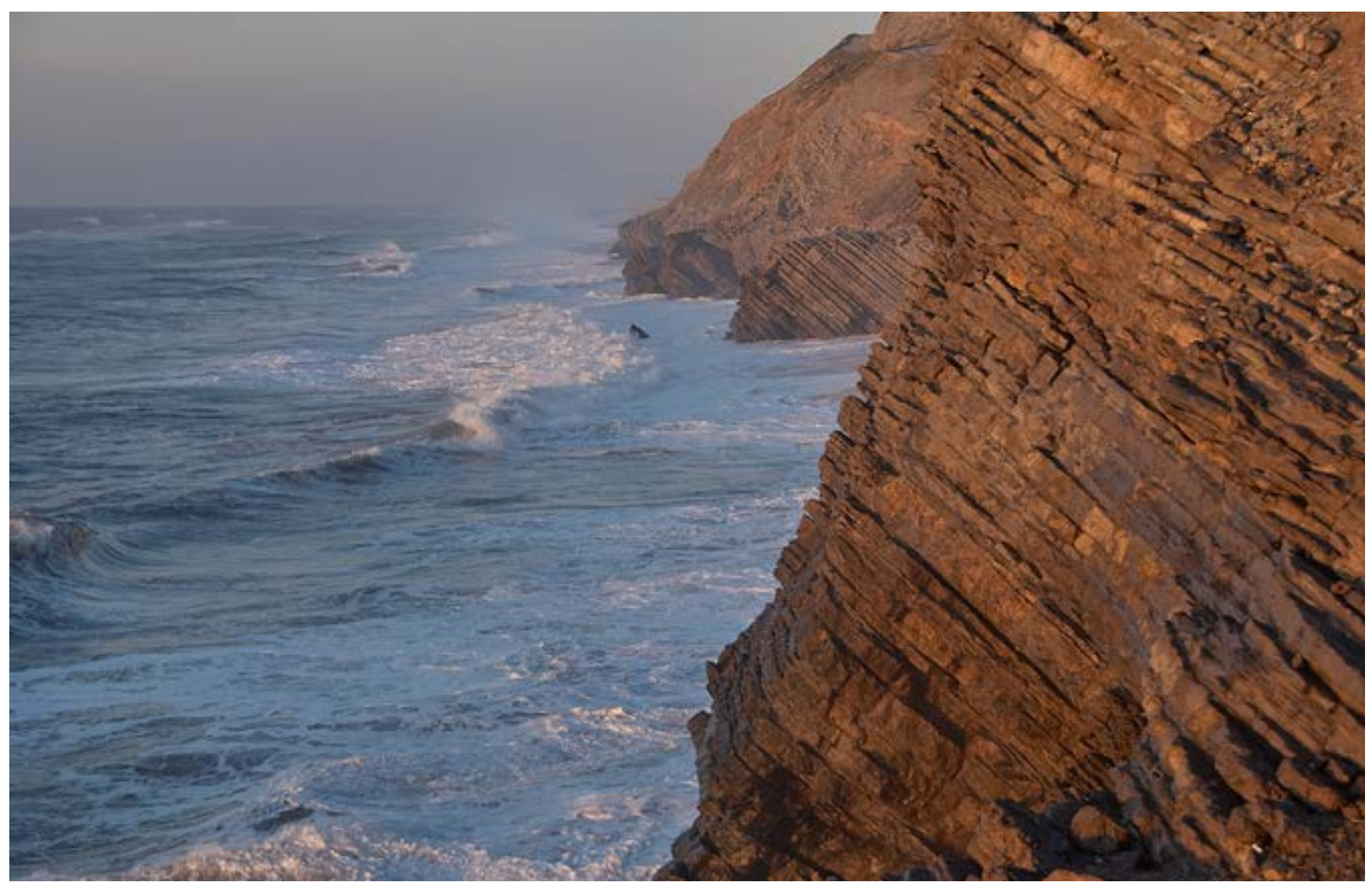

Foto 3.2. O Cabo Mondego, Portugal, é um geossítio valorizado por atividades de educação e geoturismo, estando protegido como Monumento Natural. $\odot$ José Brilha 
3. Aplicação dos princípios gerais de geoconservação em áreas protegidas

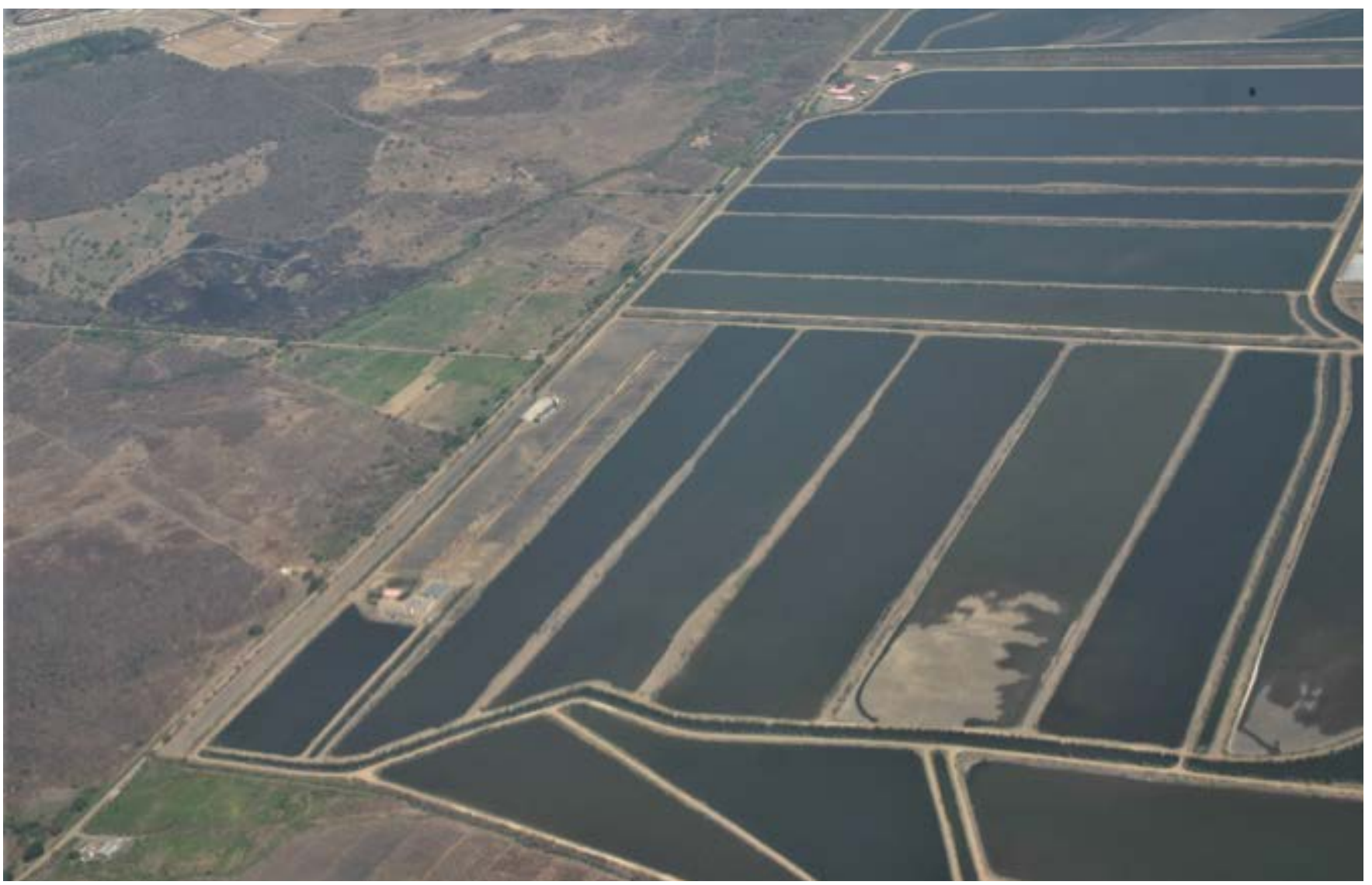

Foto 3.3. A remoção dos manguezais para cultivo torna as áreas costeiras mais vulneráveis à erosão, como nesta área ao norte de Guayaquil, Equador. ( ) Roger Crofts

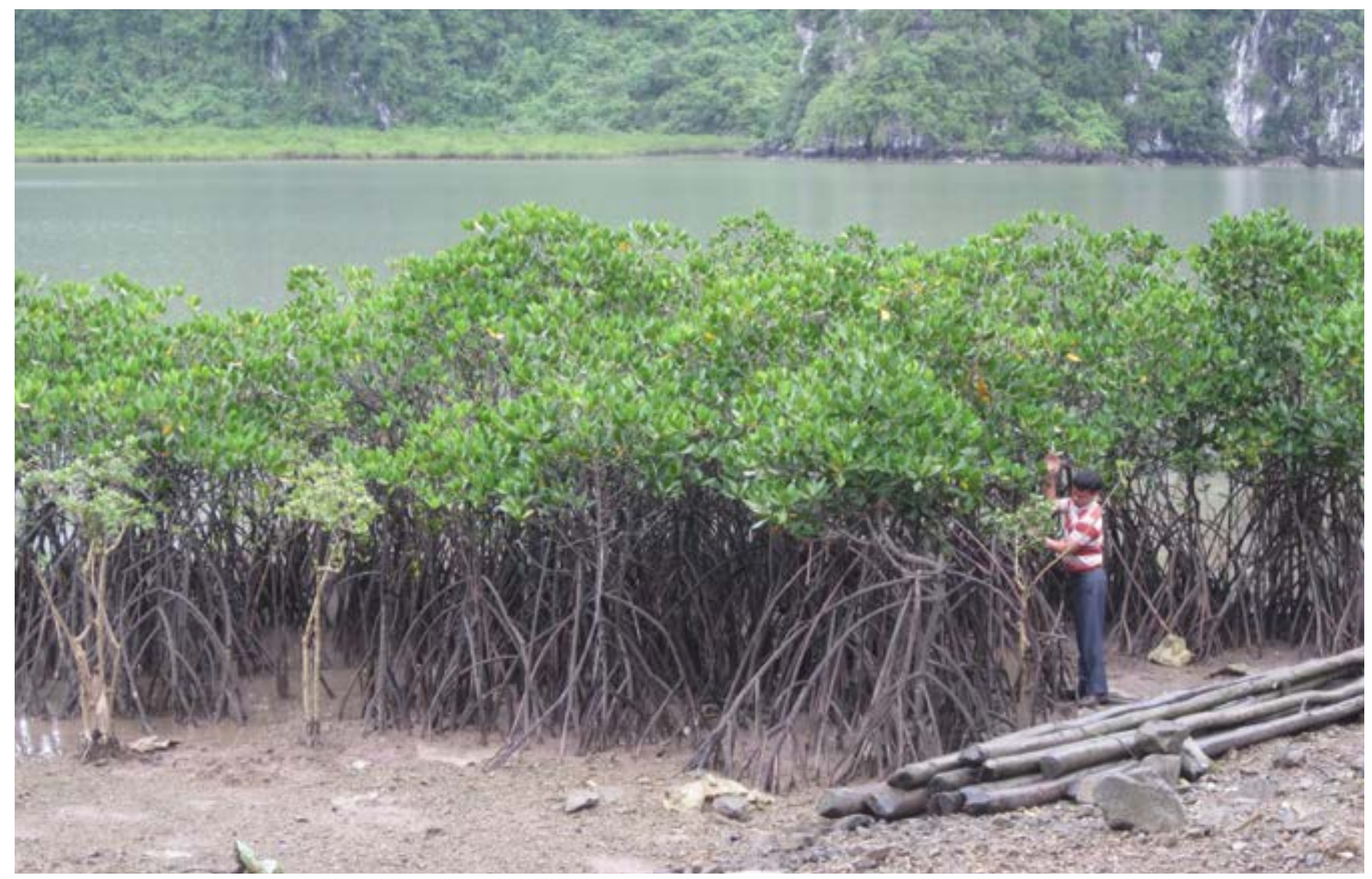

Foto 3.4. A restauracão de mangues na llha Cat $\mathrm{Ba}$, ao largo do Vietnã, procura restaurar a vegetação natural que, por sua vez, proporciona proteção aos habitats e à zona costeira contra a erosão marinha @ Nigel Dudley 


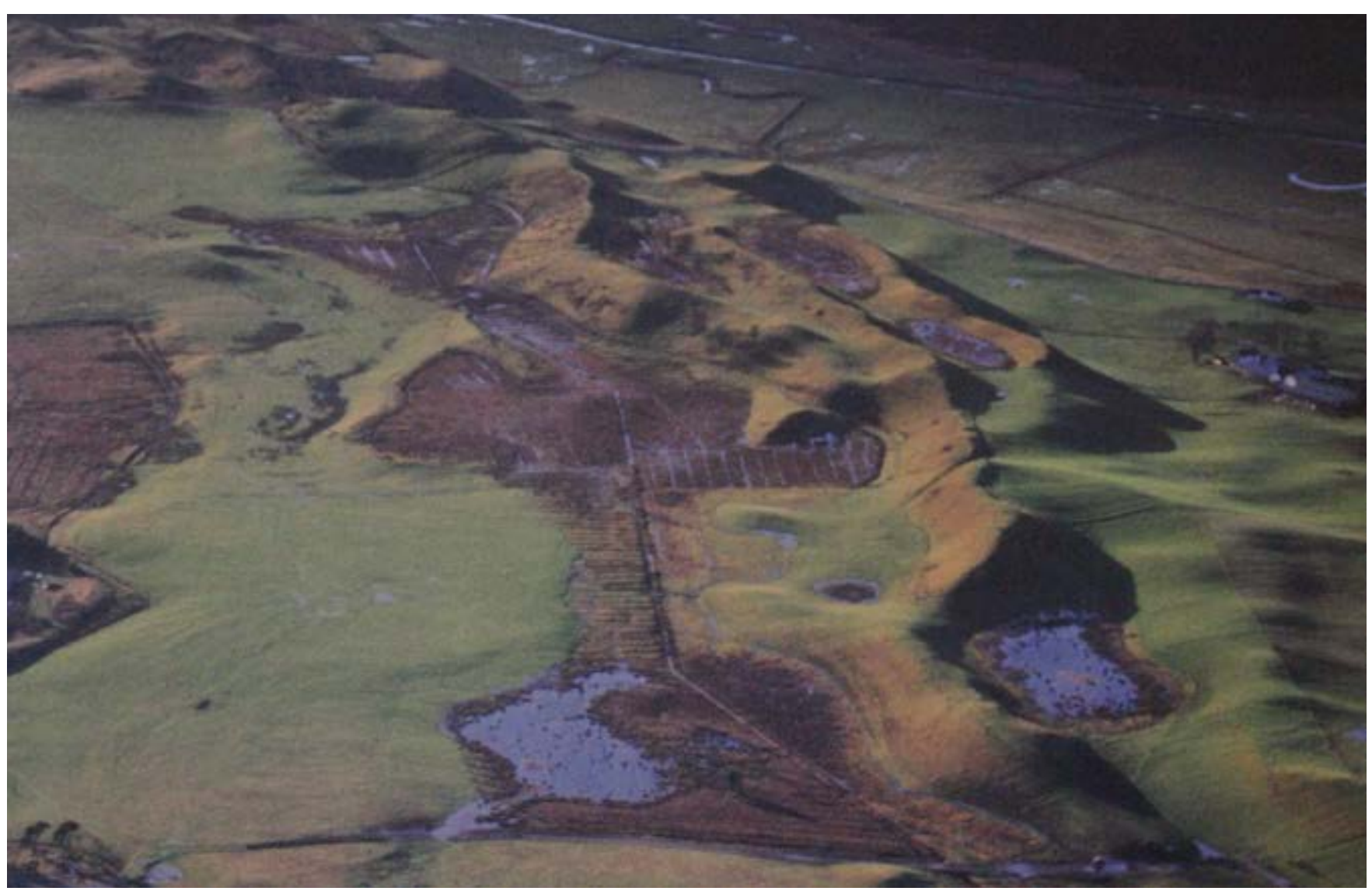

Foto 3.5. A extração de areia e cascalho de um esker da Idade do Gelo protegido na Escócia destruiu permanentemente a integridade do relevo. @ P \& A Macdonald/SNH

sedimentos pode resultar na degradação de praias, dunas, pântanos salgados e seus habitats associados. Em vez disso, são recomendadas abordagens alternativas, incluindo alimentação das praias, realinhamento controlado ou uso de "infraestruturas verdes" para melhorar as formas naturais de defesa, tais como dunas, pântanos salgados ou mangues (Temmerman et al., 2013; Pontee et al., 2016).

\section{Princípio 4. Os sistemas e processos naturais devem ser entendidos cientificamente e geridos de forma espacialmente integrada.}

A gestão da conservação de sistemas ativos deve ser suportada por um bom conhecimento dos processos abióticos subjacentes. Isto inclui, por exemplo, a dinâmica sedimentar costeira (erosão e deposição, incluindo fontes sedimentares, mecanismos de transporte e sumidouros) em unidades individuais (células litorâneas) na preparação de planos de gestão costeira; integração de processos fluviais, pedológicos e de vertentes em planos de gestão de bacias hidrográficas; e monitoramento de processos ativos.

A gestão de parte de um sistema natural de maneira isolada de outros elementos do sistema deve ser evitada. Ao longo de uma linha costeira ou em uma área montanhosa ou uma bacia hidrográfica, a gestão deve reconhecer os efeitos da interligação e da interdependência entre diferentes partes do sistema à escala da paisagem (por exemplo, a dependência das praias de areia do fornecimento de sedimentos pelos rios ou por fontes offshore, ou as consequências para habitats situados a jusante de mudanças na transferência de sedimentos entre as vertentes e cursos de água situados a montante) (Bruneau et al., 2011). De modo geral, a gestão espacialmente interligada deve reconhecer os padrões de geodiversidade e as suas ligações com a biodiversidade e os serviços ecossistêmicos como parte da conservação à escala da paisagem (Anderson et al., 2014; Theobald et al., 2015; Zarnetske et al., 2019; Hilty et al., 2020).

\section{Princípio 5. As estratégias de geoconservação devem incluir a avaliação de vulnerabilidade e de risco.}

A gestão da geoconservação deve incluir a avaliação de risco, envolvendo a avaliação da vulnerabilidade e da resiliência dos espaços a pressões humanas e mudanças naturais. Deve também considerar os riscos geológicos para os seres humanos, como por exemplo os que derivam da atividade vulcânica. O geopatrimônio apresenta vários graus de sensibilidade a diferentes tipos de atividade humana e mudanças naturais (Secção 6.1). Alguns elementos podem ser relativamente robustos, suportando perturbações e, portanto, requerendo relativamente pouca intervenção de gestão. No entanto, outros são altamente sensíveis, sendo suscetíveis à degradação provocada por atividades humanas, da qual poderão se recuperar apenas a longo prazo ou mesmo não se recuperar de todo (Seções 5.2 e 6.1). Na maioria dos geossítios, danos e destruição são irreversíveis. Apenas em sistemas ativos como, por exemplo, ambientes glaciais, fluviais e vulcânicos, os elementos degradados ou destruídos podem ser substituídos por novas características semelhantes. 


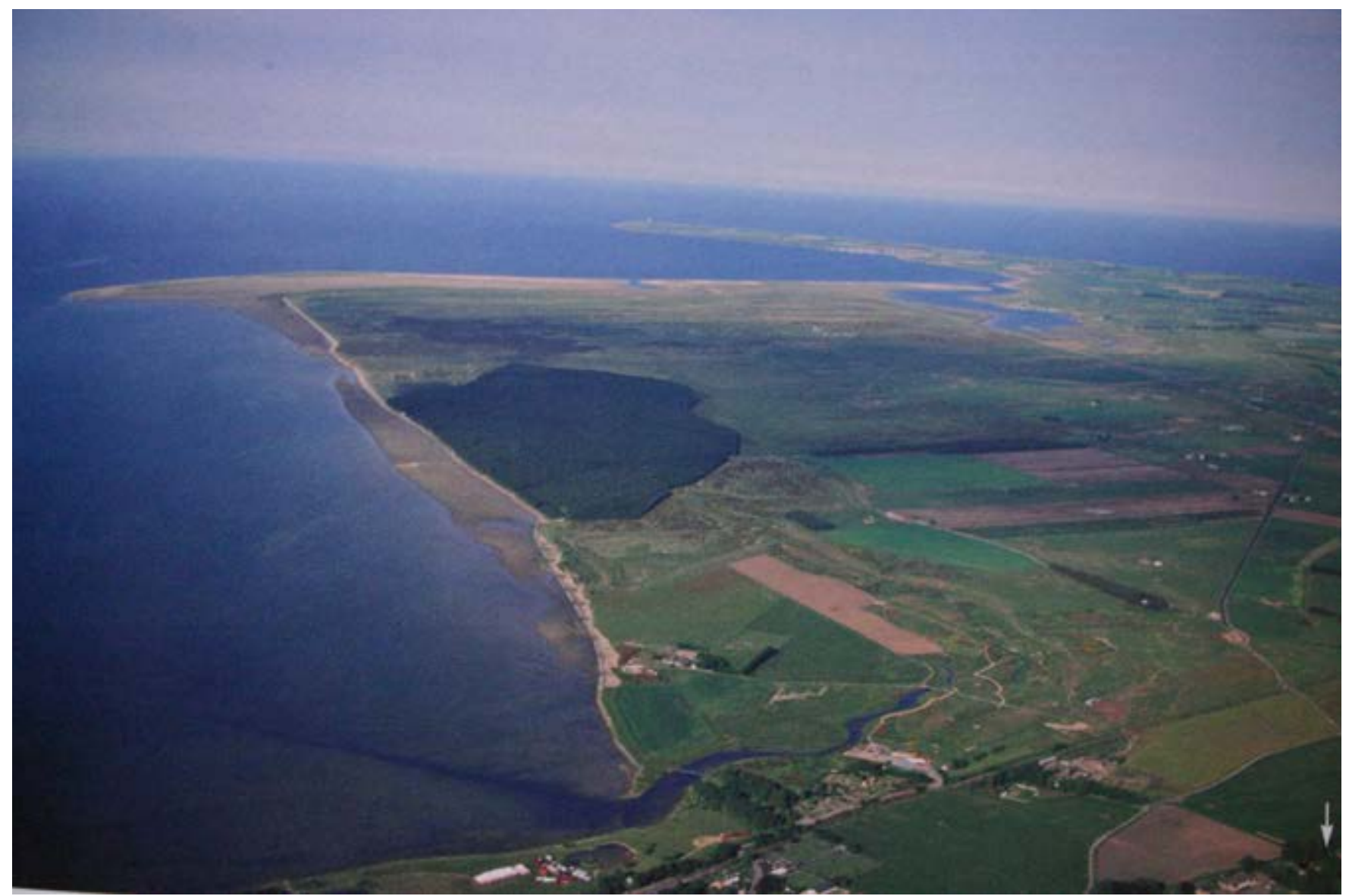

Foto 3.6. Morrich More, em Dornoch Firth, Escócia, está classificado como Sítio de Interesse Científico Especial (SSSI) e como Área Especial de Conservação da União Europeia. Nos últimos 7000 anos, uma grande variedade de geoformas costeiras se desenvolveram em ambientes altamente dinâmicos, suportando uma diversidade de habitats costeiros ricos em espécies, incluindo planícies arenosas com vegetação, planícies intertidais, pântanos salgados, dunas, piscinas salobras e charnecas.

(c) P \& A Macdonald/SNH

\section{Princípio 6. A inevitabilidade da mudança natural deve ser reconhecida.}

Deve admitir-se que a mudança natural é inevitável. Nenhum elemento de um sistema natural é estático e as mudanças ocorrerão naturalmente. A abordagem habitual de manter ou melhorar o estado atual de preservação pode ser útil quando é improvável que ocorra degradação significativa devido a mudanças naturais. Por exemplo, em montanhas icônicas e elementos rochosos resistentes à erosão, ou no caso de alguns elementos de pequena dimensão, mas de alto valor, onde medidas de proteção podem ser efetivamente implementadas. Contudo, em muitos casos em que os processos naturais são um fator chave na manutenção ou proteção dos elementos de interesse, reconhecer as mudanças naturais e permitir que os processos geomorfológicos se adaptem a novas condições pode ser a única estratégia eficaz. Esta abordagem pode significar a perda de alguns elementos, mudanças em suas localizações (possivelmente fora dos limites da área protegida) ou a sua reconfiguração. Quando a intervenção humana é considerada necessária (por exemplo, para proteger infraestruturas valiosas no litoral), é recomendada uma abordagem artificial que imite a natureza na medida do possível, em vez de se modificar substancialmente o espaço natural ou destruir os elementos do geopatrimônio.

\section{Princípio 7. Os efeitos da mudança climática global} devem ser avaliados e geridos na medida do possível.

Inevitavelmente, os efeitos das mudanças climáticas colocarão em causa os objetivos de gestão das áreas protegidas (Groves et al., 2012; Gross et al., 2016). Será necessária uma atenção redobrada onde, por exemplo, haja perda significativa de elementos patrimoniais ou onde processos sejam diminuídos ou intensificados, alterandose assim os patamares de proteção. Isso poderá significar que o status de proteção da área não possa mais ser justificado de forma alguma ou que outras áreas possam passar a requerer proteção. Os limites das áreas protegidas também podem precisar ser alterados para levar em conta a erosão costeira ou mudanças na localização de elementos dinâmicos de interesse. Uma abordagem baseada no risco deve ser considerada para priorizar locais e elementos para monitoramento (Wignall et al. 2018).

\section{Princípio 8. Os sistemas naturais devem ser geridos dentro dos limites de sua capacidade de absorver as mudanças.}

A sensibilidade dos sistemas naturais deve ser reconhecida, devendo estes ser geridos dentro dos limites de sua capacidade de absorver mudanças (ver seção 6.1 para mais detalhes sobre sensibilidade). É raro que os sistemas naturais sejam tão robustos que possam absorver qualquer 


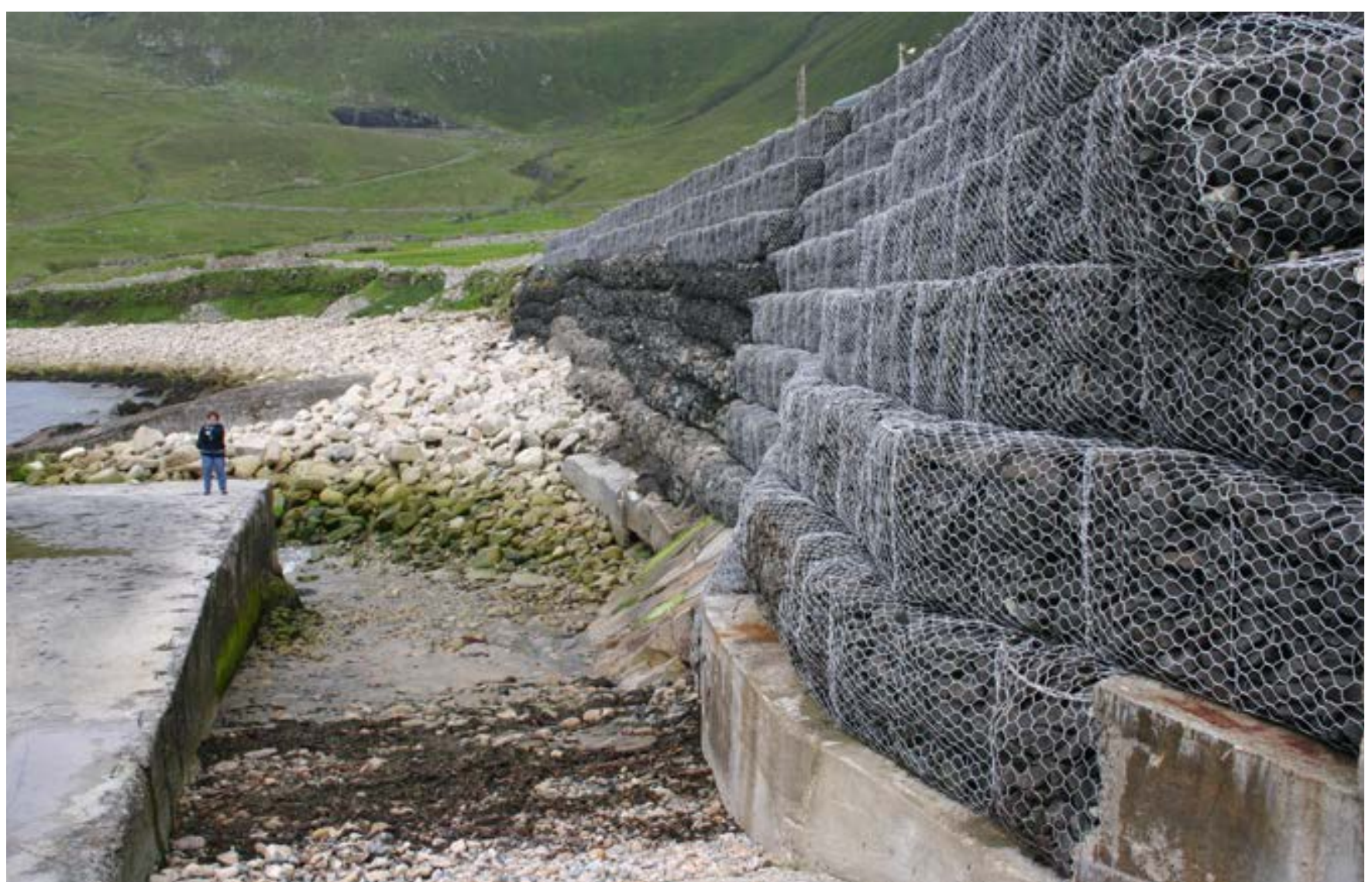

Foto 3.7. As mudanças climáticas e a subida do nível do mar provavelmente levarão a mudanças nos processos geomorfológicos e na distribuição das geoformas, habitats e espécies à medida que a orla costeira se desloca para o interior, mesmo que sejam usadas soluções de engenharia dura, como aqui na Reserva Natural Nacional e Sítio do Patrimônio Mundial de St Kilda, na Escócia. @ Roger Crofts

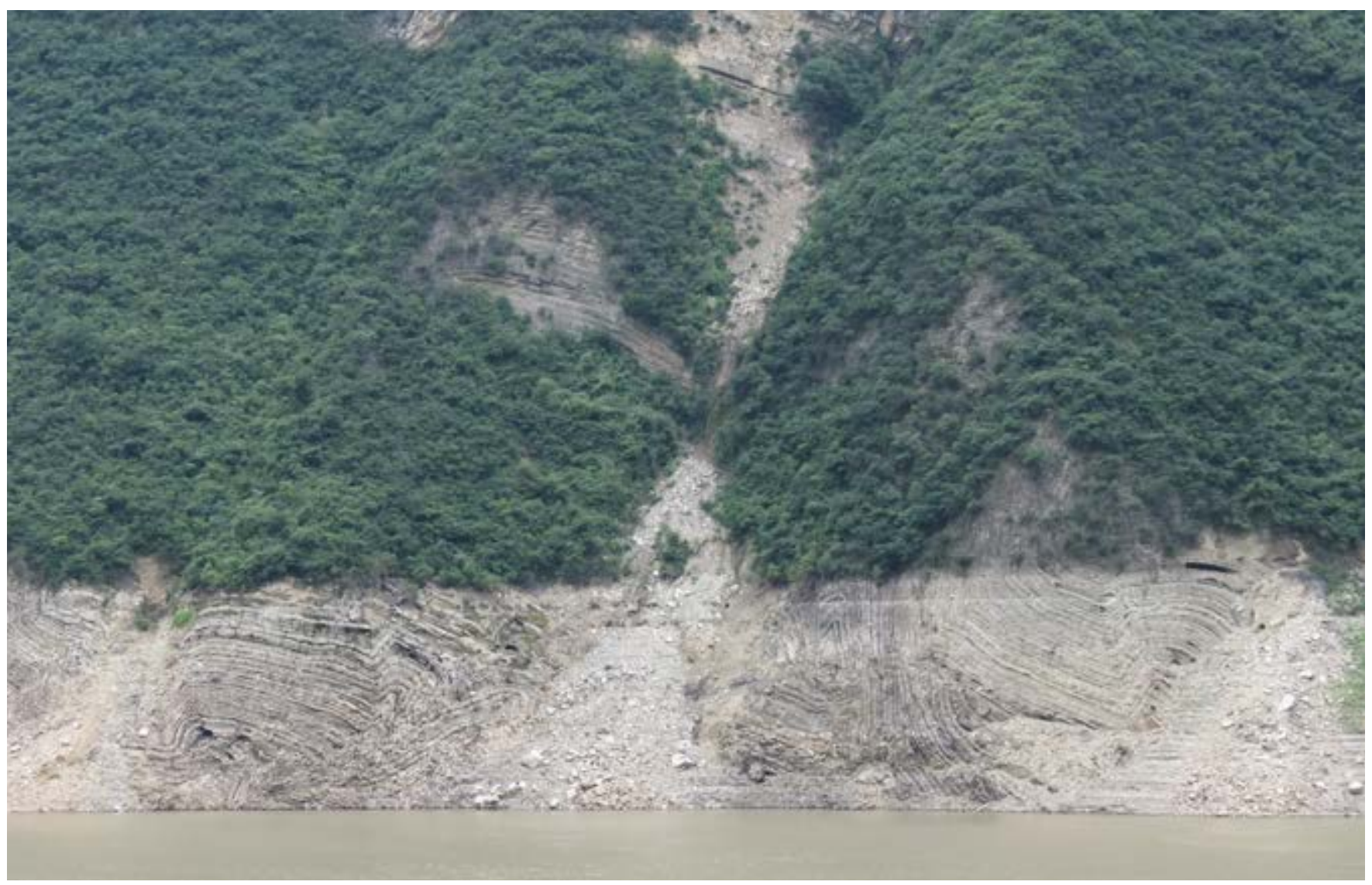

Foto 3.8. Um sistema fluvial fortemente gerido: o rio Yangtze, a montante da Barragem das Três Gargantas, China, evidenciando os efeitos da variação das margens na perda dos solos e da vegetação, com a exposição das estruturas rochosas. ( Roger Crofts 


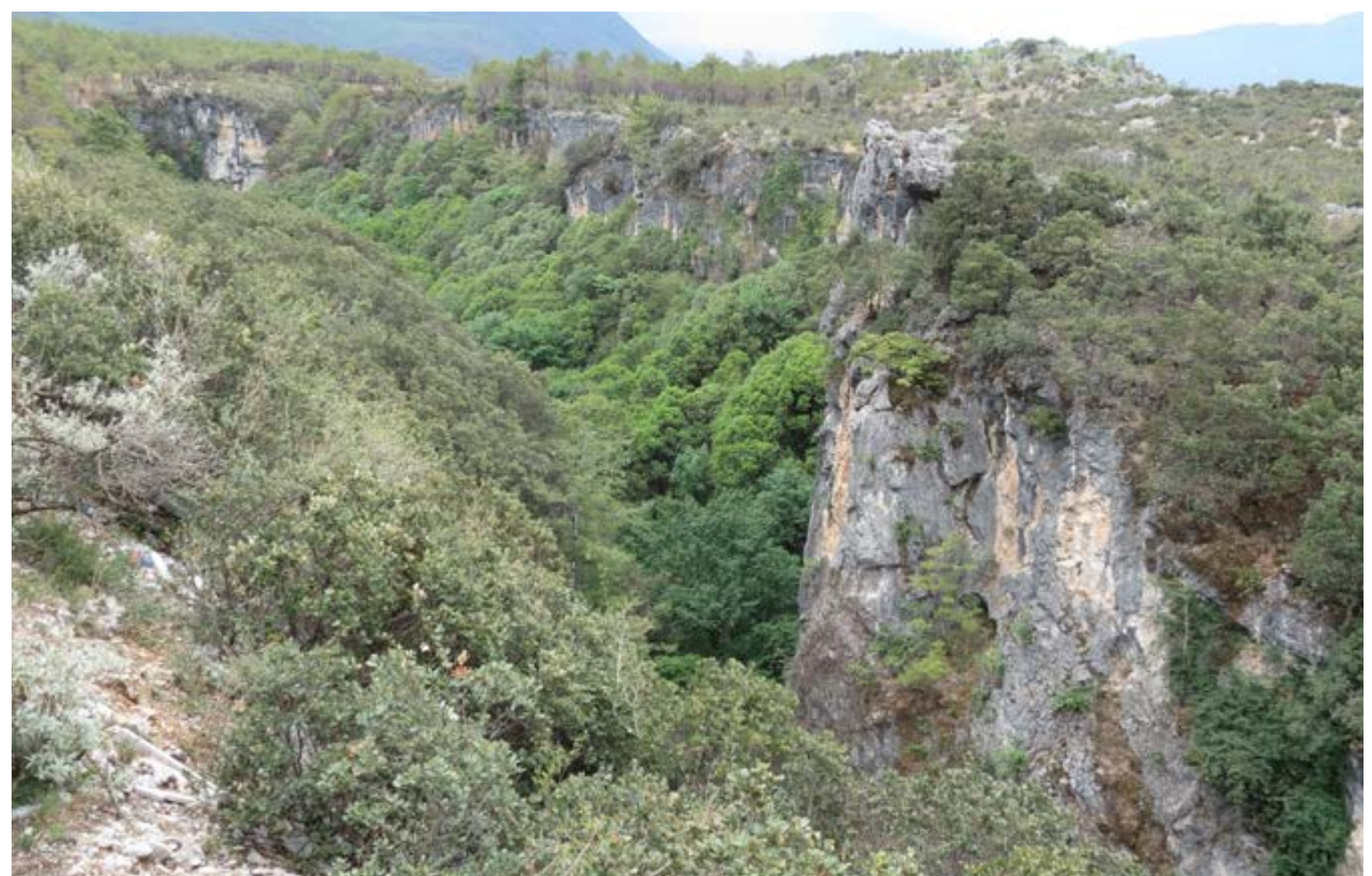

Foto 3.9. É importante entender a interação entre crescimento da vegetação e visibilidade dos elementos geológicos, como aqui no Parque Nacional Jade Dragon, Província de Yunnan, China. @ (Roger Crofts

mudança imposta sobre eles. Alguns serão mais resistentes à mudança (por exemplo, um afloramento rochoso em uma encosta), enquanto outros serão muito frágeis com baixos limiares de mudança (por exemplo, vegetação em uma duna de areia costeira, que pode ser perdida devido ao pisoteio, levando à erosão). Se os limiares de mudança forem ultrapassados, os esforços de conservação podem ser em vão porque os elementos e processos originais terão sido alterados irreversivelmente. Por exemplo, a implementação de grandes estruturas de defesa costeira pode interromper o fornecimento de sedimentos às praias, dunas e pântanos salgados, resultando em uma mudança de regime de deposição para erosão, com a consequente perda de geoformas e habitats.

\section{Princípio 9. A interação e a interdependência da geodiversidade, da biodiversidade e do patrimônio cultural devem ser reconhecidas.}

A interação e a interdependência da geodiversidade e da biodiversidade devem ser reconhecidas na gestão da conservação. Muitas das áreas que foram protegidas devido à biodiversidade possuem uma alta dependência da geodiversidade, e em outros locais haverá uma interrelação significativa entre os elementos bióticos e abióticos (por exemplo, nas dunas de areia) (Seção 6.5). Os gestores devem levar em conta estas interdependências, bem como as questões de patrimônio cultural, na gestão das áreas protegidas.
Boa Prática No 3: Utilize os nove princípios de geoconservação no inventário, no planejamento, no estabelecimento de objetivos, na gestão e no monitoramento dos elementos e processos do geopatrimônio. 


\section{Criação de áreas protegidas destinadas à geoconservação}

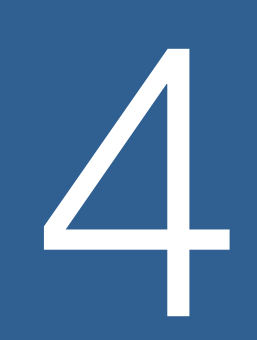

A importância dos processos naturais modernos como, por exemplo, geoformas vulcânicas recentes e resultantes da atividade nas margens de placas tectônicas, aqui representada em San Bartolome, Parque Nacional de Galápagos e sítio do Patrimônio Mundial, Equador. () Roger Crofts 
Esta seção apresenta as principais etapas e protocolos para criar áreas protegidas destinadas à geoconservação, seja em escala nacional, regional ou local, aplicáveis onde essas áreas são inexistentes ou onde não foram estabelecidas de forma sistemática. Estas orientações podem também ser usadas por gestores de áreas protegidas para proteger o geopatrimônio existente em suas áreas protegidas. Esta seção aborda os seguintes aspectos:

- Definição da finalidade e da escala operacional (4.1)

- Inventariação (4.2)

- Critérios de avaliação (4.3)

- Exemplos de inventários e avaliações de patrimônio geológico (4.4)

- Integração do geopatrimônio em planos de ação nacionais, regionais e locais (4.5)

Mecanismos de proteção (4.6)

- Tipos de governança (4.7)

- Conhecimentos necessários (4.8)

Abordagens internacionais (4.9)

As principais etapas no desenvolvimento de uma estratégia de geoconservação para uma área protegida compreendem o inventário, a avaliação, a gestão e a proteção, o monitoramento e a interpretação e divulgação do geopatrimônio. As diretrizes que serão aqui apresentadas tratam de cada uma dessas etapas. Esta abordagem segue, de uma forma geral, a que é prevista no manejo adaptativo estabelecida nos Padrões Abertos para a Prática da Conservação, utilizada por muitas organizações de conservação no mundo para conservar a biodiversidade em áreas protegidas (Conservation Measures Partnership, 2013). Esta seção fornece orientações sobre inventário e avaliação dos sítios geológicos, incluindo o estabelecimento de uma rede de geossítios e a avaliação do geopatrimônio em áreas protegidas. A seção 5 aborda as questões da conservação e monitoramento. A seção 6 discute sobre ameaças à geoconservação e como as mitigar. A Seção 7 apresenta exemplos de geoconservação em diferentes ambientes e, finalmente, a seção 8 incide sobre interpretação e divulgação.

O estabelecimento de um procedimento sistemático é essencial para a identificação, categorização, avaliação e seleção de geossítios que merecem conservação a todos os níveis, desde o internacional até ao local. Este procedimento deve seguir uma abordagem em três etapas: (1) definição da finalidade e escala operacional; (2) aplicação criteriosa do método mais apropriado de inventário; e (3) definição dos critérios de avaliação do sítio geológico.

\section{1. Definição da finalidade e escala operacional de um geossítio ou conjunto de geossítios}

Os geossítios são identificados, principalmente, com base em seu valor científico especial. Valores educacionais, espirituais, culturais e estéticos podem fornecer justificativas adicionais, assim como outros valores científicos que não estejam vinculados a aspectos da geodiversidade, tais como os valores ecológicos. Os princípios que serão aqui apresentados e discutidos se aplicam tanto no estabelecimento de um sistema de sítios geológicos e sua avaliação, como a geossítios existentes em áreas protegidas.
Uma questão chave no início do planejamento da geoconservação em áreas protegidas é relativa à escala da operação. Pretende-se estabelecer um sistema de áreas protegidas para a geoconservação em larga escala (por exemplo, para toda a nação, uma região ou uma área menor, mas ainda extensa), ou determinar os interesses e valores do geopatrimônio dentro de uma área protegida individual? Ambas as situações são essenciais para uma geoconservação eficaz, pelo que as iremos abordar em seguida.

O objetivo de um geossítio ou conjunto de geossítios determinará os valores do geopatrimônio a serem avaliados. Alguns geossítios terão um propósito relativamente específico - proteger, por exemplo, os aspectos com valor científico (Tabela 4.1). Outros geossítios podem ser polivalentes, apesar de serem baseados em valores científicos, têm igualmente relevância educacional, estética, cultural, geoturística ou ecológica.

Em geral, os temas de geopatrimônio listados na Tabela 4.1, se enquadram em três categorias principais: locais tipo e sítios de referência, sítios com exemplos únicos ou notáveis de feições geológicas particulares, e sítios representativos da geologia ou geomorfologia de uma área, região ou país.

\section{Locais tipo e sítios de referência}

A estratigrafia é uma componente fundamental das geociências. Ela envolve a subdivisão do registro geológico, a correlação de unidades de rochas mapeáveis e o estabelecimento de suas relações temporais para interpretar a sucessão de eventos do longo do tempo. A estratigrafia requer a identificação de seções tipo e de referência para definir os limites entre os andares na escala do tempo geológico, seguindo as normas internacionalmente acordadas. A Comissão Internacional de Estratigrafia (ICS), uma comissão da União Internacional de Ciências Geológicas (IUGS), está trabalhando para chegar a um acordo internacional sobre a definição de unidades padrão globais. Uma unidade padrão é referida como Global Boundary Stratotype Section and Point (GSSP) (Cohen et al., 2013; Smith et al., 2015; Finney \& Hilario, 2018). 
Tabela 4.1. Principais interesses do geopatrimônio a serem considerados para a geoconservação em áreas protegidas.

\begin{tabular}{|c|c|c|c|}
\hline $\begin{array}{l}\text { Temas do } \\
\text { geopatrimônio }\end{array}$ & $\begin{array}{l}\text { Importância dos sítios e das } \\
\text { feições }\end{array}$ & $\begin{array}{l}\text { Exemplo de geoconservação em } \\
\text { área protegida }\end{array}$ & Foto \\
\hline $\begin{array}{l}\text { Principais etapas na } \\
\text { história da Terra }\end{array}$ & $\begin{array}{l}\text { Inclui os principais intervalos de tempo } \\
\text { de eventos marcantes na história da } \\
\text { Terra, ou seus limites, tais como os } \\
\text { locais internacionalmente definidos } \\
\text { como Global Stratotype Section and } \\
\text { Point (GSSP), que marcam o limite } \\
\text { inferior de um intervalo específico da } \\
\text { escala de tempo geológico. Alguns } \\
\text { destes GSSPs são marcados com um } \\
\text { "prego dourado". }\end{array}$ & $\begin{array}{l}\text { O GSSP para a base do Período } \\
\text { Ediacarano, do Pré-Cambriano, está } \\
\text { localizado no córrego Enorama no Parque } \\
\text { Nacional de Flinders Ranges, Austrália } \\
\text { Meridional. Este é o único "prego dourado" } \\
\text { no hemisfério sul. }\end{array}$ & $\begin{array}{l}\text { (๑) ediacaran.org/flinders-rang- } \\
\text { es-southaustralia }\end{array}$ \\
\hline $\begin{array}{l}\text { Principais feições estru- } \\
\text { turais e tectônicas }\end{array}$ & $\begin{array}{l}\text { Incluem as feições associadas a } \\
\text { colisões de placas tectônicas, tais } \\
\text { como cadeias de montanhas, que são } \\
\text { acompanhadas por cavalgamentos, } \\
\text { dobramento e compressão de estratos. } \\
\text { Podem também incluir a formação de } \\
\text { arcos de ilhas, complexos vulcânicos } \\
\text { centrais e escoadas de lava. }\end{array}$ & $\begin{array}{l}\text { Os parques nacionais de Banff, Jasper, } \\
\text { Kootenay e Yoho, localizados em Alberta } \\
\text { and British Columbia, no Canadá, ajudam } \\
\text { a proteger a seção sul e intensamente } \\
\text { dobrada das Montanhas Rochosas } \\
\text { canadenses, uma área montanhosa } \\
\text { soerguida como consequência da colisão } \\
\text { de placas tectônicas. }\end{array}$ & ๑ Roger Crofts \\
\hline $\begin{array}{l}\text { Tipos, ocorrência e } \\
\text { formação de minerais }\end{array}$ & $\begin{array}{l}\text { Alguns locais apresentam minerais raros } \\
\text { e cristais particulares, que podem ter } \\
\text { sido reconhecidos como localidade-tipo } \\
\text { desses minerais. }\end{array}$ & $\begin{array}{l}\text { Minerais ricos em urânio encontrados em } \\
\text { depósitos secundários formados a partir do } \\
\text { nível freático no Mount Painter, na Área de } \\
\text { Proteção de Arkaroola, Austrália Meridional, } \\
\text { deram origem a importantes descobertas } \\
\text { científicas e a espécimes para museus. }\end{array}$ & (๑) Mindat.org \\
\hline $\begin{array}{l}\text { Tipos raros de rochas e } \\
\text { das suas estruturas }\end{array}$ & $\begin{array}{l}\text { Qualquer que seja seu processo de } \\
\text { formação, rochas e estruturas rochosas } \\
\text { raras podem ser reconhecidas como } \\
\text { geopatrimônio devido aos seus valores } \\
\text { especiais. A determinação da raridade } \\
\text { depende da escala espacial do } \\
\text { inventário (por exemplo, 'ocorrências } \\
\text { raras' localmente podem não o ser } \\
\text { internacionalmente). }\end{array}$ & $\begin{array}{l}\text { O Mount Gee, a 'montanha de cristal', na } \\
\text { Área de Proteção Arkaroola, na Austrália } \\
\text { Meridional, é um produto da atividade } \\
\text { vulcânica. As estruturas rochosas ricas } \\
\text { em sílica estão nos locais por onde a } \\
\text { rocha fundida fluía e incluem cavernas e } \\
\text { cavidades, contendo cristais raros a nível } \\
\text { internacional. }\end{array}$ & \\
\hline Evolução da vida & $\begin{array}{l}\text { Alguns locais possuem fósseis e suas } \\
\text { associações representativas de etapas } \\
\text { da evolução da vida na Terra. Estes locais } \\
\text { podem apresentar registros fossiliferos } \\
\text { do desenvolvimento e da interrupção de } \\
\text { sequências de vida refletindo tendências } \\
\text { evolutivas e eventos catastróficos, tais } \\
\text { como impactos de meteoritos e erupções } \\
\text { de supervulcões. }\end{array}$ & $\begin{array}{l}\text { Em Bletterbach Gorge, uma área protegida } \\
\text { no norte de Itália, ocorre uma sequência } \\
\text { de rochas que marca o evento de extinção } \\
\text { do final do Permiano, a maior extinção em } \\
\text { massa da vida na história da Terra. }\end{array}$ & \\
\hline Processos atuais & $\begin{array}{l}\text { Estes sítios incluem processos atuais, } \\
\text { tais como vulcanismo, processos em } \\
\text { ambientes desérticos, costeiros, fluviais } \\
\text { e atividade glacial e periglacial. }\end{array}$ & $\begin{array}{l}\text { No Parque Nacional Hawai'i Volcanoes dos } \\
\text { EUA, existe um vulcão continuamente em } \\
\text { atividade com lavas de tipo pahoehoe e aa. }\end{array}$ & \\
\hline $\begin{array}{l}\text { Fenômenos de superfí- } \\
\text { cie e de subsuperfície }\end{array}$ & $\begin{array}{l}\text { Sítios representativos de períodos } \\
\text { particulares da história da Terra, ou } \\
\text { de formações rochosas e processos } \\
\text { peculiares da Terra, ou ainda de feições } \\
\text { distintas ou raras, tais como cavernas. }\end{array}$ & $\begin{array}{l}\text { Deer Cave in the Gunung Mulu National } \\
\text { Park in Malaysia is a World Heritage site } \\
\text { that protects outstanding karst resources } \\
\text { and provides visitor access to a suite of } \\
\text { caves. }\end{array}$ & ○ John Gunn \\
\hline $\begin{array}{l}\text { Registros de antigos } \\
\text { ambientes }\end{array}$ & $\begin{array}{l}\text { Estes sítios registram condições } \\
\text { ambientais pretéritas, tais como fases } \\
\text { glaciais do Período Quaternário, e } \\
\text { incluem geoformas, sedimentos e } \\
\text { sequências de rochas formadas em } \\
\text { todos os períodos da história da Terra. }\end{array}$ & $\begin{array}{l}\text { No Parque Nacional Kosciuszko existe } \\
\text { a montanha mais alta da Austrália } \\
\text { continental e ocorrem raras evidências da } \\
\text { glaciação pleistocênica no hemisfério sul, } \\
\text { nomeadamente cinco lagos glaciais, um } \\
\text { circo glacial e morenas glaciais. }\end{array}$ & (c) Roger Crofts \\
\hline
\end{tabular}




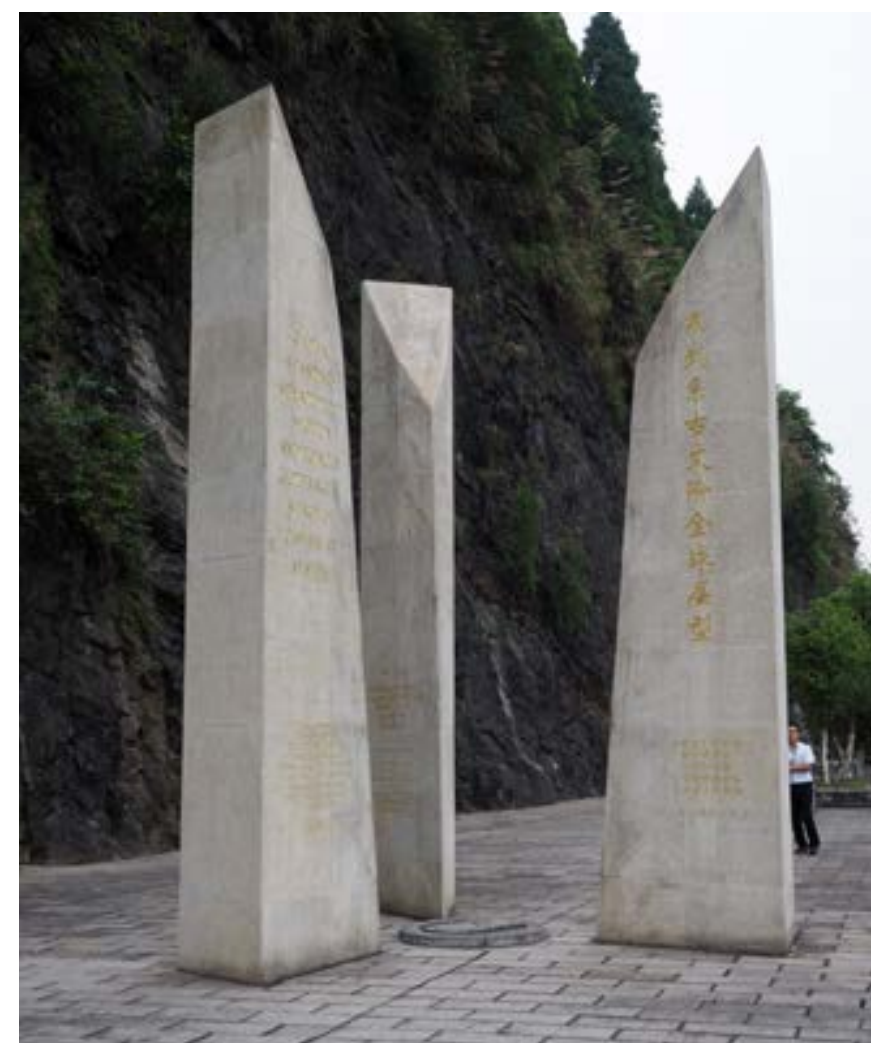

Foto 4.1. GSSP na cidade de Luoyixi, Condado de Guzhang, Província de Hunan, China: um local tipo e de referência reconhecido internacionalmente, protegido e parte integrante do Xiangxi Geoparque Mundial da UNESCO. ( $)$ John Gunn

A geoconservação é fundamental para garantir que estes locais permaneçam acessíveis como sítios de referência para o futuro. Apesar das diretrizes de conservação e proteção estabelecidas nos critérios dos GSSPs (Gradstein \& Ogg, 2012), não há legislação internacional ou medidas de conservação para garantir a proteção desses sítios. Há, portanto, um forte argumento a favor de que os GSSPS devem ser considerados como uma terceira rede de sítios de geoconservação, reconhecida internacionalmente, para funcionar em paralelo com os Sítios do Patrimônio Mundial e com os Geoparques Mundiais (Gray, 2011). Tal reconhecimento ajudaria a conscientizar os governos nacionais sobre a necessidade de proteger os GSSPs. Independentemente deste objetivo de longo prazo, a proteção de tais sítios deve ter uma alta prioridade para os gestores de áreas protegidas.

Alguns países criaram sistemas nacionais de sítios geológicos de referência para as geociências. Estes sítios são também de alta prioridade para a geoconservação. Para mais informações, os gestores de áreas protegidas devem consultar os especialistas em patrimônio geológico nos serviços geológicos nacionais, sociedades geológicas ou em instituições de pesquisa.

\section{Sítios com exemplos únicos ou notáveis de feições geológicas particulares}

Alguns locais apresentam exemplos únicos, raros ou notáveis de determinados estratos rochosos, depósitos, geoformas ou processos geomorfológicos. Exemplos internacionalmente conhecidos incluem o Grand Canyon (Parque Nacional de
Grand Canyon, EUA), Uluru (Parque Nacional de Uluru-Kata Tjuta, Austrália) e a seção com a discordância identificada por Hutton, em Siccar Point e as margens do lago glacial Glen Roy (ambos na Escócia).

Sítios representativos da geologia ou geomorfologia de uma área, região ou país

A maioria dos sítios considerados como detentores de valor geológico será representativa da história geológica de uma região ou país. Eles correspondem aos locais tipo e aos melhores exemplos que são fundamentais para compreender os processos e eventos passados e presentes, preservados nas rochas e que moldaram a paisagem. Normalmente, estes sítios farão parte de uma rede coerente de sítios associados e que representam, coletivamente, um determinado período de tempo, um evento ou um conjunto de processos geomorfológicos e geoformas (por exemplo, sítios que representam os aspectos chave do Período Devoniano ou a geomorfologia costeira de um país).

Boa Prática $n^{\circ} 4$ : Usar os oito temas do geopatrimônio (Tabela 4.1) para ajudar a definir os objetivos de uma área protegida destinada à geoconservação ou de uma rede de geossítios.

\subsection{Inventariação}

A grande maioria das áreas protegidas no mundo foi estabelecida para conservar a biodiversidade e/ou paisagens icônicas terrestres ou marinhas. A ausência de informações sobre a ocorrência de geopatrimônio em áreas protegidas, significa que feições naturais importantes nem sempre estão incluídas nas estratégias de gestão destas áreas. Portanto, a realização de inventários do patrimônio geológico em áreas protegidas é de suma importância. Os inventários são tão importantes como é a etapa seguinte de desenvolvimento de um sistema nacional ou regional de áreas protegidas destinadas à geoconservação.

Sempre que possível, deve ser realizado um inventário do geopatrimônio - geologia, geomorfologia e solos - na área protegida, região ou país, dependendo da escala em que se desenvolve o trabalho . Questões práticas, como a avaliação do risco de degradação e a ligação com áreas-chave do habitat, devem ser avaliadas se os recursos permitirem. Um inventário de sítios pode avaliar seu valor potencial para a ciência, educação, recreação e/ou geoturismo, assim como seu risco de degradação (Brilha, 2016). Estas informações auxiliam no estabelecimento de prioridades e oportunidades de gestão.

Os inventários do patrimônio geológico devem fornecer aos gestores de áreas protegidas informações e dados cruciais para serem incluídos nos planos de manejo e também para ajudar a responder a perguntas simples, como por exemplo:

- Quantos geossítios existem na área protegida e onde estão localizados?

- Qual é seu principal valor (científico, estético, cultural, educacional) e relevância (internacional, nacional, local)? 


\section{Figura 4.1 Inventário e gestão do patrimônio geológico em áreas protegidas}

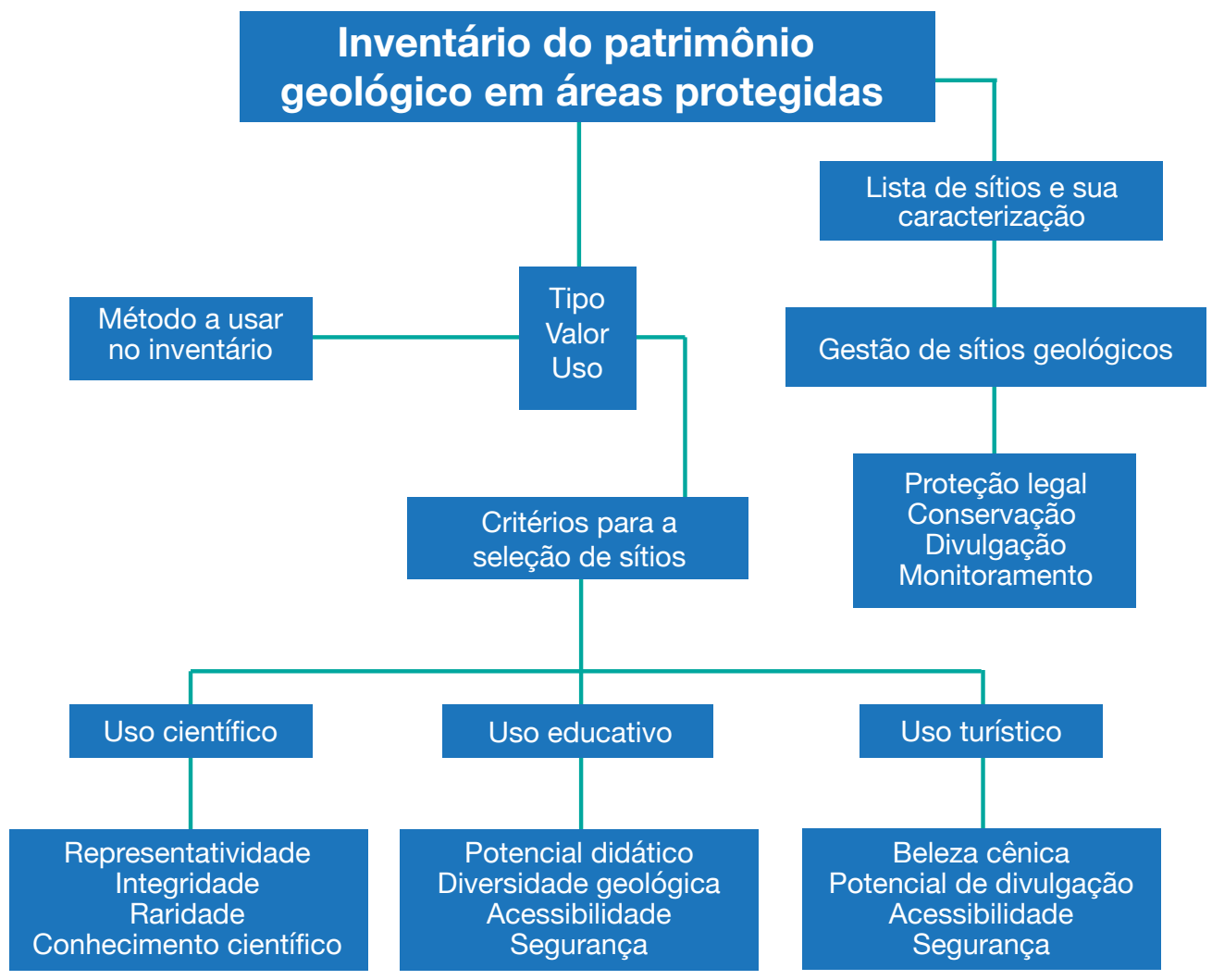

Fonte: ๑ José Brilha

- Estarão em risco, agora ou no futuro, de sofrerem danos ou perdas devido a fatores antrópicos e/ou naturais?

Deve ser tomada uma decisão crítica sobre quais sítios e feições a inventariar e por quê e, por esta razão, é melhor usar métodos experimentados e testados, como indicado na Tabela 4.1, o que requer ajuda especializada. A solução mais comum para gestores de áreas protegidas é obter apoio externo para desenvolver um inventário do geopatrimônio, o que pode ser feito por serviços geológicos locais, universidades, empresas privadas ou especialistas individuais.

Há várias etapas envolvidas em um inventário do patrimônio geológico (Figura 4.1; Caixa 4.1). A primeira é definir o objetivo do inventário com base no tipo, valor e usos do geopatrimônio. Em algumas situações, podem ser feitos inventários parciais, tais como os de paleontologia (fósseis), geomorfologia (geoformas e suas paisagens), mineralogia (minerais) ou petrologia (rochas). Porém, na maioria das vezes, será necessário um inventário completo para garantir que todos os elementos-chave do patrimônio geológico sejam identificados e protegidos. Os valores de um geossítio determinarão o tipo de uso ali permitido.

Cada sítio selecionado durante o inventário deve ser descrito e caracterizado de modo completo (Brilha, 2016):

1. nome;

2. localização geográfica, incluindo coordenadas GPS;

3. propriedade pública ou privada, incluindo a subsuperfície;

4. proteção legal em vigor;
5. acessibilidade;

6. fragilidade e vulnerabilidade;

7. estado de conservação das principais feições e processos de geodiversidade;

8. descrição geológica;

9. feições mais importantes que justificam o sítio geológico;

10. feições com potenciais usos educacionais e/ou geoturísticos;

11. eventual associação com valores ecológicos e culturais;

12. limitações e restrições ao acesso e uso científicos;

13. limitações ao número de visitantes; e

14. condições de segurança para todos os tipos de visitantes.

Estas informações são cruciais para o estabelecimento de um plano de ação apropriado para o geopatrimônio e para a integração do inventário nos planos de manejo de áreas protegidas. O inventário pode incluir geossítios de relevância internacional, nacional, regional ou mesmo local. Isto tem implicações no estabelecimento de prioridades no plano de manejo, a ser determinado pela equipe técnica responsável pelo inventário.

Um bom exemplo do envolvimento de estudantes e profissionais das geociências em áreas protegidas é o programa 'Geoscientistas nos Parques', da Sociedade Geológica da América. Este programa oferece aos participantes uma oportunidade única de contribuir para a conservação dos parques nacionais da América e permite que o Serviço de Parques Nacionais dos EUA atue melhor 
4. Criação de áreas protegidas destinadas à geoconservação

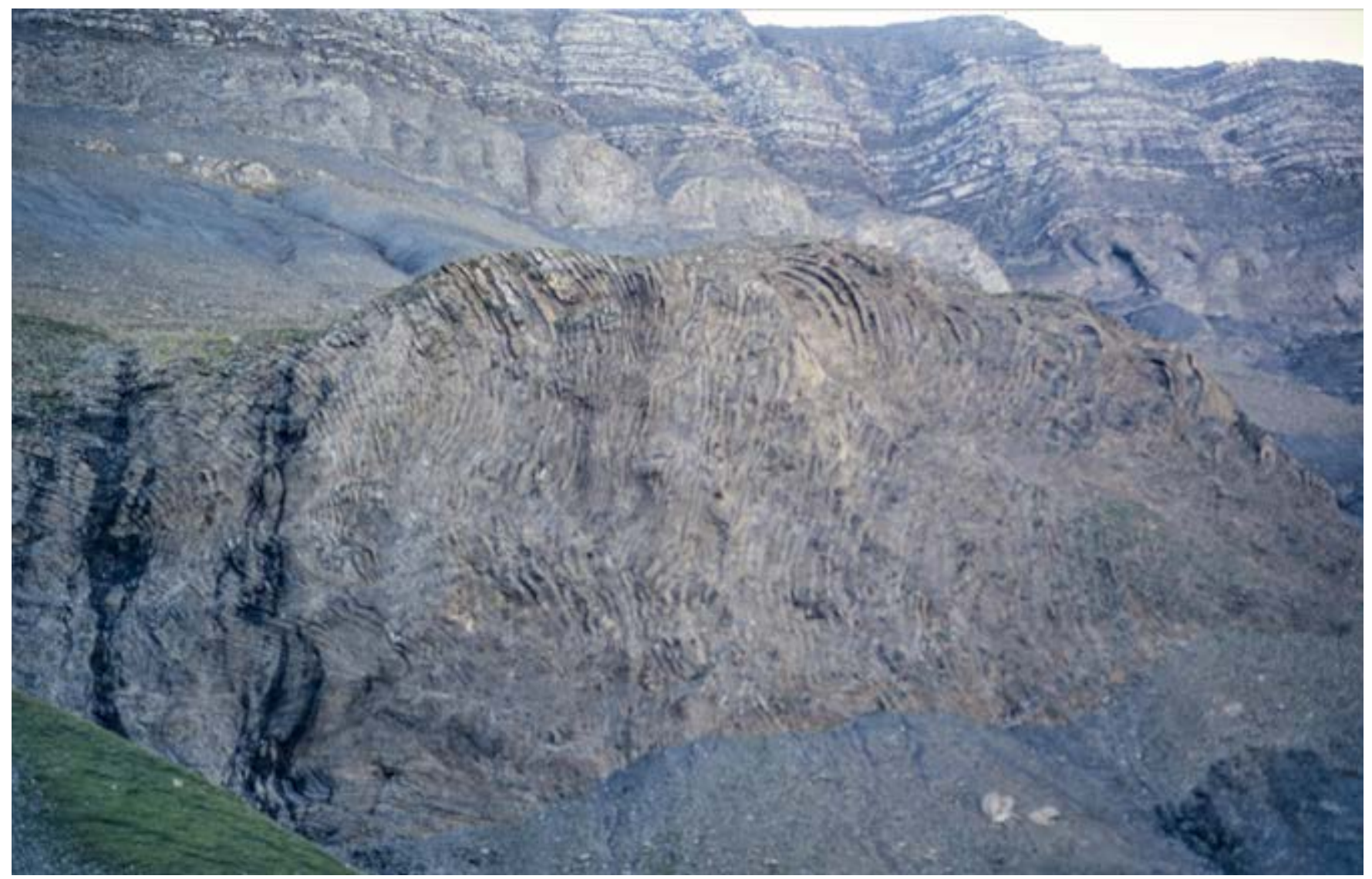

Foto 4.2 Exemplo de representatividade: rochas sedimentares dobradas formando cadeias de montanhas onde placas tectônicas colidiram, tal como ocorrido nos Andes, Himalaias, Montanhas Rochosas e Alpes Europeus, estes últimos aqui ilustrados no Parque Nacional de Ecrins, França. @ Roger Crofts

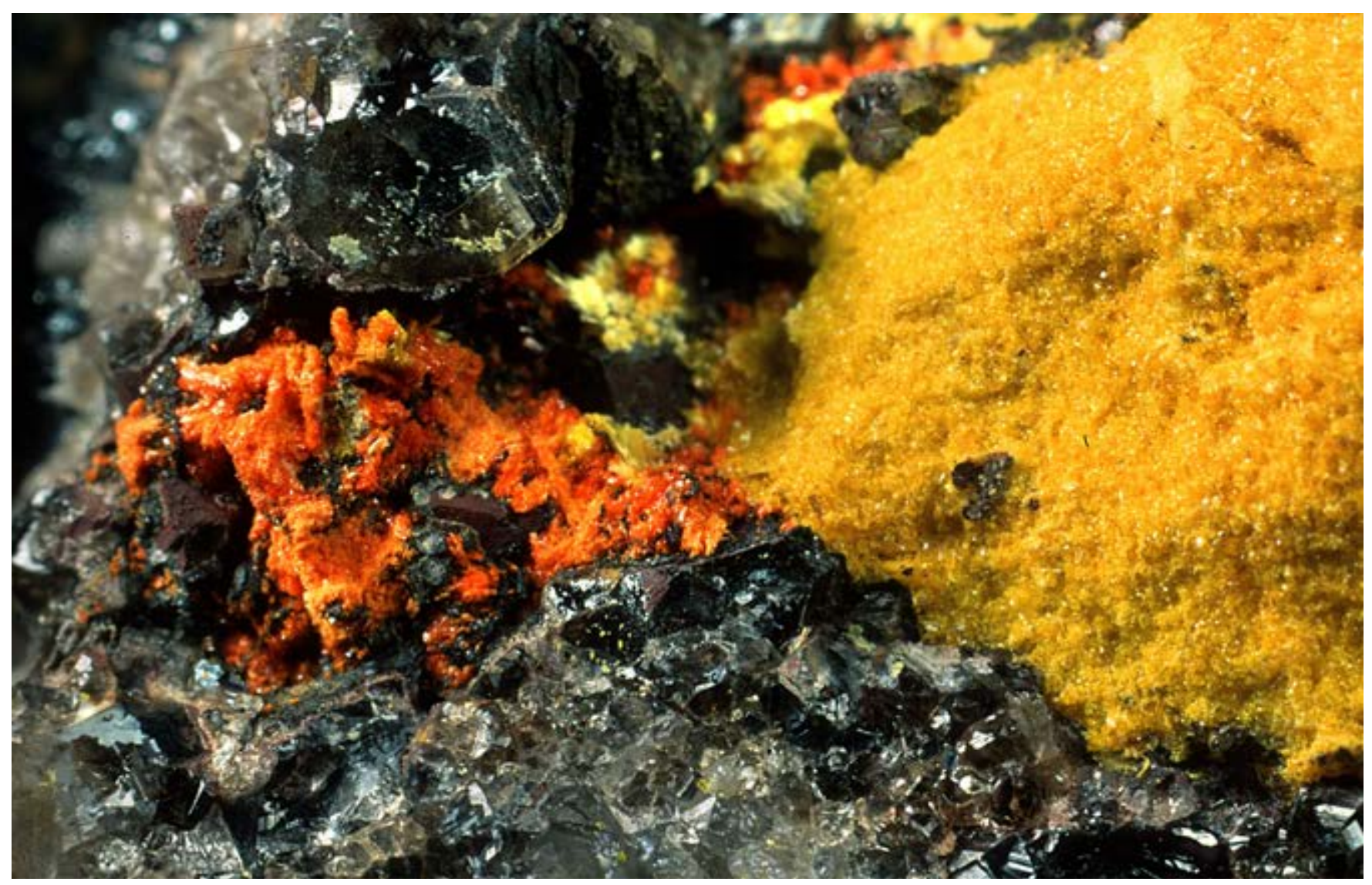

Foto 4.3 Exemplo de raridade: Spriggite, um mineral amarelo raro cujo nome homenageia o geólogo Reg Sprigg. A sua localidade tipo situa-se no Mount Painter, no interior da Área de Proteção de Arkaroola, Flinders Rangers, Austrália Meridional. @ Joel Brugger 


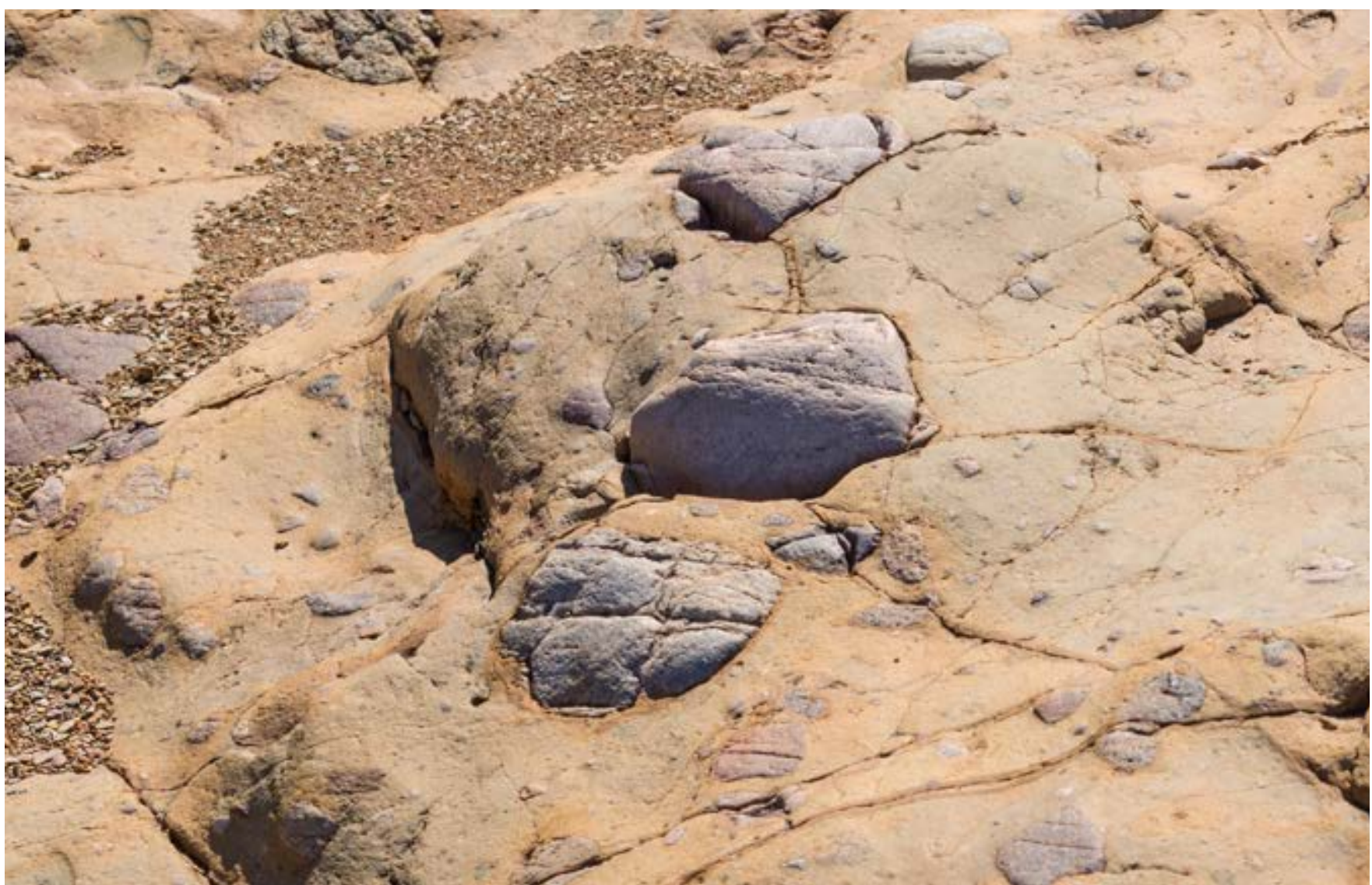

Foto 4.4 Exemplo da produção de conhecimento científico a partir do estudo das formações rochosas e suas origens: um antigo depósito glacial, relacionado com o evento de glaciação global, ocorrido há cerca de 700 milhões de anos atrás e normalmente chamado de "Terra Bola de Neve". Desfiladeiro de Tillite, Área de Proteção de Arkaroola, Austrália Meridional. @ Graeme L. Worboys

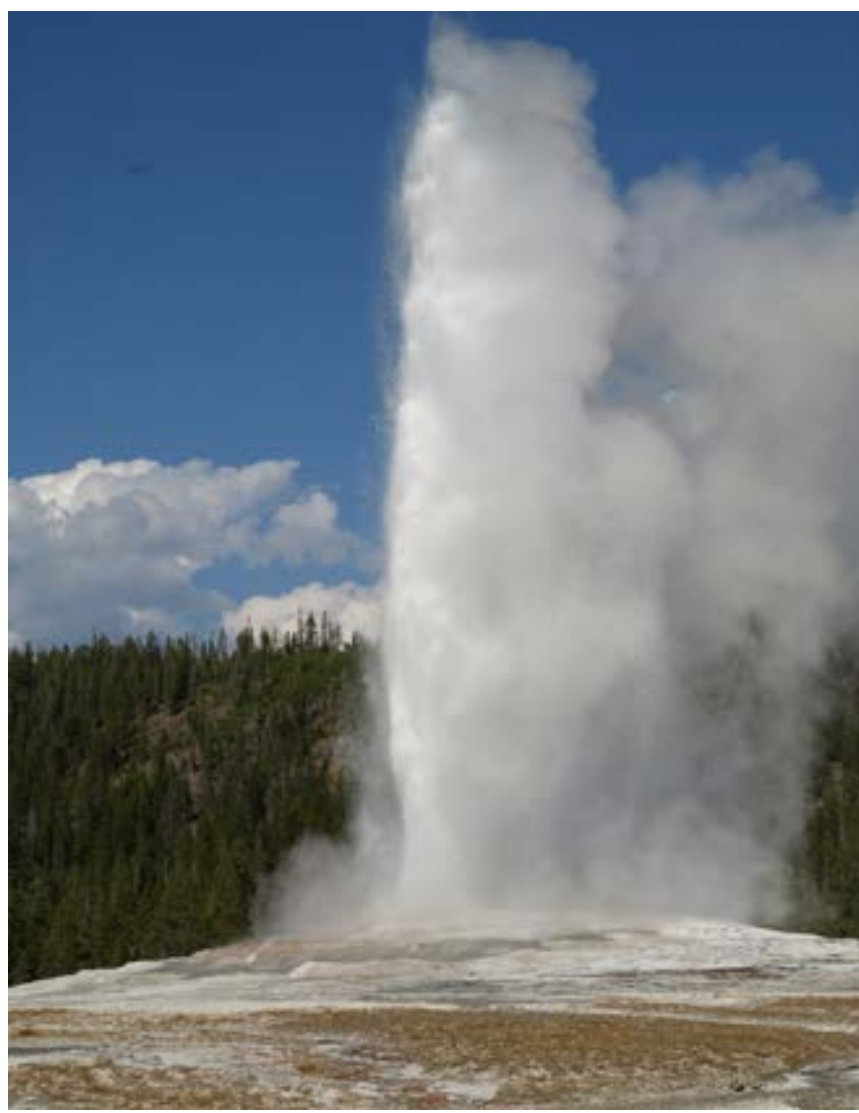

Foto 4.5 Exemplo de potencial educacional: Geiser Old Faithful e área de atividade geotérmica adjacente, Parque Nacional de Yellowstone e Sítio do Patrimônio Mundial, EUA. @ Graeme L. Worboys. sobre os seus recursos naturais (Geological Society of America, 2019).

\section{Boa Prática $\mathrm{n}^{\circ}$ 5: Fazer um inventário de geossítios} usando a abordagem indicada no fluxograma da Figura 4.1.

\subsection{Critérios de avaliação}

A avaliação de geossítios de acordo com os três principais tipos de uso - científico, educacional e geoturístico/recreativo é já uma prática bem estabelecida.

A seleção de geossítios importantes para estudos científicos é baseada em quatro critérios:

\section{Representatividade: capacidade do geossítio para} ilustrar um processo ou feição do planeta, fazendo uma contribuição significativa para a compreensão do tema, processo, feição ou enquadramento geológico (Foto 4.2);

2. Integridade: o atual estado de conservação do geossítio, levando em conta tanto os processos naturais quanto os fatores humanos (Foto 4.6);

3. Raridade: o número de geossítios que apresentam características geológicas similares (Foto 4.3); e

4. Conhecimento científico: a extensão das informações científicas já publicadas sobre o geossítio (Foto 4.4). 
4. Criação de áreas protegidas destinadas à geoconservação

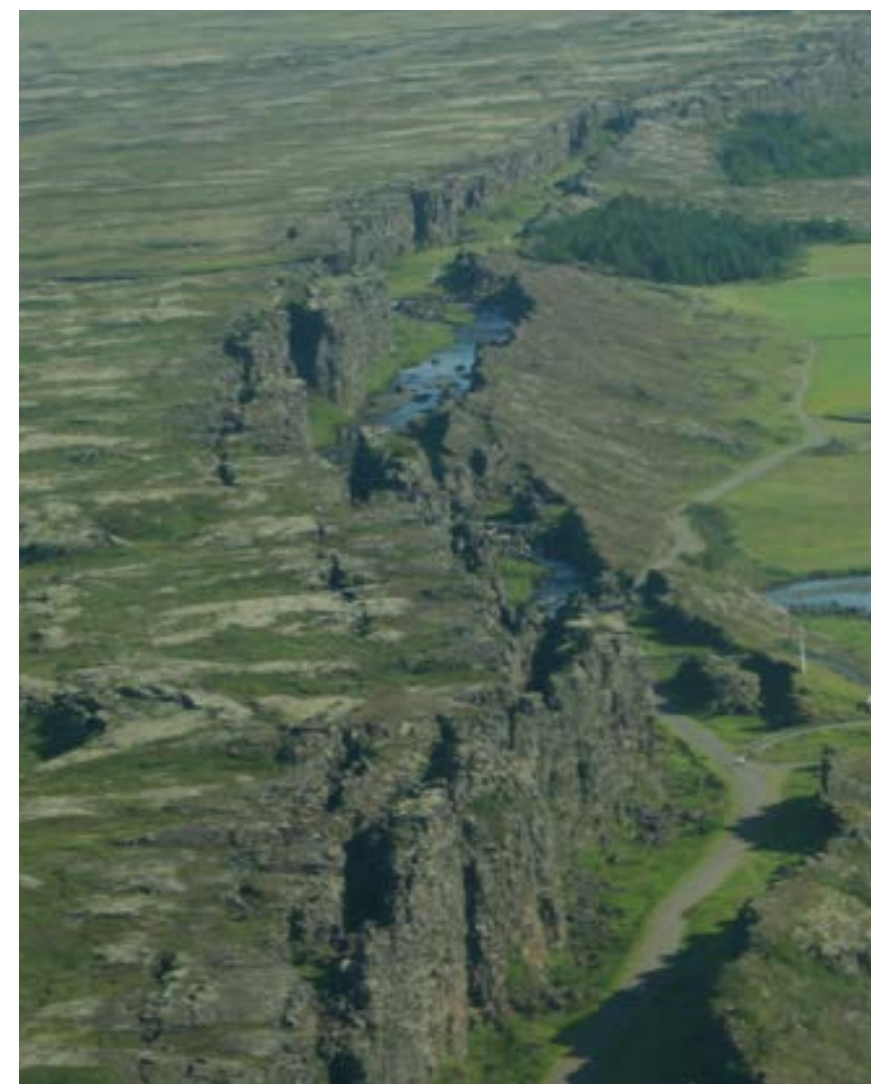

Foto 4.6 Exemplo de um sítio da geodiversidade: pequeno vale de rift e um lago profundo com fumarolas vulcânicas limitado por fraturas de tensão na margem das placas tectônicas eurasiáticanorte-americana, Parque Nacional de Thingvellir, Islândia. A área tem um interesse cultural significativo uma vez que é a localização do primeiro parlamento da Islândia, sendo igualmente um sítio do Patrimônio Mundial. @ Roger Crofts

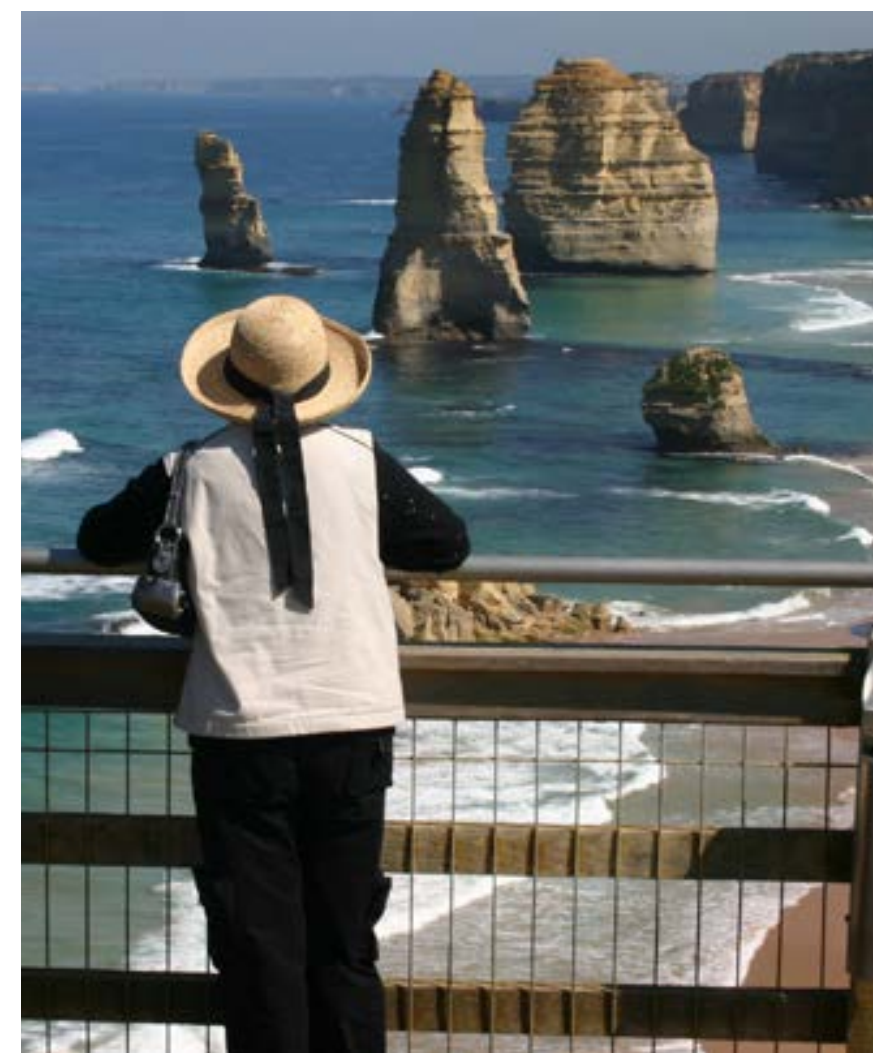

Foto 4.7 Exemplo de acessibilidade: acesso à beira da estrada para ver as torres rochosas residuais marinhas no Parque Nacional Marinho dos Doze Apóstolos, Victoria, Austrália. ( Roger Crofts

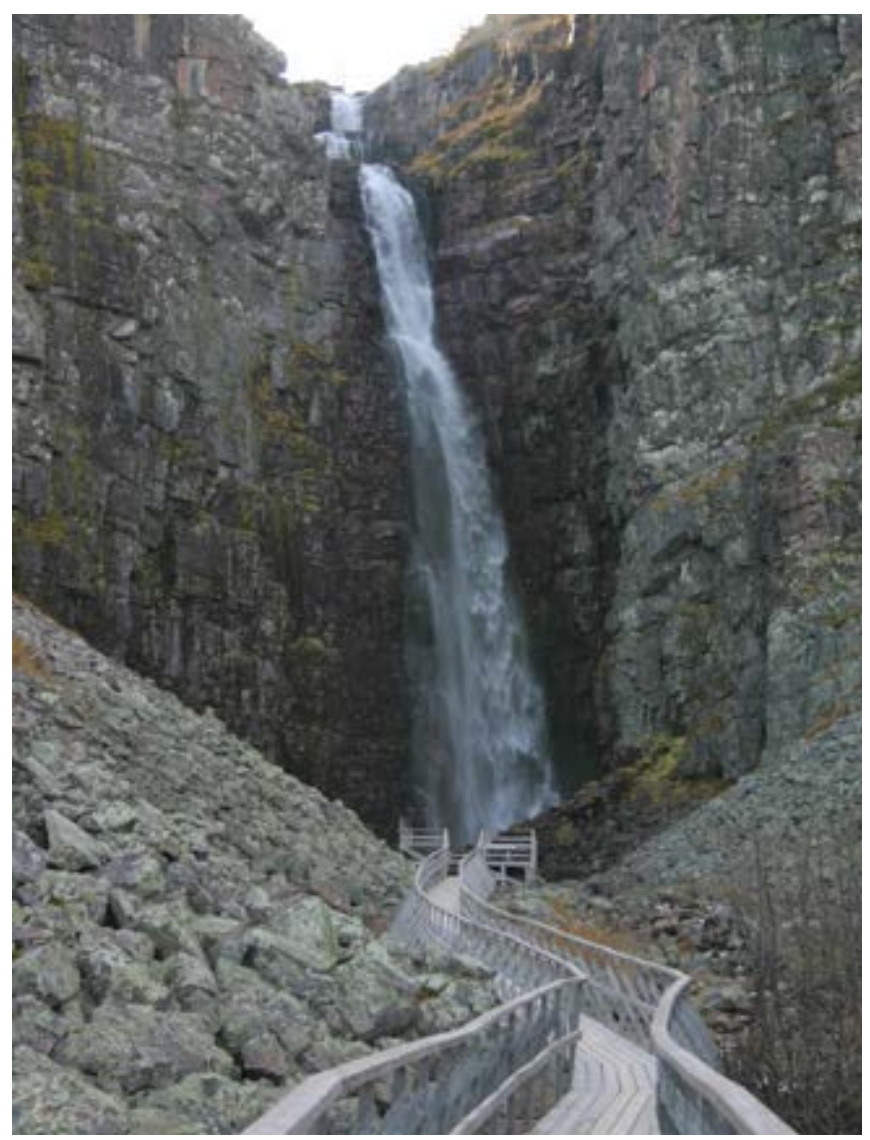

Foto 4.8 Exemplo de segurança: vista sobre a cachoeira a partir de uma plataforma de observação. Parque Nacional Fulufjällets, Suécia. @ Roger Crofts

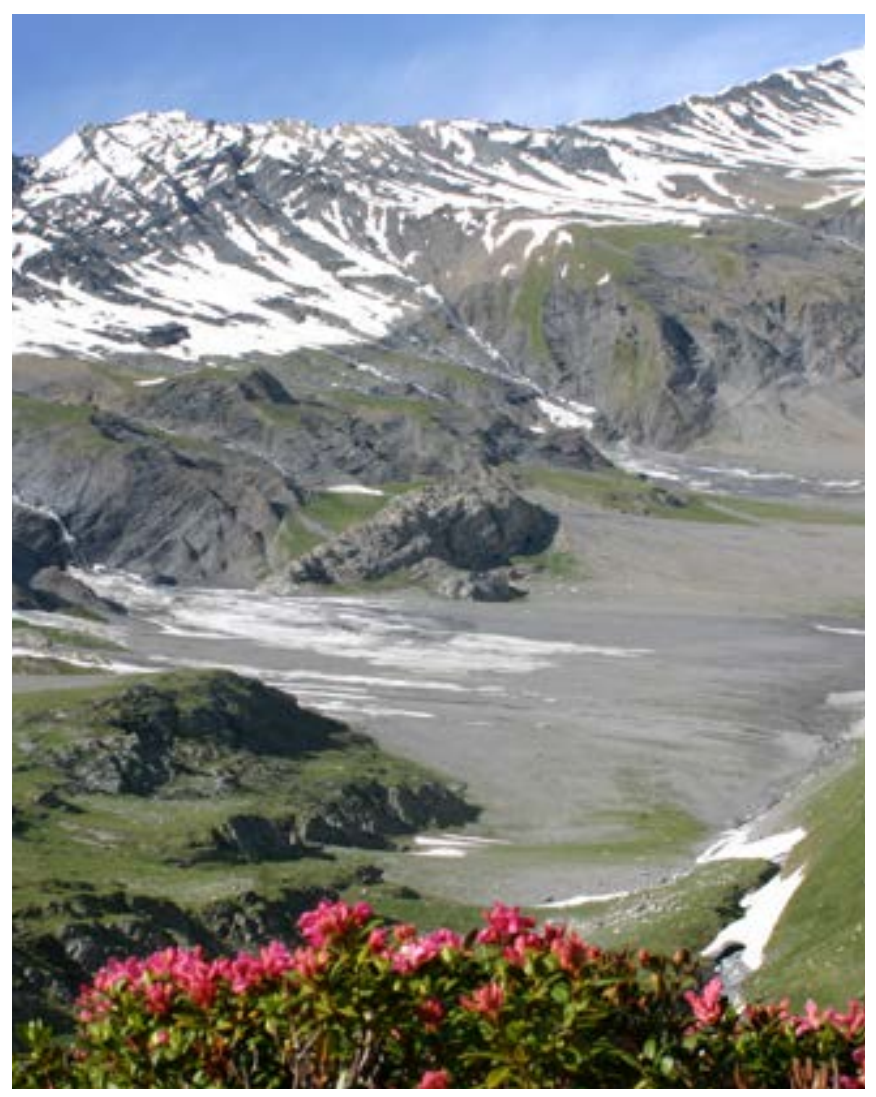

Foto 4.9 Exemplo da ligação entre geodiversidade e beleza cénica: a sobreposição de rochas sedimentares dobradas, neve e gelo, e a flora alpina fornecem uma justificativa cênica para a proteção. Parque Nacional Vanoise, França. @ Roger Crofts 


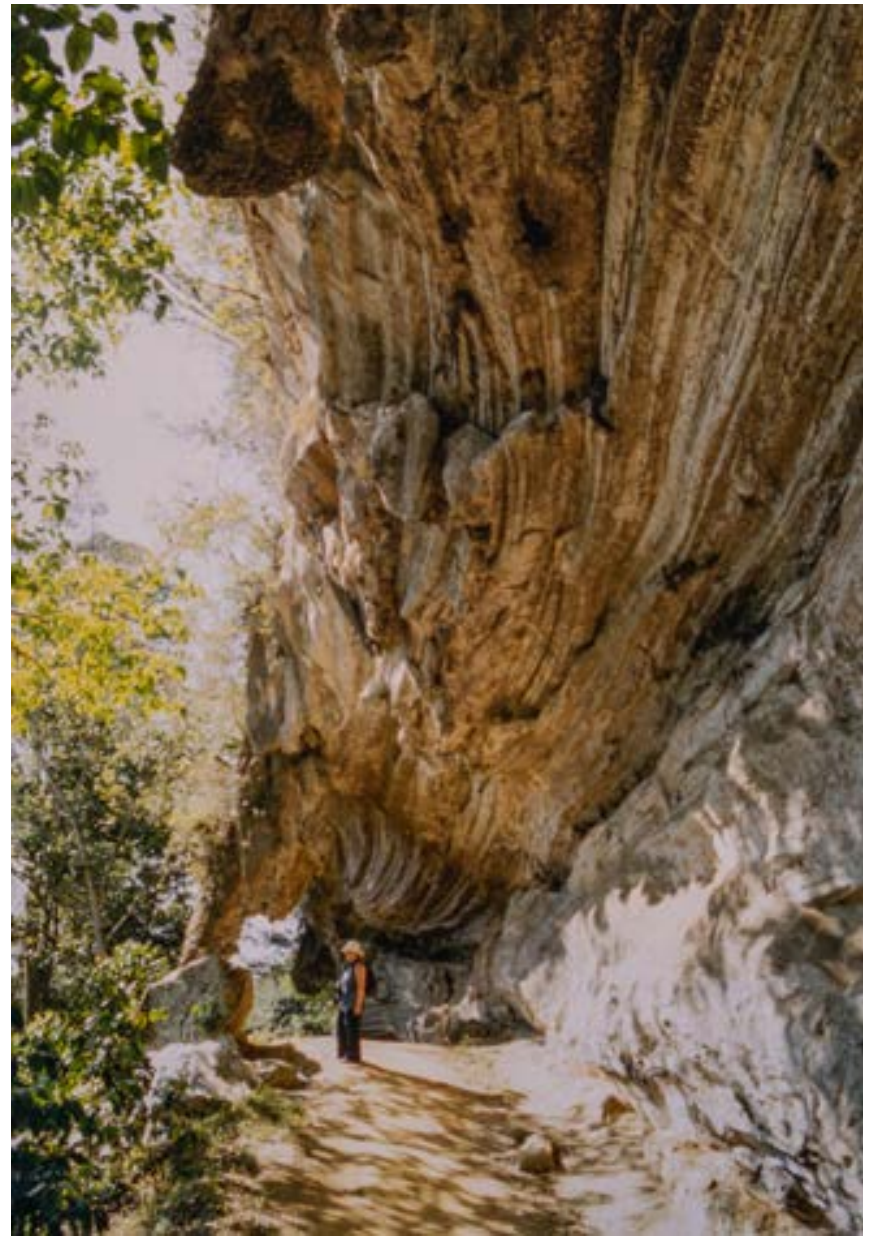

Foto 4.10 Exemplo de potencial interpretativo: uma formação rochosa incomum no Elephant Rock, Parque Natural Topes de Collantes, Cuba. $\odot$ Roger Crofts

Para a seleção de sítios para uso educacional são recomendados cinco critérios:

1. Potencial educacional: capacidade de uma determinada feição geológica ser facilmente compreendida por estudantes de diferentes níveis de ensino (escolas primárias e secundárias, universidades) (Foto 4.5);

2. Diversidade geológica: número de diferentes tipos de feições e processos geológicos que ocorrem no sítio (Foto 4.6);

3. Acessibilidade: condições de acesso ao sítio em termos de dificuldade e segurança, e o tempo que estudantes e visitantes precisariam para se deslocar a pé até ao sítio geológico (Foto 4.7);

4. Segurança: relacionada com as condições no local de visita, levando em consideração o risco mínimo para estudantes e visitantes (Foto 4.8); e

5. Conexão cultural e espiritual: associação do sítio com valores culturais e espirituais das comunidades indígenas (ver fotos 5.12 a 5.16).

Para a seleção de sítios para geoturismo/uso recreativo são recomendados três critérios:

1. Beleza cênica: qualidade estética visual da paisagem ou da feição (Foto 4.9);
2. Potencial interpretativo: capacidade do sítio em ser facilmente compreendido por não especialistas (Foto 4.10); e

3. Acessibilidade: condições de acesso ao sítio em termos de dificuldade e segurança, e o tempo que o público em geral precisaria para caminhar até ao local (Foto 4.7).

Uma vez estabelecidos estes critérios, a abrangência geográfica pode ser definida (Brocx \& Semeniuk, 2007; Crofts \& Gordon, 2015). Brocx \& Semeniuk $(2007,2015)$ apresentam um método comparativo global para permitir a identificação sistemática e categorização de regiões, áreas, geossítios ou feições dotados de valor geopatrimonial em todas as escalas; atribuem uma categoria conceitual do patrimônio geológico e uma escala de referência; e avaliam o seu nível de significância (Figura 4.2).

Os gestores de áreas protegidas devem usar os resultados da avaliação dos sítios geológicos para definir as respectivas ações de conservação e seus usos potenciais. Por exemplo, locais de importância internacional, provavelmente, exigirão um nível mais alto de gestão e proteção do que outros.

\subsection{Exemplos de inventários e avaliações de patrimônio geológico}

Para auxiliar os administradores de áreas protegidas, há inúmeros exemplos na literatura de inventários e avaliações de sítios geológicos em escala nacional, regional e local, e também para áreas protegidas. Em nível nacional, os exemplos incluem os dos EUA (Santucci \& Koch, 2003), Espanha (Carcavilla Urquí et al., 2007), Portugal (Pereira et al., 2009) e Grã-Bretanha (Ellis, 2008 e 2011). Exemplos de áreas protegidas específicas incluem o Parque Nacional Cilento Vallo di Diano, Itália (Santangelo et al., 2005), o Parque Natural de Montesinho, Portugal (Pereira et al., 2007), o Parque Regional dos Picos de Europa, Espanha (Fuertes-Gutiérrez \& Fernández-Martínez, 2012), o Parque Nacional dos Pirineus, França (Feuillet \& Sourp, 2011) e o Parque Natural dos Pilares Lena, Rússia (Gogin \& Vdovets, 2014). Vários exemplos estão descritos nas caixas 4.1, 4.2 e 4.3. Estes inventários também ajudam a identificar locais-chave para geoconservação de áreas marinhas protegidas (por exemplo, Gordon et al., 2016).

Boa Prática n 6: Garantir que sejam utilizados critérios claros de avaliação de geossítios, contemplando os usos científico, educacional, geoturístico e recreativo.

\subsection{Integração da geoconservação em planos de ação nacionais, regionais e locais}

A geoconservação em áreas protegidas poderá ser consideravelmente reforçada se os planos em nível nacional, regional e local já incorporarem essa temática (ver Crofts, 2018). Por exemplo, um enquadramento ou plano de ação nacional pode ajudar numa abordagem ampla e estratégica à geoconservação, estabelecendo objetivos e ações nacionais (Gordon \& Barron, 2011). Martín-Duque et al. (2012) demonstram como a existência destes inventários e respectivo mapeamento de geopatrimônio pode subsidiar o planejamento local do uso do solo. Eles podem ser usados para avaliar sobre o progresso da ação, ajudar a identificar parceiros e a coordenar as suas atividades, e promover a geoconservação em nível 
Figura 4.2. Representação dos níveis de significância aplicáveis a feições do patrimônio geológico

A: Internacional; B: Nacional; C: Estadual a regional; e D: Local. Esta abordagem pode ser usada na concepção de novas áreas protegidas e também para acrescentar os interesses relativos ao patrimônio geológico em áreas protegidas já existentes.

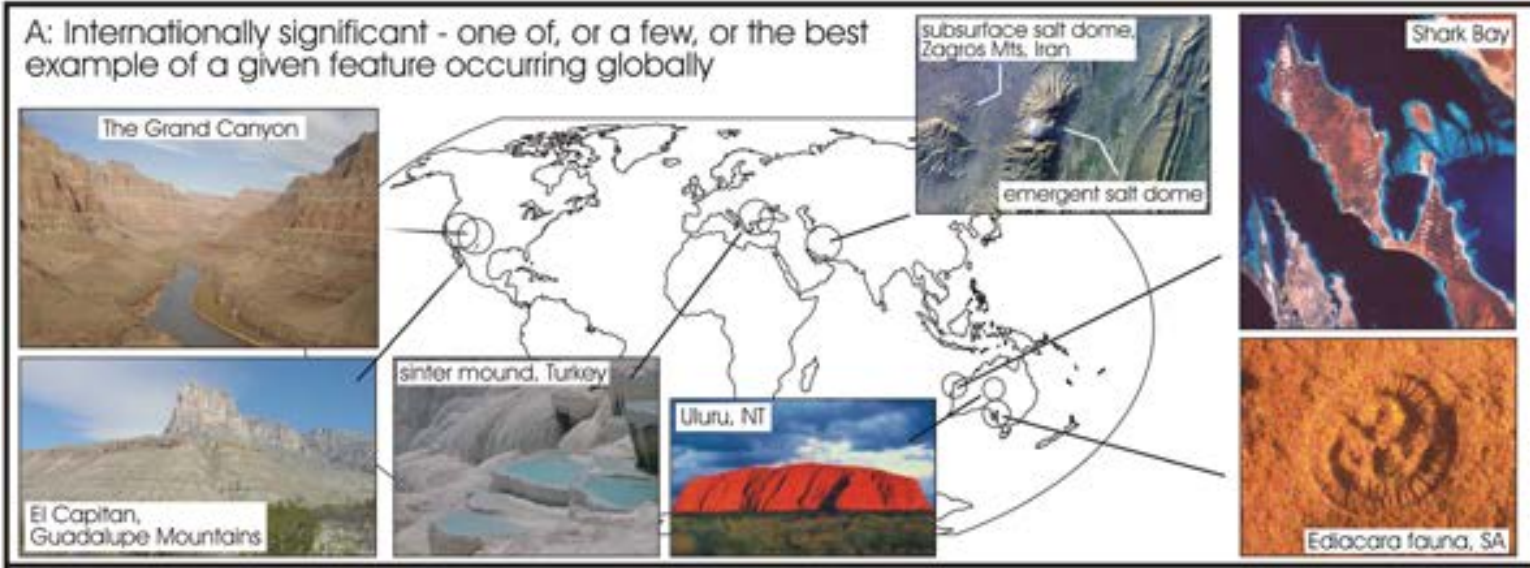

B: Nationally significant - though globally relatively common, one of, or a few, or the best example of a given feature occurring Nationally: example of inselbergs, and landscapes formed on Cainozoic volcanoes

occurrence of some notable inselbergs

occurrence of some notable landforms derlved from

Cainozolic volcanic landscapes
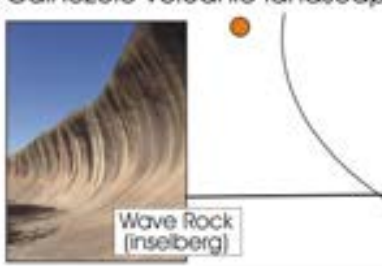

seiberg

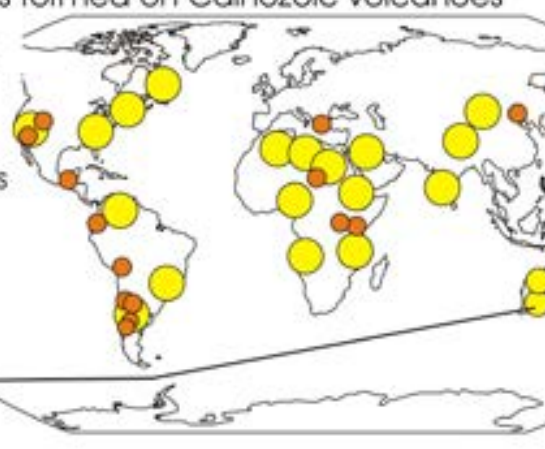

The Breacknife and Butterknte Wamumbungle Ranges

C: State-wide/Regionally significant - though globally relatively common, and occurring throughout a Nation, only one of, or a few, or the best example of the given feature occurs State-wide or Regionally: example of paleosols in Pleistocene aeolianites

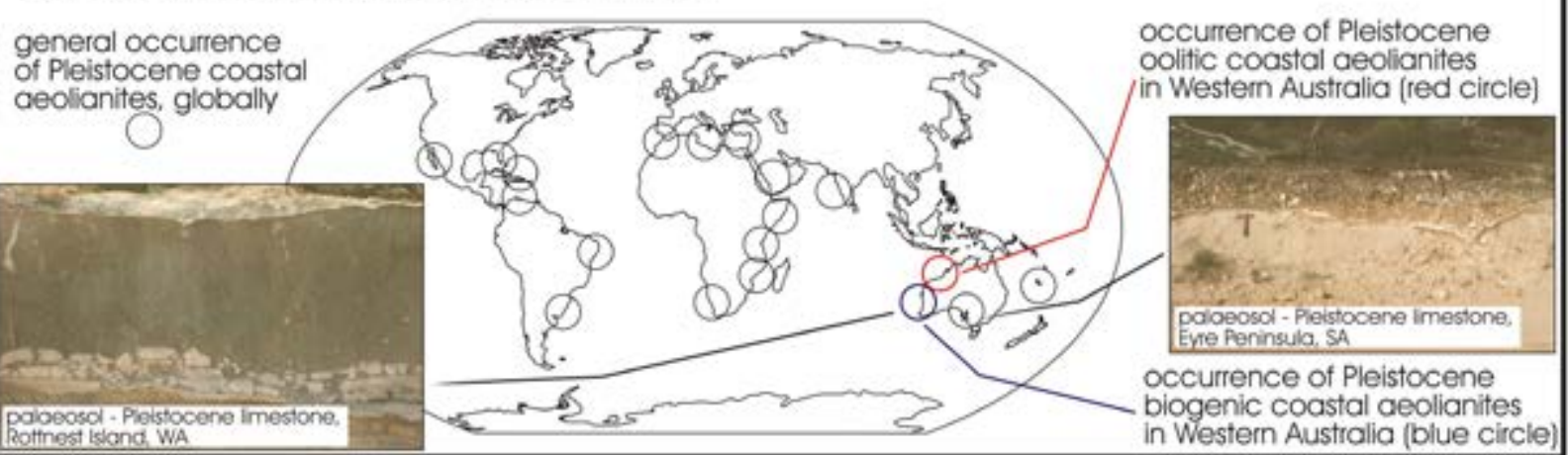

D: Locally significant - occurring commonly through the world, as well as Nationally, to regionally, but specifically important to local communities: examples of well-preserved cross-lamination in aeolianites in Western Australia

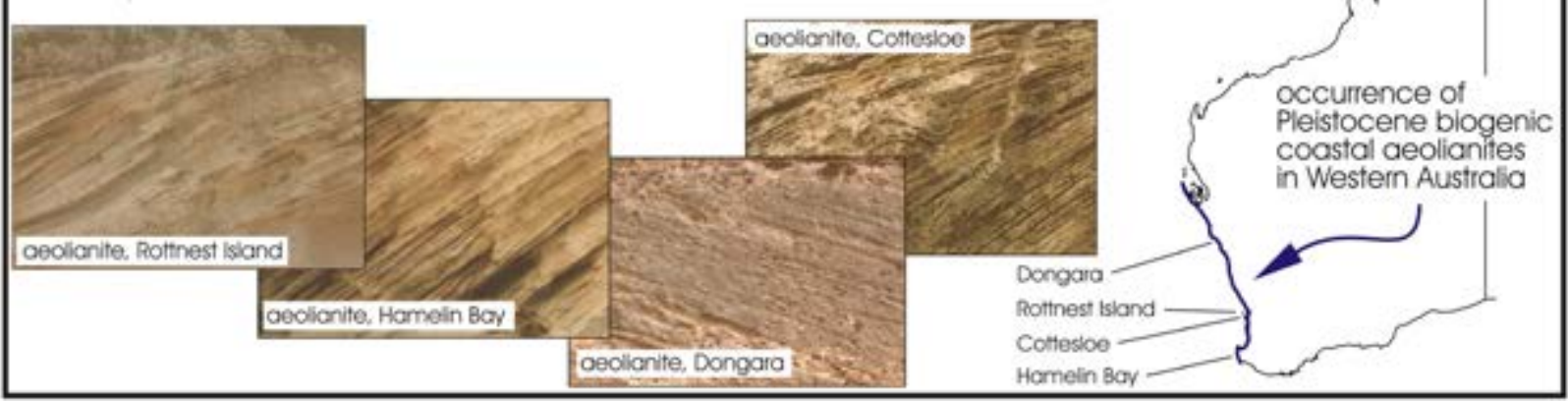

Fonte: Brocx \& Semeniuk, 2007. 


\section{Caixa 4.1}

\section{Kit de ferramentas para o geopatrimônio}

O seguinte diagrama conceitual resume as etapas necessárias para identificar e avaliar os sítios geológicos, com vista a promover a sua gestão e conservação. As feições com valor geopatrimônial deverão ser avaliadas por categoria (A), abrangência e escala (B) e nível de relevância (C). Esta abordagem pode ser usada para criar novas áreas protegidas e também para agregar os interesses relativos ao patrimônio geológico em áreas protegidas existentes. O Kit de Ferramentas Geológicas (Caixa 4.1) desenvolvido na Austrália Ocidental foi aí aplicado com sucesso (Brocx \& Semeniuk, 2011; Brocx et al., 2019) e também em Marrocos (Errami et al., 2015).

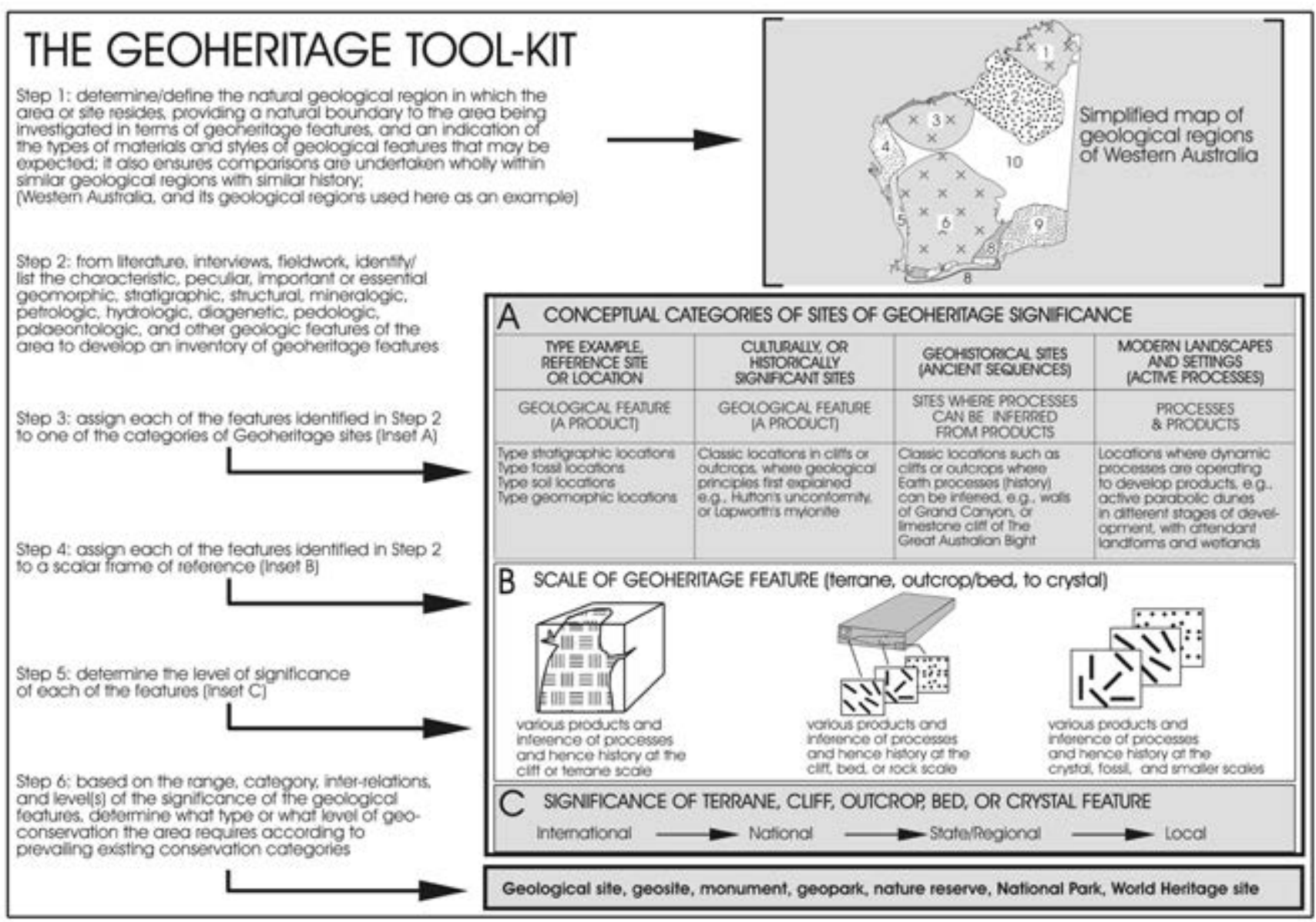

Etapas para uso do kit de ferramentas para o geopatrimônio na identificação e avaliação de sítios de importância patrimonial de Brocx \& Semeniuk (2011).

Contribuinte: Margaret Brocx.

nacional e em políticas e estratégias subnacionais. Um exemplo de uma estrutura nacional é o Plano de Ação de Geodiversidade do Reino Unido; exemplos subnacionais incluem a Estratégia de Geodiversidade do País Basco e a Estratégia da Andaluzia para a Gestão da Geodiversidade A nota da CBD sobre a Estratégia Nacional e Planos de Ação da Biodiversidade pode servir de modelo para a gestão da geodiversidade.

Um plano de ação para a geodiversidade deve estar baseado emum inventário de sítios geológicos, de forma a determinar os requisitos de gestão para os diferentes elementos. O plano de ação define metas e objetivos claros a longo prazo, estabelece metas e ações mensuráveis a curto prazo para conservar e melhorar a geodiversidade e o patrimônio geológico de uma determinada área, e identifica os recursos humanos e financeiros necessários para alcançá-los. Tais planos também podem auxiliar na integração da geodiversidade e do geopatrimônio na gestão da conservação de diferentes categorias de áreas protegidas.

Na Itália, o programa multidisciplinar PROGEO-Piemonte (PROactive management of the GEOlogical heritage in the Piemonte) está desenvolvendo um plano de ação para a geoconservação na região do Piemonte para atender às necessidades das comunidades locais, em relação ao turismo, desenvolvimento sustentável, educação e conscientização sobre os riscos geológicos (Ferrero et al., 2012). O programa é baseado em um levantamento sistemático de geossítios e uma avaliação do seu valor patrimonial do ponto de vista científico, educacional, cultural e estético. Ele envolve a participação de parceiros locais e considera não apenas as características geológicas da região, mas também os componentes físicos, geográficos, políticos, econômicos, históricos e culturais. Outros exemplos de redes regionais de geossítios incluem os da 
Espanha (Fuertes-Gutiérrez \& Fernández-Martínez, 2010), Suíça e Portugal.

Na Grã-Bretanha, os Planos de Ação para a Geodiversidade Local (LGAPs) estabeleceram uma estrutura, princípios orientadores e prioridades para a conservação do geopatrimônio e a criação de redes de geossítios em escala regional (English Nature, 2004; Dunlop et al., 2018). Os LGAPs estabelecem metas e objetivos claros, com metas mensuráveis, para a geoconservação local. Tipicamente, eles incluem os seguintes elementos:

- um inventário dos elementos da geodiversidade de uma área;

- comunicação e educação junto do público;

- incentivo à proteção da geodiversidade através de planos e orientações do governo local;

- metas de gestão e conservação para geossítios, processos naturais e geodiversidade da paisagem; e

- objetivos claros para o fornecimento de recursos para o processo de planejamento da ação, a fim de garantir o futuro do processo.

Uma vez concluídos, os Planos de Ação da Geodiversidade devem ser incorporados aos planos de manejo de áreas protegidas na escala apropriada, quer seja nacional, regional ou para uma área protegida individual. Estes planos devem então ser integrados no sistema nacional para a tomada de decisões sobre desenvolvimento e uso da terra. Isto pode ser feito de forma independente ou através da integração com planos locais de biodiversidade, permitindo que as políticas de planos de desenvolvimento e as decisões de planejamento de controle de desenvolvimento sejam baseadas em informações atualizadas sobre a geodiversidade de uma área. Os inventários e planos de ação devem ajudar o planejamento de desenvolvimento, avaliação ambiental estratégica (AAE), avaliação de impacto ambiental (AIA), planos de biodiversidade local e atividades baseadas no turismo. Além de conservar exemplos importantes de geopatrimônio local, os LGAPs podem contribuir para a qualidade dos ambientes locais, proporcionar oportunidades de recreação informal e contribuir para as políticas de saúde pública. $\bigcirc$ envolvimento da comunidade no cuidado e desfrute dos geossítios locais também ajudará a fomentar um sentimento de orgulho em relação ao geopatrimônio local e, assim, ajudar a conservá-lo.

Boa Prática $\mathrm{n}^{\circ}$ 7: Incentivar o desenvolvimento de planos de ação em escala nacional, regional e local para garantir que a geoconservação seja incluída nos principais instrumentos de decisão.

\subsection{Mecanismos de proteção}

Todas as áreas protegidas, incluindo os geossítios, devem ser reconhecidas ao abrigo de uma convenção ou acordo internacional, ou administradas através de outros meios eficazes. Na prática, as áreas protegidas podem ser administradas por governos, organizações privadas, povos indígenas e comunidades locais ou combinações destas (governança compartilhada). Mas, há também outras áreas naturais que não são áreas protegidas mas onde a conservação é um objetivo principal e que podem ser administradas de outras formas que, no final, resultam na conservação da natureza a longo prazo. Estão incluídas as "outras medidas efetivas de conservação baseadas em áreas" (OECMs) definidas pela Convenção sobre Diversidade Biológica (Decisão 14/8 da CBD). A WCPA da UICN publicou diretrizes para Identificar e Relatar Outras Medidas de Conservação Eficazes. Estas áreas conservadas e OECMs também podem ser efetivas para promover a geoconservação.

\section{Boa Prática n 8: Aplicar as diretrizes da WCPA sobre áreas protegidas $\mathrm{e}$ "outras medidas efetivas de conservação baseadas em áreas" para garantir o mecanismo de proteção mais eficaz para os geossítios.}

\subsection{Tipos de governança}

Nas caixas 4.2 e 4.3 apresentam-se dois exemplos de governança relacionados com a geoconservação em áreas protegidas. Mais orientações gerais sobre governança de áreas protegidas podem ser encontradas em Borrini-Feyerabend et al., (2013).

\subsection{Conhecimentos necessários}

As necessidades da gestão da geoconservação devem determinar o tipo e o nível de especialização necessários, seja na própria área protegida ou em sua entidade gestora, ou ainda através de acordos especiais com organismos externos especializados, tais como institutos de pesquisa. Idealmente, para conjuntos de sítios com forte componente das geociências, ou para um sítio onde a geoconservação seja o objetivo principal, é preferível empregar especialistas em geoconservação na entidade que administra as áreas protegidas. Porém, os recursos existentes nem sempre permitirão esta contratação pelo que devem ser feitos acordos informais com especialistas de instituições acadêmicas ou com indivíduos particulares que possam trabalhar como voluntários. Estes consultores especializados devem ajudar os administradores das áreas protegidas na definição de objetivos e de medidas de gestão, assim como na preparação de programas educativos. Além disso, devem ainda informar sobre exemplos de boas práticas implementadas em situações similares em outras partes do mundo.

O tipo de especialização dependerá do tema do sítio (por exemplo, paleontologia, mineralogia, estratigrafia, geomorfologia). É geralmente preferível envolver pessoas que tenham tanto o conhecimento específico necessário, quanto um conhecimento mais geral sobre geodiversidade, geopatrimônio e geoconservação. A capacidade de comunicação com colegas, não-especialistas e com o público em geral é essencial se houver uma forte abordagem educativa sobre geopatrimônio e geoconservação.

Algumas áreas protegidas, ao invés disso, terão um forte foco científico e de pesquisa. Aqui, um programa coordenado de atividade científica deve ser desenvolvido entre os administradores da área protegida e a comunidade científica, com um programa de trabalho bem estabelecido. Os gestores de áreas protegidas poderão considerar mais eficaz o envolvimento com cientistas de universidades e institutos de pesquisa, em vez de contratar 
Caixa 4.2

\section{Gestão comunitária de geoconservação em Gunung Sewu Geoparque Mundial da UNESCO,} Indonésia

O Geoparque Gunung Sewu foi aceite como Geoparque Mundial da UNESCO em outubro de 2015. O geoparque tem uma área de 1802 km2 e inclui 33 geossítios numa paisagem clássica do carste tropical (Figura 4.5), oito dos quais com envolvimento das comunidades locais. A gestão do geoparque está sob um acordo conjunto entre três administrações provinciais e é rotativa entre elas. A gestão da maioria dos geossítios é feita pelas comunidades locais, iniciada e organizada pela população local, sob a égide de um grupo de gestão turística de base comunitária.

A gestão comunitária da geoconservação protege os geossítios do geoparque e gera renda para a população local e para o desenvolvimento regional através do geoturismo. Como exemplo, apresenta-se a gestão da geoconservação realizada pela vila de Nglanggeran que promove destinos, produtos e comportamentos turísticos responsáveis, inclusivos e sustentáveis. As melhores práticas comunitárias de geoconservação em Nglanggeran foram reconhecidas por prêmios nacionais e regionais.

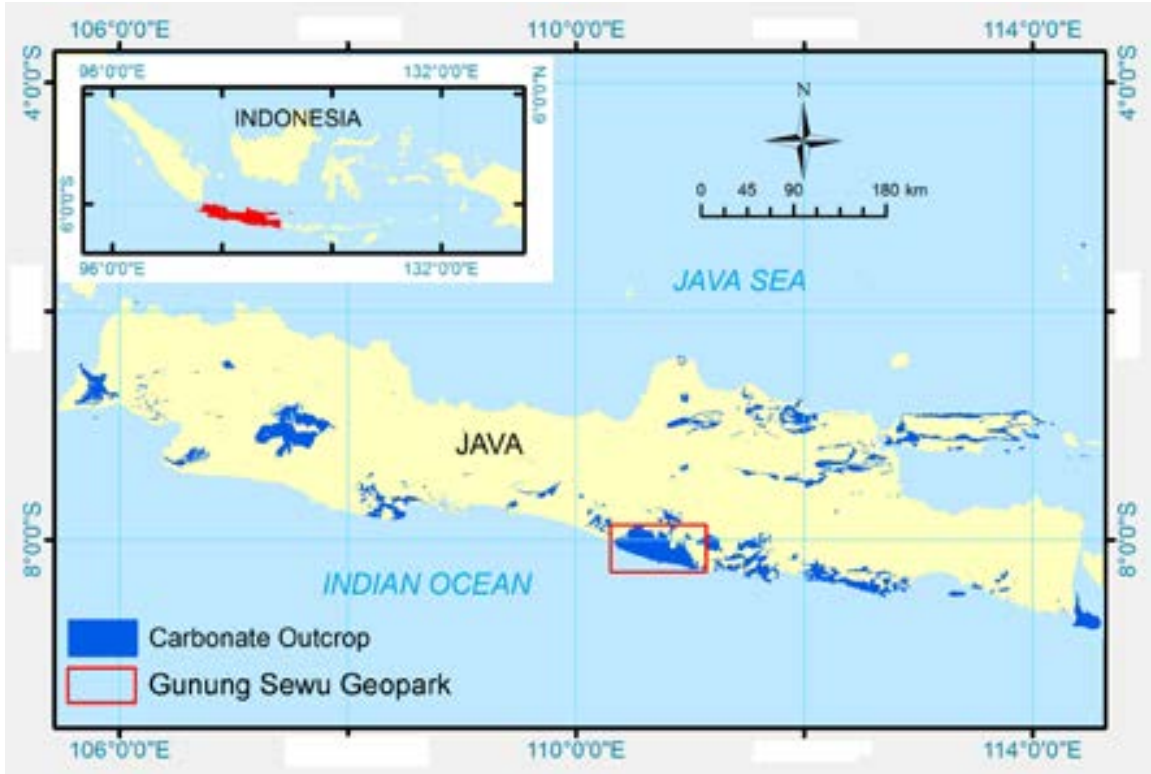

Contribuinte: Eko Haryono

Tabela 4.2. Breves considerações sobre a capacitação de pessoal de áreas protegidas.

Mapeamento Introdução à geologia da área protegida e à extensão e qualidade do mapeamento geológico geológico disponível.

Patrimônio geológico especial

\section{Segurança para os} visitantes

\section{Recursos}

\section{Monitoramento}

\section{incidentes de natureza geológica}

Planejamento sobre
Identificação da localização e natureza dos geossítios e de quaisquer operações especiais de manejo em vigor que existam para proteger esse patrimônio. Devem ser fornecidos recursos bibliográficos sobre as feições geológicas.

Descrição sobre quaisquer perigos ou fenômenos geológicos que possam provocar um problema de segurança aos visitantes. Deve ser apresentado um histórico de incidentes de segurança na área protegida, incluindo as ações tomadas para aumentar a segurança.

Descrição dos recursos utilizados (tais como materiais rodoviários), sua fonte e a adequação ao uso.

Esboço dos fenômenos geológicos que estão sendo monitorados, a base para o monitoramento e a logística associada a ele. Deve ser incluída a descrição dos custos do monitoramento e de como essa informação é utilizada.

Esboço de qualquer planejamento que esteja em vigor para lidar com possíveis incidentes geológicos. Isto deve incluir o estado em que se encontram os documentos do planejamento e cronograma para revisão. 


\section{Caixa 4.3}

\section{Sítio de Especial Interesse Científico da Floresta Petrificada de Brymbo, Wrexham, Reino Unido}

A Floresta Petrificada de Brymbo é um importante sítio paleobotânico situado perto de Wrexham no nordeste do País de Gales, Reino Unido. A característica fóssil de interesse foi descoberta em 2005, durante a recuperação de uma usina siderúrgica abandonada e compreende uma sequência de sedimentos carboníferos com $14 \mathrm{~m}$ de espessura. O rico conjunto de fósseis de plantas, muitos em posição de vida, conferem ao local um alto valor científico e geopatrimonial.

O sítio é atualmente propriedade da Brymbo Development Ltd mas existe a intenção de o transferir para o Brymbo Heritage Trust. Esta organização e os seus parceiros concentraram-se na preparação de um plano diretor para desenvolver o local em uma atração turística de classe mundial. O financiamento existente permitirá trabalhos de estabilização do patrimônio industrial e a conservação da floresta fóssil.

\section{Desafios de conservação}

Embora a classificação como Sítio de Especial Interesse Científico (SSSI) proporcione uma proteção legal, a conservação e o manejo das feições frágeis continuam sendo um desafio. O objetivo é construir infraestruturas no local para conservar e permitir a visitação de fósseis in situ. Um paleontólogo coordenador conduzirá a escavação e tem treinado voluntários para recuperar, preparar e catalogar os muitos espécimes armazenados durante a fase inicial de resgate dos fósseis.

A Floresta Petrificada de Brymbo é um exemplo de trabalho em parceria para proteger e administrar um recurso geológico frágil e finito e promover as ligações entre o geopatrimônio e o patrimônio industrial. O edifício incluirá instalações para pesquisa científica, será aberto ao público e formará a peça central de uma atração mais ampla de visitantes, olhando para séculos de herança industrial. Para mais informações, ver Appleton et al. (2015) e Roberts et al. (2016).
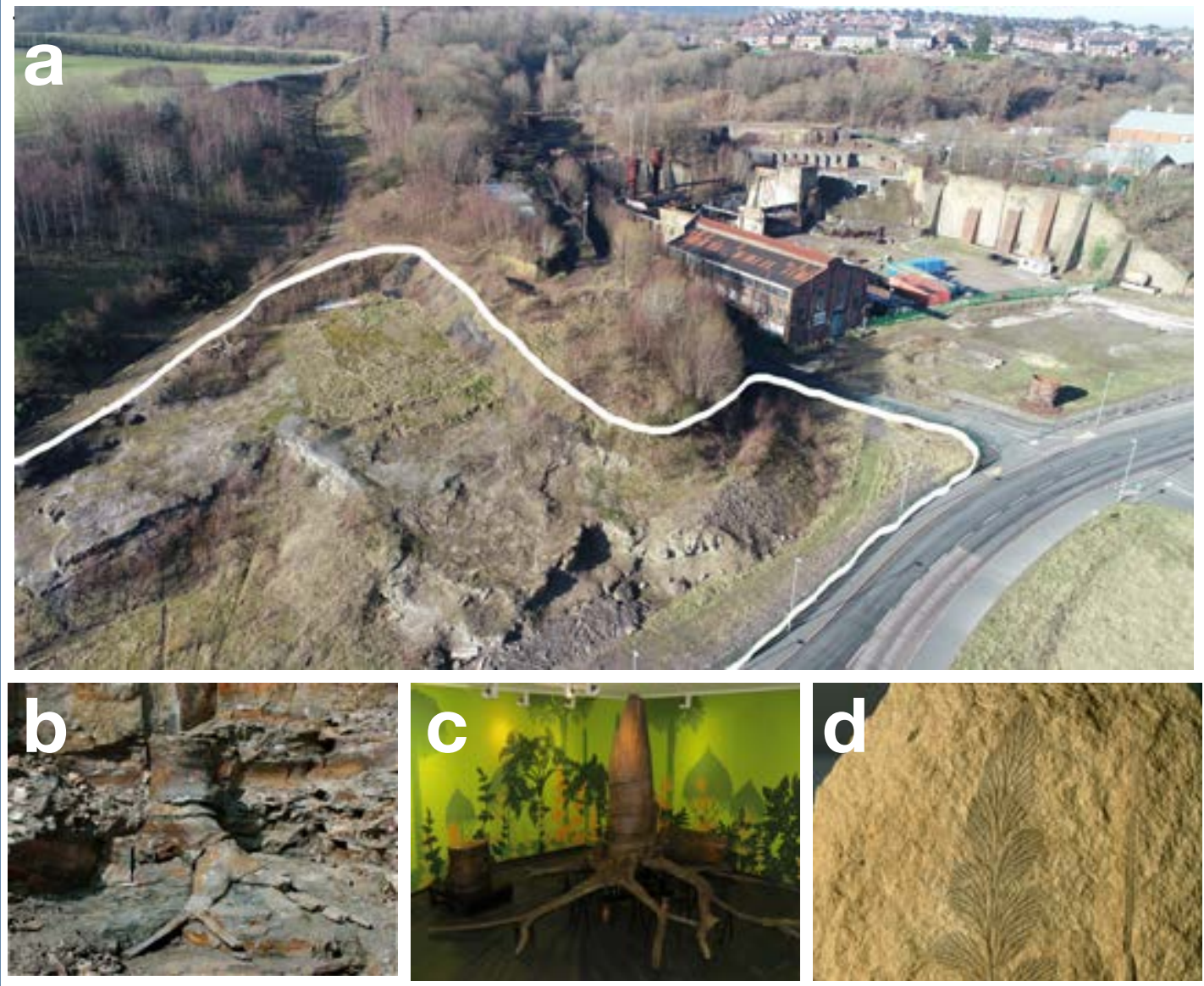

a. Vista aérea oblíqua da Floresta Petrificada de Brymbo (limites do SSSI a branco). Imediatamente ao lado está o conjunto de edifícios industriais onde se produziu ferro e aço ao longo de mais de 200 anos (c) Brymbo Heritage Trust

b. Licófita gigante in situ (C) Peter Appleton

c. A licófita em (b) resgatada do local, limpa e reconstruída em posição de vida para exposição no Museu Wrexham @ Nigel Larkin

d. Espécime de Neuropteris semireticulata (C Peter Appleton

Contribuinte: Raymond Roberts 


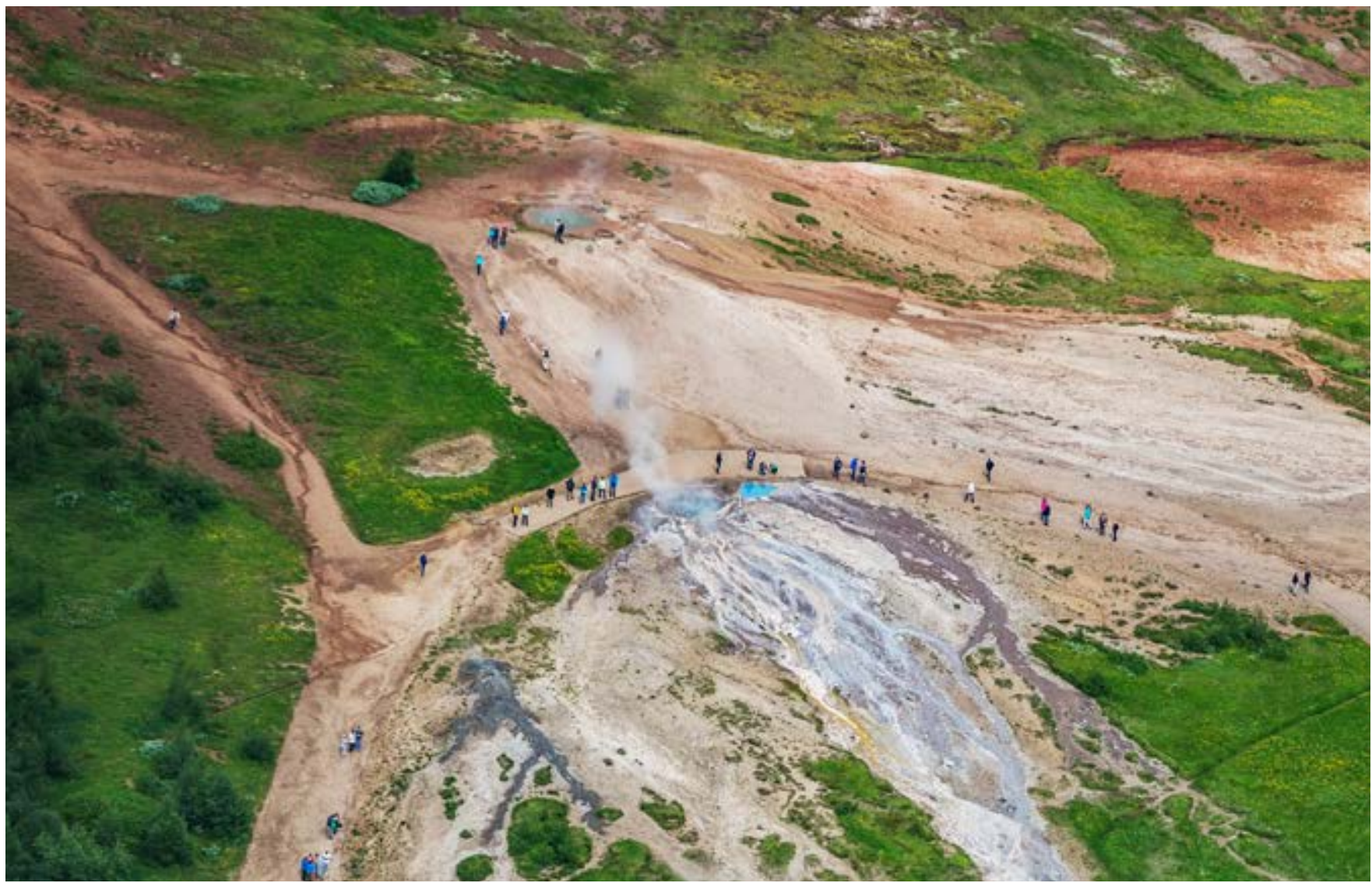

Foto 4.11 Alguns geossítios de importância internacional estão em propriedade privada, tal como se encontrava, até recentemente, o mundialmente famoso campo geotermal Geyser na Islândia. Apesar de existirem tensões administrativas, de um modo geral, a relativa resistência do sítio a sofrer danos significa que a sua integridade permanece intacta e que o acesso dos visitantes é bem regulado. (c) Ragnar Th. Sigurdsson

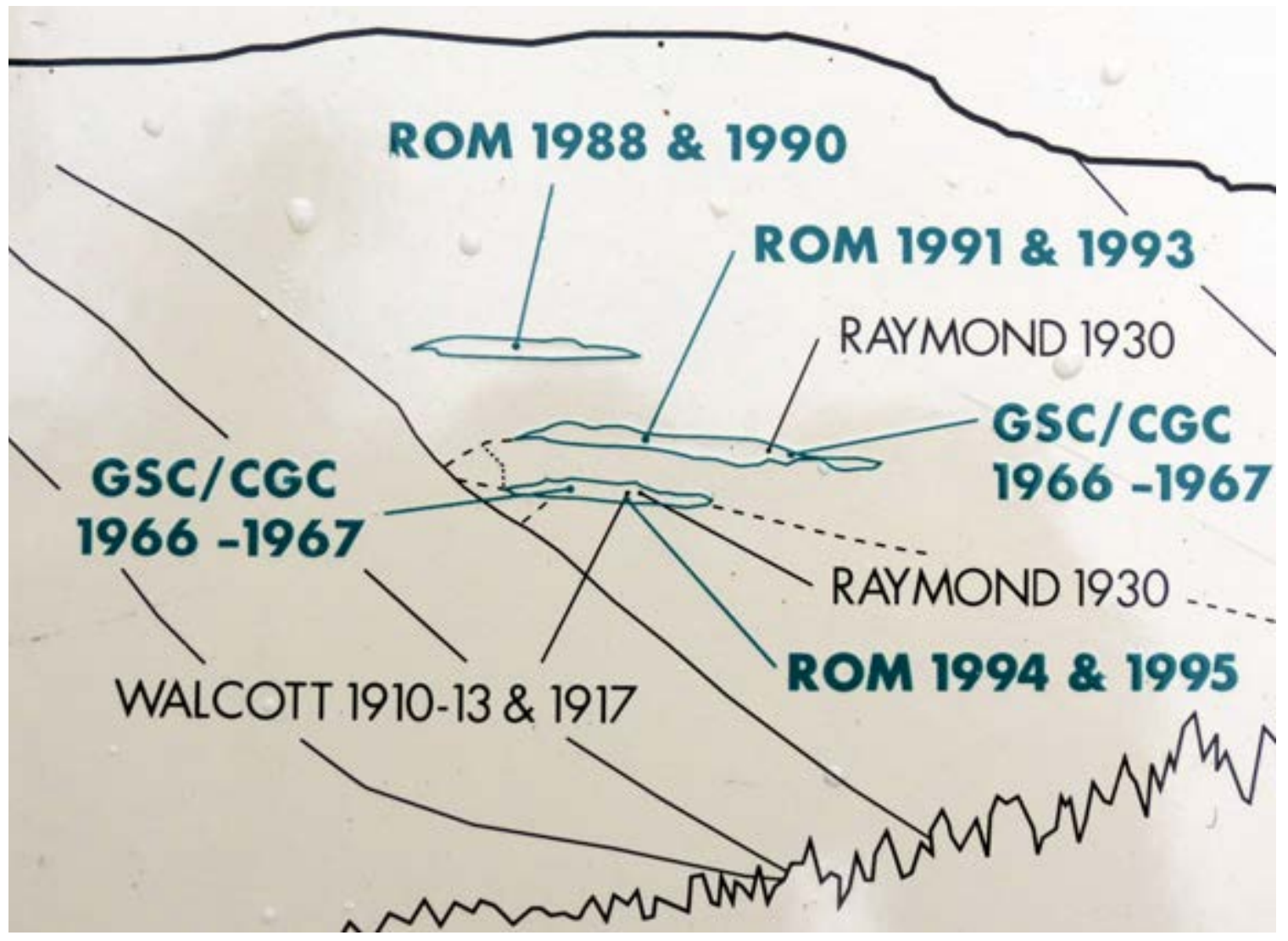

Foto 4.12 Novas mentes com novas ideias resultam em novo conhecimento que podem ser aplicados à avaliação e gestão de áreas protegidas. A foto mostra a localização de sucessivos projetos de pesquisa no Burgess Shales, Parque Nacional Yoho, Canadá. (C) Roger Crofts 


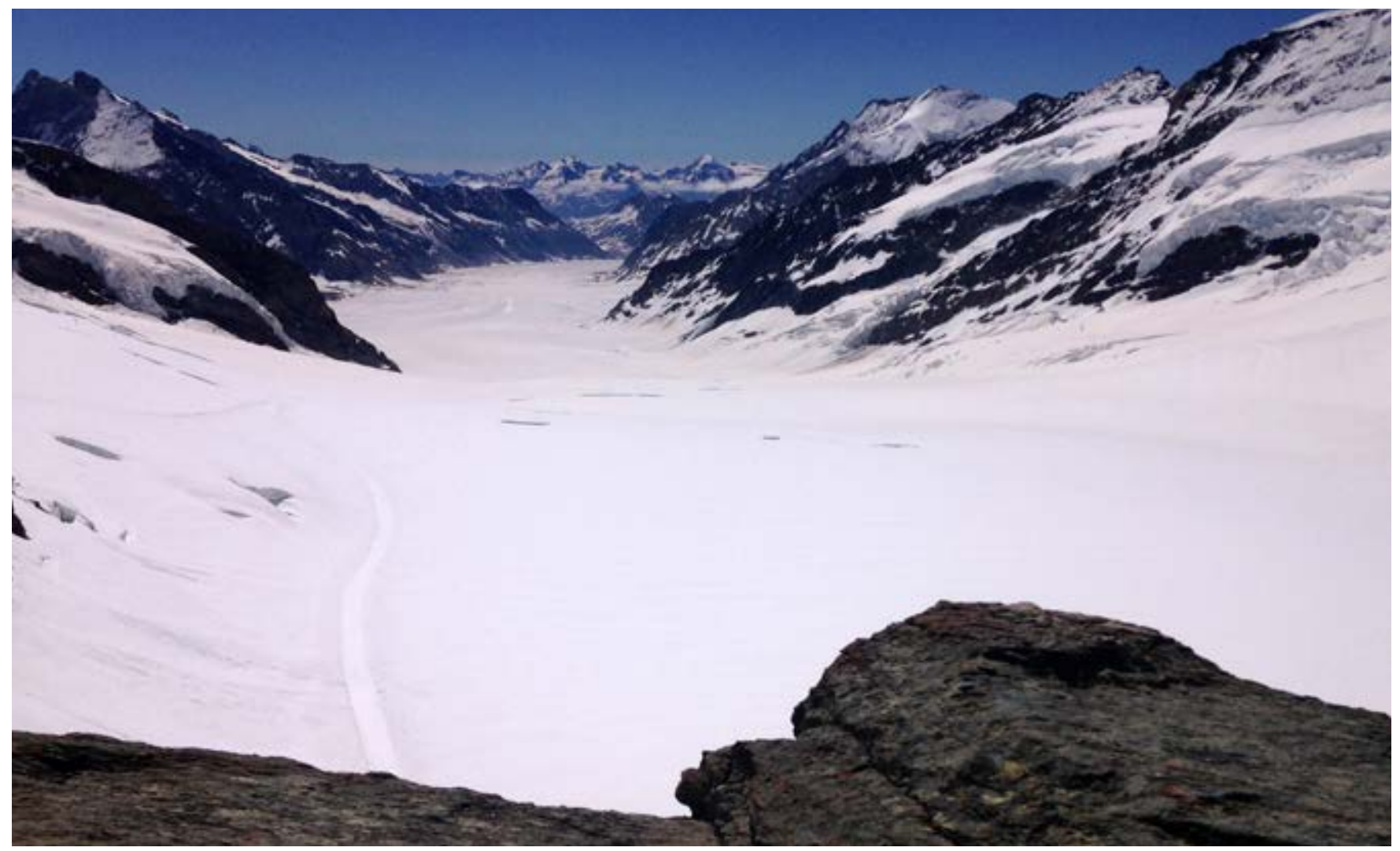

Foto 4.13 O Glaciar Aletsch é um dos primeiros sítios classificados sob o critério (viii) no sítio do Patrimônio Mundial Jungfrau-Aletsch, Suíça. @ Roger Crofts

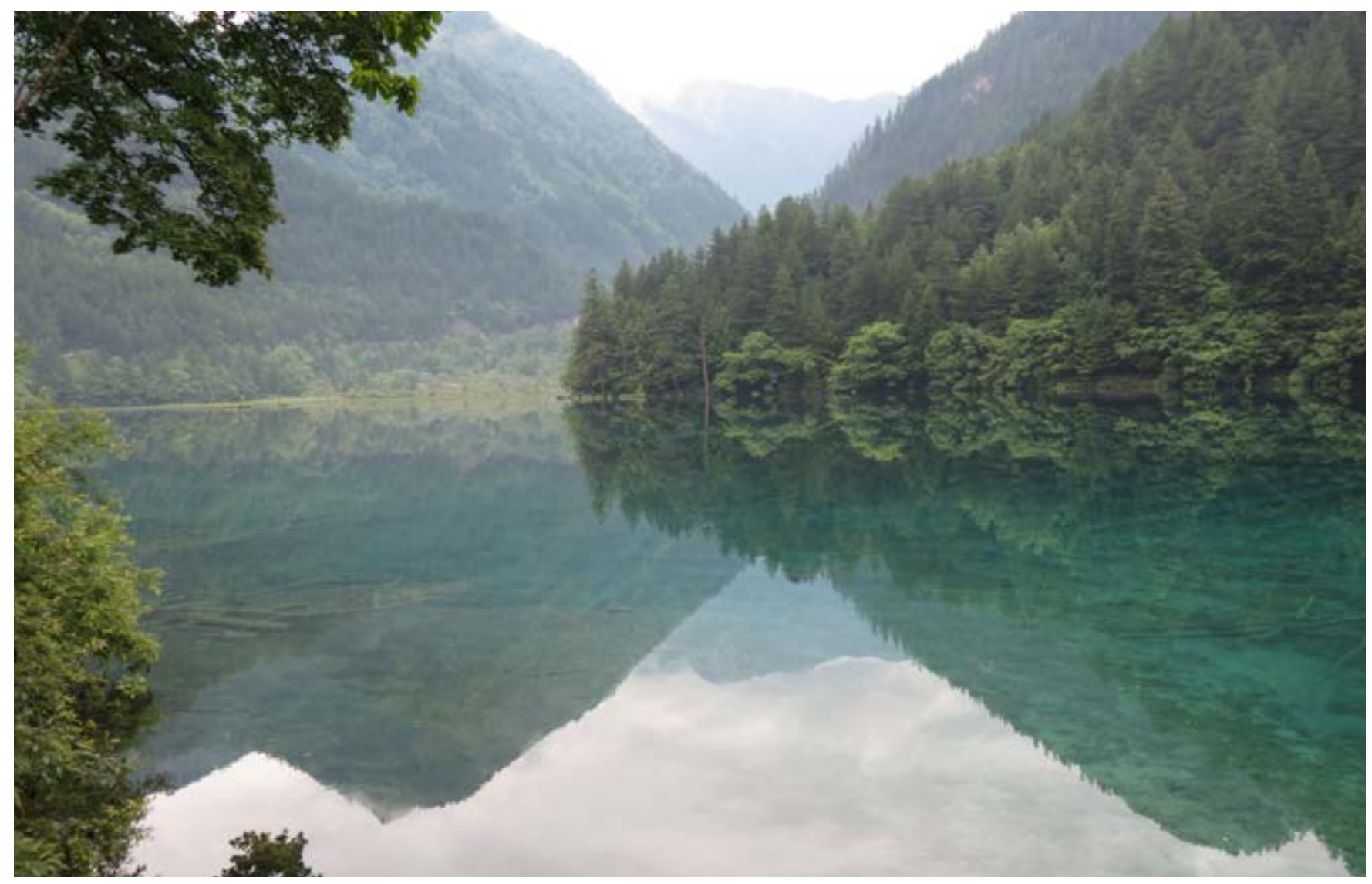

Foto 4.14 O Lago Espelho no Parque Nacional de Jiuzhaigou, China. Kishore Rao do Centro do Patrimônio Mundial da UNESCO, disse ao avaliar este local: "este é um parque nacional verdadeiramente excepcional, plenamente merecedor do enquadramento como sítio do patrimônio mundial. Estou muito impressionado com a beleza cênica e natural da área, bem como com o alto grau de atenção e comprometimento da administração". @) Roger Crofts 


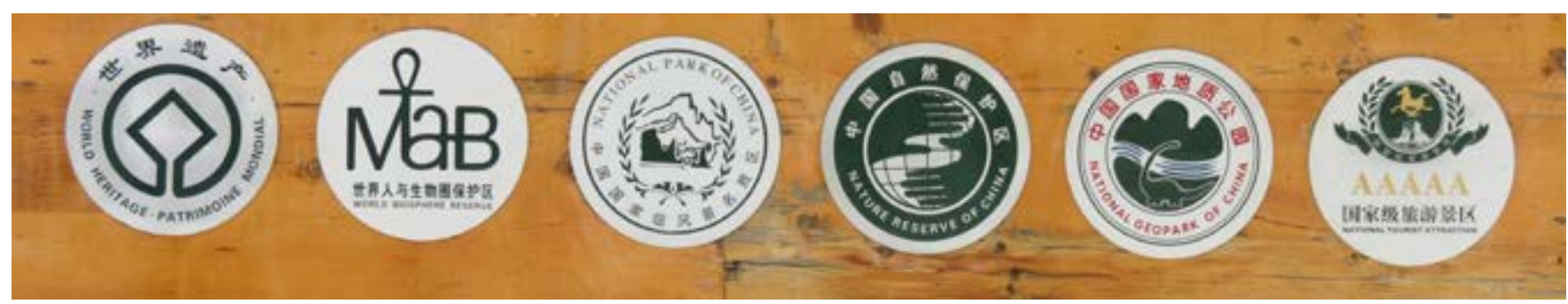

Foto: 4.15 Garantir que todas as classificações internacionais relevantes sejam atribuídas a uma área com geopatrimônio. Parque Nacional Huanlong, China. (c) Roger Crofts

os seus próprios geocientistas. É essencial, entretanto, que haja um acordo claro de que os resultados da pesquisa sejam disponibilizados aos gestores da área protegida e ao público em geral, de forma compreensível e que seja útil para o manejo da área.

A ciência cidadã (participação pública na pesquisa científica) é agora frequentemente utilizada para aumentar a capacidade de coleta de conhecimento e informações. É uma abordagem valiosa desde que haja protocolos para seu uso e para o recrutamento e treinamento de voluntários (Irwin, 2018, explicita as vantagens e desvantagens).

Com a possibilidade de contratação de novos funcionários que se podem transferir para outras áreas protegidas durante as suas carreiras, é essencial que a capacitação em geopatrimônio e geoconservação seja assegurada (Tabela 4.2).

Boa Prática $n^{\circ}$ 9: Usar especialistas para garantir a contribuição técnica ao planejamento, gestão e comunicação da geoconservação.

\subsection{Abordagens internacionais}

É importante reconhecer os instrumentos internacionais específicos que existem em apoio à geoconservação.

A Convenção da UNESCO para a Proteção do Patrimônio Mundial, Cultural e Natural enfoca o conceito de "Valor Universal Excepcional" como base para o reconhecimento dos Sítios do Patrimônio Mundial. A convenção reconhece a geodiversidade como parte da natureza através do critério (viii), que afirma que os sítios que constituem "exemplos notáveis representando as principais etapas da história da Terra, incluindo o registro da vida, processos geológicos significativos ativos no desenvolvimento de formas de relevo, ou características geomórficas ou fisiográficas significativas" podem se qualificar para Patrimônio Mundial (UNESCO, 1972).

Mais detalhes sobre a aplicação do critério (viii) podem ser encontrados no estudo temático da UICN (Dingwall et al., 2005), que analisa os diferentes aspectos da geodiversidade cobertos por esse critério, estabelece 13 temas que caracterizam como as principais ideias geológicas e geomorfológicas se traduzem na identificação de sítios. Podem ser consultadas mais informações sobre desertos em Goudie e Seely (2011), sobre cavernas e carste em Williams (2008), e sobre vulcões em Wood (2009) atualizado por Casadevall et al. (2019). Uma perspectiva geral sobre
Sítios do Patrimônio Mundial e geopatrimônio é dada por Migoń (2018).

Em 2015, os 195 Estados-Membro da UNESCO ratificaram a criação da designação Geoparques Mundiais da UNESCO para expressar o reconhecimento internacional da importância da gestão de sítios geológicos excepcionais. Os Geoparques Mundiais da UNESCO são áreas geográficas únicas e unificadas onde sítios e paisagens de importância geológica internacional são geridos com um conceito holístico de proteção, educação e desenvolvimento sustentável. Existem quatro pré-requisitos fundamentais para que uma área se torne um Geoparque Mundial da UNESCO:

- possuir patrimônio geológico de relevância internacional;

- ter um órgão de gestão legalmente reconhecido e um plano de gestão abrangente;

- ter visibilidade para promover o desenvolvimento econômico local sustentável, principalmente através do geoturismo; e

- desenvolver trabalho em rede com pessoas que vivem na área do geoparque e cooperar com outros geoparques mundiais através da Rede Mundial de Geoparques da UNESCO (GGN).

Boa Prática $n^{\circ}$ 10: Verificar se a área protegida e o geopatrimônio existente poderiam atender aos critérios para o reconhecimento pela UNESCO, sob a Convenção do Patrimônio Mundial e/ou pela Rede Mundial de Geoparques.

Além disso, a Convenção Ramsar sobre Zonas Úmidas de Importância Internacional e o Programa Homem e Biosfera da UNESCO estabelecem sistemas globais e reconhecimento global para áreas de importância para a biodiversidade (sítios Ramsar e Reservas da Biosfera, respectivamente) onde existem ligações com a geoconservação.

Boa Prática $n^{\circ}$ 11: Verificar como a geodiversidade e o geopatrimônio em Reservas da Biosfera e sítios Ramsar podem ser gerenciados para alcançar a conservação da biodiversidade e das áreas úmidas, respectivamente, juntamente com o geopatrimônio. 


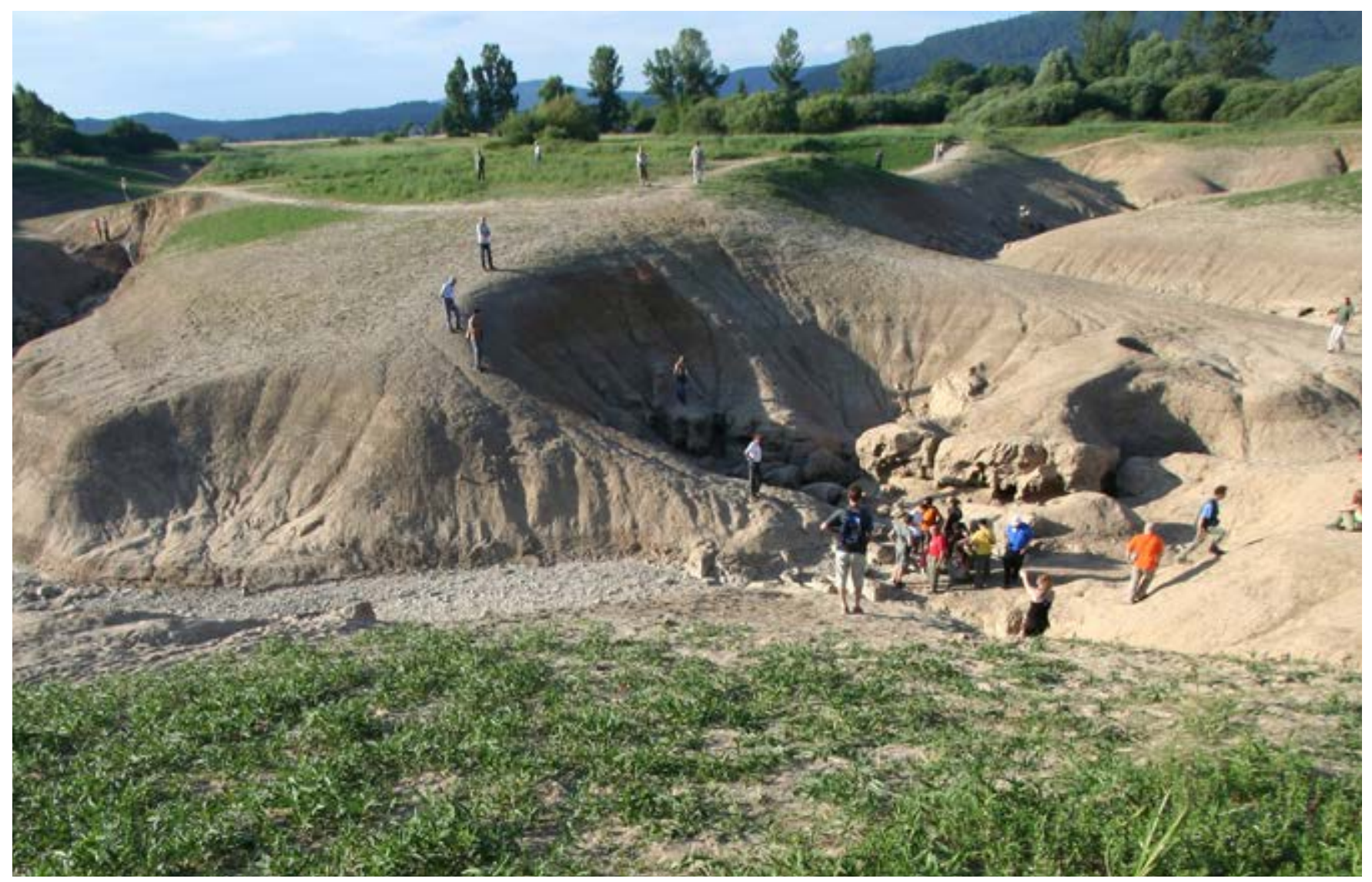

Foto 4.16 Um sítio Ramsar que é protegido devido ao geopatrimônio, representado por um lago sazonal na área mundialmente famosa de Karst, na Eslovênia. Cerknisk Jezero. ( ) John Gunn

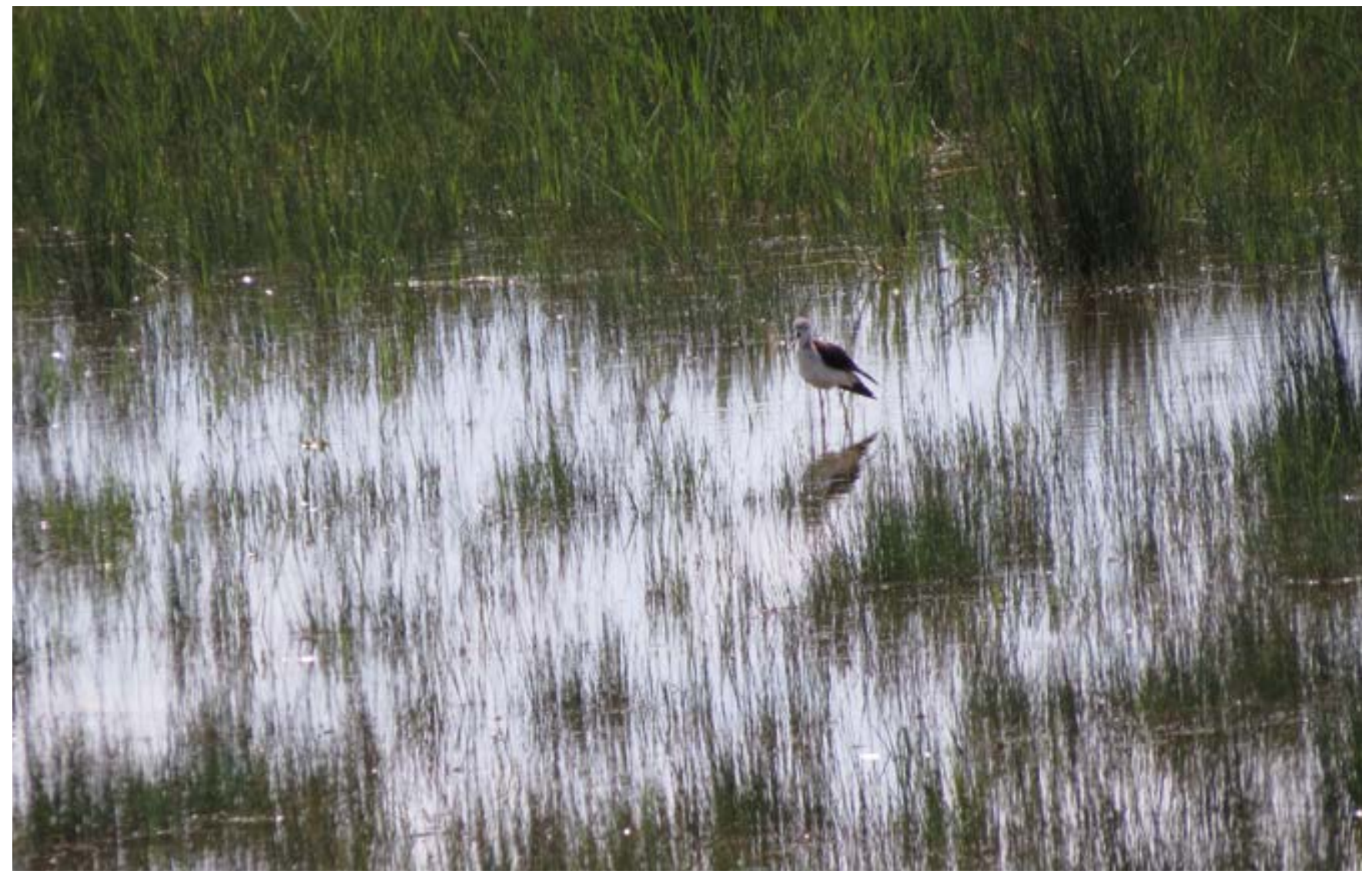

Foto 4.17 Sítio do Patrimônio Mundial, Ramsar e geopatrimônio no Parque Nacional Neusiedler See, Áustria. @ Roger Crofts 


\section{Gestão de patrimônio geológico em áreas protegidas}
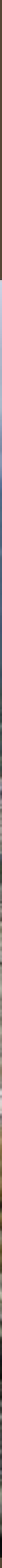

A gestão das montanhas do Parque Nacional de Rila na Bulgária é um verdadeiro desafio. A captação de água para abastecimento, existência de infraestruturas desnecessárias não adaptadas ao local e a prática de esqui, afetam negativamente o valor do geopatrimônio da área. Avaliações independentes feitas por especialistas internacionais ajudaram a administração local a focar-se em ações prioritárias. (๑) Roger Crofts 
Esta seção fornece orientação detalhada sobre todos os aspectos da gestão de geopatrimônio, incluindo planejamento de gestão, aspectos operacionais, incorporação de valores espirituais e culturais, pesquisa, monitoramento e avaliação. São abordados os seguintes temas:

planejamento de gestão (5.1)

geoconservação e ações em áreas protegidas (5.2)

u uso das categorias de gestão da UICN aplicadas ao geopatrimônio (5.3)

associação dos valores espirituais e culturais ao geopatrimônio (5.4)

[ implementação de um sistema de monitoramento e avaliação (5.5)

exemplos de manejo da geoconservação em áreas protegidas (5.6)

Esta seção se concentra na gestão do geopatrimônio, a partir de quatro pilares: planejamento, organização, liderança e avaliação. Todos esses aspectos são relevantes para a geoconservação em uma área protegida. Sugere-se aos leitores consultar Worboys et al. (2015, capítulo 8) que explicita estes pontos de forma pormenorizada.

\subsection{Integração da geoconservação em planos de manejo de áreas protegidas}

Prosser et al. (2018) apresentam uma estruturação genérica e funcional para a geoconservação. Após a inventariação dos sítios geológicos, deve ser efetuada: (1) uma análise das necessidades de conservação, que requer a avaliação do uso, caráter e ameaças/risco de degradação de cada sítio; e (2) o planejamento e execução das ações de conservação.

Essencialmente, estas duas etapas envolvem seis requisitoschave para a preparação de planos de manejo de geossítios e sua posterior incorporação nos planos de manejo da área protegida, caso se aplique, tal como propõe Wimbledon et al. (2004). Os planos de manejo dos geossítios devem ser revisados e atualizados regularmente e, quando oportuno, inseridos nos planos de ação das áreas protegidas e das OECM.
1. Inventário de sítios geológicos e caracterização dos valores principais

O geopatrimônio engloba uma variedade de elementos, incluindo exposições rochosas, formas de relevo e solos, que ocorrem numa variedade de escalas geográficas, desde pequenos afloramentos rochosos até paisagens que integram conjuntos de rochas, relevo e solos. Estes elementos devem ser localizados com precisão e documentados adequadamente em cada sítio geológico. Dependendo da dimensão do geossítio, isto geralmente será conseguido por uma combinação de levantamentos de campo, fotografias ou outros meios remotos de observação, realizados por especialistas. Esta informação deve ser apresentada de forma a que seja compreendida por não-especialistas (Caixa 5.1). O inventário e caracterização do geossítio deve incluir detalhes suficientes para catalogar e mapear a localização precisa de cada feição relevante no geossítio. É importante fornecer detalhes do substrato rochoso, com fotos e anotações, de modo que seja possível indicar aos gestores das áreas protegidas qual é exatamente o elemento de interesse e onde ele se encontra no geossítio. Em alguns casos, este pode ser um processo feito em duas etapas: inventário inicial de todos dos sítios potenciais, dentro de uma área protegida, para identificar os valores e a importância de cada

\section{Caixa 5.1. \\ Relatórios de caracterização dos geossítios e planos de manejo}

Todos os 900 geossítios identificados na Escócia como sendo nacional e internacionalmente importantes contam com uma avaliação detalhada do seu valor científico, documentada no Geological Conservation Review (Ellis, 2011). Para além disso, para auxiliar os gestores dos geossítios, proprietários e administradores, cada geossítio tem um Relatório de Documentação e uma Declaração de Gestão produzida pela Scottish Natural Heritage (SNH).

O Relatório de Documentação do geossítio identifica e descreve as principais feições do sítio. É destinado tanto aos especialistas em geociências da SNH que têm a tarefa de criar os instrumentos detalhados de gestão, como ao pessoal não especialista que vai executar as ações de manejo. Esse relatório é elaborado a partir de trabalhos de campo e é escrito em uma linguagem não-técnica ou com termos técnicos claramente explicados. Normalmente, o relatório inclui explicações simplificadas, mas cientificamente precisas, sobre as feições geológicas relevantes, um mapa geológico ou geomorfológico com a localização destas feições, fotografias com legendas explicativas e a indicação do local exato de ocorrência. O relatório também contém recomendações para o manejo e deve estar disponível para proprietários e administradores dos terrenos onde se localizam os geossítios, mas não deve ser disponibilizado online. Quando os geossítios são extensos e complexos, são produzidos relatórios mais detalhados que são integrados nos Commissioned Reports Series da SNH (ex.: Gemmell et al., 2001).

A Declaração de Gestão do geossítio é elaborada pela SNH e destina-se a proprietários, gestores ou administradores dos terrenos que têm Sítios de Especial Interesse Científico (SSSIs). Descreve as razões pelas quais um geossítio é classificado como SSSI e fornece orientações sobre como as feições naturais especiais devem ser conservadas ou objeto de melhoria. Elas incluem uma descrição simplificada das feições de interesse, uma avaliação do seu estado de conservação, um esboço das ações de gestão já efetuadas e as atuais e os objetivos de gestão para o geossítio. Estes objetivos podem ser, por exemplo, manter os afloramentos em condições favoráveis para que sejam claramente visíveis e acessíveis para fins de pesquisa e educação ou incentivar o acesso responsável do visitante ao local para fins de recreação, educação e interpretação. A Declaração de Gestão dos geossítios devem ficar disponíveis online, através da página de internet da SNH. 
Tabela 5.1. Classificação dos tipos de sítios geológicos, ameaças e objetivos de conservação habituais (Prosser et al., 2018 reproduzido com permissão).

\begin{tabular}{|c|c|c|c|c|}
\hline \multirow{9}{*}{ 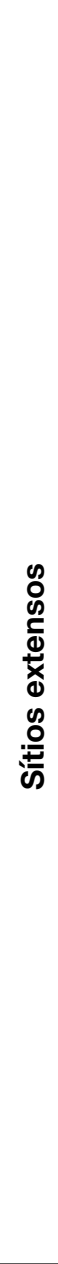 } & Tipo de sítio & $\begin{array}{l}\text { Código } \\
\text { do sítio }\end{array}$ & Ameaças & Objetivos de conservação e gestão \\
\hline & $\begin{array}{l}\text { Pedreiras e cavas } \\
\text { ativas }\end{array}$ & EA & $\begin{array}{l}\text { Obstrução das frentes das pedreiras com } \\
\text { material rejeitado }\end{array}$ & $\begin{array}{l}\text { Garantir o acesso para registro e coleta de amostras } \\
\text { Garantir recuperação do espaço mantendo a } \\
\text { observação e acesso às frentes da pedreira. }\end{array}$ \\
\hline & $\begin{array}{l}\text { Pedreiras e cavas } \\
\text { inativas }\end{array}$ & ED & $\begin{array}{l}\text { Enchimento das cavas } \\
\text { Degradação das faces expostas pelo } \\
\text { intemperismo e pela vegetação }\end{array}$ & $\begin{array}{l}\text { Manutenção das faces expostas nas cavas } \\
\text { Controle da invasão e crescimento da vegetação }\end{array}$ \\
\hline & Falésias costeiras & $\mathrm{EC}$ & $\begin{array}{l}\text { Estruturas para proteção costeira } \\
\text { Intervenções em falésias } \\
\text { Marinas e outras estruturas na costa }\end{array}$ & $\begin{array}{l}\text { Manutenção de processos naturais } \\
\text { Desencorajar a instalação de estruturas em frente ou } \\
\text { sobre falésias costeiras }\end{array}$ \\
\hline & $\begin{array}{l}\text { Seções de rios e } \\
\text { riachos }\end{array}$ & EW & $\begin{array}{l}\text { Gestão de bacias e estabilização de } \\
\text { margens } \\
\text { Represamentos } \\
\text { Invasão da cobertura vegetal } \\
\end{array}$ & $\begin{array}{l}\text { Manutenção de processos naturais } \\
\text { Controle da cobertura vegetal }\end{array}$ \\
\hline & Afloramentos & EO & $\begin{array}{l}\text { Invasão da cobertura vegetal } \\
\text { Atividades recreativas inapropriadas }\end{array}$ & $\begin{array}{l}\text { Desencorajar a instalação de estruturas sobre os } \\
\text { afloramentos } \\
\text { Controle da cobertura vegetal }\end{array}$ \\
\hline & $\begin{array}{l}\text { Afloramentos em } \\
\text { minas e túneis }\end{array}$ & EU & $\begin{array}{l}\text { Feições inacessíveis } \\
\text { Inundações e desmoronamentos }\end{array}$ & $\begin{array}{l}\text { Garantir o acesso para registro e coleta } \\
\text { Buscar soluções de longo prazo para evitar inundações } \\
\text { e desmoronamentos }\end{array}$ \\
\hline & $\begin{array}{l}\text { Feições extensas } \\
\text { no subsolo }\end{array}$ & EB & $\begin{array}{l}\text { Instalação de estruturas sobre as feições } \\
\text { enterradas } \\
\text { Práticas agrícolas que danificam os } \\
\text { elementos no subsolo }\end{array}$ & $\begin{array}{l}\text { Garantir a possibilidade de acesso aos elementos no } \\
\text { subsolo, quando necessário }\end{array}$ \\
\hline & $\begin{array}{l}\text { Corte de } \\
\text { estradas, ferrovias } \\
\text { e canais }\end{array}$ & ER & $\begin{array}{l}\text { Afloramentos encobertos por intervenções } \\
\text { para estabilização de taludes, utilizando } \\
\text { concreto ou malhas para impedir a queda de } \\
\text { blocos } \\
\text { Degradação dos afloramentos devido ao } \\
\text { intemperismo ou vegetação }\end{array}$ & $\begin{array}{l}\text { Garantir que os afloramentos sejam mantidos no caso } \\
\text { de alargamento das vias } \\
\text { Controle da cobertura vegetal }\end{array}$ \\
\hline \multirow{4}{*}{ 离 } & $\begin{array}{l}\text { Geoformas } \\
\text { estáticas (fósseis) }\end{array}$ & IS & $\begin{array}{l}\text { Extração mineral } \\
\text { Invasão da vegetação ou plantação de árvores }\end{array}$ & $\begin{array}{l}\text { Manutenção da integridade da feição } \\
\text { Desencorajar a extração mineral ou o plantio de árvores }\end{array}$ \\
\hline & $\begin{array}{l}\text { Processo } \\
\text { geomorfológico } \\
\text { ativo }\end{array}$ & IA & $\begin{array}{l}\text { Estruturas para proteção costeira } \\
\text { Estruturas para gestão de rios } \\
\text { Exploração mineral e dragagem }\end{array}$ & $\begin{array}{l}\text { Manutenção de processos naturais } \\
\text { Desencorajar intervenções em áreas que possam ser } \\
\text { afetadas no futuro pelo processo em curso }\end{array}$ \\
\hline & Cavernas & IC & $\begin{array}{l}\text { Extração mineral em minas e pedreiras } \\
\text { Poluição } \\
\text { Coleta irresponsável de espécimes } \\
\text { geológicos }\end{array}$ & $\begin{array}{l}\text { Manutenção do sistema hidrológico } \\
\text { Promover boas práticas com assoiações de } \\
\text { espeleologia }\end{array}$ \\
\hline & Carste & IK & $\begin{array}{l}\text { Mineração de diversos tipos } \\
\text { Invasão da cobertura vegetal }\end{array}$ & $\begin{array}{l}\text { Manutenção da integridade da feição } \\
\text { Controle da invasão da vegetação }\end{array}$ \\
\hline \multirow{4}{*}{ 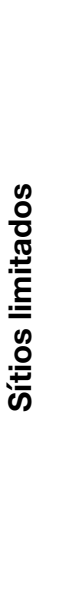 } & $\begin{array}{l}\text { Minerais, } \\
\text { fósseis ou } \\
\text { outros materiais } \\
\text { geológicos finitos }\end{array}$ & FM & $\begin{array}{l}\text { Exploração em pedreiras e mineração } \\
\text { Coleta irresponsável de espécimes } \\
\text { geológicos } \\
\text { Reconformação topográfica, corte e aterro. }\end{array}$ & $\begin{array}{l}\text { Gestão da coleta para garantir o valor científico dos } \\
\text { espécimes }\end{array}$ \\
\hline & Rejeitos de mina & FD & $\begin{array}{l}\text { Reconformação topográfica, corte e aterro. } \\
\text { Coleta irresponsável de espécimes geológicos } \\
\text { Invasão da cobertura vegetal }\end{array}$ & $\begin{array}{l}\text { Gestão da coleta para garantir o valor científico dos } \\
\text { espécimes } \\
\text { Controle da vegetação }\end{array}$ \\
\hline & $\begin{array}{l}\text { Feições finitas em } \\
\text { minas e túneis }\end{array}$ & FU & $\begin{array}{l}\text { Inundações e desmoronamentos } \\
\text { Coleta irresponsável de espécimes geológicos }\end{array}$ & $\begin{array}{l}\text { Garantir o acesso para registro e coleta } \\
\text { Buscar soluções de longo prazo para evitar inundações } \\
\text { e desmoronamentos }\end{array}$ \\
\hline & $\begin{array}{l}\text { Feições finitas no } \\
\text { subsolo }\end{array}$ & FB & $\begin{array}{l}\text { Exploração em pedreiras e mineração } \\
\text { Instalação de estruturas sobre as feições } \\
\text { enterradas } \\
\text { Práticas agrícolas que danificam os } \\
\text { elementos no subsolo }\end{array}$ & $\begin{array}{l}\text { Garantir a possibilidade de acesso aos elementos no } \\
\text { subsolo, quando necessário } \\
\text { Gestão da coleta para garantir o valor científico dos } \\
\text { espécimes }\end{array}$ \\
\hline
\end{tabular}


um deles (Seção 4.2); seguida da caracterização mais detalhada dos geossítios já confirmados na etapa inicial.

\section{Especificação dos objetivos gerais de gestão e indicadores de desempenho}

A geoconservação, bem como qualquer área protegida ou projeto de conservação, requer objetivos claros de manejo, que reflitam os diferentes tipos de interesse do geopatrimônio, seus usos potenciais e a identificação dos seus elementos principais, de modo a assegurar que as ações de manejo tenham foco e alcancem seus objetivos. Deverão ser estabelecidos objetivos específicos para cada local refletindo a orientação geral, mas direcionados para as especificidades do geossítio, como exemplificado por Wimbledon et al. (2004). Estes objetivos devem estabelecer, de modo claro, as condições mais favoráveis para o local (por exemplo, pelo menos 50\% do sítio deverá ter os afloramentos de uma determinada sequência de rochas e suas feições-chave limpas e acessíveis). Os fatores que podem afetar a condição de um local devem ser identificados (por exemplo, acúmulo de tálus, crescimento da vegetação, despejo de resíduos, danos causados pelo acesso público irrestrito). Além disso, devem ser especificados atributos mensuráveis que serão usados para desencadear uma resposta e ação de manejo (por exemplo, se menos de 70\% de um horizonte-chave não for mais visível devido à deterioração da exposição).

Na Grã-Bretanha, foram estabelecidos princípios genéricos de conservação e manejo para diferentes categorias de sítios, com uma importante distinção entre sítios extensos, vulneráveis e limitados (ou "temporários") (Tabela 5.1) (Prosser et al., 2006, 2018). O esquema se baseia na premissa de que diferentes categorias de sítios têm requisitos de conservação diferentes; por exemplo, as questões de manejo em pedreiras desativadas são diferentes daquelas para sítios costeiros. Esta abordagem pode ter ainda uma aplicabilidade mais ampla. Prosser et al. (2006) fornecem estudos de casos específicos para cada uma destas categorias.

\section{Sítios extensos}

Nos sítios deste tipo, os elementos geológicos relevantes (unidades rochosas ou depósitos sedimentares) ocorrem com grande extensão abaixo do nível do solo, de modo que se um afloramento for perdido, outra exposição pode ser criada nas proximidades. Incluem-se afloramentos em pedreiras ativas ou inativas, falésias costeiras e fluviais, cortes de estradas ou ferrovias e afloramentos naturais de rochas. O princípio básico deste tipo de sítio quanto à conservação refere que a remoção de material não danifica necessariamente o elemento geológico de interesse, uma vez que novos afloramentos do mesmo tipo poderão ser criados com facilidade. O principal objetivo de gestão para estes sítios é o de atingir e manter um nível aceitável de exposição das feições de interesse, embora a localização precisa da exposição não seja crucial. Os sítios extensos não são normalmente danificados pela atividade de pedreiras ou erosão, mas os afloramentos podem ficar inacessíveis devido a aterros, acumulação de resíduos ou crescimento da cobertura vegetal. Todavia, a perda de afloramentos pode ser compensada pela abertura de novos afloramentos nas imediações.

\section{Sítios vulneráveis}

Os sítios vulneráveis incluem tanto aspectos geomorfológicos estáticos ou inativos (por exemplo, geoformas glaciais pleistocênicas), quanto feições e processos ativos como, por exemplo, aqueles formados por processos atuais fluviais,

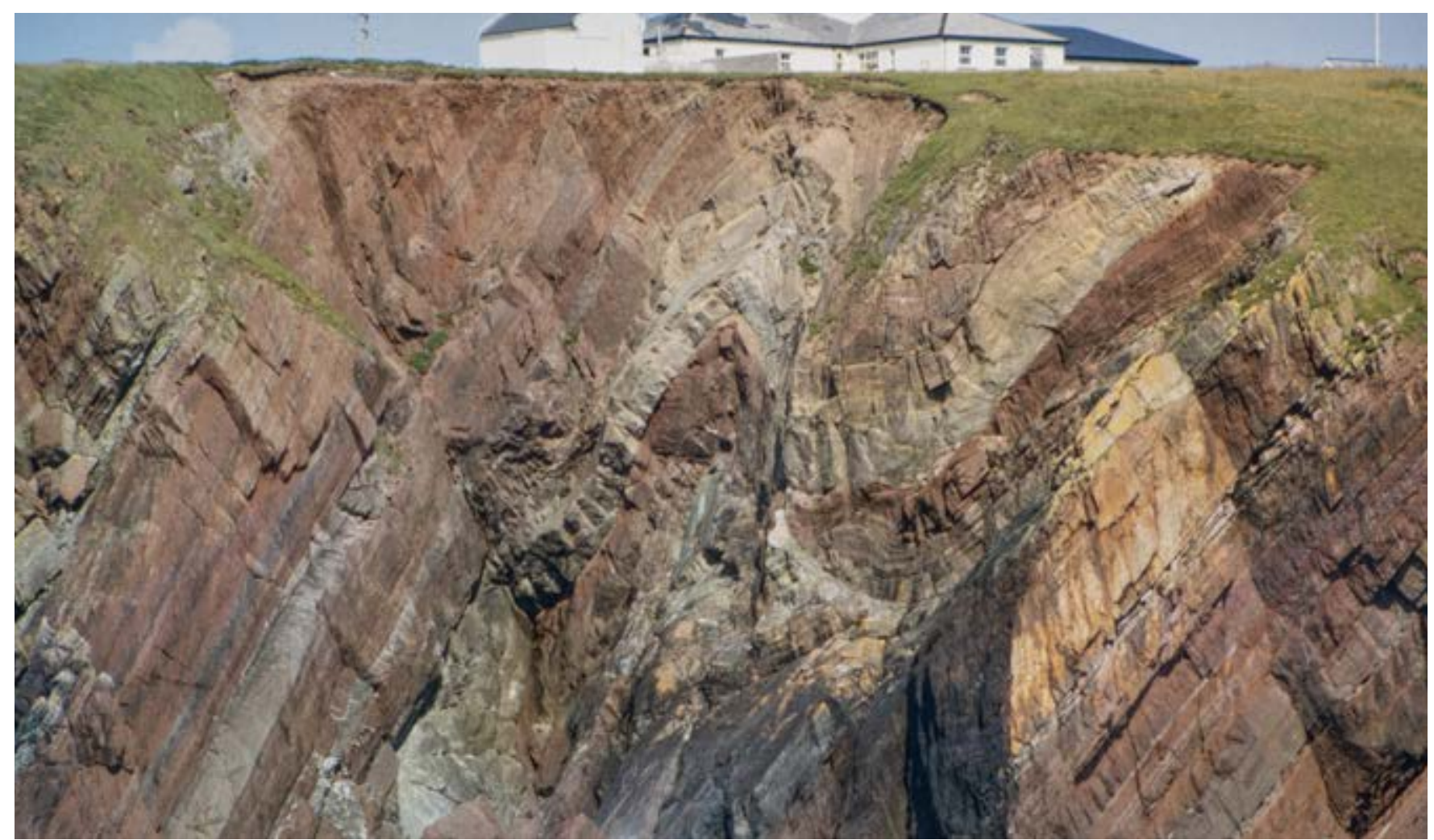

Foto 5.1 Exemplo de sítio extenso visto do mar, península de Dale, Parque Nacional de Pembrokeshire Coast, País de Gales. @ Roger Crofts 


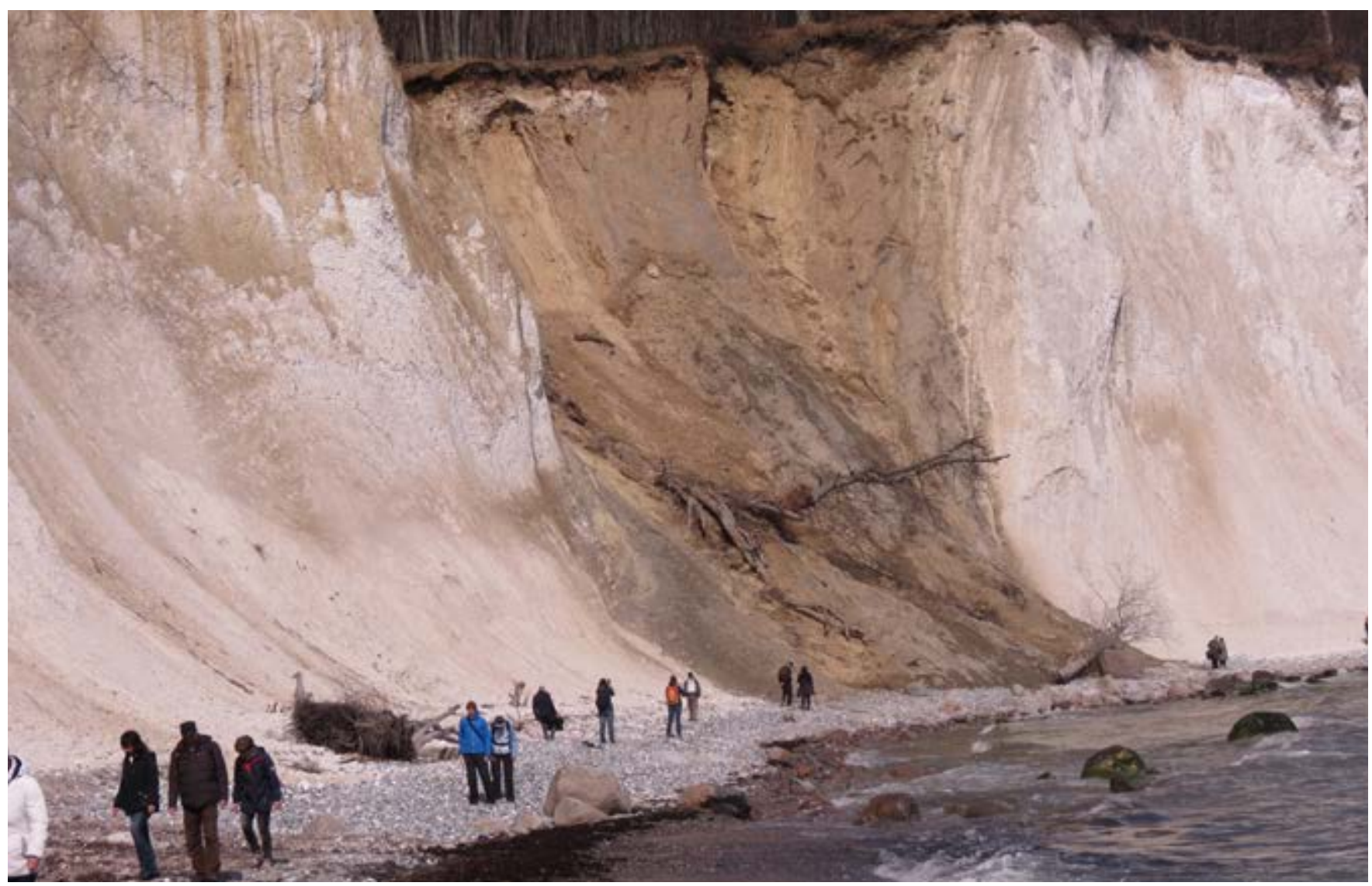

Foto 5.2 Exemplo de sítio extenso devido ao desmoronamento natural das falésias costeiras, revelando novas exposições rochosas. Parque Nacional Jasmund, Alemanha. @ Roger Crofts

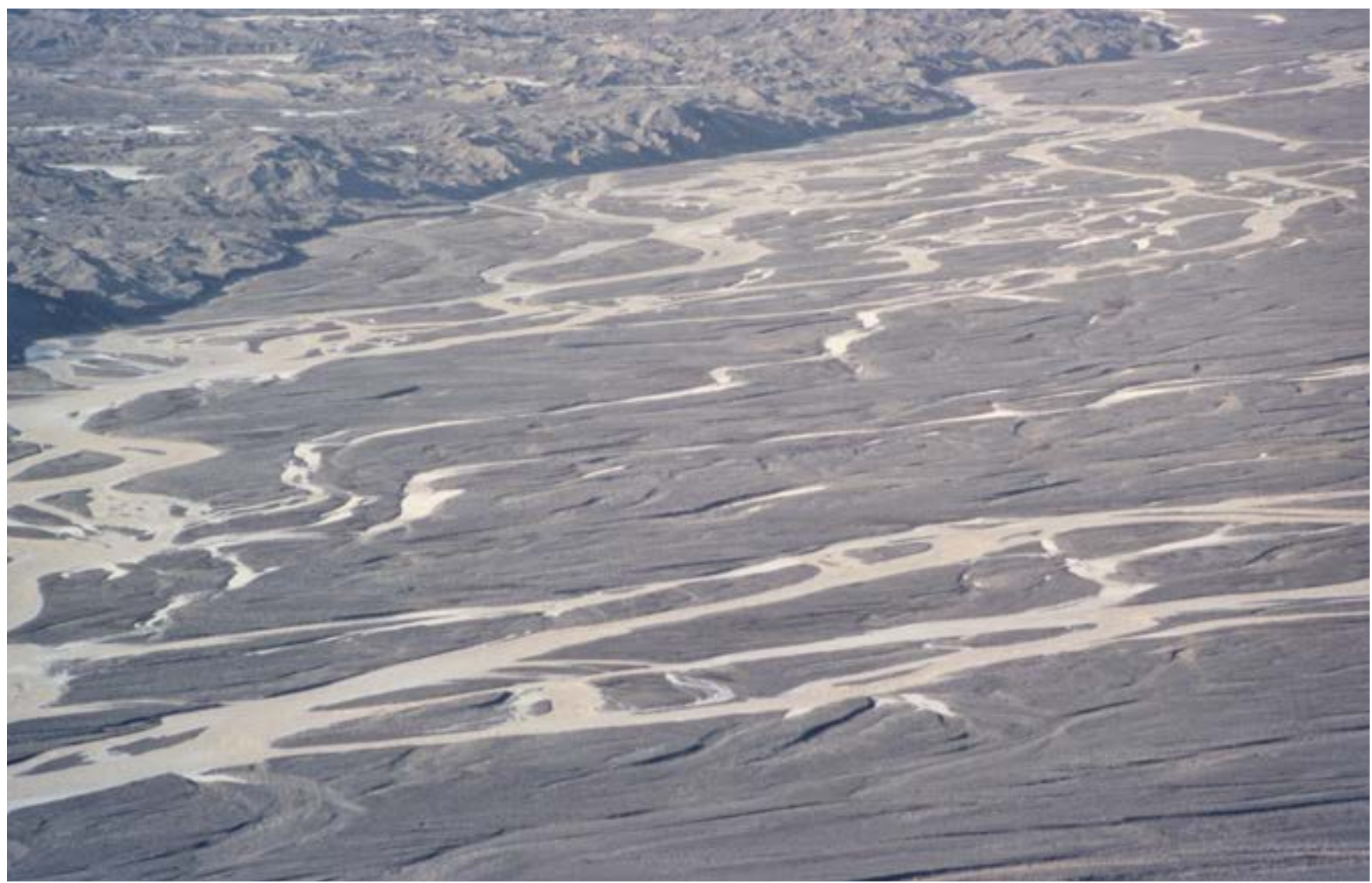

Foto 5.3 Exemplo de um sítio vulnerável ativo onde o rio glacial Jökulsá á Fjöllum emerge do glaciar Dyngjujökull. Parque Nacional de Vatnajökull, Islândia. @ Roger Crofts 
5. Gestão de patrimônio geológico em áreas protegidas

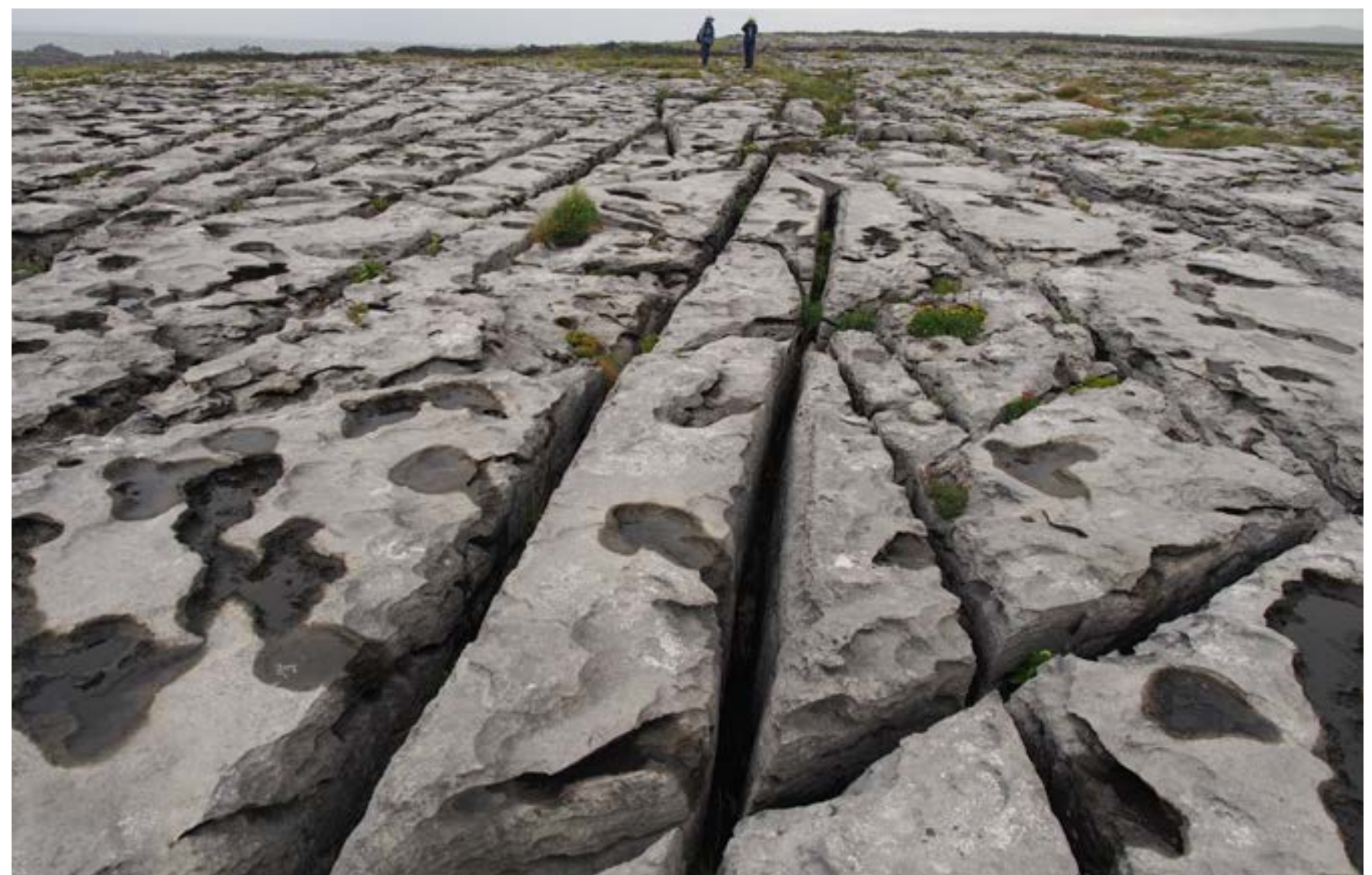

Foto 5.4 Exemplo de sítio vulnerável inativo. Pavimento de calcário próximo a Doolin no Burren e Cliffs de Moher Geoparque Mundial UNESCO e Parque Nacional de Burren, Irlanda. @ John Gunn

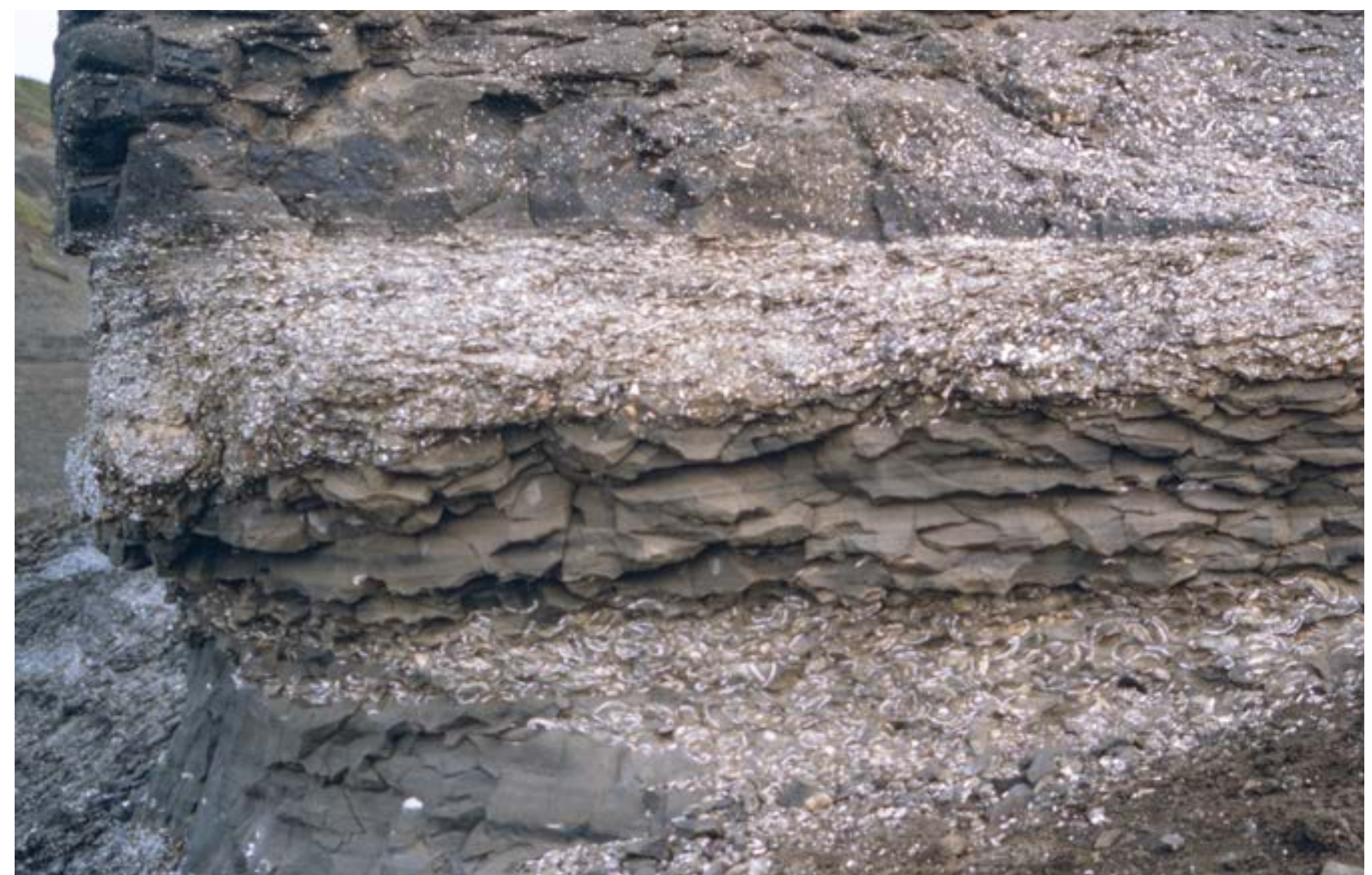

Foto 5.5 Exemplo de um sítio limitado. Ocorrência extremamente rara, na Islândia, de fósseis de plantas cobertas por lavas mais jovens. Ytritunga Tjornes, Islândia. @) Roger Crofts 


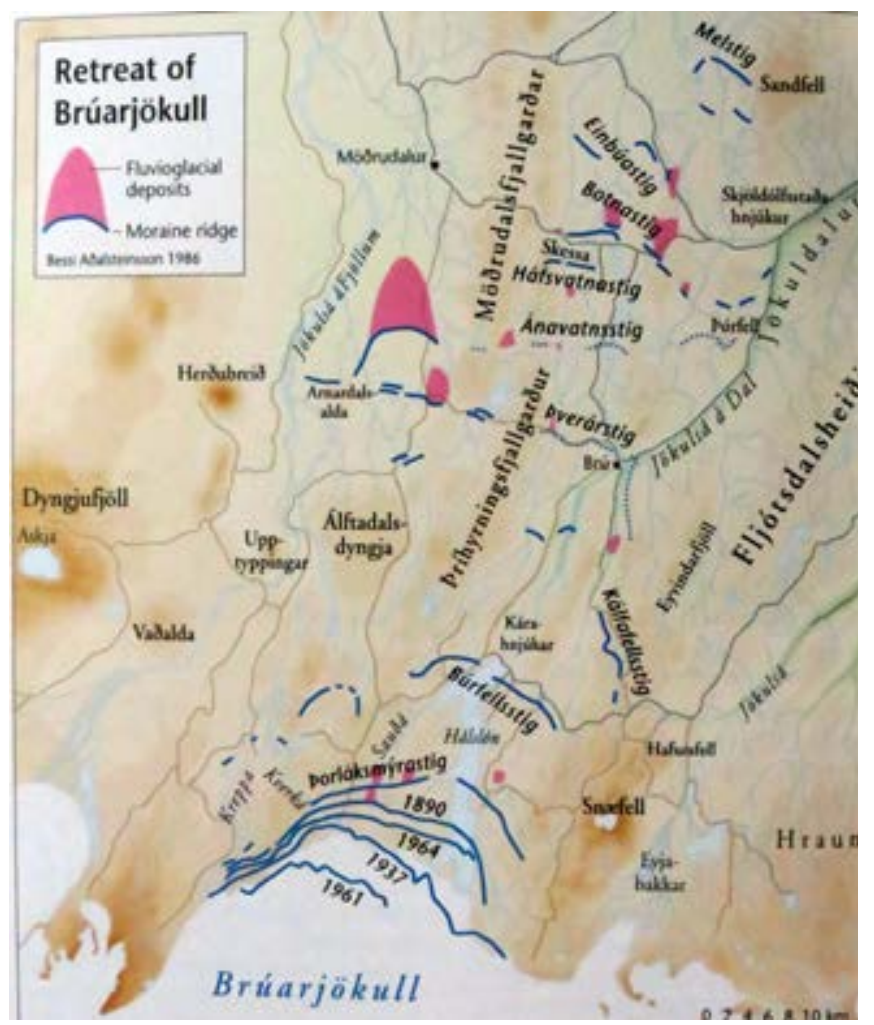

Foto 5.60 registro das mudanças naturais é importante para o planejamento e gestão de áreas protegidas. Mapas do recuo de um glaciar islandês no Parque Nacional de Vatnajökull. @ Roger Crofts

costeiros, cársticos ou glaciais. Estes sítios podem corresponder a áreas extensas e incluir conjuntos de geoformas inativas e ativas. Os danos em uma parte de um sítio vulnerável podem ter impacto sobre o valor total do sítio. O principal objetivo de gestão das feições estáticas é o de proteger a integridade do elemento de interesse: se danificadas ou destruídas, as feições não podem ser recuperadas ou substituídas, pois são únicas e os processos que as formaram não estão mais ativos. Estes sítios são também suscetíveis a danos parciais e à interrupção espacial das feições, de modo que a integridade das relações espaciais entre geoformas individuais pode ser perdida.

Geralmente há poucas opções para conciliar conservação e intervenções nestes sítios. A mitigação de danos ambientais nestes sítios dependerá das circunstâncias locais, mas pode incluir a recolocação de estruturas para evitar a perda de relevantes geoformas. Ocasionalmente, a reconstrução ou replicação de formas de relevo pode ser possível, para fins estéticos ou educacionais, embora a integridade se perca. Em outras situações, podem ser justificadas restrições de acesso ao público ou mesmo a não divulgação da existência de um sítio.

O principal objetivo da conservação de sítios vulneráveis é o de manter a possibilidade dos processos ativos seguirem seu curso natural, permitindo que decorram dentro da sua variabilidade natural em termos de velocidade e magnitude, de forma a manter a relação entre as diferentes feições (por exemplo, entre rios e suas planícies de inundação). A evolução natural destes processos pode implicar que algumas geoformas podem ser temporárias, podem sofrer modificações al longo do tempo ou podem ainda ser formadas em outro local. Por exemplo, barras de cascalho no leito de um rio podem ser destruídas em uma grande inundação, mas podem se formar novamente à medida que a descarga e o transporte de sedimentos se reajustam às condições "normais" de caudal. Os sítios onde decorrem processos ativos também são suscetíveis a sofrer alterações fora dos limites do sítio (por exemplo, através de mudanças a montante que afetam a descarga do rio e a chegada de sedimentos). Isto é mais provável que ocorra em locais com processos fluviais ou costeiros, em cavernas ou declives e suas geoformas associadas. Alguns sítios com processos ativos também podem conter geoformas inativas, que fazem parte do conjunto total de geoformas deste sítio.

\section{Sítios limitados}

Nos sítios limitados, os elementos geológicos existem em número reduzido e a sua remoção ou destruição pode implicar dano ou destruição desses mesmos sítios, como é o caso, por exemplo, de sítios com fósseis. Os sítios limitados podem ocorrer em diversas situações, como em pedreiras ativas e inativas e em seções costeiras e fluviais. Em alguns casos, os elementos geológicos de interesse podem ficar enterrados devido à dificuldade em manter afloramentos em sedimentos pouco consolidados, ou intencionalmente, como uma medida prática de conservação, para proteger elementos particularmente vulneráveis. Os sítios limitados demandam um controle cuidadoso na remoção ou perda de material. Estes sítios incluem muitos depósitos minerais e fósseis, pilhas de rejeito de minas, minas subterrâneas e elementos soterrados (locais onde se sabe que um determinado elemento ocorre sob o solo e só pode ser exposto após escavação). Geralmente, medidas de mitigação ou de deslocação das estruturas que ameaçam estes sítios raramente são possíveis. Quando um local é usado principalmente para fins de pesquisa, pode não ser prático ou necessário manter a sua exposição. Nesses casos, o acesso deve ser assegurado através de escavação, de forma a ficar disponível para estudo.

Em geral, devem-se evitar intervenções em áreas protegidas que possam danificar e prejudicar os elementos que motivaram a sua proteção. Quando uma intervenção implica danos significativos numa área protegida que não podem ser prevenidos ou mitigados adequadamente, devem-se procurar ocorrências alternativas antes de permitir a realização dessas intervenções. $\mathrm{Na}$ ausência de tais alternativas, a atividade que afetaria seriamente o sítio só deverá ser permitida quando houver razões imperiosas de sustentabilidade ou de importância nacional. Nesses casos, devem ser previstas medidas de compensação, incluindo a criação de outras exposições dos elementos de interesse deste sítio, ou ações para melhoria da condição de outros elementos geológicos de interesse em outro lugar do sítio, para manter, restaurar e sempre que possível aumentar o valor de geoconservação deste sítio ou da área protegida. A seção 6 fornece orientações mais detalhadas sobre ameaças específicas e de como lidar com elas.

\section{Análise de ameaças: Avaliação de risco e vulnerabilidade a pressões e ameaças}

Para ajudar a priorizar as ações de gestão, será necessário realizar análises de ameaças e avaliações de risco dos diferentes tipos de atividades humanas e mudanças naturais (ver seção 6 para detalhes). Os princípios e métodos da avaliação ambiental 

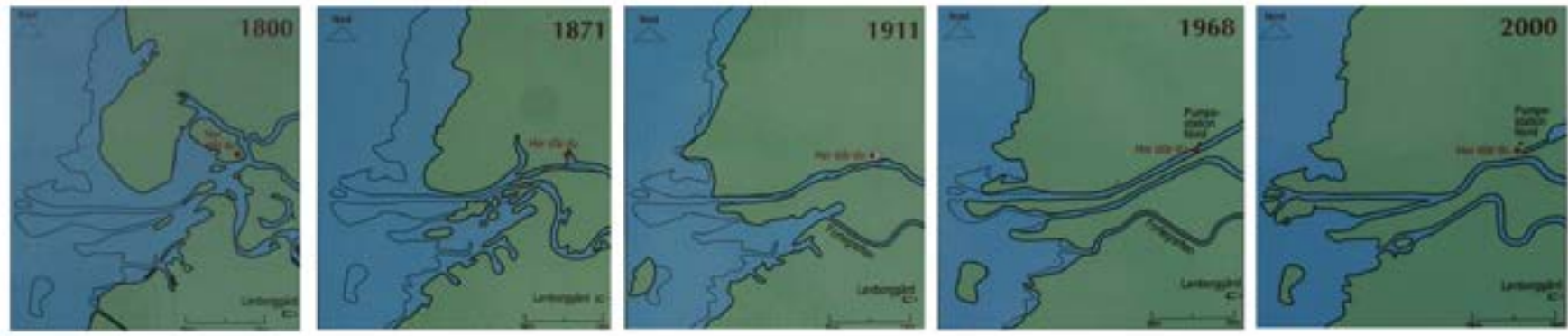

Foto 5.7 É essencial mapear as mudanças históricas que ocorrem na foz do rio para conseguir assegurar a gestão da área protegida. Parque Nacional Skjern Å, Dinamarca. @ Roger Crofts

estratégica e da avaliação de impacto ambiental, assim como a aplicação do princípio da precaução, fornecem modelos importantes para este contexto (Cooney, 2004; Cooney \& Dickson, 2005).

\section{Monitoramento sobre o estado de conservação do sítio}

O monitoramento periódico das áreas protegidas destinadas à geoconservação é essencial para conhecer qual o estado de conservação dos elementos geológicos relevantes, como este estado se altera e se as metas de conservação estão sendo atingidas. O monitoramento pode ser difícil de ser efetivado e é frequentemente ignorado, especialmente se os recursos são limitados.

Esta seção trata do monitoramento relativamente simples e rápido do estado de conservação do sítio que pode gerar informações necessárias para a sua gestão. Na seção 5.5 são apresentadas abordagens mais detalhadas sobre o monitoramento de áreas protegidas e sobre o monitoramento relacionado a questões de segurança.

Existem várias propostas sobre como fazer o monitoramento de sítios, como por exemplo na Grã-Bretanha (Werritty et al., 1998; Ellis, 2004), Espanha (García-Cortés et al., 2012) e na Tasmânia, Austrália (RPDC, 2013). O Serviço de Parques Nacionais dos EUA estabeleceu, de maneira mais específica, diretrizes para o monitoramento de elementos geológicos e paleontológicos (Santucci \& Koch, 2003; Santucci et al., 2009). Os protocolos para monitoramento precisam ser definidos, incluindo o estabelecimento de um marco de referência, uma lista de atributos-chave a serem monitorados e as metas (Tabela 5.2). Os indicadores sobre o grau de integridade dos elementos se aplicam a sítios de importância particular para a geoconservação, onde o grau de integridade física ou degradação dos sítios e suas feições foi identificado como um problema para a geoconservação; isto foi feito no exemplo da Tasmânia supramencionado. Os indicadores de integridade do processo medem o grau de integridade ou degradação dos processos geomorfológicos e pedológicos: estes processos condicionam a integridade a longo prazo dos sítios, suas feições e os sistemas de importância para a geoconservação (e para a conservação em geral). Os indicadores de integridade do processo fornecem uma medida da sustentabilidade dos processos naturais atuantes sobre as formas de relevo e sobre o solo (RPDC, 2013). Um conjunto de geoindicadores também foi desenvolvido para os parques nacionais do Canadá (Welch, 2004).
A frequência do monitoramento é determinada pelo potencial de degradação do local. O monitoramento deve ser seguido por ações corretivas apropriadas em parceria com proprietários e gestores do sítio, como parte da revisão do plano de manejo (Wimbledon et al., 2004). A fotografia é uma ferramenta importante. Por exemplo, um ciclo de monitoramento de cinco anos é, provavelmente, justificado para feições frágeis, tais como travertinos, com um ciclo muito mais longo de mais de dez anos, para feições em rochas mais resistentes.

Na Espanha, foi implementada uma nova abordagem de monitoramento e gestão de geossítios. Trata-se do programa nacional, "Apadrinha Uma Rocha", no qual voluntários se alistam para visitar anualmente os sítios e para relatar ao Serviço

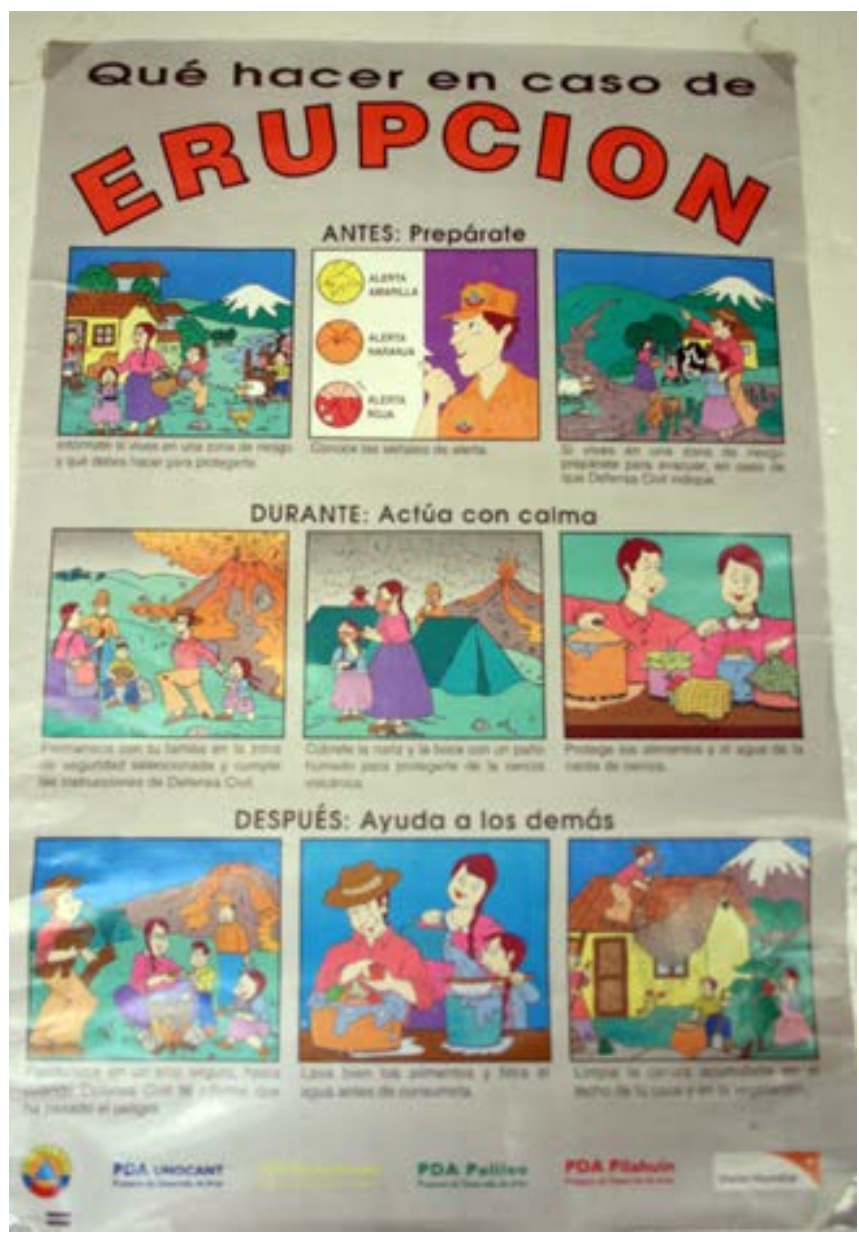

Foto 5.8 Transmitir a mensagem sobre perigos naturais, de uma maneira simples e para todos. Uma história em quadrinhos produzida pelo Parque Nacional Cotopaxi, Equador. ( Roger Crofts 
Tabela 5.2. Atributos recomendados para monitoramento de sítios e metas gerais (adaptado de Ellis, 2004; RPDC, 2013; Wignall, 2019).

\begin{tabular}{|c|c|c|}
\hline Atributo & Descrição & $\begin{array}{l}\text { Meta geral para o estado de } \\
\text { conservação favorável }\end{array}$ \\
\hline $\begin{array}{l}\text { Integridade do } \\
\text { sítio: atributos } \\
\text { físicos }\end{array}$ & $\begin{array}{l}\text { Estado físico das feições de interesse do sítio e que justificaram } \\
\text { a sua seleção, incluindo a sua integridade, ausência de danos } \\
\text { físicos ou fragmentação dos elementos. Os atributos físicos } \\
\text { das feições-chave incluem a sua extensão, composição e } \\
\text { estrutura e, quando relevante, a sua quantidade e morfologia. } \\
\text { Para sítios com processos ativos, os atributos físicos também } \\
\text { incluem a presença de geoformas e outras feições físicas (por } \\
\text { exemplo, erosão ou deposição), que indicam que os processos } \\
\text { permanecem ativos. }\end{array}$ & $\begin{array}{l}\text { Os atributos físicos das feições principais } \\
\text { e a integridade física do sítio permanecem } \\
\text { intactos e sem perturbações. }\end{array}$ \\
\hline $\begin{array}{l}\text { Integridade do } \\
\text { sítio: visibilidade }\end{array}$ & $\begin{array}{l}\text { Este atributo se refere à ausência de obstáculos (por exemplo, } \\
\text { vegetação, tálus, construções ou edifícios) dos elementos } \\
\text { principais que justificaram a seleção do sítio e se existem } \\
\text { condições de observação, em segurança, de aspectos de } \\
\text { detalhe e/ou de panorâmicas. }\end{array}$ & $\begin{array}{l}\text { As feições chave do sítio permanecem } \\
\text { visíveis em detalhe e em panorâmicas, } \\
\text { conforme apropriado. }\end{array}$ \\
\hline $\begin{array}{l}\text { Integridade } \\
\text { do processo: } \\
\text { dinâmica do } \\
\text { processo }\end{array}$ & $\begin{array}{l}\text { Este atributo é monitorado apenas para feições } \\
\text { geomorfológicas com processos ativos. Ele se refere à } \\
\text { capacidade dos processos geomorfológicos, que justificaram } \\
\text { a seleção do sítio, de evoluírem naturalmente e sem } \\
\text { obstáculos. Não deve haver restrições artificiais (por exemplo, } \\
\text { das contenções costeiras ou proteção de margens fluviais). } \\
\text { Atividades como extração de areia e cascalho também podem } \\
\text { perturbar os processos naturais e são relevantes tanto para } \\
\text { este atributo quanto para os atributos físicos. Além disso, } \\
\text { fatores externos ao local também podem afetar a dinâmica } \\
\text { do processo no interior do sítio (por exemplo, instalação de } \\
\text { represas a montante em um rio). }\end{array}$ & $\begin{array}{l}\text { Os processos geomorfológicos } \\
\text { naturais, que representam as principais } \\
\text { características do sítio, incluindo seus } \\
\text { níveis de atividade e extensão espacial, } \\
\text { não são interrompidos ou impedidos. }\end{array}$ \\
\hline $\begin{array}{l}\text { Indicadores } \\
\text { negativos }\end{array}$ & $\begin{array}{l}\text { Este atributo se refere à presença de quaisquer fatores, } \\
\text { atividades ou mudanças nas proximidades do sítio que } \\
\text { possam afetá-lo negativamente no futuro (por exemplo, } \\
\text { despejo de resíduos, crescimento de árvores ou maior erosão } \\
\text { que possa levar à necessidade de intervenções de contenção). } \\
\text { Os indicadores negativos podem ser usados para decidir se } \\
\text { é necessária uma revisão da gestão do sítio. As questões } \\
\text { que afetam os outros atributos acima referidos também são } \\
\text { relevantes aqui se for provável que exijam uma revisão do } \\
\text { manejo do sítio para evitar que se tornem questões críticas. }\end{array}$ & $\begin{array}{l}\text { Não há atividades ou mudanças } \\
\text { perceptíveis nas proximidades do sítio que } \\
\text { possam, no futuro, afetar um ou mais dos } \\
\text { atributos anteriores. }\end{array}$ \\
\hline
\end{tabular}

Geológico da Espanha sobre quaisquer ameaças ou incidentes (http://www.igme.es/patrimonio/ApadrinaUnaRoca.htm). Embora não substitua o monitoramento formal, esta abordagem pode proporcionar um alerta precoce de ameaças ou deterioração significativa do estado de conservação dos sítios.

Outro exemplo de um programa bem-sucedido é o monitoramento de sítios geológicos em áreas protegidas na Grã-Bretanha, baseado em um conjunto de padrões habituais (JNCC, 2019). Wignall (2019) fornece detalhes da metodologia aplicada ao geopatrimônio em SSSIs na Escócia, durante o período 1999-2019. Dentre os 666 elementos monitorados do geopatrimônio, 3\% foram irreversivelmente danificados, e 10\% exigiram uma ação corretiva para os reverter a um estado de conservação favorável.

\section{Identificação de zonas para facilitar a gestão}

Numa área protegida, nem todas as partes terão a mesma importância para a conservação. Assim, algumas poderão precisar de uma gestão diferenciada, desde que esta esteja em concordância com o objetivo geral de conservação da área protegida. Recomendamos o uso das Categorias de Gestão de Áreas Protegidas da UICN (Seção 5.4) como ferramenta apropriada para o zoneamento. Por exemplo, um sítio para geoconservação de Categoria III pode estar cercado por áreas muito maiores de Categorias II ou V. Na verdade, haverá situações em que, o mais apropriado, será ter elementos do geopatrimônio sujeitos a conservação dentro de uma área protegida, com múltiplas zonas nucleares e zonas tampão circundantes. A identificação e gestão de zonas centrais e zonas tampão em áreas protegidas destinadas à geoconservação, dependem do motivo específico para a classificação da área protegida e, portanto, do tipo de área protegida. É provável que haja uma diferença substancial entre a definição de zonas núcleo e zonas tampão para áreas pequenas - por exemplo, para proteger uma feição particular do geopatrimônio, como um monumento nacional - e grandes geossítios que combinam muitas feições e onde é fundamental manter o funcionamento eficaz dos processos terrestres naturais. Neste último caso, 


\section{Gestão de patrimônio geológico em áreas}

protegidas
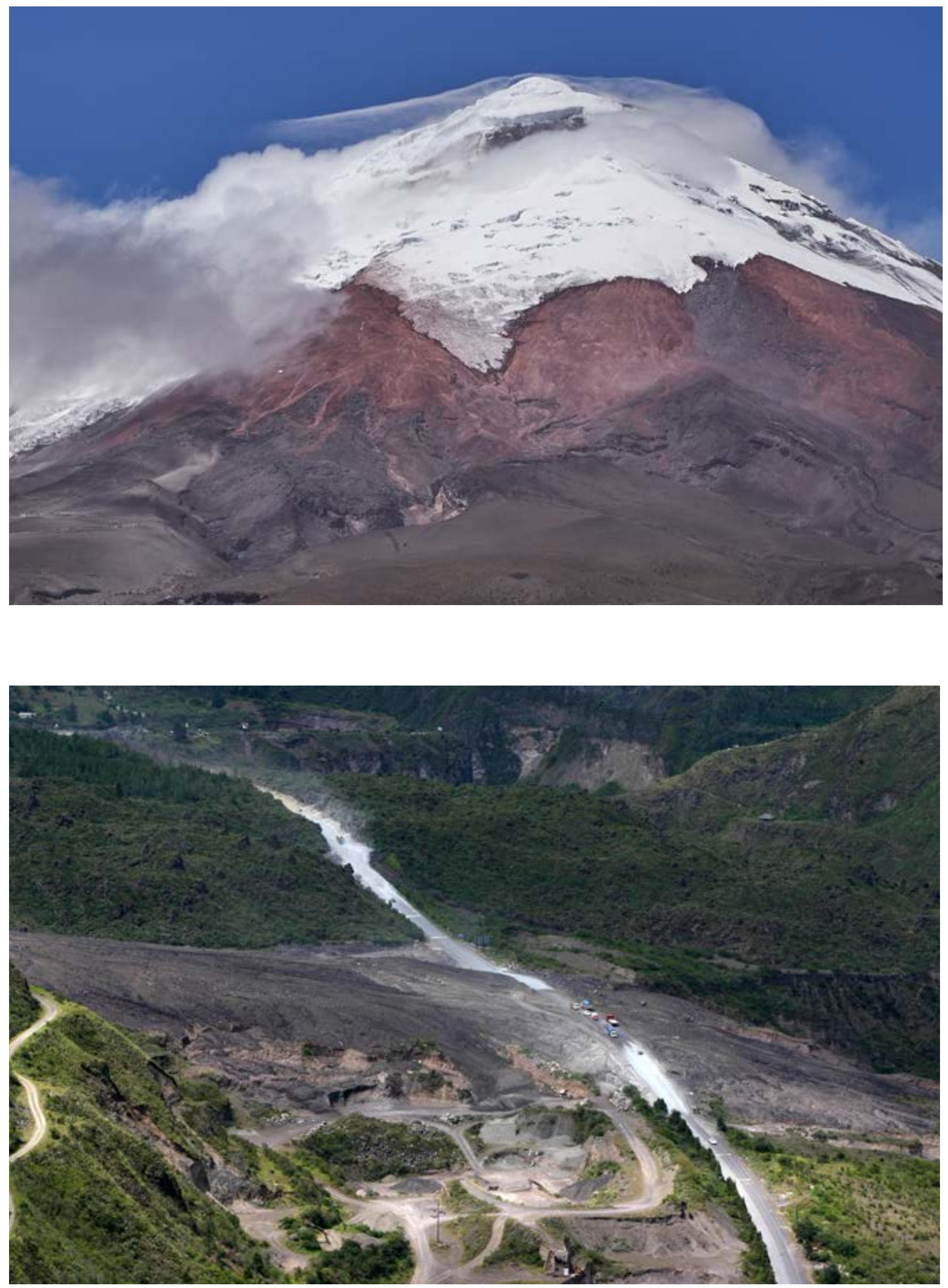

Fotos 5.9 e 5.10 Lahar, um fluxo de lama resultado de uma erupção vulcânica do Cotopaxi, Equador, causando devastação e perda de vidas humanas. 5.9 @ José Brilha 5.10 @ Roger Crofts 
Tabela 5.3. Ações em áreas protegidas que se beneficiam da existência de especialistas em geociências.

\begin{tabular}{|c|c|c|}
\hline $\begin{array}{l}\text { Ação em áreas } \\
\text { protegidas }\end{array}$ & Natureza da ação & Contribuições dos especialistas em geociências \\
\hline $\begin{array}{l}\text { Construção e } \\
\text { manutenção de } \\
\text { estradas e vias de } \\
\text { acesso }\end{array}$ & $\begin{array}{l}\text { Seleção de tipos de material } \\
\text { para estradas e trilhas }\end{array}$ & $\begin{array}{l}\text { Os materiais com proveniência fora da área protegida necessitam ser } \\
\text { avaliados quanto à sua compatibilidade ambiental e geológica dentro da } \\
\text { área protegida, sua adequação geotécnica como material rodoviário e } \\
\text { sua relação custo-benefício. Os materiais provenientes da área protegida } \\
\text { necessitam ser avaliados tanto pelo impacto de uma possível extração na } \\
\text { área protegida, quanto pela adequação geotécnica dos materiais. }\end{array}$ \\
\hline $\begin{array}{l}\text { Construção de trilhas } \\
\text { pedestres }\end{array}$ & Seleção de percursos & $\begin{array}{l}\text { É necessário ter conhecimento da fragilidade do substrato geológico } \\
\text { relativamente a possíveis danos (por exemplo, depósitos vulcânicos pouco } \\
\text { consolidados, tundra com descongelamento da superfície no verão), se a } \\
\text { superfície natural é apropriada ou se serão necessários materiais artificiais } \\
\text { (por exemplo, passarelas) e se é preferível ter percursos com um só } \\
\text { sentido ou de ida e volta. }\end{array}$ \\
\hline $\begin{array}{l}\text { Construção de trilhas } \\
\text { pedestres }\end{array}$ & $\begin{array}{l}\text { Seleção de tipos de material } \\
\text { para trilhas pedestres }\end{array}$ & $\begin{array}{l}\text { O tipo de material para trilhas pedestres deve ser adequado às técnicas } \\
\text { de construção e de manutenção da trilha. Em zonas vulcânicas, fluxos } \\
\text { sucessivos de lava de composição química distinta podem gerar tipos de } \\
\text { materiais para diferentes finalidades. }\end{array}$ \\
\hline Materiais de construção & $\begin{array}{l}\text { Seleção e uso de materiais } \\
\text { rochosos para a construção }\end{array}$ & $\begin{array}{l}\text { Os materiais rochosos com proveniência fora da área protegida devem ser } \\
\text { avaliados quanto à compatibilidade geotécnica e adequação ambiental, } \\
\text { para uso dentro da área protegida. Qualquer extração de rochas na área } \\
\text { protegida deve ser cuidadosamente analisada e sujeita a uma avaliação de } \\
\text { impacto ambiental. }\end{array}$ \\
\hline Represas de água & $\begin{array}{l}\text { Construção de represas } \\
\text { em áreas protegidas para } \\
\text { combate a incêndios ou para } \\
\text { uso da vida selvagem }\end{array}$ & $\begin{array}{l}\text { Deve ser feita uma avaliação da adequação do material geológico local } \\
\text { para a construção de represas. }\end{array}$ \\
\hline Poços de água & $\begin{array}{l}\text { Abertura de poços para } \\
\text { provisão de água para } \\
\text { consumo humano ou da } \\
\text { vida selvagem, ou ainda para } \\
\text { combate a incêndios }\end{array}$ & $\begin{array}{l}\text { Deve ser feita uma avaliação sobre a melhor localização para a abertura } \\
\text { dos poços, com base na natureza do substrato rochoso.. }\end{array}$ \\
\hline $\begin{array}{l}\text { Estruturas de controle } \\
\text { de erosão }\end{array}$ & $\begin{array}{l}\text { Construção de estruturas de } \\
\text { controle de erosão }\end{array}$ & $\begin{array}{l}\text { Devem ser disponibilizados pareceres técnicos para o projeto e construção } \\
\text { de estruturas de controle de erosão relacionados com a restauração de } \\
\text { ecossistemas ou para outros fins. }\end{array}$ \\
\hline $\begin{array}{l}\text { Segurança: } \\
\text { monitoramento da } \\
\text { estabilidade das rochas }\end{array}$ & $\begin{array}{l}\text { Monitoramento da } \\
\text { estabilidade das rochas }\end{array}$ & $\begin{array}{l}\text { Devem ser feitos monitoramentos de rotina em estruturas naturais que têm } \\
\text { problemas de segurança, como é o caso do potencial colapso de blocos. } \\
\text { Incluem-se penhascos salientes, cavernas ou acumulações instáveis de } \\
\text { blocos em vertentes íngremes. }\end{array}$ \\
\hline $\begin{array}{l}\text { Segurança: vulcões } \\
\text { perigosos }\end{array}$ & $\begin{array}{l}\text { Promover o monitoramento } \\
\text { de vulcões ativos ou } \\
\text { adormecidos }\end{array}$ & $\begin{array}{l}\text { Devem ser realizados monitoramentos de rotina em vulcões, incluindo a } \\
\text { determinação do potencial de ocorrência de erupções, em colaboração } \\
\text { com os serviços geológicos. }\end{array}$ \\
\hline $\begin{array}{l}\text { Segurança: ambientes } \\
\text { epitermais }\end{array}$ & $\begin{array}{l}\text { Promover o monitoramento } \\
\text { de gêiseres e de águas } \\
\text { subterrâneas quentes }\end{array}$ & $\begin{array}{l}\text { O monitoramento de rotina desses ambientes extremos deve ser realizado } \\
\text { para a gestão da segurança dos visitantes. Deverão ser definidas } \\
\text { responsabilidades específicas para a proteção de organismos extremófilos. }\end{array}$ \\
\hline $\begin{array}{l}\text { Segurança: fluxos de } \\
\text { lahar }\end{array}$ & $\begin{array}{l}\text { Monitoramento para alertar } \\
\text { para a ocorrências destes } \\
\text { eventos perigosos }\end{array}$ & $\begin{array}{l}\text { É necessário um monitoramento de rotina para identificar sinais da } \\
\text { ocorrência de eventos rápidos, para proteção do público. }\end{array}$ \\
\hline $\begin{array}{l}\text { Segurança: gases } \\
\text { perigosos relacionados } \\
\text { com vulcões }\end{array}$ & $\begin{array}{l}\text { Promover o monitoramento } \\
\text { de níveis perigosos de } \\
\text { gás, como o de dióxido } \\
\text { de enxofre, em zonas } \\
\text { vulcânicas }\end{array}$ & $\begin{array}{l}\text { Devem ser realizados monitoramentos de rotina em zonas vulcânicas } \\
\text { para gestão da segurança dos visitantes, em colaboração com os } \\
\text { serviços geológicos. }\end{array}$ \\
\hline $\begin{array}{l}\text { Segurança: gases } \\
\text { perigosos em cavernas }\end{array}$ & $\begin{array}{l}\text { Promover o monitoramento } \\
\text { de gases em cavernas, tais } \\
\text { como dióxido de carbono e } \\
\text { o radônio }\end{array}$ & $\begin{array}{l}\text { O monitoramento da atmosfera no interior de cavernas deve ser realizado } \\
\text { para garantir a segurança dos visitantes. Altas concentrações de } \\
\text { dióxido de carbono representam um risco à saúde e podem, em casos } \\
\text { excepcionais, atingir níveis letais. Os trabalhadores podem acumular } \\
\text { radiação pela exposição ao gás radônio. }\end{array}$ \\
\hline
\end{tabular}


Tabela 5.3. Protected area operations benefiting from Earth science expertise. (continued)

\begin{tabular}{|c|c|c|}
\hline $\begin{array}{l}\text { Ação em áreas } \\
\text { protegidas }\end{array}$ & Natureza da ação & Contribuições dos especialistas em geociências \\
\hline $\begin{array}{l}\text { Segurança: bacias } \\
\text { hidrográficas em áreas } \\
\text { de carste }\end{array}$ & $\begin{array}{l}\text { Precipitação excessiva nas } \\
\text { bacias hidrográficas }\end{array}$ & $\begin{array}{l}\text { Deve ser realizado o rastreamento das condições meteorológicas locais } \\
\text { para evitar qualquer impacto para os visitantes, incluindo espeleólogos, } \\
\text { causado por eventos extremos como chuvas intensas e fortes caudais } \\
\text { subterrâneos. }\end{array}$ \\
\hline $\begin{array}{l}\text { Segurança: atividade } \\
\text { sísmica e tsunamis }\end{array}$ & $\begin{array}{l}\text { Monitoramento colaborativo } \\
\text { da atividade sísmica }\end{array}$ & $\begin{array}{l}\text { A informação sobre a atividade sísmica é coletada para fornecer aos } \\
\text { gestores de áreas protegidas dados para prever o impacto potencial de } \\
\text { tsunamis sobre a equipe e os visitantes. Em locais vulneráveis, o risco } \\
\text { potencial de tsunamis deve ser levado em consideração no planejamento, } \\
\text { projeto e localização de trilhas pedestres costeiras. }\end{array}$ \\
\hline Mudança climática: gelo & $\begin{array}{l}\text { Monitoramento do } \\
\text { congelamento e } \\
\text { descongelamento sazonal de } \\
\text { lagos }\end{array}$ & $\begin{array}{l}\text { Deve ser realizado o rastreamento do "primeiro congelamento" e } \\
\text { "primeiro descongelamento" anual do gelo, em lagos de montanha, para } \\
\text { identificar quaisquer mudanças a longo prazo, decorrentes das mudanças } \\
\text { climáticas. }\end{array}$ \\
\hline $\begin{array}{l}\text { Mudança climática: } \\
\text { glaciares }\end{array}$ & $\begin{array}{l}\text { Monitoramento da redução } \\
\text { da dimensão dos glaciares } \\
\text { de montanha }\end{array}$ & $\begin{array}{l}\text { Deve ser feito um rastreamento da extensão e rapidez da retração dos } \\
\text { glaciares de montanha, do acúmulo de água de fusão nos lagos glaciais } \\
\text { e do potencial de inundação dos lagos, em resultado das mudanças } \\
\text { climáticas. Deve ser feita uma avaliação do risco de aumento do perigo de } \\
\text { queda de rochas e desestabilização de morenas, mediante o recuo dos } \\
\text { glaciares e o derretimento do permafrost. }\end{array}$ \\
\hline $\begin{array}{l}\text { Mudança climática: } \\
\text { mudanças nos } \\
\text { processos costeiros }\end{array}$ & $\begin{array}{l}\text { Monitoramento de mudanças } \\
\text { nas feições costeiras }\end{array}$ & $\begin{array}{l}\text { Deve ser feita uma avaliação dos efeitos da subida do nível do mar e da } \\
\text { intrusão salina, prever o efeito do potencial aumento de tempestades nas } \\
\text { feições costeiras, incluindo o aumento do risco de queda de blocos ou } \\
\text { deslizamentos de terra em falésias costeiras, como base para possíveis } \\
\text { respostas de gestão. }\end{array}$ \\
\hline
\end{tabular}

devem ser considerados os processos abióticos a uma escala maior e ecossistêmica. Por exemplo, a conservação das feições de um vale fluvial devido à importância da biodiversidade e da geodiversidade não pode ser conseguida sem assegurar que o caudal a montante da área protegida não seja radicalmente alterado de forma não natural ou significativamente perturbado pela atividade humana. Da mesma forma, no caso de elementos geomorfológicos, como cavernas, a gestão das atividades humanas na bacia hidrográfica, de maneira mais ampla, pode ser necessária para salvaguardar os elementos de interesse nos sistemas de cavernas, a jusante.

\section{Avaliação do potencial para interpretação, valorização e geoturismo}

Como parte da valorização, interpretação e educação, a gestão da visitação em sítios vulneráveis deve incluir uma avaliação apropriada do risco e da capacidade de carga (ver seção 8 para mais detalhes). Nem todos os geossítios são apropriados para o geoturismo, por exemplo, devido à fragilidade do elemento de interesse, riscos específicos ou outras restrições de manejo. Alguns locais serão muito frágeis como, por exemplo, aqueles com fósseis e minerais raros que precisam de proteção contra as atividades de coletores comerciais e de coleta irresponsável, o que pode prejudicar o interesse científico e reduzir as oportunidades para mais pesquisas. Outros locais podem ser vulneráveis ao pisoteio, o que prejudicará e talvez destrua elementos frágeis, tais como lavas recentes. Gerenciar o acesso através da necessidade de autorização prévia ou pela possibilidade de apenas ser possível fazer visitas guiadas são formas óbvias de lidar com elementos frágeis, tal como é habitual para os gestores de áreas protegidas. Quando há um valor cultural e/ou espiritual em um sítio, também é necessário manter a possibilidade de acesso tradicional. No caso de sítios com processos ativos, ou onde a mitigação dos riscos para os visitantes é impraticável, é essencial fazer uma avaliação do risco acrescido, assim como a implementação de ações apropriadas, incluindo a exclusão ou redirecionamento dos visitantes, e a gestão das suas expectativas (ver seções 5.3, 5.6, e 6.4).

\section{Boa Prática $n^{\circ}$ 12: Seguir a estrutura genérica das duas etapas na análise das necessidades de conservação e do planejamento e execução da conservação, para incorporar a geoconservação nos planos de manejo de áreas protegidas.}

\subsection{Geoconservação e ações em áreas protegidas}

As ações de gestão para uma área protegida são descritas em detalhe em Jacobs et al., 2015, que incluem diretrizes sobre programação, planejamento e execução dessas ações. As ações são descritas como a "implementação tática de projetos associados a programas estrategicamente focados" que, basicamente, cobrem a maioria das ações em uma área protegida. A compreensão dos valores das geociências é especialmente importante durante as etapas de planejamento de uma ação. A maioria dos funcionários de nível superior das áreas protegidas tiveram algum treinamento básico em geociências, seja na escola secundária ou como uma matéria da graduação. Alguns guarda parques podem ter alguma formação em geociências e trabalhar com botânicos, zoólogos, antropólogos e outros colegas especialistas em áreas protegidas. Há muitas áreas operacionais onde seus conhecimentos geológicos e treinamento podem ser usados (Tabela 5.3). 
Tabela 5.4. Geopatrimônio e as categorias de gestão de áreas protegidas da UICN.

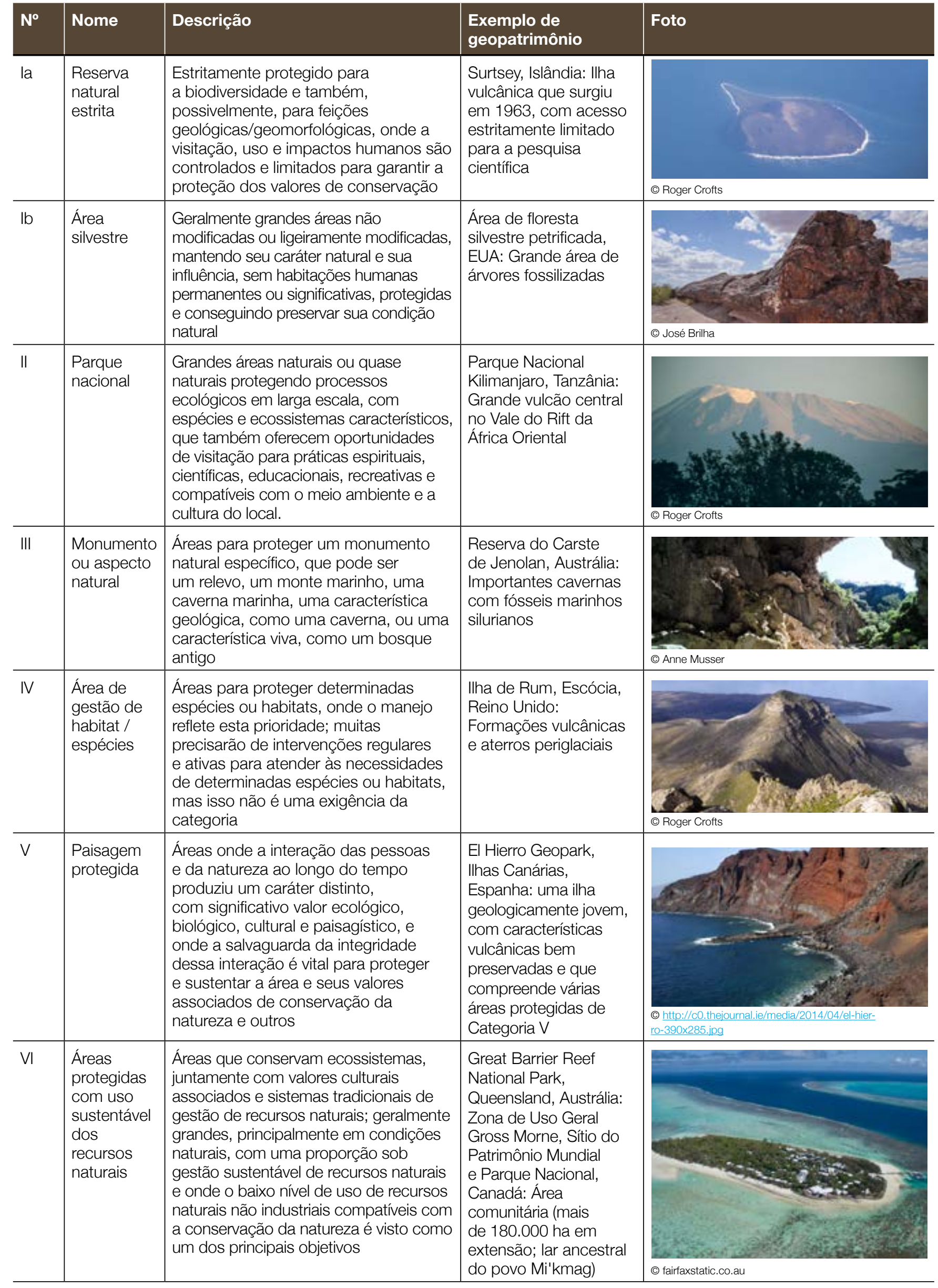


Boa Prática $n^{\circ}$ 13: Utilizar uma abordagem sistemática para orientar as operações de gestão, incluindo a adequação de materiais para trilhas e edifícios, as questões de segurança relacionadas com os principais perigos e os efeitos das mudanças climáticas.

\subsection{Aplicação das categorias de gestão de áreas protegidas da UICN à geoconservação}

A UICN identifica seis categorias de áreas protegidas (uma delas com uma subdivisão), dependendo de como a área é administrada; Dudley (2008) apresenta a base para a definição destas categorias e Stolton et al. (2013) fornecem mais detalhes. Pode ocorrer patrimônio geológico de grande relevância em qualquer uma destas categorias de áreas protegidas (Tabela 5.4).

As áreas protegidas importantes para a geodiversidade e para o geopatrimônio existem em todas as categorias, embora algumas destas categorias de gestão sejam mais habitualmente aplicadas a áreas exclusiva ou, principalmente, criadas pela sua importância geológica ou geomorfológica. A categoria la, de natureza estrita, pode ser uma opção para sítios com geopatrimônio muito frágil. As rochas e geoformas são, por vezes, mais frágeis do que a vegetação, pois uma vez degradadas, são mais difíceis de serem substituídas. A proteção de camadas com fósseis importantes para o conhecimento da história da Terra, pode ser feita através da criação de reservas da categoria la, onde os visitantes só têm acesso por trilhas restritas ou passarelas. Alguns grandes parques nacionais de categoria II são criados, principalmente, pelo seu geopatrimônio. A categoria III monumento nacional - provavelmente será útil para geossítios porque é geralmente atribuída a sítios com uma característica peculiar, como uma caverna, uma formação rochosa ou um afloramento com minerais. A categoria IV, destinada a proteger espécies e habitats, geralmente pode não ser tão adequada para geossítios, mas pode, no entanto, incluir afloramentos rochosos, penhascos ou outras feições que sejam habitats; áreas com minerais particulares, solos ou tipos de rochas (por exemplo, calcário) que suportem habitats e espécies especializadas; ou geoformas e processos geomorfológicos que suportem uma diversidade de habitats e espécies. Paisagens protegidas e áreas de uso sustentável (categorias V e VI, respectivamente) também são menos propensas a serem utilizadas para sítios dedicados, principalmente, à geoconservação, embora possam ser adequadas em casos onde a geologia ou o uso tradicional de rochas ou minerais, por exemplo, tenha contribuído para o desenvolvimento de uma paisagem cultural.

De uma forma geral, áreas protegidas com muitos valores e que também incluem, por coincidência, geopatrimônio, podem ter qualquer categoria. O Parque Nacional Thingvellir, Islândia (categoria II), é uma área onde as placas tectônicas norteamericanas e eurasiáticas estão se afastando, mas também tem um enorme valor cultural na Islândia como cenário do primeiro parlamento, o Althing, e por esse motivo está inscrito na Lista do Patrimônio Mundial (ver foto 4.6). A Ilha de Rum, Escócia (categoria IV), foi inicialmente estabelecida como reserva natural pelos valores únicos do seu geopatrimônio, mas é também uma colônia de reprodução de importância crítica para a pardela-sombria (Puffinus puffinus) e tem uma importante e muito estudada manada de cervos vermelhos selvagens (Cervus elaphus). A Zona Vulcânica de la Garrotxa, Espanha (categoria V), tem uma paisagem única de vulcões extintos, ao lado de seu importante papel na conservação de paisagens culturais tradicionais e vida selvagem associada.

Algumas das mais belas paisagens naturais do planeta são marcadas por espetaculares formações geológicas ou fenômenos geomorfológicos e muitas delas são áreas protegidas. Por exemplo, o monumental Parque Nacional Torres Del Paine de 180.000 hectares no sul do Chile é uma paisagem glaciar exemplar, que expôs um espetacular lacólito granítico branco, coberto por uma rocha sedimentar metamorfizada. Outras áreas protegidas que têm características geológicas impressionantes, como o Parque Nacional Uluru-Kata Tjuta na Austrália, o Parque Nacional Sagarmatha (Monte Everest) no Nepal, o Parque Nacional Tongariro na Nova Zelândia e o Parque Nacional Los Glaciares na Argentina, estão inscritas na Lista do Patrimônio Mundial.

Na perspectiva da geoconservação, as seis categorias de gestão de áreas protegidas da UICN permitem determinar como um determinado sítio poderia ser melhor administrado para maximizar o seu potencial, sem destruir os valores para os quais foi selecionado. Em sítios com diversos tipos de valores, pode ser uma forma de recordar aos gestores a importância de considerar o conjunto completo de valores.

\section{Boa Prática n 14: Avaliar a relevância de cada uma das categorias de gestão de áreas protegidas da UICN no estabelecimento de novas áreas protegidas para geoconservação ou na melhoria da gestão das existentes, de modo a incluir a geoconservação.}

\subsection{Incorporação dos valores espirituais e culturais do geopatrimônio}

Os valores culturais e espirituais, que em muitas culturas são indistintos, têm sido relacionados a aspectos geológicos em todo o mundo (ver Verschuuren et al., no prelo, para detalhes). Durante grande parte da história humana, os valores dominantes atribuídos ao que, atualmente, é considerado geopatrimônio, têm sido basicamente culturais e espirituais. Este também é o caso dos valores relacionados com o uso de materiais extraídos, tais como rochas, minerais ou pedras preciosas.

O simbolismo cultural e espiritual das rochas e pedras - tais como monólitos ou megalitos - é extraordinariamente rico e diversificado em toda a Terra. Além disso, uma vasta gama de pedras preciosas é utilizada em numerosos rituais e cerimônias. Por todas estas razões, numerosas características geológicas têm sido, e em muitos casos ainda são, extremamente significativas em culturas de todo o mundo (Chevalier, 1969). A estabilidade e durabilidade da maioria das feições geológicas faz delas um símbolo do que está para além dos ciclos curtos da natureza; e do que está além da experiência humana do fluxo do tempo, refletindo outros eons, ou a eternidade. Em muitas culturas, as pedras também estão simbolicamente relacionadas à sabedoria. O gelo em suas variadas formas acrescenta a estes significados o simbolismo da pureza e do rigor. 


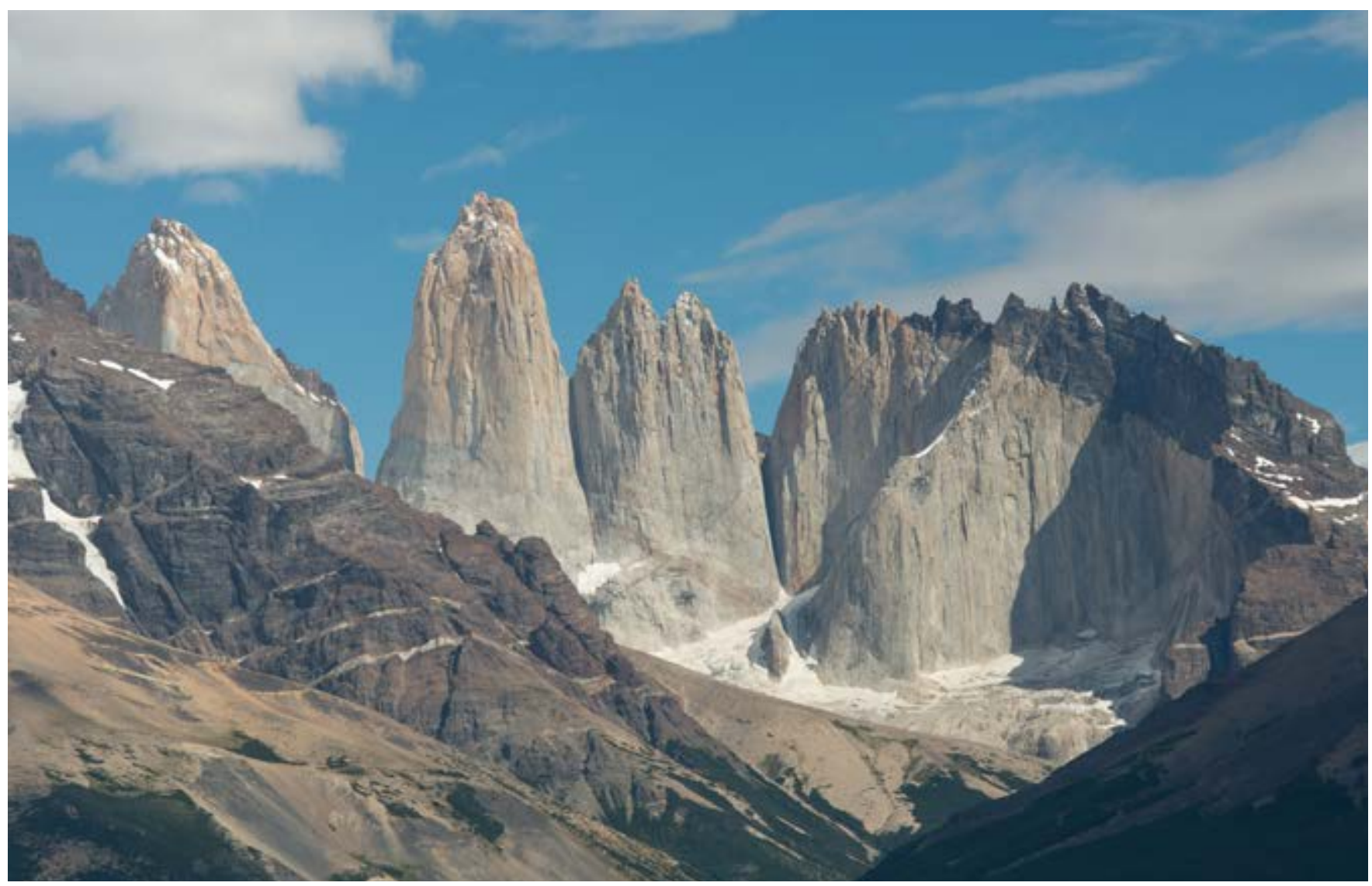

Foto 5.11 Paisagem espetacular onde a ação dos glaciares expôs rochas ígneas e metamórficas subjacentes. Parque Nacional Torres del Paine, Chile. ( ) Graeme L. Worboys

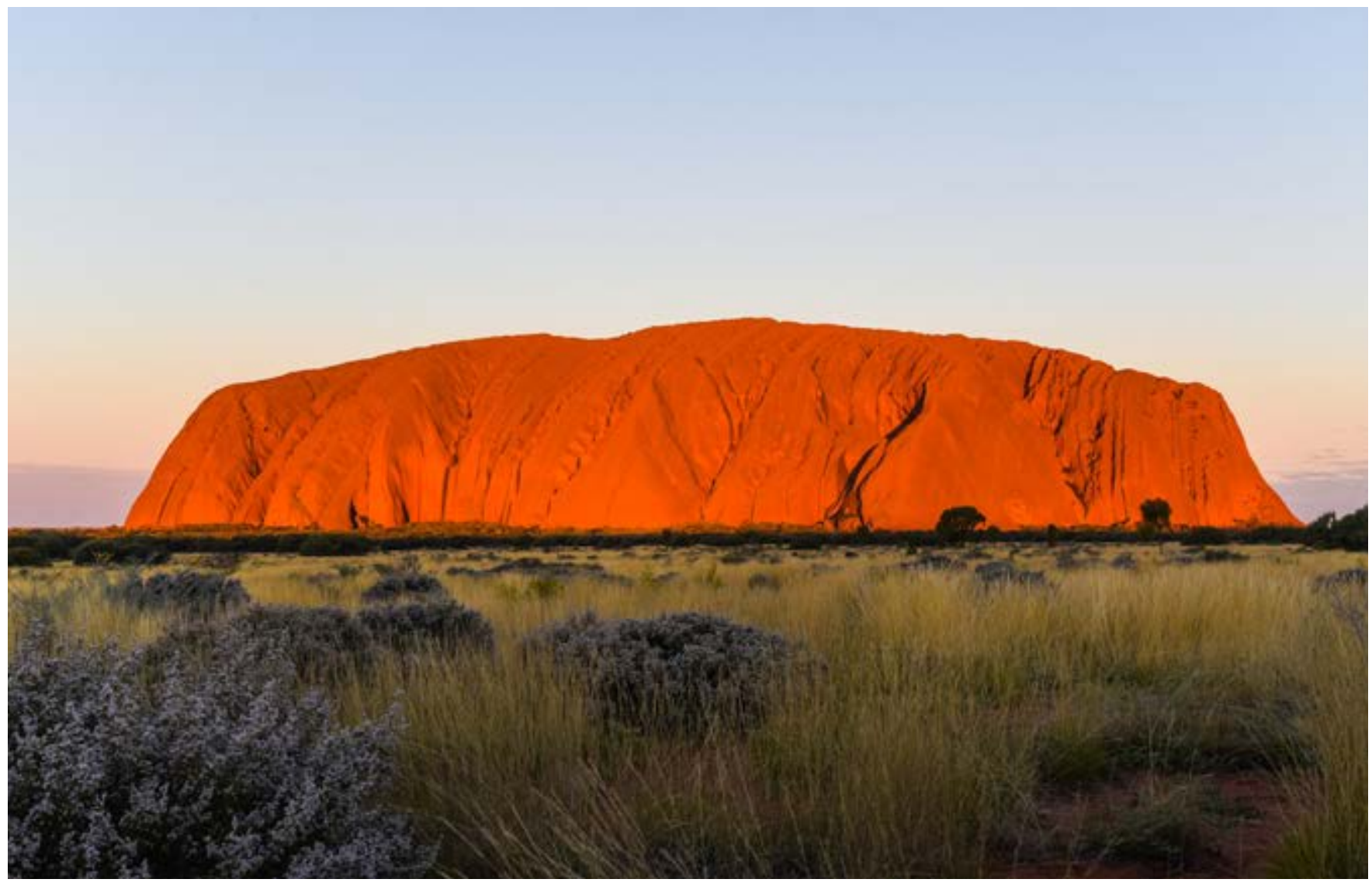

Foto 5.12 Montanha sagrada Uluru, no centro da Austrália. @ John Gordon 


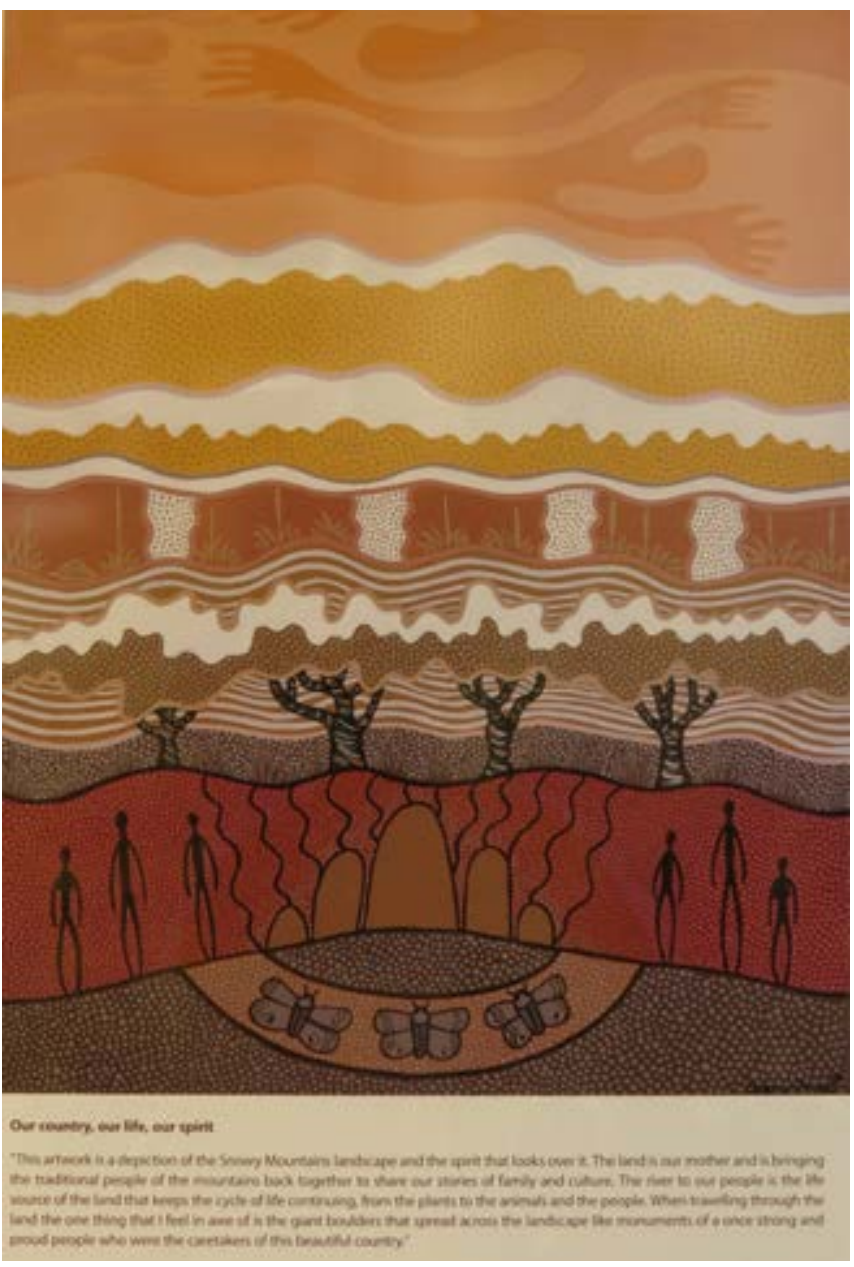

Foto 5.13 Representação aborígine da paisagem de Snowy Mountains, Nova Gales do Sul (Nova Gales do Sul). ( $)$ Roger Crofts

Sacralidade, santidade e poder ou significado espiritual têm sido atribuídos a numerosas montanhas, cavernas, poços, rios, rochas e outras feições. Por exemplo, somente na Finlândia, pelo menos 76 colinas, 74 lagos, 38 montanhas, 36 baías, 22 penínsulas, 18 lagoas, 16 ilhas, 15 rios e 12 gargantas têm o prefixo 'pyhä' ou 'hiisi' ou o genitivo 'hiiden', que significa 'sagrado' ou 'santo' (Lounema, 2003).

Os parágrafos seguintes apresentam alguns exemplos dos atributos e valores culturais e espirituais relacionados ao geopatrimônio, oriundos de todo o mundo e de diversas tradições espirituais. Mais detalhes podem ser encontrados no Centro de Documentação de Silene.

Montanhas sagradas, frequentemente com vegetação e fauna limitadas, ocorrem em todos os continentes habitados (Bernbaum, 1997). Elas incluem a maioria dos vulcões mais altos e com elevada beleza cênica (por exemplo, Mauna Kea, Hawai'i, EUA; OI Doinyo Lengai/Sabuk, Tanzânia; e Fuji-San, Japão). O grande monólito de Uluru, Austrália, é sagrado para o povo aborígine. O Monte Kailas no Tibete, China, é reverenciado pelos budistas, hindus e jaïns. A Serra Nevada de Santa Marta, Colômbia, é considerada um "coração do mundo" por seus guardiões tradicionais. Machapuchare, cordilheira Annapurna, Nepal, consagrada a Shiva, nunca foi autorizada a ser escalada. Sri Pada (Pico de Adão), no Sri Lanka, recebe peregrinos budistas, hindus, cristãos e muçulmanos. Jabal arRahmah (Monte da Misericórdia), na Arábia Saudita, faz parte da Grande Peregrinação Muçulmana (Hajj). Tur Sinâ/Jabal Mûsâ (Monte Sinai), Egito, é uma montanha sagrada para o judaísmo, cristianismo e islamismo, relacionada com a revelação ao profeta Moisés. Agios Oros/Mount Athos, faz parte de uma única república monástica cristã viva dentro da Grécia, suas encostas povoadas por eremitas e monges dedicados à oração e à contemplação.

\section{Muitas cavernas e fenômenos cársticos importantes}

têm sido utilizados como santuários naturais, preservando, em alguns casos, as pinturas e esculturas mais antigas e impressionantes da humanidade, como a Pont d'Arc, França, datada de cerca de 30.000 a.C. A civilização Maia utilizava numerosas cavernas e poços para rituais, como o Actun Tunichil Muknal (Gruta do Sepulcro da Pedra), Belize. No Sri Lanka, as Grutas de Dambulla, um complexo de cinco santuários rupestres budistas, têm recebido peregrinos por mais de dois milênios. Inúmeros hindus, eremitas e monges budistas e cristãos têm vivido em cavernas para ganhar sabedoria em lugares naturais remotos da Ásia, África e Europa.

Templos e altares esculpidos em formações rochosas são outra feição marcante encontrada em todo o mundo. Exemplos de civilizações desaparecidas incluem as dos Nabateus (por exemplo, em Petra, Jordânia), ou dos Reis Aquemênidas (Naqsh-e Rostam, Irã). Templos subterrâneos e/ou escavados impressionantes ainda estão em uso (por exemplo, as igrejas monolíticas de Lalibela, Etiópia). Um impressionante tesouro de esculturas budistas esculpidas nas colinas Xiangshan e Longmen Shan acima do rio Yi, China, é constituído por mais de 2300 cavernas e nichos e 43 pagodes, a mais antiga datada do século $\vee$ d.C., o mesmo período das cavernas de Elephanta na ilha de Gharapuri, Índia.

Rochas com morfologia especial são consideradas espiritual e/ ou culturalmente significativas em muitas culturas e tradições. Os exemplos variam desde grandes feições rochosas, como as do Monument Valley, Utah-Arizona, EUA, a mesas (como as associadas a certos Native American Pueblos, Novo México, EUA), a penhascos como Bandiagara Cliff, Doggon, Mali. No norte da Escandinávia e na Rússia, numerosas formações rochosas e pedras ofertadas têm uma longa história de sacralidade e continuam a ser significativas para os povos indígenas.

\section{As gargantas e cachoeiras têm sido consideradas} espiritualmente significativas em todo o mundo. As Cataratas do Iguaçu, Brasil-Argentina, as cachoeiras sagradas do Ganges, Índia, as Três Gargantas do rio Yangtze, China, as Cataratas do Anjo no Parque Nacional Canaima, Amazônia venezuelana e as Cataratas do Vitória, Zimbábue, são apenas alguns dos exemplos notáveis.

\section{Pedras preciosas ou semipreciosas, gemas e metais}

com numerosas associações culturais e/ou espirituais têm sido utilizados desde a pré-história, especialmente para fins religiosos, médicos e mágicos, em culturas muito diversas. $\mathrm{A}$ terapia com pedras preciosas ayurvédicas ainda é amplamente 


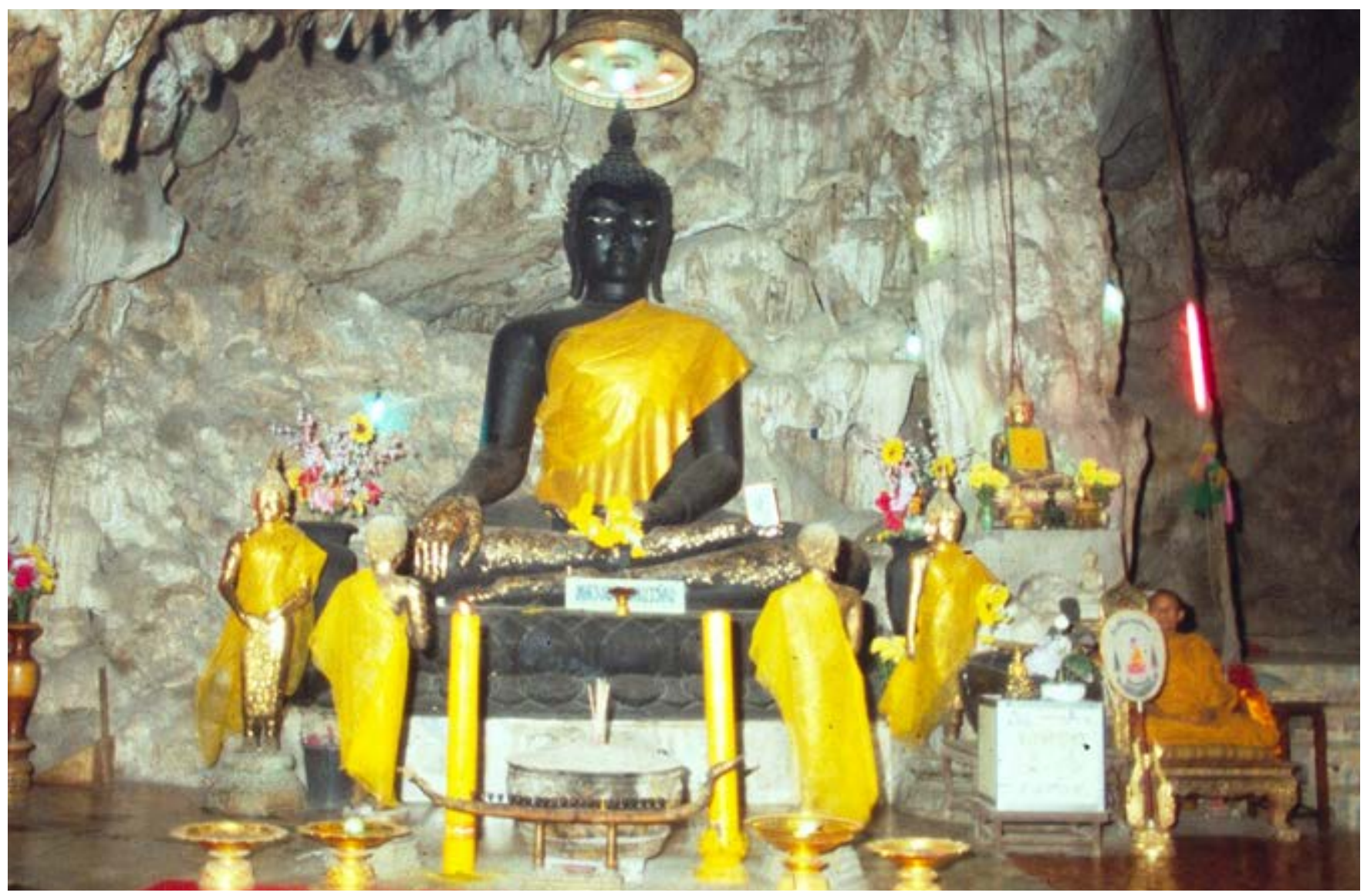

Foto 5.14 Altar budista em uma caverna em Wat Tham Sri Wilai, Tailândia. @ John Gunn

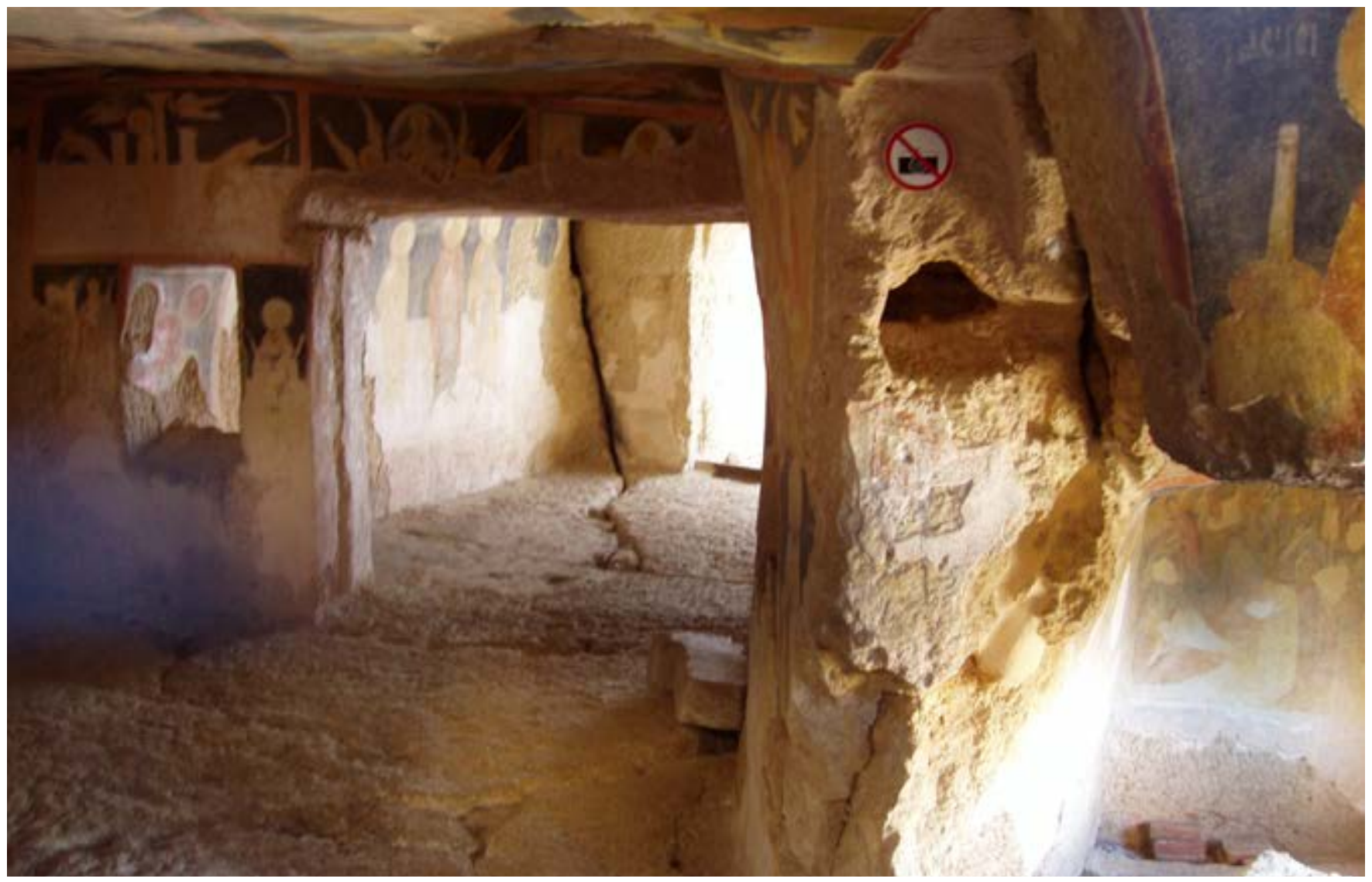

Foto 5.15 Mosteiro St Archangel Michael Rock, Bulgária. @ Roger Crofts 


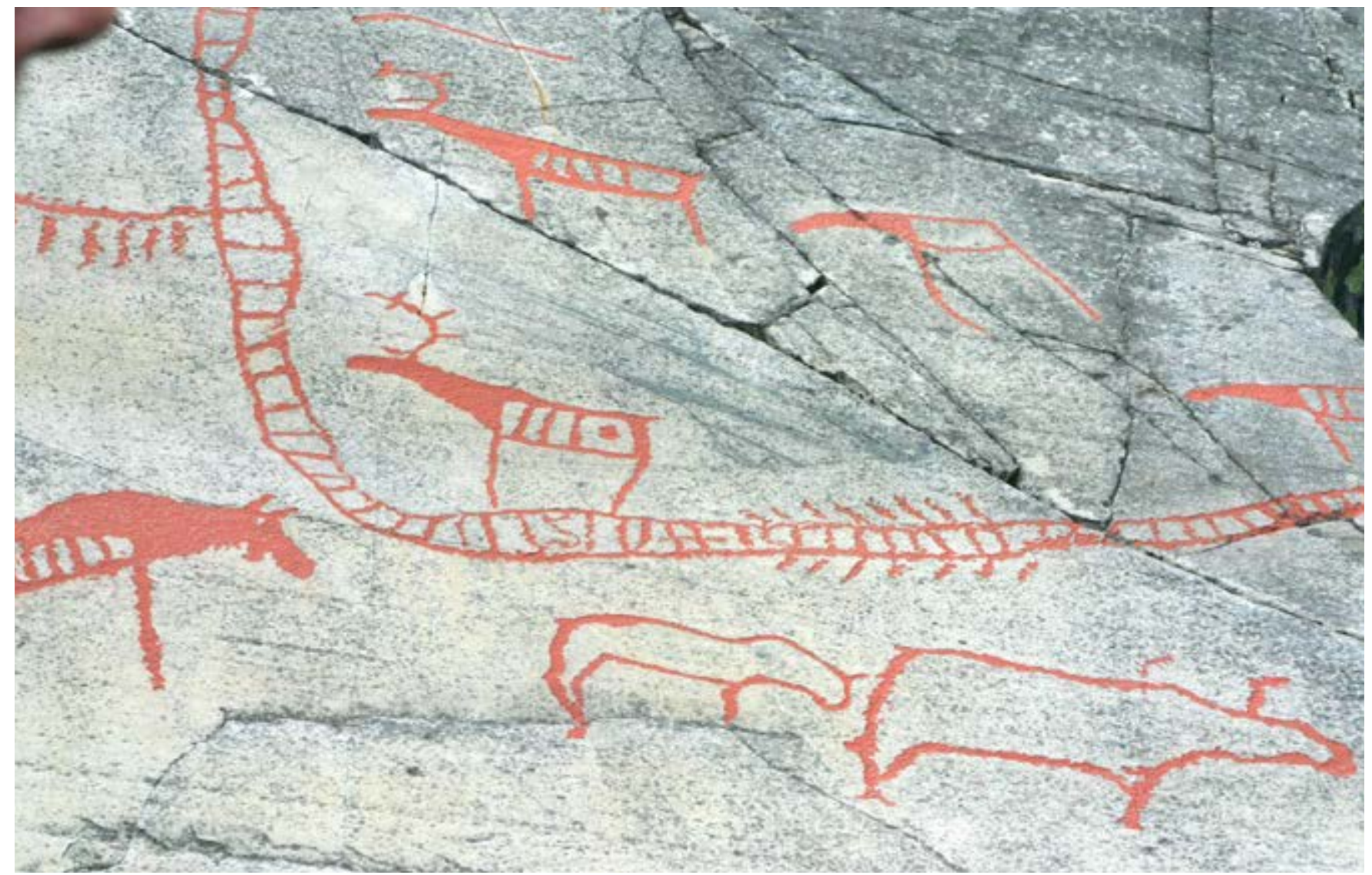

Foto 5.16 Símbolos da vida, incluindo cenas de caça e cercados de gado, esculpidos na rocha do sítio do Patrimônio Mundial de Alta, Finnmark, Noruega. () Roger Crofts

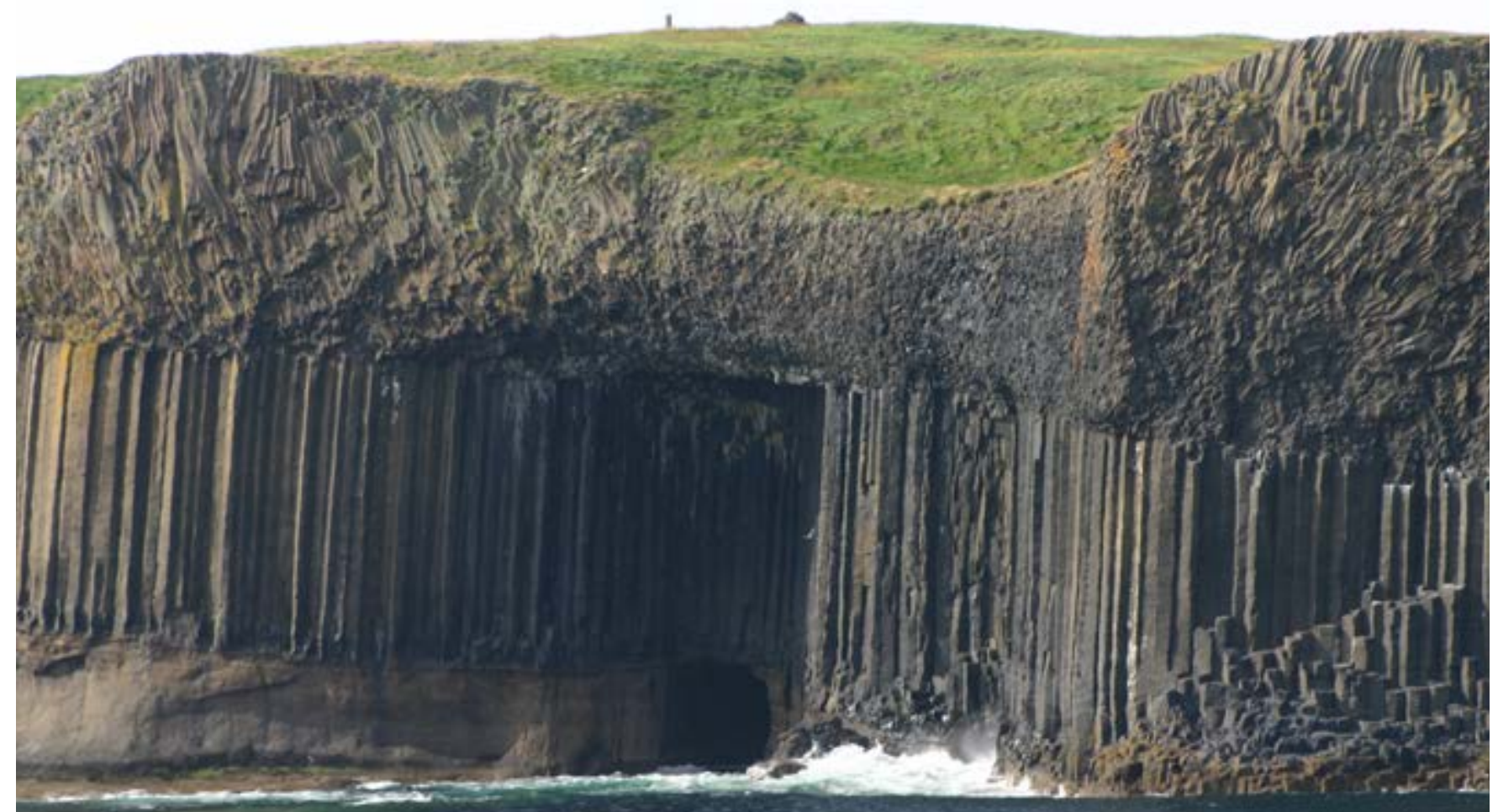

Foto 5.17 Músicos foram inspirados por fenômenos naturais, tais como Fingal's Cave, Staffa, Escócia, que inspirou Mendelssohn a compor sua Abertura das Hébridas. @ Roger Crofts 


\section{Caixa 5.2 \\ O geoarqueossítio da Necrópole Etrusca de San Giuliano, Itália}

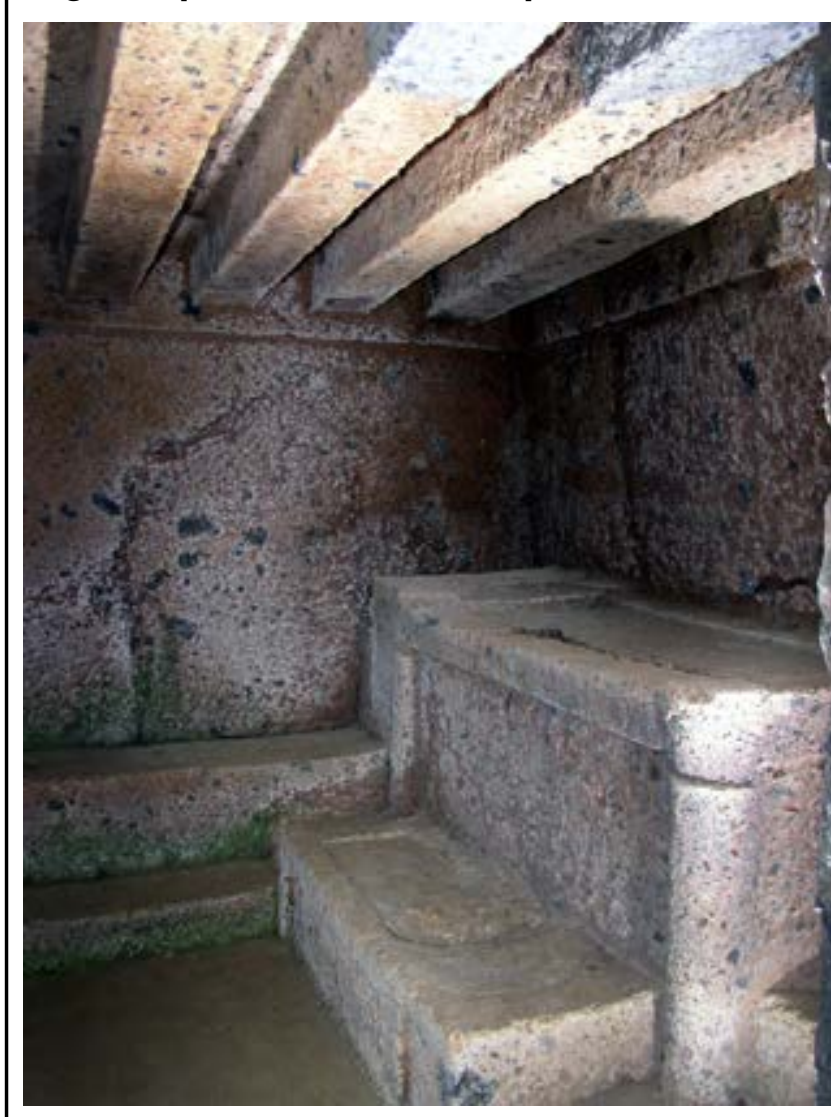

Contribuinte: Dario Mancinella
Os túmulos etruscos escavados na rocha na área de Barbarano Romano, $60 \mathrm{~km}$ ao norte de Roma, são um bom exemplo da inter-relação entre o patrimônio geológico e o patrimônio arqueológico. As rochas vulcânicas estratificadas eram relativamente macias e facilmente trabalhadas para traçar trilhas e escavar tumbas. Existem numerosas necrópoles etruscas conhecidas coletivamente como "San Giuliano", datadas do século VI a.C.

O tumulus Caiolo e os túmulos chamados 'Carruagens' e 'Camas' estão entre os primeiros aspectos encontrados, ao seguir a trilha que desce ao vale profundo, antes de chegar ao 'Túmulo da Rainha', com a sua fachada de 10m de altura. Acima de uma escadaria lateral no 'Túmulo dos Veados' está uma escultura singular em baixo relevo, representando uma luta entre um veado e um lobo. Todos os túmulos e trilhas são protegidos como Reserva Natural de Marturanum por uma agência governamental especial para a preservação e gestão do patrimônio arqueológico da região. O objetivo de gestão combina a proteção ambiental e a conservação dos vestígios arqueológicos que estão sendo erodidos pelo escoamento da água e raízes de plantas. Qualquer intervenção deve, portanto, ser equilibrada entre a salvaguarda do sistema como um todo e os elementos individuais. A componente arqueológica torna o local mais atrativo ao público, melhorando a compreensão do geossítio como um bem cultural. A presença de geoarqueossítios também contribuiu para o desenvolvimento do geoturismo. utilizada na Índia. Por todas estas razões, evidências de transporte a longa distância de pedras preciosas, vidros vulcânicos, ouro, prata, etc. têm sido documentadas em todo o mundo desde a pré-história (Piccardi \& Masse, 2007).

Em numerosas escrituras sagradas, que influenciam mais de 85\% da humanidade, alguns elementos geológicos têm papéis proeminentes. Tanto a Bíblia como o Alcorão foram escritos em ecossistemas áridos ou desérticos, onde as características geológicas dominam a paisagem, pelo que símbolos e metáforas geológicas sejam frequentemente utilizados. Na Bíblia, a palavra "rocha" é usada cerca de 150 vezes, sendo mais frequentemente uma referência a Deus do que qualquer outra coisa (Wellman, 2015). "Deus, a Rocha" aparece nos Salmos, Deuteronômio e em vários livros proféticos. No Novo Testamento ocorrem referências a "beber de uma rocha espiritual" e "a rocha era Cristo" (1 Coríntios 10:4). A Kaaba, o santuário em forma cúbica, atribuído ao profeta Abraão/lbrahim, está localizada no centro da mesquita sagrada de Meca, a cidade mais santa do Islã. No canto oriental da Kaaba encontra-se a famosa Pedra Negra, provavelmente um meteorito, que "caiu do céu" e tem sido mantida em reverência pelos peregrinos ao longo dos séculos. Diz-se que a revelação do Alcorão começou em uma pequena caverna do monte An Nur, onde Muhammad costumava fazer retiros. A pureza atribuída às pedras e areias limpas na tradição islâmica é atestada pelo fato que, na escassez de água, ambas podem ser usadas para purificações rituais.
Em geral, uma grande variedade de valores culturais e espirituais fornecem um significado adicional a muitos aspectos geológicos, desde gemas ou pedras individuais até extensas faixas rochosas, tanto na superfície da Terra como abaixo dela. Estes valores conectam a vida das culturas e comunidades atuais ao significado e simbolismo das feições mais permanentes do nosso lar terrestre e, através deles, às gerações passadas e futuras. As conexões culturais e espirituais entre comunidades e culturas locais e sua herança geológica têm um significado profundo, que não deve ser negligenciado pelos conservacionistas.

Existem muitos mecanismos de gestão nos sítios geológicos para garantir que os valores culturais e espirituais sejam adequadamente protegidos. Estes incluem o uso de vigilantes da comunidade local para guardar o local e atuar como intérpretes do valor cultural e espiritual aos visitantes, por exemplo no Parque Nacional Gwaii Haanas com seu sítio do Patrimônio Mundial S'Gang Gwaay, Columbia Britânica, Canadá, e restrições de acesso para salvaguardar os valores espirituais do local, como em Uluru, na Austrália. Mais detalhes são apresentados em Verschuuren et al. (no prelo).

Boa Prática n 15: Incluir valores culturais e espirituais nos objetivos de gestão de áreas protegidas e, quando apropriado, incluir o geopatrimônio em áreas protegidas criadas devido a valores espirituais e culturais. 


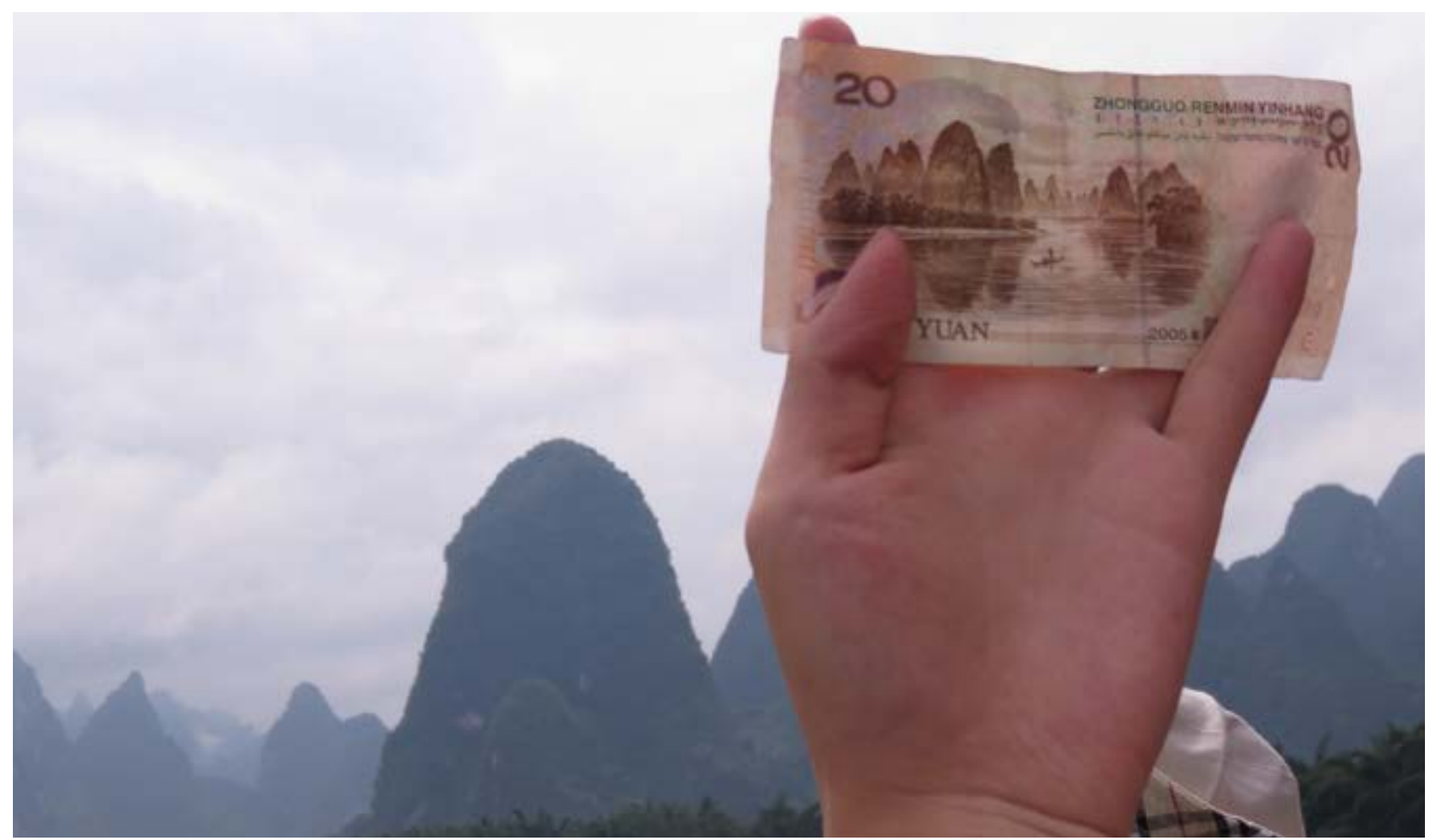

Foto 5.18 A ligação do geopatrimônio à moeda nacional pode ajudar a aumentar o reconhecimento da necessidade de proteção. Guilin Karst, sítio do Patrimônio Mundial Carste do Sul da China. @ Roger Crofts

\subsection{Monitoramento e avaliação dos geossítios}

O monitoramento de geossítios pode ser feito tendo em conta uma série de usos possíveis:

avaliar e informar sobre as condições atuais e tendências de longo prazo de geossítios ou feições e processos específicos (ver seção 5.1);

- avaliar a eficácia da gestão de um sítio ou de feições e processos do geopatrimônio; e

- fornecer informação sobre a vigilância, proteção e segurança do sítio e das feições e processos específicos.

Os dados do monitoramento e as subsequentes informações sobre a avaliação podem então ser utilizados pelos gestores para:

- relatórios oficiais de prestação de contas do plano de gestão e relatórios para os financiadores e administradores, bem como para o público, em relatórios anuais e outros documentos;

- relatórios de segurança e da gestão do acesso; e

- revisão da eficácia da gestão ou de características específicas do geossítio.

Muitos tipos de monitoramento do foram desenvolvidos por organizações gestoras de áreas protegidas (Tabelas 5.5 e 5.6), sendo aqui apresentados como considerações genéricas de monitoramento e avaliação, com apresentação de exemplos específicos. Deve-se ter em conta que muitas feições e processos geológicos são monitorados por organizações especializadas (como a agência governamental de pesquisa geofísica ou uma equipe de vulcanologia) que têm parcerias de trabalho com a administração de áreas protegidas. É improvável que as áreas protegidas tenham os recursos ou a capacidade técnica para realizar elas mesmas essas operações de monitoramento especializado; em vez disso, elas dependerão da contribuição voluntária de especialistas, provenientes de entidades credenciadas. Além disso, muito tem sido escrito sobre monitoramento e avaliação em relação a projetos e iniciativas de conservação da natureza, incluindo os diferentes propósitos de monitoramento, sua relação com a gestão adaptativa e os desafios para fazer programas de monitoramento bem sucedidos. Muito do que foi escrito é aplicável ao monitoramento de geopatrimônio. Para um resumo do monitoramento e avaliação relacionados com a conservação da natureza, consulte o capítulo 10 de Groves \& Game (2016).

Os métodos usados para monitorar geossítios, suas feições e processos precisam ser cuidadosamente planejados. Eles são normalmente sustentados por um plano de monitoramento que identifica o propósito do monitoramento, os protocolos e procedimentos que serão usados e como os dados do monitoramento serão usados. Os indicadores serão selecionados de acordo com a coleta de informações a serem usadas por uma organização (ou seja, avaliação baseada na utilização). Uma armadilha comum para quem se inicia na avaliação é a de iniciar o processo pela escolha de indicadores. A seleção dos indicadores é feita após a conclusão das decisões sobre quais informações serão utilizadas. Os indicadores podem então ser selecionados de acordo com as informações necessárias. Tipicamente, os indicadores escolhidos serão 'SMART': Específicos (Specific), Mensuráveis (Measurable), Alcançáveis (Achievable/Attainable), Relevantes (Relevant) e Temporais (Timely). Outra armadilha habitual é a de preparar um plano de monitoramento bem após o início de um projeto quando, na verdade, ele deve ser uma parte integrante do planejamento inicial do projeto. 
Tabela 5.5. Tipos de monitoramento e sua utilização.

\begin{tabular}{|c|c|c|c|}
\hline Tipo de monitoramento & $\begin{array}{l}\text { Monitoramento das } \\
\text { informações coletadas }\end{array}$ & Avaliação e utilização & Justificativa \\
\hline Contexto & $\begin{array}{l}\text { Qual é o estado do sítio e } \\
\text { qual a sua tendência? Está } \\
\text { ameaçado? }\end{array}$ & $\begin{array}{l}\text { Usado para determinar se é } \\
\text { necessária uma intervenção } \\
\text { para proteger o geossítio. }\end{array}$ & $\begin{array}{l}\text { Necessário para todos } \\
\text { os geossítios, feições e } \\
\text { processos específicos. }\end{array}$ \\
\hline Planejamento & $\begin{array}{l}\text { Identifica as metas e objetivos } \\
\text { e como atingi-los. }\end{array}$ & $\begin{array}{l}\text { Utilizado para identificar } \\
\text { e avaliar cuidadosamente } \\
\text { os objetivos da gestão } \\
\text { estratégica e as ações } \\
\text { associadas necessárias para } \\
\text { a proteção do geossítio ou } \\
\text { fenômenos presentes. }\end{array}$ & $\begin{array}{l}\text { A avaliação da eficácia dos } \\
\text { objetivos de planejamento } \\
\text { deve ser uma avaliação de } \\
\text { rotina da administração, } \\
\text { ocorrendo talvez a cada } 5 \text { a } \\
10 \text { anos. }\end{array}$ \\
\hline Entradas & $\begin{array}{l}\text { As ações de geoconservação } \\
\text { necessitam de recursos } \\
\text { que normalmente incluem } \\
\text { pessoas, financiamento e } \\
\text { materiais. }\end{array}$ & $\begin{array}{l}\text { A avaliação é utilizada } \\
\text { para assegurar que o } \\
\text { financiamento, os recursos } \\
\text { humanos e os materiais } \\
\text { sejam direcionados para os } \\
\text { sítios definidos, para que a } \\
\text { tarefa seja concluída de forma } \\
\text { oportuna e eficiente. }\end{array}$ & $\begin{array}{l}\text { Tais avaliações garantem } \\
\text { que os recursos humanos e } \\
\text { financeiros foram alocados } \\
\text { corretamente para garantir o } \\
\text { sucesso do monitoramento, } \\
\text { bem como para assegurar } \\
\text { que a alocação tenha sido } \\
\text { eficaz. }\end{array}$ \\
\hline Processo & $\begin{array}{l}\text { A avaliação de sistemas de } \\
\text { gestão e procedimentos é } \\
\text { uma parte importante da } \\
\text { geoconservação. }\end{array}$ & $\begin{array}{l}\text { Isto pode-se aplicar aos } \\
\text { procedimentos de gestão de } \\
\text { incidentes de emergência, tais } \\
\text { como erupções vulcânicas, } \\
\text { lahares e sismos. }\end{array}$ & $\begin{array}{l}\text { O monitoramento } \\
\text { da adequação dos } \\
\text { procedimentos e sistemas } \\
\text { para a gestão de eventos e } \\
\text { incidentes em geossítios é } \\
\text { uma parte crítica da gestão. } \\
\end{array}$ \\
\hline Saídas & $\begin{array}{l}\text { Dado o planejamento, } \\
\text { organização de entradas e } \\
\text { processos, a eficácia dos } \\
\text { resultados pode ser avaliada. }\end{array}$ & $\begin{array}{l}\text { Pode ser avaliado o que foi } \\
\text { feito, quais os produtos e } \\
\text { serviços alcançados, tendo } \\
\text { em conta as entradas. }\end{array}$ & $\begin{array}{l}\text { O monitoramento de ações } \\
\text { individuais fornece um } \\
\text { feedback importante para os } \\
\text { gestores, especialmente na } \\
\text { fase de conclusão da tarefa e } \\
\text { fornece uma base para uma } \\
\text { gestão adaptável. }\end{array}$ \\
\hline Resultados & $\begin{array}{l}\text { A medição dos resultados } \\
\text { é normalmente avaliada em } \\
\text { relação aos objetivos originais } \\
\text { do planejamento, mas } \\
\text { também deve levar em conta } \\
\text { avaliações mais genéricas de } \\
\text { como a geoconservação tem } \\
\text { avançado com as ações de } \\
\text { gestão empreendidas. }\end{array}$ & $\begin{array}{l}\text { A medição dos resultados } \\
\text { pode ser quantificada e, } \\
\text { como tal, fornece informações } \\
\text { inestimáveis para que as } \\
\text { organizações demonstrem } \\
\text { sucesso, bem como para uso } \\
\text { por auditorias independentes } \\
\text { da eficácia da gestão, exigida } \\
\text { pelo governo ou por um } \\
\text { conselho de administração. }\end{array}$ & $\begin{array}{l}\text { O progresso da conservação } \\
\text { na gestão de um geossítio } \\
\text { pode ser identificado e } \\
\text { publicado dentro do relatório } \\
\text { anual de uma organização ou } \\
\text { usado para em outros meios } \\
\text { legais de reportar resultados. }\end{array}$ \\
\hline
\end{tabular}

\section{Caixa 5.3 \\ Geoconservação e estratégias de gestão: Componentes para o sucesso de dois Geoparques Mundiais da ÚNESCO em Espanha}

A análise das estratégias de geoconservação e gestão de dois Geoparques Mundiais da UNESCO, Las Loras e Molina

de Aragón-Alto Tajo, Espanha, destaca seis componentes cruciais para o sucesso de qualquer geoparque. Primeiro,

é o estabelecimento de um banco de dados com todas as ações e atividades organizadas no geoparque, quer pela

entidade responsável pelo geoparque, como pelas entidades parceiras. Em segundo lugar, a presença de especialistas em geoconservação na equipe do geoparque ajuda a reforçar o papel do geopatrimônio no geoparque e a sensibilizar o restante pessoal. Terceiro, a criação e implementação de um plano de ação de geoconservação fornece uma nova base para o planejamento e ação da gestão do geoparque. Em quarto lugar, a existência de uma equipe multidisciplinar cria uma nova dinâmica. Quinto, os planos de gestão e estratégicos que cobrem atividades chave dos geoparques - a saber, educação, turismo, comunicação e desenvolvimento sustentável - ficam completos. Sexto, a promoção da gestão participativa, incluindo as partes interessadas e a população local, constitui uma ferramenta para o desenvolvimento de todo o território.

Para maiores informações, ver Canesin et al. (2020).

Contribuintes: Thais Canesin, José Brilha, Enrique Díaz-Martínez 
Tabela 5.6. Exemplos de monitoramento, avaliação e relatórios do geopatrimônio.

\begin{tabular}{|c|c|c|c|}
\hline Categoria & $\begin{array}{l}\text { Informações de } \\
\text { monitoramento }\end{array}$ & Utilização & Exemplos \\
\hline Atividade sísmica & $\begin{array}{l}\text { Frequência e severidade da } \\
\text { atividade sísmica }\end{array}$ & $\begin{array}{l}\text { Utilizado para: pesquisa, } \\
\text { determinação do acesso ou } \\
\text { interrupções de visitas e respostas } \\
\text { de emergência. }\end{array}$ & $\begin{array}{l}\text { Point Reyes National Seashore e } \\
\text { Parque Nacional dos Vulcões do } \\
\text { Hawai'i (EUA), US Geological Survey }\end{array}$ \\
\hline $\begin{array}{l}\text { Erupções vulcânicas: } \\
\text { vulcanismo ácido }\end{array}$ & $\begin{array}{l}\text { Atividade sísmica; mudança } \\
\text { no comportamento } \\
\text { epitérmico; composição } \\
\text { das emissões de gases; } \\
\text { soerguimento e subsidência } \\
\text { do terreno }\end{array}$ & $\begin{array}{l}\text { Utilizado para: pesquisa, definição } \\
\text { do acesso ou suspensão de visitas e } \\
\text { respostas de emergência. }\end{array}$ & $\begin{array}{l}\text { Parque Nacional de Yellowstone (EUA), } \\
\text { US Geological Survey }\end{array}$ \\
\hline $\begin{array}{l}\text { Erupções vulcânicas: } \\
\text { vulcanismo básico }\end{array}$ & $\begin{array}{l}\text { Atividade sísmica; dinâmica da } \\
\text { lava; atividade eruptiva }\end{array}$ & $\begin{array}{l}\text { Utilizado para: pesquisa, definição } \\
\text { do acesso ou suspensão de visitas e } \\
\text { respostas de emergência. }\end{array}$ & $\begin{array}{l}\text { Parque Nacional dos Vulcões do } \\
\text { Hawai'i (EUA), US Geological Survey }\end{array}$ \\
\hline $\begin{array}{l}\text { Tsunami: realizado por entidades } \\
\text { especializadas, mas com } \\
\text { ligação à administração de áreas } \\
\text { protegidas }\end{array}$ & $\begin{array}{l}\text { Sismo intenso em ambiente } \\
\text { marinho }\end{array}$ & $\begin{array}{l}\text { Usado para: segurança do visitante } \\
\text { e ações de resposta de emergência }\end{array}$ & $\begin{array}{l}\text { Parques costeiros do Hawai'i (EUA) } \\
\text { sujeitos a tsunamis frequentes }\end{array}$ \\
\hline Emissões de gás vulcânico & $\begin{array}{l}\text { Composição e concentração } \\
\text { de gás }\end{array}$ & $\begin{array}{l}\text { Utilizado para: pesquisa, definição } \\
\text { de acesso ou interrupção de visitas }\end{array}$ & $\begin{array}{l}\text { Parque Nacional dos Vulcões do } \\
\text { Hawai'i (EUA), US Geological Survey }\end{array}$ \\
\hline Lahar & $\begin{array}{l}\text { Monitoramento de eventos } \\
\text { de lahares ativos após uma } \\
\text { erupção vulcânica }\end{array}$ & $\begin{array}{l}\text { Utilizado para: evacuação de } \\
\text { emergência e corte de estradas }\end{array}$ & $\begin{array}{l}\text { Parque Nacional de Tongariro (Nova } \\
\text { Zelândia) }\end{array}$ \\
\hline Estabilidade de taludes & $\begin{array}{l}\text { Monitoramento de encostas } \\
\text { instáveis incluindo falésias } \\
\text { e fraturas em formações } \\
\text { rochosas }\end{array}$ & $\begin{array}{l}\text { Usado para: segurança do visitante } \\
\text { e encerramento do parque }\end{array}$ & $\begin{array}{l}\text { Tendo em consideração a segurança } \\
\text { dos alpinistas, as Dolomitas - } \\
\text { Patrimônio Mundial (Alpes europeus) } \\
\text { monitora como, em um ambiente de } \\
\text { mudança climática, as temperaturas } \\
\text { mais altas afetam as faces dos } \\
\text { penhascos em alta altitude }\end{array}$ \\
\hline $\begin{array}{l}\text { Estabilidade do teto das } \\
\text { cavernas }\end{array}$ & $\begin{array}{l}\text { Monitoramento da estabilidade } \\
\text { do teto das cavernas }\end{array}$ & $\begin{array}{l}\text { Usado para: segurança do visitante } \\
\text { e encerramento de cavernas }\end{array}$ & $\begin{array}{l}\text { Caverna de lava Manjanggul (República } \\
\text { da Coréia). A queda de rochas foi } \\
\text { monitorada com equipamento de alta } \\
\text { resolução ou placas de vidro }\end{array}$ \\
\hline Espeleotemas de caverna & $\begin{array}{l}\text { Identificação de qualquer } \\
\text { mudança em espeleotemas }\end{array}$ & $\begin{array}{l}\text { Usado para: pesquisa e proteção } \\
\text { contra a ameaça de vandalismo }\end{array}$ & $\begin{array}{l}\text { Caverna Baegnyong (República da } \\
\text { Coréia), onde um monitoramento } \\
\text { fotográfico ("antes" e "depois") } \\
\text { identificou mudanças }\end{array}$ \\
\hline Atmosfera das cavernas & $\begin{array}{l}\text { Monitoramento do nível de } \\
\text { dióxido de carbono dentro de } \\
\text { uma caverna utilizada pelos } \\
\text { visitantes }\end{array}$ & $\begin{array}{l}\text { Usado para: segurança dos } \\
\text { visitantes, especialmente em } \\
\text { cavernas turísticas }\end{array}$ & $\begin{array}{l}\text { A área protegida Waitomo Glowworm } \\
\text { Caves (llha do Norte, Nova Zelândia) } \\
\text { tem um sistema de monitoramento } \\
\text { automático e contínuo da qualidade } \\
\text { do ar }\end{array}$ \\
\hline Radioatividade em cavernas & $\begin{array}{l}\text { Monitoramento do nível de } \\
\text { gás radônio radioativo dentro } \\
\text { das cavernas }\end{array}$ & $\begin{array}{l}\text { Utilizado para a segurança dos } \\
\text { trabalhadores em cavernas, } \\
\text { especialmente guias }\end{array}$ & $\begin{array}{l}\text { Parque Nacional de Carlsbad Caverns } \\
\text { (EUA) }\end{array}$ \\
\hline $\begin{array}{l}\text { Morfologia das camadas } \\
\text { fossilíferas em Mistaken Point, } \\
\text { sítio do Patrimônio Mundial }\end{array}$ & $\begin{array}{l}\text { Monitoramento por Lidar } \\
\text { (satélite) do estado e } \\
\text { tendência da conservação das } \\
\text { camadas fossiliferas costeiras } \\
\end{array}$ & $\begin{array}{l}\text { Realizado a cada } 10 \text { anos, para } \\
\text { monitorar a erosão a longo prazo } \\
\text { do local }\end{array}$ & $\begin{array}{l}\text { Mistaken Point Patrimônio Mundial } \\
\text { (Terra Nova e Labrador, Canadá) }\end{array}$ \\
\hline $\begin{array}{l}\text { Erosão provocada pelo pisoteio } \\
\text { em camadas fossilíferas } \\
\text { em Mistaken Point, sítio do } \\
\text { Patrimônio Mundial }\end{array}$ & $\begin{array}{l}\text { Fotografias em posições fixas } \\
\text { e determinadas para avaliar a } \\
\text { erosão }\end{array}$ & $\begin{array}{l}\text { Realizado a cada dois meses e após } \\
\text { grandes tempestades }\end{array}$ & $\begin{array}{l}\text { Mistaken Point Patrimônio Mundial } \\
\text { (Terra Nova e Labrador, Canadá) }\end{array}$ \\
\hline $\begin{array}{l}\text { Estado e tendência de } \\
\text { conservação da Grande Barreira } \\
\text { de Corais }\end{array}$ & $\begin{array}{l}\text { Monitoramento do estado } \\
\text { de conservação da Grande } \\
\text { Barreira de Corais }\end{array}$ & $\begin{array}{l}\text { Realizada após grandes eventos } \\
\text { como ciclones tropicais e eventos } \\
\text { de branqueamento resultantes } \\
\text { de temperaturas elevadas, por } \\
\text { universidades e organizações de } \\
\text { pesquisa. Fornece relatórios públicos } \\
\text { sobre o estado do recife. }\end{array}$ & $\begin{array}{l}\text { Parque Marinho da Grande Barreira de } \\
\text { Corais (Queensland, Austrália) }\end{array}$ \\
\hline
\end{tabular}




\section{Caixa 5.4}

\section{Ações de proteção em paisagens vulcânicas}

Os vulcões ativos são feições geológicas e geomorfológicas espetaculares. Muitos estão localizados em áreas protegidas e alguns já foram inscritos na Lista do Patrimônio Mundial, como o Parque Nacional dos Vulcões do Hawai'i (EUA). Os gestores de áreas protegidas responsáveis por fenômenos vulcânicos conhecem bem a distinção entre vulcanismo ácido e básico. Eles sabem que vulcões com lava ácida são perigosos e emanam abundantes gases, para além de formarem riolitos, traquitos e lavas andesíticas, assim como eventos piroclásticos tais como as nuvens ardentes. Estas nuvens de pequenos fragmentos sobreaquecidos de material vulcânico, envolveram Pompéia antiga e mataram muitos de seus residentes. Os responsáveis pelas áreas protegidas vulcânicas estão constantemente envolvidos na segurança dos visitantes que se encontram num ambiente vulcânico dinâmico (Tabela 5.7).

\section{Caixa 5.5 Jenolan Karst Conservation Reserve, Nova Gales do Sul, Austrália}

Jenolan Karst Conservation Reserve (JKCR), no flanco oriental da Great Dividing Range da Austrália, é uma área protegida de 3085 hectares, santuário de vida selvagem e com oferta turística. A JKCR possui um extenso sistema de cavernas em calcário siluriano, visitado anualmente por mais de 200.000 pessoas.

A JKCR é administrada conjuntamente pelo Jenolan Caves Reserve Trust e pelo New South Wales National Parks and Wildlife Service (NPWS). Faz parte da Área de Patrimônio Mundial das Grandes Montanhas Azuis (GBMWHA), listada pela diversidade e singularidade dos invertebrados das cavernas (específicos do JKCR). Possui as maiores cavernas turísticas da Austrália e fornece habitat crítico para espécies raras, ameaçadas e reliquiares e faunas troglobíticas / estigobíticas únicas ou endêmicas.

\section{Questões de conservação}

Duas características são de importância crítica. Primeiro, os invertebrados das cavernas são de especial valor de conservação e incluem faunas troglóbias e especializadas, completamente dependentes do ambiente das cavernas e adaptadas às condições atuais dentro das cavernas; mudanças drásticas no ambiente das cavernas têm, portanto, o potencial de afetar seriamente essas faunas. Em segundo lugar, o Vale McKeowns (o Vale do Rio Jenolan) é um exemplo globalmente significativo de escavação de vales em zonas cársticas.

As ameaças à geodiversidade e à biodiversidade incluem a possibilidade de poluição do sistema cárstico e das águas subterrâneas, incêndios, alterações na hidrologia, construção de infraestruturas e riscos associados com a mudança climática. As ameaças específicas das cavernas incluem iluminação artificial, mudanças na temperatura e umidade, ruído, existência de estruturas de controle do acesso, perturbação causada pelo público e, no caso de morcegos, potencial para a introdução da síndrome do nariz branco. O envelhecimento da infraestrutura, o assoreamento e o acúmulo de sedimentos no Lago Azul (artificial), a manutenção das instalações de tratamento de água e de esgoto, tudo isso representa desafios.

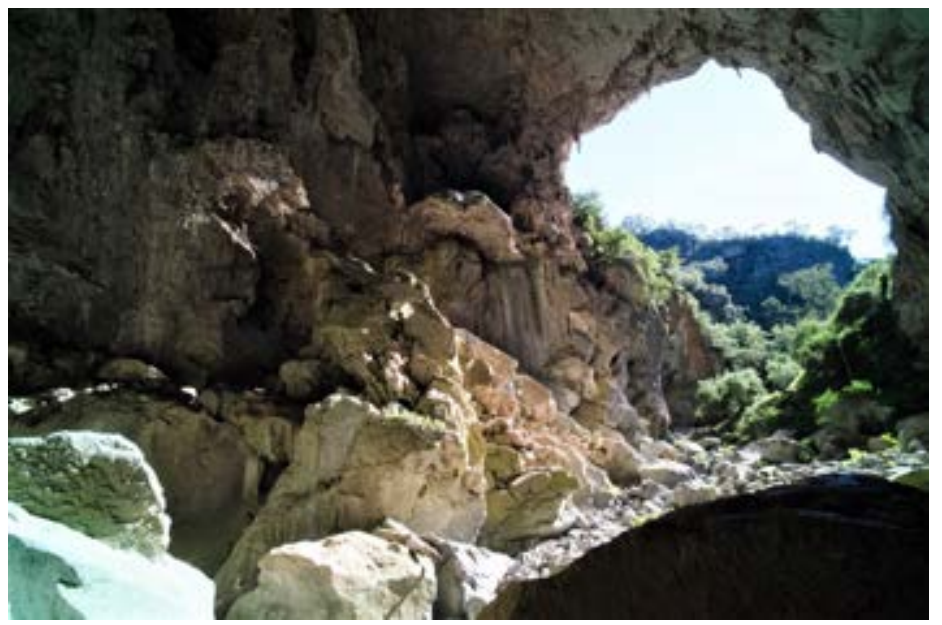

Objetivos de gestão e inovações

O atual plano de gestão (Office of Environment and Heritage New South Wales, 2019) beneficiou-se de novas informações de pesquisa e, juntamente com recursos adicionais, permite que muitas das ameaças sejam superadas. Para mitigar ameaças específicas das cavernas, os sistemas de iluminação foram atualizados para minimizar os impactos da luz e da temperatura; foram seguidas as 'boas práticas' relativamente à infraestrutura das cavernas (incluindo a instalação de grades de aço inoxidável não-ferroso); as permissões de acesso às cavernas são estritamente monitoradas (o acesso às cavernas é feito apenas por autorização da NPWS específica do local e data para grupos de espeleologia credenciados); e foram desenvolvidos planos para evitar a introdução da síndrome do nariz branco em locais de aglomeração de morcegos e wallaby (marsupial da família dos cangurus).

\section{Contribuinte: Anne M. Musser}


É necessário apoio de alto nível na gestão de áreas protegidas para garantir o sucesso contínuo de um monitoramento eficaz. O apoio a projetos de monitoramento de pequena ou grande escala implicam que:

- As organizações aprovaram plenamente um plano de monitoramento e avaliação.

- Existe um compromisso para garantir um financiamento contínuo.

- Sejam contratados técnicos com formação adequada para gerenciar e conduzir o monitoramento.

- Foram montados sistemas para gerir os dados que serão gerados pelo monitoramento.

- O pessoal responsável pelos sistemas de gestão das informações recebeu treinamento adequado.

Esta abordagem enfatiza a relação funcional entre as responsabilidades estatutárias de uma organização e o monitoramento, tais como a proteção contínua do geossítio e todos os seus aspectos importantes, assim como a segurança dos visitantes.

\section{Tabela 5.7. Segurança dos visitantes em zonas vulcânicas.}

Boa Prática $n^{\circ}$ 16: Desenvolver planos de monitoramento para avaliar feições críticas e processos naturais, e ajustar os planos (em uma estrutura de gerenciamento adaptável) para garantir que as metas de geoconservação sejam atingidas.

\subsection{Exemplos de gestão de geoconservação em áreas protegidas}

As caixas 5.3, 5.4 e 5.5 apresentam exemplos de gestão de geoconservação. Há muitos exemplos já publicados; ver capítulos 19 a 24 de Reynard \& Brilha (2018) para exemplos da Etiópia, Brasil, República da Coréia, Tasmânia (Austrália), Colorado (EUA) e Espanha. A revista científica Geoheritage, publicada pela Springer e produzida conjuntamente com a ProGEO (The European Association for the Conservation of the Geological Heritage) e pela IUGS (International Union of Geological Sciences) disponibiliza artigos sobre estudos de caso de todo o mundo.

\begin{tabular}{|c|c|}
\hline Erupções & $\begin{array}{l}\text { A erupção de vulcões é fascinante e inspiradora e pode ser uma grande atração para os visitantes. Os vulcões } \\
\text { com lavas básicas, como o vulcão Kilauea em Hawai'i (EUA), são relativamente seguros e podem estar em } \\
\text { erupção de forma constante, entre erupções mais vigorosas. Vulcões ativos com lavas mais viscosas e ricas em } \\
\text { sílica são altamente perigosos e, normalmente, não são permitidos visitantes nas suas proximidades. O encer- } \\
\text { ramento de áreas protegidas ocorre quando as condições são potencialmente ou realmente inseguras. Normal- } \\
\text { mente, há uma estreita parceria de trabalho entre vulcanólogos e gestores de áreas protegidas. }\end{array}$ \\
\hline Lahars & $\begin{array}{l}\text { A mistura de material vulcânico e água no topo de um vulcão é muito perigosa e pode levar ao rápido movi- } \\
\text { mento descendente deste material lamacento, conhecido como lahar. No Parque Nacional de Tongariro, Nova } \\
\text { Zelândia, os lahares têm historicamente emanado do lago da cratera do Monte Ruapehu. O vulcão é monitorado } \\
\text { e foram implementados sistemas de alerta de segurança nas zonas mais baixas onde o público poderia ser atin- } \\
\text { gido. }\end{array}$ \\
\hline Sismos & $\begin{array}{l}\text { Os sismos de intensidade variável podem estar associados a erupções vulcânicas. Isso pode significar que algu- } \\
\text { mas zonas das áreas protegidas precisam ser encerradas, pois as estradas de acesso ou encostas íngremes se } \\
\text { tornaram inseguras devido à existência de rochas instáveis, movimentos de vertente e estradas desmoronadas } \\
\text { ou fraturadas. }\end{array}$ \\
\hline Explosões & $\begin{array}{l}\text { Podem ocorrer explosões imprevisíveis durante erupções vulcânicas, quer durante erupção ou mesmo como } \\
\text { resultado posterior da interação entre a água subterrânea e o magma quente. Esta é uma razão pela qual muitas } \\
\text { áreas protegidas são fechadas durante as erupções. Os gestores precisam trabalhar em conjunto com os vulca- } \\
\text { nólogos para garantir que o público e o pessoal estejam seguros. }\end{array}$ \\
\hline Gases & $\begin{array}{l}\text { Dióxido de carbono, dióxido de enxofre, metano e outros gases podem estar presentes nos vulcões, estejam } \\
\text { eles em erupção ou não. A concentração e a área que ocupam esses gases é uma questão de segurança } \\
\text { para os visitantes. As áreas podem precisar ser monitoradas, e os encerramentos podem ocorrer conforme } \\
\text { necessário. }\end{array}$ \\
\hline Orientação & $\begin{array}{l}\text { Marcos de pedra são utilizados para auxiliar a orientação dos visitantes em trilhas pedestres no Parque Nacional } \\
\text { dos Vulcões do Hawai'i, dada a dupla possibilidade de ocorrência regular de espessa névoa de montanha e de } \\
\text { campos magnéticos associados às lavas basálticas recentes e à lava derretida subterrânea, que tornam inútil o } \\
\text { uso de bússolas. As autoridades fornecem bons mapas, as rotas das trilhas são marcadas e os visitantes são } \\
\text { avisados sobre as questões de orientação. }\end{array}$ \\
\hline $\begin{array}{l}\text { Sinalização, } \\
\text { corrimões e } \\
\text { cercas de } \\
\text { segurança }\end{array}$ & $\begin{array}{l}\text { Os gestores, ao instalar sinalização e cercas e corrimões de segurança, necessitam ter em conta a natureza } \\
\text { corrosiva da combinação de gases vulcânicos, como dióxido de enxofre, com a chuva. A seleção de materiais é } \\
\text { crítica pois muitos metais têm uma vida útil curta nestas condições extremas e as barreiras de segurança, feitas } \\
\text { com um tipo errado de material, podem-se tornar inseguras com o tempo. }\end{array}$ \\
\hline
\end{tabular}




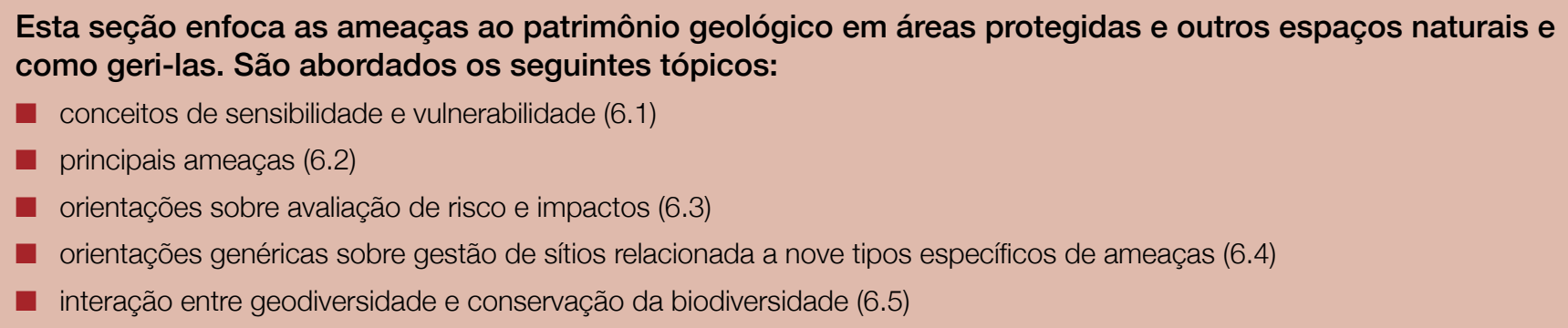

Muitas atividades humanas têm impacto na superfície terrestre. Hooke (1994) utilizou dados sobre o transporte de sedimentos natural e induzido pelo homem para concluir que "os humanos são agentes geomorfológicos. Movem grandes quantidades de solo e de rocha e têm um grande impacto visível na paisagem.... Os humanos são, sem dúvida, o agente geomorfológico mais importante que atualmente molda a superfície da Terra". Nesta seção, são descritas as principais ameaças humanas aos elementos que compõem o patrimônio geológico, com recomendações sobre como lidar com elas. A análise das ameaças é um elemento importante do processo de planejamento da gestão descrito na Seção 5.

\subsection{Conceitos de sensibilidade e vulnerabilidade}

Uma concepção errônea comum sobre o mundo natural é que, enquanto as plantas e os animais estão frequentemente em risco e são suscetíveis a muitas ameaças, as rochas e as formas de relevo são sólidas, robustas e abundantes e, portanto, não necessitam de proteção. Isto está longe de ser a realidade. Há muitas feições do meio físico que são altamente frágeis e suscetíveis à perturbação humana, como por exemplo algumas delicadas estalactites, que podem ser facilmente arrancadas, intencional ou acidentalmente, por geoturistas em cavernas abertas ao público. Dois conceitos são particularmente importantes neste aspecto - sensibilidade e vulnerabilidade. A "sensibilidade" refere-se à suscetibilidade de um determinado elemento a danos e o grau em que será afetada por eles, enquanto que a "vulnerabilidade" refere-se à probabilidade de danos devido a intervenção humana real ou potencial. Alguns locais são altamente sensíveis, mas não são vulneráveis devido à sua localização remota ou à sua proteção física.

A avaliação da sensibilidade de elementos reliquiares (ou seja, resultantes de processos passados que já cessaram) é relativamente simples e baseia-se numa avaliação da escala provável de impacto e de perda do elemento de interesse (Tabela 6.1). Para sistemas geomorfológicos ativos, fatores adicionais a considerar são a resiliência do sistema e a sua potencial resposta dinâmica, incluindo o reajuste prolongado (que pode ou não levar à recuperação) ou a mudança de estado (por exemplo, de um rio entrelaçado para meandrante) (Kirkbride \& Gordon, 2010).

Na tabela 6.1 apresenta-se a escala de 10 pontos de geosensibilidade da Tasmânia, que varia de 1 (altamente sensível) a 10 (altamente robusta). Atividades que causam danos graves em sítios sensíveis podem ter pouco impacto em sítios mais robustos. Alguns sistemas são capazes de reparar a si próprios (por exemplo, pegadas numa praia erodidas pela próxima maré alta), enquanto que outras alterações são irreversíveis, porque os processos que os criaram já não são ativos nessa área (por exemplo, formas de relevo glaciais em áreas onde já não existem glaciares). Em geral, a maior necessidade de gestão e proteção ocorre em locais sensíveis e vulneráveis a perturbações humanas.

Muitos processos naturais atuam na superfície terrestre, erodindo, transportando e depositando sedimentos. É importante proteger também estes processos, pois a geoconservação não é apenas sobre proteger sítios estáticos:

Tabela 6.1. A escala de 10 pontos de geosensibilidade da Tasmânia (modificada de Kiernan, 1996; Sharples, 2002).

1. Elementos sensíveis a danos inadvertidos por mera passagem difusa e livre de pedestres, mesmo com cuidado (por exemplo, superfícies frágeis que podem ser esmagadas sob os pés).

2. Elementos sensíveis aos efeitos de acessos pedestres mais localizados (por exemplo, erosão do caminho pedestre).

3. Elementos sensíveis a danos por coleta científica ou recreativa ou por vandalismo deliberado ou roubo (por exemplo, coleta fóssil ou mineral).

4. Elementos sensíveis a danos por processos remotos (por exemplo, alterações hidrológicas a montante).

5. Elementos sensíveis a danos por impactos lineares de maior intensidade (por exemplo, rastros de veículos).

6. Elementos sensíveis a perturbações de maior intensidade, mas pouco profundas no local (por exemplo, erosão do solo devido a má gestão do solo).

7. Elementos sensíveis à escavação linear ou generalizada superficial deliberada (por exemplo, remoção de troncos de árvores, construção de pequenos diques).

8. Elementos sensíveis à remoção ou à adição importante de geomateriais (por exemplo, pedreiras).

9. Elementos sensíveis apenas a alterações em larga escala (por exemplo, reservatórios ou grandes projetos de canalização de rios).

10. Elementos sensíveis apenas a eventos catastróficos (por exemplo, grandes movimentos de massa ou tsunamis). 
Tabela 6.2. Principais ameaças induzidas pelo homem ao patrimônio geológico em áreas protegidas (adaptado de Gordon \& Barron, 2011; Brooks, 2013; Gray, 2013; Crofts \& Gordon, 2015).

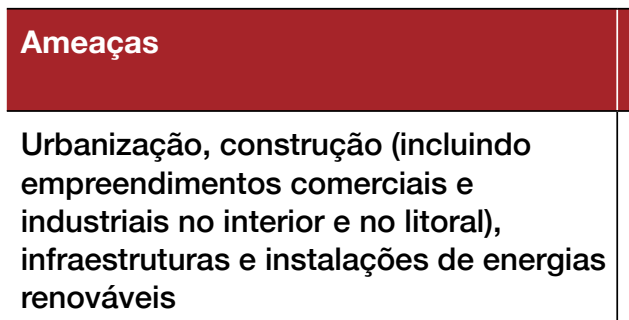

Mineração e extração de minérios (incluindo extração em minas a céu aberto, poços, pedreiras, dunas e praias, leitos de rios, extração de agregados marinhos e extração em alto mar)
Exemplos de impactos sobre o patrimônio geológico em áreas protegidas

- destruição de formas de relevo e de exposições de sedimentos e de rochas

- fragmentação da integridade do sítio e perda das relações entre os elementos

- perturbação dos processos geomorfológicos

- destruição dos solos e da estrutura do solo

- alterações nos regimes do solo e da água

- destruição de formas de relevo e de exposições de sedimentos e de rochas

- fragmentação da integridade do sítio e perda das relações entre os elementos

- perturbação dos processos geomorfológicos

- destruição dos solos e da estrutura do solo

- alterações nos regimes do solo e da água

Alterações na utilização e na gestão do solo (incluindo agricultura e silvicultura) - danos causados por tempestades devido a lavoura, nivelamento do solo e drenagem

- perda de visibilidade de formas de relevo e de afloramentos e do acesso às exposições

- estabilização de feições dinâmicas (por exemplo, dunas de areia)

- erosão do solo

- alterações na química e nos regimes hídricos do solo

- compactação do solo e perda de matéria orgânica

Proteção costeira e gestão e engenharia fluvial (incluindo barragens e captações de água)

- danos a formas de relevo e a exposições de sedimentos e rochas

- perda de acesso às exposições

- perturbação dos processos geomorfológicos

- inibição da erosão favorece a degradação de exposições

Atividades offshore (incluindo dragagem, arrasto, empreendimentos de energias renováveis, exploração de hidrocarbonetos e eliminação de resíduos)

Recreação e geoturismo

- danos físicos a formas de relevo e sedimentos do fundo marinho

- perturbação dos processos geomorfológicos costeiros e marinhos
- danos físicos a formas de relevo, afloramentos, processos e solos (compactação) devido a visitação

- fragmentação da integridade do sítio

- erosão do caminho pedestre e outras erosões localizadas do solo e perda de matéria orgânica do solo

Mudanças climáticas

- mudanças nos processos ativos do sistema

- alterações no estado do sistema (estabilização ou mudança para um estado ativo)

- perda de elementos, tais como calotas polares e glaciares e de processos periglaciais

Subida do nível do mar (por causas antropogênicas)
- perda de visibilidade e acesso a exposições e afloramentos costeiros devido à submersão

- perda de exposições devido ao aumento da erosão

- alterações nas formas de relevo costeiras

- perda da totalidade ou de partes substanciais de áreas protegidas

- desenvolvimento de novos elementos (por exemplo, devido a ondas fortes)

\begin{tabular}{l|l}
\hline $\begin{array}{l}\text { Restauração de minas e pedreiras } \\
\text { (incluindo aterramento) }\end{array}$ & perda de exposições e de formas de relevo naturais \\
\hline $\begin{array}{l}\text { Estabilização de faces rochosas (por } \\
\text { exemplo, cortes de estradas) com redes } \\
\text { e concreto }\end{array}$ & perda de exposições \\
\hline $\begin{array}{l}\text { Coleta irresponsável de fósseis e } \\
\text { minerais e perfuração de rochas }\end{array}$ & $\begin{array}{l}\text { danos físicos a exposições de rochas e perda de registros e do contexto } \\
\text { fossilifero }\end{array}$ \\
\hline
\end{tabular}


trata-se também de criar espaço para que os processos dinâmicos continuem a funcionar dentro da sua gama natural de variabilidade. No entanto, as atividades humanas podem ter impacto nas taxas destes processos, por exemplo, ao remover a vegetação e provocar o aumento das taxas de escoamento nos rios e a erosão do solo. Nestes casos, o papel da geoconservação é fazer com que a variação natural destes processos seja retomada por meio da gestão sustentável da terra e da água (Seção 6.3).

\section{Boa Prática N. 17: Utilizar os conceitos de sensibilidade e vulnerabilidade para orientar as avaliações das ameaças e dos seus potenciais impactos nos elementos que compõem o patrimônio geológico.}

\subsection{Principais ameaças}

Os processos naturais podem resultar na perda de geodiversidade (por exemplo, erosão costeira levando ao colapso de um depósito marinho ou de um arco natural). Isto deve ser aceito como parte da evolução natural da paisagem - o funcionamento contínuo dos processos criará novos depósitos ou arcos. Mais preocupantes para os gestores são os impactos induzidos pelo homem que podem levar a uma ou mais das seguintes consequências:
- destruição completa de um geossítio;
- perda parcial ou dano físico a um geossítio;
- fragmentação do elemento de interesse;
- perda de visibilidade (por exemplo, devido ao crescimento da vegetação);
- perda de acesso;
- interrupção de processos naturais e impactos para além da área do geossítio;
- poluição;
- perda de naturalidade; e
impactos visuais (por exemplo, pichações).

A tabela 6.2 apresenta uma lista de ameaças específicas, com exemplos de impactos sobre o patrimônio geológico em áreas protegidas. O restante do capítulo descreve as ameaças, pressões e impactos e fornece recomendações sobre abordagens de gestão e fontes de orientação prática. Para mais detalhes, ver Gray (2013).

\subsection{Enfrentando as ameaças: Avaliando riscos e impactos}

Os sítios e feições associadas possuem graus de sensibilidade variados aos diferentes tipos de atividade humana. A determinação do impacto provável e das opções para contrapor potenciais ameaças é uma componente importante da gestão de sítios. É necessário realizar avaliações de risco e estabelecer prioridades de ações de gestão para determinar a probabilidade e os efeitos potenciais dos diferentes tipos de atividade humana e de alterações naturais. Aqui devem ser aplicados os princípios e os métodos de avaliação ambiental estratégica e de análise de impacto ambiental. Note-se que, no caso de sistemas dinâmicos, as atividades externas à área protegida podem ter impacto sobre a mesma.

\subsection{Enfrentando as ameaças: Orientações sobre melhores práticas com base em tópicos-chave}

A seguir serão descritos os efeitos de ameaças específicas a geossítios, juntamente com recomendações sobre princípios e abordagens de gestão. Para orientação e exemplos práticos consultar Prosser et al. (2006), que estabelecem orientações abrangentes sobre a gestão de sítios com base nos objetivos de conservação para as três categorias principais de geossítios: extensos, vulneráveis e limitados - ou temporários (Seção 5.2 e Tabela 5.1). Na Seção 7 são fornecidos exemplos da aplicação destas orientações para áreas protegidas com cavernas e carste, glaciares e ambientes periglaciais (isto é, associados a processos de congelamento/descongelamento), elementos paleontológicos e minerais e áreas vulcânicas. Quando existentes, são também referenciadas fontes de orientação adicionais (por exemplo, para a gestão de rios e zonas costeiras). Além disso, são incluídos vários estudos de caso (caixas 6.1-6.7; ver também caixa 4.5). Sempre que apropriado e possível, devem-se considerar as Soluções baseadas na Natureza (ou seja, aquelas que procuram imitar a natureza ou restaurá-la). A UICN publicou a primeira edição de uma Norma Global para Soluções Baseadas na Natureza (UICN, 2020).

\section{Mineração e restauração de pedreiras}

Minas antigas no interior de áreas protegidas podem apresentar problemas de segurança e ambientais. Muitos elementos históricos, tais como poços verticais e entradas de minas, são deixados expostos e podem ser perigosos, necessitando de vedações ou tampas de segurança para proteger os visitantes de acidentes. Em muitas destas minas eram explorados minerais de minério sulfídricos, tais como chumbo, cobre e zinco, sendo o escoamento de água subterrânea destes locais tipicamente ácido e tóxico para a vida animal. Os sulfuretos ricos em arsênio constituem um problema particular devido à sua toxicidade. Eventualmente os gestores de áreas protegidas podem se associar a outras organizações, tais como um departamento de minas ou um órgão de proteção ambiental, para a limpeza dessa poluição tóxica da água. Antigos rejeitos de mineração ricos em sulfetos constituem um problema semelhante para o escoamento da poluição.

Os minerais são importantes na sociedade moderna e sua extração revela frequentemente importantes exposições de rochas. Quando o local de onde o material está sendo extraído é extenso e o impacto paisagístico limitado, não há tanto problema. As situações mais graves são aquelas em que solos raros, formas de relevo importantes ou sítios fossilíferos de extensão limitada são destruídos pela exploração em superfície. Infelizmente, a escavação ilegal ou descontrolada ocorre em várias partes do mundo, deixando paisagens devastadas e não restauradas.

Para além dos impactos diretos no geopatrimônio e na paisagem, outros efeitos possíveis da exploração de pedreiras e minas incluem a produção de pilhas de resíduos, poluição devido a rejeitos, drenagem ácida ou rompimento de barragens onde o material de rejeito é armazenado, 


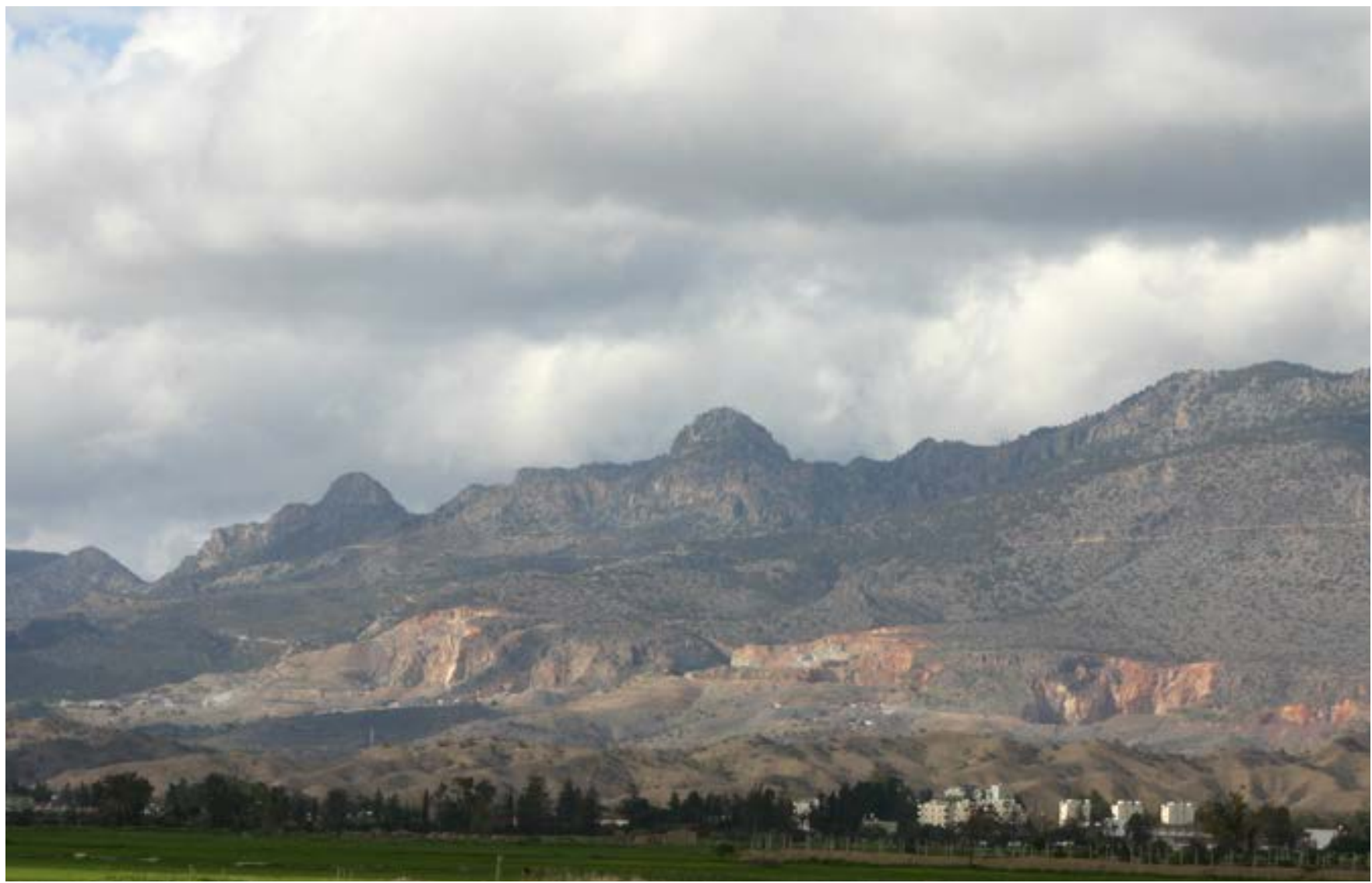

Foto 6.1 As pedreiras proporcionam novas exposições para pesquisas por geólogos, especialmente rochas mantélicas raras do fundo oceânico, como visto no Parque Nacional de Troodos, Chipre do Norte. Os fragmentos podem ser perigosos e o acesso precisa de manutenção. () Roger Crofts

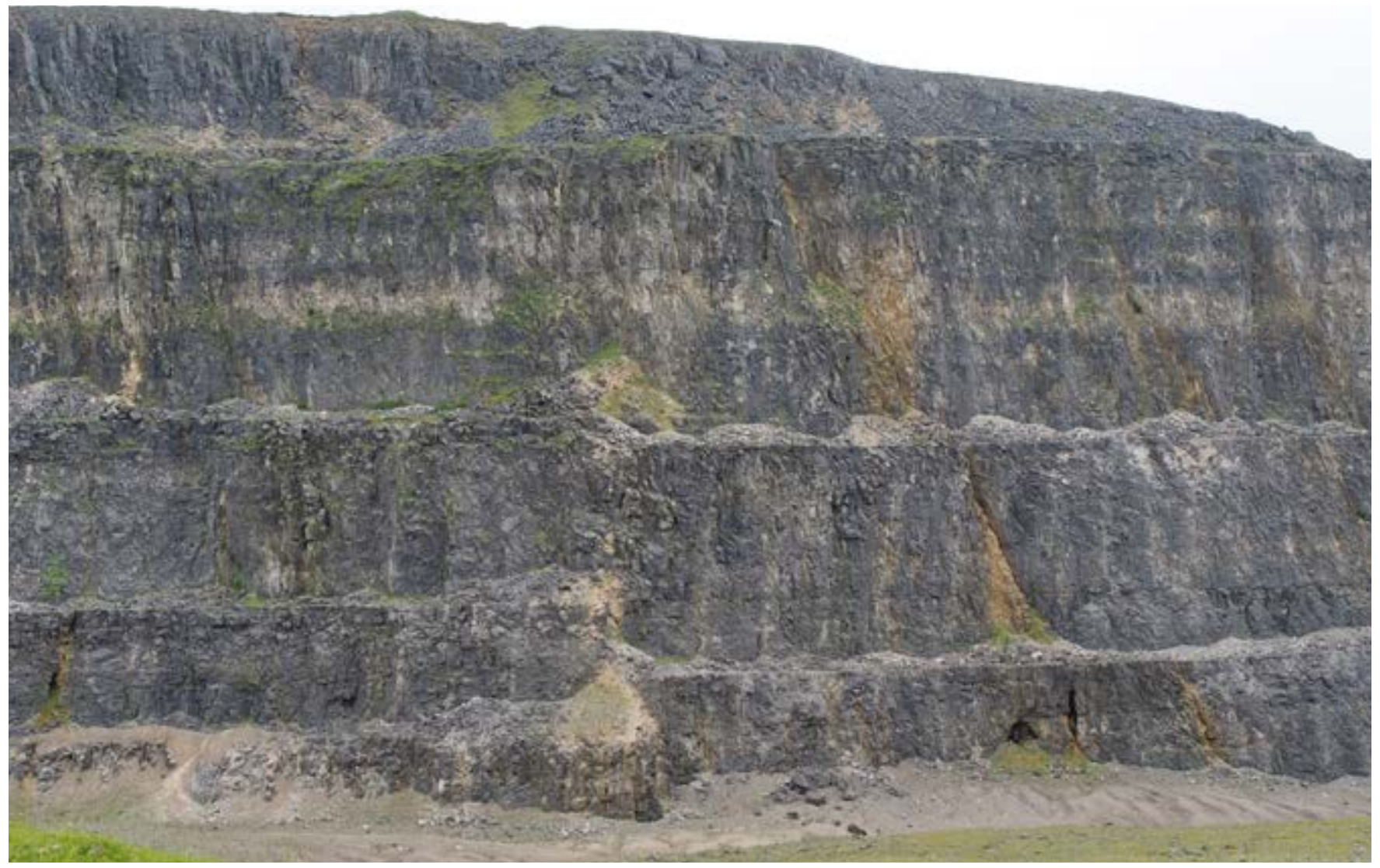

Foto 6.2 llustração mostrando que minerações aprovadas antes de um local receber a designação de área protegida podem ser interrompidas ou sua ampliação recusada dependendo da relevância do patrimônio geológico. Pedreira de Eldon Hill no Parque Nacional de Peak District e Sítio de Interesse Científico Especial de Castleton, Inglaterra. Após a desativação da pedreira, em 1999, importantes espeleotemas e depósitos de sedimentos foram descobertos (ver pessoa à entrada da caverna). ( John Gunn 


\section{Caixa 6.1}

\section{Pedreira Horn Park, Sítio de Especial Interesse Científico (SSSI) e Reserva Natural Nacional, Reino Unido}

A Pedreira Horn Park, uma pedreira desativada perto de Beaminster, Dorset, Reino Unido, é um exemplo de retenção de interesses de conservação para visitantes e para estudos por cientistas após o encerramento da lavra e aprovação de um novo uso para a pedreira.

O SEIC e Reserva Natural Nacional da Pedreira Horn Park é uma das localidades mais famosas e ricamente fossilíferas da Formação Oolite, do Médio Jurássico Inferior do sudoeste da Inglaterra, particularmente notável pela camada mineralizada única e pela fauna de invertebrados fósseis diversificada e bem preservada, em particular as amonitas.

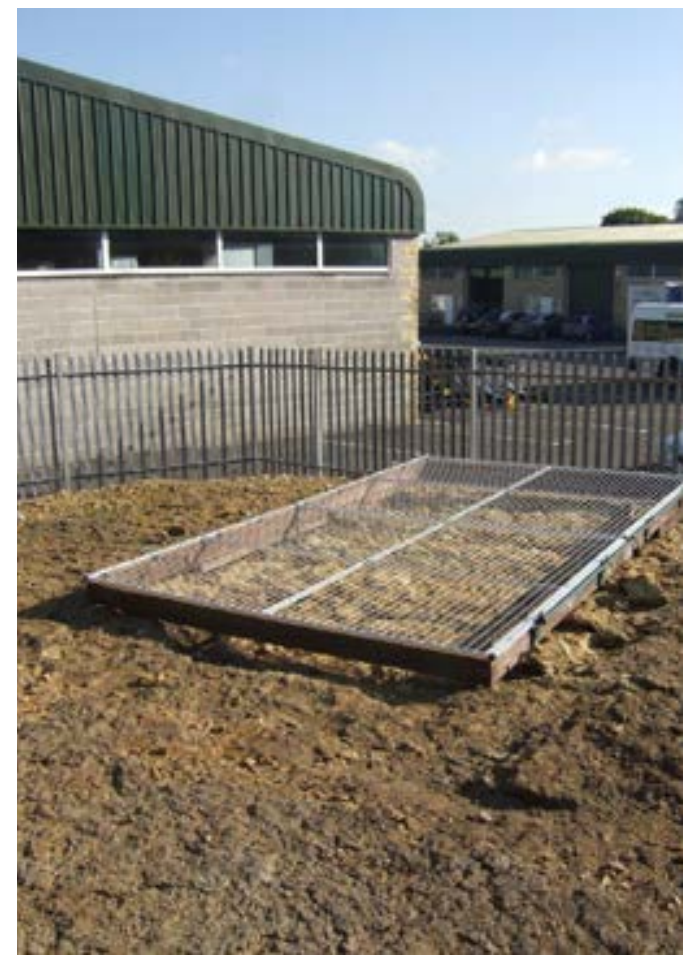

Questões de conservação e ações implementadas

A Pedreira Horn Park apresenta dois importantes desafios de conservação (Larwood \& Chandler, 2016). Primeiro, como o calcário foi em grande parte extraído, o recurso fóssil restante é finito e particularmente vulnerável à coleta excessiva e ilegal. Segundo, o desenvolvimento de um parque empresarial exigiu um planejamento cuidadoso e sensível para manter exposições representativas e acessíveis ao longo da sequência estratigráfica.

Após um levantamento detalhado, as faces principais da pedreira superior foram reexpostas e escalonadas, permitindo a retenção de uma sequência estratigráfica completa. A área foi cercada de forma segura para restringir o acesso, protegendo assim o recurso fóssil e demarcando a área mais sensível do local durante a construção de unidades industriais. O acesso ao local é feito apenas mediante autorização prévia.

Com o auxílio de voluntários e do Jurassic Coast Trust, a parte inferior da sequência foi alargada e a parte superior, incluindo os fósseis, reexposta. Sobre esta área foi colocada uma caixa de segurança, com gradeamento de rede metálica. Isto permite aos visitantes observar detalhes da fauna fóssil diversa sem perturbar ou haver perda dos fósseis. O material excedente dos trabalhos de pesquisa e de limpeza foi deixado no local para que os visitantes possam coletar. Além disso, foram doados espécimes ao vizinho Museu Beaminster, onde foram incorporados a uma exposição de geologia e a caixas educativas com fósseis para trabalhos com escolas locais.

Caixa com rede metálica protegendo camadas fossiliferas expostas $\odot$ Jonathan Larwoodd

ruído, vibração ou tráfego/acesso, impactos rodoviários e impactos visuais por instalações e maquinaria.

Em grande parte dos países a mineração em áreas protegidas é proibida. Isto inclui todas as formas de mineração, tais como perfuração e levantamentos geofísicos. Para as áreas protegidas que seguem esta legislação, esta proibição estende-se ao centro da Terra, ou pode ser restringida em profundidade. Um exemplo disso são as áreas protegidas que incluem zonas de captação de água que ocorrem sobre camadas de carvão sub horizontais perto de Sidney, Austrália, cujos limites foram estabelecidos com base na profundidade durante sua criação, o que significa que o carvão poderia ser extraído em profundidade. Isso gerou problemas na gestão de superfície para as equipes gestoras destas áreas, tais como o desaparecimento de cursos de água e fugas de gás metano, sendo necessária uma ação governamental.

A colaboração entre a UICN e o Conselho Internacional em Minas e Metais resultou em códigos de prática (ICMM, 2003). O compromisso-chave é: "Respeitar as áreas protegidas legalmente designadas e assegurar que quaisquer novas operações ou alterações às operações existentes não sejam incompatíveis com os valores para os quais foram designadas" (ICMM, 2003). A UICN considera que nenhuma atividade mineira deve ter lugar numa área protegida (UICN, 2016b).

Um exemplo de preocupação sobre operações de mineração em áreas protegidas ou em suas proximidades é a mina Los Frailes, em Aznalcóllar, próximo a Sevilha, Espanha. Em 1998, uma barragem de rejeitos rompeu e 5 milhões de metros cúbicos de iodo tóxico correram para o rio Guadiamar, por pouco não atingindo as importantes zonas úmidas do Parque Nacional de Doñana, um Patrimônio Mundial. Foi necessária uma operação de limpeza no valor de 240 milhões de euros. Como resultado, a mina foi fechada, mas foi autorizada a reabrir em 2015, e a construção de uma nova barragem de rejeitos proibida.

Algumas áreas protegidas sofrem com a mineração ilegal, como é o caso da mineração de ouro. O Parque Nacional Corcovado, na Costa Rica, é um exemplo de extensiva 
atividade de extração artesanal de ouro nas margens do rio, o que levou as autoridades a agir. Normalmente, tais ações de resposta envolvem a polícia. Se os gestores de áreas protegidas conhecerem adequadamente o patrimônio geológico da sua área, podem eventualmente antecipar a atividade ilegal e implementar medidas de proteção. Uma vez interrompidos, os danos causados pela mineração ilegal exigirão também medidas de limpeza e restauração que terão como base o conhecimento geológico e de restauração.

No Parque Nacional de Kakadu, na Austrália, a extração de urânio foi iniciada em 1980. Quando o parque nacional foi criado, no ano seguinte, as minas Ranger e Jabiluka foram excluídas de seu território, mas estão completamente cercadas por ele. As preocupações aqui incluem o vazamento diário de 100.000 litros de água contaminada de uma barragem de rejeitos por meio de fissuras nas rochas abaixo da mina Ranger, em 2009.

As exigências associadas a planos de recuperação de pedreiras incluem normalmente restauração e paisagismo, e frequentemente envolvem aterramento, o que pode resultar na perda de exposições geológicas. O diálogo prévio entre as partes interessadas (por exemplo, operadores de pedreiras, autoridades locais, acadêmicos e organismos de geoconservação) é essencial para assegurar que, na medida do possível, o patrimônio geológico seja incorporado aos planos de recuperação por meio do estabelecimento de locais nos quais os elementos geológicos possam ser conservados, observados e interpretados para pesquisa, educação e geoturismo (caixas 4.5 e 6.1). Estes planos podem incluir a conservação de seções ou de pilhas de rejeito que contenham espécimes minerais importantes. Quando aplicável, a restauração do patrimônio geológico deve ser integrada com a de mineração para biodiversidade e ganho de habitat (por exemplo, o programa Nature After Minerals, na Inglaterra, operado conjuntamente pela Natural England e a Sociedade Real para a Proteção de Pássaros juntamente com a comunidade mineira). Na ausência de legislação, Prosser (2016) destaca o valor de "desenvolver parcerias mutuamente benéficas que celebrem a contribuição positiva da indústria de mineração para as geociências, a educação e a conservação, ao mesmo tempo que conservam as características geológicas, espécimes e dados que possam surgir das suas operações".

Recomendações para a gestão e restauro de pedreiras:

- assegurar um diálogo prévio entre as partes interessadas para que o geopatrimônio seja incorporado a projetos de recuperação;

- garantir o acesso para registro e coleta nas pedreiras ativas;

- integrar o patrimônio geológico e a biodiversidade no plano de recuperação;

- assegurar e manter exposições chave ou pilhas de rejeitos como áreas de conservação, utilizando técnicas apropriadas;

- controlar a invasão da vegetação; e

- desenvolver oportunidades de interpretação.

\section{Construções e urbanização}

A preparação de terras para a construção de estradas, casas, indústria e outros usos pode ter enormes impactos

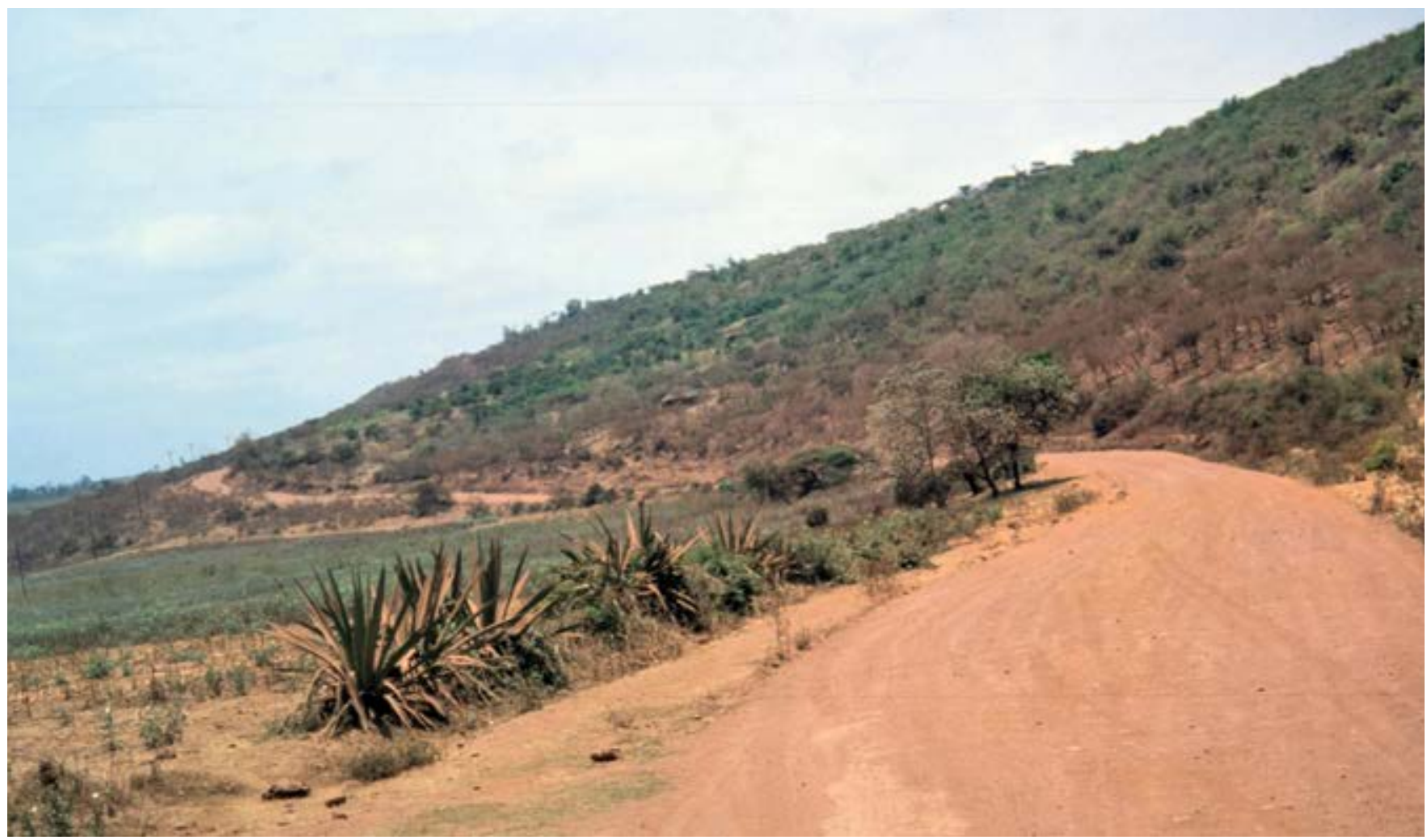

Foto 6.3 A construção de estradas facilita o acesso de turistas à Área de Conservação de Ngorongoro, Tanzânia e à sua importante vida selvagem, mas cria grandes pressões sobre a gestão da conservação da área. @ ( Roger Crofts 
no patrimônio geológico, remodelando a topografia natural, danificando estruturas do solo, interrompendo processos geomorfológicos e alterando a hidrologia da área, por exemplo, por meio da instalação de superfícies de baixa permeabilidade. A construção de novos edifícios em áreas protegidas deve ser feita com cuidado, para que suas localização e concepção se enquadrem harmoniosamente na paisagem local. $\mathrm{Na}$ construção de estradas, estas devem tentar acompanhar a topografia existente e ser concebidas de modo a evitar cortes e aterros extensos. Se forem necessários cortes, quaisquer estratos geológicos revelados devem ser deixados expostos para pesquisa e estudo futuros, seguindo as orientações de Prosser et al. (2006). Em alguns casos, a restauração parcial pode ser possível após danos causados pelas construções.

\section{Recomendações para gestão e restauração:}

- assegurar um diálogo prévio entre as partes interessadas para que o patrimônio geológico seja incorporados a procedimentos de construção e recuperação;

- assegurar o acesso para registro e coleta durante os trabalhos de construção;

- integrar a conservação do patrimônio geológico à recuperação da paisagem;

- assegurar e manter exposições ou formas de relevo importantes como seções ou sítios para conservação, utilizando técnicas apropriadas; e

- desenvolver oportunidades de interpretação.

\section{Gestão e engenharia costeiras}

A instalação de obras de defesa costeira rígidas pode ter vários efeitos importantes sobre a geodiversidade. Em primeiro lugar, são concebidas para impedir a evolução natural da linha de costa. Em segundo lugar, podem obliterar importantes exposições geológicas costeiras e assim torná-las inacessíveis para estudo futuro. Em terceiro lugar, podem levar à estabilização de formas de relevo costeiras ativas, tais como sistemas de dunas. e impedir o intercâmbio de sedimentos entre praias e dunas. Em Burnie, na Tasmânia, Austrália, por exemplo, um monumento geológico protegido (diques de diabásio précambrianos) foi recoberto durante um projeto de recuperação costeira (C. Sharples, com. pessoal.). Quando a proteção costeira é necessária, recomenda-se a utilização de métodos de engenharia "suave", tais como a reposição de areia de praia.

Abordagens mais estratégicas, baseadas na compreensão dos processos à escala dos sistemas costeiros regionais ou das células litorâneas, vêm sendo cada vez mais adotadas. Isto permite avaliar possíveis efeitos adversos mais amplos, identificar e resolver áreas de conflito e desenvolver uma gestão mais integrada por meio de planos de gestão da linha de costa. Embora as obras de proteção duras continuem provavelmente a ser necessárias a fim de assegurar a infraestrutura essencial, soluções mais naturais vêm sendo cada vez mais discutidas e implementadas em vários locais, tanto por razões ambientais como de custos (Spalding et al., 2014; Cohen-Shacham et al., 2016; Williams et al., 2018; Morris et al., 2019); (ver também a Seção 5 e o website da UICN/CMAP Natural Solutions). Um bom exemplo de mitigação e adaptação às alterações climáticas em manguezais é o Estudo de Caso 1.1 em Gross et al. (2016). A equipe de defesa costeira da Science for Nature and People Partnership dispõe de excelente material para auxiliar os gestores de áreas protegidas.

A alimentação artificial de praias com areia trazida de outros locais e depositada na praia (muitas vezes em combinação com outras estratégias) vem sendo também cada vez mais utilizada. Existe uma extensa literatura sobre soluções sustentáveis para gestão costeira; Williams et al. (2018) fornecem uma revisão atualizada.

As atividades próximas à zona costeira ou em alto mar podem também ter um impacto prejudicial nas características do patrimônio geológico costeiro e marinho, tais como danos a formas de relevo ou perturbação de processos naturais. Ver Spalding et al. (2014) e Pontee et al. (2016) para recomendações adicionais.

Recomendações para gestão e restauração costeira:

- adotar uma estratégia de gestão das células litorâneas;

- adotar técnicas naturais de gestão de inundações e de proteção costeira;

- trabalhar com intervenções mínimas aos processos naturais (por exemplo, realinhamento monitorado, recarga de praias e restabelecimento da conexão entre fontes e sumidouros de sedimentos), ao invés de "fixar e controlar";

- integrar os objetivos da geodiversidade e da biodiversidade; e

- instalar ou reinstalar infraestruturas longe das linhas de costa ativas.

\section{Gestão e engenharia fluviais}

Tal como a engenharia costeira, a engenharia fluvial também tem impacto nas feições e processos naturais. Muitos rios têm sido "canalizados, retificados, aterrados, represados, desviados, cultivados, dragados e isolados das suas planícies aluviais" (Gray, 2013). Em qualquer um destes casos ou suas combinações, a dinâmica do rio é alterada e seu leito natural, suas margens ou os habitats das planícies aluviais são afetados de maneira adversa.

A construção de barragens é a ação mais significativa na alteração do regime de fluxo a jusante e no impacto sobre a paisagem. Uma das barragens mais controversas em áreas protegidas é a barragem O'Shaughnessy, construída em 1913 ao longo do vale Hetch Hetchy, no Parque Nacional de Yosemite, Califórnia, EUA, para fornecer água a São Francisco. A controvérsia sobre sua construção foi e continua grande. Um exemplo mais positivo é uma ação oposta - remoção de barragem - tal como a empreendida no Parque Nacional Olympic, em Washington, EUA. Duas barragens, Elwha e Glines Canyon, foram removidas. Elas haviam sido construídas no início do século XX para fornecer energia hidrelétrica à indústria madeireira e às cidades locais. No entanto, a construção das barragens também bloqueou a migração do salmão para montante, alterou o fluxo de sedimentos para jusante e inundou as terras históricas e sítios culturais da Tribo Lower Elwha Klallam. Em 1992, a história do rio mudou quando o Congresso dos EUA aprovou a Lei do Ecossistema do Rio Elwha e de Restauração da Pesca, autorizando a 


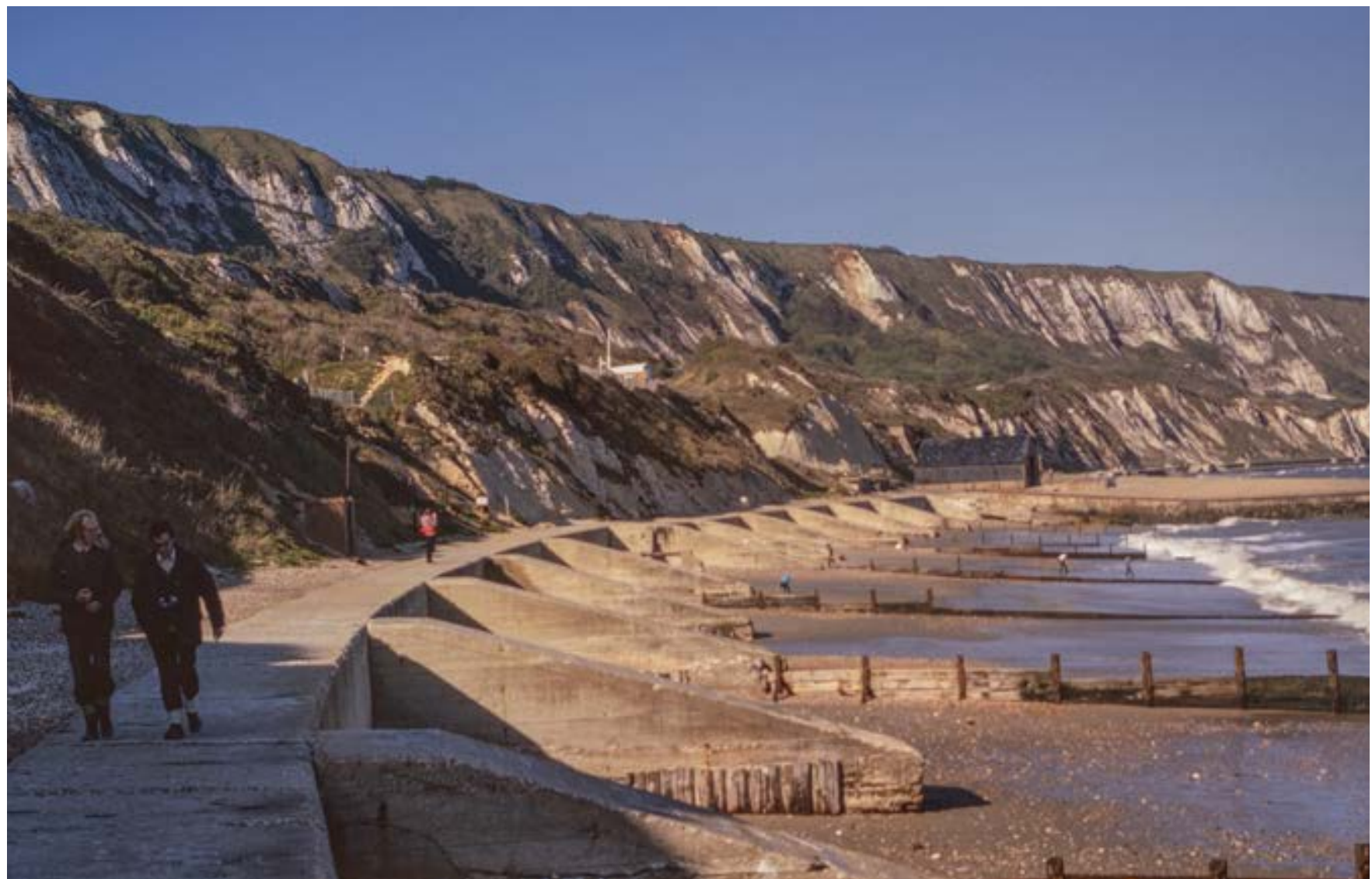

Foto 6.4 Estruturas rígidas, tais como muros para barrar a erosão das falésias e quebra-mares para capturar areia podem ser necessárias localmente, mas formas alternativas de engenharia devem ser testadas inicialmente. Folkestone, Inglaterra. () Roger Crofts

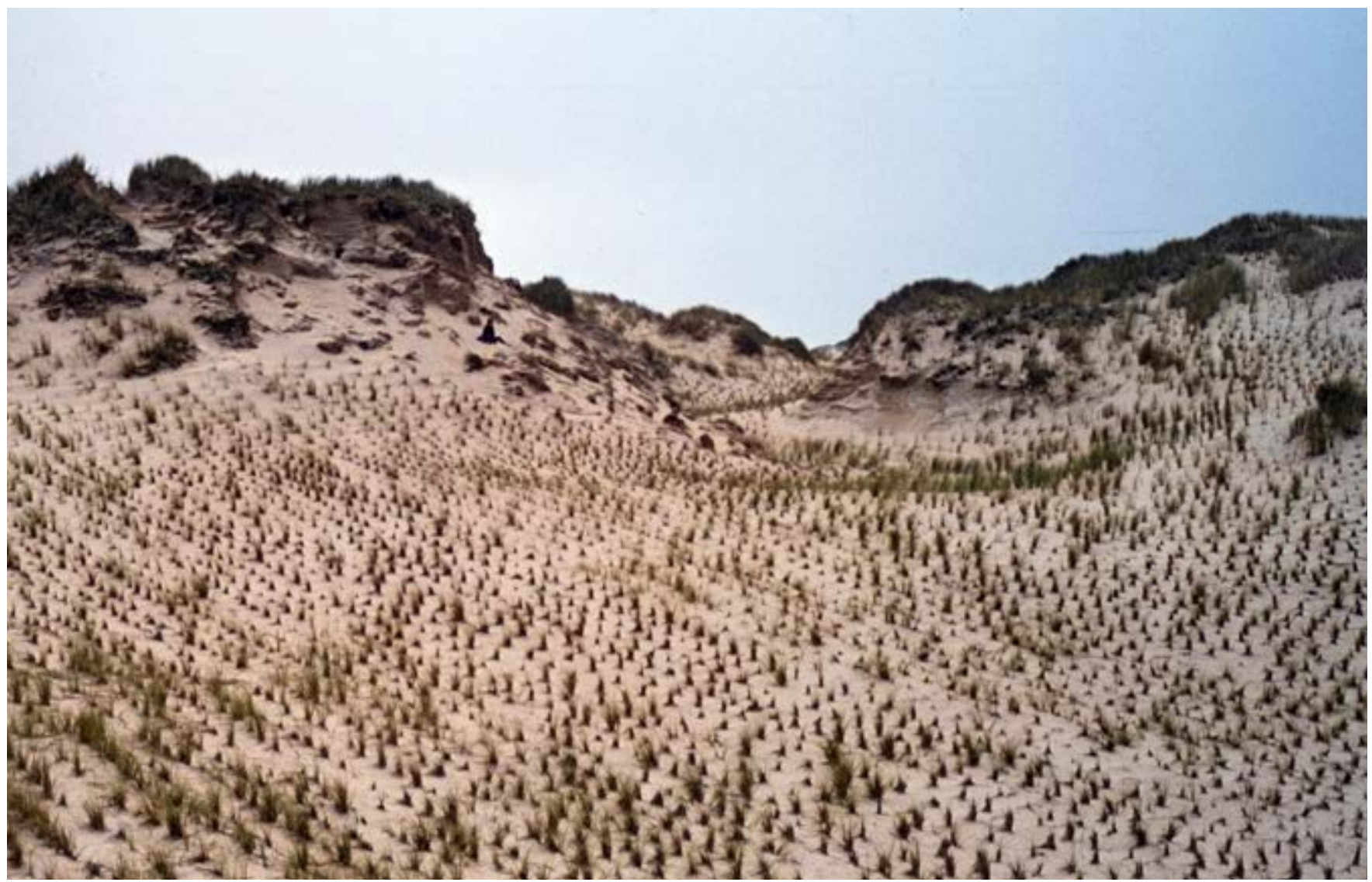

Foto 6.5 A estabilização de areia por meio da plantação de gramíneas nativas é um excelente método. Sítio natural Doolough dunes, Mayo, Irlanda. () Roger Crofts 
6. Enfrentando as ameaças ao geopatrimônio em áreas protegidas

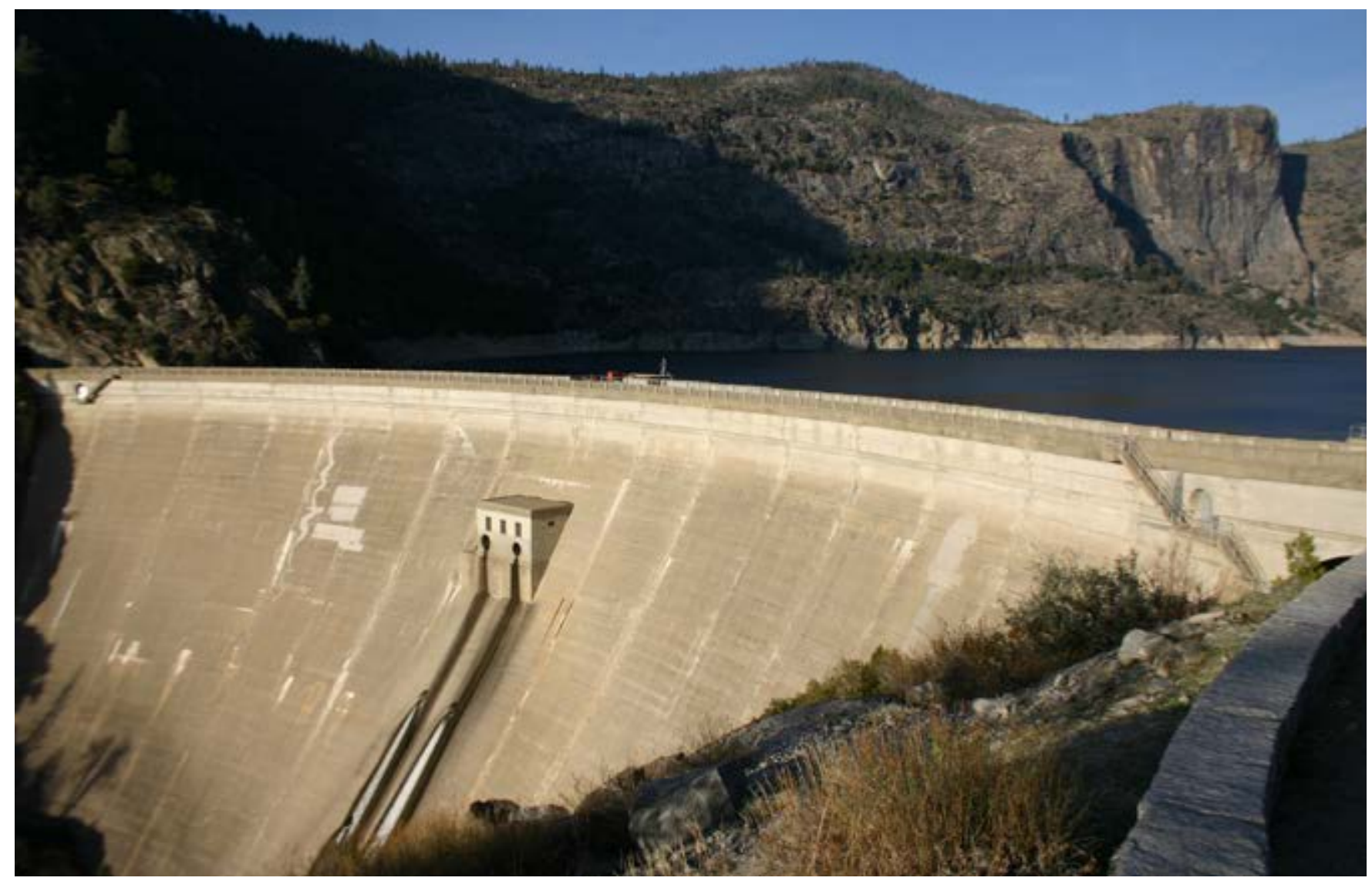

Foto 6.6 A altamente controversa barragem de O'Shaughnessy, ao longo do vale Hetch Hetchy no Parque Nacional de Yosemite, Califórnia, EUA. A construção de barragens e a inundação de terras é um problema antigo em muitas áreas protegidas de montanha. A mitigação é muito limitada, a menos que as estruturas possam ser removidas. () Murray Gray

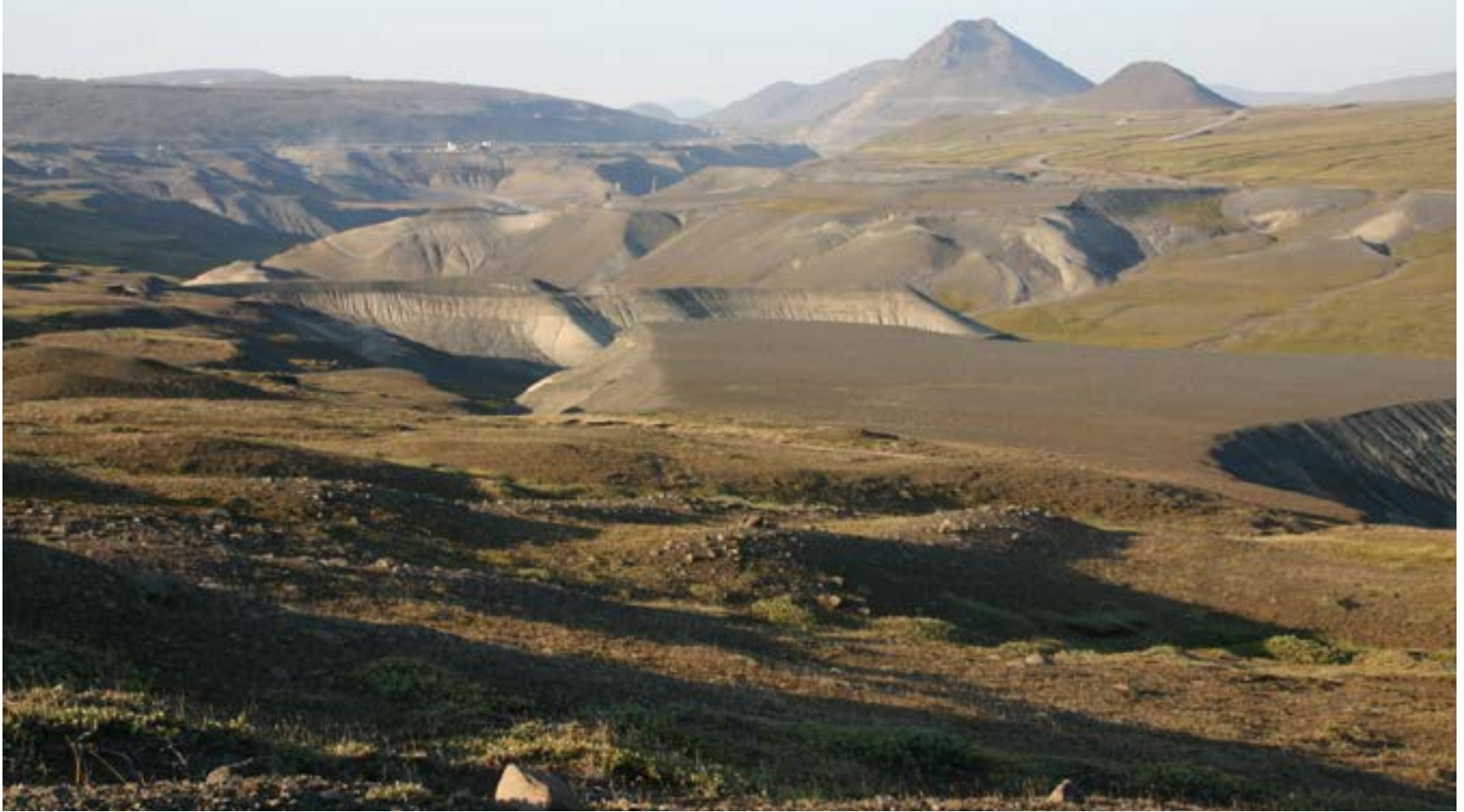

Foto 6.7 Alguns dos melhores exemplos a nível mundial de terraços formados por água de degelo estão agora submersos sob as águas do reservatóriode Hálslón, Islândia, afetando o transporte de água e de sedimentos tanto a montante como a jusante. Houve grande oposição à construção da barragem. O local foi excluído do Parque Nacional de Vatnajökull, Islândia, apesar da intensa oposição. ○) Roger Crofts 


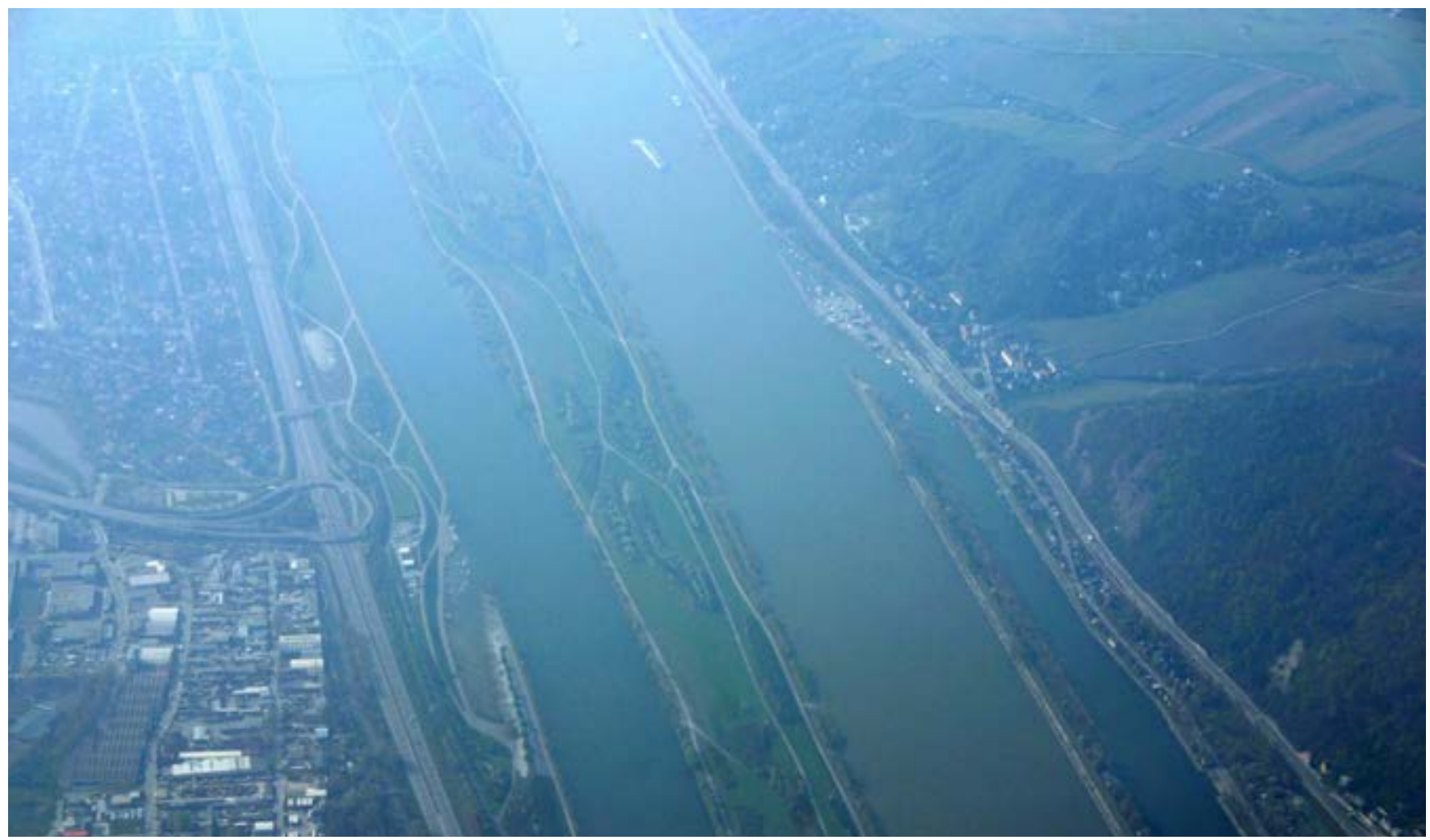

Foto 6.8 O rio Donau e o canal a jusante de Viena, Áustria, foram retificados para melhorar a navegação. Novas medidas foram implementadas para restaurar os canais naturais de inundação do rio no Parque Nacional Donau-Auern. $\odot$ Roger Crofts

remoção das barragens. Após duas décadas de planejamento, a maior remoção de barragens na história dos EUA teve início em 2011, com a Barragem de Elwha, e foi seguida pela remoção da Barragem do Glines Canyon, em 2014. Hoje, o rio Elwha e a sua carga sedimentar fluem livremente de novo a partir das cabeceiras, nas Montanhas Olympic, para o Estreito de Juan de Fuca (ver foto de rosto desta seção).

As abordagens convencionais em gestão de rios envolvem normalmente obras de engenharia rígidas, por meio da utilização de armaduras ou gabiões para estabilizar as margens do canal. Estas abordagens não apenas limitam a dinâmica natural do sistema fluvial, mas também podem danificar as margens do rio e os habitats e espécies do canal e levar à transferência de problemas em direção a jusante. Do ponto de vista da conservação, as obras de engenharia rígidas devem restringirse à proteção de serviços essenciais, edifícios e infraestruturas. Novas abordagens reconhecem cada vez mais a importância da gestão em escala de bacia hidrográfica e o valor das Soluções baseadas na Natureza que envolvem medidas para restabelecer os regimes de fluxo naturais do rio, retardando o fluxo da água e permitindo um maior armazenamento das águas nas planícies de inundação (Poff et al., 1997; Poff, 2018; Palmer \& Ruhi,

2019). Orientações específicas e exemplos de soluções naturais estão disponíveis em várias fontes, incluindo o River Restoration Centre e o website da WCPA-UICN, Natural Solutions. A caixa 6.2 mostra um exemplo específico.

Em janeiro de 1997, o Parque Nacional de Yosemite, na Califórnia, EUA, sofreu a maior inundação em pelo menos 100 anos. Por mais devastadora que tenha sido, numa perspectiva humana, a inundação constituiu uma oportunidade para a implementação de uma restauração positiva. Os gestores da área protegida se empenharam em reposicionar o maior número possível de edifícios para fora da planície de inundação do Rio Merced ou do Vale de Yosemite. Os novos edifícios estão localizados fora da planície de inundação e longe de zonas úmidas sensíveis, prados, bosques e do próprio leito do rio. A finalização dos projetos de recuperação de enchentes havia sido estimada para quatro a cinco anos. Porém, a necessidade de preparação de documentos adicionais devido a uma série de processos judiciais relacionados a projetos específicos fez com que este prazo fosse ampliado para 15 anos. O relatório final das atividades de recuperação está disponível on-line (US National Park Service, 2013).

\section{Recomendações para a gestão e recuperação de rios:}

- adotar uma estratégia de gestão da bacia hidrográfica;

- adotar técnicas naturais de gestão de inundações (por exemplo, restauração de rios e planícies aluviais);

- restabelecimento de regimes de fluxo naturais;

- trabalhar com processos naturais utilizando o mínimo de intervenção, ao invés de "fixar e controlar", criando espaço para reconectar rios e suas planícies aluviais e restaurando a conectividade a montante e a jusante;

- buscar acordos para a remoção de obstáculos ao fluxo natural e ao transporte de sedimentos, tais como barragens;

- integrar os objetivos da geodiversidade e da biodiversidade; e

- instalar ou reinstalar infraestruturas fora das planícies de inundação ativas. 


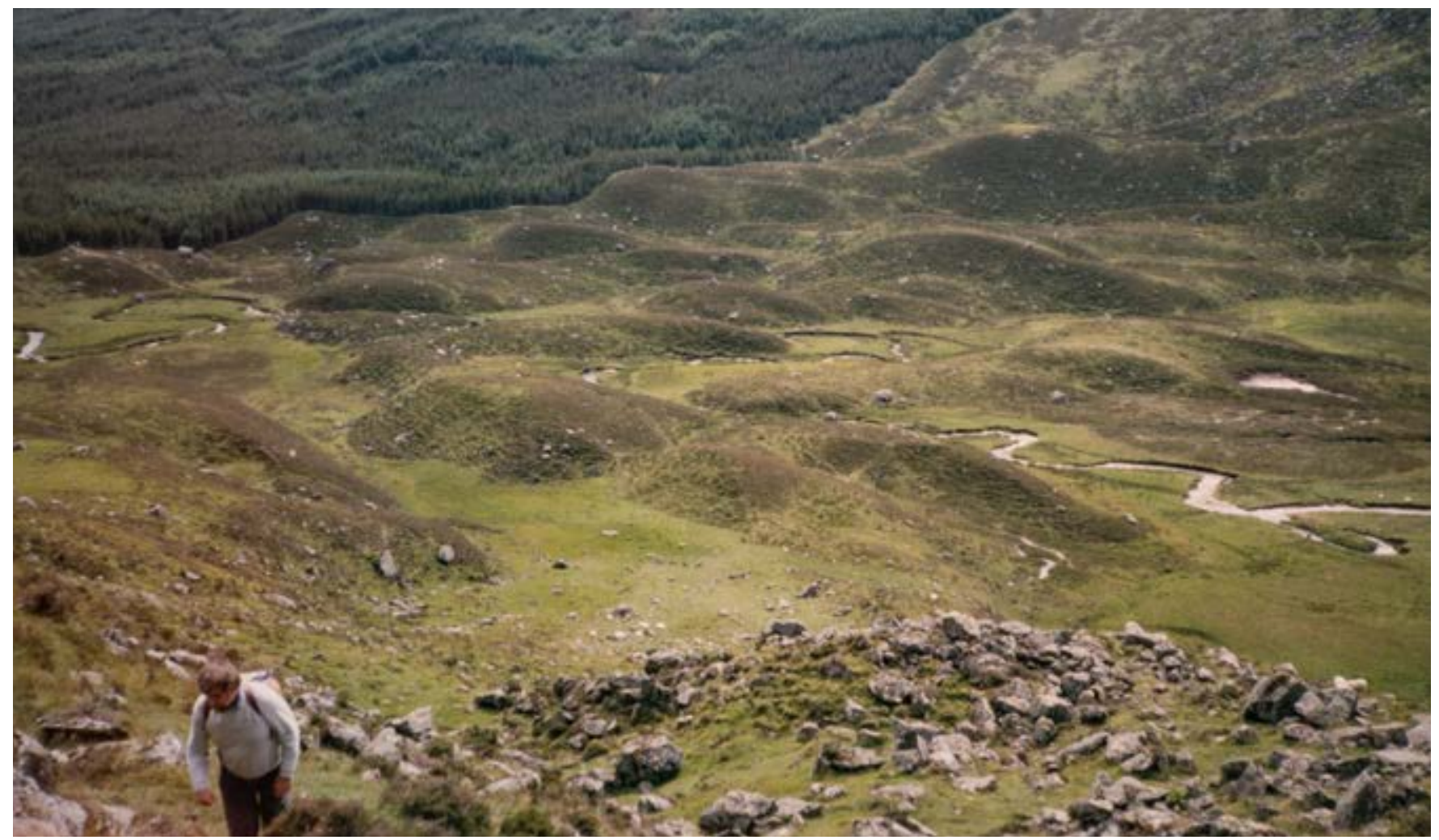

Foto 6.10 Formas de relevo produzidas pelo recuo de um glaciar da idade do gelo não podem ser observadas pela maioria dos visitantes, pois foram obstruídas pela floresta plantada, vista na parte superior da foto. Para fotografar a vista, os visitantes têm que subir uma colina íngreme. Claramente, a visibilidade do geopatrimônio não foi uma preocupação durante o florestamento. Reserva Natural Nacional Coire Fee, Escócia. @ Roger Crofts

\section{Silvicultura e vegetação}

Os principais impactos da silvicultura e da vegetação são o seu potencial de obscurecer afloramentos e formas de relevo individuais ou em conjunto dentro de uma área, reduzindo a continuidade visual e obstruindo pontos de observação. No caso de plantações, a utilização de equipamentos mecânicos em grande escala pode compactar solos, alterar sua hidrologia e destruir formas de relevo suaves. O mesmo se aplica às operações de abate de árvores, que devem ser realizadas com a maior sensibilidade ambiental possível. A remoção de árvores pode aumentar também o escoamento superficial, a erosão do solo e a entrada de sedimentos nos rios.

O florestamento em grande escala é geralmente incompatível com os objetivos de gestão da conservação para grandes sítios geomorfológicos. Na década de 1970, a Comissão Florestal do Reino Unido tinha planos para plantações de coníferas na Reserva Natural Nacional de Glen Roy, onde as famosas Estradas Paralelas de Glen Roy podem ser vistas continuamente ao longo de vários quilômetros. Estas feições, que correspondem a bordas de lagos glaciais, teriam sido totalmente obstruídas por estas plantações, mas felizmente o projeto foi abandonado quando os impactos foram apontados pela comunidade geocientífica. Nos locais já utilizados para silvicultura comercial, podem existir oportunidades, por meio do diálogo com as empresas florestais, para desobstruir formas de relevo ou pontos de observação específicos. No caso de formas de relevo e afloramentos de pequenas dimensões, o principal requisito de gestão é deixar as feições livres de plantações e manter o acesso e os mirantes.
A regeneração natural da vegetação em grandes sítios geomorfológicos é potencialmente ainda mais difícil de controlar. Ainda que não seja possível manter o acesso livre a todos os locais, os sítios mais representativos e valiosos devem ser identificados e sua visibilidade e acesso garantidos por meio de intervenções e gestão, considerando as questões discutidas na Seção 6.5 (Ver Caixa 6.3).

Em uma escala de detalhe, a invasão de vegetação é uma preocupação frequente na gestão de formas de relevo e afloramentos de pequenas dimensões. Intervenções no sentido de limpar a vegetação podem ser necessárias e devem estar especificadas no plano e nos objetivos de gestão do local (por exemplo, se mais de $50 \%$ da exposição for coberta; ver Seção 5.2). Isto dependerá da natureza do elemento de interesse (por exemplo, a limpeza repetida de afloramentos sedimentares frágeis pode danificá-los progressivamente) e do tipo e frequência de utilização (por exemplo, um local utilizado para pesquisa pode requerer apenas uma limpeza ocasional, quando novos estudos forem realizados, enquanto que um local robusto e muito visitado utilizado para geoturismo pode requerer uma limpeza regular).

Na Seção 6.5 são fornecidas informações e orientações sobre como lidar com conflitos entre a biodiversidade e a conservação da geodiversidade.

Recomendações para a gestão da silvicultura e da invasão da vegetação:

- evitar a arborização em grande escala, que obscureçam as características chave de sítios; 


\section{Caixa 6.2}

\section{Melhoria da qualidade da água do rio Reka, Parque Regional Sekocjanske jame, Eslovênia}

O Parque Regional Sekocjanske jame situa-se no planalto de Kras, no sudoeste da Eslovênia. A área protegida de 413 ha conserva um sistema excepcional de cavernas calcárias que inclui um dos maiores cânions subterrâneos conhecidos do mundo, escavado em camadas de calcário pelo rio Reka. A zona de amortecimento abrange 45.000 ha e engloba toda a bacia do rio Reka.

O Sekocjanske jame é protegido como monumento natural desde 1980 e foi inscrito na Lista do Patrimônio Mundial em 1986. A Lei do Parque Regional do Sekocjanske jame, de 1996, designou um órgão público para gerir a área protegida. As grutas foram incluídas na Lista de Zonas Úmidas de Importância Internacional de Ramsar em 1999. Desde 2004, o parque é também reconhecido pelo Programa O Homem e a Biosfera, da UNESCO, como Reserva da Biosfera de Carste.

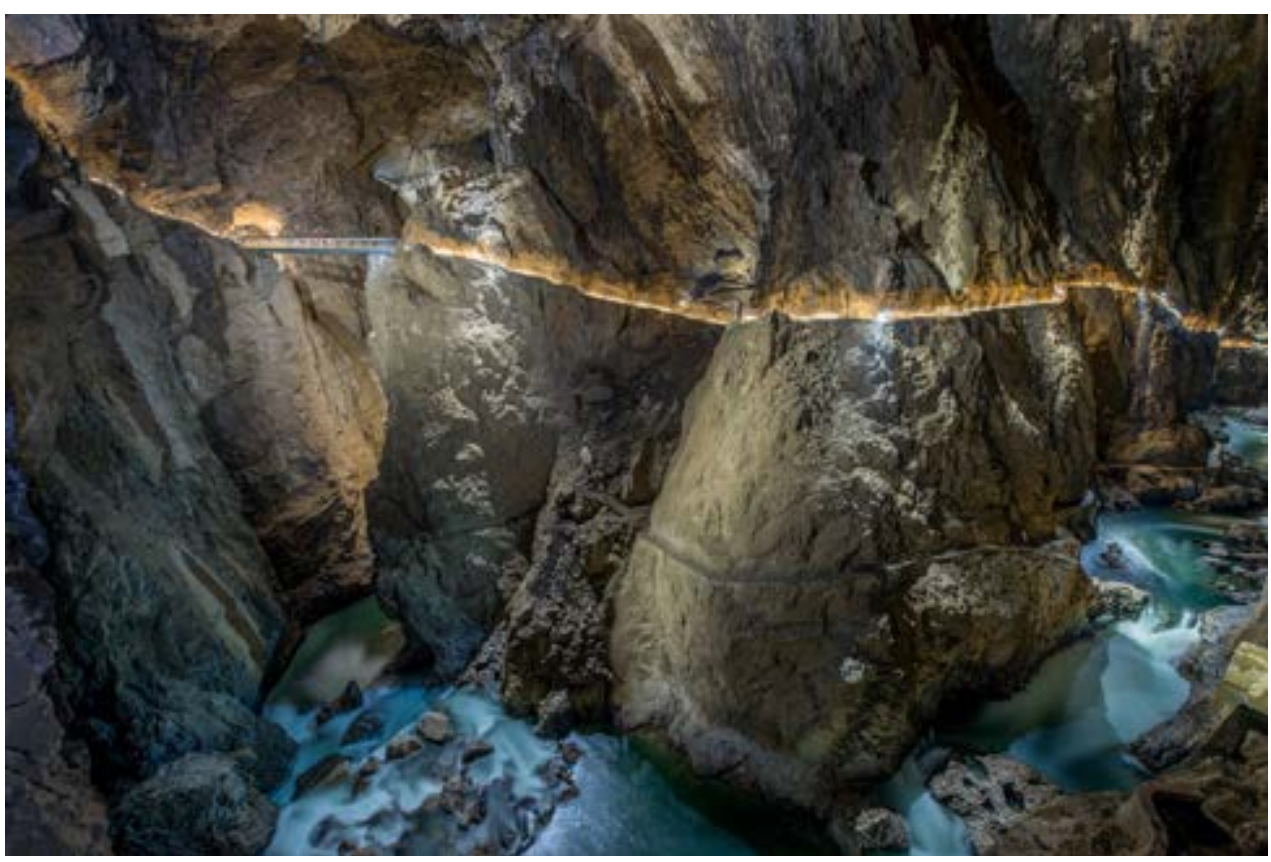

Foto 6.9 Rio Reka correndo ao longo da caverna de Sekocjanske jame. @ Borut Lozej

A poluição do rio Reka começou em 1960, com a industrialização. Os maiores poluidores eram as fábricas locais de processamento de madeira e de ácido orgânico e um aterro sanitário associado. A má qualidade da água foi resultante de processos de decomposição ou de digestão anaeróbia intensiva, com microrganismos consumindo a substância orgânica que servia de fonte de alimentação e energia e produzindo principalmente biomassa residual e produtos gasosos ou altamente voláteis. Esses micro-organismos (como mucilagem, algas e bactérias filamentosas) se fixavam no fundo do leito e nas margens do rio durante os períodos de baixo fluxo, sendo transportados para longe com eventuais aumentos no fluxo de água. As partículas sedimentares, os materiais decompostos durante os processos de digestão e a biomassa eram então carregados para jusante, onde eram depositados. No ambiente cárstico subterrâneo, eles eram submetidos a processos de digestão anaeróbia, que migravam de um trecho para outro ao longo do Rio Reka.

A qualidade do rio melhorou após 1990, quando uma das fábricas foi fechada. Mesmo antes disso, algumas medidas de prétratamento foram introduzidas no setor de produção de painéis de madeira local, tais como encerramento do circuito de águas residuais, recuperação de uma parte da massa de madeira a ser reutilizada na produção e construção de uma estação de tratamento de água dentro da instalação.

De acordo com a Agência Eslovena do Ambiente, o estado ecológico e químico das águas na zona de amortecimento é bom. Ocasionalmente, poluição e espuma aparecem na corrente superficial no trecho anterior à entrada do rio Reka na gruta no parque.

Em 2017, o Ministério do Ambiente e do Ordenamento do Território, juntamente com o Parque das Grutas de Sekocjanske e o Município de lirska Bistrica, iniciaram a remediação do aterro sanitário industrial. Um estudo documentando de modo preciso o estado, a estrutura e quantidade de resíduos do aterro, e a análise dos lixiviados, acaba de ser concluído e representa o primeiro passo no caminho para iniciar a remediação.

A agência está também ativamente envolvida em várias atividades educativas e de sensibilização dentro da zona de amortecimento e incentiva a resolução de antigas questões ecológicas e ações para prevenir novas poluições.

Contribuinte: Rosana Cerkvenik 


\section{Caixa 6.3 \\ Tors e gestão da vegetação}

Tors são formas de relevo destacadas, que se erguem até 20-30 m acima dos pontos mais altos de planaltos ou montanhas. Os tors ocorrem geralmente em granitos, mas outros tipos de rochas cristalinas (gnaisse e quartzito, em particular) e alguns tipos de arenito também podem formar tors. Os tors não têm apenas valor científico considerável para a interpretação da evolução geomorfológica de uma área, como também têm valor cultural, estando associados a povoações antigas, contos populares, arte, turismo e interpretação paisagística (Migoń, 2006).

Uma questão importante na gestão da conservação em áreas abaixo da linha de árvores é o crescimento de arbustos e árvores, o que obstrui os tors. A experiência de países como Áustria, República Tcheca, Alemanha, Hungria e Polônia, onde os tors se encontram principalmente dentro dos limites de crescimento das florestas, ilustra várias abordagens à questão e diferentes políticas das partes interessadas.

Os tors de Kogelsteine, Áustria, ocorrem num terreno em grande parte sem árvores, com arbustos dispersos, superfícies herbáceas com vegetação de estepe e vinhedos nas redondezas de considerável apelo estético. Em 2009, foi criada uma reserva natural, cobrindo 2,5 ha, para proteger as valiosas comunidades de vegetação da estepe. A gestão da conservação inclui a remoção de espécies invasoras, tais como a acácia, e a introdução de pastagens. Assim, a principal motivação para a remoção periódica da vegetação é a manutenção de prados secos, mas esta gestão também se revelou benéfica para a visibilidade do geopatrimônio. Este exemplo ilustra como as demandas de gestão da biodiversidade e do patrimônio geológico não entram necessariamente em conflito, mas podem, ao contrário, produzir benefícios mútuos.

Em outros locais, a motivação principal é manter os tors expostos e visíveis, principalmente devido ao seu significado cultural. $A$ localidade de Teufelsmauer em Harz, Alemanha, onde uma escarpa de arenito permanece em campo aberto desde o século XIX, é reconhecida como um marco regional. Ao contrário, outros tors de granito em Waldviertel desapareceram progressivamente do campo de visão devido tanto ao florestamento espontâneo e descontrolado como planejado. A localidade de Steingarten, perto de Litschau, inclui tors com elementos intempéricos menores espetaculares (alvéolos, flutes e tafoni) e rochedos com exemplos clássicos de declives alargados, indicativos do seu aparecimento gradual a partir do solo. No entanto, medidas de conservação têm sido negligenciadas e em uma parte considerável da área existe uma floresta recém plantada. Alguns tors já estão escondidos na floresta e alguns picos que se destacam no relevo serão em breve completamente cobertos de vegetação. Embora não seja possível manter todos os tors em condições de campo aberto, o inventário dos tors e a avaliação abrangente do geopatrimônio devem servir para subsidiar as políticas florestais de modo a manter os locais mais valiosos visíveis e acessíveis.

\section{Contribuinte: Piotr Migoń}

manter o acesso e a visibilidade das principais exposições e das formas de relevo;

- realizar monitoramento sobre o estado dos sítios para subsidiar as decisões sobre necessidade de limpeza da vegetação, de acordo com os objetivos de gestão; e

n integrar, tanto quanto possível, os objetivos de gestão da geodiversidade e da biodiversidade.

\section{Agricultura}

A agricultura tem o potencial de transformar os solos, resultando em erosão, compactação, contaminação, salinização e alterações na sua hidrologia e ecologia. O plantio em encostas pode aumentar o escoamento superficial e a erosão do solo e ter efeitos prejudiciais em eventuais elementos protegidos situados na parte inferior. A lavoura pode também destruir formas de relevo frágeis, tais como elementos periglaciais (ou seja, formados por processos de congelamento/descongelamento), dunas de areia baixas ou canais abandonados em terraços fluviais. Uma questão particular surge quando a agricultura é praticada em áreas cársticas, tendo, dentre seus impactos, poluição ou sedimentação de sistemas de cavernas e águas devido a escoamento ao longo de pastos ou uso excessivo de produtos agroquímicos, alterações na hidrologia cárstica devido a agricultura em superfície ou deposição de resíduos agrícolas em feições de erosão cársticas e entradas de cavernas. Em algumas paisagens, encostas inteiras e seus solos foram transformados devido à construção de terraços para cultivo de arroz ou uva.

Recomendações para a gestão das ameaças e pressões da agricultura:

rever o tipo de agricultura na região adjacente à área protegida para avaliar as ameaças aos elementos e processos que compõem o geopatrimônio dentro da mesma;

- fornecer orientações aos agricultores e gestores de terras para garantir que compreendam a necessidade de mudanças em suas práticas para proteger os elementos que compõem o geopatrimônio; e

- assegurar acordos de gestão, quando apropriado, para restringir atividades agrícolas prejudiciais e assegurar uma gestão de terras agrícolas que beneficie a geoconservação.

\section{Recreação e turismo}

Alguns ambientes são particularmente vulneráveis aos impactos de visitantes. Estes incluem áreas de dunas de areia, cuja estabilidade pode ser afetada pelo movimento de veículos ou pedestres, e sedimentos vulcânicos ou campos de lavas frágeis, nos quais a direção off-road e o pisoteio por visitantes deixam marcas permanentes na paisagem. No Monumento Nacional Craters of the Moon, em Idaho, EUA, a lava é frágil 


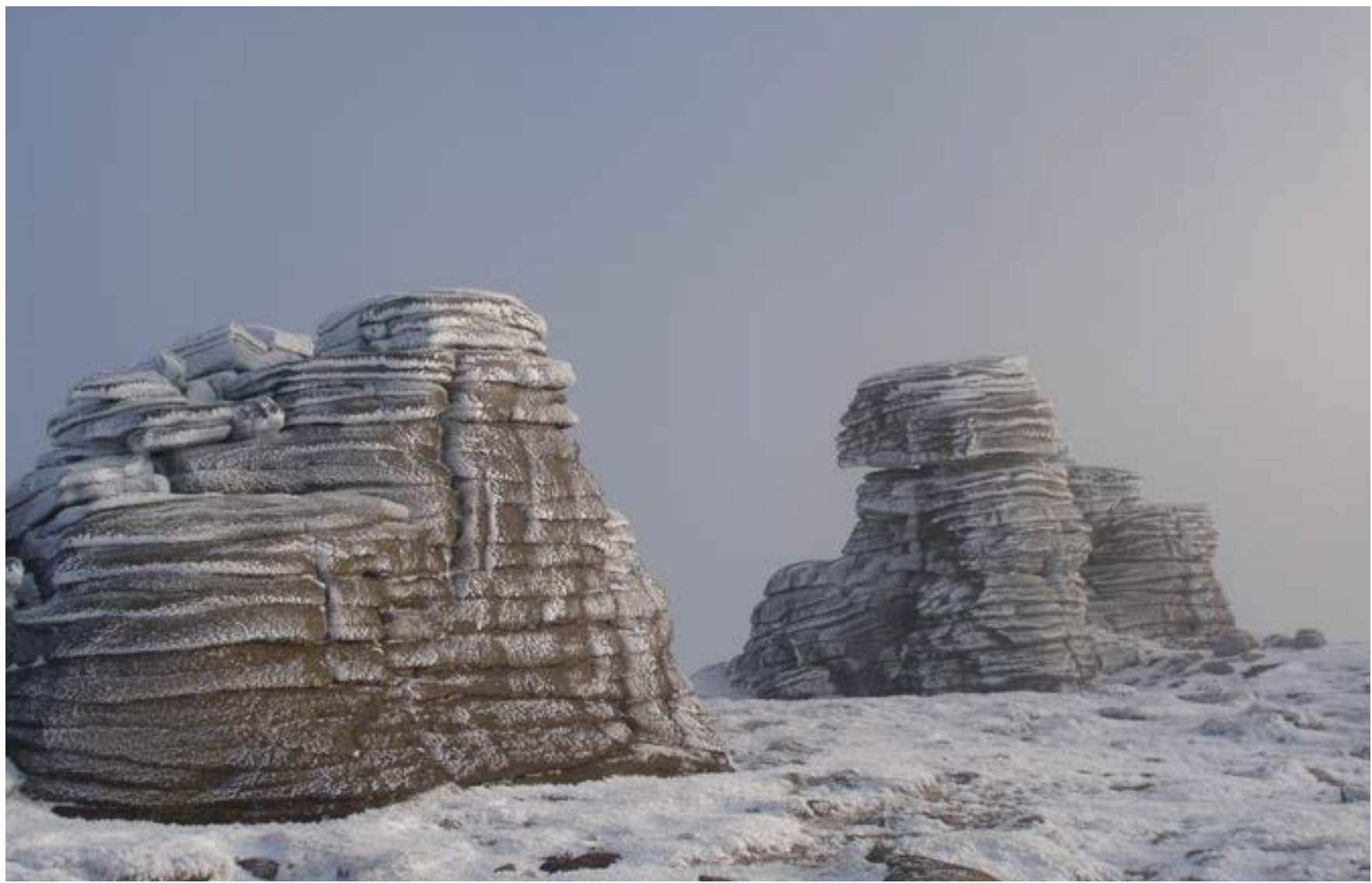

Foto 6.11 Tors na Área Montanhosa de Excepcional Beleza Natural Morne Mountains, Irlanda, mostrando a estrutura e forma quando não obstruídas pela vegetação. @ Bob Aitken

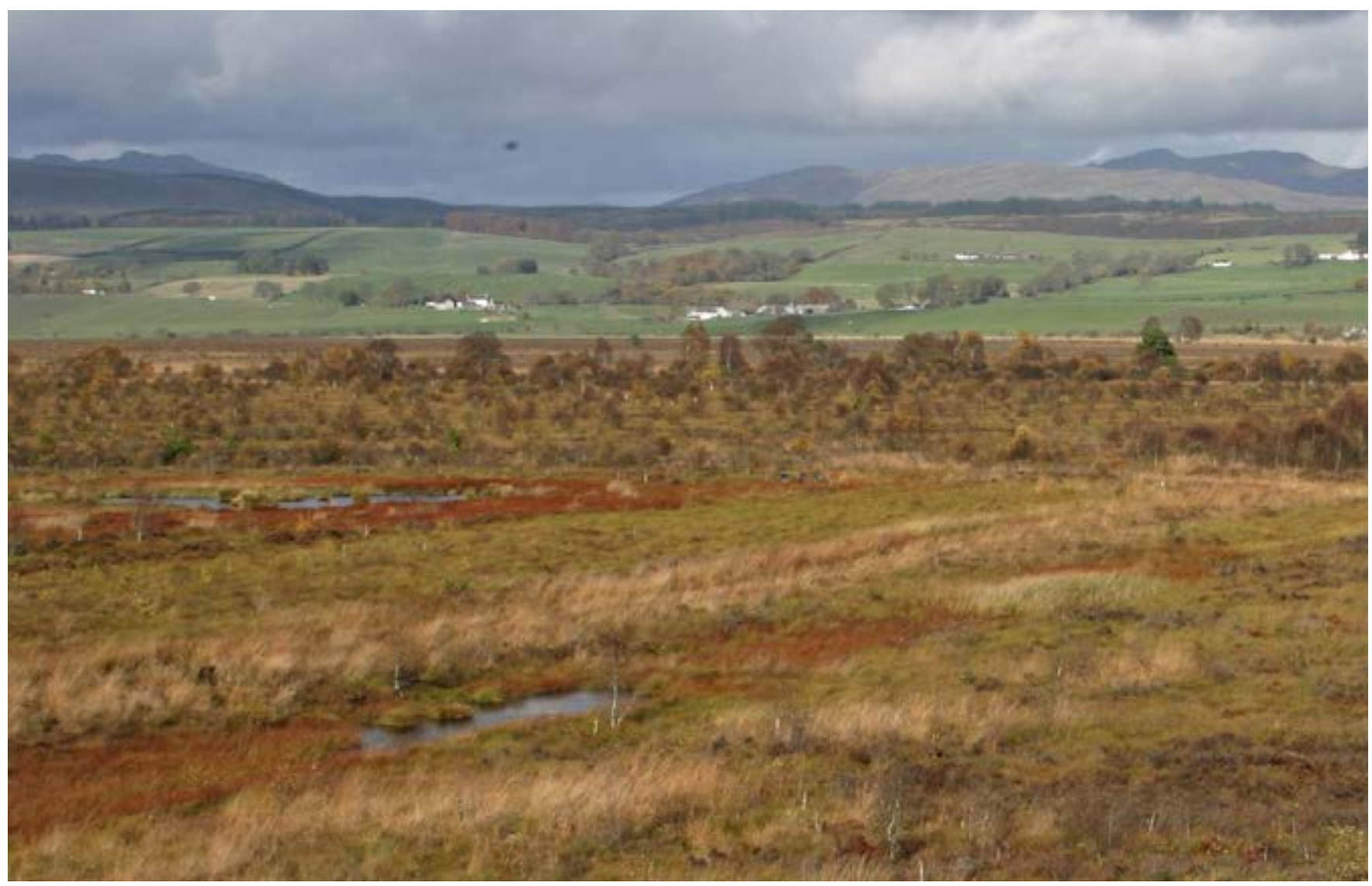

Foto 6.12 Exemplo do efeito dramático do uso de terras para agricultura na funcionalidade de uma turfeira alta pela remoção da camada superficial de turfa, drenagem do solo e plantação de árvores. Atualmente, a única maneira de gerir os elementos naturais que restam é com a elevação do lençol freático da turfeira. Reserva Natural Flanders Moss, Escócia. @ Roger Crofts 


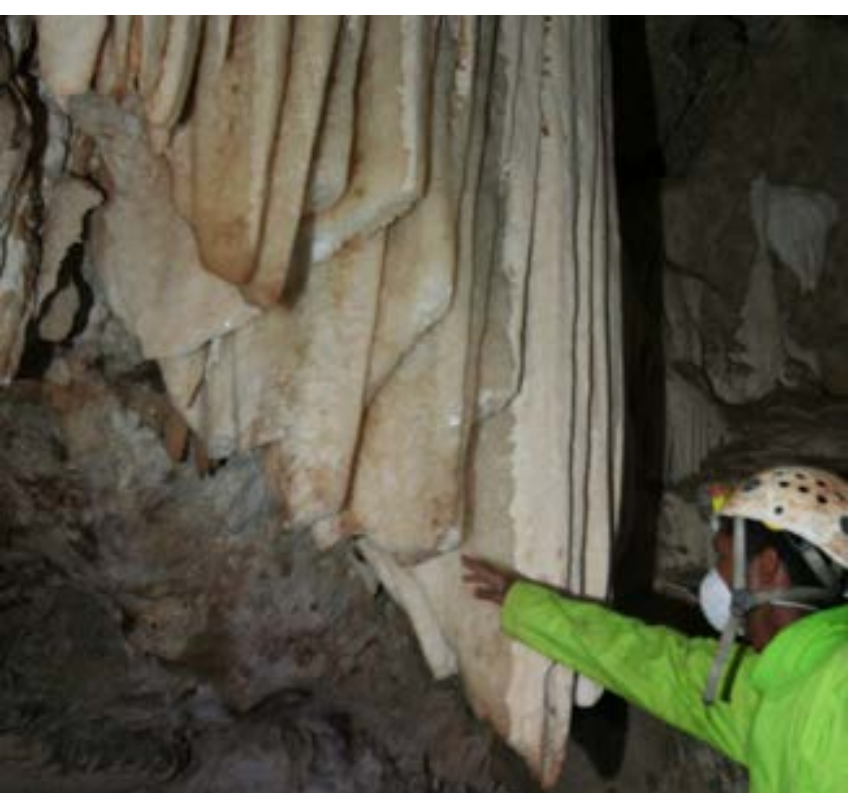

Foto 6.13 Os espeleotemas são depósitos de cavernas particularmente vulneráveis. Nesta caverna etíope uma fina cortina calcária foi quebrada pelos aldeões locais para vender as peças como lembranças. Dissuadir visitantes a comprar espeleotemas e persuadir os habitantes locais a proteger suas cavernas e cobrar a visita é uma prática mais sustentável. @ John Gunn

e pode ser facilmente esmagada com os pés, sendo os visitantes convidados a permanecer nas trilhas demarcadas. Uma solução é fornecer meios de acesso alternativos, que reduzam os danos. Por exemplo, o acesso ao vulcão no Parque Nacional de Teide, patrimônio mundial em Tenerife, Ilhas Canárias, Espanha, é feito em grande parte por gôndolas e o centro de visitantes foi instalado fora dos limites do parque.

Em cavernas de calcário, espeleotemas frágeis (depósitos formados por dissolução de rochas e subsequente deposição) podem ser facilmente danificados e mesmo o toque, a respiração e a luz podem propiciar o crescimento de algas. Áreas como estas necessitam de uma gestão muito cuidadosa. Em ambientes montanhosos, os impactos na geodiversidade podem incluir a utilização de grampos em paredes de escalada de rochas, caminhos pedestres e erosão do solo devido a caminhadas e ciclismo de montanha, compactação do solo devido a acampamentos, eliminação inadequada de resíduos humanos, escurecimento da terra devido a fogueiras e movimentação de blocos de rochas para construção de lareiras, quebra-ventos ou totens de pedras. No Parque Nacional de Yellowstone, EUA, visitantes foram encontrados jogando moedas, pedras, galhos, artigos de vestuário e outros objetos em gêiseres. Por outro lado, nas fumarolas (respiradouros térmicos) em algumas das ilhas portuguesas do arquipélago dos Açores, no Atlântico, as famílias têm o costume de cavar o solo, colocando aí grandes panelas de carne e legumes e permitindo que o calor geotérmico cozinhe o conteúdo. No Monumento Natural Regional Furnas do Enxofre, na ilha Terceira, Açores, esta perturbação do solo é proibida por lei.

Nem todos os geossítios são apropriados para geoturismo, devido à sensibilidade dos seus elementos de interesse (por exemplo, a presença de fósseis raros e minerais que devem ser protegidos contra atividades de venda e coleta irresponsável de fósseis) ou ao risco de desastres naturais específicos (por exemplo, erupções vulcânicas). Existem várias formas de controlar o acesso, tais como a delimitação de áreas proibidas a visitantes, ou permitir a entrada apenas com autorização ou acompanhada por um guia cadastrado. Em outros sítios que sejam sensíveis, poderá ser necessária uma avaliação da capacidade de carga à visitação, tanto para proteger elementos frágeis como para manter a qualidade da experiência do visitante. A restrição do acesso a partes de um sistema de cavernas em que existem formas de relevo frágeis e a autorização de visitação apenas com um guia tem sido bem aplicada, por exemplo, na caverna de Aven d'Orgnac, na região de Ardeche, na França.

O geoturismo deve também ser sensível aos valores e culturas das comunidades locais, reconhecendo que estas últimas podem ter normas, valores e interpretações diferentes da paisagem, bem como incorporar conhecimentos locais fundamentais para a gestão sustentável dos recursos do geoturismo. Por exemplo, quando os geossítios têm características culturais e/ou espirituais de interesse, pode haver sensibilidades específicas e a necessidade de manutenção dos acessos tradicionais. O zoneamento ou o emprego de guias locais, tanto em áreas sensíveis como para apresentar interpretações da paisagem advindas de povos originários, também podem ser considerados.

A avaliação do uso potencial e de gestão de locais para turismo deve levar em conta a avaliação de risco de desastres reais e potenciais. As Diretrizes de Melhores Práticas da WCPA-UICN sobre Turismo e Gestão de Visitantes em Áreas Protegidas é uma fonte valiosa (Leung et al., 2019). Os visitantes de sítios intrinsecamente dinâmicos podem ser expostos a desastres, com risco de ferimentos ou morte. Alguns destes riscos podem ser potencializados pelas mudanças climáticas; por exemplo, o aumento da instabilidade de um declive devido a movimentos de vertente e queda de blocos resultantes de chuvas mais intensas ou degelo do permafrost. Há um número crescente de estudos de casos sobre mapeamento de riscos em trilhas de geoturismo em diferentes ambientes (por exemplo, Pelfini et al., 2009; Brandolini \& Pelfini, 2010; Bollatti et al., 2013). Por exemplo, os ambientes glaciais de montanha têm um interesse significativo para o geopatrimônio do ponto de vista científico, cultural, estético, paisagístico e educativo. Muitos destes são atrações turísticas populares, acessíveis por trilhas para caminhadas ou interpretação. No entanto, são ambientes dinâmicos e instáveis, que podem apresentar muitos perigos para os visitantes, incluindo quedas de blocos de escarpas, detritos que caem de morenas laterais mais elevadas, desprendimento de blocos de gelo em lagos e erosão de rios. Alguns destes perigos têm sido exacerbados como consequência das mudanças climáticas. As avaliações de riscos têm sido utilizadas para subsidiar a adequação de trilhas turísticas que ligam sítios geomorfológicos perto do glaciar Miage nos Alpes italianos para diferentes usuários (Bollati et al., 2013). Na Nova Zelândia, o acesso às frentes dos glaciares Fox e Franz Josef foi fechado desde que o 


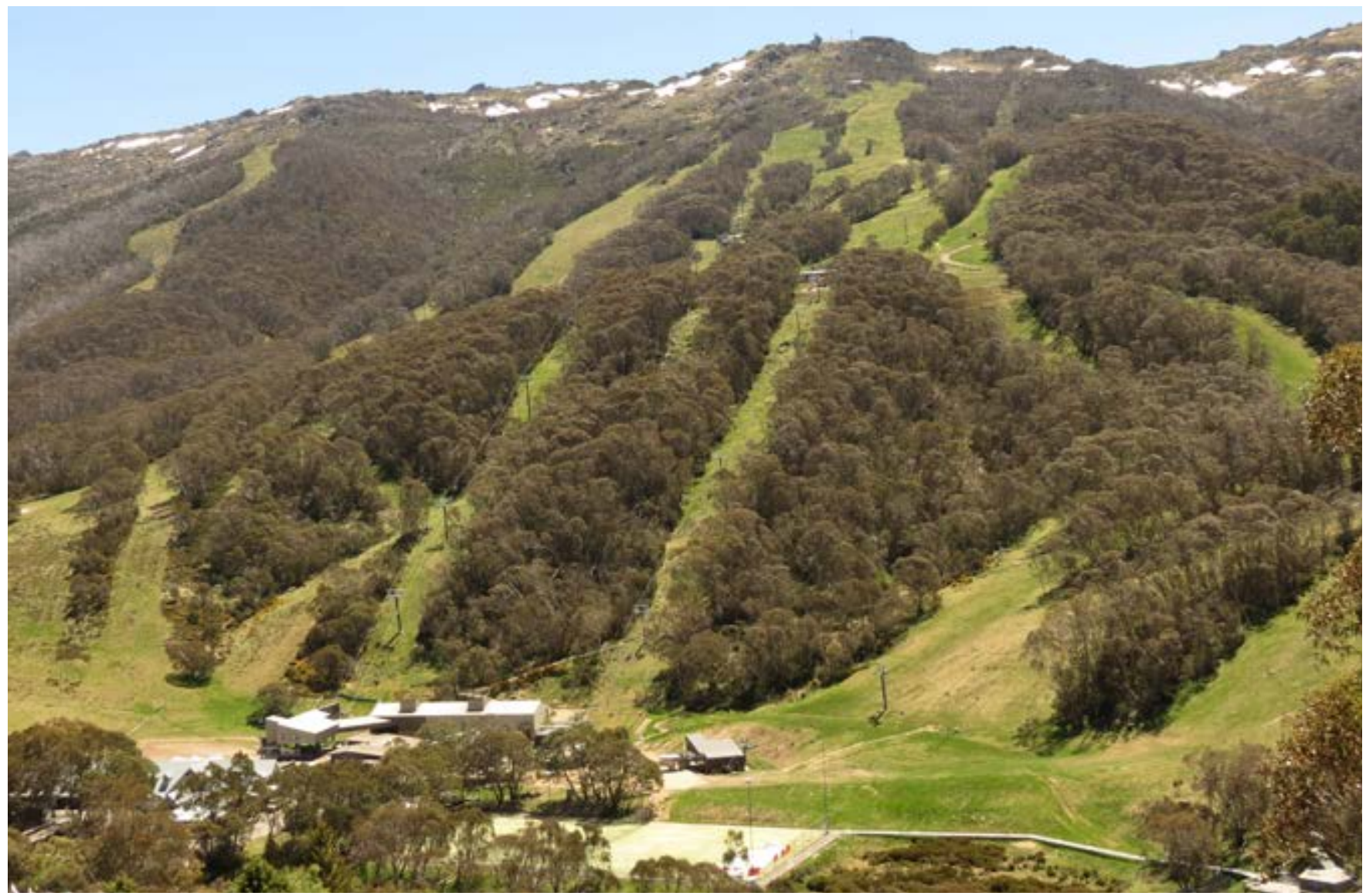

Foto 6.14 Se não for devidamente gerida, a prática de esqui nos limites das áreas protegidas pode causar erosão de encostas e afetar a integridade do local. Parque Nacional Kosciuszko, Austrália. ㅇ Roger Crofts

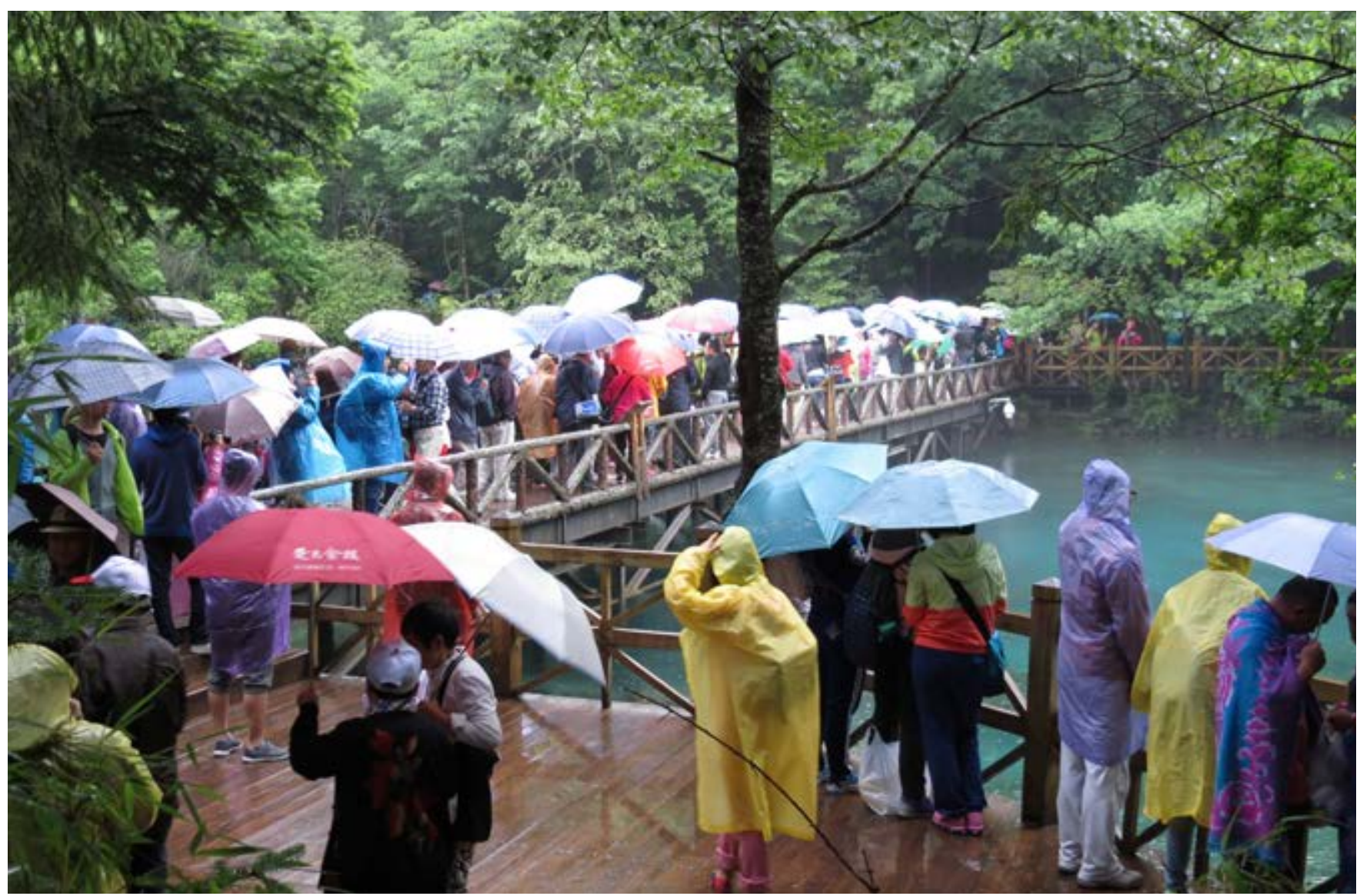

Foto 6.15 Um grande número de pessoas pode prejudicar a experiência dos visitantes. Lago Five Coloured, Parque Nacional de Jiuzhaigou, China. @ Roger Crofts 


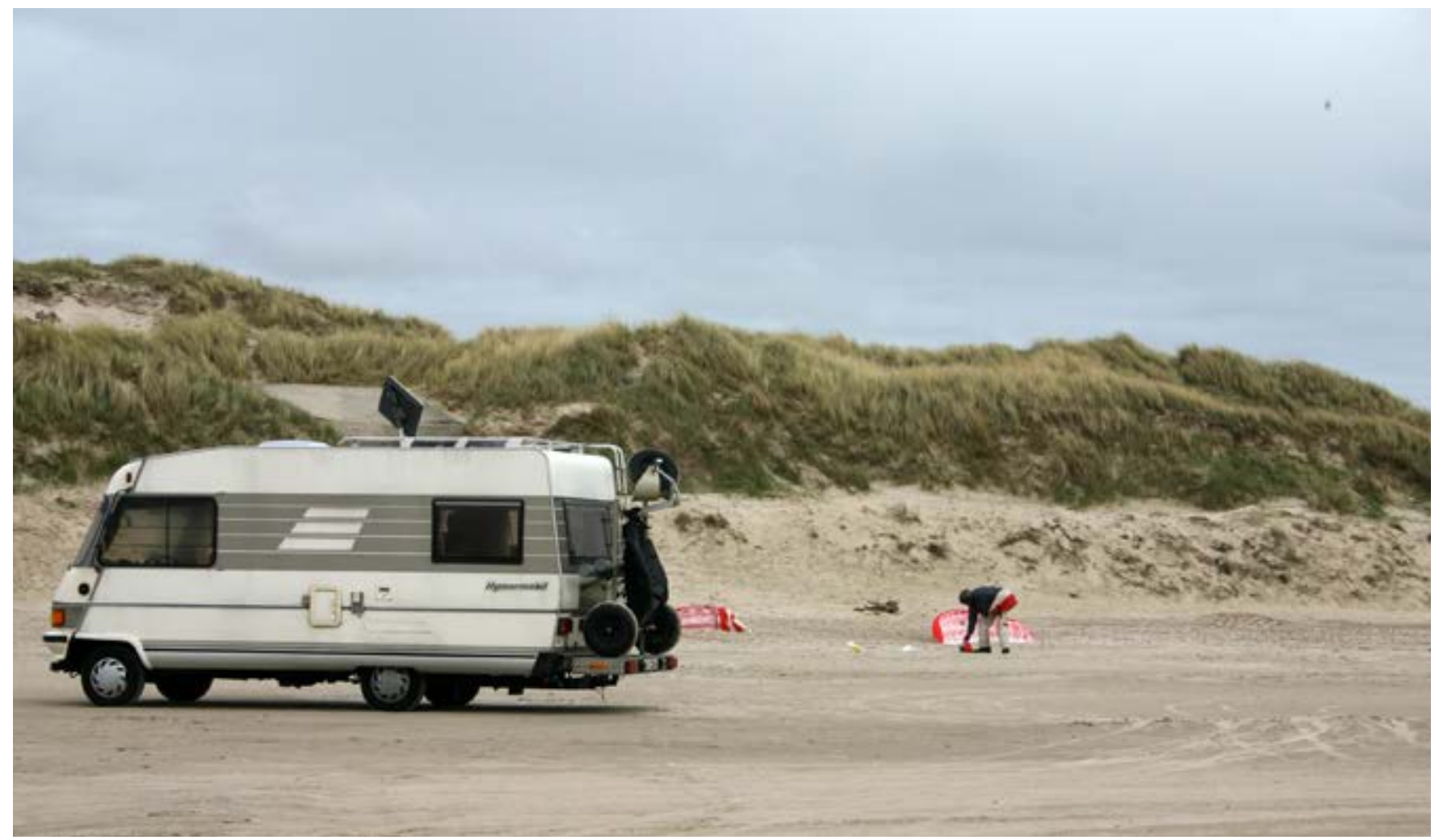

Foto 6.16 Permitir que veículos transitem em meio a dunas de areia costeiras e sobre praias gera erosão bastante difícil de recuperar em locais onde há transporte de areia pelo vento. $\mathrm{O}$ acesso de veículos deve ser proibido. Parque Nacional de Vadehavet, Dinamarca. (C) Roger Crofts

rápido recuo destes aumentou significativamente o risco de queda de blocos, enquanto que modelagens indicam o risco com o aumento do fluxo de detritos ao longo da superfície rebaixada do glaciar Fox, afetando as atividades de caminhada em glaciar (Purdie et al., 2018).

As áreas vulcânicas são um bom exemplo dos riscos que representam aos seres humanos em áreas protegidas destinadas à geoconservação. Se o estabelecimento de uma área protegida vulcânica não levar em conta seus atributos geológicos, existe o potencial de que os riscos associados (por exemplo erupções, emissões de gases, movimentos de massa e outros riscos vulcânicos) não sejam adequadamente abordados no plano de gestão de sítios, ou da equipe da área protegida não ser adequadamente treinada na identificação, mitigação e evacuação em áreas de desastres. Atrair visitantes para áreas vulcânicas ativas implica uma responsabilidade de monitorar a atividade vulcânica e desenvolver planos de contingência de risco como partes essenciais do processo de gestão, levando eventualmente a restrições de acesso. Contudo, se as características geológicas do local não forem adequadamente identificadas, o plano de gestão pode não abranger estas considerações de risco, e as feições vulcânicas chave do local podem não receber ênfase ou proteção adequadas por parte dos gestores.

No caso de sítios geomorfológicos dinâmicos, em que o interesse principal são os processos ativos ou nos quais seria impraticável a atenuação dos riscos para os visitantes, é essencial fazer uma avaliação do aumento do risco, bem como ações apropriadas, possivelmente incluindo supressão ou reposicionamento do acesso e gestão das expectativas dos visitantes. Ao mesmo tempo, são necessárias campanhas de

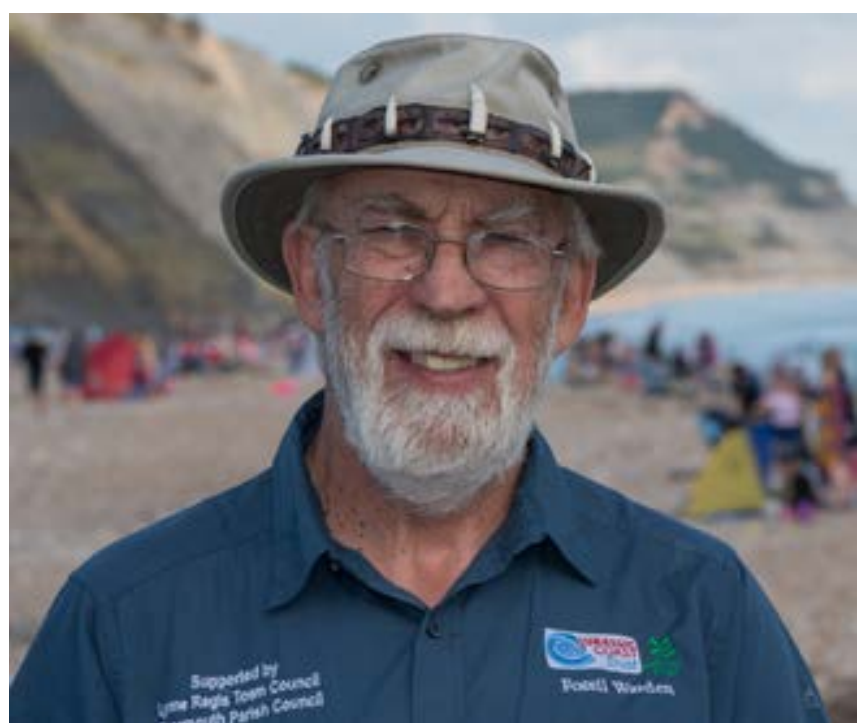

Foto 6.17 A coleta de fósseis no sítio do Patrimônio Mundial da Costa Jurássica, Inglaterra, é gerida por um administrador especificamente nomeado e por um código de conduta. ( Sam Rose

educação para aumentar os conhecimentos dos visitantes, dos operadores do local e dos funcionários acerca dos perigos e das medidas de resposta de emergência. Uma boa comunicação entre cientistas e gestores de risco é essencial para uma tomada de decisão robusta e defensável por parte dos gestores.

Recomendações para a gestão das ameaças e pressões do geoturismo:

- realizar avaliações de risco sobre todas as ameaças e perigos para os visitantes e identificar as ações necessárias; 
avaliar o nível de suscetibilidade à visitação que os elementos ou processos associados ao geopatrimônio podem absorver sem sofrer danos, e tomar medidas para minimizar estes danos;

- restringir o acesso parcial ou totalmente, dependendo do risco para os elementos do patrimônio geológico ou do risco para os visitantes; e

- estabelecer uma comunicação eficaz com os visitantes sobre as medidas de gestão tomadas para proteger os elementos que compõem o geopatrimônio (ver Leung et al., 2019 para recomendações mais detalhadas).

\section{Coleta irresponsável de espécimes}

Os visitantes gostam frequentemente de coletar espécimes geológicos, quer sejam pedras coloridas atraentes, pedaços de estalactites ou fósseis. Quando o recurso geológico é abundante, pode não haver problemas em atividades de coleta controlada, que podem mesmo ser encorajadas a fim de estimular a educação e o entusiasmo pela geologia. A coleta de fósseis deve ser também encorajada quando o material estiver ameaçado por erosão costeira, pedreiras ou outras perdas inevitáveis. O principal problema é quando existe uma quantidade limitada de um recurso geológico ou quando existem espécimes muito raros ou cientificamente valiosos.

Uma questão importante emerge quando coletores comerciais utilizam ferramentas elétricas para remover fósseis ilegalmente de sítios protegidos sem o registro adequado de seus achados. Muitas vezes, a coleta excessiva ocorre por parte dos próprios geólogos, como na Reserva Fóssil de Ediacara, no Sul da Austrália. A designação desta e de outras áreas protegidas pode chamar a atenção para a importância destes sítios fósseis. Geólogos também têm causado danos a sítios ao retirar testemunhos para pesquisas paleomagnéticas. Orientações mais detalhadas, recomendações de gestão e links para códigos de conduta são fornecidos na Seção 7.3 e especialmente na Tabela 7.4.

\section{Mudanças climáticas e variações do nível do mar}

As mudanças climáticas induzidas pelo homem estão em curso e provavelmente já vêm causando alterações significativas nos padrões climáticos e, consequentemente, nos sistemas físicos e nos elementos que compõem o geopatrimônio. Isto está claramente destacado nos últimos relatórios do IPCC (IPCC 2019a, 2019b). Em particular, o aumento na frequência e na magnitude de eventos extremos, que vem sendo previsto, pode trazer mudanças imediatas, incluindo erosão do solo, grandes inundações, transporte de sedimentos e aumento da dissolução de rochas calcárias. Os pequenos glaciares de montanha devem desaparecer à medida que o clima aquece, resultando na redução dos fluxos fluviais de verão nestas áreas. Em áreas periglaciais sujeitas a congelamento e descongelamento alternados, o aquecimento pode resultar na perturbação do permafrost e consequente subsidência e erosão das áreas em degelo e maior incidência de queda de blocos. Alterações nas condições das ondas podem exacerbar a erosão costeira, enquanto a subida do nível do mar pode resultar em inundações costeiras, perda de áreas de marismas e invasão de águas salinas.

As mudanças climáticas são reconhecidas como uma questão emergente para a geoconservação (Gross et al., 2016; Wignall et al., 2018). Por exemplo, análises do impacto das mudanças climáticas em geossítios protegidos na Grã-Bretanha concluíram que os maiores impactos ocorrerrão em elementos costeiros e fluviais ativos em sedimentos pouco coesos, em sequências sedimentares quaternárias restritas, em formas de relevo costeiras e fluviais, em elementos periglaciais ativos, em locais com registros de ambientes passados e em locais com exposições de rochas e fósseis restritos (Prosser et al. 2010; Wignall et al. 2018). Sharples (2011) investigou os impactos das mudanças climáticas na geodiversidade da região do Sítio do Patrimônio Mundial das Áreas Selvagens da Tasmânia, Austrália. Estes incluem a degradação de solos orgânicos de charnecas, turfa, pântanos, aumento da erosão e sedimentação de canais, e de enchentes e sedimentação em cavernas. Tais avaliações sistemáticas dos impactos sobre o geopatrimônio permitiriam priorizar ações de monitoramento e gestão com base no risco, como parte de um plano de ação sobre mudanças climáticas. Uma parte fundamental deste processo será o estabelecimento prévio de limites para estas alterações que, quando ultrapassados, ativarão intervenções de gestão para mitigar as ameaças.

Tabela 6.3. Impactos das mudanças climáticas nos geossítios.

Impactos em sítios extensos, vulneráveis e limitados

(-) aceleração do intemperismo, da erosão e do crescimento da vegetação, exigindo um aumento na frequência da intervenção

(-) perda de elementos devido ao aumento da erosão ou soterramento devido ao aumento da deposição

(-) bloqueio de exposições devido ao aumento da necessidade de obras de defesa costeiras/fluviais

(-) submersão de exposições

(-) mudanças no uso do solo que afetam a visibilidade e o acesso

(+) novas exposições criadas pela erosão e por deslizamentos de terra

(+/-) reposicionamento de exposições devido à alteração dos padrões de erosão

\section{Impactos em sítios com processo ativos}

(-) respostas humanas ao aumento de eventos que perturbam os processos naturais

(-) mudanças no uso do solo afetando as descargas de sedimentos/água

(+) aumento nas taxas de atividade dos processos - maior dinamismo e diversidade

(+/-) migração de elementos devido à alteração dos padrões de erosão

(-) impacto negativo; (+) impacto positivo; (+/-) impactos podem ser positivos ou negativos 
6. Enfrentando as ameaças ao geopatrimônio em áreas protegidas

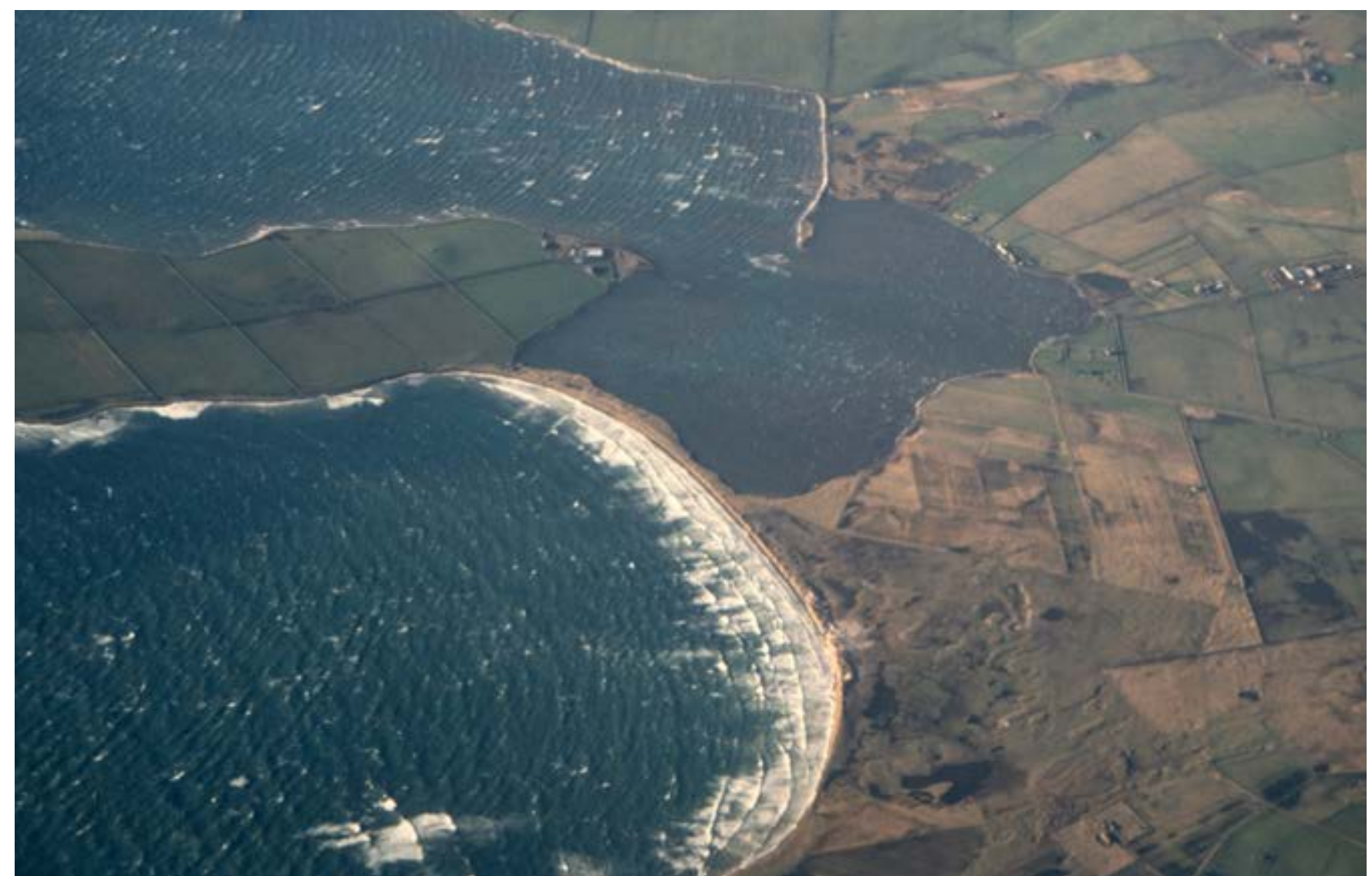

Foto 6.18 A variação do nível do mar terá um efeito profundo na funcionalidade dos sistemas costeiros, com erosão costeira e perda de amortecedores naturais, tais como praias e dunas de areia, permitindo que o mar penetre em direção ao interior e patrimônio geológico seja perdido. Sítio de Interesse Científico Especial East Sandy Coast, Orkney, Escócia. As obras de engenharia não oferecem uma solução e o recuo controlado da linha de costa é provavelmente o único mecanismo possível. @ Roger Crofts

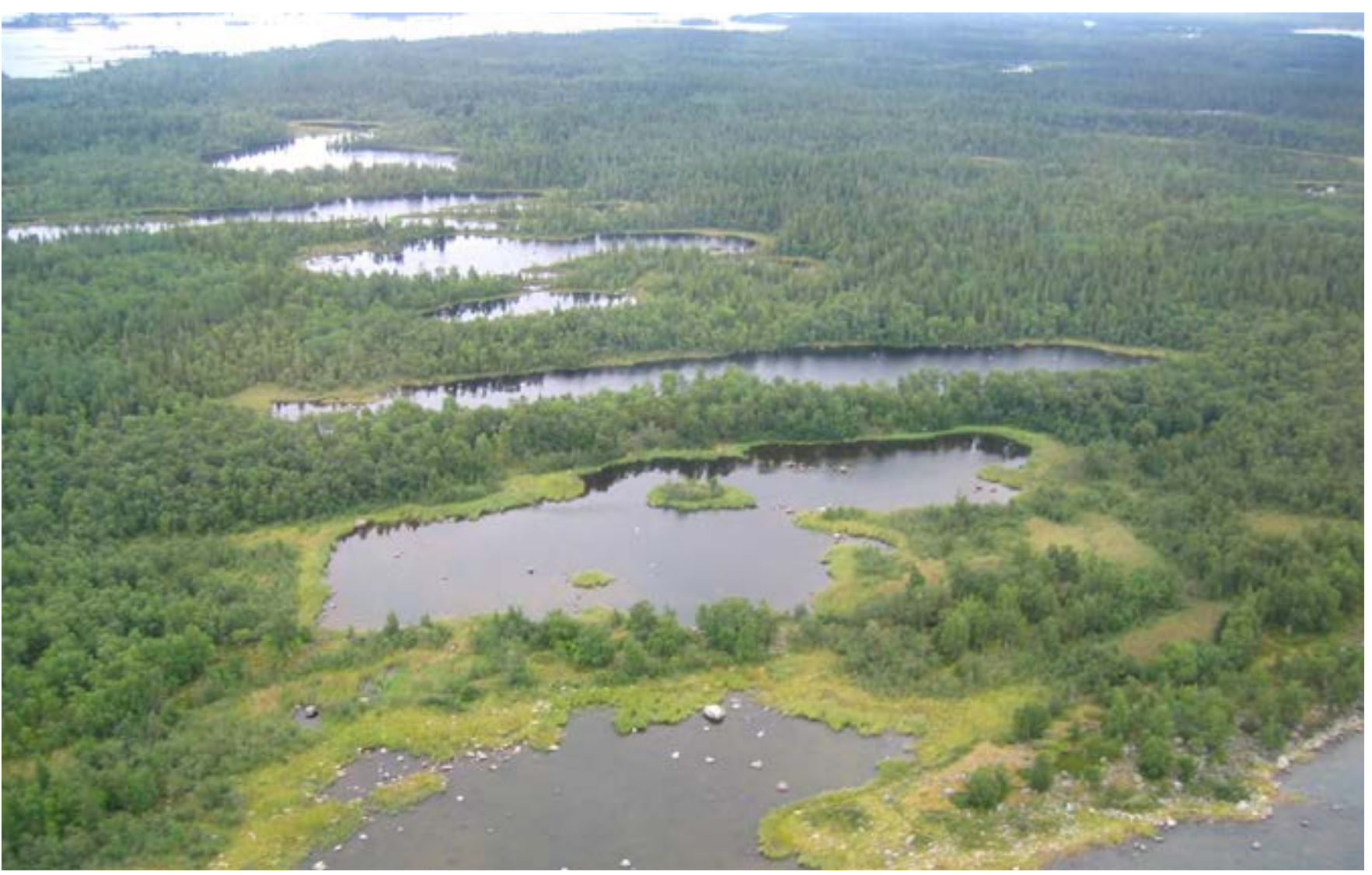

Foto 6.19 O soerguimento por isostasia, após a liberação do peso dos glaciares vem ocorrendo em muitas partes do mundo e continuará a acontecer, especialmente com o degelo das calotas e mantos de gelo. Novas terras serão reveladas, como no Kvarken Gulf of Bothnia, Sítio do Patrimônio Mundial na Finlândia, resultando em novos sítios para proteção. Inversamente, alguns sítios costeiros poderão ser submersos como resultado da subida do nível do mar.๑ UNESCO 


\section{Caixa 6.4}

\section{Restauração após a erupção do Monte Santa Helena, EUA}

A erupção do Monte Santa Helena de 1980 - que começou com uma série de pequenos terremotos em meados de março e culminou com um colapso cataclísmico do lado da montanha, avalanche e explosão em 18 de maio - não foi a maior nem a mais duradoura erupção na história recente da montanha. Mas, como a primeira erupção no território continental dos EUA observável durante a era da ciência moderna, foi excepcionalmente significativa. Uma vasta paisagem cinzenta substituiu as encostas antes arborizadas do Monte Santa Helena. Em 1982, o Presidente e o Congresso criaram o Monumento Vulcânico Nacional do Monte Santa Helena, de 110.000 acres, para pesquisa, recreação e educação. Dentro da área protegida, o ambiente responde naturalmente às perturbações. Nas décadas seguintes à erupção, o Monte Santa Helena deu aos cientistas uma oportunidade sem precedentes de testemunhar as intrincadas etapas por meio das quais a vida recupera uma paisagem devastada (Brantley e Meyers, 2000).

\section{Caixa 6.5 \\ Restauração do geossítio Alto Vez, Serra da Peneda, Portugal}

O geossítio Alto Vez compreende um dos mais notáveis campos de blocos graníticos erráticos glaciais em Portugal. Este e outros elementos glaciais, tais como um vale em $U$ e morenas, justificam a inclusão do Alto Vez como um dos geossítios mais importantes no inventário do geopatrimônio português. Apesar da sua relevância científica, está situado fora do contíguo Parque Nacional da Peneda-Gerês, a mais importante área protegida em Portugal. Este parque nacional foi fundado em 1971 e os seus limites foram definidos antes da descoberta das feições glaciais.

Em 2012, uma pista de corrida de cavalos foi construída no geossítio pela população local, com a remoção de blocos erráticos dos seus locais originais, afetando a paisagem natural e a integridade do geossítio. Após o alerta de um cidadão, ações legais e administrativas tomadas pelo Instituto da Conservação da Natureza e das Florestas e pelas autoridades municipais resultaram no encerramento da pista, numa avaliação da degradação e na definição de uma estratégia para mitigar os danos. Em 2017 foi desenvolvido um plano de restauração com o uso de fotografias aéreas captadas por veículos aéreos não tripulados, GPS e procedimentos SIG. A topografia inicial foi restaurada com o uso de máquinas de terraplanagem e os blocos erráticos soterrados foram identificados e cuidadosamente deslocados para as suas posições originais. Um plano de gestão para o geossítio está sendo desenvolvido a fim de protegê-lo de modo mais eficiente por meio de uma designação legal e de promover seu uso para turismo e educação. Este estudo de caso mostra que uma sociedade bem informada é essencial para ajudar as autoridades a proteger o geossítio e que a remediação de um geossítio é possível quando os principais elementos de interesse não são totalmente destruídos.

\section{Contribuintes: Paulo Pereira, José Brilha, Diamantino Pereira e Renato Henriques.}

É bastante provável que os sistemas geomorfológicos, hidrológicos e pedológicos ativos, em particular, venham a sofrer grandes alterações em resposta às mudanças climáticas. Além da modificação de características geomorfológicas per se, estas alterações podem resultar em erosão ou soterramento de outros elementos de interesse do geopatrimônio (Tabela 6.3). Ademais, as feições geomorfológicas dinâmicas podem migrar para fora dos limites das áreas protegidas existentes. As ameaças relacionadas às mudanças climáticas podem advir dos efeitos da subida do nível do mar e do aumento de tempestades em algumas partes do mundo e, particularmente, da resposta humana (por exemplo, em demandas para a instalação de obras de proteção contra inundações ao longo de rios e na zona costeira) que ocultam exposições e perturbam processos naturais. Como a proteção contra potenciais perdas de propriedades ou infraestruturas é normalmente considerada mais importante do que a perda do geopatrimônio, estas ameaças apresentam desafios particulares de gestão que exigirão a colaboração entre governos, gestores, tomadores de decisões e comunidades locais para assegurar uma gestão sustentável do patrimônio geológico como parte de estratégias de adaptação mais amplas e a longo prazo para proteger os serviços ecossistêmicos. No entanto, num caso jurídico histórico na Inglaterra, os tribunais reafirmaram os princípios fundamentais de designação de sítios e geoconservação, o que inclui permitir que os processos naturais mantivessem o seu curso numa costa em erosão onde uma propriedade estava sendo ameaçada (Prosser, 2011). Em muitos casos, Soluções Baseadas na Natureza ou soluções "paliativas" intermediárias, como o realinhamento monitorado, têm benefícios adicionais ao reduzir os riscos de desastres naturais, como erosão costeira, inundações, movimentos de massa e erosão do solo e os impactos das mudanças climáticas. Em alguns casos, a realocação de atividades ou instalações para o interior pode ser, em última análise, a única opção vantajosa. Onde for necessária alguma forma de proteção para resguardar os interesses do capital (por exemplo, infraestrutura essencial) e o espaço disponível ou a ser criado permitir, formas "naturais" de intervenção devem ser a primeira opção (ver exemplos acima sobre gestão fluvial e costeira).

É possível evitar a perda ou mitigar a degradação de alguns sítios específicos, mas em alguns casos pode ser necessário conformar-se com a perda ou com a deterioração de elementos de interesse. Neste último caso, pode ser apropriado realizar um registro detalhado para uso futuro ou recuperar elementos específicos, tais como fósseis, para 


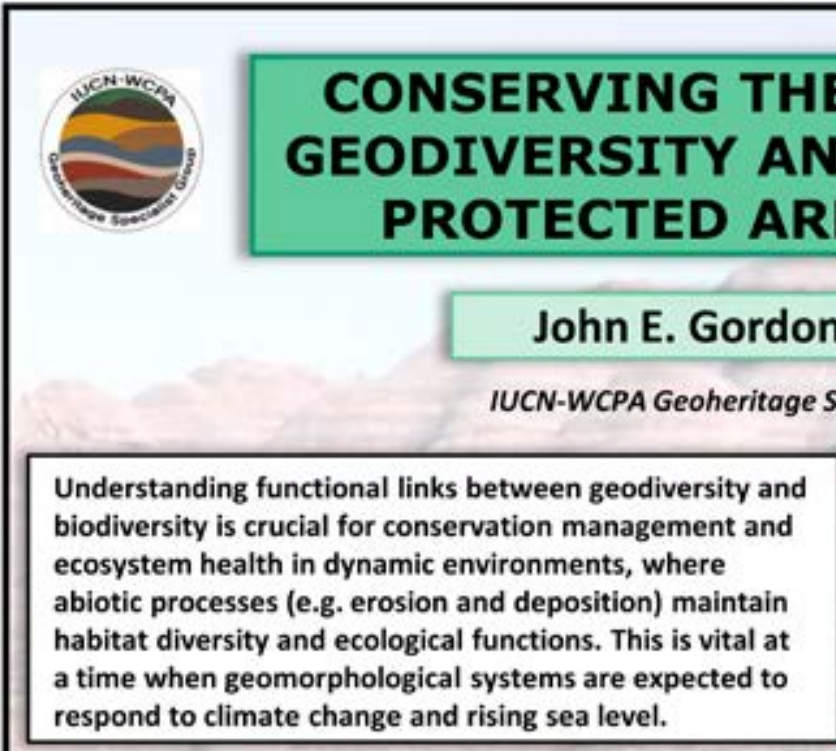

\section{Conserving the stage}

Geodiversity provides the foundation for life on Earth and for the diversity of species, habitats, ecosystems and landscapes. Most species depend on the abiotic 'stage' on which they exist and the linkages and interdependencies between abiotic and biotic nature are clear at global to local scales.

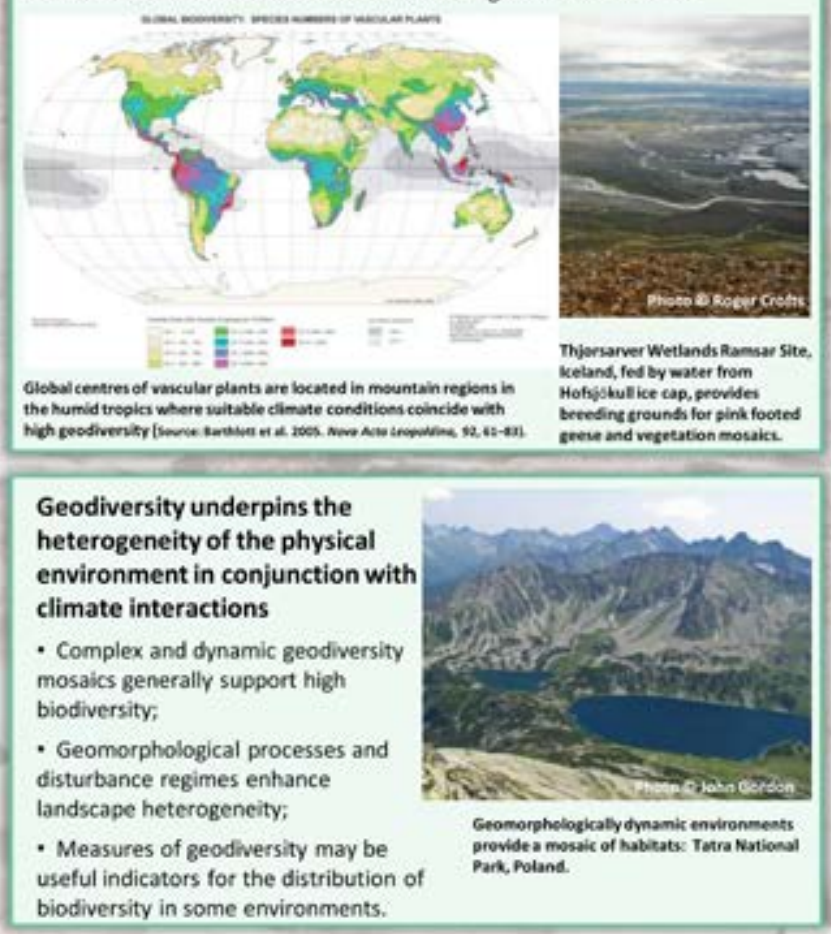

Geodiversity assists biodiversity resilience to climate change through:

- providing a range of potential macro- and micro-refugia;

- enabling species to adapt or relocate through the availability of suitable environmental mosaics, connections, corridors and elevational opportunities. Geodiverityunderpins landvape heterogereiby.
Geomorphological sensitivity to climate change will influence biodiversity adaptations

- Changes in the magnitude, frequency and rate of geomorphological processes may alter distributions of landforms, reduce recovery time between extreme events and lead to longer landform readjustment times following extreme events.

- In extreme cases, the frequency and speed of geomorphological change may mean that habitat recovery is never fully established or that there is a change in process regime.

- Geomorphological responses in one part of a river catchment or coastal cell will also have downstream implications for habitats and species (e.g. arising from changes in discharge or sediment transfer).

- Managing biodiversity adaptations effectively will therefore require consideration of geomorphological sensitivity and making space for natural processes to readjust.

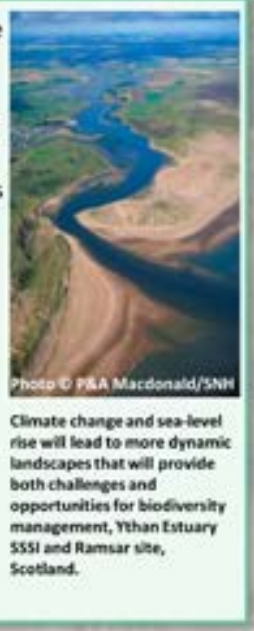

Improving protected area design

- Where geodiversity is a useful indicator of biodiversity, combining abiotic targets with biotic targets can result in a system of protected areas that is more representative of a region's biodiversity.

- In the face of climate change, protected area design that incorporates geodiversity should enhance resilience and sustain key processes.

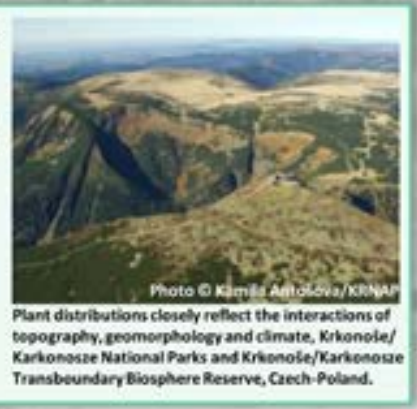

Informing restoration and adaptive management

- Conservation of geosites with records of past environmental changes ensures that temporal records can inform restoration and adaptive management, not to provide static baselines, but to help understand past ranges of natural variability and future trajectories of change.

- Effective restoration requires reinstating functional links (e.g. between rivers and their floodplains).

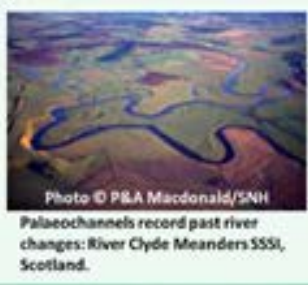

Conclusions \& implications for protected area management

- Delivering long-term biodiversity targets where communities are likely to change may be enhanced by protecting geodiversity and making space for natural processes that enhance landscape heterogeneity.

- Conservation of geodiverse, heterogeneous landscapes should underpin the development of robust protected area networks that help to maintain the resilience and adaptive capacity of biodiversity in the face of climate change.

- It is vital that geodiversity and geoheritage are fully integrated into the selection, management and monitoring of protected areas as part of an ecosystem approach that recognises the value and integrity of both abiotic and biotic processes in nature conservation. 
curadoria em coleções de museus ou em acervos ex situ. As medidas de mitigação podem incluir o soterramento de determinados locais para proteger elementos de interesse finitos altamente vulneráveis. Em casos excepcionais, pode ser necessário construir estruturas físicas para proteger alguns elementos únicos. No caso de sítios de exposição, pode ser interessante escavar seções que possam servir para substituição.

Na escala da paisagem, prevenir alterações generalizadas nos processos geomorfológicos é impraticável. Uma estratégia mais apropriada e com melhor custo-benefício é permitir que os processos geomorfológicos ativos se adaptem naturalmente às condições climáticas em transformação. Isto pode exigir a criação de espaços (por exemplo, por meio da remoção de diques para permitir que os rios se espalhem sobre as suas planícies aluviais) e a gestão das consequências destas mudanças (por exemplo, adaptar os limites dos sítios), ao invés de tentar estabilizar e controlar o sistema ativo.

O monitoramento das alterações que ocorrem nos sítios e nos seus elementos de interesse é parte fundamental do processo de gestão para auxiliar nas decisões sobre quando intervir e o tipo de intervenção necessária. Ações mais gerais incluem a comunicação com os gestores e as comunidades locais para integrar a geoconservação a estratégias e a planos mais amplos de adaptação às mudanças climáticas.

Recomendações para a gestão dos efeitos das alterações climáticas:

- realizar avaliações de risco em sítios vulneráveis;

- adotar Soluções Baseadas na Natureza e permitir que os processos geomorfológicos ativos se adaptem naturalmente às condições climáticas em transformação;

- rever os limites das áreas protegidas sempre que necessário;

- identificar medidas de mitigação ou potenciais exposições de substituição para sítios de alto risco;

- implementar registros para a posteridade e, quando apropriado, recuperar elementos específicos, tais como fósseis, para curadoria em coleções de museus;

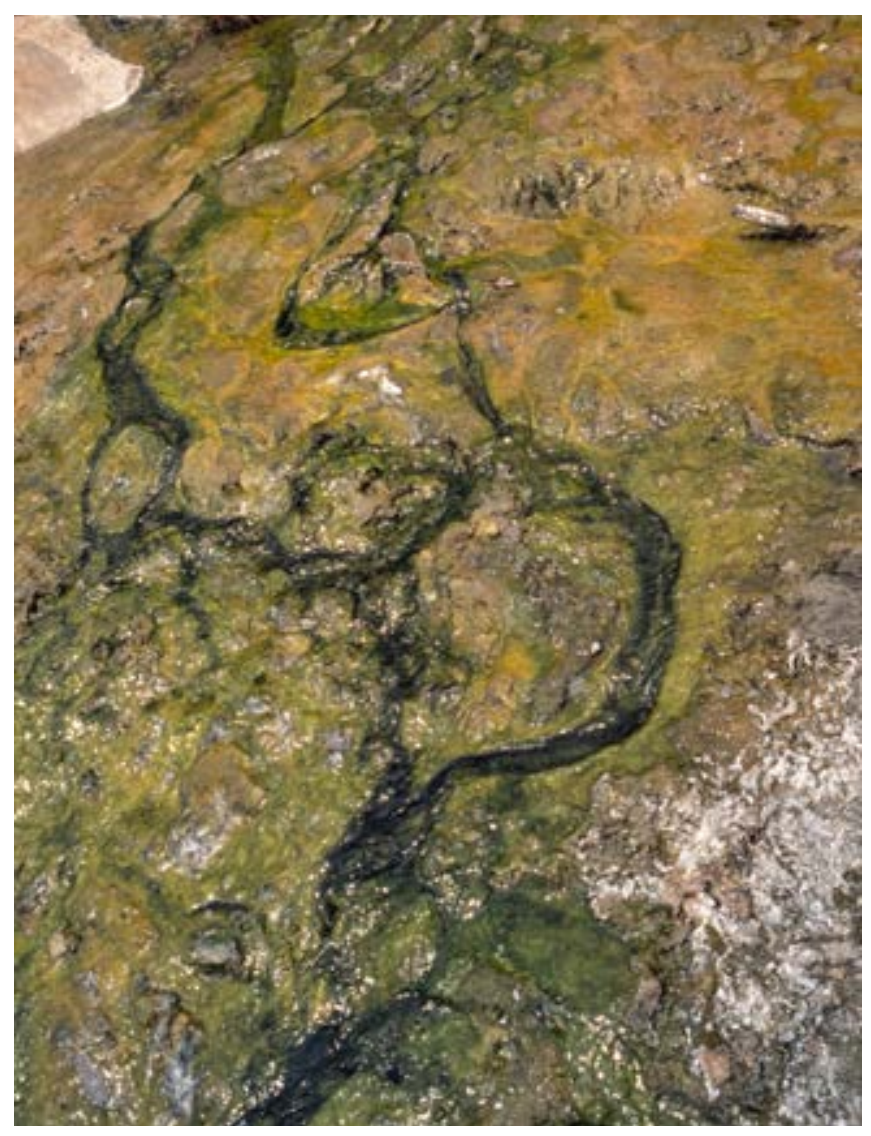

Foto 6.20 Espécies de plantas especialistas, denominadas extremófilas, ocorrem em abundância nos coquetéis químicos quentes que emanam de zonas geotérmicas subterrâneas. Parque Nacional do Lago Manyara, República Unida da Tanzânia. @ Roger Crofts

- monitorar as alterações para informar a tomada de decisões; e

- comunicar-se com os gestores e comunidades locais para integrar a geoconservação a estratégias e a planos mais amplos de adaptação às mudanças climáticas.

Boa Prática N. ${ }^{\circ}$ 18: Adotar uma estratégia em várias etapas para enfrentar as ameaças ao patrimônio geológico, incluindo identificação do tipo de ameaça, sensibilidade do local à ameaça, avaliação de riscos e priorização de ações de gestão.

Tabela 6.4. Exemplos de relações entre geodiversidade e biodiversidade.

\begin{tabular}{l|l}
$\begin{array}{l}\text { Interdependência geo/bio } \\
\begin{array}{l}\text { Espécies de plantas especialistas refletin- } \\
\text { do a química das rochas e da água }\end{array}\end{array}$ & $\begin{array}{l}\text { Grande Fonte Prismática, Parque Nacional de Yellowstone, EUA; Vale vulcânico de } \\
\text { Waimangu, Rotorua, Nova Zelândia. }\end{array}$ \\
\hline Nichos para animais em rochas & $\begin{array}{l}\text { Reserva de Conservação Jenolan Karst, Austrália; Parque Nacional White Desert, } \\
\text { Egito; Parque Nacional Galápagos, Equador. }\end{array}$ \\
\hline $\begin{array}{l}\text { Novos habitats devido ao surgimento de } \\
\text { terras resultante do degelo de glaciares e } \\
\text { soerguimento isostático associado }\end{array}$ & $\begin{array}{l}\text { Sítio do Patrimônio Mundial Kvarken, Finlândia; Skeidarásandur, Parque Nacional de } \\
\text { Vatnajl, Islândia. }\end{array}$ \\
\hline $\begin{array}{l}\text { Estratos rochosos importantes para } \\
\text { traçar a evolução biológica }\end{array}$ & $\begin{array}{l}\text { Folhelhos de Burgess, Parque Nacional Yoho, British Columbia, Canadá; Falésias } \\
\text { fossilíferas de Joggins, Nova Escócia, Canadá. }\end{array}$ \\
\hline $\begin{array}{l}\text { Ecossistemas totalmente dependentes } \\
\text { do abastecimento adequado de água e } \\
\text { nutrientes }\end{array}$ & $\begin{array}{l}\text { Reserva Shaumari, Jordânia, para a reintrodução do Órix-da-arábia. SSSI turfeiras } \\
\text { de manta de Flow Country para habitats e proteção de pássaros, Escócia. }\end{array}$ \\
\hline
\end{tabular}

Fonte: Crofts, 2019. 


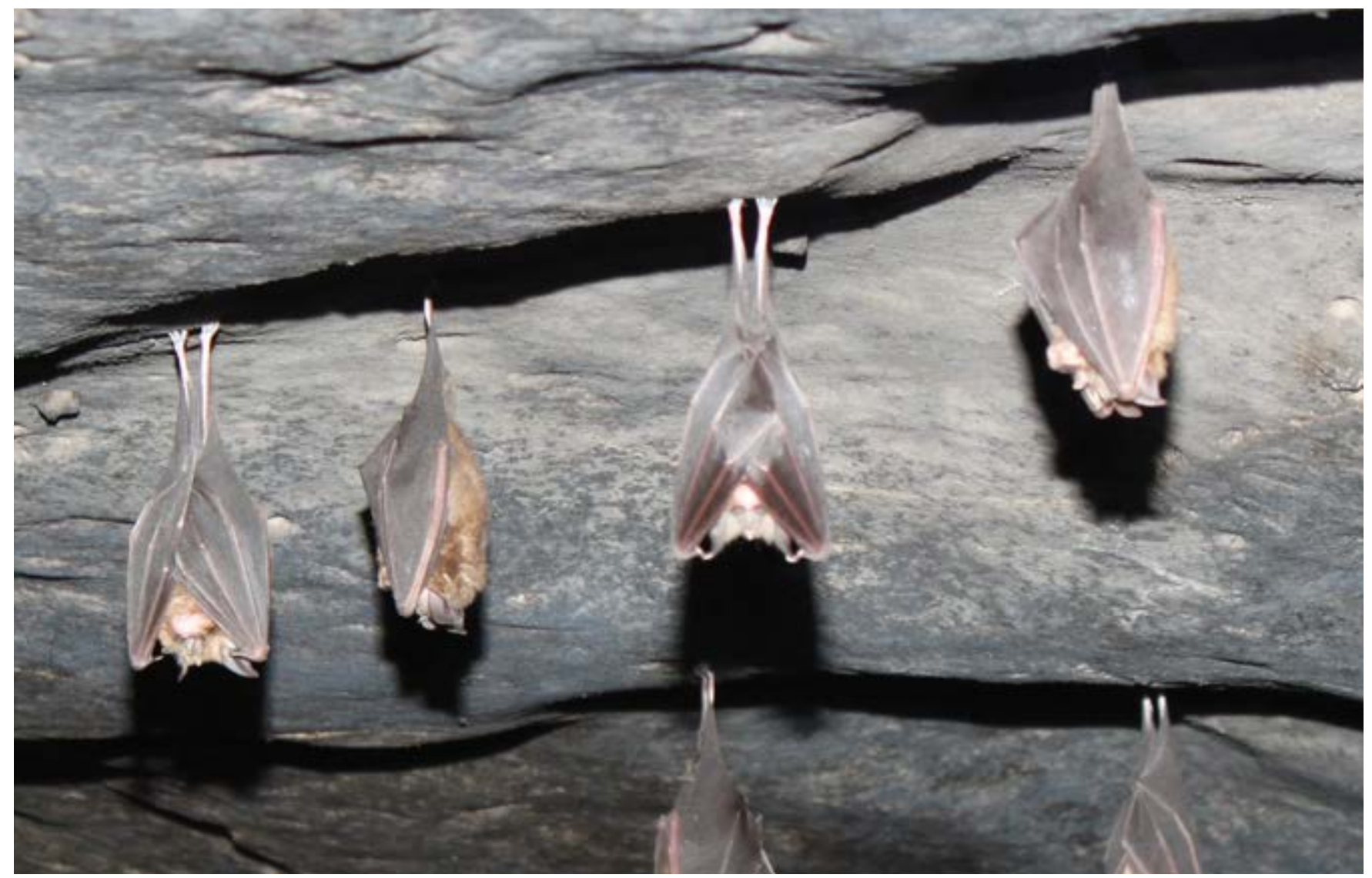

Foto 6.210 sucesso da reintrodução do Órix-da-arábia depende de um abastecimento regular e suficiente de água. A extração para servir às necessidades crescentes de Amã cria escassez. Reserva Natural Shaumari, Jordânia. @ Roger Crofts

\subsection{Lidando com a interação entre geodiversidade e conservação da biodiversidade}

A geodiversidade é o suporte para uma diversidade de habitats num vasto espectro de escalas temporais e espaciais (Tabela 6.4). Em uma escala global, por exemplo, pesquisas sugerem que os centros de diversidade de plantas vasculares coincidem com áreas de montanha em zonas tropicais úmidas e subtropicais com elevada geodiversidade (Barthlott et al., 2005). Em escalas regional e local, a geodiversidade é a base para a heterogeneidade dos habitats que decorrem das características do substrato físico, das propriedades e da estabilidade do solo, dos processos geomorfológicos e formas de relevo, dos efeitos topográficos no microclima, da disponibilidade de água e dos regimes de perturbação resultantes de processos contínuos e episódicos.

Consequentemente, a diversidade de habitats e a riqueza de espécies são frequentemente maiores em áreas de elevada heterogeneidade geológica e geomorfológica (e.g. Tukiainen et al., 2019).

A geoconservação em áreas protegidas é, portanto, crucial para sustentar espécies vivas e habitats, tanto para manter o cenário ou "palco" como os processos naturais (por exemplo, inundações, erosão e deposição) necessários para a diversidade de habitats e funções ecológicas. Isto é particularmente relevante para a concepção e gestão de áreas protegidas no contexto das mudanças climáticas, uma vez que a geodiversidade pode aumentar o grau de resiliência e permitir a sobrevivência das espécies por meio da disponibilidade de mosaicos ambientais adequados, corredores e variações de altitude que proporcionam uma variedade de macro e micro-refúgios. Em locais onde espécies e comunidades são suscetíveis a mudanças, redes robustas de áreas protegidas baseadas na conservação de paisagens geodiversas e heterogêneas podem ajudar a otimizar a resiliência e a capacidade de adaptação da biodiversidade e dos processos chave dos ecossistemas sob as condições climáticas atuais e futuras (Anderson et al., 2014; Comer et al., 2015; Knudson et al., 2018). Assim, a integração da conservação da geodiversidade e da biodiversidade é vital não apenas para o desenvolvimento de redes de áreas protegidas representativas de diferentes ecossistemas e habitats, mas também no apoio à gestão da biodiversidade em áreas protegidas individuais.

As interações entre a conservação da geodiversidade e da biodiversidade podem ser tanto positivas como negativas (Crofts e Gordon, 2015; Crofts, 2019; Tabela 6.4). As interações positivas surgem onde há convergência entre os interesses da geodiversidade e da biodiversidade, como nos sistemas costeiros e fluviais dinâmicos com forte interdependência entre vegetação e processos geomorfológicos, ou onde a geodiversidade fornece as bases para a biodiversidade. Interações negativas podem ocorrer onde o elemento de interesse do geopatrimônio é mais restrito e não depende funcionalmente da biodiversidade, tais como um afloramento que ilustra a história geológica de uma área ou formações rochosas e formas de relevo frágeis 
associados a áreas cársticas ou glaciais. Embora a rocha ou as estruturas possam fornecer habitats valiosos, o crescimento da vegetação pode impedir a visibilidade ou o acesso às feições geológicas em situações em que a necessidade primordial de geoconservação seria manter a sua visibilidade. Tais interações negativas devem ser reconhecidas, para que os gestores de áreas protegidas possam encontrar uma solução (Caixa 6.3). Esta solução deve ser baseada no reconhecimento das inter-relações entre as características bióticas e abióticas e os processos que as originaram e os que as mantêm.

As questões-chave são:

- Qual é a base do conflito entre a conservação dos valores do patrimônio geológico e da biodiversidade dentro e no entorno da área protegida?

- O conflito pode ser resolvido sem prejudicar um ou ambos os conjuntos de valores, ou é mais importante que estes?

- Se a última opção for verdadeira, seria um dos conjuntos de valores mais importante a longo prazo para a conservação da natureza, de modo a ser salvaguardado e o outro sacrificado?

- O elemento da geodiversidade deve ser retirado do local ou sua obstrução pelo crescimento de vegetação permitida, desde que possa ser periodicamente reexposto para a realização de pesquisas à luz de novos conhecimentos?

- A única solução disponível está além da área protegida e dentro da biorregião?

Finalmente, é importante desencorajar as tentativas de maximizar a diversidade de habitats/espécies por meio de modificações da paisagem ou restauros que resultem na criação de formas de relevo/paisagens incongruentes (por exemplo, elevação da superfície do terreno por meio do aterramento de áreas de topografia plana ou criação de lagoas com formas atípicas em relação às características naturais locais).

Boa Prática N. 19: Reconhecer as inter-relações positivas e negativas entre biodiversidade e conservação da geodiversidade para obter a melhor solução possível para a conservação da natureza. 


\section{Gestão da geoconservação em casos selecionados}

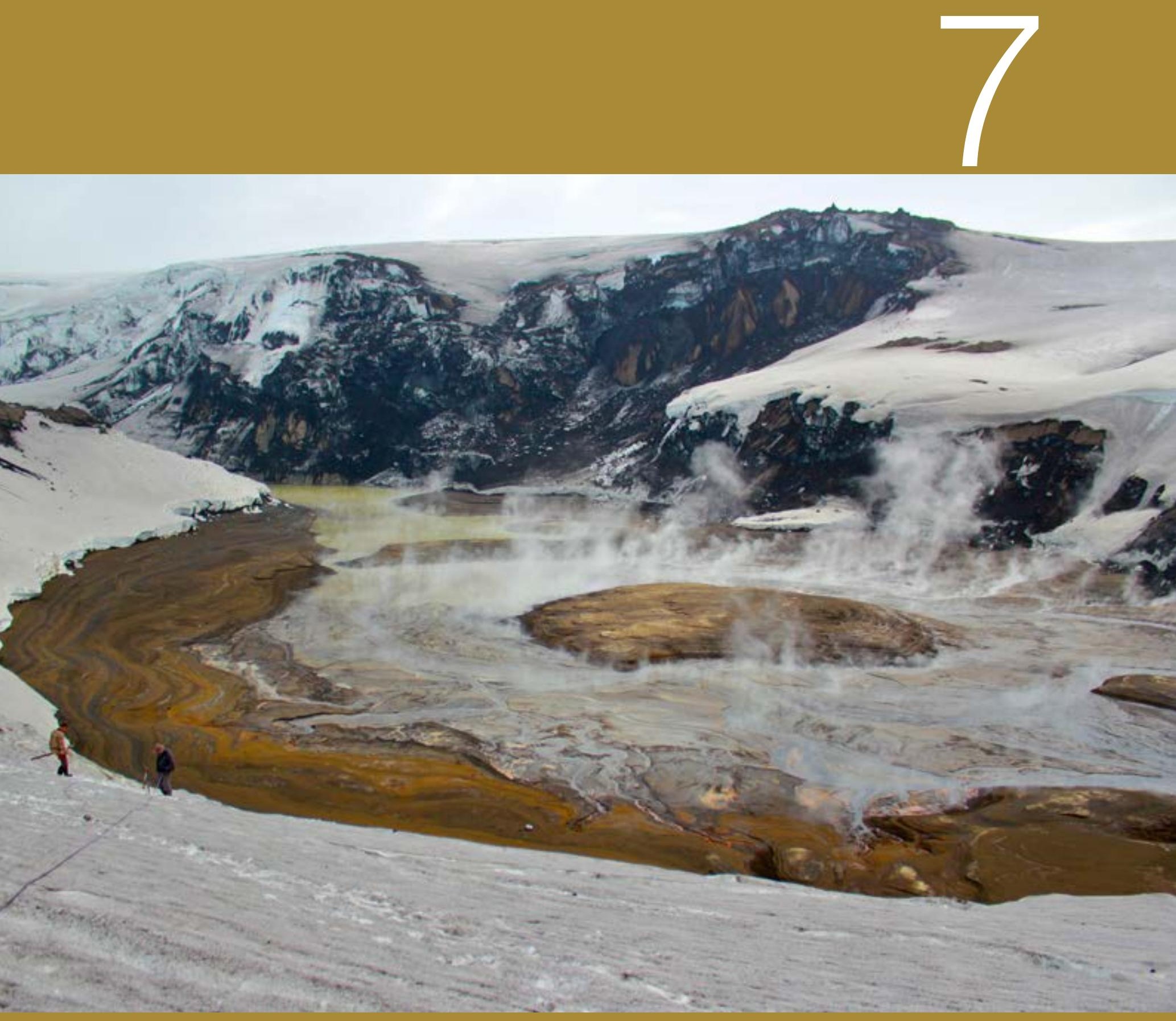

À combinação única de atividade geotérmica e glaciação foi conferida uma maior proteção em 2020, com a Reserva Natural e Área de Paisagem Protegida de Kerlingarfjöll, Islândia. @ Roger Crofts 


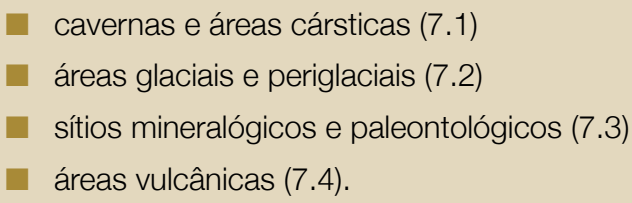

- cavernas e áreas cársticas (7.1)

áreas glaciais e periglaciais (7.2)

sítios mineralógicos e paleontológicos (7.3)

áreas vulcânicas (7.4).

É apresentada uma orientação detalhada para a gestão de áreas protegidas com

Neste capítulo, são apresentadas diretrizes de gestão para tipos particulares de interesse geopatrimonial em áreas protegidas, especialmente cavernas e elementos cársticos, elementos glaciais e periglaciais, geossítios mineralógicos e paleontológicos, e geossítios vulcânicos. Para cada um destes quatro tipos de geopatrimônio, são fornecidas informações sobre geoformas e processos, ameaças, e princípios e diretrizes de gestão. Os quatro ambientes geológicos foram selecionados para representar a variedade dos tipos de geossítios apresentados na Seção 5.3 e para ilustrar os tipos de abordagem de gestão necessários. As seções sobre elementos glaciais e periglaciais ilustram os três tipos de geossítios (extensos, vulneráveis e limitados), enquanto as seções sobre cavernas e elementos cársticos, e sobre minerais e fósseis, ilustram geossítios do tipo vulneráveis e limitados, respectivamente.

\subsection{Gestão de áreas protegidas com cavernas e áreas cársticas}

\section{Geoformas, processos e elementos com valor}

Algumas das paisagens mais deslumbrantes da Terra Uma caverna é um vazio formado naturalmente em um material terrestre, que é suficientemente grande para permitir a entrada humana. Esta definição distingue cavernas de túneis artificiais e outros vazios subterrâneos construídos e que, às vezes, são chamados incorretamente de "cavernas". As cavernas são encontradas em muitas litologias e ambientes, mas globalmente a maioria é formada pela dissolução de rochas carbonáticas. As cavernas formadas pela dissolução também são encontradas em rochas evaporíticas e, mais raramente, silicatadas. Há também um número substancial de cavernas vulcânicas (também chamadas cavernas de lava). Somente cavernas que ocorrem em ambientes cársticos são aqui consideradas.

Uma paisagem cárstica de superfície bem definida depende do desenvolvimento da drenagem subterrânea. Nas rochas carbonáticas, as águas subterrâneas fluem através de canais resultantes da dissolução e da erosão. Quando o diâmetro do canal se torna suficientemente grande para um fluxo turbulento, é comumente chamado de "conduto"; quando estes se tornam suficientemente grandes que permitam o acesso a seres humanos são chamadas de "cavernas".

O desenvolvimento de geoformas cársticas é impulsionado pela água que flui sobre, para dentro, através e para fora das rochas com alta solubilidade. Assim sendo, às geoformas cársticas podem ser geralmente atribuídas as funções de sumidouros, reservatórios e nascentes de águas (Williams, 2008). Maiores detalhes podem ser encontrados em publicações especializadas como Ford \& Williams (2007), Gillieson (1996), Gunn (2004), Palmer (2007) e White \& Culver (2012).

As depressões fechadas com drenagem interna (dolinas e poljes de fundo plano) são as geoformas cársticas de superfície mais típicas. Funcionam como uma bacia de drenagem centrípeta, conduzindo água, solutos e sedimentos para um ponto ou pontos de injeção e daí para o subsolo. Uma importante característica distintiva do carste é que o fluxo das águas possui velocidades com várias ordens de magnitude mais rápidas, do que é comum em sistemas de águas subterrâneas não cársticas. Isto significa que sedimentos e poluentes podem ser transportados por longas distâncias em um curto período de tempo. Uma segunda característica distintiva é que a maioria das áreas cársticas tem uma zona de maior dissolução, e, portanto, de maior permeabilidade, no substrato rochoso mais próximo da superfície. A escala e a velocidade destes processos específicos levam a que a gestão de cavernas e do carste enquanto áreas protegidas tenha que ser bastante diferente de outros tipos de geopatrimônio.

A maioria das cavernas cársticas é formada por águas que migram de forma vertical descendente da superfície da terra para o nível freático, mas algumas foram formadas por águas subterrâneas ascendentes. Os condutos nas cavernas podem estar ativos (em processo de ampliação devido ao fluxo de água) ou inativos (sem fluxo permanente de água). O número de cavernas cársticas, extensão e profundidade explorados aumentam globalmente ano após ano e as novas descobertas fora das áreas protegidas podem ter maior valor geopatrimonial, do que aquelas já incluídas em áreas protegidas. Como tal, novas áreas protegidas podem precisar ser designadas ou os limites das áreas existentes reavaliados.

Em algumas áreas cársticas, os condutos não possuem tamanho suficiente para serem acessíveis pelo homem. Assim sendo, pode haver carste de superfície com geoformas típicas e rápido fluxo de águas subterrâneas através de condutos, mas sem cavernas. Em contraste, em algumas áreas onde as rochas suscetíveis à carstificação não afloram (e, portanto, não existem geoformas cársticas superficiais) as águas subterrâneas que circulam em profundidade através de rochas carbonáticas ou evaporíticas formam canais, condutos e, em alguns casos, cavernas. É, portanto, essencial que seja feito um levantamento completo de uma área antes que qualquer decisão sobre proteção seja tomada. 


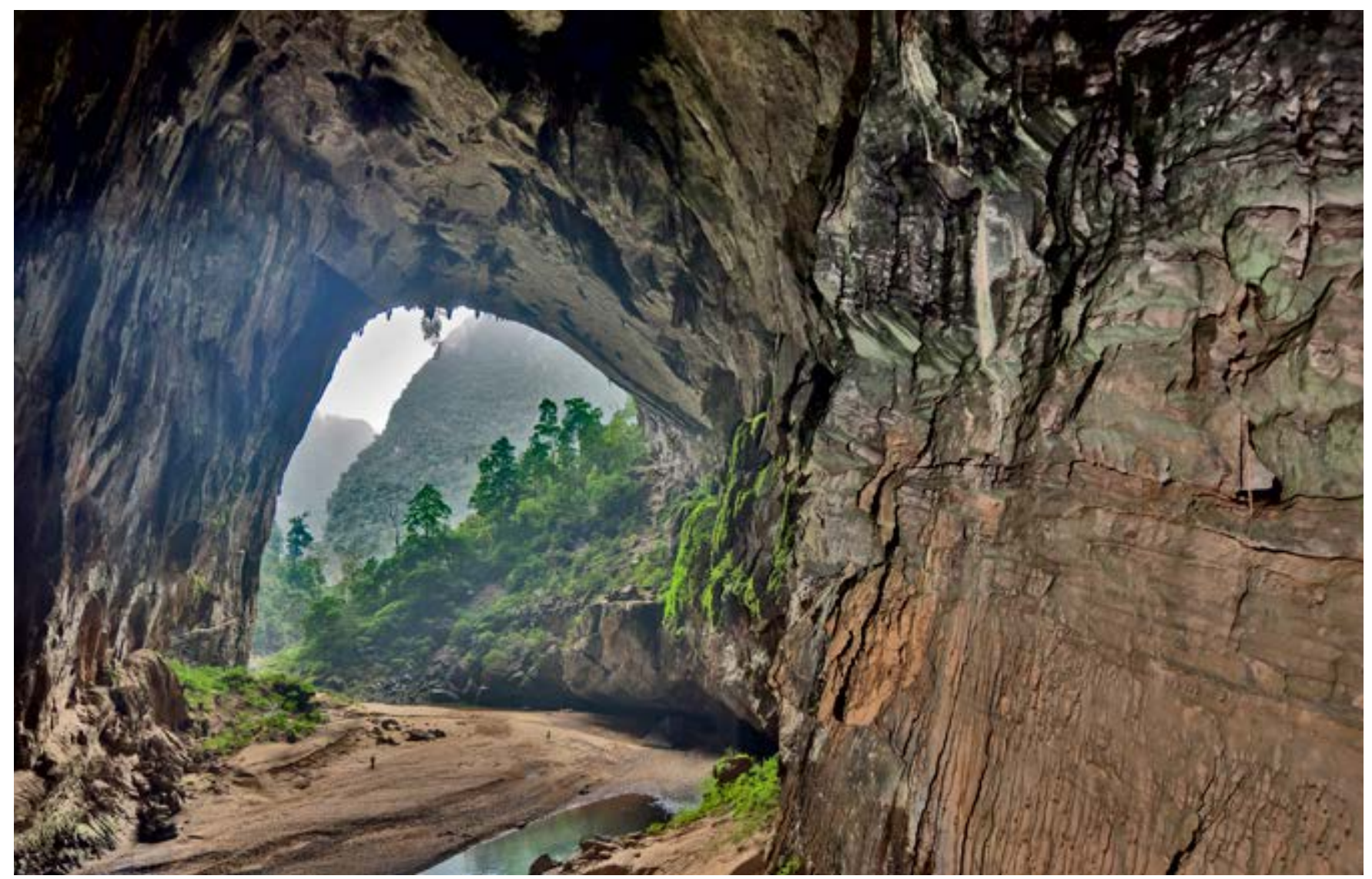

Foto 7.1 A entrada da Gruta Hang Son Doong, no Parque Nacional Phong Nha-Kẻ Bàng, Vietnã, explorada e pesquisada pela primeira vez em 2009, a maior entrada de uma caverna em volume no mundo (5000m x 145m x 200m). @ Dave Bunnel

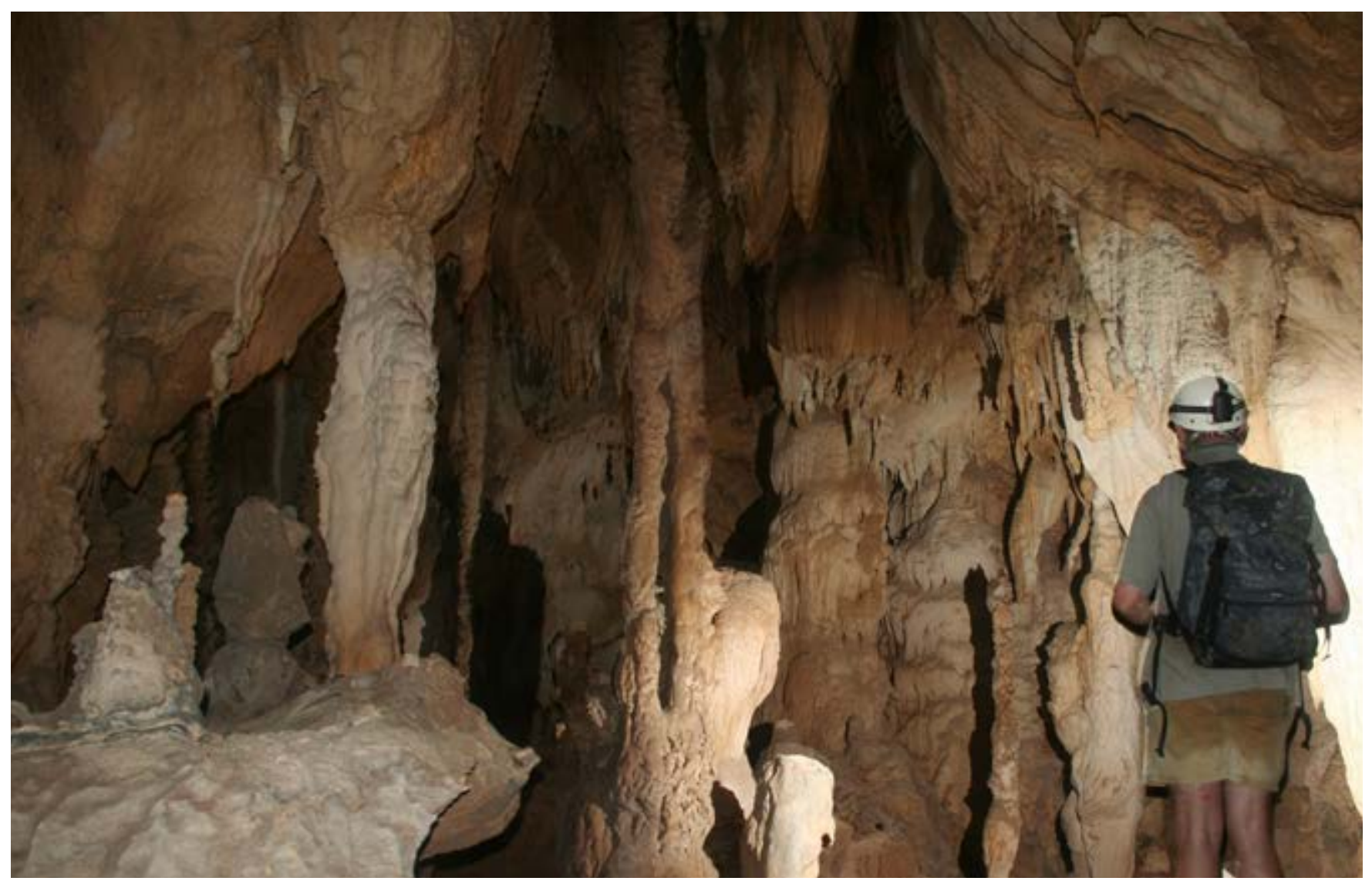

Foto 7.2 Espeleotemas intactos (estalactites, estalagmites e escorrimentos) na caverna Wild Boar, Parque Nacional e Sítio do Patrimônio Mundial Mulu, Sarawak, Malásia. @ John Gunn 


\section{Ameaças}

Como cerca de $20-25 \%$ da população global depende da água potável do carste, existe uma literatura substancial sobre ameaças às águas subterrâneas nestas áreas (por exemplo, Drew \& Hotzl, 1999; Kresic, 2013). As águas subterrâneas do carste são particularmente suscetíveis à ocorrência de bactérias, derivadas, por exemplo, de sistemas de águas residuais mal projetados, e de poluentes, tais como pesticidas e herbicidas de terras agrícolas, hidrocarbonetos oriundos de estradas ou instalações de armazenamento de combustível e sedimentos da agricultura, indústria extrativa e de construção. Há também muitos exemplos de captação excessiva de águas subterrâneas do carste, o que geralmente leva à subsidência ou ao colapso catastrófico (Veni et al., 2001). Há um alto grau de endemismo em muitas áreas do carste e as ameaças à biodiversidade em rochas calcárias, particularmente das pedreiras, foram discutidas por Vermeulen \& Whitten (1999) e BirdLife et al. (2014). A formação de vazios subterrâneos por dissolução de rochas e o rápido transporte subterrâneo de sedimentos por águas subterrâneas são características distintivas das áreas cársticas e a ameaça que representam para as infraestruturas e construções em superfície tem sido amplamente discutida (Waltham et al., 2005).

Tem sido dada pouca atenção às ameaças à geodiversidade cárstica, embora muitas das ameaças discutidas em outros contextos também tenham impacto nestas geoformas superficiais e subterrâneas. A variedade de cenários cársticos e a complexidade tridimensional integrada do carste significam que as geoformas cársticas em áreas protegidas geralmente enfrentam ameaças específicas do local, tais como a extração de rochas. Além disso, uma área que tem baixa geodiversidade, à superfície, pode ser protegida devido à existência de cavernas e sedimentos de elevado valor para a geodiversidade no meio subterrâneo. Também por esse motivo, a potencial ocorrência de geoformas subterrâneas deve ser sempre considerada na avaliação de propostas de implantação de edifícios e outras atividades humanas à superfície em terrenos cársticos.

A intervenção humana nas cavernas para permitir o acesso de visitantes pode resultar em danos significativos nos elementos de interesse geológico, mas se realizada com bom senso pode proporcionar um melhor acesso para o seu estudo científico. Por exemplo, quando a caverna Poll an Ionain (Doolin), na Irlanda, sofreu intervenções, a passagem foi cuidadosamente ampliada para manter o máximo possível da morfologia original, com a nova passagem a permitir que os cientistas transportassem equipamento de perfuração até uma câmara com sedimentos profundos que anteriormente só era acessível através de uma passagem baixa e estreita.

Além dos impactos diretos, quaisquer mudanças no fluxo de água, sedimentos ou dióxido de carbono no carste representam uma ameaça potencial à geodiversidade, por exemplo, através do enchimento ou soterramento dos elementos cársticos com sedimentos atuais, ou de mudanças na química da água de percolação, que levam à interrupção na formação de espeleotemas. As principais atividades que

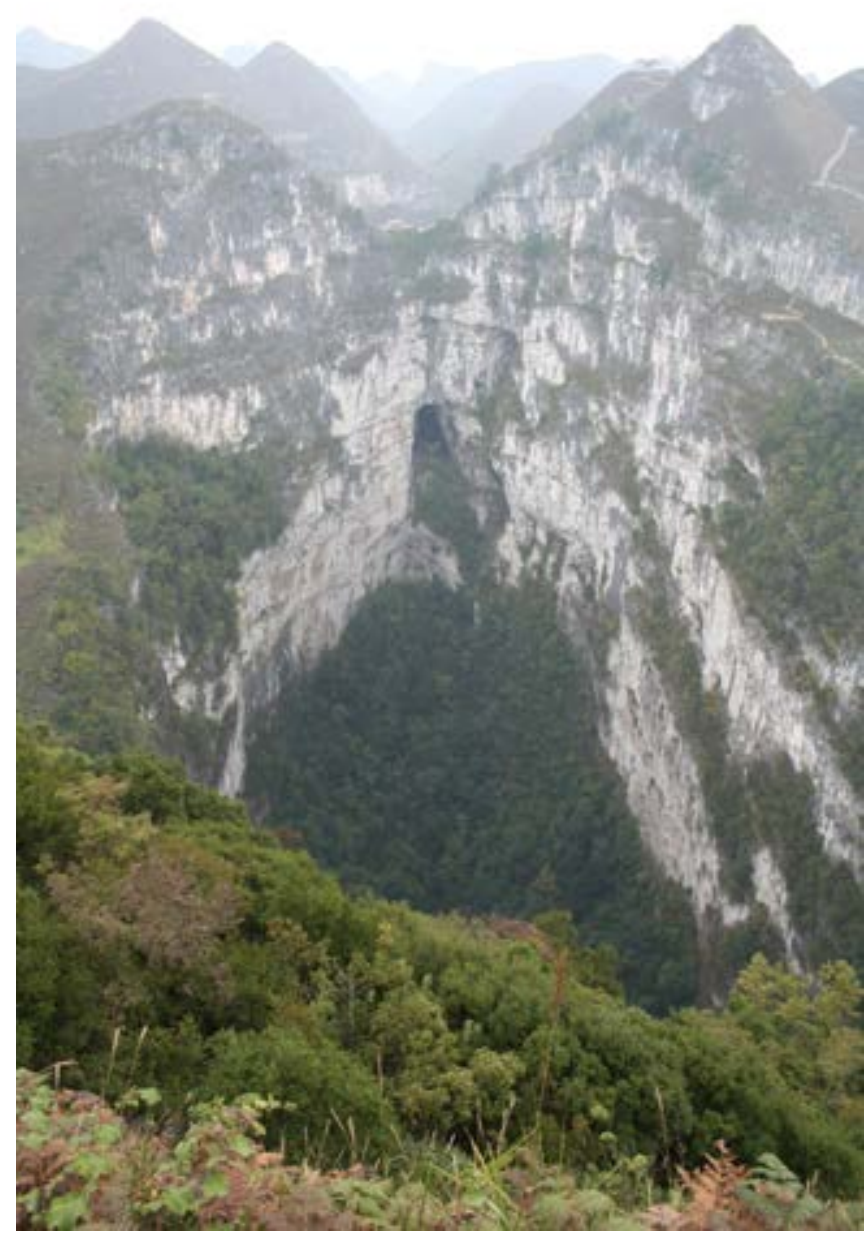

Foto 7.3 A gigantesca dolina de colapso Dashiwei Tiankeng, medindo $600 \mathrm{~m}$ de comprimento, $420 \mathrm{~m}$ de largura e $613 \mathrm{~m}$ de profundidade, Geoparque Global Leye-Fengshan, China. @ John Gunn

produzem tais mudanças são a agricultura, a silvicultura, a indústria extrativa, a exploração de água, a construção/ urbanização e o turismo/recreação. A agricultura e a silvicultura são as atividades humanas mais comuns nas áreas protegidas com carste e nas suas proximidades, e ambas apresentam vários impactos. Por exemplo, mudanças na vegetação de superfície, como resultado de incêndios, geralmente levam à erosão do solo e, em casos extremos, à desertificação, bem como à redução das concentrações de dióxido de carbono no solo. A exploração da água geralmente tem impactos indiretos na geodiversidade; por exemplo, pela extração de água baixando o nível dos lençóis freáticos, ou pela recarga rápida e localizada, acumulando sedimentos em condutos. Veja a Caixa 6.2, com um exemplo na Eslovênia.

\section{Princípios e diretrizes de gestão}

As áreas cársticas têm recebido proteção ao nível local, nacional ou internacional por uma variedade de razões das quais a geodiversidade é apenas uma delas; em alguns casos, ela nem sequer é mencionada. Por exemplo, cinco dos 52 bens do Patrimônio Mundial identificados por Williams (2008, e com. pess.) como tendo elementos cársticos relevantes a nível internacional (incluindo dois com Valor Universal Excecional, conforme definido pela Convenção) foram inscritos na Lista do Patrimônio Mundial somente por causa de seu interesse cultural; 


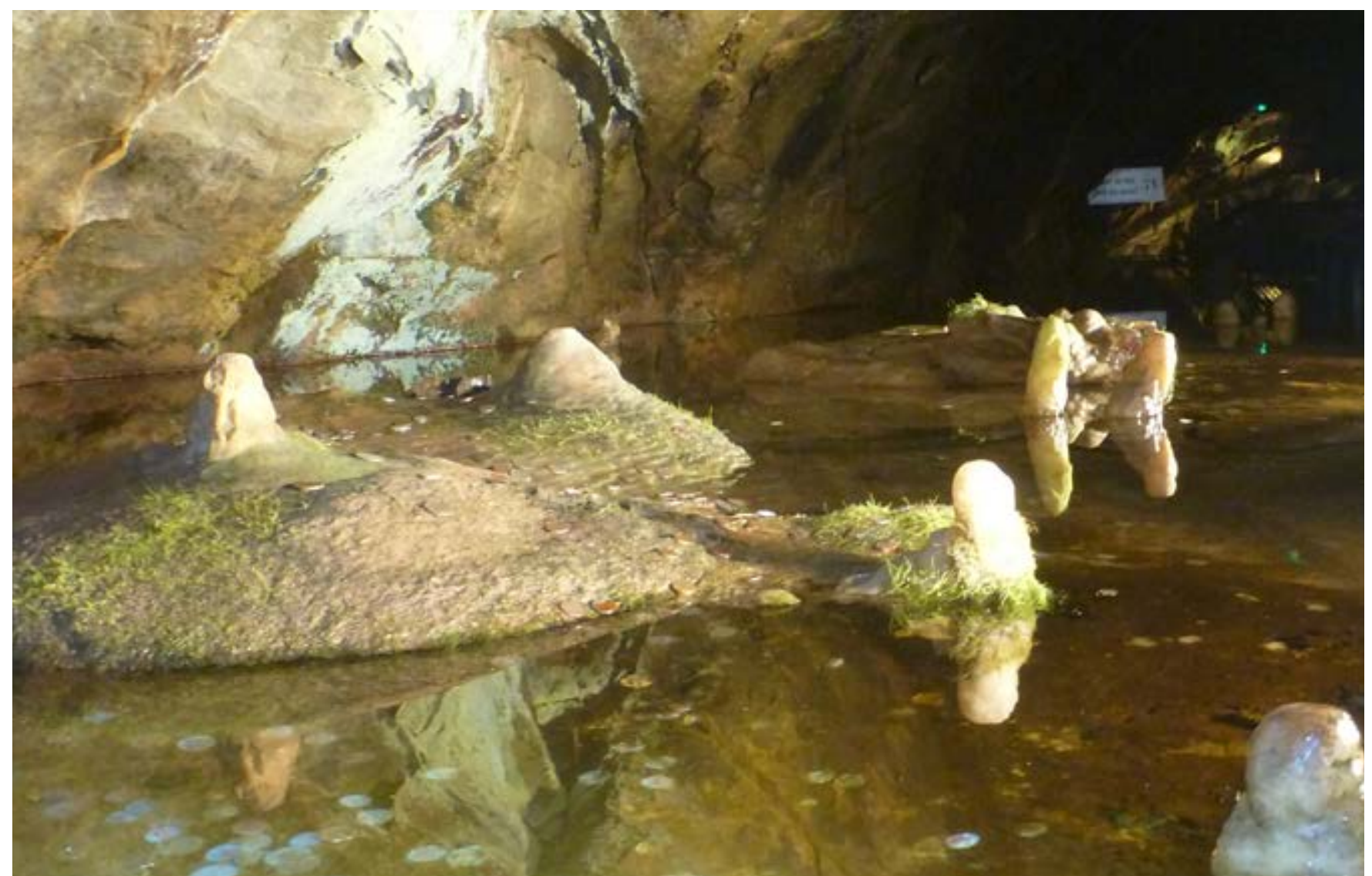

Foto 7.4 A caverna Gough, no Sítio de Especial Interesse Científico (SSSI) Cheddar Caves, Somerset, Inglaterra, está aberta ao público há mais de 100 anos. Infelizmente, o mau uso da iluminação tem levado ao crescimento da lampenflora em muitas partes da caverna. A lagoa é artificial e contém espeleotemas trazidos de outras partes da caverna, bem como moedas jogadas pelos visitantes para "pedir um desejo". @ John Gunn

deste modo, não é claro se a geodiversidade recebe algum tipo de proteção nessas áreas. Da mesma forma, Gunn (2020) identificou 151 Reservas da Biosfera em 62 países (numa área total de 42.181.357 ha) e 124 Sítios Ramsar em 55 países (numa área total de 4.766 .652 ha) que contêm águas subterrâneas cársticas e muito provavelmente também uma geodiversidade cárstica significativa. Mesmo em Geoparques Globais em áreas cársticas, o foco de conservação é muitas vezes guiado pelos interesses económicos, em cavernas turísticas com pouca ou nenhuma consideração pelas exigências de gestão existentes em outras cavernas nem, em alguns casos, na geodiversidade cárstica em geral. Portanto, o princípio mais importante na gestão de áreas protegidas cársticas é adotar uma abordagem holística que considere todo o sistema cárstico. Isto compreende as geoformas e águas superficiais e subterrâneas, a flora e a fauna, assim como quaisquer valores espirituais, religiosos e outros valores culturais.

Diretrizes internacionais para proteção de cavernas e áreas cársticas foram publicadas pela UICN (Watson et al., 1997) e por Veni et al. (2001). Exemplos de diretrizes com as melhores práticas para a conservação de cavernas e áreas cársticas ao nível regional ou nacional incluem Prosser et al. (2006) para a Inglaterra; o manual de gestão do carste de 2003 para a Colúmbia Britânica, Canadá, com ligações para um módulo de treinamento on-line (British Columbia, 2003; 2020) e as diretrizes do governo da Tasmânia para proteção e gestão do carste (Tasmanian Government, sem data). Muitas associações nacionais de espeleologia publicam diretrizes de espeleologia responsável, como por exemplo a British Caving Association (sem data) e a National Speleological Society in the USA (2016). Woo e Kim (2018) tratam de exemplos da Coreia. A Tabela 7.1 apresenta algumas considerações essenciais de gestão.

\subsection{Gestão de áreas protegidas glaciais e periglaciais}

\section{Geoformas, processos e elementos com valor}

As áreas protegidas glaciais e periglaciais (estas estão sujeitas à ação alternada do gelo/degelo em altitudes elevadas ou próximo de ambientes glaciais) incluem uma ampla variedade de elementos ativos (atuais) e inativos (vestígios do Quaternário). Os ambientes glaciais atuais estão associados, por exemplo, aos mantos de gelo (inlandsis) na Antártida e na Groenlândia; as calotas e campos de gelo na Patagônia, Alasca (EUA) e Islândia; e os glaciares de montanha nos Alpes, Himalaia, Montanhas Rochosas e ilhas subantárticas compreendem conjuntos derivados de uma combinação variável de processos glaciais, lacustres, fluviais e marinhos. Nessas áreas, há também conjuntos de geoformas e depósitos glaciais que registram mudanças de longo prazo, em escalas temporais que variam de décadas a centenas de milhares de anos (Kiernan, 1996; Benn \& Evans, 2010). As áreas protegidas com elementos glaciais ativos são normalmente de grande dimensão e incluem muitas das paisagens mais espetaculares do mundo e importantes reservas de biodiversidade (por exemplo, Parque Nacional Sagarmatha -Monte Everest - 
Tabela 7.1. Considerações essenciais de geoconservação em cavernas e áreas cársticas.

GESTÃO À SUPERFÍCIE Em uma área protegida cárstica, qualquer atividade planejada deve ser avaliada para determinar o impacto potencial nos cursos de água e no ar (especialmente nos níveis de dióxido de carbono), condicionador dos processos cársticos.

\begin{tabular}{l|l}
\hline $\begin{array}{l}\text { Bacias } \\
\text { hidrográficas }\end{array}$ & $\begin{array}{l}\text { Muitas áreas cársticas recebem um fluxo substancial de água e sedimentos de bacias adjacentes não } \\
\text { cársticas, e as águas subterrâneas do carste geralmente se movem sob as bacias topográficas e podem } \\
\text { seguir caminhos convergentes e divergentes. As bacias hidrográficas cársticas são, geralmente, dinâmicas, } \\
\text { expandindo-se e contraindo-se em resposta à precipitação. Portanto, é essencial identificar todas as bacias } \\
\text { hidrográficas das áreas protegidas existentes ou a serem criadas através de métodos de levantamento } \\
\text { dos fluxos de água e do mapeamento de cavernas. Quando a bacia hidrográfica se estende para além } \\
\text { dos limites da área protegida à superfície, essas áreas adicionais devem ser consideradas como uma } \\
\text { zona tampão ou deve haver um plano de gestão integrado da bacia hidrográfica para proteger elementos } \\
\text { cársticos de interesse a jusante ou montante. }\end{array}$
\end{tabular}

\section{Indústria} extrativa

Deve-se evitar a indústria extrativa em áreas protegidas cársticas, pois desta decorre, inevitavelmente, perda de geodiversidade e modificação de processos. Se existir a necessidade de um mineral que não possa ser obtido fora da área protegida, os potenciais locais de extração precisam ser avaliados, tanto em termos de geoformas superficiais e subterrâneas, como de conectividade hidrogeológica para identificar áreas de "mínimo impacto".

\section{Construções de grande dimensão}

Existem protocolos para reduzir os riscos que o carste representa para a implantação de rodovias e ferrovias, mas os riscos de tais construções para o carste não recebem a mesma atenção. Onde é necessário atravessar áreas protegidas, o mapeamento do terreno à superfície, investigações espeleológicas, com levantamentos detalhados de cavernas e investigações hidrogeológicas são essenciais para identificar uma rota "menos prejudicial". Medidas específicas devem incluir a prevenção da entrada direta nas águas subterrâneas do escoamento proveniente de estradas contendo hidrocarbonetos e sedimentos; obstrução cuidadosa das entradas junto à superfície, em vez de simples enchimento com argamassa; e provisão de acesso alternativo às cavernas.

\section{Construções e} acessos locais

\section{Considerações semelhantes se aplicam à construção de estradas locais e trilhas para caminhadas dentro} de áreas protegidas cársticas, embora um maior controle na delimitação do traçado destas seja mais viável. O mapeamento das cavernas, associado ao mapeamento do terreno à superfície é essencial para identificar os corredores menos prejudiciais. Para projetos maiores, devem ser realizados levantamentos geofísicos para identificar grandes vazios. A drenagem de estradas e trilhas deve ser canalizada através de armadilhas de sedimentos (e hidrocarbonetos) que recebem manutenção regular.

\begin{tabular}{|c|c|}
\hline Edifícios & $\begin{array}{l}\text { Quaisquer novas construções em áreas protegidas cársticas, tais como centros de acolhimento de visitantes, } \\
\text { requerem levantamentos de superfície e subterrâneos para evitar que a construção ocorra sobre vazios. }\end{array}$ \\
\hline $\begin{array}{l}\text { Estacionamento } \\
\text { e transporte de } \\
\text { visitantes }\end{array}$ & $\begin{array}{l}\text { Sempre que possível, os estacionamentos devem estar bem longe de geoformas cársticas superficiais } \\
\text { importantes. Também nunca devem ser construídos por cima de cavernas, tanto para evitar infiltrações } \\
\text { quanto porque os estacionamentos formam uma "cobertura" impermeável que restringe a infiltração } \\
\text { de água e pode causar a secagem das cavernas. Cada vez mais, veículos elétricos são usados para } \\
\text { transportar os visitantes desde grandes estacionamentos bem projetados até aos elementos de interesse. }\end{array}$ \\
\hline $\begin{array}{l}\text { Geração de } \\
\text { energia e } \\
\text { armazenamento } \\
\text { de combustível }\end{array}$ & $\begin{array}{l}\text { Estruturas de apoio aos visitantes em algumas áreas protegidas cársticas são remotas e sem acesso à rede } \\
\text { elétrica. Sempre que possível, a eletricidade deve ser gerada no local usando unidades eólicas, hídricas ou } \\
\text { solares. Se os geradores de energia a diesel forem essenciais, o combustível para eles e para quaisquer } \\
\text { outros usos essenciais deve ser armazenado adequadamente, com procedimentos de segurança para } \\
\text { evitar derramamentos. }\end{array}$ \\
\hline $\begin{array}{l}\text { Abastecimento } \\
\text { de água }\end{array}$ & $\begin{array}{l}\text { Como as áreas cársticas são caracterizadas pela falta de água em superfície, a água subterrânea é } \\
\text { comumente explorada para uso humano. A coleta de água de percolação, que migra para as cavernas, } \\
\text { provavelmente, terá pouco impacto, mas antes que qualquer água seja captada dos cursos d'água } \\
\text { subterrâneos é essencial estabelecer (através de traçadores) de onde ela vem e para onde drena. Decisões } \\
\text { mais embasadas podem então ser tomadas sobre os impactos potenciais da captação. }\end{array}$ \\
\hline $\begin{array}{l}\text { Tratamento de } \\
\text { águas residuais } \\
\text { e esgotos }\end{array}$ & $\begin{array}{l}\text { As águas residuais não tratadas não devem ser descartadas no carste, pois isso resultará em poluição com } \\
\text { potencial impacto sobre espeleotemas, biota de cavernas e nascentes. A transferência de águas residuais } \\
\text { para fora do carste pode perturbar o equilíbrio hídrico, sendo a melhor prática tratar adequadamente a água } \\
\text { antes de descartá-la no carste, junto a um ponto de recarga natural. Por exemplo, no Geoparque Global } \\
\text { Marble Arch Caves (Irlanda), as águas residuais do centro de visitantes fluem através de uma pequena estação } \\
\text { de tratamento no local e, posteriormente, a água tratada de elevada qualidade é direcionada para a caverna. }\end{array}$ \\
\hline $\begin{array}{l}\text { Plantas e } \\
\text { animais }\end{array}$ & $\begin{array}{l}\text { Áreas calcárias, com seus solos ricos em carbonatos, podem promover a ocorrência de algumas } \\
\text { espécies vegetais e produzir uma flora característica. A geomorfologia cárstica também pode influenciar } \\
\text { associações florísticas. Por exemplo, as dolinas que funcionam como células de ar frio podem incluir uma } \\
\text { flora que é mais distinta de altitudes mais elevadas ou de climas mais frios do passado. O terreno cárstico } \\
\text { também favorece muitos nichos ecológicos para animais de superfície. A gestão da geoconservação em } \\
\text { áreas protegidas cársticas deve sempre levar em conta a flora e a fauna, e vice-versa. }\end{array}$ \\
\hline
\end{tabular}

Fonte: Compilado a partir de uma variedade de fontes, mas principalmente de Watson et al. (1997) 
GESTÃO SUBTERRÂNEA

\begin{tabular}{l|l}
$\begin{array}{l}\text { Bacias } \\
\text { hidrográficas }\end{array}$ & $\begin{array}{l}\text { É essencial proteger toda a bacia hidrográfica, mas as cavernas que se estendem em profundidade, sob terrenos } \\
\text { não cársticos, apresentam uma dificuldade particular. Se for possível garantir que não há ligação entre a superfície } \\
\text { e a caverna, não se justifica uma área protegida à superfície. No entanto, se existir essa ligação, por exemplo, } \\
\text { através de dolinas de colapso, então é importante que as geoformas de superfície sejam igualmente protegidas. }\end{array}$ \\
\hline $\begin{array}{l}\text { Acesso dos } \\
\text { visitantes }\end{array}$ & $\begin{array}{l}\text { A grande maioria das cavernas não foi alvo de intervenções, mas mesmo estas podem receber muitos visitantes } \\
\text { que praticam "espeleologia de aventura" sem guia, incluindo mergulho. Em áreas protegidas, um sistema de } \\
\text { controle de acesso pode ser necessário para restringir o número de visitantes. Portões trancados são necessários } \\
\text { para proteger cavernas com alto valor geopatrimonial, biológico ou arqueológico. Todos os visitantes devem } \\
\text { aderir a um código de conduta de espeleologia com mínimo impacto, e em cavernas muito frequentadas as rotas } \\
\text { principais devem ser marcadas de forma clara, mas discreta. }\end{array}$
\end{tabular}

\section{Zoneamento em cavernas}

O levantamento e a caracterização de cavernas em áreas protegidas deve incluir informações detalhadas do geopatrimônio para facilitar a gestão através de zoneamento. Devem ser identificadas as seções de uma caverna mais adequadas para o acesso de visitantes, juntamente com as áreas onde devem ser aplicadas restrições de acesso devido à ocorrência de espeleotemas excepcionais, sedimentos ou depósitos arqueológicos, ou aquelas com altas concentrações de gases nocivos, tais como dióxido de carbono ou radônio.

Cavernas
turísticas já
existentes

Muitas cavernas turísticas foram alvo de intervenções antes da criação das áreas protegidas onde ocorrem. existentes Infelizmente, em algumas houve danos significativos ao geopatrimônio, como a destruição de sedimentos e espeleotemas, devido à construção de caminhos, introdução de materiais orgânicos e desenvolvimento de lampenflora (algas, musgos e plantas que crescem com luz artificial). Grandes números de visitantes também podem aumentar as concentrações de dióxido de carbono para níveis onde os espeleotemas começam a se dissolver. As cavernas turísticas em áreas protegidas devem ser avaliadas e um plano de gestão desenvolvido para restaurar os elementos de interesse, sempre que possivel e para proteger contra danos futuros. Por exemplo, sistemas de iluminação antigos devem ser substituídos por modernos sistemas LED. Para mais detalhes, ver ISCA (2014). $\begin{array}{lll}\begin{array}{l}\text { Novas cavernas } \\ \text { turísticas }\end{array} & \begin{array}{l}\text { As cavernas turísticas são geralmente uma importante fonte de renda para uma área protegida e pode haver } \\ \text { pressão para a abertura de novas cavernas. Isto só deve ser permitido onde uma demanda clara possa ser }\end{array}\end{array}$ explicada e uma caverna adequada a esse fim possa ser identificada. Um plano de gestão espeleológico deve ser elaborado com o envolvimento de espeleólogos experientes para minimizar danos na morfologia das galerias, espeleotemas e sedimentos. Devem também ser instalados sensores para permitir o monitoramento em tempo real da qualidade do ar.

\begin{tabular}{l|l}
\hline $\begin{array}{l}\text { Limpeza de } \\
\text { cavernas }\end{array}$ & $\begin{array}{l}\text { As cavernas turísticas variam nas quantidades de limpeza necessárias, sendo os requisitos mais comuns a } \\
\text { remoção de acúmulos de poeiras, lanugem e resíduos humanos provenientes dos visitantes, além do controle } \\
\text { da lampenflora. Sempre que possivel, deve ser usada água da própria caverna. Água quente de alta pressão } \\
\text { somente deve ser usada em último recurso. A lampenflora pode ser controlada com a redução da iluminação } \\
\text { artificial e o uso de LED, mas uma solução de 5\% de hipoclorito de sódio pode ser usada para a sua remoção, } \\
\text { desde que sejam tomados cuidados para evitar que o escoamento resultante entre na circulação hídrica da } \\
\text { caverna. }\end{array}$ \\
\hline $\begin{array}{l}\text { Banheiros nas } \\
\text { cavernas }\end{array}$ & $\begin{array}{l}\text { Os visitantes precisam ser claramente informados sobre a sua última parada antes de entrar em uma caverna e } \\
\text { não devem ser instalados banheiros em cavernas, embora eles possam ser necessários em cavernas turísticas } \\
\text { extensas, onde os visitantes ficam no subsolo por mais de uma hora. Banheiros com desenho moderno podem } \\
\text { minimizar a quantidade de resíduos, mas para evitar a poluição é necessário cuidado no esvaziamento e na } \\
\text { limpeza. }\end{array}$ \\
\hline $\begin{array}{l}\text { Fauna das } \\
\text { cavernas }\end{array}$ & $\begin{array}{l}\text { As cavernas são locais preferenciais de descanso para uma gama de diferentes espécies de morcegos. O } \\
\text { seu guano é de especial importância para as espécies de decompositores invertebrados, que habitam um } \\
\text { ecossistema deste tipo. No passado, o guano era frequentemente extraído por seu valor como fertilizante, } \\
\text { deixando algumas cavernas com necessidade de recuperação. Outras espécies, como aves, répteis, mamíferos } \\
\text { e anfíbios habitam as entradas das cavernas e áreas envolventes e precisam ser protegidas. Algumas espécies } \\
\text { vivem nas partes mais profundas das cavernas e evoluíram com ausência de luz. }\end{array}$ \\
\hline
\end{tabular}

Fonte: Compilado a partir de uma variedade de fontes, mas principalmente de Watson et al. (1997).

Nepal; Parque Nacional Aoraki/Mount Cook, Nova Zelândia; Parque Nacional Los Glaciares, Argentina; Parque Nacional Torres del Paine, Chile; Parque Nacional Glacier, EUA; Parque Nacional do Nordeste da Groenlândia, Dinamarca; Parque Nacional Vatnajökull, Islândia; Parque Nacional Jotunheimen, Noruega; e Parque Nacional Sarek, Suécia). Nestas áreas ocorrem, invariavelmente, complexos de geoformas e sistemas geomorfológicos dinâmicos em diferentes escalas.

Os ambientes glaciais inativos contêm geoformas e depósitos originados, principalmente, durante as glaciações quaternárias dos últimos 2,6 milhões de anos. Ocorrem em uma ampla área de latitude média da América do Norte e da Eurásia e também nas imediações e vales inferiores dos atuais sistemas de glaciares de montanha e mantos de gelo (Ehlers et al., 2011). As áreas protegidas nestes ambientes variam muito em tamanho, desde paisagens de grande dimensão com alta geodiversidade (por exemplo, a Área de Patrimônio Mundial da Tasmânia, na Austrália, e os Parques Nacionais de Lake District e Cairngorms, no Reino Unido) até pequenos geossítios ( $<1 \mathrm{~km} 2)$ que contêm registros estratigráficos excepcionais ou representativos da glaciação quaternária e de mudanças ambientais, muitas vezes expostos 


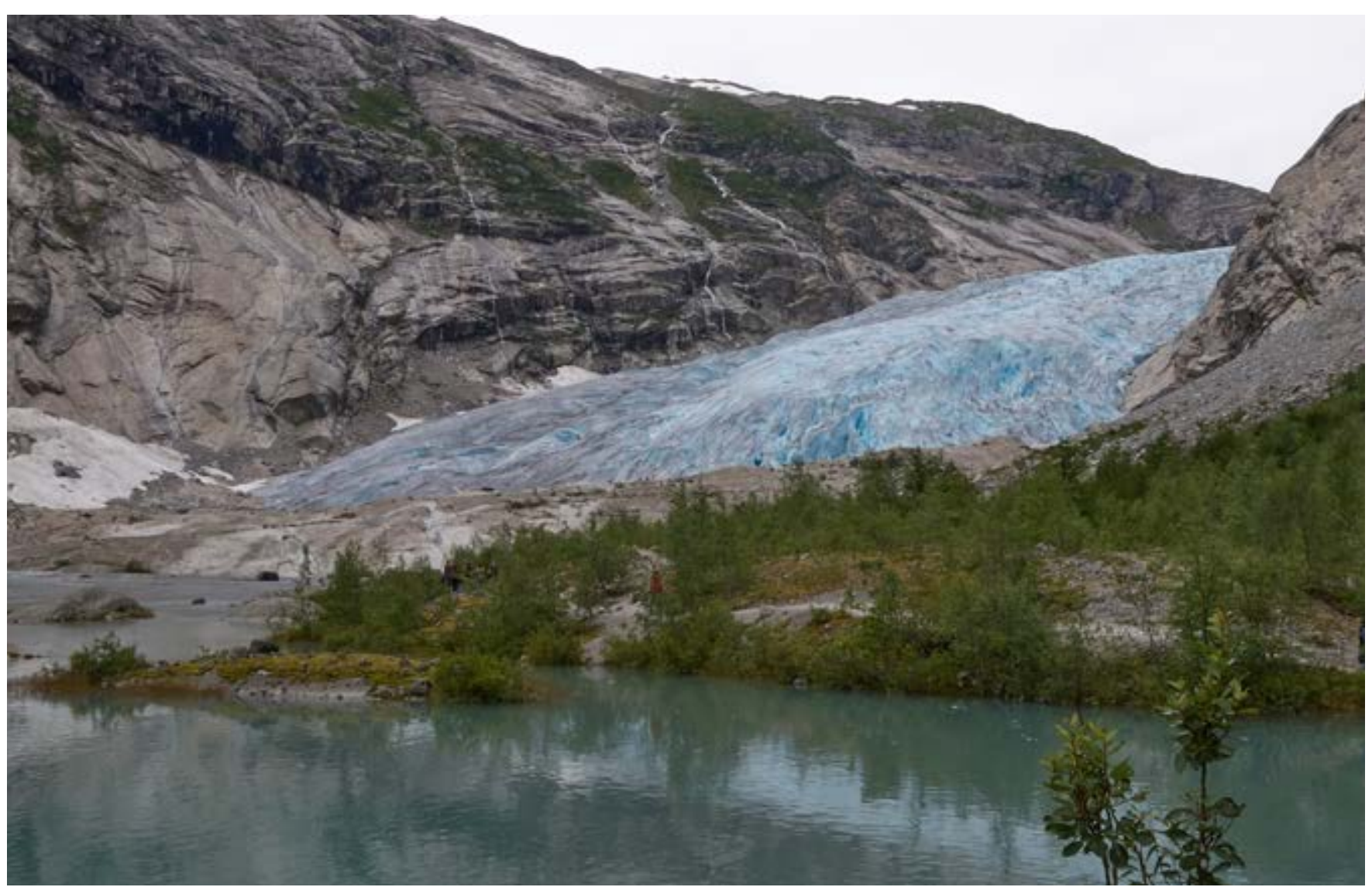

Foto 7.5 O glaciar Nigardsbreen, facilmente acessível, e suas morenas, um braço do glaciar Jostedal, a maior calota de gelo da Europa Continental. Localiza-se na Reserva Natural Nigardsbreen, parte do Parque Nacional Jostedalsbreen, Noruega. @ José Brilha

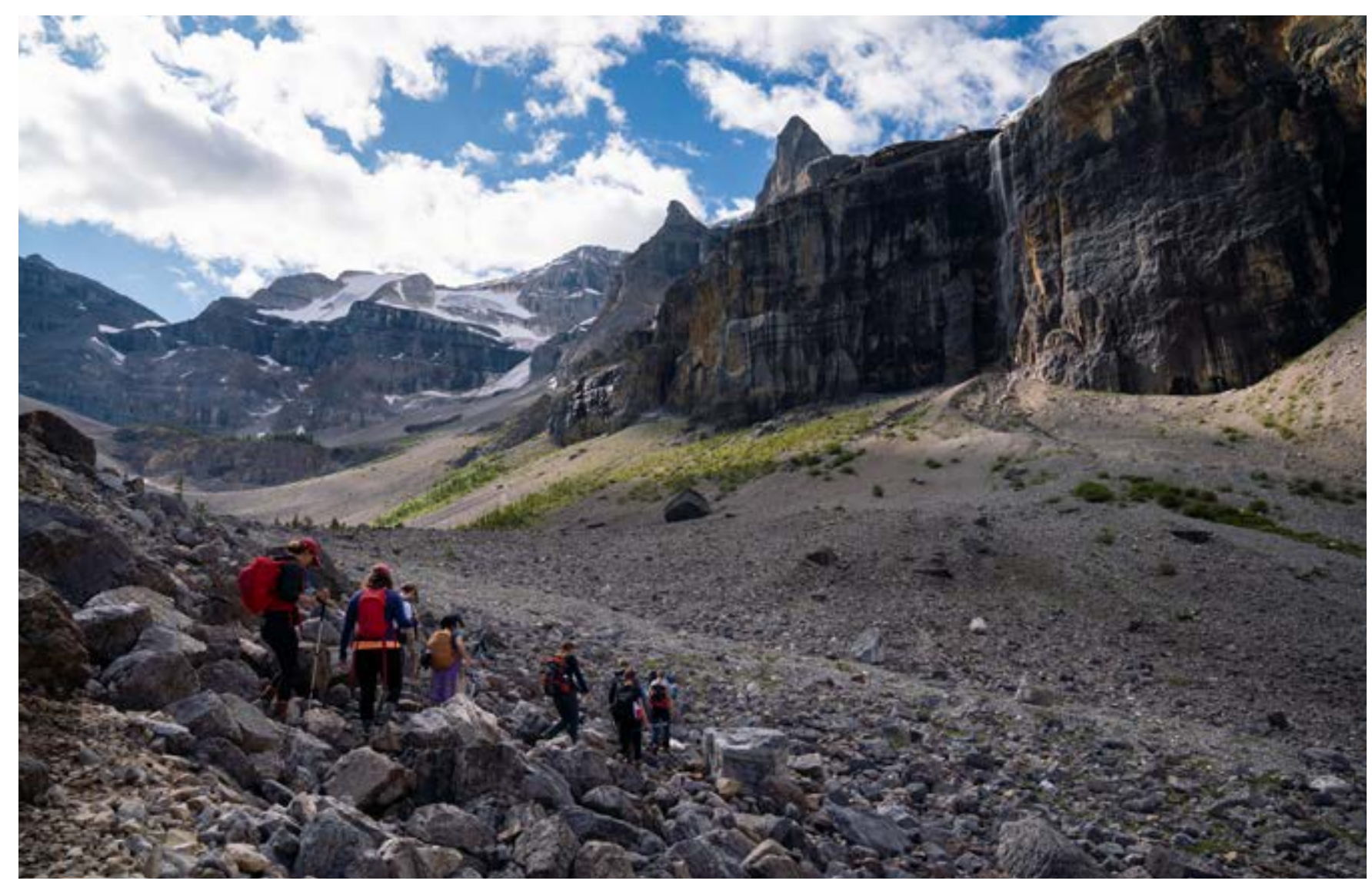

Foto 7.6 A área recentemente deglaciada, pelo recuo do glaciar Stanley, está agora sujeita a processos periglaciais, Parque Nacional Kootenay, Canadá. @ Parks Canada, Zoya Lynch 
pela erosão costeira ou fluvial. Quando os afloramentos naturais são raros, as pedreiras ativas e inativas muitas vezes oferecem um recurso importante, devido à exposição de registros sedimentares.

Da mesma forma, os ambientes periglaciais incluem geoformas e depósitos ativos e inativos formados por processos não glaciais em climas frios (Ballantyne, 2018). Os primeiros ocorrem em áreas polares e de alta montanha sem glaciares, e também em muitas montanhas de menor altitude, em latitudes médias, que perderam condições para a ocorrência de glaciação ou onde ocorrem pequenos glaciares. Os elementos periglaciais inativos também estão presentes nas mesmas áreas, mas a menor altitude e em áreas baixas de média latitude, particularmente, nas regiões do hemisfério norte próximas dos limites dos mantos de gelo quaternários.

As áreas protegidas glaciais e periglaciais possuem elevado valor geopatrimonial por uma série de razões. Elas são importantes para a pesquisa científica e para a compreensão da dinâmica glacial, das mudanças climáticas do passado registradas no gelo, geoformas e depósitos glaciais e periglaciais e dos depósitos marinhos e lacustres de origem glacial. Tal conhecimento é essencial para compreender as possíveis respostas dinâmicas dos mantos de gelo da Antártida e da Groenlândia ao aquecimento global. Geoformas e solos glaciais e periglaciais constituem o suporte físico, ou "palco", para a biodiversidade em grandes áreas das altas e médias latitudes e em ambientes montanhosos, em escalas que variam entre cadeias montanhosas inteiras até mosaicos de habitats, em encostas individuais de montanhas. Muitas áreas protegidas glaciais e periglaciais também têm valor elevado no âmbito do turismo, de atividades educacionais e recreativas, de ligações com o patrimônio cultural (por exemplo, através do folclore e lendas, e como símbolos nacionais), da estética da paisagem e como fontes de inspiração para arte e literatura (Kiernan, 1996; Gordon, 2018). Além disso, são importantes fontes de água para as áreas planas adjacentes e para a exploração de energia hidroelétrica.

\section{Ameaças}

Todas as ameaças referidas na Tabela 6.2 se aplicam potencialmente aos interesses geopatrimoniais em áreas protegidas glaciais e periglaciais (Tabela 7.2). Os principais impactos são:

- destruição total ou parcial de geoformas e afloramentos de sedimentos;

- fragmentação da integridade dos geossítios e perda das relações entre os elementos, particularmente, quando os valores residem na associação entre geoformas;

- interrupção de processos geomorfológicos;

- perda de acesso a geoformas e afloramentos de sedimentos; e

- perda de visibilidade dos principais elementos (por exemplo, devido ao crescimento da vegetação ou ao acúmulo de depósitos de encosta sobre sedimentos glaciais e periglaciais).

Áreas protegidas de grande dimensão são, em geral, relativamente robustas diante da maioria das atividades humanas e ameaças de pequena dimensão. Ainda assim, deve haver preocupações com a perda de integridade e naturalidade, e o risco de danos significativos ou destruição de características específicas de valor excepcional com alguns tipos de construções, como são os casos de infraestruturas de esqui (Reynard, 2009a) ou o nivelamento da superfície de um glaciar rochoso para criar pistas de esqui (Lambiel \& Reynard, 2003). Portanto, é essencial que seja feita a caracterização detalhada dos interesses geopatrimoniais, e uma avaliação da vulnerabilidade a quaisquer intervenções humanas. Os geossítios de menor dimensão são mais sensíveis a atividades humanas e ameaças, e muitas vezes com menos espaço para evitar ou mitigar os impactos, dependendo das características do local. Mais uma vez, a caracterização detalhada dos interesses geopatrimoniais e a avaliação da vulnerabilidade a intervenções humanas são essenciais.

\section{Princípios e diretrizes de gestão}

Os seguintes princípios gerais se aplicam, seguindo a classificação de geossítios apresentada na Tabela 5.2:

- geossítios vulneráveis / elementos estáticos - proteger a integridade física do recurso e evitar a sua fragmentação (por exemplo, devido a pedreiras, construção de trilhas), de modo que as relações entre os elementos sejam evidentes (por exemplo, entre eskers e canais de água de degelo);

- geossítios/elementos geomorfológicos ativos - manter os processos naturais e a capacidade de os processos ativos evoluírem naturalmente;

- geossítios extensos - monitorar os afloramentos de sedimentos e fazer manutenção (por exemplo, limpeza da vegetação), se necessário, dependendo do nível e tipo de uso; e

- geossítios limitados / elementos únicos - manter uma proteção rigorosa para evitar a perda de valores essenciais (por exemplo, depósitos interglaciais); em alguns casos, quando os elementos com interesse são particularmente vulneráveis, pode ser necessário o seu enterramento.

Algumas pequenas áreas protegidas podem ser geridas como entidades isoladas, mas geralmente os elementos glaciais e periglaciais ocorrem como conjuntos complexos de geoformas e processos (Kiernan, 1996; Reynard, 2009b), e a vulnerabilidade dos elementos isolados a determinadas ameaças varia muito. A fragmentação e a perda de contexto e integridade dos conjuntos de geoformas são, por isso, potenciais impactos a considerar.

Em ambientes glaciais atuais, os objetivos de geoconservação na gestão de áreas protegidas devem ser a manutenção dos processos ativos e a proteção da integridade e do contexto dos conjuntos de geoformas. As principais ameaças provêm provavelmente do turismo e da recreação, da exploração de energia hidrelétrica e das explorações florestais. Os impactos podem surgir diretamente da implantação de edifícios e infraestruturas associadas e indiretamente de medidas de mitigação de risco, consideradas necessárias para proteger essas construções (por exemplo, proteção 


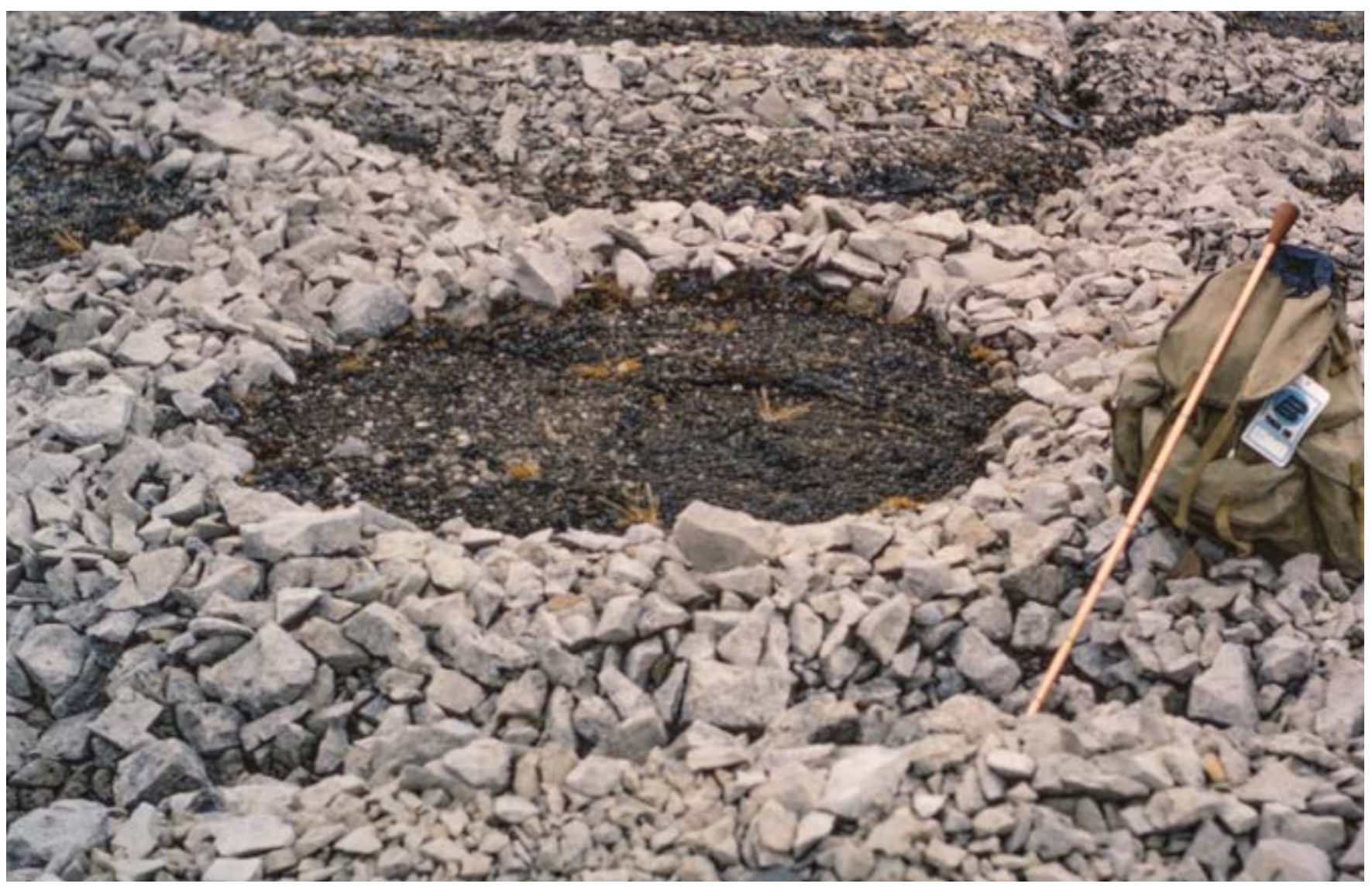

Foto 7.7 Círculo de pedras perfeitamente definido, por processos periglaciais (frost heave), Kvadehuksletta, Parque Nacional Nordaust-Spitsbergen, Svalbard, Noruega. Estas geoformas são extremamente suscetíveis ao pisoteio humano. () Roger Crofts

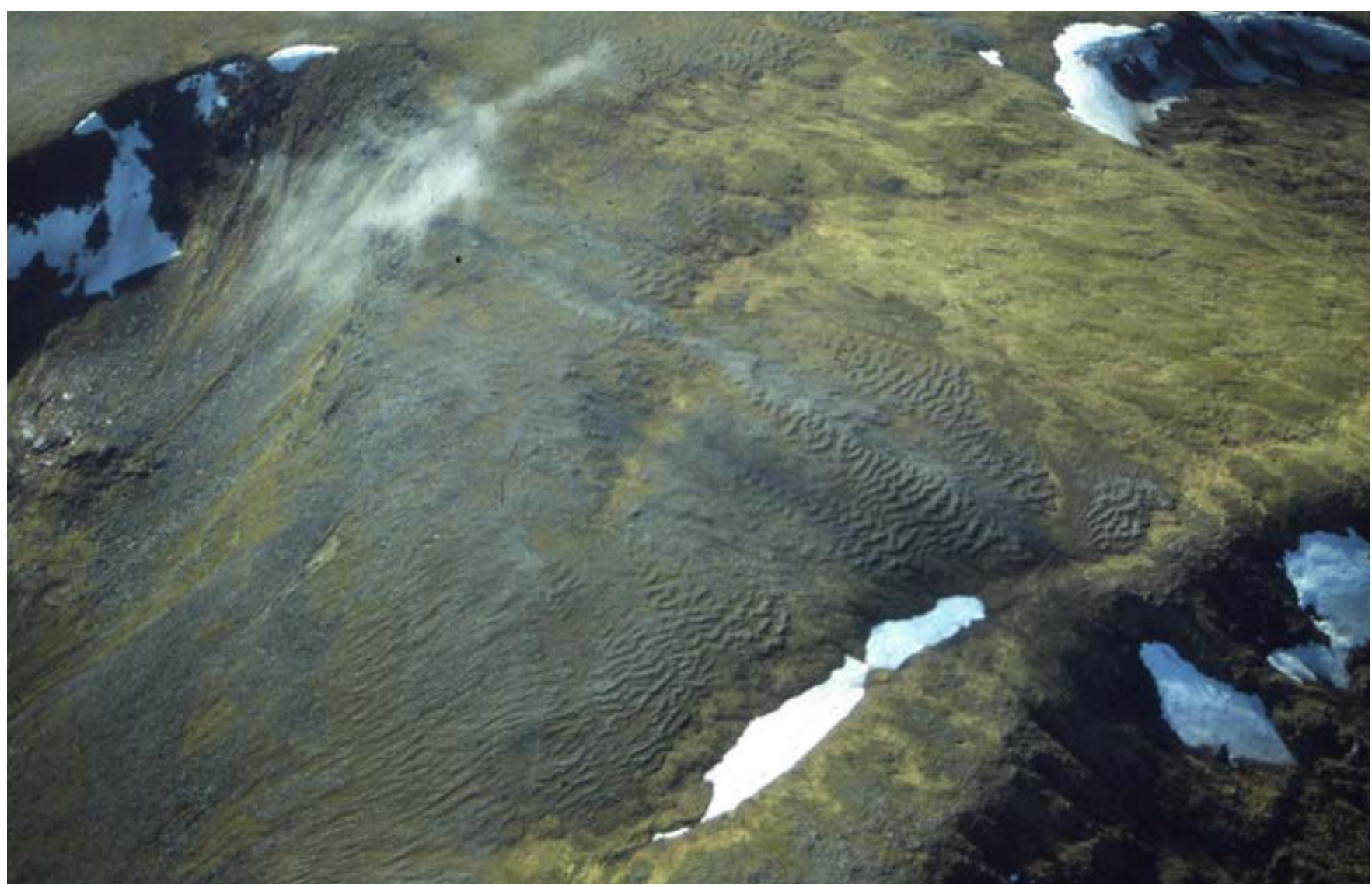

Foto 7.8 Lóbulos e terraços periglaciais, originados pelo movimento descendente do solo nas encostas com alternância de gelo/degelo (solifluxão) são geoformas muito frágeis e facilmente danificadas pelo pastoreio excessivo ou por veículos com rodas. Sítio de Especial Interesse Científico (SSSI) de Fannich Hills, Escócia. @ Roger Crofts 


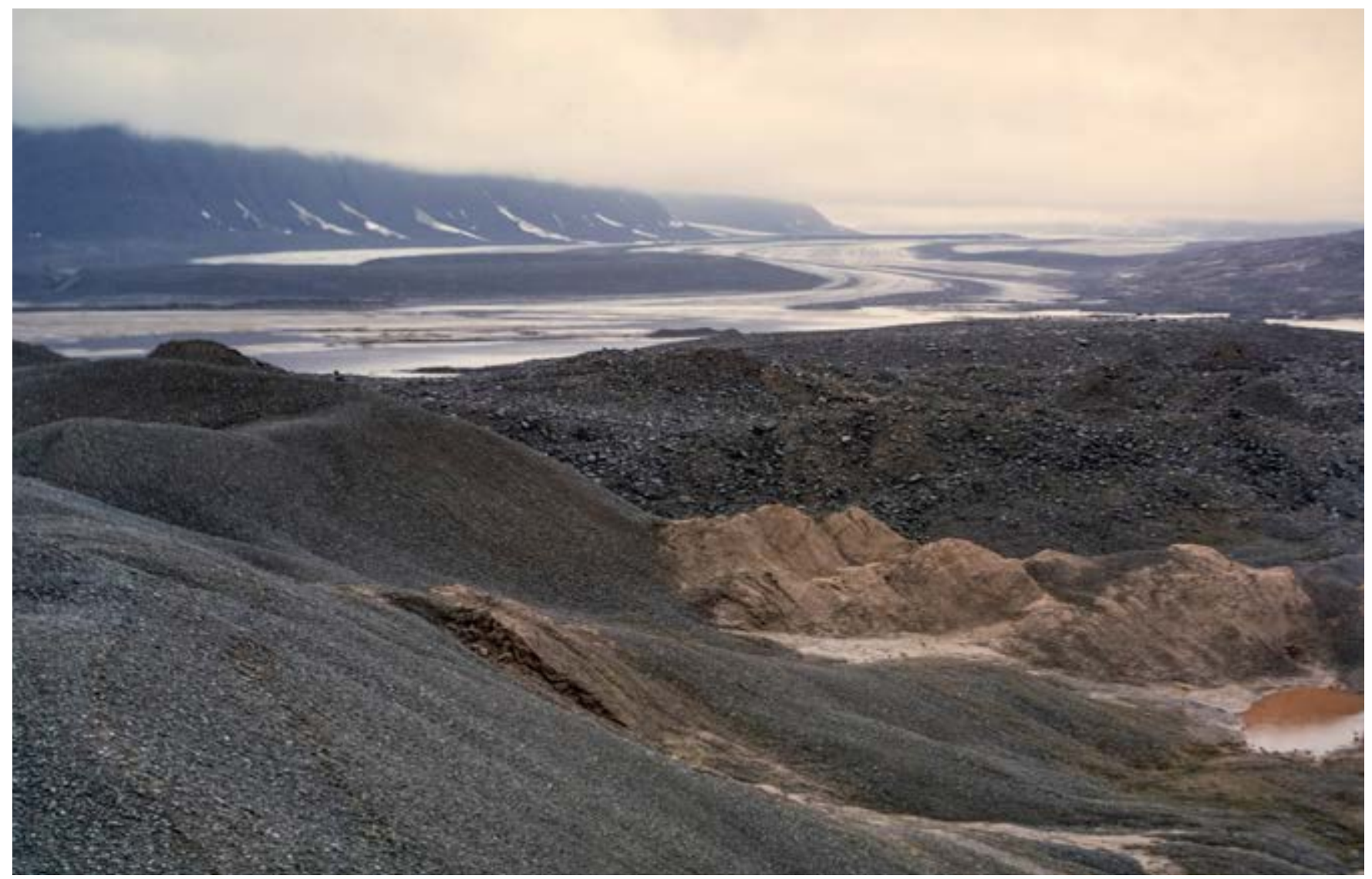

Foto 7.9 Conjunto de geoformas glaciais na frente do glaciar Battybreen, no Parque Nacional Nordre Isfjorden, Svalbard, Noruega. A sua localização remota significa que dificilmente serão perturbadas, embora o surgimento recente de pequenas expedições e do uso de barcos rápidos para aceder a lugares remotos no arquipélago de Svalbard seja uma ameaça potencial. @ Roger Crofts

\section{Caixa 7.1 \\ Estudo de caso de restauro: SSSI da Pedreira de Pitstone, Buckinghamshire, Reino Unido}

O SSSI da Pedreira de Pitstone é um bom exemplo da associação entre conservação de geopatrimônio e de biodiversidade no restauro planejado de uma antiga exploração mineira. No local ocorrem evidências de dois episódios interglaciais, de um período mais frio e de elementos periglaciais com restos vegetais e animais, testemunhando mudanças nos ambientes e processos. Trata-se de uma antiga pedreira de gesso parcialmente inundada, agora gerida como uma reserva natural local por uma ONG ambiental local. Alguns dos depósitos quaternários principais estão atualmente escondidos pela vegetação e por depósitos de encosta. Como parte de um plano de gestão integrada do local, os proprietários da pedreira, em parceria com geólogos locais, procederão à limpeza da vegetação, exporão os depósitos periglaciais representativos, e desenvolverão recursos educacionais e interpretativos do geopatrimônio e melhores acessos para visitantes e pesquisadores. As condições na área serão monitoradas com auxílio de fotografia de ponto fixo, para suportar a gestão no âmbito da geoconservação.

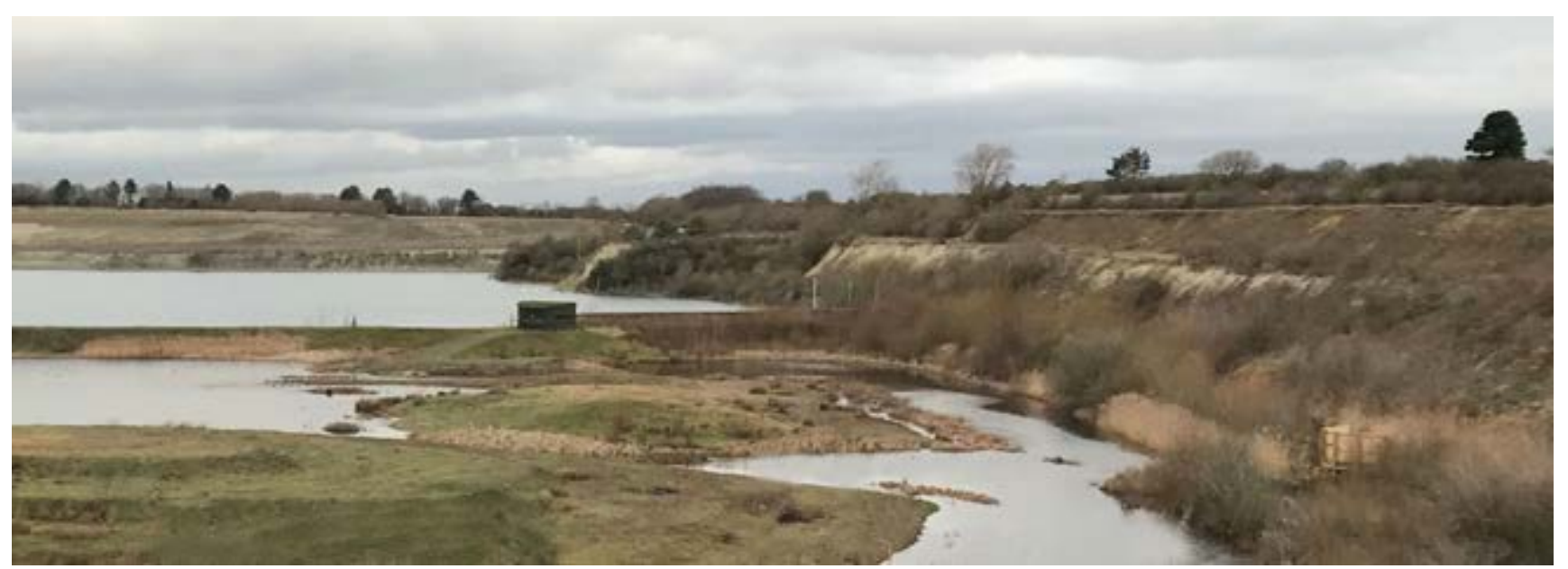

Foto 7.10 Os depósitos quaternários mais importantes na Pedreira de Pitstone ocorrem acima da frente de exploração de gesso, no lado direito da imagem. (C) Eleanor Brown, Natural England 
Tabela 7.2. Principais ameaças e orientações de gestão da conservação para diferentes categorias de geossítios glaciais e periglaciais.

\begin{tabular}{|c|c|c|c|c|}
\hline $\begin{array}{l}\text { Código de } \\
\text { Geoconservação }\end{array}$ & $\begin{array}{l}\text { Tipo de } \\
\text { geossítio }\end{array}$ & $\begin{array}{l}\text { Elementos } \\
\text { típicos de } \\
\text { interesse }\end{array}$ & Principais ameaças & $\begin{array}{l}\text { Orientações de gestão da } \\
\text { conservação }\end{array}$ \\
\hline \multirow[t]{6}{*}{$\begin{array}{l}\text { Geossítios } \\
\text { extensos }\end{array}$} & $\begin{array}{l}\text { Pedreiras e } \\
\text { escavações } \\
\text { ativas }\end{array}$ & $\begin{array}{l}\text { Afloramentos } \\
\text { de depósitos } \\
\text { glaciais, } \\
\text { periglaciais e de } \\
\text { outros depósitos } \\
\text { quaternários }\end{array}$ & $\begin{array}{l}\text { Acesso restrito para } \\
\text { estudos científicos; } \\
\text { armazenamento } \\
\text { de escombreiras; } \\
\text { soterramento de } \\
\text { afloramentos; extração } \\
\text { extensiva não deixando } \\
\text { reservas para pesquisas } \\
\text { futuras; restauro e/ } \\
\text { ou intervenção pós- } \\
\text { exploração. }\end{array}$ & $\begin{array}{l}\text { Consultar o proprietário da exploração } \\
\text { para assegurar o acesso para pesquisa } \\
\text { científica; consultar as autoridades de } \\
\text { gestão do território e o operador da } \\
\text { exploração para incorporar requisitos } \\
\text { de geoconservação durante e após } \\
\text { a exploração (incluindo esquemas de } \\
\text { monitoramento e registro geológico, } \\
\text { recolha e conservação de seções e } \\
\text { manutenção dos acessos como parte do } \\
\text { plano de restauro) }\end{array}$ \\
\hline & $\begin{array}{l}\text { Pedreiras e } \\
\text { escavações } \\
\text { inativas }\end{array}$ & $\begin{array}{l}\text { Afloramentos } \\
\text { de depósitos } \\
\text { glaciais, } \\
\text { periglaciais e de } \\
\text { outros depósitos } \\
\text { quaternários }\end{array}$ & $\begin{array}{l}\text { Aterro sanitário; restauro } \\
\text { inadequado; construções } \\
\text { inadequadas; degradação } \\
\text { dos afloramentos; } \\
\text { crescimento de vegetação }\end{array}$ & $\begin{array}{l}\text { Negociar colheita e conservação de } \\
\text { seções e a permissão de acesso a } \\
\text { longo prazo; restringir construções a } \\
\text { áreas vizinhas; gerir o crescimento da } \\
\text { vegetação; recolher seções para pesquisa } \\
\text { onde seja impraticável ou desnecessário } \\
\text { manter afloramentos contínuos. }\end{array}$ \\
\hline & $\begin{array}{l}\text { Arribas e } \\
\text { afloramentos } \\
\text { costeiros }\end{array}$ & $\begin{array}{l}\text { Afloramentos } \\
\text { de depósitos } \\
\text { glaciais, } \\
\text { periglaciais e de } \\
\text { outros depósitos } \\
\text { quaternários }\end{array}$ & $\begin{array}{l}\text { Obras de proteção } \\
\text { costeira; dragagens; } \\
\text { degradação de } \\
\text { afloramentos pela erosão } \\
\text { marinha; crescimento da } \\
\text { vegetação; implantação de } \\
\text { portos, cais e marinas }\end{array}$ & $\begin{array}{l}\text { Manter processos naturais (erosão); } \\
\text { garantir a acessibilidade; evitar a } \\
\text { instalação de proteção costeira de } \\
\text { engenharia "dura"; evitar construções } \\
\text { nas falésias e planícies costeiras que } \\
\text { possam exigir proteção futura; em } \\
\text { costas em acumulação sedimentar, } \\
\text { gerir o crescimento da vegetação e } \\
\text { recolher seções para pesquisa, conforme } \\
\text { necessário }\end{array}$ \\
\hline & $\begin{array}{l}\text { Afloramentos } \\
\text { em rios e } \\
\text { riachos }\end{array}$ & $\begin{array}{l}\text { Afloramentos } \\
\text { de depósitos } \\
\text { glaciais, } \\
\text { periglaciais e de } \\
\text { outros depósitos } \\
\text { quaternários }\end{array}$ & $\begin{array}{l}\text { Engenharia fluvial } \\
\text { e estabilização de } \\
\text { margens; degradação de } \\
\text { afloramentos pela erosão } \\
\text { fluvial; crescimento da } \\
\text { vegetação }\end{array}$ & $\begin{array}{l}\text { Manter processos naturais (erosão); } \\
\text { garantir a acessibilidade; evitar a } \\
\text { instalação de proteção de margens de } \\
\text { engenharia "dura"; evitar construções } \\
\text { nas planícies aluviais que possam } \\
\text { exigir proteção futura; em afloramentos } \\
\text { sem erosão ativa, gerir o crescimento } \\
\text { da vegetação e colher seções para } \\
\text { pesquisa, conforme necessário }\end{array}$ \\
\hline & $\begin{array}{l}\text { Elementos } \\
\text { com } \\
\text { interesse } \\
\text { enterrados }\end{array}$ & $\begin{array}{l}\text { Depósitos } \\
\text { glaciais, } \\
\text { periglaciais e } \\
\text { outros depósitos } \\
\text { quaternários }\end{array}$ & $\begin{array}{l}\text { Práticas agrícolas e de } \\
\text { uso do solo inapropriadas } \\
\text { (por exemplo, drenagem } \\
\text { de turfeiras); reflorestação; } \\
\text { construções sobre } \\
\text { elementos enterrados; } \\
\text { pedreiras }\end{array}$ & $\begin{array}{l}\text { Evitar atividades inadequadas em áreas } \\
\text { essenciais para que permaneçam } \\
\text { intactas e acessíveis para a pesquisa } \\
\text { científica }\end{array}$ \\
\hline & $\begin{array}{l}\text { Taludes de } \\
\text { estradas, } \\
\text { ferrovias e } \\
\text { canais }\end{array}$ & $\begin{array}{l}\text { Afloramentos } \\
\text { de depósitos } \\
\text { glaciais, } \\
\text { periglaciais e de } \\
\text { outros depósitos } \\
\text { quaternários }\end{array}$ & $\begin{array}{l}\text { Obras de estabilização } \\
\text { e terraços nos } \\
\text { afloramentos; } \\
\text { crescimento da } \\
\text { vegetação; plantação de } \\
\text { árvores; alargamento de } \\
\text { estradas; construção em } \\
\text { vias abandonadas. }\end{array}$ & $\begin{array}{l}\text { Evitar soluções de engenharia } \\
\text { "dura", tais como a cobertura de } \\
\text { afloramentos com concreto; gerir o } \\
\text { crescimento da vegetação e colher } \\
\text { seções para pesquisa; incluir a recolha } \\
\text { e a conservação de seções e a } \\
\text { manutenção dos acessos como parte do } \\
\text { planejamento de novos taludes }\end{array}$ \\
\hline
\end{tabular}




\begin{tabular}{|c|c|c|c|c|}
\hline $\begin{array}{l}\text { Código de } \\
\text { Geoconservação }\end{array}$ & $\begin{array}{l}\text { Tipo de } \\
\text { geossítio }\end{array}$ & $\begin{array}{l}\text { Elementos } \\
\text { típicos de } \\
\text { interesse }\end{array}$ & Principais ameaças & $\begin{array}{l}\text { Orientações de gestão da } \\
\text { conservação }\end{array}$ \\
\hline \multirow[t]{3}{*}{$\begin{array}{l}\text { Geossítios } \\
\text { vulneráveis }\end{array}$} & $\begin{array}{l}\text { Elementos } \\
\text { geomor- } \\
\text { fológicos } \\
\text { estáticos } \\
\text { (inativos) }\end{array}$ & $\begin{array}{l}\text { Geoformas e } \\
\text { conjuntos de } \\
\text { geoformas } \\
\text { glaciais e } \\
\text { periglaciais }\end{array}$ & $\begin{array}{l}\text { Exploração mineral; } \\
\text { urbanização, } \\
\text { empreendimentos } \\
\text { comerciais e industriais; } \\
\text { barragens; florestação; } \\
\text { crescimento vegetal; } \\
\text { atividades recreativas } \\
\text { desadequadas (por } \\
\text { exemplo, reconfiguração } \\
\text { do relevo para campos } \\
\text { de golfe); práticas } \\
\text { agrícolas e de uso do } \\
\text { solo desadequadas (por } \\
\text { exemplo, preenchimento } \\
\text { de kettles, construção de } \\
\text { caminhos) } \\
\text { Para elementos offshore: } \\
\text { parques eólicos e } \\
\text { empreendimentos para } \\
\text { produção de energia e } \\
\text { infraestruturas associadas; } \\
\text { dragagens; pesca de } \\
\text { arrasto }\end{array}$ & $\begin{array}{l}\text { Manter a integridade das geoformas } \\
\text { e conjuntos de geoformas; evitar a } \\
\text { instalação de pedreiras e de construções; } \\
\text { evitar a exploração florestal, o despejo } \\
\text { de resíduos e o preenchimento de } \\
\text { depressões; gerir o crescimento da } \\
\text { vegetação; evitar atividades recreativas } \\
\text { inadequadas } \\
\text { Para elementos offshore: evitar atividades } \\
\text { que perturbem o fundo do mar }\end{array}$ \\
\hline & $\begin{array}{l}\text { Sistemas } \\
\text { geomor- } \\
\text { fológicos } \\
\text { com proces- } \\
\text { sos ativos }\end{array}$ & $\begin{array}{l}\text { Processos e } \\
\text { geoformas glaci- } \\
\text { ais e periglaciais } \\
\text { ativas }\end{array}$ & $\begin{array}{l}\text { Construções (por } \\
\text { exemplo, infraestruturas } \\
\text { e edifícios para o esqui); } \\
\text { respostas de engenharia } \\
\text { "dura" para mitigação de } \\
\text { riscos em áreas turísticas } \\
\text { e em povoações e } \\
\text { infraestruturas a jusante; } \\
\text { engenharia fluvial e } \\
\text { barragens }\end{array}$ & $\begin{array}{l}\text { Manter processos naturais; implementar } \\
\text { construções afastadas dos processos } \\
\text { ativos e em áreas de baixo risco; } \\
\text { relocalizar caminhos e trilhas de } \\
\text { interpretação conforme necessário. }\end{array}$ \\
\hline & Carste & Glacio-carste & $\begin{array}{l}\text { Exploração mineral; } \\
\text { construções (por exemplo, } \\
\text { infraestruturas e edifícios } \\
\text { para o esqui); crescimento } \\
\text { da vegetação }\end{array}$ & $\begin{array}{l}\text { Manter os processos naturais e a } \\
\text { integridade das geoformas; evitar a } \\
\text { instalação de pedreiras e de construções; } \\
\text { gerir o crescimento da vegetação }\end{array}$ \\
\hline $\begin{array}{l}\text { Geossítios } \\
\text { limitados }\end{array}$ & $\begin{array}{l}\text { Elementos } \\
\text { de dimensão } \\
\text { reduzida em } \\
\text { várias situ- } \\
\text { ações (por } \\
\text { exemplo, } \\
\text { pedreiras } \\
\text { ativas e inati- } \\
\text { vas, falésias } \\
\text { costeiras, } \\
\text { margens } \\
\text { costeiras e } \\
\text { fluviais, e } \\
\text { cavernas) }\end{array}$ & $\begin{array}{l}\text { Depósitos } \\
\text { glaciais e } \\
\text { interglaciais } \\
\text { quaternários }\end{array}$ & $\begin{array}{l}\text { Exploração mineral; } \\
\text { construções; práticas } \\
\text { agrícolas e de uso } \\
\text { do solo e atividades } \\
\text { recreativas desadequadas; } \\
\text { florestação; crescimento } \\
\text { da vegetação }\end{array}$ & $\begin{array}{l}\text { Evitar a instalação de pedreiras e de } \\
\text { construções, a exploração florestal, o } \\
\text { despejo de resíduos e o preenchimento } \\
\text { de depressões, soluções de engenharia } \\
\text { 'dura' para proteção costeira e fluvial, } \\
\text { atividades recreativas inadequadas, e a } \\
\text { escavação irresponsável de depósitos } \\
\text { em cavernas; assegurar o acesso; gerir o } \\
\text { crescimento da vegetação }\end{array}$ \\
\hline
\end{tabular}




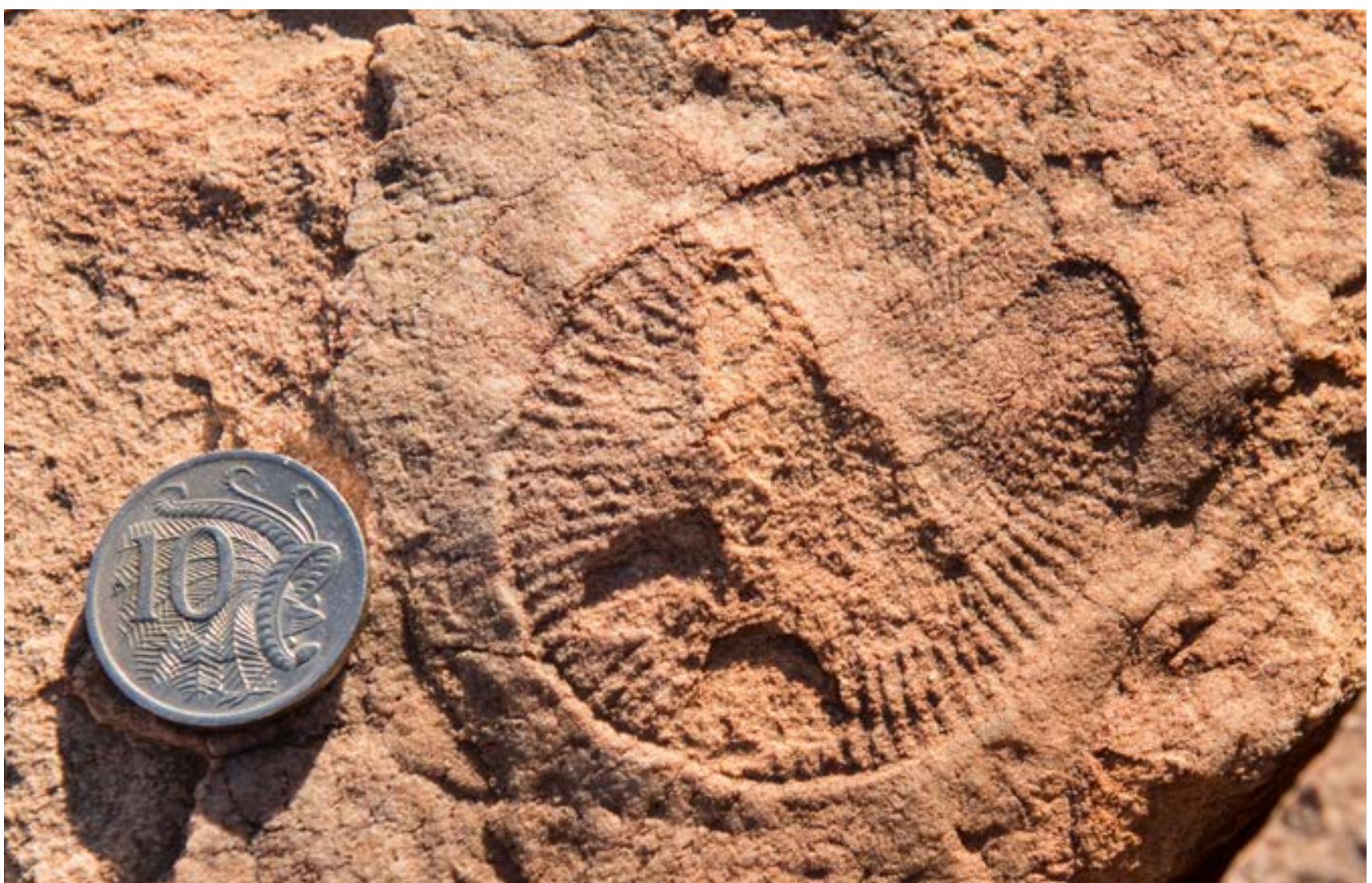

Foto 7.11 Fóssil do animal Dickinsonia, com $560 \mathrm{Ma}$, localizado em Nilpena, no Ediacara Conservation Park, Austrália. Um dos primeiros animais, movia-se e alimentava-se de esteiras bacterianas. ( $)$ Graeme L. Worboys

de margens de rios). Tanto os impactos diretos como os indiretos no geopatrimônio, derivados da implantação de novas construções, devem ser avaliados, assim como os riscos para a população, particularmente à medida que as rápidas mudanças ambientais aumentam os riscos associados a glaciares e ao permafrost (Kääb et al., 2005). Em algumas regiões, como os Himalaias, o aumento do risco de cheias em lagos glaciais representa uma elevada preocupação para as comunidades e visitantes a jusante, sendo necessária a implementação de medidas de alerta e operações de engenharia para a redução dos níveis dos lagos.

Geoformas inativas e depósitos finitos são particularmente suscetíveis a danos por uma variedade de ameaças (Tabela 7.2) (ver foto 3.5). Os principais objetivos de gestão destes elementos são a manutenção da integridade das geoformas e o acesso a afloramentos ou sítios onde os sedimentos possam ser facilmente reexpostos para pesquisa científica e, quando apropriado, para interpretação. No caso das geoformas, o principal requisito de gestão é evitar danos causados por atividades como as de mineração, de construção e de exploração florestal (Tabela 7.3). No caso de pedreiras em atividade, há dois requisitos principais: primeiro, assegurar que o acesso seja permitido para a pesquisa científica (sujeito a condições de saúde e segurança, definidas com razoabilidade), particularmente onde elementos cientificamente importantes (por exemplo, depósitos interglaciais) possam ser perdidos definitivamente; e segundo, coletar porções representativas e materiais não explorados após o término dos trabalhos, sempre que possível. Este último requisito exige uma negociação prévia com os proprietários da exploração e com autoridades de ordenamento do território (Prosser, 2016).

No caso de pedreiras inativas, há dois requisitos de gestão e para a recuperação das áreas quando os trabalhos terminam. Primeiro, o acesso às frentes de exploração deve ser mantido para fins de estudo e de limpeza das mesmas (por exemplo, manualmente ou através de meios mecânicos). Desde que o acesso seja mantido, a implantação de aterros sanitários, a construção de edifícios ou a exploração florestal podem ocorrer nas imediações dessas áreas de conservação através de projeto técnico e planejamento apropriados; pode também ser possível associar objetivos de geoconservação e biodiversidade. Em segundo lugar, se as frentes de exploração não forem mantidas expostas, deve considerar-se a opção de futuramente se aceder a elas, de modo a suportar encontros científicos ou projetos de pesquisa. Após esses eventos, as frentes poderão ser tapadas novamente. Na Tabela 7.2 resumem-se as orientações sobre abordagens e soluções de conservação para várias situações inativas, com mais detalhes fornecidos por Kiernan (1996), Prosser et al. (2006) e Kirkbride \& Gordon (2010).

Em casos excepcionais (por exemplo, quando os elementos com interesse são extremamente vulneráveis e/ou espacialmente muito restritos), o método de conservação mais apropriado pode ser tapar os elementos essenciais e 


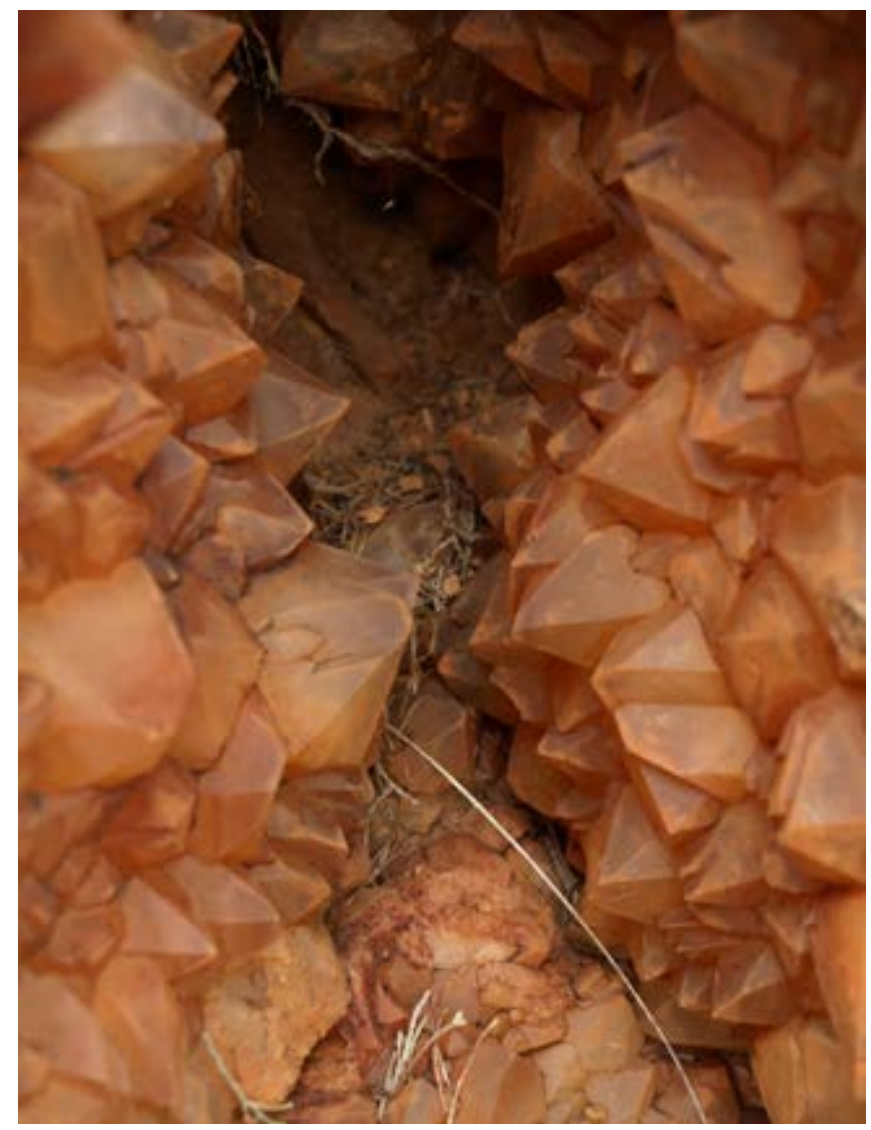

Foto 7.12 Cavidade com revestimento de cristais de quartzo, Monte Gee, Área de Proteção Arkaroola, Austrália. Quando se formou, a atividade epitermal seria semelhante à de Yellowstone, com gêiseres e piscinas quentes. (๑) Graeme L. Worboys

exumá-los apenas aquando for necessário (por exemplo, pesquisa científica ou visita organizada por um órgão profissional) (Bridgland, 2013). Isto pode ser feito colocando um geotêxtil sobre esses elementos e cobrindo-o com escombreira. Esta pode vir a vegetar, mas as espécies com raízes mais profundas não conseguem penetrar no geotêxtil. Este procedimento facilita a reexposição ao mesmo tempo que protege os sedimentos.

Onde as geoformas inativas foram danificadas, deve ser considerado um restauro adequado (ver Caixa 7.1).

Em alguns casos, pode ser possível imitar as condições originais (por exemplo, Gray, 2013). No entanto, o preferível é evitar os danos, em primeiro lugar.

A interpretação deve ser uma parte fundamental dos objetivos de gestão em determinados locais, seguindo as diretrizes de melhores práticas descritas mais adiante nesta seção. Exemplos incluem o Parque Nacional Glacier (EUA) (https://www.nps.gov/ glac/index.htm) e o Museu Glacier da Noruega ( http://www.bre. museum.no/).

\subsection{Gestão de geossítios paleontológicos e mineralógicos}

\section{Elementos com valor}

Geossítios com fósseis e minerais são uma parte muito importante do geopatrimônio. A sua conservação - na verdade, em alguns casos, a sua rigorosa preservação - é necessária para que tanto os geossítios como os espécimes cientificamente importantes a eles associados não sejam perdidos e não possam ser estudados e desfrutados pelas gerações do presente e do futuro.

Os elementos paleontológicos (fósseis) são os vestígios de vida do passado, preservados num determinado contexto geológico; como tal, eles são um recurso não renovável. Os fósseis possuem valor científico e educacional ao fornecer dados importantes relacionados à história da vida, à evolução dos paleo-ecossistemas e a eventos geológicos passados. A ciência da paleontologia continua a se expandir à medida que novas descobertas de fósseis são feitas.

Minerais e geossítios mineralógicos fornecem provas valiosas da evolução física da Terra. Eles nos ajudam a compreender o processo da tectônica de placas e a complexidade das intrusões ígneas (magmas solidificados abaixo da superfície), das erupções vulcânicas e do metamorfismo (mudanças na temperatura, na pressão e na composição química das rochas originais). Os minerais também constituem uma fonte de matéria-prima industrial e estão entre nossas mercadorias mais valiosas. Como os fósseis, os minerais são amplamente colecionados, e a pesquisa, particularmente apoiada por modernas técnicas analíticas, continua a aprofundar o nosso conhecimento da mineralogia.

A gestão de geossítios paleontológicos e mineralógicos deve ser suportada por princípios científicos, por práticas de gestão localizadas e rigorosas e por autoridade legal, quando necessário.

\section{Ameaças}

Processos naturais e atividades humanas podem influenciar o estado dos fósseis que afloram à superfície da Terra. A meteorização natural e a erosão física, juntamente com as atividades humanas, como a exploração de pedreiras, estão entre os agentes mais importantes na revelação tanto de fósseis quanto de minerais; por exemplo, alguns dos sítios fósseis mais produtivos se encontram ao longo da costa em erosão e em pedreiras ativas. No entanto, quando estes elementos são raros, os mesmos processos naturais podem representar uma ameaça, acabando por remover o recurso fóssil ou mineral. Tanto atividades humanas inadvertidas como intencionais, tais como atividades de construção ou coleta intensiva, podem ameaçar geossítios e elementos paleontológicos e mineralógicos (Tabela 7.3) (Santucci \& Koch, 2003; Santucci et al., 2009). Um caso notável é a desclassificação, promovida pelo Congresso dos EUA, do Monumento Nacional Fossil Cycad, no estado do Dakota do Sul, porque todos os espécimes foram coletados, tendo-se perdido os principais elementos de interesse na área (Santucci e Hughes, 1998).

\section{Princípios e diretrizes de gestão}

Diretrizes e códigos de conduta úteis à conservação de geossítios paleontológicos e mineralógicos e à coleta 
Tabela 7.3. Proteção contra ameaças em geossítios paleontológicos.

\begin{tabular}{|c|c|}
\hline $\begin{array}{l}\text { Potenciais } \\
\text { Fontes de ameaça }\end{array}$ & Ação preferencial de gestão \\
\hline $\begin{array}{l}\text { Coletores } \\
\text { amadores }\end{array}$ & $\begin{array}{l}\text { A coleta de fósseis é normalmente proibida dentro das áreas protegidas, onde todos os fenômenos } \\
\text { naturais são protegidos. } \\
\text { Pode haver algumas exceções a essa norma, mas somente sob controle rigoroso e após a autoridade } \\
\text { de gestão determinar que os benefícios de permitir a coleta (como forma de promover o interesse na } \\
\text { paleontologia entre o público) superam os prejuízos com a remoção de fósseis. A área de Patrimônio } \\
\text { Mundial de Jurassic Coast, perto de Lyme Regis, na Inglaterra, por exemplo, permite a coleta de fósseis } \\
\text { nas falésias, expostos pela erosão marinha, até ao limite da maré alta (ver foto 6.15). }\end{array}$ \\
\hline $\begin{array}{l}\text { Ladrões } \\
\text { profissionais }\end{array}$ & $\begin{array}{l}\text { Os métodos usados para impedir o roubo de fósseis raros por ladrões profissionais incluem: a presença } \\
\text { de guardas no local, uso de vigilância eletrônica, construção de estruturas de proteção que envolvam o } \\
\text { local e, como último recurso, a trasladação de fósseis preciosos para museus. }\end{array}$ \\
\hline Pesquisadores & $\begin{array}{l}\text { A pesquisa científica em áreas protegidas é geralmente gerida através de um sistema de permissão, com } \\
\text { permissões concedidas a pesquisadores para escavar e estudar fósseis com o mínimo de impactos, como } \\
\text { parte de suas investigações. Pode haver muitos casos em que os pesquisadores não têm permissão } \\
\text { como, por exemplo, onde ocorra um conjunto inestimável de conchas fósseis. Pode haver também muitos } \\
\text { casos em que os cientistas são ativamente encorajados à coleta, como por exemplo, quando haja fósseis } \\
\text { encontrados em uma plataforma de erosão costeira. Na prática, os gestores de áreas protegidas devem } \\
\text { desenvolver uma boa relação de trabalho com os pesquisadores; o envolvimento de pessoal técnico da } \\
\text { área protegida para ligação com os pesquisadores e de guardas/vigilantes deve assegurar que as regras } \\
\text { sejam aplicadas e informações partilhadas, e também que os novos conhecimentos adquiridos sejam } \\
\text { incluídos nos instrumentos de divulgação da área protegida e nos programas interpretativos. }\end{array}$ \\
\hline $\begin{array}{l}\text { Gestão de } \\
\text { visitantes }\end{array}$ & $\begin{array}{l}\text { Os visitantes são frequentemente encorajados a visitar geossítios com fósseis e a apreciar um "extrato } \\
\text { da história da Terra". Dependendo da natureza dos fósseis, o acesso dos visitantes a afloramentos } \\
\text { a céu aberto é normalmente organizado com rotas fixas. Para geossítios especialmente vulneráveis, } \\
\text { são normalmente disponibilizadas visitas guiadas; em muitos afloramentos/espécimes, podem ser } \\
\text { colocadas estruturas de proteção. Alguns espécimes são tão vulneráveis que podem ser trasladados do } \\
\text { afloramento original para um centro de acolhimento a visitantes no local. }\end{array}$ \\
\hline $\begin{array}{l}\text { Centros de } \\
\text { acolhimento a } \\
\text { visitantes }\end{array}$ & $\begin{array}{l}\text { Alguns geossítios fósseis são tão importantes que foram protegidos com grandes estruturas construídas } \\
\text { propositadamente, as quais podem combinar um centro de visitantes e um museu. O edifício da pedreira } \\
\text { do Monumento Nacional dos Dinossauros (Utah, EUA), por exemplo, abriga uma escavação de um } \\
\text { emaranhado de ossos de dinossauros. A estrutura serve como local de escavação e de trabalho para } \\
\text { paleontólogos e como local de exposição para o público. }\end{array}$ \\
\hline
\end{tabular}

Tabela 7.4. Princípios práticos de conservação de geossítios paleontológicos e mineralógicos.

Incentivar sempre a prática responsável da coleta em áreas protegidas.

- Tornar as medidas de gestão de conservação proporcionais à importância científica da área protegida e dos fósseis/minerais que aí ocorrem.

- Adaptar a gestão da conservação às condições locais, considerando questões como a quantidade de elementos de interesse procurados para coleta, sua taxa de renovação e a provável pressão derivada da coleta, e assim por diante.

- Permitir pesquisas e estudos confiáveis nos geossítios, a fim de auxiliar o desenvolvimento das geociências.

- Conservar o geopatrimônio paleontológico e mineralógico in situ sempre que possível. Em circunstâncias extremas, considere a remoção e conservação em um museu, mas tendo o cuidado de registrar todas as informações contextuais antes da remoção.

- Limitar qualquer coleta às partes do geossítio que são menos vulneráveis, ou aos geossítios de menor importância e incentivar apenas a coleta de elementos soltos.

- Considerar o soterramento (onde as ameaças de meteorização, de erosão ou de coleta não possam ser controladas) de geossítios essenciais para conservar os fósseis e minerais no seu contexto original e para que estejam disponíveis para estudo no futuro.

Desenvolver protocolos para conservar geossítios paleontológicos e mineralógicos e acordar um código de conduta para coleta responsável que inclua coletores amadores, acadêmicos, institucionais e comerciais.

Desenvolver esquemas de registro de espécimes de geossítios essenciais, incentivando os coletores a compartilhar informações. Incentivar a comunicação regular entre proprietários das terras, gestores, coletores, museus e pesquisadores.

Assegurar que visitas regulares e monitoramento dos geossítios ocorram para avaliar o seu estado e se estão ocorrendo danos, estimulando um regime de gestão adequado. 
7. Gestão da geoconservação em casos selecionados

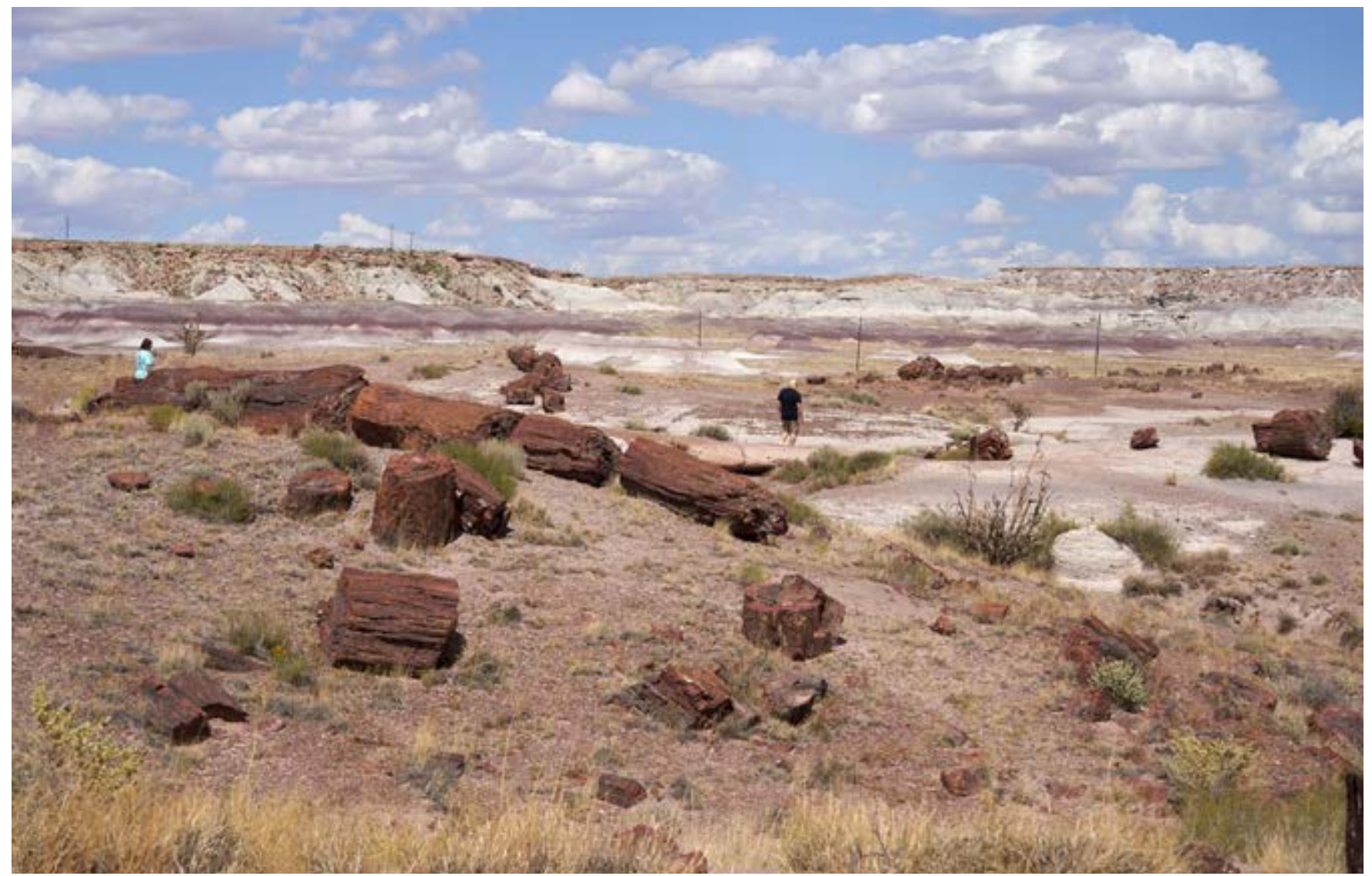

Foto 7.13 Parque Nacional Petrified Forest, Arizona, EUA. Fósseis da floresta tropical do período Triássico (cerca de 225 Ma) $\odot$ José Brilha

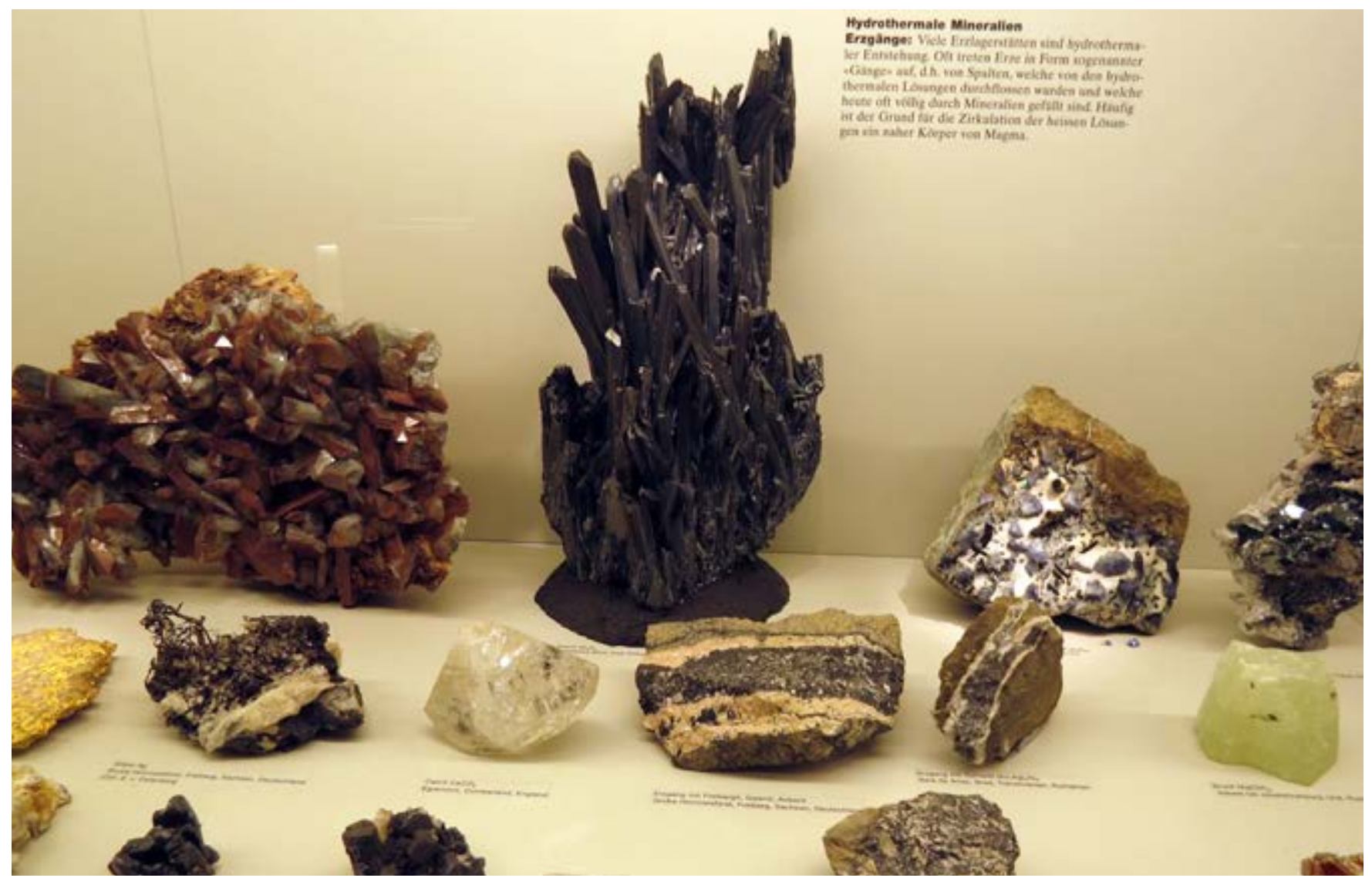

Foto 7.14 A proteção de espécimes raros em um ambiente cuidadosamente controlado é uma abordagem experimentada e testada. Museu de História Natural de Berna, Suiça. @ Roger Crofts 


\section{Caixa 7.2}

\section{Estudo de caso de geossítios paleontológicos nos Parques Nacionais dos EUA}

O Serviço de Parques Nacionais dos EUA (USNPS) gere pelo menos 242 parques onde recursos paleontológicos foram documentados em inventários de base.

O princípio primordial para os recursos paleontológicos não renováveis nos Parques Nacionais dos EUA, conforme estabelecido na lei que criou o USNPS, é preservá-los e protegê-los "de tal forma e por meios que permaneçam resguardados para usufruto pelas gerações futuras". A Lei para a Preservação de Recursos Paleontológicos de 2009 é a principal norma legal nos Estados Unidos usada para a gestão e a proteção de fósseis. A USNPS e outras agências federais de gestão do território desenvolveram regulamentos, políticas e diretrizes para apoiar uma gestão de recursos paleontológicos não renováveis baseada na ciência. As atividades específicas de gestão associadas a geossítios paleontológicos incluem: inventário, monitoramento, pesquisa, coleta de fósseis, curadoria de museus, gestão de dados, conservação, proteção, interpretação e educação. Alguns fósseis justificam a implementação de um plano de gestão de recursos paleontológicos no sentido de uma abordagem estratégica na gestão de geossítios paleontológicos.

Os inventários de recursos paleontológicos (também chamados de "levantamentos paleontológicos") são importantes ferramentas de gestão para se estabelecer o contexto, a relevância e a distribuição dos recursos paleontológicos. A partir de trabalhos publicados e inéditos analisados ao longo de 10 anos, a compilação de inventários de base dos recursos paleontológicos de toda a USNPS foi concluída em 2011 (Santucci et al., 2012). Estes inventários sistemáticos mais que duplicaram o número de parques identificados como tendo fósseis. Os inventários também revelaram novas informações científicas anteriormente não conhecidas pelo pessoal técnico dos parques, resultando em uma melhor gestão dos fósseis dessas áreas protegidas e em novas oportunidades para educação e pesquisa.

Catorze áreas protegidas da USNSP foram estabelecidas total ou parcialmente devido aos seus recursos fósseis. Uma das mais conhecidas é o Monumento Nacional Dinosaur (Colorado e Utah), que preserva a mundialmente famosa pedreira Douglass e é considerado como um "Jurassic Park" da vida real. Esqueletos fossilizados de dinossauros do parque podem ser vistos em museus por todo o mundo. O Parque Nacional Petrified Forest, no Arizona, é outro parque popular que oferece aos visitantes a oportunidade de recuar no tempo 200 milhões de anos para observar vestígios de um ecossistema terrestre do período Triásico. Além dos troncos petrificados excelentemente preservados, no parque ocorrem fósseis dos primeiros dinossauros, juntamente com um conjunto diversificado de outros vertebrados pré-históricos, invertebrados, plantas e icnofósseis. O parque sustenta um programa ativo de pesquisa geológica e paleontológica, mantém coleções fósseis de elevado valor e proporciona uma experiência educacional aos visitantes do parque, provenientes de todo o mundo.

Dada a natureza não renovável dos fósseis, os impactos a longo prazo da coleta não autorizada representam um problema significativo na gestão e na proteção destes recursos. Esta questão está claramente exemplificada pela história infeliz do Monumento Nacional Fossil Cycad, no Dakota do Sul, que existiu enquanto tal entre 1952 e 1957. A coleta não autorizada das cicadáceas fósseis no parque resultou na perda completa de todos os exemplares expostos à superfície. A perda dos fósseis neste local levou à desclassificação do Monumento Nacional, que foi abolido enquanto área protegida do USNPS em 1957. As lições aprendidas com o caso de Fossil Cycad servem para a implementação de práticas atuais de gestão em geossítios paleontológicos localizados em terras públicas (Santucci e Hughes, 1998).

responsável foram desenvolvidos (ProGEO, 2011) e aplicados em alguns países, como por exemplo, pelo Serviço de Parques Nacionais dos EUA (Caixa 8.5). Outros exemplos incluem diretrizes para coleta de espécimes geológicos (incluindo fósseis e minerais) na Inglaterra, juntamente com orientações sobre a gestão de diferentes tipos de geossítios paleontológicos e mineralógicos (Natural England, 2012); o Código de Conduta para a Coleta de Fósseis de West Dorset (Dorset e East Devon Coast World Heritage site, 2011); e o Código Fóssil da Escócia, para a coleta, a conservação e o armazenamento de fósseis (Scottish Natural Heritage, 2008).

O Serviço de Parques Nacionais dos EUA definiu um conjunto de indicadores do estado dos recursos paleontológicos, incluindo informações sobre o clima, taxas de erosão, atitudes e comportamentos humanos e perda ou ganho de espécimes à superfície (Santucci e Koch, 2003). Estes indicadores evoluíram posteriormente para o sistema de monitoramento Vital Signs, de cinco etapas, incluindo taxas de mudanças naturais em variáveis geológicas e climáticas, processos geológicos catastróficos, hidrologia e batimetria, e impactos humanos (Santucci et al., 2009). Na Tabela 7.4 apresentam-se princípios de conservação e na Caixa 7.2 um estudo de caso.

Existe um consenso de que a coleta responsável de fósseis pode promover a ciência e contribuir para a pesquisa, além de contribuir positivamente para a compreensão e a conservação da geodiversidade, desde que um código de boas práticas seja seguido (como está referido nos princípios apresentados na Tabela 7.4). No entanto, a coleta irresponsável de espécimes fósseis e minerais raros representa uma perda significativa para a ciência e também pode causar danos nos afloramentos e perdas de outros tipos de elementos. Escavadeiras mecânicas, explosivos, pés-de-cabra e serras de rocha já foram utilizados para remover material fóssil e minerais, em busca de espécimes raros, valiosos ou de alta qualidade. É importante lidar de forma construtiva com diferentes grupos de coleta. Por exemplo, no sítio do Patrimônio Mundial Jurassic Coast (Reino Unido), os coletores locais (incluindo coletores comerciais) são incentivados através do Código de Conduta para a Coleta 


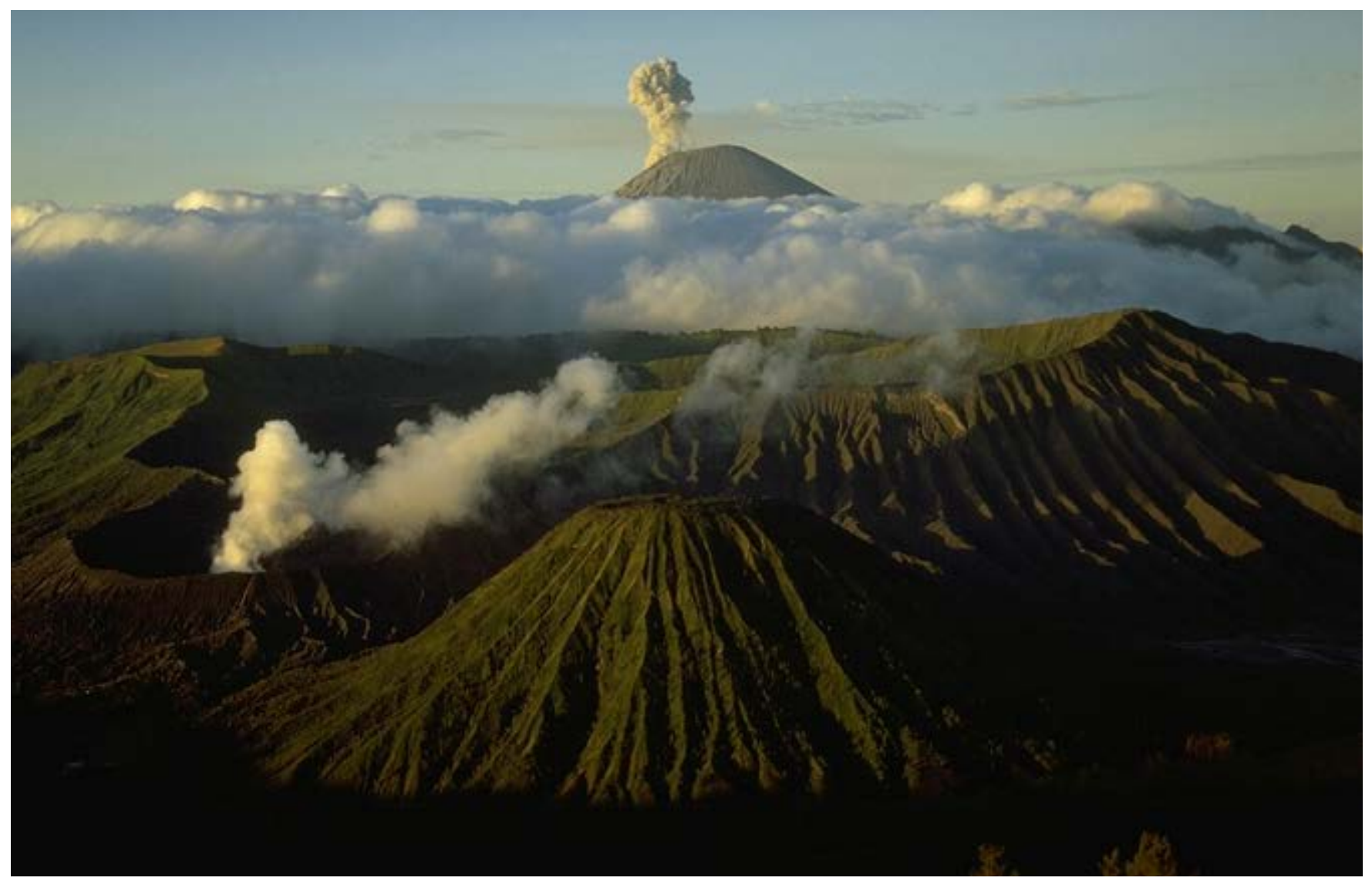

Foto 7.15 Vulcão Semeru, o mais alto da ilha de Java, em erupção na linha do horizonte. Em primeiro plano observa-se a caldeira Tengger, com o cone de Batok ao centro e o cone fumegante de Bromo à esquerda. ( ) Lee Siebert, Parque Nacional Indonesian

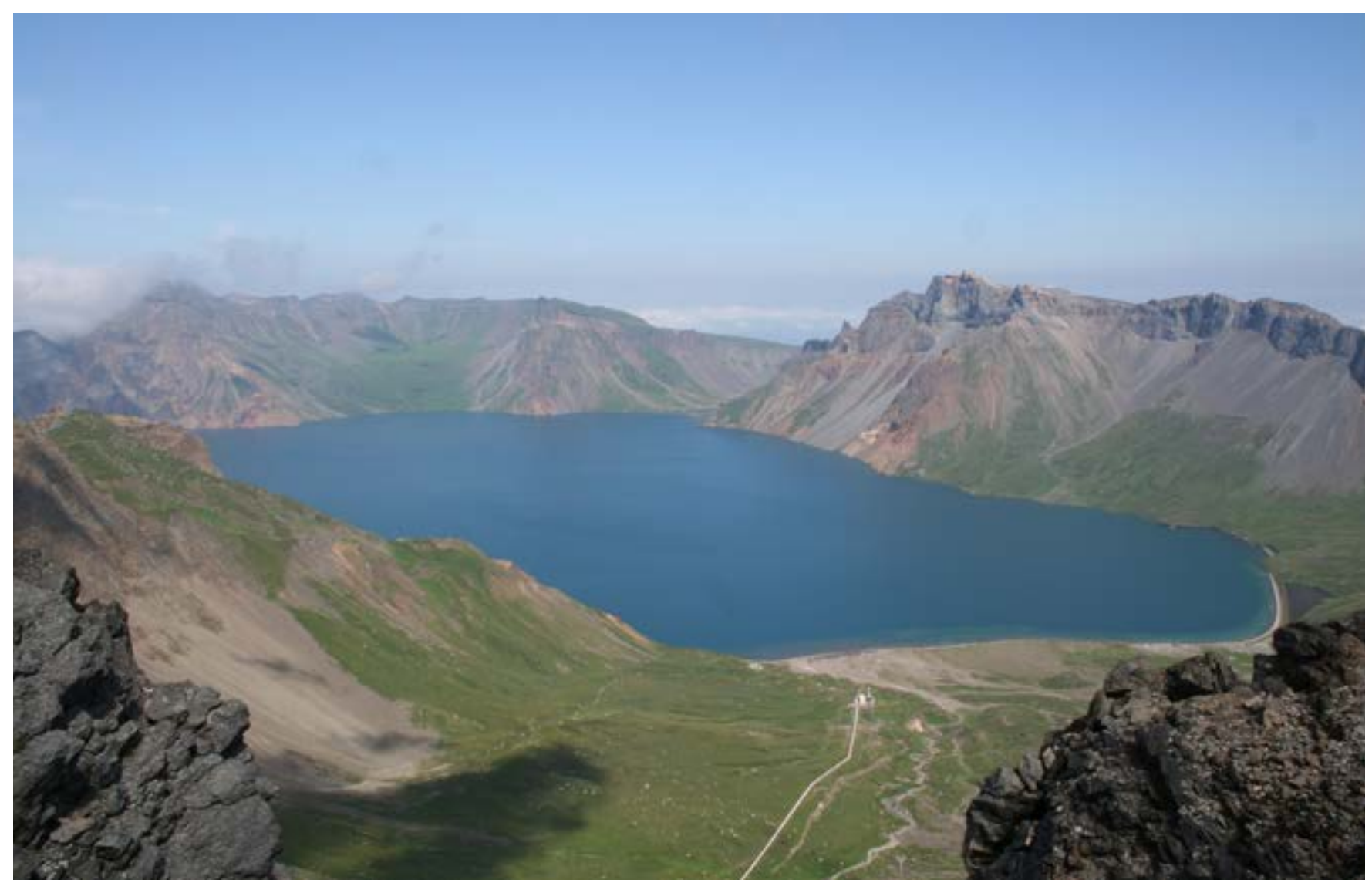

Foto 7.16 Um lago na mega caldeira formada após erupção, na área protegida transfronteiriça do Monte Changbaishan/Vulcão do Monte Paekdu, China/ República Popular Democrática da Coreia. @ Kayla lacavino 
de Fósseis de West Dorset a trabalhar com especialistas e curadores de museus para garantir que o material seja registrado e estudado e que os espécimes de maior valor científico sejam conservados em instituições públicas para usufruto de todos.

Nos locais onde fósseis e minerais muito raros estão ameaçados, uma solução possível é retirá-los para um museu onde eles estejam disponíveis para ser apreciados pelo público e estudados pelos cientistas. Em geossítios onde a remoção desses elementos seja difícil, uma abordagem alternativa é fazer moldes e contramoldes de elevada qualidade (Williams e Edwards, 2013). Este procedimento fornece réplicas detalhadas e um recurso que pode ser usado para pesquisa e educação exteriormente ao geossítio, reduzindo as pressões no local. É particularmente proveitoso para o registro de icnofósseis.

\subsection{Gestão de áreas protegidas vulcânicas}

\section{Geoformas, processos e elementos com valor}

As paisagens vulcânicas contêm processos geológicos e geomorfológicos fundamentais para entender como funciona a dinâmica da Terra, desde a escala global até a escala local e ligando os processos do interior da Terra com os da sua superfície. Além de seu valor científico fundamental, os vulcões constituem um dos estágios mais dinâmicos da natureza, que tem expressões na grande biodiversidade encontrada em muitas paisagens vulcânicas, nas conexões culturais entre as pessoas e seu ambiente, e como um registro do desenvolvimento humano em todos os continentes. Esta orientação para a gestão é extraída principalmente de Wood (2009), complementada por Casadevall et al. (2019).

As geoformas vulcânicas variam muito em forma e tamanho, variando de pequenos cones de cinza a enormes vulcões. Os vulcões podem ser fenômenos de extrema longevidade, formados a partir de repetidos episódios de atividade vulcânica que podem ter ocorrido durante centenas de milhares a milhões de anos (por exemplo, a ilha da Islândia pode ter sido formada durante um período de cerca de 20 milhões de anos; a caldeira Las Cañadas, em Tenerife, Espanha, pode ter uma idade superior a 3,5 milhões de anos; a atividade que construiu a ilha de Jeju (Monte Halla), na República da Coreia, começou há cerca de 0,8 milhões de anos; enquanto a ilha de Santa Lúcia, no Caribe, é um exemplo de uma sequência de colapsos complexos e explosivos). Isto significa que os aparelhos vulcânicos mais antigos podem ser sobreposições complexas de diferentes geoformas e composições de lava ao longo do tempo, incluindo colapsos. Além dos processos vulcânicos atuais, os cientistas se interessam em restos de vulcões antigos que são preservados na superfície. Evidências de atividade vulcânica antiga podem ser encontradas em seções geológicas verticais expostas em falésias e vales, ou em padrões de estruturas rochosas na superfície do solo.

As paisagens vulcânicas podem também conter fenômenos hidrotermais, tais como nascentes termais, gêiseres, piscinas de lama e fumarolas. Nascentes termais ocorrem onde águas subterrâneas aquecidas geotermicamente emergem da crosta terrestre. Elas são encontradas em todo o planeta, inclusive no fundo do oceano.

\section{Ameaças}

Existem muitas ameaças do geopatrimônio vulcânico para as pessoas, e também ameaças das pessoas para o geopatrimônio vulcânico. Em algumas áreas protegidas não se reconhece que determinados elementos vulcânicos podem estar ativos. Assim, existe uma probabilidade de o risco de condições perigosas (por exemplo, erupções, emissões de gases, atividade de fumarolas, movimentos de massa e outros riscos vulcânicos) não ser adequadamente abordado no plano de gestão da área protegida. Atrair visitantes para áreas geofisicamente ativas acarreta uma responsabilidade de monitorar a atividade vulcânica e desenvolver planos de contingência de risco, como partes essenciais do processo de gestão. Muitas áreas vulcânicas incluem monitoramento do local, sistemas de comunicação e resposta de emergência projetados para residentes. No entanto, estes podem não tratar de perigos específicos de áreas protegidas, como um sistema de alerta para turistas e um método ordenado de evacuação ou proteção. As áreas protegidas são um bom local para divulgar tais informações, mas frequentemente são omitidas do planejamento da gestão. Além disso, existe também um valor educativo no aumento da conscientização dos perigos vulcânicos de modo cientificamente válido.

O Parque Nacional de Tongariro, na Nova Zelândia, é um bom exemplo de um esquema bem-sucedido de redução de riscos em um sítio do Patrimônio Mundial vulcânico. A ameaça de lahares (fluxos de lama) causada pelo derramamento de água do lago do cume do Monte Ruapehu tem sido uma preocupação especial para a segurança dos esquiadores e da infraestrutura de esqui em suas encostas, bem como para as estradas, terras agrícolas e assentamentos nas vizinhanças. Sofisticados sistemas de monitoramento do lago da cratera e de alerta de lahar foram instalados, os quais provaram ser de vital importância para reduzir a perda de vidas e danos materiais durante um recente evento de lahar.

Além de colaborar com cientistas para documentar as possíveis ameaças de um vulcão, os gestores das áreas protegidas também devem trabalhar com as autoridades civis e de emergência e com as comunidades locais para preparar um plano de contingência no caso de um incidente grave. Os planos de contingência são reconhecidos hoje em dia como muito importantes para proteger as pessoas em uma ampla gama de situações de risco, embora, além do risco público, os gestores de áreas protegidas vulcânicas também devem gerir os riscos para os bens naturais de alto valor de conservação. Existem tais planos de gestão, por exemplo, no Monte Fuji, no Japão, onde já se realizaram exercícios de evacuação. Planos semelhantes existem no sul da Islândia, como preparação para a erupção do vulcão Katla, os quais foram implantados em 2010 quando o vulcão adjacente entrou em erupção.

Na gestão das ameaças das pessoas ao geopatrimônio vulcânico, é importante que os planos e a gestão das áreas 
Foto 7.17 A erupção da fissura Holuhraun, em Outubro de 2014, no Parque Nacional de Vatnajökull, Islândia originou a maior escoada de lava na Islândia em mais de 200 anos. O perigo para visitantes e residentes foi diminuído pelo fechamento da área ao tráfego de pessoas e veículos, embora os aviões tenham sido autorizados a sobrevoar o local, como se vê na foto. @) Roger Crofts

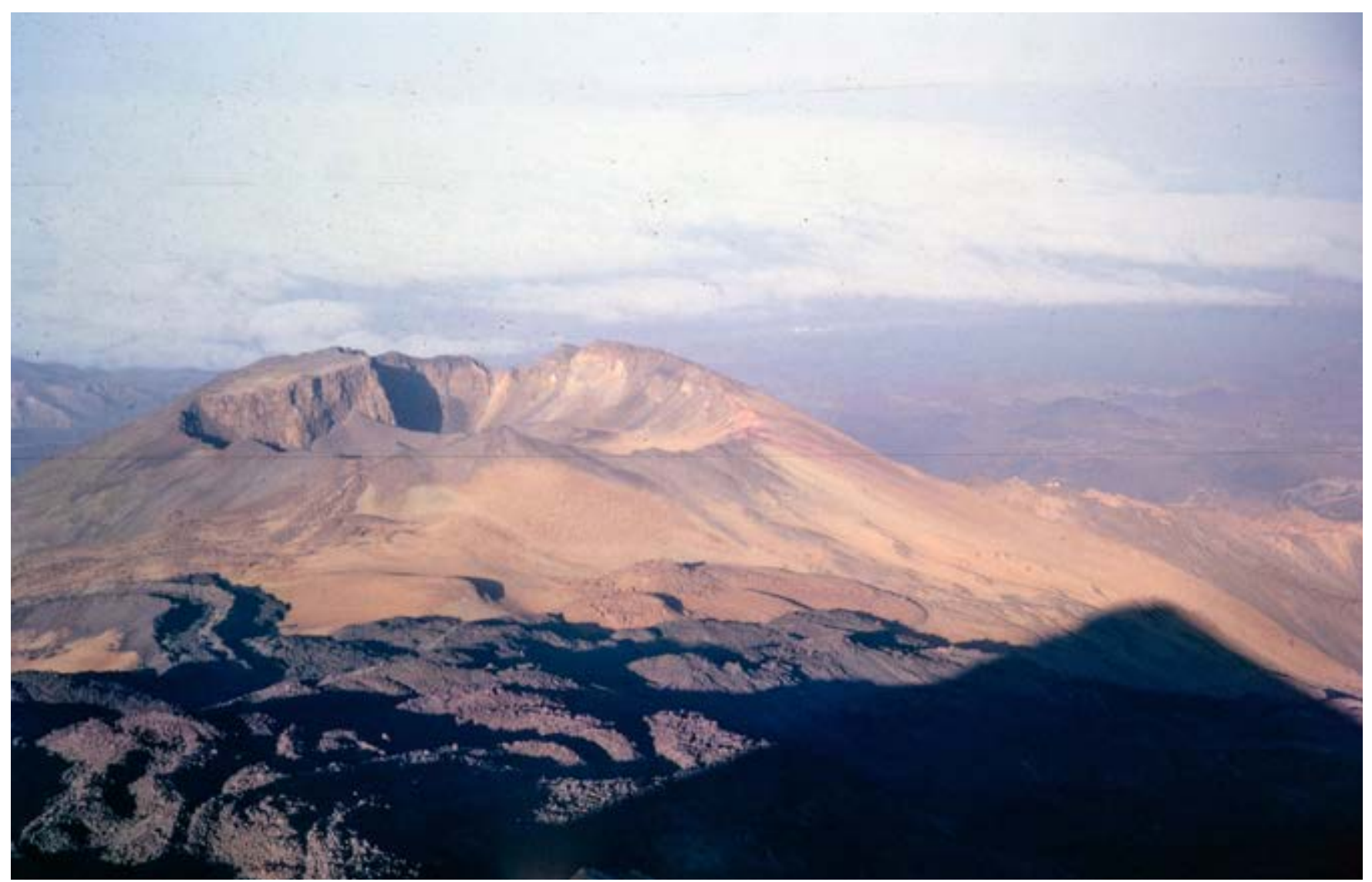

Foto 7.18 Cone da erupção de 1910, em parte do vulcão Teide (sombra do cume em primeiro plano, à direita), no Parque Nacional de Teide, Tenerife, Ilhas Canárias, Espanha. O acesso à área vulnerável e potencialmente perigosa do cume é hoje em dia feito através de um teleférico e é necessária uma autorização para entrar na cratera. @ Roger Crofts 
Tabela 7.5. Aspectos de gestão de risco a serem considerados em áreas vulcânicas.

\begin{tabular}{|c|c|}
\hline Bacias hidrográficas & $\begin{array}{l}\text { Os riscos vulcânicos podem se estender a muitas dezenas de quilômetros do centro de atividade } \\
\text { por meio de movimentos de massa, fluxos de lama, lahares e colapsos de encostas. Considerar a } \\
\text { avaliação dos riscos vulcânicos municipais e incorporar recomendações no plano de gestão. }\end{array}$ \\
\hline Indústria extrativa & $\begin{array}{l}\text { Deve-se evitar a indústria extrativa em áreas protegidas, pois desta decorre inevitavelmente perda de } \\
\text { geodiversidade e modificação de processos. Se existir a necessidade de um mineral que não possa } \\
\text { ser obtido fora da área protegida, os potenciais locais de extração precisam ser avaliados em termos } \\
\text { de seus potenciais impactos nos principais geossítios. }\end{array}$ \\
\hline $\begin{array}{l}\text { Elementos vulcânicos } \\
\text { vulneráveis }\end{array}$ & $\begin{array}{l}\text { Muitas áreas hidrotermais, elementos vulcânicos recentes e rochas vulcânicas menos coesas estão } \\
\text { sujeitas a danos e destruição se não forem devidamente geridas. Deve ser feito um inventário para } \\
\text { priorizar as áreas que necessitam de proteção. Poderão ser necessárias medidas para manter os } \\
\text { visitantes afastados desses elementos. Para elementos particularmente sensíveis, deve ser consid- } \\
\text { erada a proibição de acesso ou a não divulgação de sua localização. }\end{array}$ \\
\hline Coleta não autorizada & $\begin{array}{l}\text { Muitos produtos vulcânicos são valorizados por coletores, incluindo obsidiana vítrea, bombas vul- } \\
\text { cânicas e outros depósitos. Os gestores devem enfatizar que estes são recursos não renováveis. }\end{array}$ \\
\hline Edifícios & $\begin{array}{l}\text { Quaisquer novas construções em áreas protegidas vulcânicas, tais como centros de acolhimento } \\
\text { a visitantes, requerem estudos prévios, subterrâneos e à superfície, para evitar que a construção } \\
\text { ocorra sobre elementos subterrâneos como tubos de lava ou em áreas que constituam risco à } \\
\text { estabilidade do edifício. }\end{array}$ \\
\hline $\begin{array}{l}\text { Estacionamento e } \\
\text { transporte de visitantes }\end{array}$ & $\begin{array}{l}\text { Sempre que possível, os estacionamentos devem estar bem longe de geoformas e geossítios } \\
\text { importantes. }\end{array}$ \\
\hline $\begin{array}{l}\text { Geração de energia } \\
\text { e armazenamento de } \\
\text { combustível }\end{array}$ & $\begin{array}{l}\text { Estruturas de apoio aos visitantes em algumas áreas protegidas vulcânicas são remotas e sem } \\
\text { acesso à rede elétrica. Sempre que possível, a eletricidade deve ser gerada no local usando } \\
\text { unidades eólicas, hídricas ou solares. Se os geradores de energia a diesel forem essenciais, } \\
\text { o combustível para eles e para quaisquer outros usos essenciais deve ser armazenado } \\
\text { adequadamente, com procedimentos de segurança para evitar derramamentos. }\end{array}$ \\
\hline
\end{tabular}

Gestão de Visitantes

Acesso dos visitantes $\quad$ A grande maioria das áreas vulcânicas protegidas não foi objeto de intervenções, mas mesmo assim podem receber muitos visitantes caminheiros e mochileiros. Em áreas protegidas, um sistema de permissão pode ser necessário para restringir o número de visitantes. Todos os visitantes devem aderir a um código de conduta de visitação de mínimo impacto e as áreas muito utilizadas devem ter rotas preferenciais, mas discretamente marcadas.

Zoneamento da área protegida

O levantamento e a caracterização de áreas vulcânicas deve incluir a inventariação dos geossítios principais e informações detalhadas do geopatrimônio para facilitar a gestão através de zoneamento. Devem ser identificadas as seções mais adequadas para o acesso de visitantes, juntamente com as áreas onde devem ser aplicadas restrições de acesso devido à fragilidade dos elementos ou ao perigo para os visitantes.

Infraestruturas já existentes
Muitas áreas vulcânicas foram alvo de intervenções antes de serem designadas como áreas protegidas. Infelizmente, em algumas áreas isso gerou danos significativos devido à destruição de elementos vulcânicos e mirantes. Essas infraestruturas podem ainda ser importantes para a área protegida, mas os gestores poderão ter que considerar a sua remoção e a recuperação dos elementos vulcânicos degradados. Em alguns casos, após um episódio vulcânico, tais instalações poderão ser danificadas ou destruídas, dando motivos para a sua não reconstrução.

\section{Pesquisa científica}

Nas áreas vulcânicas existe normalmente pesquisa científica ativa devido ao valioso registro de processos que ocorrem desde o interior da Terra até a superfície. O interesse pela pesquisa é particularmente elevado após eventos vulcânicos. Embora a pesquisa deva ser encorajada, os gestores de áreas protegidas devem estar cientes de que alguns tipos de pesquisa envolvem perfuração de núcleos, ou remoção de volumes relativamente grandes de rocha. Para estes tipos de pesquisa, um sistema de permissão é recomendado, com ênfase na proteção da integridade dos geossítios e das áreas onde ocorra geopatrimônio, no geral. Em locais onde tais pesquisas tenham destruído ou danificado elementos geopatrimoniais relevantes, devem ser implementadas medidas de recuperação para minimizar os danos a longo prazo. 
protegidas ofereçam proteção adequada ao sistema vulcânico completo, incluindo evidências de seus estilos de erupção, produtos e geoformas (Tabela 7.5). Embora geralmente se considere que a geologia vulcânica é geralmente bastante robusta, muitos elementos vulcânicos recentes, tais como depósitos hidrotermais e alguns produtos eruptivos, são bastante frágeis. Além disso, existem ameaças humanas a valores geológicos que podem exigir intervenção da gestão. Na maioria dos casos, estas ameaças também afetam a ecologia e os valores culturais do local, e onde estes valores são importantes, tais locais devem ser geridos como sistemas integrados.

\section{Princípios e diretrizes de gestão dos geossítios}

As áreas vulcânicas possuem outros valores naturais, os quais frequentemente dependem de fatores abióticos especiais da geologia vulcânica. A ecologia de um vulcão é influenciada, ou depende mesmo, do tipo de rocha, do solo, da geomorfologia e de características como a morfologia de detalhe, a exposição das encostas, a altitude, a aridez e às vezes até mesmo a intensidade ou o tipo da atividade vulcânica. Os vulcões têm também frequentemente uma forte relevância cultural.

Em geral, devido à sua elevada dimensão, à longa durabilidade da atividade eruptiva (geralmente abrangendo muitas centenas de milhares de anos) e aos perigos inerentes, os sistemas vulcânicos mais ativos são relativamente não perturbados e pouco influenciados pelo comportamento humano. Em muitos casos, a interação entre humanos e vulcões é oposta à que influencia outros sistemas naturais, porque os vulcões representam riscos substanciais à vida e à propriedade e, de fato, à conservação de importantes características geológicas, biológicas e culturais. No entanto, a atividade humana representa uma ameaça para muitas áreas vulcânicas protegidas. Estas ameaças incluem despejos ilegais, poluição das águas subterrâneas, implantação inadequada de rodovias, degradação da qualidade da natureza selvagem, turismo comercial (incluindo a implementação de infraestruturas do esqui), uso excessivo de atividades recreativas, condução com veículos todo terreno e extração de minerais.

\section{Educação e interpretação}

Os objetivos de gestão também podem ser alcançados através de programas de educação e interpretação. Os vulcões são alguns dos destinos turísticos mais visitados do mundo. Por exemplo, o Parque Nacional Fuji-Hakone-Izu, no Japão, (ou seja, a área ao redor do Monte Fuji) recebe até 100 milhões de visitantes anuais, enquanto cerca de 300.000 pessoas sobem ao cume do vulcão a cada ano. O sítio do Patrimônio Mundial mais visitado é o Parque Nacional de Teide, em Tenerife, Espanha, com 3,2 milhões de visitas por ano. Todas as áreas vulcânicas inscritas como Patrimônio Mundial proporcionam alguma forma de acesso para os turistas. Por exemplo, em Kilauea, no Parque Nacional Hawai'i Volcanoes, nos EUA, e em Stromboli, nas Ilhas Eólicas, na Itália, visitantes casuais podem ver com segurança o vulcanismo ativo em curso. $O$ valor educativo da experiência de ver um vulcão, adormecido ou ativo, é imenso, porque mais do que em qualquer outro lugar na Terra, os vulcões ilustram o poder e a importância da geologia e dos processos magmáticos que construíram o planeta.

Excelentes instalações interpretativas estão sendo implementadas em muitos sítios vulcânicos do Patrimônio Mundial e em muitas outras áreas protegidas vulcânicas pelo mundo, sendo exemplos notáveis o Parque Nacional de Thingvellir, na Islândia, e Heimay, nas Ilhas Vestmann, na costa sul da Islândia; o Parque Nacional Hawai'i Volcanoes e o Parque Nacional de Yellowstone, EUA; o Parque Nacional de Teide, em Tenerife, na Espanha; e o Parque Nacional de Tongariro, na Nova Zelândia. No inovador Stone Park na Ilha de Jeju, na República da Coréia, mostras gráficas notáveis, tridimensionais e interativas, que explicam a geologia vulcânica da ilha também estão ligadas à interpretação artística da rocha basáltica e do folclore da ilha. Tais exposições e publicações interpretativas e serviços de orientação associados, cumprem um papel essencial na sensibilização, na compreensão e na apreciação da beleza e do interesse dos vulcões, e também da importância de proteger este recurso geológico.

\section{Monitoramento}

Os métodos usados para monitorar o comportamento de um vulcão são bastante sofisticados e envolvem tanto a detecção remota como medições no vulcão e ao redor dele para detectar o movimento do magma em profundidade. A instrumentação mede a atividade sísmica subterrânea, perfis geofísicos e térmicos, deformação do solo, geoquímica dos gases emitidos, dados hidrológicos e química, calor e viscosidade da lava. Na maioria dos casos, os gestores de áreas protegidas precisarão consultar os vulcanólogos e outros geólogos especialistas em métodos de monitoramento e sua análise.

Além disso, muitos vulcões Holocênicos foram já alvo de uma avaliação de risco vulcânico, que é um resumo descritivo dos perigos potenciais, complementado com um mapa das áreas que podem ser afetadas pela atividade vulcânica futura. Esta cartografia é útil a gestores das áreas protegidas, cientistas, autoridades civis e pessoas que vivem no vulcão ou perto dele, para gerir a relação entre áreas potencialmente perigosas e as atividades humanas do dia a dia. As avaliações também são críticas para o planejamento do território a longo prazo e medidas eficazes de resposta a emergências. 


\section{Educação e comunicação para a geoconservação}

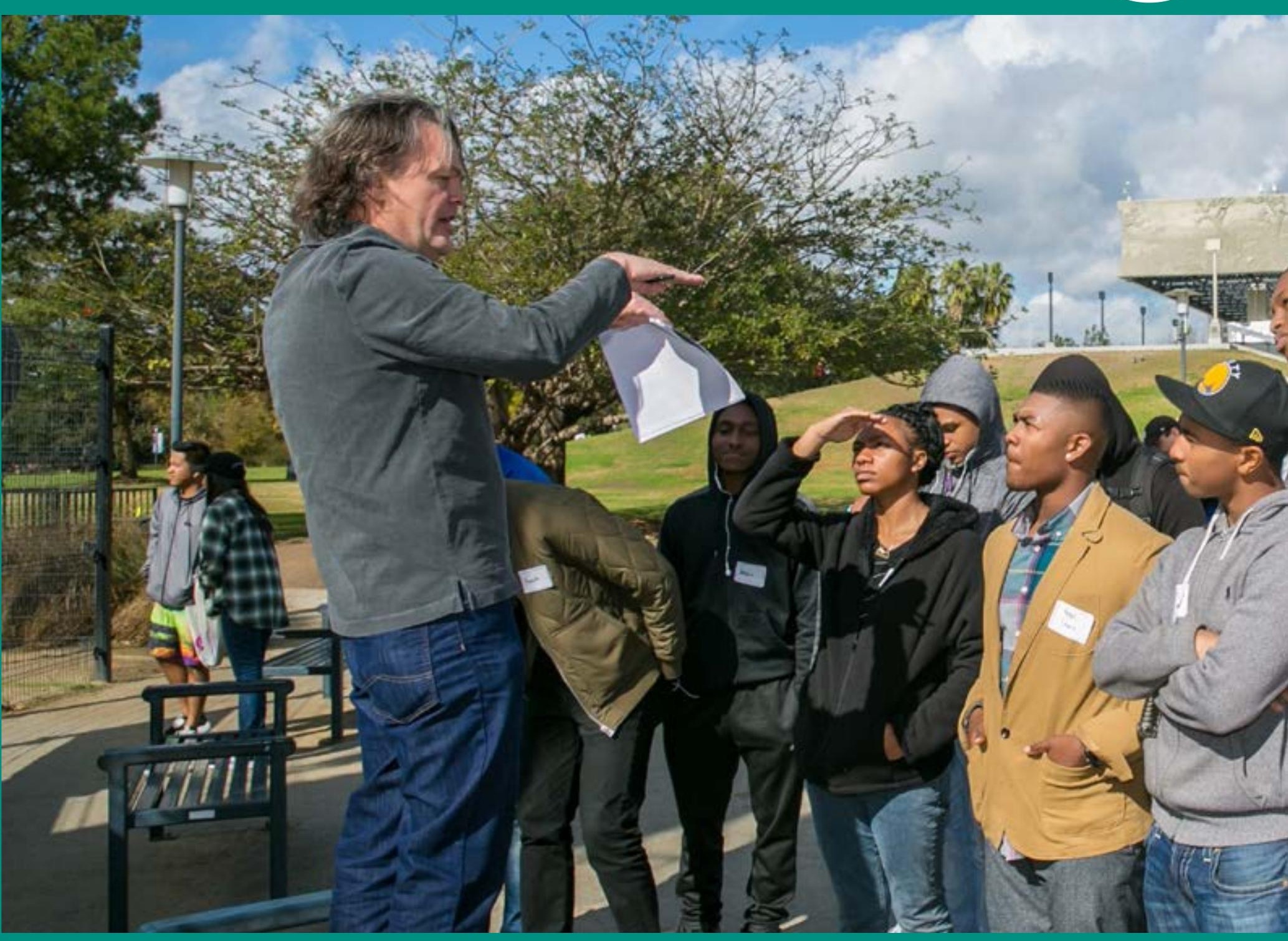

Nada substitui levar estudantes ao campo com um educador treinado. Dan Tormey, um dos autores, no sítio fossilifero La Brea Tar Pits, um Monumento Natural Nacional, Califórnia, EUA. @ Dan Tormey 


\section{Esta seção centra-se na educação e comunicação para a geoconservação. Os seguintes tópicos serão}

abordados:

princípios e práticas gerais de interpretação (8.1)

educação (8.2)

sensibilização do público (8.3)

comunicação por novos meios digitais (8.4)

comunicação por meios convencionais.

Nesta seção serão descritos os vários tipos e níveis de comunicação em patrimônio geológico, com enfoque em centros de recepção de visitantes, físicos e digitais. Estes tipos de comunicação serão descritos com base em três objetivos: interpretação, educação e divulgação pública. Em seguida, são apresentadas ferramentas de comunicação, quer sejam novas técnicas em meios digitais, como técnicas em meios tradicionais.

\subsection{Interpretação}

A interpretação é um método de comunicação que visa revelar o significado dos recursos de uma área protegida, ao invés de apenas transmitir informações fatuais. O princípio orientador de uma interpretação eficaz é "por meio da interpretação, compreensão; por meio da compreensão, apreciação; por meio da apreciação, proteção". Programas interpretativos têm, tradicionalmente, os visitantes dos parques como alvos, mas atualmente a interpretação pode ser feita em qualquer lugar, o que inclui programas de sensibilização para educação ambiental e interpretação utilizando a internet ou aplicativos para dispositivos móveis. A interpretação presencial, contudo, é particularmente poderosa, uma vez que pode complementar as experiências diretas do público com a adição dos valores do patrimônio geológico e sua relação com a biodiversidade e com os valores culturais. Uma boa perspectiva sobre como comunicar a relação entre geodiversidade e biodiversidade pode ser encontrada em Santucci (2005).

Um guia holístico clássico de interpretação do patrimônio é o livro de Freeman Tilden, Interpreting Our Heritage (1957). Tilden define a interpretação do patrimônio como uma atividade educativa que visa revelar significados e relações por meio da utilização de objetos originais, experiências diretas e meios ilustrativos, ao invés de simplesmente comunicar uma informação fatual.

O Serviço de Parques Nacionais dos EUA tem um "curso intensivo de interpretação" com base nos princípios de Tilden (Smaldone, 2003; Ham, 2013). A Associação Nacional de Interpretação, sediada nos EUA, também possui uma grande quantidade de informações e ferramentas on-line com excelentes exemplos de materiais interpretativos bem sucedidos. Bruno \& Wallace (2019) fornecem uma orientação prática para a elaboração de painéis interpretativos dedicados ao geopatrimônio.

Há muitas maneiras pelas quais a interpretação pode melhorar a apreciação dos recursos associados ao patrimônio geológico, em particular destacando as conexões entre paisagem e substrato geológico e definindo as relações entre a geologia e a flora, a fauna e a história humana de uma área protegida. Além disso, a observação de rochas e paisagens a partir de diferentes perspectivas e escalas permite uma melhor compreensão do valor dos recursos geológicos como partes integrantes dos diversos ambientes do parque. Uma comunicação eficaz, incluindo programas interpretativos, permite que o público compreenda a importância dos valores do geopatrimônio no âmbito das sociedades e comunidades em geral e pode fomentar uma maior apreciação do seu significado. Isto, por sua vez, pode promover uma ética de conservação em relação ao patrimônio geológico.

O plano interpretativo é uma etapa inicial no processo de planejamento e desenvolvimento de estratégias para geossítios e locais similares, nos quais a interpretação é utilizada para comunicar mensagens, histórias, informações e experiências. É um processo de tomada de decisões que combina as necessidades de gestão e análise de recursos às necessidades e desejos dos visitantes para determinar a forma mais eficaz de comunicar uma mensagem a um público alvo. O objetivo é relacionar o conteúdo à experiência pessoal do visitante de uma maneira significativa, provocando emoção, reflexão ou pesquisa adicional sobre um determinado tema. A maior parte dos planos interpretativos baseia-se na definição de temas que sejam importantes para se comunicar com vários públicos. O planejamento interpretativo pode também orientar a forma como o público irá reagir e interagir com um determinado local ou exposição. Este planejamento deve identificar e analisar objetivos e questões sobre interpretação, educação e experiência do visitante, além de sugerir formas mais eficazes, eficientes e práticas de abordá-los. O plano deve orientar a concepção e o desenvolvimento do projeto, tornando-se um recurso para a comunicação, a divulgação e a obtenção de financiamento. Detalhes gerais podem ser obtidos nas Diretrizes de Melhores Práticas em Turismo e Gestão de Visitantes da WCPA-UICN (Leung et al. 2019).

Uma boa comparação sobre a utilização do geoturismo como um sistema completo de comunicação contextual na China e nos Estados Unidos é apresentada por Fang et al. (2013), que compararam os sistemas de interpretação de dois geoparques mundiais na China com os do Parque Nacional de Zion, nos EUA. A partir de lições e experiências, este documento sugere a utilização do geoturismo como um sistema completo de comunicação contextual, no qual a equipe gestora de um geossítio (a fonte) fornece informações aos turistas (os receptores) sobre os valores culturais e naturais únicos, por meio de atividades turísticas (os canais). 


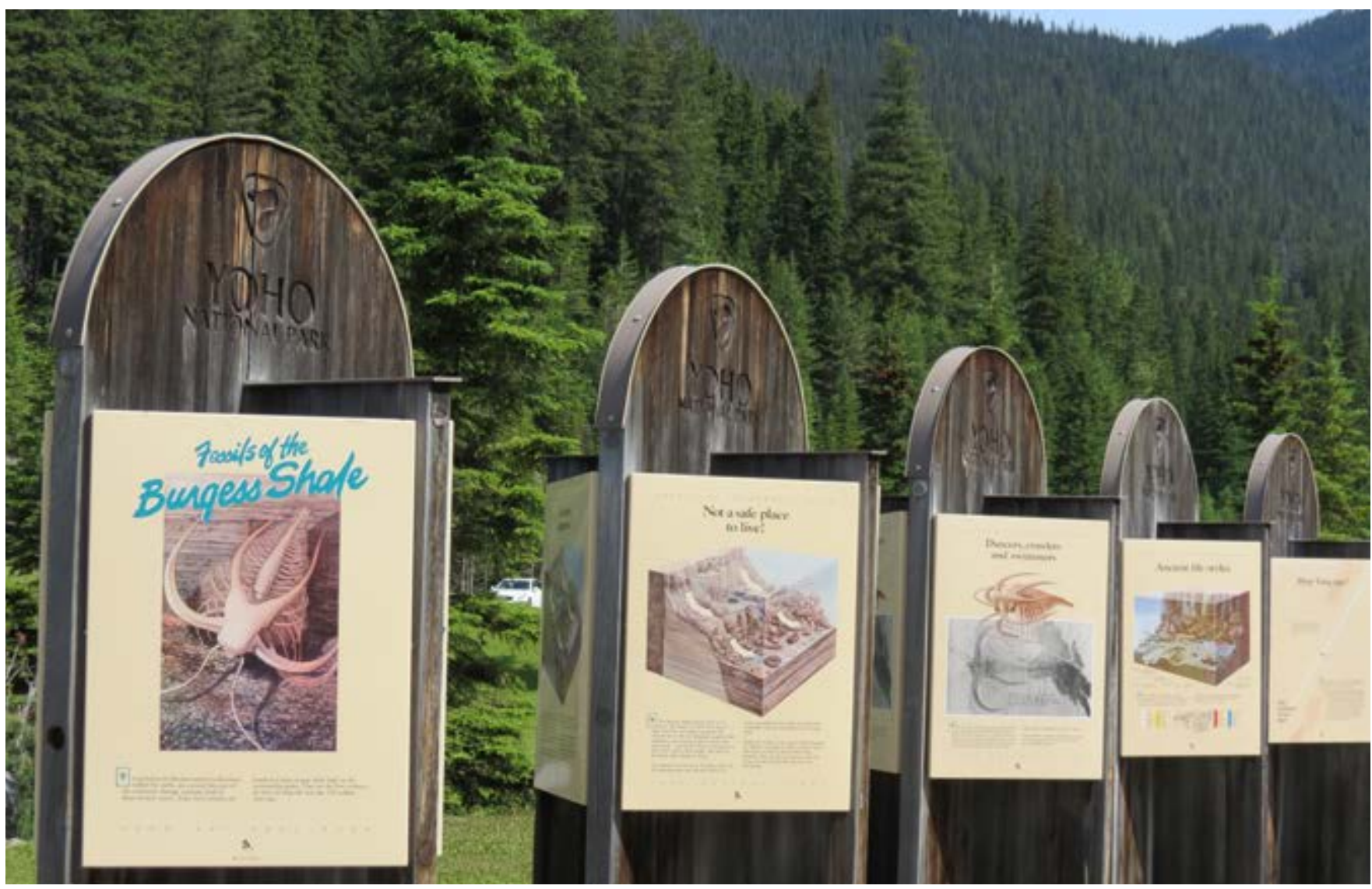

Foto 8.1 Interpretação seguindo um modelo clássico: facilmente acessível, com gráficos de fácil compreensão e frases simples sobre os Folhelhos de Burgess e a evolução da vida no Período Cambriano. Parque Nacional Yoho, Canadá. @ Roger Crofts

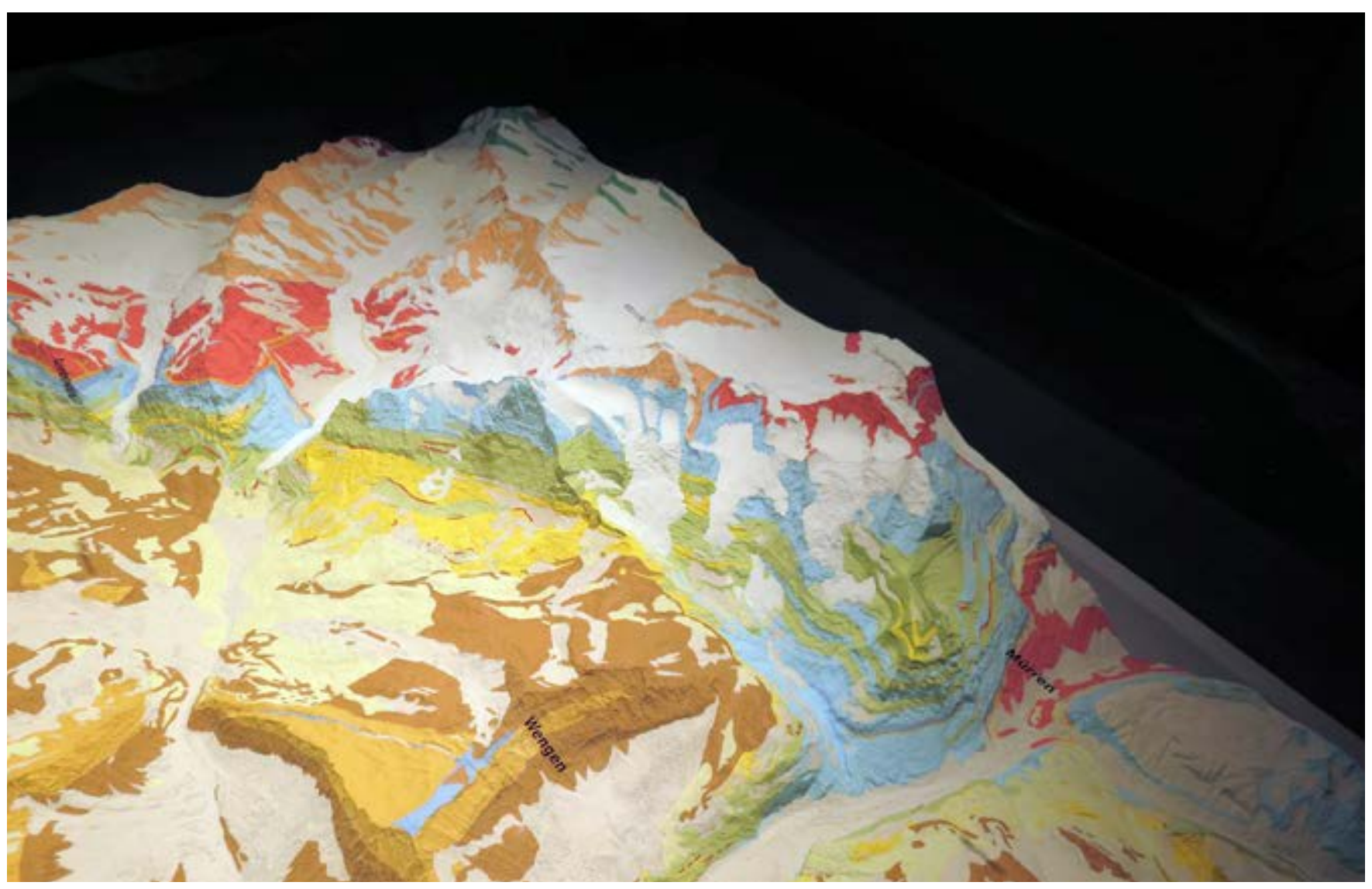

Foto 8.2 Um modelo tridimensional é um bom recurso para mostrar a relação entre as rochas subjacentes e a paisagem. Museu de História Natural de Berna, Suíça. @ Roger Crofts 


\section{Educação e comunicação para a}

geoconservação

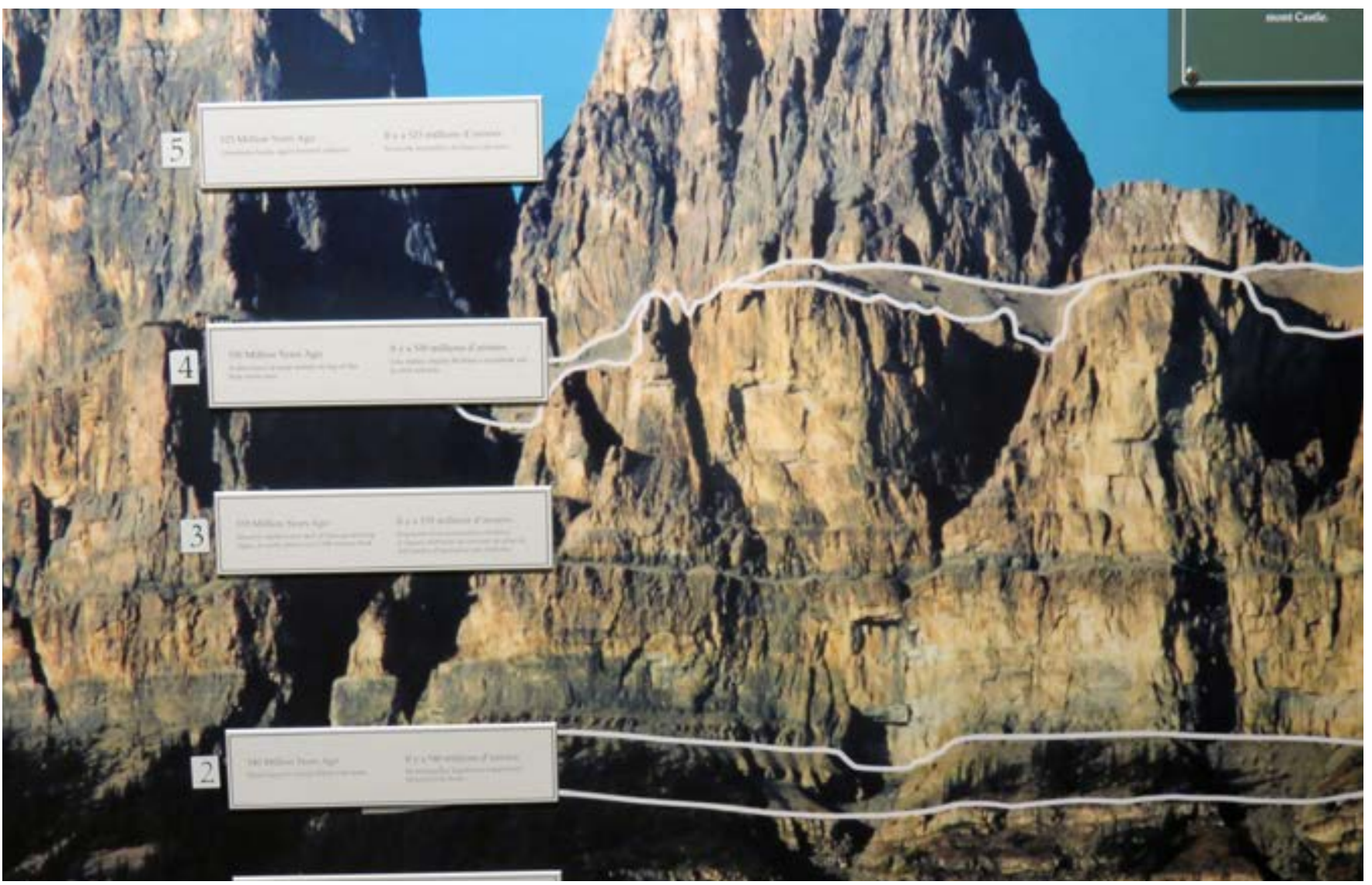

Foto 8.3 Outro método para facilitar a compreensão pelos visitantes consiste em colocar notas sobre fotos de afloramentos rochosos com informações de fácil entendimento, como aqui nas Montanhas Rochosas no Canadá. @ Roger Crofts

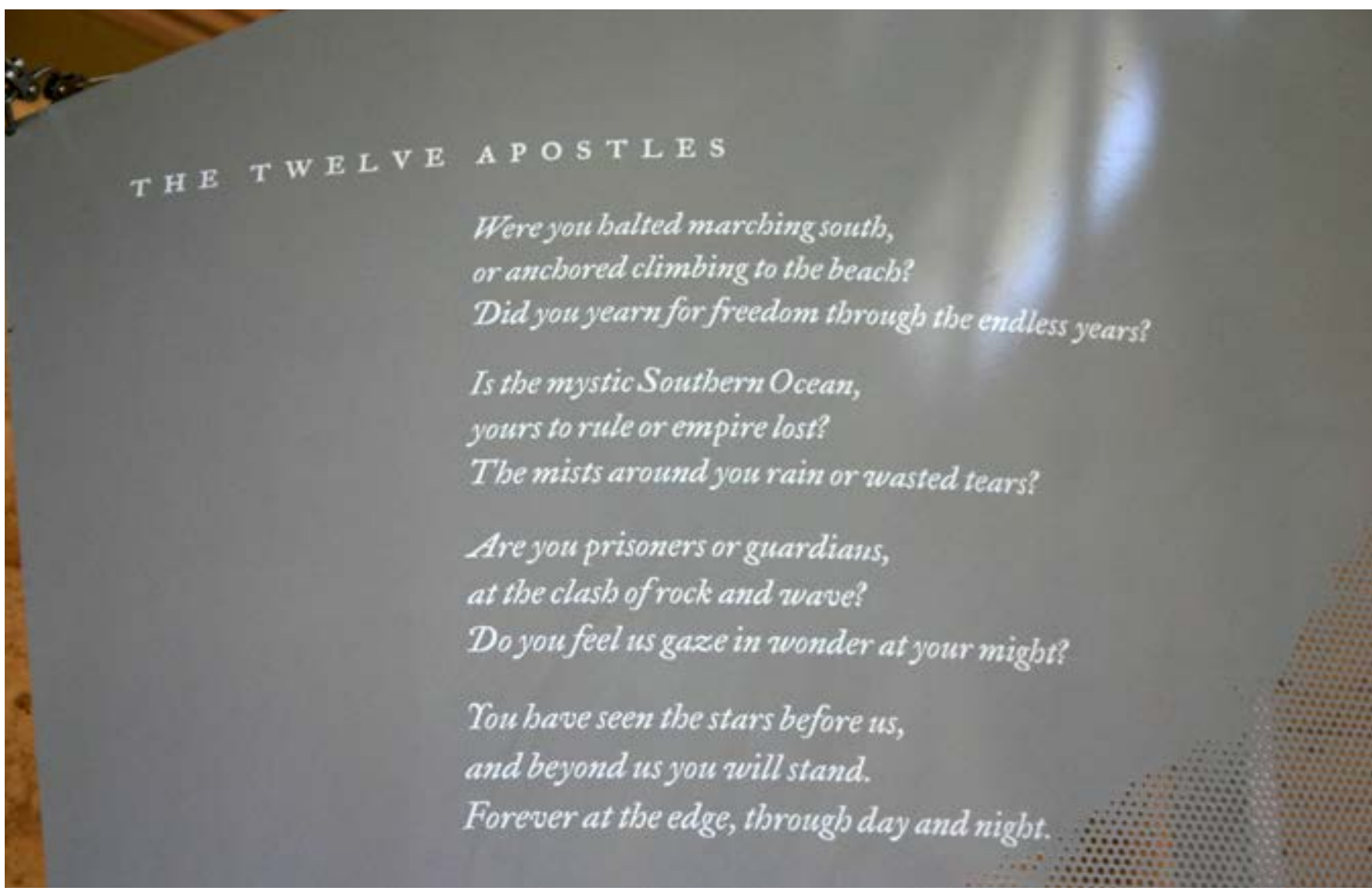

Foto 8.4 A utilização de poesia pode ajudar a estimular o interesse e a evocar uma reação à paisagem. Poema no Parque Nacional Marinho dos Doze Apóstolos, estado de Vitória, Austrália. @ Roger Crofts 

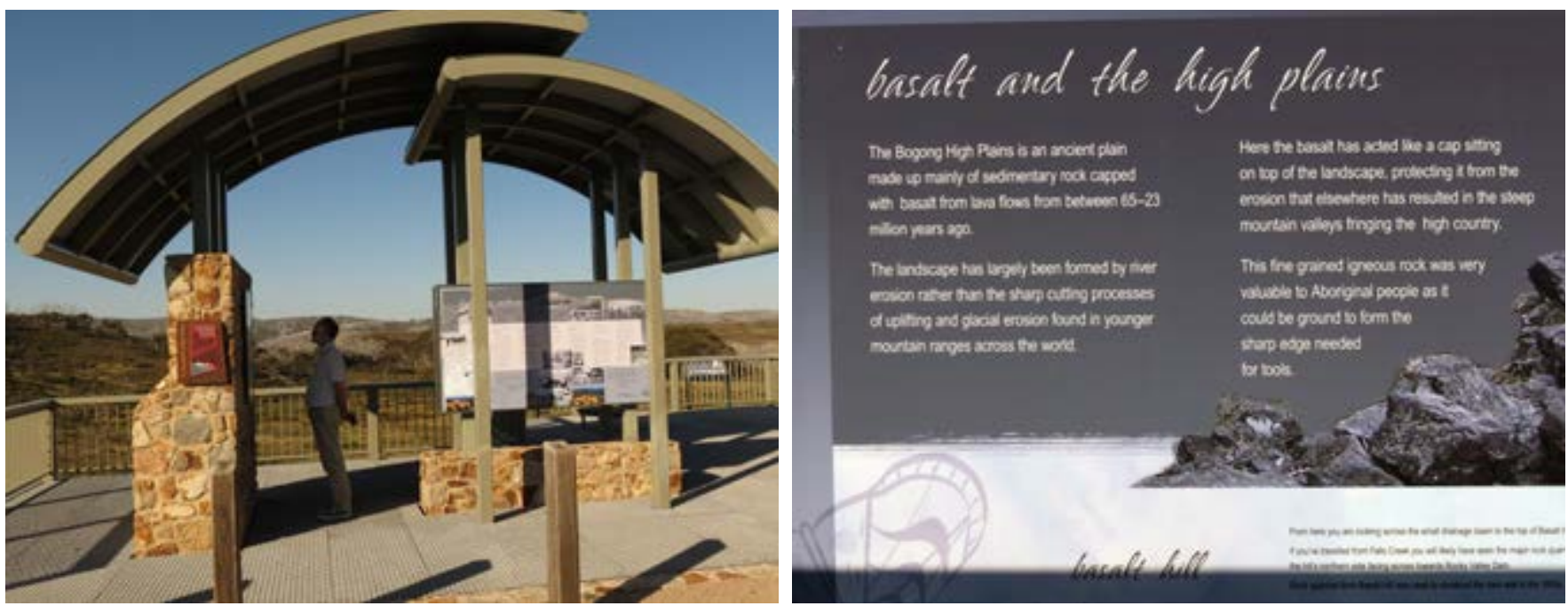

Fotos 8.5 e 8.6 Centros de interpretação sobre patrimônio geológico muito elaborados e dispendiosos são desnecessários. É mais barato e eficaz contar a história de maneira simples numa instalação ao ar livre, como no Parque Nacional Bogong, estado de Vitória, Austrália. () Roger Crofts

\subsection{Educação}

Ampliar a conscientização e o envolvimento por meio da educação e da interpretação são partes essenciais da geoconservação. Contar a história geológica de uma área protegida equivale a contar às pessoas uma parte da história da Terra. É algo naturalmente fascinante e, organizado de forma atraente, pode ser cativante. Um dos desafios é tornar a história inovadora e fácil de compreender, uma vez que algumas informações sobre geopatrimônio podem ser bastante complexas. O objetivo deve ser o de informar e entreter, bem como de educar, como reconhece a perspicaz observação de James Hutton (1795) de que o estudo da Terra "pode proporcionar à mente humana tanto informação como entretenimento". A eficácia da geoconservação vai depender, em última análise, de uma melhor sensibilização, compreensão e apoio do público.

Um dos maiores desafios é comunicar a vastidão do tempo geológico a um público não-especializado. O Parque Nacional Torres Del Paine, no Chile, preparou uma interessante explicação da sua extraordinária geologia (http://www. parquetorresdelpaine.cl/en/patrimonio). O centro de visitantes fornece painéis com explicações muito acessíveis sobre a geologia do parque, apoiados por uma exposição ao ar livre com amostras de rochas encontradas no parque, montada e organizada para que os visitantes possam passear e tocar. É o tipo de exposição que comunica de modo adequado a geologia especial de um parque especial.

A interpretação da geodiversidade por meio do geoturismo não é recente, como demonstrado pelo apelo e interesse cultural, desde há muito tempo, em mostrar cavernas, geleiras, montanhas sagradas e outras maravilhas geológicas naturais. Nos séculos 18 e 19, as pessoas se conectavam à paisagem física de uma forma experimental e as características naturais, lugares e eventos passados inspiravam uma sensação de encantamento por meio das relações com a paisagem, a literatura, a poesia, a arte e o turismo. Hoje em dia, é menos importante possuir conhecimento do que saber onde encontrálo, selecioná-lo e aplicá-lo - tudo isso de modo rápido. O foco está em encontrar e utilizar a informação para abordar temas e questões; ensinar as pessoas a pensar (UICN, 2015).
Um exemplo relevante de um excelente programa de educação em geopatrimônio é desenvolvido nos EUA pelo Serviço Nacional de Parques, focado na paleontologia - o Dia Nacional do Fóssil, celebrado anualmente em outubro. Desde o estabelecimento deste dia como parte da Semana das Ciências da Terra, em 2010, as parcerias têm crescido de forma constante e incluem mais de 360 parceiros em todos os estados dos EUA. Estes parceiros são capazes de proporcionar ações locais de educação e divulgação sobre fósseis a crianças, famílias, escolas e outros grupos de interesse. Embora o foco principal das parcerias seja aumentar o interesse das crianças pelo registo fóssil, outros públicos alvo são também alcançados, e mais de 100.000 cadernetas de Paleontólogos Mirins (Júnior) foram distribuídas.

\subsection{Divulgação pública}

Embora toda a comunicação e educação possam ser consideradas como "divulgação pública", nesta seção o termo significa chegar às comunidades, empresas turísticas e outros interessados que possam ter influência ou interesse na preservação do local, mas que têm pouca ou nenhuma compreensão acerca da geodiversidade. Por definição, a criação de uma área protegida implica que não serão permitidos usos que prejudiquem os objetivos de conservação. Portanto, a divulgação de uma área protegida para as comunidades locais e outros interessados em nível regional é uma ação primordial para obter o apoio de gestores públicos e de interesses econômicos conflitantes aos objetivos de conservação.

Um excelente exemplo de divulgação, em nível global, é a Comissão de Educação e Comunicação da UICN; muitos dos seus programas fornecem exemplos valiosos de divulgação relacionados ao patrimônio geológico. O material elaborado fornece elementos frequentemente ausentes na pesquisa científica e nas políticas de conservação: como comunicar de forma mais eficaz, como incentivar ações por meio da ciência comportamental e como fazer sua mensagem ser ouvida em um mundo barulhento. 


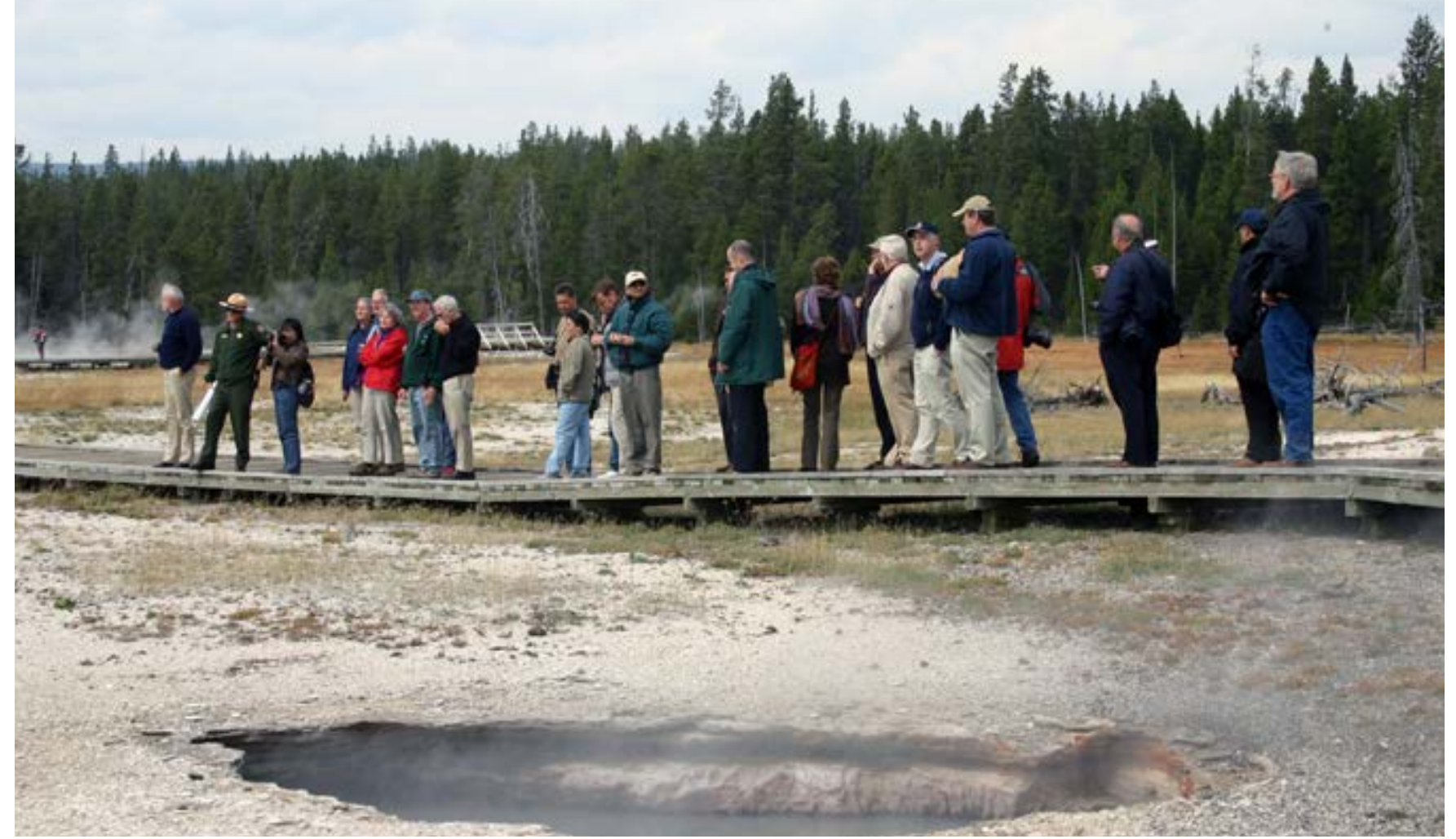

Foto 8.7 Mesmo os especialistas precisam de um guia especializado. Membros do Comitê Diretor da WCPA-UICN sendo assessorados por um geólogo do Serviço de Parques Nacionais dos EUA no Parque Nacional de Yellowstone. @ Roger Crofts

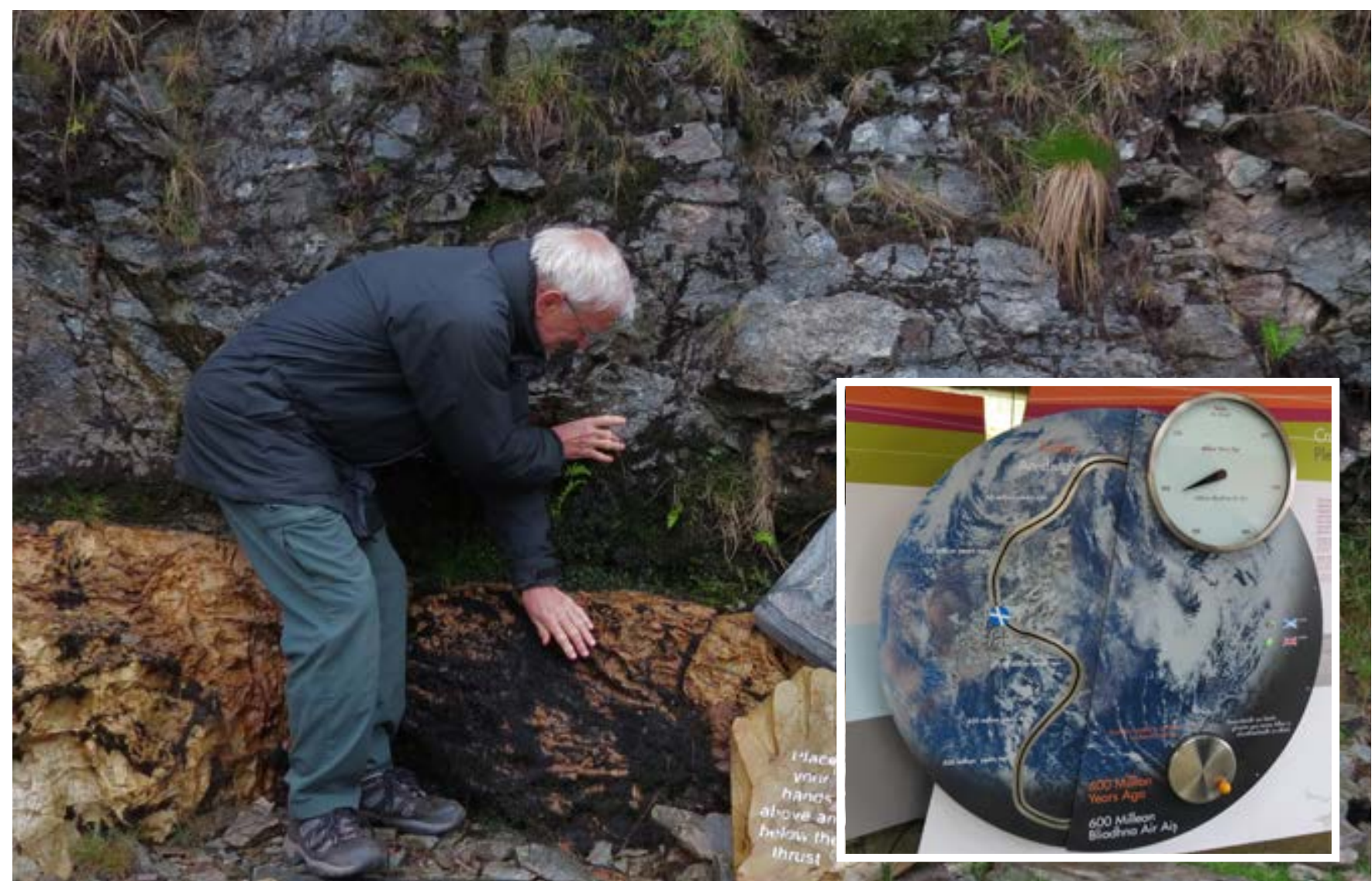

Fotos 8.8 e 8.9 Explicar a vastidão do tempo geológico não é fácil. Aqui são mostrados dois métodos utilizados na Reserva Natural Nacional de Knockan Crag, Escócia. A foto superior mostra rochas invertidas, onde as rochas mais antigas estão sobre as mais novas. (c) Roger Crofts. Na foto inferior, o usuário pode girar uma manivela para mostrar como uma parte da crosta terrestre, a Escócia, se deslocou ao longo do tempo do hemisfério sul para o hemisfério norte. @ Roger Crofts 


\section{Caixa 8.1}

\section{Falésias fossilíferas de Joggins, Canadá}

Um belo estudo de caso de educação e interpretação é o sítio Falésias fossilíferas de Joggins, um sítio do Patrimônio Mundial da UNESCO situado na Baía de Fundy, na Nova Escócia, Canadá (ver Foto 1.2). O sítio foi descrito como a "Galápagos da Idade do Carvão" devido à riqueza de fósseis do Período Carbonífero (354 a 290 milhões de anos atrás). Estas rochas são consideradas icônicas para este período da história da Terra e são o registo mais espesso e abrangente dos estratos Pensilvanianos (318 a 303 milhões de anos), com o mais completo registo fóssil conhecido da vida terrestre daquela época.

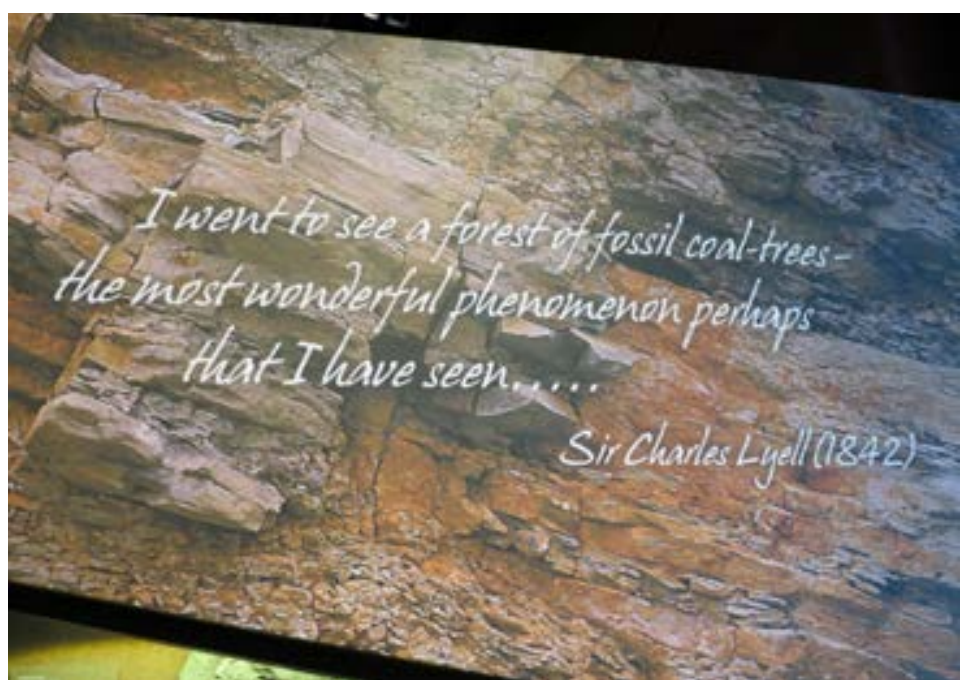

Foto 8.10 Pode ser útil destacar as visitas feitas no passado por pesquisadores famosos. No sítio do Patrimônio Mundial Falésias fossilíferas de Joggins, as visitas de Charles Lyell, um dos geólogos mais eminentes de meados do século 19, e de Charles Darwin, têm sido utilizadas com eficácia pelo centro de visitantes. () Roger Crofts

A associação para o desenvolvimento econômico local e três níveis de autoridades governamentais atuaram em conjunto na criação do Instituto Joggins Fossil para apresentar, promover e gerir as falésias por meio de um centro de pesquisa e interpretação de última geração. A comunicação de uma grande quantidade de informações científicas, muitas vezes complexas, a públicos variados e num curto espaço de tempo, foi um dos principais desafios enfrentados pela entidade. Em colaboração com várias partes interessadas e simultaneamente à candidatura a Patrimônio Mundial, o planejamento e a concepção interpretativa foram conduzidos de modo a definir a abordagem a ser utilizada para contar a história natural e cultural em Joggins. O plano interpretativo promoveu o aprendizado por livre escolha, por meio de vários mecanismos de acesso que auxiliam os indivíduos na formulação de conclusões por si próprios. O instituto desenvolveu materiais educativos que permitem o ensino da ciência de uma forma que prepara as pessoas, não apenas para compreenderem a geologia, mas também para a abordarem de forma crítica. Pesquisas em curso no novo Centro Joggins Fossil dão apoio adicional aos visitantes no reconhecimento do grau de incerteza associado à paleontologia, conectando-os ao método científico. Cientistas, educadores, designers e leigos validaram as mensagens e a abordagem na comunicação do significado das Falésias fossiliferas de Joggins de forma inovadora, envolvente e até divertida (Boon and Calder, 2008).

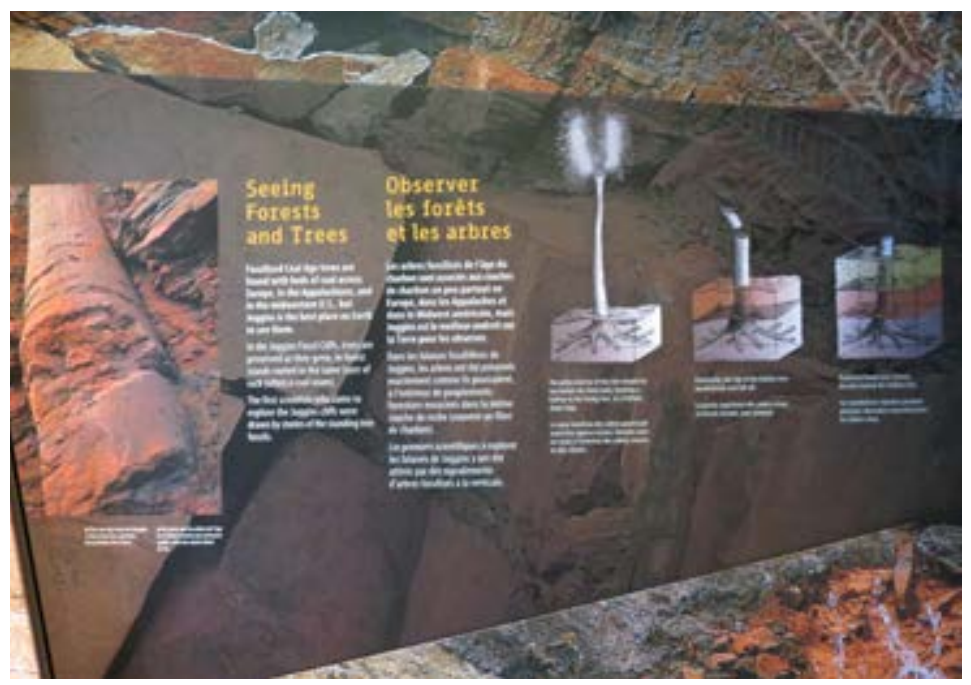

Foto 8.11 Uma exposição de fácil entendimento sobre a formação das árvores fósseis nas Falésias fossilíferas de Joggins. @ Roger Crofts 


\section{Caixa 8.2 \\ Promover a educação e a formação: Um curso on-line sobre geoparques globais}

Um novo curso on-line foi desenvolvido na Universidade do Minho, em Portugal, (https://cursosonline.uminho.pt/EN/geoparks4/ Pages/default.aspx) para auxiliar equipes de áreas protegidas inseridas em geoparques mundiais da UNESCO a atender às necessidades de mais informação sobre seus princípios e estratégias. O curso é dirigido tanto àqueles que pretendem se envolver em projetos de geoparques como a um público mais geral. O curso de quatro semanas é composto por quatro módulos: (1) conceitos gerais sobre geoparques; (2) estruturas e estratégias de geoparques; (3) geoparques como ferramentas para o desenvolvimento sustentável; e (4) Programa Internacional de Geociências e Geoparques da UNESCO. A universidade fornece um certificado para os que concluem o curso. A primeira edição do curso foi realizada em português, em abril de 2016, com 23 estudantes de diferentes países (Argentina, Brasil, Chile, Equador, Itália, México e Portugal). A fim de aumentar o número de estudantes potenciais, as edições em inglês do curso começaram em outubro de 2016. O curso on-line é uma forma eficiente de garantir uma educação de alta qualidade para pessoas interessadas em trabalhar em geoparques mundiais e também de promover a formação das equipes de geoparques existentes, com a flexibilidade de estudar em qualquer lugar e em qualquer horário pela Internet.

Um exemplo mais local é fornecido pela Sociedade Geológica da Espanha (SGE), que organiza uma atividade de divulgação pública anual em nível nacional no dia 5 de junho: o Geolodía, ou o Dia da Geologia. O Geolodía é uma iniciativa de sensibilização pública e educação ambiental baseada na interpretação do patrimônio geológico e na explicação dos processos geológicos que ocorrem na natureza. O Geolodía nasceu como resultado de uma análise que mostrou que a compreensão da geologia por parte do público é insuficiente. A participação tem aumentado desde a primeira edição, em 2005. O evento consiste principalmente em visitas de campo guiadas por geólogos. A SGE, membro da UICN, decidiu em 2010 fazer do Geolodía uma iniciativa nacional, após vários anos de sucesso a nível local.

\section{Boa Prática $\mathrm{n}^{\circ}$ 20: Determinar a natureza e as características do público alvo na concepção de uma divulgação eficaz em geoconservação.}

\subsection{Comunicação por novos meios digitais}

Os alvos de uma estratégia de comunicação variam desde o público em geral, para o qual é necessária uma estratégia interpretativa abrangente; grupos de vários níveis, para os quais requer-se uma abordagem mais focada, com objetivos educacionais; até grupos específicos da comunidade e partes interessadas referidas anteriormente (Seção 8.3), para os quais é necessária uma estratégia ainda mais focada. Esta subseção sobre meios digitais e a subseção seguinte, sobre meios tradicionais, descrevem mais detalhadamente as ferramentas disponíveis para atingir todos estes públicos.

\section{Aplicativos para dispositivos móveis}

Os aplicativos - programas desenvolvidos especificamente para utilização em pequenos dispositivos informáticos sem fio - são particularmente eficazes na comunicação do geopatrimônio. Por exemplo, muitos parques do Sistema de Parques Nacionais dos EUA desenvolveram aplicativos para auxiliar e informar os visitantes por meio do Centro de Mídias Interpretativas (US National Park Service, 2019). Estes aplicativos têm desempenhado um papel importante na ampliação da divulgação de áreas protegidas, conectando os visitantes virtuais aos recursos de aprendizagem.

Há espaço para novas ideias e para o aumento do uso destes aplicativos aplicados aos valores do patrimônio geológico. Por exemplo, um aplicativo pode ser utilizado para disponibilizar conteúdos desenvolvidos por guarda-parques, tais como instruções sobre o trajeto de automóvel a áreas de interesse. 0 aplicativo pode também apresentar conteúdos adicionais sobre sítios de interesse específicos da área protegida. O objetivo geral seria ter um guia virtual que falasse aos usuários, conectando-os a mais conteúdos, caso se interessem em saber mais.

\section{Outras abordagens digitais em comunicação}

As ferramentas digitais revolucionaram a ciência e vêm impulsionando novas abordagens ao geopatrimônio e ao geoturismo. A geoinformação, a geovisualização, o monitoramento digital e os SIG desempenharam um papel importante no desenvolvimento de novos métodos de avaliação e cartografia, bem como na avaliação de geossítios para turismo e educação. Os meios digitais têm revolucionado a interação direta entre uma instituição e sua base mundial de usuários. O volume de Junho de 2014 da Geoheritage foi uma edição especial sobre "Novas Tecnologias Digitais Aplicadas à Gestão do Patrimônio Geológico" (Cayla et al., 2014). Com respeito à representação digital, o volume aborda georreferenciamento e mapeamento do geopatrimônio, imagens digitais 3D (incluindo fotogrametria e digitalização a laser) e experiências na promoção do patrimônio geológico com o uso de realidade aumentada (um processo que enriquece a descoberta por meio de recursos digitais ou fornece uma realidade virtual com a qual se pode interagir). Montanhas e sistemas de cavernas e carste são utilizados como estudos de caso. São apresentados métodos e técnicas de webmapping para avaliação e promoção do patrimônio geológico, utilizando a plataforma Google Maps API para divulgação de inventários de geossítios identificados na Suiça, tanto em escala nacional como regional.

Em outro estudo de caso, foram selecionados quatro geossítios vulcânicos na República Tcheca para apresentar novas tecnologias de comunicação dos resultados recentes de pesquisas científicas a um público não-especializado mais amplo. Os resultados de cada sítio vulcânico foram resumidos e transformados em imagens utilizadas em animações 3D. As mesmas fontes utilizadas para as animações 3D foram também usadas para a geração de modelos virtuais de realidade aumentada. Os produtos foram testados em crianças em idade escolar e os resultados indicam que o uso de métodos modernos na popularização do geopatrimônio vulcânico são altamente atrativos (Rapprich et al., 2017). 


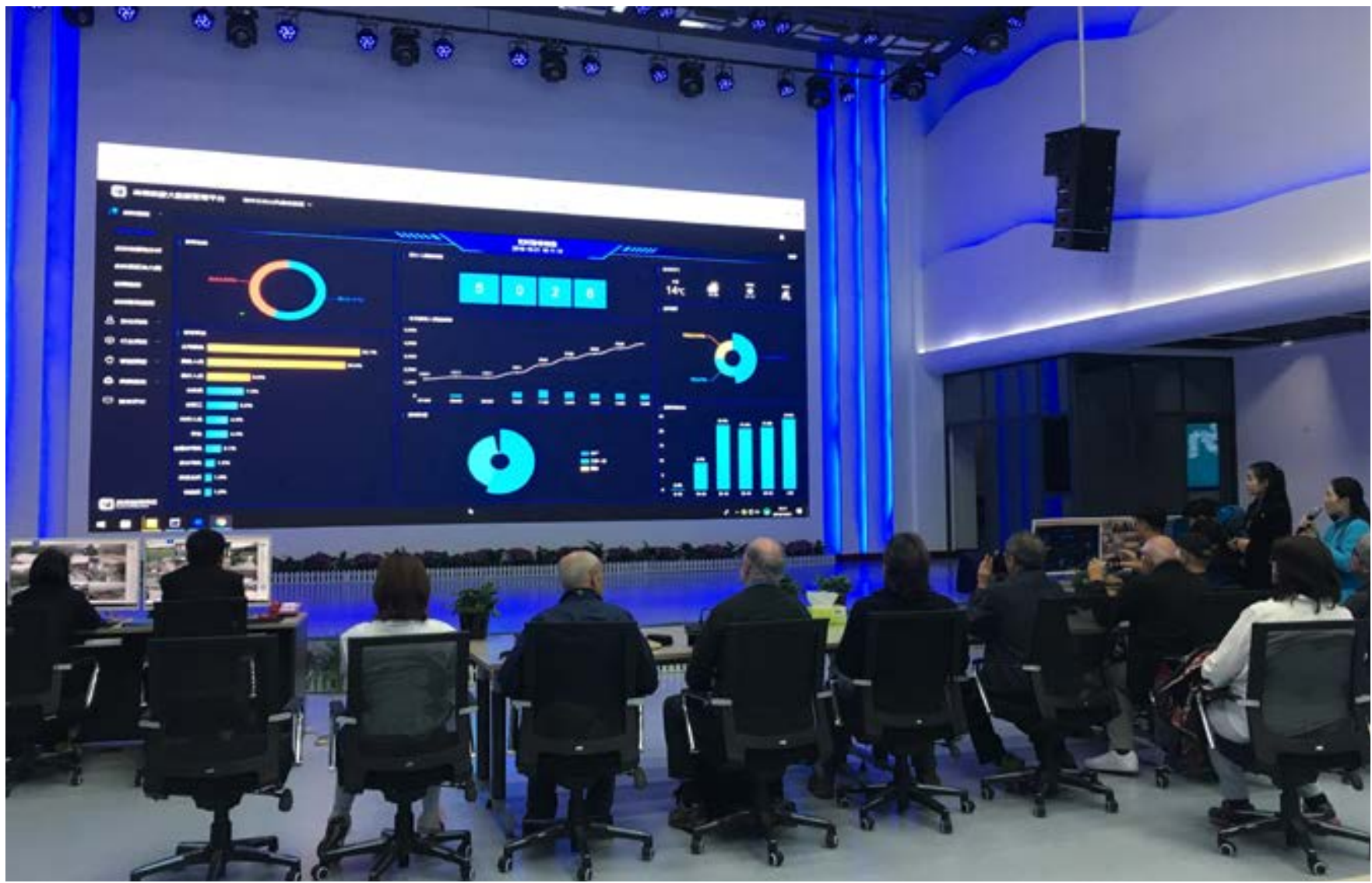

Foto 8.12 Sala de controle no Geoparque Mundial Yuntaishan, Henan, China, registrando toda a atividade da área protegida e outras informações. () Dan Tormey

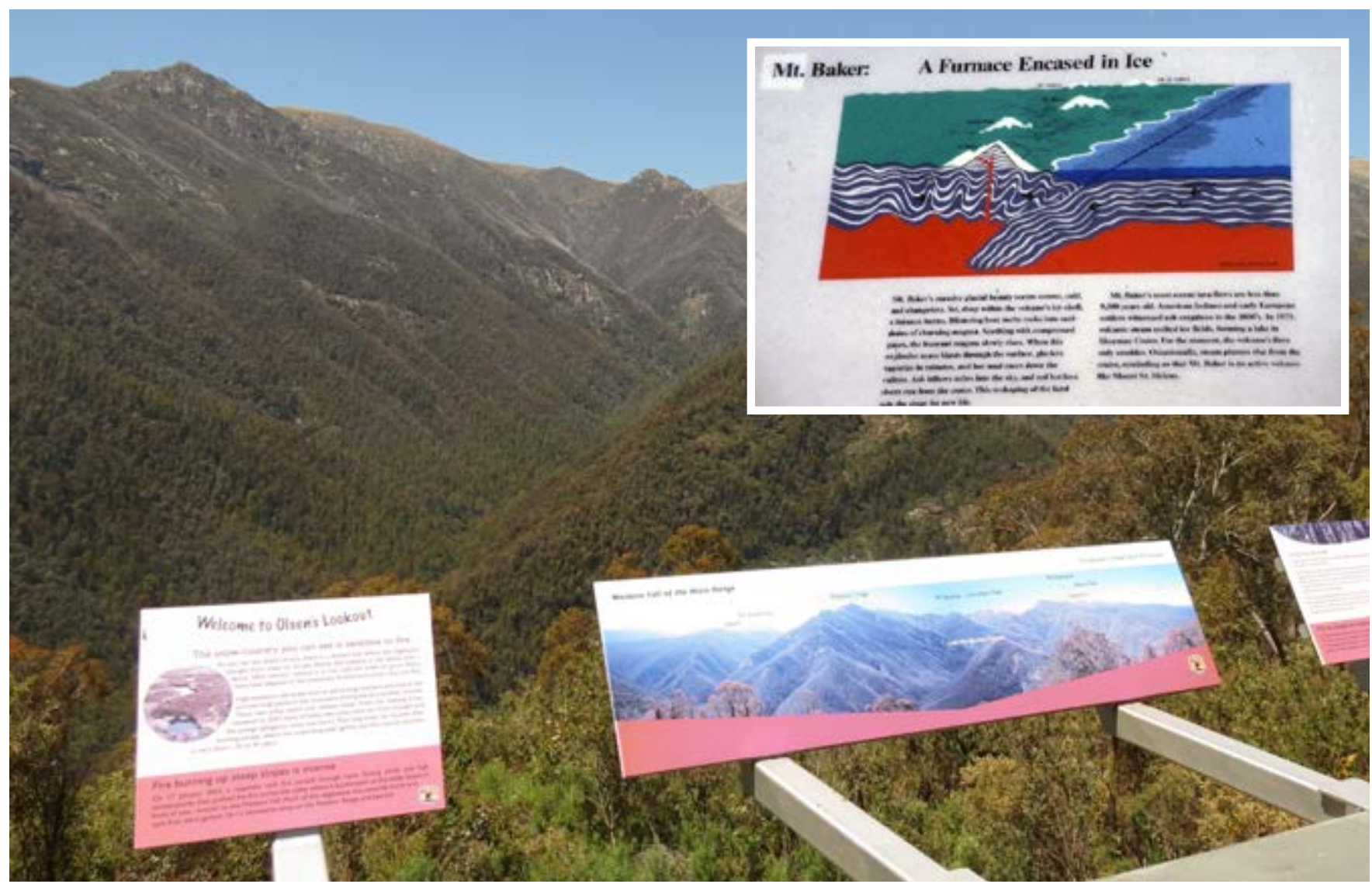

Fotos 8.13 e 8.14 Colocar placas em mirantes e em trilhas, desde que de forma discreta, proporciona um benefício adicional aos usuários, como mostrado nas duas fotos. Parque Nacional Kosciuszko, Nova Gales do Sul, Austrália (esquerda) e Parque Nacional Mount Baker, Estado de Washington, EUA (no topo à direita). @ Roger Crofts 
O Street View da Google é um recurso valioso para explorar o patrimônio geológico, uma vez que nos transporta visualmente para muitos locais espetaculares no país e em todo o mundo. O Street View permite que se investigue um local mesmo não o conhecendo bem, o que pode resultar em importantes aprendizagens. O verdadeiro poder e diversão do Street View é que este permite a exploração movendo a sua perspectiva visual em torno da imagem; instruções muito úteis para a aplicação desta ferramenta ao patrimônio geológico podem ser encontradas em: (http://www. earthsciweek.org/classroomactivities/geoheritage-google-street-view).

O advento e rápido crescimento das redes sociais e da comunicação via internet revolucionaram a divulgação da informação, incluindo dados sobre patrimônio geológico e geoconservação, bem como a capacidade das pessoas de se corresponderem e se conectarem. A comunicação do tipo um para um, um para muitos e muitos para muitos nunca foi tão fácil, desde as escalas hiperlocais às globais. O público já não depende apenas de fontes tradicionais de comunicação de massa para receber notícias e informações.

Boa Prática $n^{\circ}$ 21: Incluir planejamento interpretativo, programas de educação ambiental em ambientes externos e interpretação com base na internet ou em aplicativos para dispositivos móveis em áreas protegidas destinadas à geoconservação, a fim de atrair visitantes e melhorar a compreensão da geoconservação e a experiência do visitante.

\subsection{Comunicação por meios convencionais}

As mídias convencionais (imprensa escrita, televisão, rádio) são essenciais para alcançar uma audiência maior mas, na maioria das vezes, o trabalho a ser feito para comunicar geopatrimônio ao público e aos principais interessados, começa muito antes de fornecer qualquer informação aos meios de comunicação (Cohen, 2015). Em relação às mídias convencionais, é importante informar as pessoas ou grupos que se sintam diretamente afetados por qualquer informação que venha a ser divulgada. Na prática, isto quer dizer que os principais interessados não devem tomar conhecimento de planos que os afetem diretamente por meio de um jornal, sem terem sido avisados previamente. Isto exige um plano de comunicação mais amplo, que identifique objetivos e ações de comunicação, no qual a mídia seja apenas um elemento no processo de comunicação - não o primeiro e, certamente, não o único.

Os gestores de áreas protegidas utilizam os meios de comunicação para alcançar um público amplo, utilizando mensagens e informações que apoiem os objetivos de gestão, seja por meio da sensibilização e da compreensão das justificativas para as ações, seja para alcançar a confiança e a cooperação do público porque compreendem e apoiam os objetivos. Os meios de comunicação de massa são muito importantes para controlar a forma como as mensagens sobre conservação e sobre a entidade gestora da área protegida são recebidas em todo o mundo.

Os meios de comunicação desempenham um papel importante na construção de argumentos sobre um tema de importância para a gestão de áreas protegidas. Seja sobre gestão de incêndios ou pragas ou questões relacionadas ao acesso de visitantes, um plano de mídia cuidadosamente elaborado pode ser muito útil para fazer a opinião pública pender na direção certa. Isso pode ser feito encontrando-se situações e circunstâncias diretamente relacionadas com a questão e promovendo-as nos meios de comunicação durante um certo período, de forma que continuem a validar e a reforçar o seu argumento.

Tomemos o exemplo da comunicação de risco geológico e da restrição do acesso a áreas protegidas. Os processos geológicos resultam em terremotos, erupções vulcânicas, tsunamis e outros riscos geológicos que podem afetar o acesso a áreas protegidas. Para destacar e promover o compromisso da entidade gestora da área protegida com a segurança no uso da área, mensagens apoiadas por fatos e números atualizados, vídeos, fotografias devem ser preparadas, além de uma sólida presença nas mídias sempre que possível. Isto transforma o aspecto negativo da restrição em um aspecto positivo de interpretação, educação e apreciação das forças naturais protegidas como um geopatrimônio.

\section{Boa Prática n²2: Utilizar várias mídias convencionais para informar o público sobre geoconservação.}

Alguns princípios gerais para interpretação e educação em geopatrimônio são apresentados na Tabela 8.1.

\section{Tabela 8.1. Alguns princípios gerais para interpretação e educação em geopatrimônio.}

1. Incorporar o planejamento interpretativo à concepção de áreas protegidas destinadas à geoconservação.

2. Evitar termos geocientíficos complexos e privilegiar o uso de linguagem cotidiana, tornando-a informativa, interessante e divertida.

3. Projetar a interpretação com base na habilidade do usuário em compreender a complexidade da história e dos processos terrestres representados numa área protegida.

4. Ampliar a compreensão por meio da relação entre o que as pessoas veem e as rochas e estruturas subjacentes.

5. Apontar as relações entre as rochas e os solos da área protegida e a flora e a cobertura de superfície.

6. Oferecer descrições de fácil compreensão sobre a origem das feições associadas ao patrimônio geológico da área protegida.

7. Fornecer informações sobre a área no contexto da história da Terra para melhorar a compreensão das forças naturais que atuaram na sua evolução.

8. Disponibilizar perspectivas visuais da paisagem e do que está por baixo em diferentes escalas.

9. Estabelecer relações entre o patrimônio geológico da área protegida e a história cultural e econômica humana. 


\section{Visão geral}

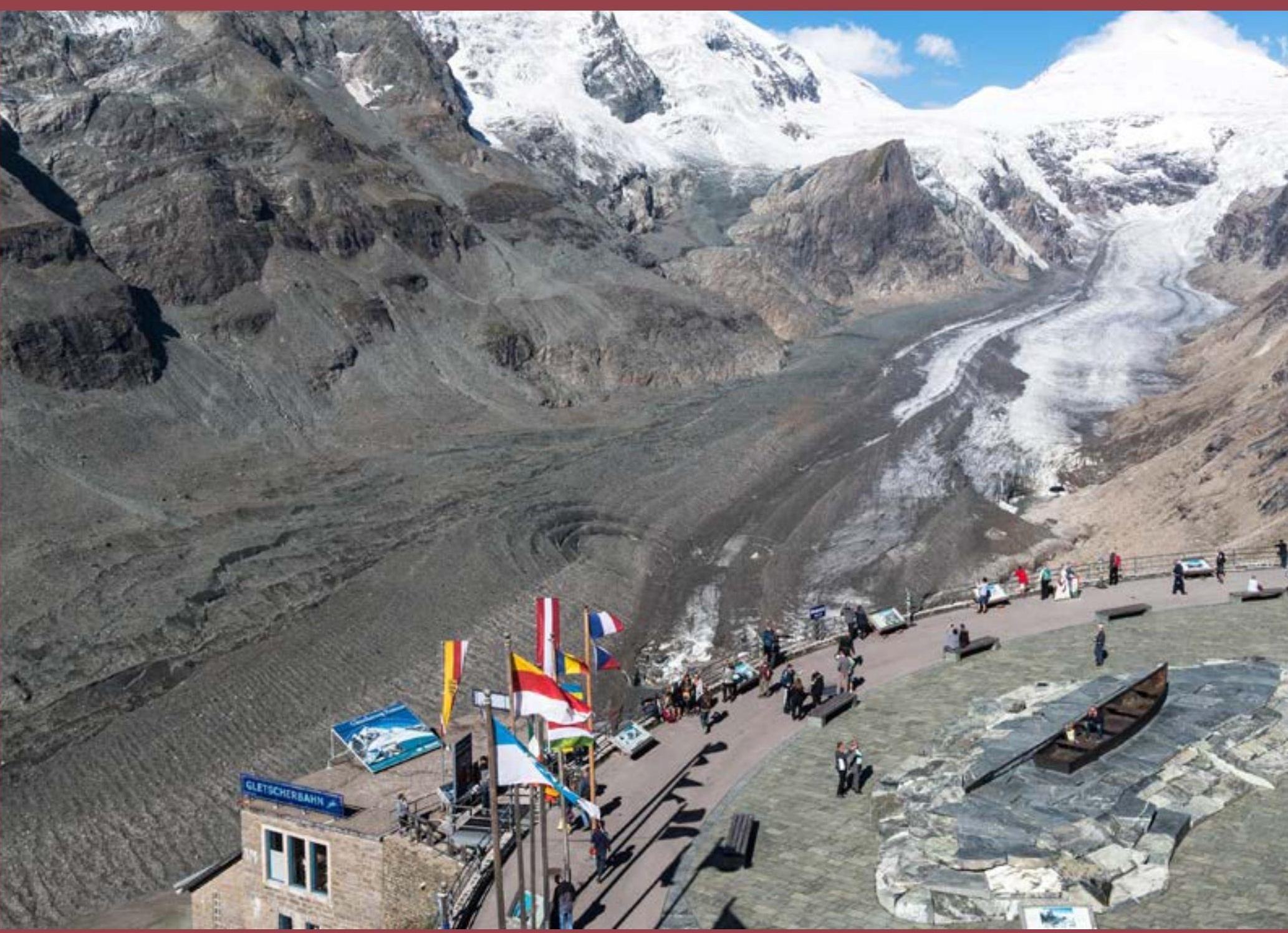

Exemplo de gestão integrada de áreas protegidas, no Parque Nacional Hohe Tauern, Áustria. Perspectiva espetacular para o Grossglockner, a montanha mais alta da Áustria, com o interesse científico relacionado ao recuo do glaciar Pasterze, devido às mudanças climáticas, disponibilizando infraestruturas para os

visitantes apreciarem a área e aprenderem sobre ela, bem como a oportunidade de escalar a montanha e visitar o glaciar. @) John Gordon 
Estas Diretrizes de Melhores Práticas de geoconservação em áreas protegidas identificam as razões para a proteção, os métodos para se estabelecer e desenvolver um sistema de gestão, como lidar com as ameaças naturais e humanas e como comunicar com o público. É a primeira publicação da UICN sobre este assunto, seguindo-se à redefinição do conceito de área protegida presente nas Diretrizes para Aplicação de Categorias de Gestão de Áreas Protegidas revisadas (Dudley, 2008) o qual inclui toda a natureza, abrangendo os elementos abióticos.

\section{A geoconservação tem sido cada vez mais reconhecida} como uma importante componente na criação e na gestão de áreas protegidas, particularmente através de resoluções em Congressos Mundiais de Conservação da UICN, do desenvolvimento do programa de Geoparques Globais da UNESCO e de ações concretas no terreno. Embora não haja uma convenção internacional semelhante à Convenção Sobre Diversidade Biológica para conferir um reconhecimento formal, a Declaração de Digne (citada na Seção 2) é a manifestação mais parecida. O trabalho desenvolvido pelo Grupo de Especialistas em Geopatrimônio da WCPA-UICN é uma referência que pode ser usada por todos aqueles envolvidos em áreas protegidas e foi a fonte principal para a produção desta publicação.

As diretrizes apresentam abordagens que podem não ser totalmente familiares aos técnicos das áreas protegidas e seus assessores especializados. Nesse sentido, fornecemos uma introdução contextual detalhada sobre geoconservação nas Seções 2 e 3, que esperamos que ajude a melhorar o entendimento sobre o tema e que todos leiam. Também fornecemos um glossário de termos para ajudar o leitor a entender a terminologia e conceitos muitas vezes complexos.

O ponto de partida para a geoconservação em áreas protegidas deve ser o reconhecimento de que, embora o geopatrimônio pareça eterno e imutável, este não é definitivamente o caso. O geopatrimônio pode ser danificado de muitas maneiras por ação humana, como exposto na Seção 6, por exemplo, com a colheita de fósseis ou de outros elementos valiosos, ou inadvertidamente por escavações para construir estradas ou edifícios. Também pode ser naturalmente frágil, devido aos materiais de que é constituído, tais como solos ou lavas facilmente erodíveis, devido a alterações dos cursos naturais dos rios, a mudanças no nível do mar e aos efeitos das mudanças climáticas globais, cada vez mais presentes.

A consequência dessas mudanças e ameaças significa que o geopatrimônio requer uma gestão ativa baseada no conhecimento e envolvendo planejamento, monitoramento e avaliação eficazes.

Como referimos, existe uma estrutura teórica e prática robusta para a geoconservação em áreas protegidas. Até hoje, nem sempre esta estrutura foi reconhecida como parte essencial da criação e gestão de áreas protegidas. Estas diretrizes procuram preencher essa lacuna, ajudando os gestores, o pessoal técnico e os seus assessores a ter acesso imediato aos principais tópicos de geoconservação de forma sistemática, aquando de estratégias e ações de conservação.

A geoconservação é importante por si só. Em muitos locais no mundo ela é ou pode ser a única ou principal razão para a existência de uma área protegida. Ela pode assumir uma importância ainda maior quando suas ligações com a conservação da biodiversidade são reconhecidas e geridas de forma adequada. É por isso que enfatizamos, repetidamente, a integração do planejamento e da gestão da conservação da biodiversidade e da geodiversidade em áreas protegidas. O conceito de geodiversidade como "base da natureza", subjacente a muitos processos e funções biológicas e a sua aplicação na gestão efetiva, ajudará ainda mais à interligação da bioconservação e da geoconservação. Este é um caso típico em que o todo, ou seja, toda a natureza em uma área protegida, é maior do que a soma de suas partes individuais. Por outras palavras, é realçada a enorme importância de proteger e gerir a funcionalidade dos ecossistemas em sua totalidade.

Durante grande parte da história humana, os principais valores atribuídos ao que, atualmente, é considerado geopatrimônio foram essencialmente culturais e espirituais. É o caso dos valores de uso relacionados a certos materiais extraídos, tais como rochas, minerais ou pedras preciosas. Daí a importância que atribuímos a este tópico na descrição dos valores e da sua gestão na Seção 5.

Atualmente, existe uma grande quantidade de conhecimento especializado sobre geoconservação. Este está aumentando o tempo todo, como testemunham os artigos da revista Geoheritage e a crescente importância da geoconservação nos objetivos e iniciativas de instituições geológicas e geomorfológicas, como a União Internacional de Ciências Geológicas e a Associação Internacional de Geomorfólogos. Dentro da WCPA da UICN, a dimensão e a experiência do Grupo de Especialistas em Patrimônio Geológico está se expandindo como uma base de aconselhamento e orientação a outros técnicos e cientistas pertencentes à Comissão, assim como para todos que trabalham dentro da família UICN.

As abordagens de geoconservação são sistemáticas em sua lógica e sua aplicação, como esperamos ter demonstrado nas seções anteriores destas diretrizes. Isso significa que uma abordagem de gestão sistemática não só é necessária, como também é relativamente simples de ser implementada. E como sugerimos anteriormente, você, leitor, não está por conta própria, dada a riqueza de conhecimentos especializados disponíveis. É provável que a maioria dos especialistas esteja disposta a ajudar e a aconselhar, sem custos adicionais.

A abordagem da geoconservação em áreas protegidas é diferente da de conservação da biodiversidade. Por exemplo, a duração dos processos geológicos pode ser muito longa, e uma gestão eficaz requer o reconhecimento de que alguns elementos e/ou processos com muitas centenas de milhões de anos podem ser importantes por isso. A proteção de locais especiais que demonstram como a Terra evoluiu é, portanto, uma componente importante da geoconservação. Uma 
frase bem conhecida em geologia: "o passado é a chave do presente", significa que aprender com o passado é relevante para entender a evolução das paisagens e ecossistemas de hoje. Outra diferença é que elementos vulneráveis podem precisar ser soterrados para protegê-los da degradação humana, mas mantendo a capacidade de exumá-los para fins científicos em um momento apropriado no futuro. Em um mundo natural em rápida mudança, também é importante proteger os processos atuais e os elementos geológicos que originam. Esta característica dinâmica proporciona um 'laboratório vivo', requerendo uma abordagem ativa, em vez de uma abordagem estritamente protetora, na gestão das áreas protegidas. Pode ser necessário mais espaço para que os processos naturais evoluam, ampliando a dimensão das áreas protegidas ou designando novas, em vez de tentar fixá-los e controlá-los. Com as mudanças climáticas, a preservação de especificidades da natureza abiótica e biótica pode não ser possível, de modo que uma abordagem adaptativa é essencial, permitindo a evolução do sistema e a construção de resiliência dentro dele.

Os gestores de áreas protegidas não podem limitar-se às tarefas tradicionais de gestão, correndo o risco de se perder um elemento muito importante: a interpretação e a comunicação do geopatrimônio e da sua conservação. Reconhecemos que este é um grande desafio porque a linguagem é muitas vezes demasiadamente complexa, as características geológicas podem ser de dimensão muito grande para a sua fácil compreensão e os especialistas em geologia e geoconservação nem sempre são bons comunicadores para o público em geral e até mesmo para os outros técnicos das áreas protegidas. O uso de abordagens modernas de comunicação, como exposto na seção 8, é o caminho a seguir. Também é vital o uso de comunicadores capazes de interpretar e contar a história da paisagem natural. Eles podem não ser especialistas em geoconservação, mas serão hábeis em desmistificar a ciência e colocar o ouvinte dentro da cena.

Ao longo desta publicação, estabelecemos as Diretrizes de Melhores Práticas. Elas estão deliberadamente redigidas como "ações a tomar" e estão listadas no Sumário Executivo. 


\section{Glossário}

As palavras em itálico correspondem a termos definidos neste glossário.

Afloramento: local onde uma rocha se encontra exposta à superfície, sem estar coberta por solo, vegetação ou estruturas construídas.

Água subterrânea: água armazenada e fluindo através de rochas e sedimentos abaixo da superfície, a partir da infiltração superficial. Durante os períodos de seca, as águas superficiais são alimentadas pela água subterrânea.

Alimentação de praias: deposição artificial de sedimentos numa praia, geralmente areia, proveniente de outra fonte, frequentemente de offshore, para ajudar a manter a estabilidade da praia e reduzir a intensidade da erosão litoral.

Área protegida: espaço geográfico claramente definido, reconhecido, dedicado e gerido, através de meios legais ou outros, de forma a alcançar a conservação da natureza a longo prazo, incluindo os serviços ecossistêmicos e valores culturais associados.

Atividade epitermal: processos que ocorrem a baixa profundidade, com temperatura e pressão também reduzidas, resultando na formação de mineralizações variadas.

Atividade sísmica: movimentos de terra sentidos à superfície, resultantes de atividades tectônicas e vulcânicas na crusta terrestre.

Avaliação ambiental estratégica (AAE): processo sistemático de apoio à decisão, com o objetivo de assegurar que as questões ambientais sejam consideradas de forma eficaz na elaboração de políticas, planos e programas.

Avaliação de Impacto Ambiental (AIA): processo analítico empreendido antes das decisões sobre projetos de desenvolvimento serem tomadas, para evitar consequências adversas imprevistas. O processo envolve a identificação, previsão, avaliação e mitigação dos efeitos naturais, sociais e ambientais relevantes dos projetos de desenvolvimento.

Bacia hidrográfica: área total de um sistema fluvial, desde a nascente até à foz, incluindo todos os seus tributários e as áreas entre eles.

Calcário: rocha sedimentar constituída principalmente por calcita e/ou dolomita, formada pela precipitação de material não orgânico e pela acumulação de material orgânico em ambientes marinhos ou, menos frequentemente, de água doce. Tufo e travertino são exemplos de rochas calcárias formadas em água doce.

Calcário oolítico: calcário formado por oólitos, isto é, partículas esféricas formadas por acreção em redor de um núcleo, em ambientes marinhos profundos.

Câmara magmática: reservatório de rocha fundida (magma) localizado em profundidade, contendo materiais que podem alcançar a superfície (lava) na forma de elementos fluidos, sólidos ou gasosos.

Carste (ou karst): conjuntos de formas de relevo, geralmente incluindo rios subterrâneos, vales cegos e secos, depressões fechadas (denominadas dolinas e poljes de fundo plano), cavernas, formadas em grande parte como um produto da dissolução de rochas que têm uma alta solubilidade em água.

Células sedimentares: segmento da costa onde o sedimento circula entre limites fixos, normalmente designados por saliências costeiras.

Circo: uma forma de relevo em anfiteatro no topo de um vale de montanha, formado pela erosão glaciar e pela ação do gelo, com a consequente fragmentação das paredes rochosas adjacentes.

Conservação do palco natural: conceito relativamente recente onde a flora e fauna são os "atores" e a geodiversidade o "palco" onde elas se desenvolvem. Destaca a importância da interdependência entre biodiversidade e geodiversidade e a sua conservação coordenada.

Cristais: sólido homogêneo natural delimitado por faces planas. Os minerais podem apresentar cristais com dimensão e geometria variadas.

Deposição: (a) queda de partículas transportadas pela água, gelo ou vento, devido à gravidade; (b) precipitação de minerais a partir de uma solução.

Descontinuidade: interrupção nas rochas indicando que ocorreu um lapso de tempo (que pode envolver muitos milhões de anos) entre as camadas inferior e superior. 
Devoniano: Ver Escala de tempo geológico.

Dissolução: passagem de minerais e rochas a uma solução, por ação da água.

Dolina: depressão fechada de dimensões moderadas ( $<1 \mathrm{~km}$ de largura ou profundidade) que constitui uma unidade fundamental de relevo em terrenos cársticos, tendo uma função hidrológica semelhante a uma bacia hidrográfica. O termo "sinkhole" é comumente usado como sinônimo de dolina.

Ecossistemas: um complexo dinâmico de comunidades de plantas, animais e microorganismos e o ambiente não vivo interagindo como uma unidade funcional. Compreende a soma total de todos processos abióticos e bióticos em curso, tais como ciclos biogeoquímicos e produção primária.

- Funcionamento dos ecossistemas: atividade coletiva de plantas, animais e micróbios e os seus efeitos - alimentação, crescimento, locomoção, excreção, etc. - nas condições físicas e químicas do ambiente.

- Serviços de ecossistemas: os benefícios obtidos pelos seres humanos fornecidos pelos ecossistemas. Inclui os serviços de provisão, tais como a produção de alimentos e de água; serviços de regulação, como o controle de doenças e de inundações; serviços culturais, como os benefícios espirituais, recreativos e culturais; e os serviços de suporte, como o ciclo dos nutrientes que mantêm as condições necessárias à vida na Terra (Millennium Ecosystem Assessment, 2005). Os serviços dos ecossistemas são providenciados pela geodiversidade e pela biodiversidade.

- Estrutura dos ecossistemas: a arquitetura biofísica de um ecossistema; a composição e arranjo de toda a matéria física viva e não viva, num determinado local.

Engenharia 'dura': uso de métodos e técnicas pesadas de engenharia que ignoram parcial ou totalmente os processos naturais que decorrem num dado local ou área criando, portanto, uma situação não natural. (Cf. engenharia 'suave').

Engenharia 'suave': uso de abordagens naturais, tais como alimentação de praias ou regeneração de dunas, evitando a construção de estruturas fixas, em oposição à engenharia 'dura'.

Erosão: desgaste dos materiais à superfície terrestre devido à ação de forças naturais como a água, gelo ou vento.

Escala da paisagem: uma abordagem de conservação abrangendo a vasta área de toda uma paisagem, ao contrário do que ocorre numa abordagem pontual em um local particular.

Escala de tempo geológico: sistema de datação cronológica dos estratos geológicos (estratigrafia). É usado pelos geocientistas para descrever o tempo e as relações dos eventos ocorridos ao longo da história da Terra, medidos em milhões e múltiplos de milhões de anos.

Escoamento superficial: fluxo disperso de água à superfície, antes de estar concentrado num canal.

Espeleologia: o estudo científico das cavernas, da sua formação e processos associados.

Espeleotema: termo geral para todos os depósitos minerais formados em cavernas. A maioria é formada por calcita, sendo o processo de precipitação inverso ao processo de dissolução do calcário. As estalactites e estalagmites são exemplos comuns de espeleotemas.

Estratigrafia: ramo da geologia relacionado com a forma, disposição, distribuição geográfica, sucessão cronológica e correlação dos estratos rochosos de origem sedimentar.

Explosão cambriana: súbito e forte aumento do número de espécies registradas em rochas durante o Cambriano (ver Escala de tempo geológico).

Exposição rochosa: local onde rochas ou sedimentos estão visíveis à superfície. Também designada por afloramento.

Extinção: num contexto geológico corresponde a um evento no passado que provocou o desaparecimento, por causas naturais, de um número significativo de espécies.

Extremófilos: espécies que resistem a condições extremas, tais como a escuridão em grutas ou temperaturas muito elevadas relacionadas com atividade vulcânica.

Fenômenos hidrotermais: aqueles que ocorrem onde a atividade geotérmica atinge a superfície sob a forma de água superaquecida e vapor. Estes fenômenos interagem com os materiais vulcânicos formando aspectos especiais como, tais como fontes termais, gêiseres, piscinas de lama e fumarolas.

Fóssil: vestígio da atividade biológica ou um resto de matéria viva do passado enterrado por processos naturais e, posteriormente, preservado nas rochas de forma permanente.

Fumarolas: fonte quente numa zona vulcânica onde existe libertação de água muito quente, vapor de água e gases tóxicos.

Gêiser: ejeção de água superaquecida e vapor, a partir de fontes subterrâneas, em regiões vulcânicas ativas. 


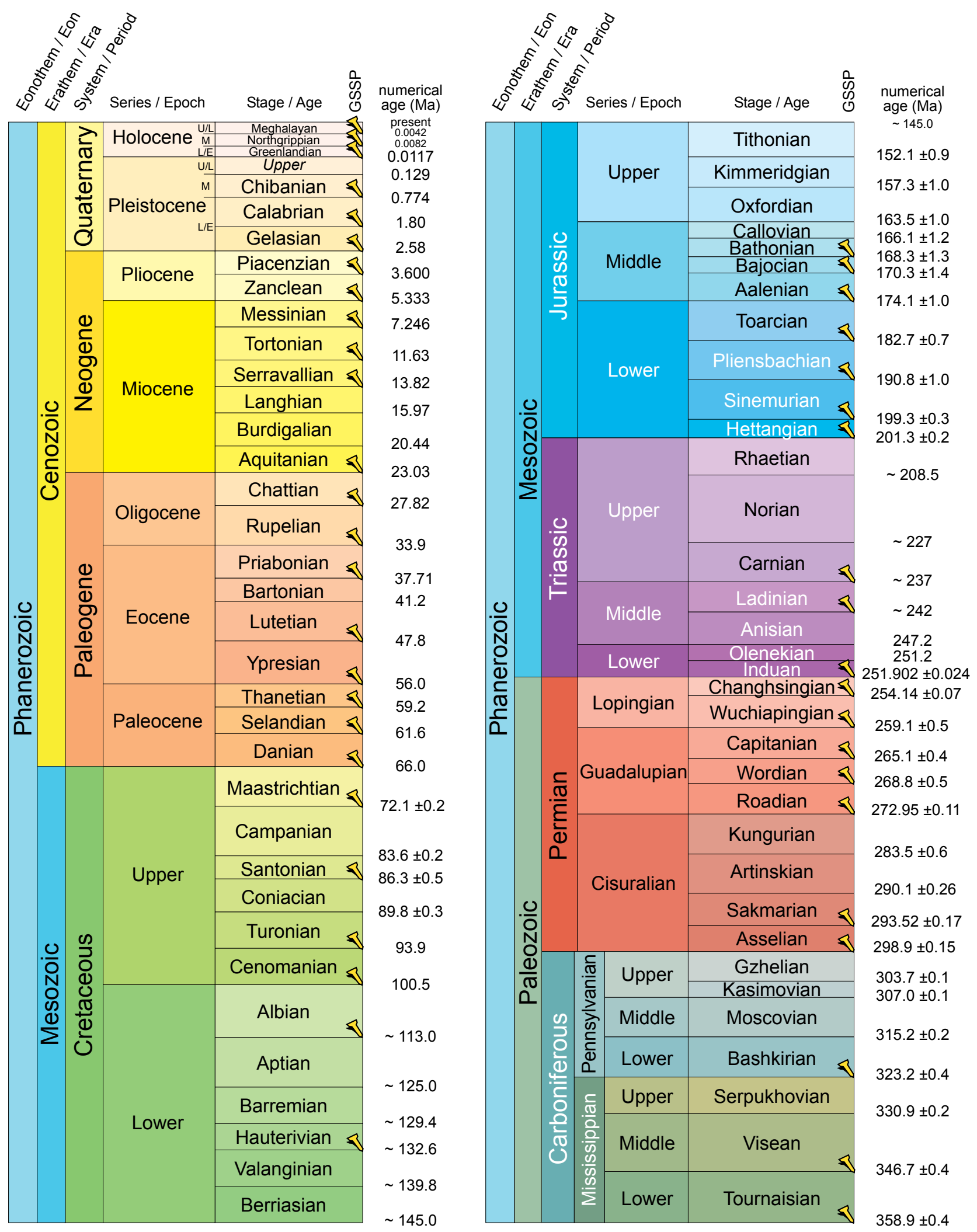




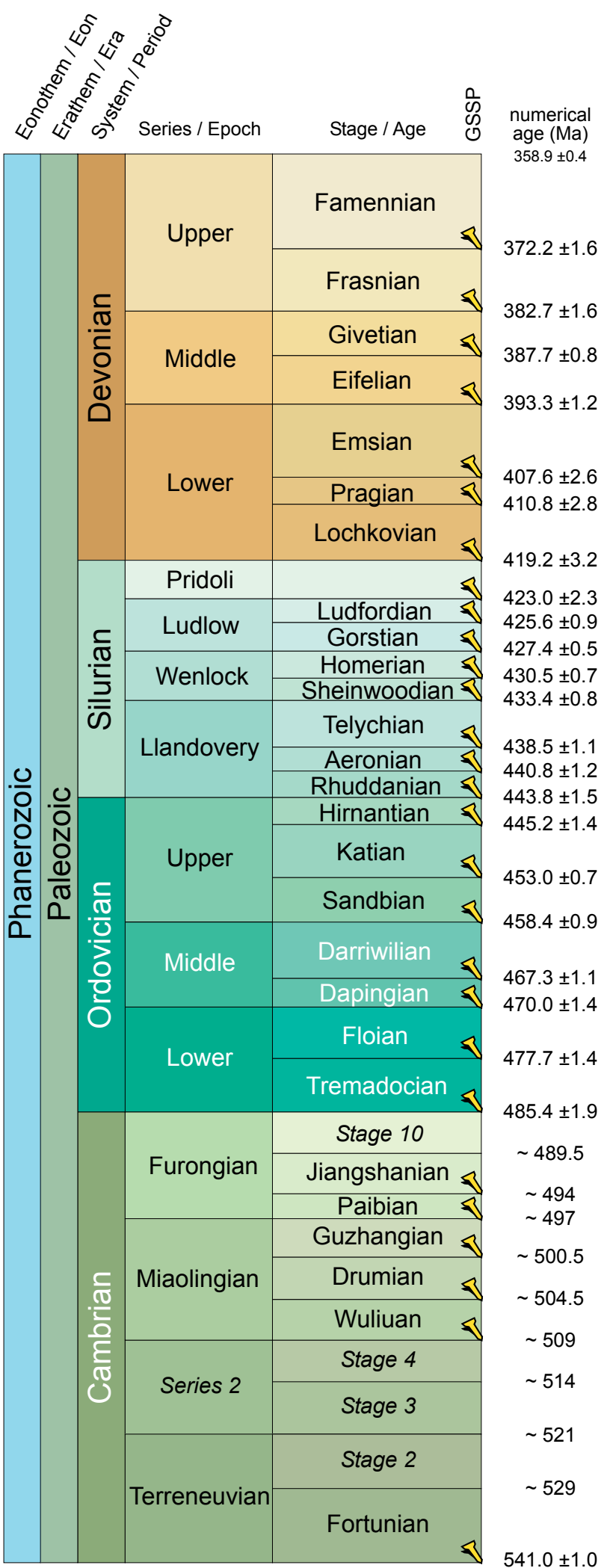

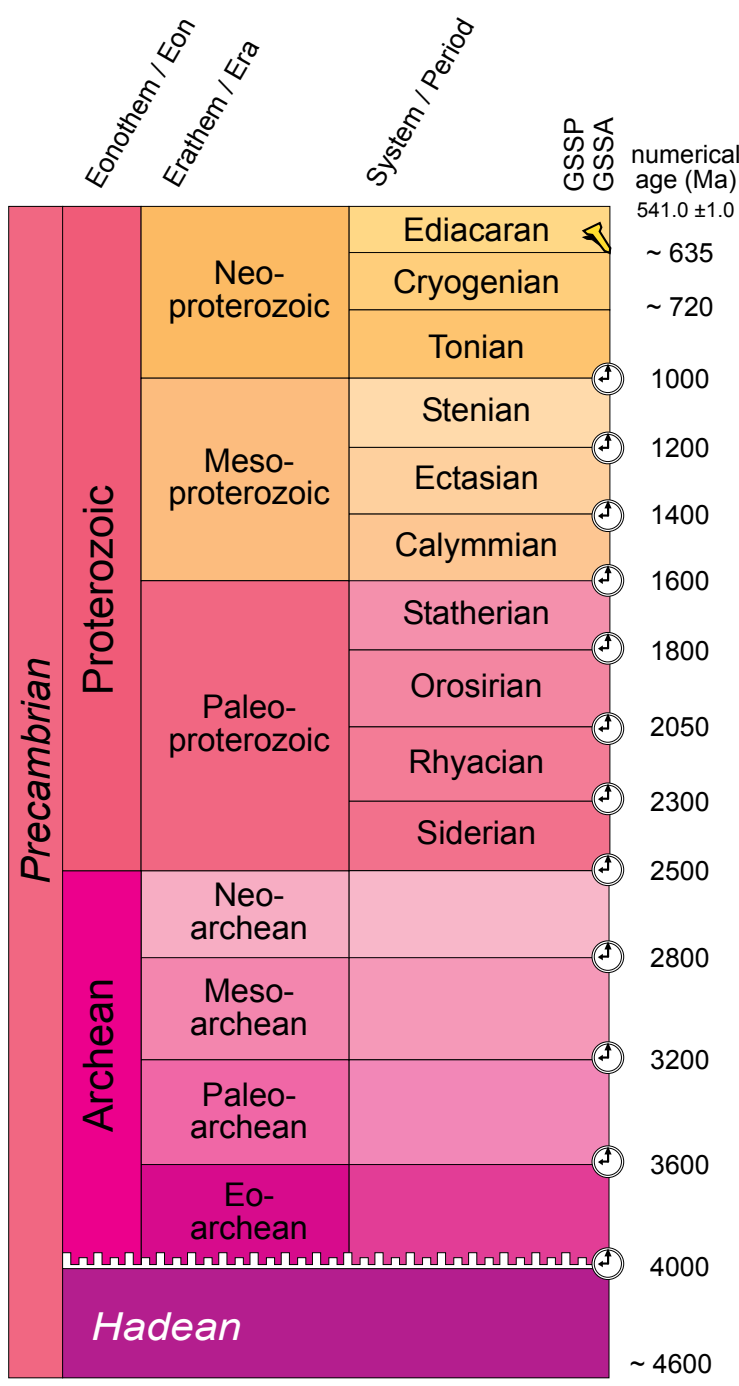

Units of all ranks are in the process of being defined by Global Boundary Stratotype Section and Points (GSSP) for their lower boundaries, including those of the Archean and Proterozoic, long defined by Global Standard Stratigraphic Ages (GSSA). Italic fonts indicate informal units and placeholders for unnamed units. Versioned charts and detailed information on ratified GSSPs are available at the website http://www.stratigraphy.org. The URL to this chart is found below.

Numerical ages are subject to revision and do not define units in the Phanerozoic and the Ediacaran; only GSSPs do. For boundaries in the Phanerozoic without ratified GSSPs or without constrained numerical ages, an approximate numerical age $(\sim)$ is provided.

Ratified Subseries/Subepochs are abbreviated as U/L (Upper/Late), $M$ (Middle) and L/E (Lower/Early). Numerical ages for all systems except Quaternary, upper Paleogene, Cretaceous, Triassic, Permian and Precambrian are taken from 'A Geologic Time Scale 2012' by Gradstein et al. (2012), those for the Quaternary, upper Paleogene, Cretaceous, Triassic, Permian and Precambrian were provided by the relevant ICS subcommissions.

Colouring follows the Commission for the Geological Map of the World (www.ccgm.org)

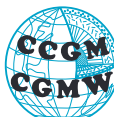

Chart drafted by K.M. Cohen, D.A.T. Harper, P.L. Gibbard, J.-X. Fan (c) International Commission on Stratigraphy, March 2020

To cite: Cohen, K.M., Finney, S.C., Gibbard, P.L. \& Fan, J.-X. (2013; updated) The ICS International Chronostratigraphic Chart. Episodes 36: 199-204.

URL: http://www.stratigraphy.org/ICSchart/ChronostratChart2020-03.pdf 
Geociências: estudo da evolução da Terra e a situação atual de seus aspectos abióticos. O termo compreende a geologia, geomorfologia, geofísica, hidrologia e geografia física.

Geoconservação: conservação e gestão de patrimônio geológico.

Geodiversidade: variedade de rochas, minerais, fósseis, formas de relevo, sedimentos e solos, juntamente com os processos naturais que os formam e os modificam. Inclui aspectos e processos geológicos e geomorfológicos passados e atuais que registram a história da Terra e a evolução das formas de vida, tal como estão representadas no registro geológico, incluindo os fósseis de plantas e animais e seus habitats.

Geoformas (ou formas de relevo): feições superficiais ou subterrâneas originadas por processos naturais, tais como uma morena glaciária, uma duna ou uma caverna.

Geoformas dinâmicas: geoformas em evolução ou em movimento, tais como dunas em desertos ou em zonas costeiras, barras de areia ou de cascalho no leito de rios e acumulações instáveis de solos e rochas em vertentes inclinadas de montanhas.

Geologia: estudo da Terra como um todo, desde a sua origem, estrutura, composição e história, até à natureza dos processos que deram origem ao seu passado e ao seu estado atual.

Geomonitoramento (ou monitoramento das condições do sítio): monitoramento de aspectos e processos particulares para verificar o estado de conservação dos componentes de um geossítio ou de todo o sistema.

Geomorfologia: estudo das formas de relevo (geoformas) e dos processos que as originam, que ocorrem à superfície do planeta ou muito próximo dela.

Geoparque: termo genérico atribuído a uma área com patrimônio geológico excecional, visando tanto a sua conservação quanto a promoção do seu uso de forma sustentável. A maioria dos geoparques não são áreas protegidas, mas podem conter áreas protegidas. Veja também Geoparque Mundial da UNESCO.

Geoparque Mundial da UNESCO: território reconhecido pela UNESCO onde sítios e paisagens de importância geológica internacional são administrados dentro de um conceito holístico de proteção, educação e desenvolvimento sustentável. Os geoparques não são considerados áreas protegidas, mas sim estratégias de envolvimento das comunidades e dos interesses económicos.

Geopatrimônio (ou patrimônio geológico): conjunto de elementos e processos da geodiversidade, quer sejam considerados individualmente ou em combinação, com valor significativo por razões intrínsecas, científicas, educacionais, culturais, espirituais, estéticas, ecológicas ou ecossistêmicas e que, portanto, merecem ser conservados. O geopatrimônio constitui um legado do passado a ser mantido no presente e transmitido para o benefício das gerações futuras. O geopatrimônio registra a história acumulada da Terra preservada nas suas rochas e formas de relevo, como nas páginas de um livro. Ocorre em lugares especiais (ver geossítios) e está representado por objetos (espécimes geológicos in situ e ex situ, em coleções de museus) que são fundamentais para o nosso conhecimento sobre a história da Terra e a evolução da vida.

Geopatrimônio móvel: fósseis, minerais e rochas com valor excecional deslocados para um local ex situ para garantir a sua proteção formando, por exemplo, coleções de museus.

Geossítio: local de ocorrência de um ou vários aspectos geológicos ou geomorfológicos ou processos associados, dignos de proteção por causa do seu valor científico. Versão abreviada de "sítio geológico" ou "sítio geomorfológico".

Geoturismo: turismo sustentável baseado nos aspectos e processos geológicos e geomorfológicos de uma área, desde um local específico, como uma caverna turística, até extensas áreas com paisagens espetaculares.

Glaciação: período de clima frio que resulta na expansão generalizada dos mantos de gelo polares, das calotas e dos glaciares de montanha. As idades do gelo incluem episódios de frio intenso (glaciais) e alternam com períodos mais quentes (interglaciais) quando há uma redução da cobertura de gelo.

Glaciar (ou geleira): corresponde a uma acumulação de neve comprimida que forma um corpo sólido de gelo que se move por ação da gravidade, assumindo várias formas. Os mantos de gelo são extensas camadas de gelo que cobrem grandes áreas como a Antártida e a Gronelândia, podendo ocorrer em áreas menores (calotas) como na Islândia e em Svalbard. As geleiras de vale preenchem vales preexistentes podendo, muitas vezes, alargá-los, como por exemplo nos Andes e nos Alpes.

Gnaisse: rocha metamórfica formada pela temperatura e pressão intensas, exercidas sobre rochas preexistentes.

Granito: rocha magmática com cristais visíveis a olho nu, formada abaixo da superfície da Terra em resultado do arrefecimento lento do magma, formando minerais dos quais o quartzo e o feldspato são dominantes.

GSSP (Global Boundary Stratotype Section and Point): padrão utilizado na identificação das seções-tipo e pontos de referência na definição dos limites dos andares da escala de tempo geológica, de acordo com normas acordadas internacionalmente. A Comissão Internacional de Estratigrafia, integrada na União Internacional de Ciências Geológicas (IUGS) tem a responsabilidade de obter um consenso internacional sobre a definição de unidades padrão globais. No local onde um GSSP é identificado e aprovado é colocado um Prego Dourado simbólico. 
Infiltração: processo pelo qual a água entra à superfície e se desloca para a profundidade, através do solo e das rochas.

Lahar: fluxo de lama ou fluxo de detritos, composto por material piroclástico, detritos rochosos e água, causado por uma erupção vulcânica. Este fluxo desloca-se pelas vertentes de um vulcão, tipicamente aproveitando vales preexistentes.

Lampenflora: algas, musgos e plantas vasculares que crescem sob a luz artificial em cavernas turísticas.

Lava: material fundido com origem num vulcão e que flui à superfície. A lava solidifica à medida que arrefece originando aspectos conhecidos por termos havaianos como "aa" (formas rugosas) e "pahoehoe" (formas encordoadas).

Material parental: rochas ou sedimentos a partir dos quais se formam os materiais sobrejacentes, especialmente os solos.

Minerais: substância inorgânica com uma composição química característica e um arranjo ordenado de átomos, iões ou moléculas, que ocorre por processos geológicos naturais.

Mineralogia: o estudo de minerais, a sua origem, estrutura e composição.

Monitorização das condições do sítio: ver Geomonitorização.

Morenas (ou moreias): geoformas nas margens dos glaciares ou próximo a eles, formadas pela acumulação de sedimentos não consolidados de todos os tamanhos, desde argilas até blocos. As morenas terminais ocorrem na frente de um glaciar e morenas laterais nas zonas contíguas ao glaciar.

Mudanças hidrológicas: alterações na velocidade e no caudal dos fluxos de água em canais e sobre a superfície do solo, causando mudanças na distribuição dos sedimentos não consolidados em direção a jusante.

OMEC (Outras Medidas Efetivas de Conservação baseadas em áreas): área geograficamente definida que não seja uma área protegida, que é governada e gerida de forma a alcançar resultados positivos e sustentáveis a longo prazo para a conservação in situ da biodiversidade, com funções e serviços ecossistêmicos associados. São também conservados valores culturais, espirituais, sócio-econômicos e outros valores localmente relevantes, se for o caso.

Paleontologia: estudo de fósseis de plantas e animais originando um conhecimento sobre a origem e evolução da vida na Terra e respetivos ambientes do passado.

Periglacial: descreve o clima, os processos naturais e as formas de relevo em ambientes frios, não glaciais, em regiões montanhosas ou polares. O processo principal compreende ciclos sucessivos de congelamento e descongelamento do solo, resultando na formação de polígonos com bordos em gelo e padrões no solo (círculos e faixas), na deslocação lenta de fragmentos rochosos pelas encostas e no colapso das rochas.

Período Ediacarano: ver Escala de tempo geológico.

Permafrost: solo permanentemente congelado, principalmente nas regiões polares e nas altas montanhas.

Permiano: ver Escala de tempo geológico.

Petrologia: estudo das rochas, incluindo os constituintes minerais, texturas, estrutura e origens.

Piroclastos: material libertado para a atmosfera pela atividade vulcânica, como pedra-pomes e cinzas, vindo a depositar-se na superfície da Terra.

Plano de ação da geodiversidade: programa de intervenção com metas e objetivos claros de longo prazo, com o estabelecimento de metas e ações mensuráveis a curto prazo, com vista a conservar e reforçar o papel da geodiversidade e do geopatrimônio em uma determinada área. Este programa também identifica o pessoal e os recursos financeiros necessários para a sua implementação. Estes planos podem ainda ajudar na integração da geodiversidade e do geopatrimônio na gestão das diferentes categorias de áreas protegidas.

Planos locais de ação da geodiversidade: planos que estabelecem uma estrutura, princípios orientadores e prioridades para garantir a conservação do geopatrimônio e das redes de geossítios à escala regional ou local.

Pleistoceno: ver Escala de tempo geológico.

Pré-Cambriano: ver Escala de tempo geológico.

Processos ativos: processos abióticos naturais responsáveis pela formação e evolução de formas de relevo e materiais, tais como a deposição de areia ao longo da costa, deposição de areia e cascalho nas margens de geleiras, erupções vulcânicas, deslizamento de terras e erosão.

Processos fluviais: processos naturais terrestres associados com o movimento de água, normalmente em rios.

Quartzo: mineral composto por sílica e presente em rochas ígneas, metamórficas e sedimentares. É um dos minerais mais comuns na Terra e também o principal constituinte da areia nos desertos e nas costas. 
Quaternário: ver Escala de tempo geológico.

Radônio: gás radioativo de ocorrência natural inerte, incolor e inodoro, produzido, em certas rochas, pelo decaimento de minerais ricos em tório e urânio.

Recuo planejado: técnica geralmente aplicada a litorais arenosos, onde se permite que o mar avance sobre a costa, pela remoção de estruturas feitas pelo homem, formando-se pântanos salgados que absorvem a energia das ondas. É utilizado para restaurar a costa de uma forma mais natural.

Risco de degradação: medida da suscetibilidade ou robustez de uma característica particular ou de um processo, de sofrer danos, independentemente de serem produzidos por causas naturais ou antrópicas.

Robustez: capacidade de uma determinada feição ou processo com valor patrimonial de resistir a danos decorrentes de ações naturais ou antrópicas.

Rochas: material sólido que forma parte da crusta terrestre. De acordo com a sua formação, as rochas dividem-se em três tipos principais: sedimentares, ígneas e metamórficas.

As rochas sedimentares são formadas a partir de fragmentos de rochas preeexistentes (sedimentos), depositados pela água, gelo ou vento em rios, lagos e oceanos ou à superfície, e posteriormente transformados de modo a formar material compacto e coeso. As rochas carbonatadas, tais como o calcário ou as margas e as rochas evaporíticas, como o gesso, anidrita e sal, são tipos de rochas sedimentares em áreas cársicas. Calcários, arenitos e argilitos são exemplos comuns de rochas sedimentares.

As rochas ígneas ou magmáticas resultam da lenta solidificação do magma abaixo da superfície terrestre e são chamadas de rochas intrusivas (por exemplo, granito). Estas rochas também podem ser formadas à superfície devido ao arrefecimento da lava associada à atividade vulcânica e são chamadas de rochas extrusivas (por exemplo, basalto).

As rochas metamórficas são rochas previamente formadas por processos sedimentares ou ígneos que foram transformadas em diferentes minerais e estruturas como resultado do aumento da temperatura e/ou pressão, frequentemente associada com o movimento de placas tectônicas ou com a proximidade ao magma. Por exemplo, o mármore resulta do metamorfismo de um calcário.

Rocha branda: rocha facilmente alterada e desgastada pela água, gelo ou vento. Alguns arenitos são um bom exemplo deste tipo de rocha.

\section{Rochas carbonatadas: Ver Rochas.}

Rochas cristalinas: termo antigo referente a rochas constituídas por cristais formados ao longo de um lento arrefecimento, depois de terem estado sujeitas a temperatura e/ou pressão elevadas. Podem ser rochas metamórficas, como o gnaisse, ou rochas ígneas, como o granito (ver definições de tipos específicos de rochas).

Rochas evaporíticas: Ver Rochas.

Rochas ígneas (ou Rochas magmáticas): ver Rochas.

Rochas metamórficas: ver Rochas.

Rochas sedimentares: ver Rochas.

Sedimento: material não consolidado, de dimensões variáveis, desde os mais finos (argilas e siltes), passando por areias grosseiras e seixos, até aos maiores (blocos).

Significância: uma expressão comparativa baseada ou numa característica específica ou rara ou no fato de determinado aspecto ou processo ser o melhor exemplo.

Silicoso: substância cujo principal componente é a sílica (SiO2).

Siluriano: ver Escala de tempo geológico.

Sismo: abalo súbito do solo, habitualmente provocando destruição intensa, em resultado de movimentos na crosta terrestre ou processos vulcânicos explosivos.

Sistemas ativos: feições que ainda estão em formação e desenvolvimento, tais como dunas, vales fluviais, manguezais e solos.

Sítios vulneráveis (“integrity sites”): ocorrência de feições geomorfológicas, quer inativas, tais como geoformas glaciais pleistocênicas, como ativas, tais como geoformas formadas por processos fluviais, costeiros, cársticos ou glaciais.

Sítios extensos ("exposure or extensive sites"): ocorrência de elementos geológicos em grande extensão abaixo do nível do solo e que são renovados pela erosão. Assim, se um afloramento for perdido, outro pode ser criado nas proximidades. Inclui afloramentos em pedreiras ativas e inativas, falésias costeiras e fluviais, cortes de estradas e ferrovias, e afloramentos naturais. 
Sítios limitados ("finite sites"): ocorrência de elementos geológicos em quantidade reduzida. A remoção de uma parte da rocha pode danificar ou mesmo destruir estes elementos. Por exemplo, sítios geológicos com fósseis raros ou veios e filões mineralizados.

Solo: material composto de partículas minerais e matéria orgânica que se sobrepõe ao substrato rochoso, suportando o crescimento das raízes das plantas.

Soluções baseadas na natureza: ações para proteger, gerir de forma sustentável e restaurar ecossistemas naturais ou modificados, destinadas a responder aos desafios da sociedade de forma eficaz e adaptável, proporcionando simultaneamente bem-estar humano e benefícios para a biodiversidade.

Tectônica de placas: teoria unificadora que combina deriva continental, expansão do fundo oceânico, atividade sísmica e vulcânica, e estruturas da crosta terrestre. Na Terra, os blocos rochosos nos continentes e nos fundos oceânicos estão divididos em oito placas maiores e várias placas menores rígidas que estão em movimento, umas em relação às outras. Este termo também se refere ao estudo destes movimentos relativos ao longo do tempo que conduzem à formação de continentes e oceanos. As margens das placas podem ser de vários tipos; para a geoconservação, as mais importantes correspondem à colisão de placas e ao seu afastamento. Exemplos das primeiras são as margens entre as placas do Pacífico e da América do Norte, as placas do Pacífico e da América do Sul, as placas Africana e Euroasiática, e as placas Indiana e Eurasiática, todas elas desempenhando um papel fundamental na evolução dos principais sistemas montanhosos e na atividade vulcânica. Em outros lugares, as placas afastam-se; os melhores exemplos podem ser vistos na Islândia e sob o mar, ao longo da Cordilheira Médio Atlântica.

Terreno: área onde as rochas e estruturas são de idade e tipo similares e com uma história geológica inicial semelhante.

Tor: conjunto empilhado de blocos rochosos in situ formado pela alteração das rochas circundantes mais brandas e seu posterior desmantelamento.

Tsunami: série de ondas grandes e rápidas na superfície do mar, causada por sismos associados ao movimento nas margens de placas tectônicas.

Vale de rifte: zona deprimida alongada, delimitada de ambos os lados por falhas. O vale de rifte da África Oriental é um exemplo.

Vale em U: vale com vertentes íngremes e um fundo aplanado, formado pela erosão glacial.

Valor: o patrimônio geológico pode ter diversos tipos de valor. O valor intrínseco significa que o geopatrimônio é importante apenas por existir, independentemente da apreciação humana. O valor científico está relacionado com a importância para pesquisa e educação. Valores estéticos, culturais e espirituais referem-se à ligação, interação e apreciação antrópica do geopatrimônio. O valor ecológico está relacionado com o apoio à biodiversidade e ao funcionamento dos ecossistemas. A diversidade de substrato e solos, juntamente com processos como regimes de fluxo de água, fornecimento de sedimentos, erosão e deposição, fornecem as bases para habitats e espécies e para o funcionamento do ecossistema. Os valores dos bens ambientais e serviços ecossistêmicos estão relacionados com os benefícios diretos e indiretos que a sociedade recebe do meio ambiente natural e do funcionamento adequado dos ecossistemas.

Vulcão: geoforma construtiva formada por material que atinge a superfície da Terra através de uma abertura ou fratura a partir do interior da Terra. Os materiais que entram em erupção podem estar fundidos - lava (às vezes com cristais), sólidos - piroclastos e gasosos - vapor de água e gases ácidos. Os tipos de erupção variam desde episódios lentos e efusivos a súbitos e explosivos. Vulcões de grande dimensão são frequentemente designados por vulcões centrais ou por supervulcões devido ao elevado poder eruptivo com material piroclástico amplamente disperso ao redor do mundo através da circulação atmosférica. Os vulcões estão frequentemente, mas nem sempre, associados aos movimentos na margem das placas tectônicas. A composição química do material que é emitido pelos vulcões é variável e varia desde um caráter ácido a alcalino.

Vulnerabilidade: medida da probabilidade de um aspecto ou processo geológico ser afetado por causas naturais ou antrópicas. É normalmente determinada considerando a sensibilidade à mudança e a capacidade de adaptação à mudança. 


\section{Referências}

Anderson, M. G. and Ferree, C. E. (2010). 'Conserving the stage: Climate change and the geophysical underpinnings of species diversity'. PLoS ONE 5:e11554. https://doi.org/10.1371/journal.pone.0011554

Anderson, M. G., Clark, M. and Sheldon, A. O. (2014). 'Estimating climate resilience for conservation across geophysical settings'. Conservation Biology 28:959-970. https://doi.org/10.1111/cobi.12272

Appleton, P., Buttler, C., and Roberts, R. (2015). 'Making the most of Brymbo's plant fossils'. Earth Heritage 43:21-23.

http://www.earthheritage. org. uk/wp/wp-content/uploads/2018/03/eh43F.pdf

Ballantyne, C. K. (2018). Periglacial Geomorphology. Chichester, UK: Wiley-Blackwell.

https://www.wiley.com/en-us/Periglacial+Geomorphology-p-9781405100069

Barthlott, W., Mutke, J., Rafiqpoor, M. D., Kier, G., and Kreft, H. (2005). 'Global centres of vascular plant diversity'. Nova Acta Leopoldina 92:61-83. https://www.researchgate. net/publication/215672852 Global centers of vascular plant diversity

Benn, D. I. and Evans, D. J. A. (2010). Glaciers and Glaciation. London, UK: Hodder Education. https://www.amazon.co.uk/ Glaciers-Glaciation-Hodder-Arnold-Publication/dp/0340905794

Bernbaum, E. (1997). Sacred Mountains of the World. Berkeley, California: University of California Press.

https://www.worldcat.org/title/sacred-mountains-of-the-world/oclc/37533947

BirdLife/FFI/IUCN/WWF. (2014). Extraction and Biodiversity in Limestone Areas. Joint Briefing Paper.

https://www.birdlife.org/sites/default/files/Extraction-and-Biodiversity-in-Limestone-Areas.pdf

Bollati, I., Smiraglia, C. and Pelfini, M. (2013). 'Assessment and selection of geomorphosites and trails in the Miage Glacier area (Western Italian Alps)'. Environmental Management 51:951-967. https://doi.org/10.1007/s00267-012-9995-2

Boon, J. and Calder, J. (2008). 'Communicating the natural and cultural history of the Joggins Fossil Cliffs: A demonstration of innovation and collaboration'. Atlantic Geology 44(1). https://www.sciencedirect.com/science/article/pii/\$2577444120300046

Borrini-Feyerabend, G., Dudley, N., Jaeger, T., Lassen, B., Pathak Broome, N., Phillips, A. and Sandwith, T. (2013). Governance of Protected Areas: From Understanding to Action. Best Practice Protected Area Guidelines Series No. 20, Gland, Switzerland: IUCN. https://portals.iucn.org/library/node/29138

Borrini-Feyerabend, G. and Hill, R. (2015). Governance for the conservation of nature. In: Worboys, G. L., Lockwood, M., Kothari, A., Feary, S. and Pulsford, I. (eds). Protected Area Governance and Management, pp. 169-206, Canberra: Australian National University Press. http://press-files.anu.edu.au/downloads/press/p312491/pdf/CHAPTER7.pdf

Brandolini, P. and Pelfini, M. (2010) 'Mapping geomorphological hazards in relation to geotourism and hiking trails'. In: G. RegoliniBissig and E. Reynard (eds.). Mapping Geoheritage, pp. 31-45. Lausanne, Switzerland: Institut de Géographie, Géovisions 35. http://www.unil.ch/igd/files/live/sites/igd/files/shared/Geovisions/Geovisions35/Geovisions35 IGUL 3 Brandolini\%20\&\%20Pelfini.pdf

Brantley, S., and Myers, S. (2000). 'Mount St. Helens: From the 1980 eruption to 2000'. USGS Fact Sheet 036-00.

https://pubs.usgs.gov/fs/2000/fs036-00/

Bridgland, D.R. (2013). 'Geoconservation of Quaternary sites and interests'. Proceedings of the Geologists' Association 124:612624. https://doi.org/10.1016/j.pgeola.2012.10.004

Brilha, J. (2016). 'Inventory and quantitative assessment of geosites and geodiversity sites: A review'. Geoheritage 8:119-134. https://doi.org/10.1007/s12371-014-0139-3

Brilha, J. (2018). ‘Geoheritage: inventories and evaluation'. In: E. Reynard and J. Brilha (eds.). Geoheritage: Assessment, Protection, and Management, pp. 69-85. Amsterdam: Elsevier. https://doi.org/10.1016/B978-0-12-809531-7.00004-6

British Caving Association. (Undated). Minimal Impact Caving Guidelines.

https://british-caving.org.uk/wiki3/lib/exe/fetch.php?media=conservation access:micg.pdf.

British Columbia. (2003). Karst Management Handbook for British Columbia. Victoria, BC, Canada: British Columbia Ministry of Forests. https://www.for.gov.bc.ca/hfp/publications/00189/Karst-Mgmt-Handbook-web.pdf.

British Columbia. (2020). Online Karst Management Training Module. https://www2.gov.bc.ca/gov/content/industry/forestry/ managing-our-forest-resources/managed-resource-features/best-practices-for-karst-management-training-module. 
Brocx, M. and Semeniuk, V. (2007). 'Geoheritage and geoconservation - history, definition, scope and scale'. Journal of the Royal Society of Western Australia 90:53-87. https://www.researchgate.net/publication/285012358 Geoheritage and geoconservation - History definition scope and scale

Brocx, M. and Semeniuk, V. (2011). 'Assessing geoheritage values: A case study using Leschenault Peninsula and its estuarine lagoon, south-western Australia'. Proceedings of the Linnaean Society of New South Wales 132:115-130.

https://researchrepository.murdoch.edu.au/id/eprint/18640/1/assessing geoheritage values.pdf

Brocx, M. and Semeniuk, V. (2015). 'Using the Geoheritage Tool-Kit to identify inter-related geological features at various scales for designating geoparks: Case studies from Western Australia'. In: E. Errami, M. Brocx, and V. Semeniuk (eds.). From Geoheritage to Geoparks: Case Studies from Africa and Beyond, pp. 245-259. Cham, Switzerland: Springer.

https://doi.org/10.1007/978-3-319-10708-0 17

Brocx, M., Semeniuk, V. and Percival, I. G. (2019). 'Global geoheritage significance of Ordovician stratigraphy and sedimentology in the Cliefden Caves area, central western New South Wales'. In: M. Brocx, V. Semeniuk, and K Meney (eds.). Thematic Issue on Geoheritage and Geoconservation in Australia. Australian Journal of Earth Sciences: 66(6).

https://doi.org/10.1080/08120099.2019.1569128

Brooks, A.J. (2013). 'Assessing the sensitivity of geodiversity features in Scotland's seas to pressures associated with human activities'. Scottish Natural Heritage Commissioned Report No. 590. Inverness: Scottish Natural Heritage. https://www. nature. scot/sites/default/files/2018-09/Publication\%202013\%20-\%20SNH\%20Commissioned\%20Report\%20590\%20-\%20\%20 Assessing\%20the\%20sensitivity\%20of\%20geodiversity\%20features\%20in\%20Scotlands\%20seas\%20to\%20pressures\%20 associated\%20with\%20human\%20activities.pdf

Bruneau, P.M.C., Gordon, J.E. and Rees, S. (2011). 'Ecosystem sensitivity and responses to climate change: Understanding the links between geodiversity and biodiversity at the landscape scale'. JNCC Report No. 450.

http://archive.jncc.gov.uk/PDF/jncc450 FINALweb.pdf

Bruno B., and Wallace, A. (2019). 'Interpretive panels for geoheritage sites: Guidelines for design and evaluation'. Geoheritage 11:1315-1323. https://doi.org/10.1007/s12371-019-00375-0

Canesin, T.S., Brilha, J. and Díaz-Martínez, E. (2020). 'Best practices and constraints in geopark management: Comparative analysis of two Spanish UNESCO Global Geoparks'. Geoheritage 12:14 https://doi.org/10.1007/s12371-020-00435-w

Carcavilla Urquí L., López Martínez J. and Durán Valsero J.J. (2007). Patrimonio geológico y geodiversidade: investigación, conservación, géstion y relación con los espacios naturales protegidos. Cuadernos del Museo Geomineiro, No 7. Madrid: Instituto Geológico y Minero de España.

https://www.researchgate.net/publication/305322607 VALORACION DEL PATRIMONIO GEOLOGICO EN EUROPA

Casadevall, T., Tormey, D., and Richards, J. (2019). World Heritage Volcanoes: Classification, gap analysis, and recommendations for future listings. Gland, Switzerland: IUCN.

https://portals.iucn.org/library/node/48448 https://doi.org/10.2305/IUCN.CH.2019.07.en

Cayla, N., Hoblea, F., and Reynard, E. (2014). 'New digital technologies applied to the management of geoheritage'. Geoheritage 6:89-90. https://doi.org/10.1007/s12371-014-0118-8

Chevalier, M. (1969). Dictionnaire des symbols. Mythes, rêves, coutumes, gestes, formes, figures, couleurs, nombres. Vol. 3: PIE à Z. Paris: Ed. Seghers et Ed. Jupiter.

https://www.abebooks.co.uk/book-search/title/dictionnaire-des-symboles/author/chevalier-gheerbrant/sortby/3/

Cohen, K.M., Finney, S.C., Gibbard, P.L. and Fan, J.-X. (2013). 'The ICS International Chronostratigraphic Chart'. Episodes 36: 199-204. https://doi.org/10.18814/epiiugs/2013/v36i3/002

Cohen, S. (2015). 'The media and protected areas'. In: G.L. Worboys, M. Lockwood, A. Kothari, S. Feary, and I. Pulsford (eds.). Protected Area Governance and Management, pp. 441-472. Canberra: Australian National University Press.

http://press-files.anu.edu.au/downloads/press/p312491/pdf/CHAPTER15.pdf

Cohen-Shacham, E., Walters, G., Janzen, C., and Maginnis, S. (eds). (2016). Nature-based Solutions to Address Global Societal Challenges. Gland, Switzerland: IUCN. https://doi.org/10.2305/IUCN.CH.2016.13.en

Comer, P.J., Pressey, R.L., Hunter, M.L., Schloss, C.A., Buttrick, S.C., Heller, N.E., Tirpak, J.M., Faith, D.P., Cross, M.S. and Shaffer, M.L. (2015). 'Incorporating geodiversity into conservation decisions'. Conservation Biology 29:692-701.

https://doi.org/10.1111/cobi.12508

Conservation Measures Partnership. (2013). Open Standards for the Practice of Conservation.

https://www.conservationmeasures.org/version-4-0-of-the-conservation-standards-is-here/ 
Cooney, R. (2004). The Precautionary Principle in Biodiversity Conservation and Natural Resource Management: An Issues Paper for Policy-makers, Researchers and Practitioners. Gland, Switzerland and Cambridge, UK: IUCN.

https://portals.iucn.org/library/node/8528

Cooney, R. and Dickson, B. (2005). Biodiversity and the Precautionary Principle: Risk and Uncertainty in Conservation and Sustainable Use. London: Earthscan. https://portals.iucn.org/library/node/8773

Crofts, R. (2014). 'Promoting geodiversity: Learning lessons from biodiversity'. Proceedings of the Geologists' Association 125:263-266. https://doi.org/10.1016/j.pgeola.2014.03.002

Crofts, R. (2018). 'Putting geoheritage on all agendas'. Geoheritage 10(2):231-238. https://doi.org/10.1007/s12371-017-0239-y Crofts, R. (2019). 'Linking geoconservation with biodiversity conservation in protected areas'. International Journal of Geoheritage and Parks 7:211-217. https://doi.org/10.1016/i.ijgeop.2019.12.002.

Crofts, R. and Gordon, J.E. (2014). 'Geoconservation in protected areas'. PARKS 20:61-76.

https://doi.org/10.2305/IUCN.CH.2014.PARKS-20-2.RC.en

Crofts, R. and Gordon, J. E. (2015). Geoconservation in protected areas. In: G.L. Worboys, M. Lockwood, A. Kothari, S. Feary, and I. Pulsford (eds.). Protected Area Governance and Management, pp. 531-568. Canberra: Australian National University Press. http://press-files.anu.edu.au/downloads/press/p312491/pdf/CHAPTER18.pdf

Díaz, S., Pascual, U., Stenseke, M., Martín-López, B., Watson, R.T., Molnár, Z., Hill, R., Chan, K. M. A., Baste, I.A., Brauman, K. A., et al. (2018). 'Assessing nature's contributions to people: Recognizing culture, and diverse sources of knowledge, can improve assessments'. Science 359:270-272. https://doi.org/10.1126/science.aap8826

Digne Declaration International Declaration of the Rights of the Memory of the Earth. (1991).

http://www.geoparchauteprovence.com/les-g\%C3\%A9oparcs/d\%C3\%A9claration-internationale/texte-d\%C3\%A9claration/

Dingwall, P., Weighell, T. and Badman, T. (2005). Geological World Heritage: A Global Framework. Gland, Switzerland: IUCN. https://portals.iucn.org/library/node/12797

Dorset and East Devon Coast World Heritage Site. (2011). Promoting Responsible Fossil Collecting. Charmouth, Dorset, UK: Dorset and East Devon Coast World Heritage Site. https://jurassiccoast.org/what-is-the-jurassic-coast/world-heritage/lookingafter-the-jurassic-coast/promoting-responsible-fossil-collecting/

Drew D. and Hötzl, H. (eds.). (1999). Karst Hydrology and Human Activities. Rotterdam, Netherlands: A.A. Balkema. https://www. worldcat.org/title/karst-hydrogeology-and-human-activities-impacts-consequences-and-implications/oclc/41444640

Dudley, N. (ed.) (2008). Guidelines for Applying Protected Area Management Categories. Gland, Switzerland: IUCN. https://doi.org/10.2305/IUCN.CH.2008.PAPS.2.en

Dunlop, L., Larwood, J.G. and Burek, C.V. (2018). 'Geodiversity action plans-a method to facilitate, structure, inform and record action for geodiversity'. In: E. Reynard and J Brilha (eds.). Geoheritage: Assessment, Protection, and Management, pp. 53-66. Amsterdam: Elsevier. https://doi.org/10.1016/B978-0-12-809531-7.00003-4

Ehlers, J., Gibbard, P. L. and Hughes, P.D. (2011). Quaternary Glaciations-Extent and Chronology: A Closer Look. Amsterdam: Elsevier. https://www.elsevier.com/books/quaternary-glaciations-extent-and-chronology/ehlers/978-0-444-53447-7

Ellis, N. (2004). Common Standards Monitoring Guidance for Earth Science Sites. Peterborough, UK: Joint Nature Conservation Committee. incc.defra.gov.uk/pdf/CSM earth science.pdf

Ellis, N. (2008). 'A history of the Geological Conservation Review'. In: C.V. Burek and C.D. Prosser (eds.). The History of Geoconservation, pp. 123-135. Special Publications No. 300. London: The Geological Society. https://doi.org/10.1144/SP300.10

Ellis, N. (2011). 'The Geological Conservation Review (GCR) in Great Britain: Rationale and methods'. Proceedings of the Geologists' Association 122:353-362. https://doi.org/10.1016/i.pgeola.2011.03.008

English Geodiversity Forum. (2014). Geodiversity Charter for England.

http://www.englishgeodiversityforum.org/Downloads/Geodiversity\%20Charter\%20for\%20England.pdf

English Nature. (2004). Local Geodiversity Action Plans. Sharing Good Practice. Peterborough, UK: Natural England. http://www. publications. naturalengland. org. uk/publication/76016? category=30050

Errami, E., Brocx, M., Semeniuk, V. and Ennih, N. (2015). 'Geosites, sites of special scientific interest, and potential geoparks in the Anti-Atlas (Morocco)'. In: E. Errami, M. Brocx, and V. Semeniuk (eds.). From Geoheritage to Geoparks: Case Studies from Africa and Beyond, pp. 57-79. Cham, Switzerland: Springer. https://doi.org/10.1007/978-3-319-10708-0 4 
Fang, R., Simonson, L. and Zhixin, P. (2013). 'Interpretation of geoheritage for geotourism: A comparison of Chinese geoparks and national parks in the United States'. Czech Journal of Tourism 2: 10-125. https://doi.org/10.2478/cjot-2013-0006

Ferrero, E., Giardino, M., Lozar, F., Giordano, E., Belluso, E. and Perotti, L. (2012). 'Geodiversity action plans for the enhancement of geoheritage in the Piemonte region (north-western Italy)'. Annals of Geophysics 55:487-495. https://www.researchgate.net/ publication/267383078 Geodiversity action plans for the enhancement of geoheritage in the Piemonte region NorthWestern Italy

Feuillet, T. and Sourp, E. (2011). 'Geomorphological heritage of the Pyrenees National Park (France): Assessment, clustering, and promotion of geomorphosites'. Geoheritage 3:151-162. https://doi.org/10.1007/s12371-010-0020-y

Finney, S.C. and Hilario, A. (2018). 'GSSPs as international geostandards and as global geoheritage'. In: E. Reynard and J. Brilha (eds.). Geoheritage: Assessment, Protection, and Management, pp. 169-180. Amsterdam: Elsevier. https://doi.org/10.1016/B978-0-12-809531-7.00010-1

Ford, D.C. and Williams, P.W. (2007). Karst Hydrogeology and Geomorphology. Chichester, UK: Wiley. https://doi.org/10.1002/9781118684986

Fuertes-Gutiérrez, I. and Fernández-Martínez, E. (2010). 'Geosites inventory in the Leon Province (Northwestern Spain): A tool to introduce geoheritage into regional environmental management'. Geoheritage 2:57-75. https://doi.org/10.1007/s12371-010-0012-y

Fuertes-Gutiérrez I. and Fernández-Martínez E. (2012). 'Mapping geosites for geoheritage management: A methodological proposal for the Regional Park of Picos de Europa (León, Spain)'. Environmental Management 50:789-806.

https://doi.org/10.1007/s00267-012-9915-5

Garcia, M. G. M. (2019). 'Ecosystem services provided by geodiversity: preliminary assessment and perspectives for the sustainable use of natural resources in the coastal region of the state of São Paulo, Southeastern Brazil.' Geoheritage 11:12571266. link.springer.com/article/10.1007/s12371-019-00383-0

Garcia-Cortes, A., Vegas, J., Carcavilla, L. and Diaz-Martinez, E. (2012). 'Un sistema de indicadores para la evaluacion y seguimiento del estado de conservacion del patrimonio geologico [An indicator system to assess and follow up the state of conservation of geological heritage]'. Geo-Temas 13: 1272-1275. http://www.igme.es/patrimonio/publicaciones/congresos/Garcia\%20Cortes\%20 et\%20al\%202012\%20-\%20Sistema\%20de\%20indicadores\%20para\%20estado\%20conservacion\%20PG.pdf

Gardner, L. (2009). Protected Areas Management in the Caribbean: Core Themes for Education, Awareness, and Communication Programmes. Curepe, Trinidad and Tobago: The Trust for Sustainable Livelihoods and WCPA Caribbean. http://ess-caribbean. com/wp-content/uploads/publications/Protected\%20Areas\%20Education\%20Themes\%20in\%20the\%20Caribbean\%202009.pdf

Gemmell, S. L. G., Hansom, J.D. and Hoey, T.B. (2001). The Geomorphology, Conservation and Management of the River Spey and Spey Bay SSS/s, Moray. Scottish Natural Heritage Research Survey and Monitoring Report No. 57. Edinburgh: Scottish Natural Heritage. https://www.researchgate.net/publication/222229721 Coastal sensitivity to environmental change A view from the beach

Geological Society of America. (2019). NPS Geoscientists-in-the-Parks Program. Boulder, CO: Geological Society of America. https://www.geosociety.org/GSA/Education Careers/Field Experiences/gip/GSA/fieldexp/gip.aspx

Gillieson, D. (1996). Caves: Processes, Development, and Management. Oxford, UK: Blackwell. https://doi.org/10.1002/9781444313680

Gogin, I. Y. and Vdovets, M.S. (2014). 'Geosites of international significance in the UNESCO WHS Lena Pillars Nature Park (Sakha Republic, Russia)'. Geoheritage 6:173-184. https://doi.org/10.1007/s12371-013-0089-1

Gordon, J. E. (2018). 'Mountain geodiversity: Characteristics, values and climate change'. In: C. Hoorn, A. Perrigo, and A. Antonelli (eds.). Mountains, Climate and Biodiversity, pp. 137-154. Chichester, UK: Wiley.

Gordon, J.E. and Barron, H.F. (2011). Scotland's Geodiversity: Development of the Basis for a National Framework. Scottish Natural Heritage Commissioned Report No. 417. Edinburgh: Scottish Natural Heritage.

http://www.parliament.scot/S3 PublicPetitionsCommittee/Submissions 09/09-PE1277H.pdf

Gordon, J. E., Brooks, A.J., Chaniotis, P.D., James, B.D., Kenyon, N.H., Leslie, A.B., Long, D. and Rennie, A.F. (2016). 'Progress in marine geoconservation in Scotland's seas: Assessment of key interests and their contribution to marine protected area network planning'. Proceedings of the Geologists' Association 127:716-737. https://doi.org/10.1016/i.pgeola.2016.10.002

Goudie, A. and Seely, M. (2011). World Heritage Desert Landscapes: Potential Priorities for the Recognition of Desert Landscapes and Geomorphological Sites on the World Heritage List. Gland, Switzerland: IUCN. https://portals.iucn.org/library/node/9818

Gradstein, F.M. and Ogg, J.G. (2012). 'The chronostratigraphic scale'. In: F.M. Gradstein, J.G. Ogg, M.D. Schmitz and G.M. Ogg (eds.), The Geological Time Scale 2012, pp. 31-42. Amsterdam: Elsevier. https://doi.org/10.1016/B978-0-444-59425-9.00002-0 
Gray, M. (2011). 'GSSPs: The case for a third, internationally recognised, geoconservation network'. Geoheritage 3:83-88. https://doi.org/10.1007/s12371-010-0028-3

Gray, M. (2013). Geodiversity: Valuing and Conserving Abiotic Nature, 2nd. ed. Chichester, UK: Wiley-Blackwell. http://bcs. wiley.com/he-bcs/Books?action=index\&itemld=0470742143\&bcsld=8369

Gray, M. (2018). 'Ecosystem services'. In: B. Vogel, K.S. Woo, R. Grunewald, R. Crofts, and G. Stolpe. (eds.). Global Geoheritage: International Significance and Biodiversity Values-Workshop Proceedings, pp. 39-43. BfN Skripten 500. Leipzig: German Federal Agency for Nature Conservation. https://www.bfn.de/fileadmin/BfN/service/Dokumente/skripten/Skript500.pdf

Griscom, B.W., Adams, J. and Ellis, P.W. (2017). 'Natural climate solutions'. Proceedings of the National Academy of Sciences 114:11645-11650. https://doi.org/10.1073/pnas.1710465114

Gross, J. E., Woodley, S., Welling, L.A., and Watson, J E.M. (eds.). (2016). Adapting to Climate Change: Guidance for Protected Area Managers and Planners. Best Practice Protected Areas Guidelines Series No. 24. Gland, Switzerland: IUCN. https://doi.org/10.2305/IUCN.CH.2017.PAG.24.en

Groves, C., and Game, E.T. (2016). Conservation Planning: Informed Decisions for a Healthier Planet. Greenwood Village, CO, USA: Roberts and Co. https://link.springer.com/article/10.1007/s10980-016-0469-4

Groves, C.R., Game, E.T., Anderson, M.G., Cross, M., Enquist, C., Ferdaña, Z., Girvetz, E., Gondor, A., Hall, K.R., Higgins, J., Marshall, R., Popper, K., Schill, S., Shafer, S.L. (2012). 'Incorporating climate change into systematic conservation planning'. Biodiversity Conservation 21:1651-1671. https://doi.org/10.1007/s10531-012-0269-3

Gunn, J. (ed.). (2004). Encyclopedia of Caves and Karst Science. New York: Fitzroy Dearborn.

https://doi.org/10.4324/9780203483855

Gunn, J. (2020). Karst groundwater in UNESCO protected areas: a global overview. Hydrogeology Journal. https://doi.org/10.1007/s10040-020-02206-x

Ham, S. (2013). Interpretation: Making a Difference on Purpose. Cape Town, South Africa: Fulcrum.

Hilty, J., Worboys, G.L., Keeley, A., Woodley, S., Lausche, B., Locke, H., Carr, M., Pulsford I., Pittock, J., White, J. W., Theobald, D.M., Levine, J., Reuling, M., Watson, J.E.M., Ament, R., and Tabor, G.M. (2020). Guidelines for conserving connectivity through ecological networks and corridors. Best Practice Protected Area Guidelines Series No. 30. Gland, Switzerland: IUCN.

https://doi.org/10.2305/IUCN.CH.2020.PAG.30.en

Hooke, R.L. (1994). 'On the efficacy of humans as geomorphic agents'. GSA Today 4:217-225.

Hutton, J. (1795). Theory of the Earth. Edinburgh: William Creech.

ICMM [International Council on Mining and Metals]. (2003). Mining and Protected Areas Position Statement. London: ICMM. http://www.icmm.com/en-gb/members/member-commitments/position-statements/mining-and-protected-areas-position-statement International Commission on Stratigraphy. (Undated). The Global Boundary Stratotype Section and Point (GSSP). https://web.archive.org/web/20090113224346 http://www.stratigraphy.org:80/over.htm

Irwin, A. (2018). Citizen science comes of age. Nature 562, 480-482. https://doi.org/10.1038/d41586-018-07106-5

ISCA [International Show Caves Association]. (2014). Recommended International Guidelines for the Development and Management of Show Caves. http://www.uis-speleo.org/documents/Recommended International Guidelines published version. pdf.

IPCC [Intergovernmental Panel on Climate Change]. (2019a). Special Report on Global Warming of 1.5 Degrees. UN, New York: IPCC. https://unfccc.int/topics/science/workstreams/cooperation-with-the-ipcc/ipcc-special-report-on-global-warming-of-15-degc

IPCC. (2019b). Special Report on the Ocean and Cryosphere in a Changing Climate. New York: IPCC. https://www.ipcc.ch/site/ assets/uploads/sites/3/2019/12/SROCC FullReport FINAL.pdf

IUCN [International Union for Conservation of Nature]. (2008). 'Resolutions and Recommendations adopted at the 4th IUCN World Conservation Congress. Resolution 4.040: Conservation of geodiversity and geological heritage'. Gland, Switzerland: IUCN. https://portals.iucn.org/library/node/44190.

IUCN [International Union for Conservation of Nature]. (2012). 'Resolutions and Recommendations, World Conservation Congress, Jeju, Republic of Korea, 6-15 September 2012, WCC-2012-Res-048, Valuing and conserving geoheritage within the IUCN Programme 2013-2016'. Gland, Switzerland: IUCN. https://portals.iucn.org/library/node/44015.

IUCN. (2015). Strategic Framework for Capacity Development in Protected Areas and Other Conserved Territories 2015-2025.

Gland, Switzerland: IUCN. https://portals.iucn.org/library/node/45827. 
IUCN [International Union for Conservation of Nature]. (2016a). 'Resolutions and Recommendations, World Conservation Congress, Hawai'i, USA, Resolution 6.083, Conservation of moveable geological heritage'. Gland, Switzerland: IUCN. https:// portals.iucn.org/library/node/46500

IUCN [International Union for Conservation of Nature]. (2016b). 'Resolutions and Recommendations, World Conservation Congress, Hawai'i, USA, Resolution 6.102. Protected areas and other areas important for biodiversity in relation to environmentally damaging industrial activities and infrastructure development. Gland, Switzerland: IUCN. https://portals.iucn.org/library/sites/library/files/resrecfiles/WCC 2016 REC 102 EN.pdf

IUCN. (2020). Global Standard for Nature-based Solutions. A user-friendly framework for the verification, design and scaling up of NbS. First edition. Gland, Switzerland: IUCN. https://doi.org/10.2305/IUCN.CH.2020.08.en

IUCN-WCPA [World Commission on Protected Areas] Task Force on OECMs. (2019). Recognising and reporting other effective area-based conservation measures. Gland, Switzerland: IUCN. https://doi.org/10.2305/IUCN.CH.2019.PATRS.3.en

Jacobs, P.J., Worboys, G.L., Mossfield, S. and Varcoe, T. (2015). 'Managing operations and assets'. In: G.L. Worboys, M. Lockwood, A. Kothari, S. Feary, and I. Pulsford (eds.). Protected Area Governance and Management, pp. 751-788. Canberra: Australian National University Press. https://doi.org/10.22459/PAGM.04.2015

Jager, E. and Sanche, A. (2010). Setting the stage for visitor experiences in Canada's national heritage places. The George Wright Forum 27(2):180-190.

JNCC [Joint Nature Conservation Committee]. (2019). A Statement on Common Standards for Monitoring Protected Sites 2019. Peterborough, UK: JNCC. https://jncc.gov.uk/our-work/common-standards-monitoring/

Kääb, A., Reynolds, J.M. and Haeberli, W. (2005). 'Glacier and permafrost hazards in high mountains'. In: U.M. Huber, H.K.M Bugmann, and M.A. Reasoner (eds.). Global Change and Mountain Regions: An Overview of Current Knowledge, pp. $225-234$. Dordrecht, Netherlands: Springer. https://doi.org/10.1007/1-4020-3508-X 23

Kiernan, K. (1996.) Conserving Geodiversity and Geoheritage: The Conservation of Glacial Landforms. Hobart, Tasmania, Australia: Forest Practices Unit. https://catalogue.nla.gov.au/Record/2687484

Kirkbride, V. and Gordon, J. E. (2010). The Geomorphological Heritage of the Cairngorm Mountains. Scottish Natural Heritage Commissioned Report No. 348. Edinburgh: Scottish Natural Heritage. https://www.researchgate.net/publication/272795727. Kirkbride V and Gordon JE 2010 The geomorphological heritage of the Cairngorm Mountains

Knudson, C., Kay, K., and Fisher, S. (2018). 'Appraising geodiversity and cultural diversity approaches to building resilience through conservation'. Nature Climate Change 8:678-685. https://doi.org/10.1038/s41558-018-0188-8

Kresic, N. (2013). Water in Karst: Management, Vulnerability, and Restoration. New York: McGraw-Hill. https://www.researchgate.net/publication/263145223 Water in Karst Management Vulnerability and Restoration

Lambiel, C. and Reynard, E. (2003). 'Impacts du développement d'un domaine skiable sur la morphologie glaciaire et périglaciaire: le cas de Verbier (Valais, Suisse)'. In: E. Reynard, C. Holzmann, D. Guex, and N. Summermatter (eds.). Géomorphologie et Tourisme. Institut de Géographie, Lausanne, Travaux et Recherches 24:19-33. https://wp.unil.ch/hmg/publications/

Larwood, J.G. and Chandler, R.B., (2016). Conserving classic geological sections in the Inferior Oolite Formation, Middle Jurassic of the Wessex Basin, south-west England. Proceedings of the Geologists' Association 127:132-145.

https://doi.org/10.1016/j.pgeola.2016.03.007

Leung, Y-F., Spenceley, A., Hvenegaard, G., e Buckley, R. (eds.) (2019). Turismo e gestão da visitação em áreas protegidas. Diretrizes para sustentabilidade. Série Diretrizes para melhores Práticas para Áreas Protegidas No. 27, Gland, Suiça: UICN. xii + 120 pp. https://doi.org/10.2305/IUCN.CH.2018.PAG.27.pt

Lounema, R. (2003). Suomen kansan pyhät paikat. [Sacred Sites of the Finnish People]. Hameenlinna, Finland: Yhtyneet Kuvalehdet Oy.

Martin S., Reynard, E., Pellitero Ondicol, R. and Ghiraldi, L. (2014). 'Multi-scale web mapping for geoheritage visualisation and promotion'. Geoheritage 6:141-148. https://doi.org/10.1007/s12371-014-0102-3

Martín-Duque, J. F., Caballero García, J. and Carcavilla Urquí, L. (2012). Geoheritage information for geoconservation and geotourism through the categorization of landforms in a karstic landscape: A case study from Covalagua and Las Tuerces (Palencia, Spain). Geoheritage 4:93-108.

https://doi.org/10.1007/s12371-012-0056-2 https://doi.org/10.1007/s12371-012-0056-2

Migoń, P. (2006). Granite Landscapes of the World. Oxford: Oxford University Press.

https://global.oup.com/academic/product/granite-landscapes-of-the-world-9780199273683 
Migoń, P. (2018). Geoheritage and World Heritage Sites. In: E. Reynard and J. Brilha (eds.). Geoheritage: Assessment, Protection, and Management, pp. 237-250. Amsterdam: Elsevier. https://doi.org/10.1016/B978-0-12-809531-7.00013-7

Mitchell, B.A., Stolton, S., Bezaury-Creel, J., Bingham, H.C., Cumming, T.L., Dudley, N., Fitzsimons, J.A., Malleret-King, D., Redford, K.H. and Solano, P. (2018). Guidelines for privately protected areas. Best Practice Protected Area Guidelines Series No. 29. Gland, Switzerland: IUCN. https://doi.org/10.2305/IUCN.CH.2018.PAG.29.en

Morris, R.L., Strain, E.M.A., Konlechner, T.M., Fest, B.J., Kennedy, D.M., Arndt, S.K. and Swearer, S.E. (2019). 'Developing a nature-based coastal defence strategy for Australia'. Australian Journal of Civil Engineering 17:167-176. https://doi.org/10.1080/14488353.2019.1661062

National Speleological Society. (2016). A Guide to Responsible Caving, 5th ed. Huntsville, AL, USA: National Speleological Society. https://caves.org/brochure/Guide to Resp Caving 2016.pdf

Natural England. (2012). Managing Geological Specimen Collecting: Guidance and Case Studies. Natural England Technical Information Notes TIN111, 113. 114, 115, 117, 118, 119, 127. http://publications.naturalengland.org.uk/category/1768835

Neugarten, R.A., Langhammer, P.F., Osipova, E., Bagstad, K.J., Bhagabati, N., Butchart, S.H.M., Dudley, N., Elliott, V., Gerber, L.R., Gutierrez Arrellano, C., Ivanić, K.-Z., Kettunen, M., Mandle, L., Merriman, J.C., Mulligan, M., Peh, K.S.-H., Raudsepp-Hearne, C., Semmens, D.J., Stolton, S., and Willcock, S. (2018). Tools for measuring, modelling, and valuing ecosystem services: guidance for key biodiversity areas, natural World Heritage Sites, and protected areas. Best Practice Protected Area Guidelines Series No. 28. Gland, Switzerland: IUCN. https://doi.org/10.2305/IUCN.CH.2018.PAG.28.en

Palmer, A.N. (2007). Cave Geology. Dayton, OH, USA: Cave Books. https://www.goodreads.com/book/show/1728400.Cave Geology

Palmer, M. and Ruhi, A. (2019). 'Linkages between flow regime, biota, and ecosystem processes: Implications for river restoration'. Science 365: eaaw2087. https://doi.org/10.1126/science.aaw2087

Pelfini, M., Brandolini, P., Carton, A. and Piccazzo, M. (2009). 'Geotourist trails: A geomorphological risk impact analysis'. In E. Reynard, P. Coratza and G. Regolini-Bissig (eds.). Geomorphosites, pp. 131-144. Munich: Pfeil Verlag.

Pereira, P., Pereira, D. and Alves M.I.C. (2007). 'Geomorphosite assessment in Montesinho Natural Park (Portugal)'. Geographica Helvetica 62:159. https://doi.org/10.5194/gh-62-159-2007

Pereira P., Pereira D.I. and Alves, M.I.C. (2009). 'The geomorphological heritage approach in protected areas: Geoconservation vs. geotourism in Portuguese natural parks'. Memorie Descrittive della Carta Geologica d'Italia LXXXVII: 135-144.

Piccardi, L. and Masse, W.B. (eds.). (2007). Myth and Geology. Special Publication No. 237. London, UK: The Geological Society. https://www.cambridge.org/core/journals/geological-magazine/article/l-piccardi-w-b-masse-eds-2007-myth-and-geologygeological-society-special-publication-no-273-350-pp-geological-society-london-price-9000-us-18000-gsl-members-4500-us9000-other-qualifying-societies-5400-us-10800-hard-covers-isbn-978-1-86239-216-8/F52D20263874399E99A0755B965F8FC0

Poff, N.L. (2018). 'Beyond the natural flow regime? Broadening the hydro-ecological foundation to meet environmental flows challenges in a non-stationary world'. Freshwater Biology 63: 1011-1021.

Poff, N.L., Allan, J.D., Bain, M.B., Karr, J.R., Prestegaard, K.L., Richter, B.D., Sparks, R.E. and Stromberg, J.C. (1997). 'The natural flow regime: A paradigm for river conservation and restoration'. BioScience 47:769-784. https://doi.org/10.2307/1313099

Pontee, N., Narayan, S. and Beck, M.W. (2016). 'Nature-based solutions: Lessons from around the world'. Proceedings of the Institution of Civil Engineers - Maritime Engineering 169: 29-36. https://doi.org/10.1680/jmaen.15.00027

Prosser, C.D. (2011) 'Principles and practice of geoconservation: Lessons and case law arising from a legal challenge to sitebased conservation on an eroding coast in eastern England, UK'. Geoheritage 3:277-287. https://doi.org/10.1007/s12371$\underline{011-0042-0}$

Prosser, C.D. (2016). 'Geoconservation, quarrying and mining: Opportunities and challenges illustrated through working in partnership with the mineral extraction industry in England'. Geoheritage 10:259-270. https://doi.org/10.1007/s12371-016-0206-z

Prosser, C.D., Murphy, M. and Larwood, J. (2006). Geological Conservation: A Guide to Good Practice. Peterborough, UK: English Nature. http://publications. naturalengland.org.uk/publication/83048

Prosser, C.D., Diaz-Martinez, E. and Larwood, J. G. (2018). 'The geoconservation of geosites: Principles and practice'. In: E. Reynard and J. Brilha (eds.). Geoheritage: Assessment, Protection, and Management, pp. 193-212. Amsterdam: Elsevier. https://doi.org/10.1016/B978-0-12-809531-7.00011-3

ProGEO. (2011). Conserving Our Shared Geoheritage - A Protocol on Geoconservation Principles, Sustainable Site Use, Management, Fieldwork, Fossil and Mineral Collecting. Uppsala, Sweden: ProGEO, the European Association for the Conservation of Geological Heritage. http://www.progeo.se/progeo-protocol-definitions-20110915.pdf 
Purdie, H., Espiner, S. and Gomez, C. (2018). 'Geotourism and risk: A case study of rockfall hazard at Fox Glacier, New Zealand'. In: R. Dowling and D/ Newsome (eds.). Handbook of Geotourism, pp. 139-151. Cheltenham, UK: Edward Elgar.

https://doi.org/10.4337/9781785368868.00020

Rapprich, V., Lisec, M., Fiferna, P., and Závada, P. (2017). 'Application of modern technologies in popularization of the Czech volcanic geoheritage'. Geoheritage 9:413-420. https://doi.org/10.1007/s12371-016-0208-X

Reynard, E. (2009a). 'Geomorphosites and landscapes'. In E. Reynard, P. Coratza and G. Regolini-Bissig (eds.). Geomorphosites, pp. 21-34. Munich: Pfeil Verlag.

Reynard, E. (2009b). 'Geomorphosites: Definitions and characteristics'. In E. Reynard, P. Coratza and G. Regolini-Bissig (eds.). Geomorphosites, pp. 9-20. Munich: Pfeil Verlag.

https://www.researchgate.net/publication/288265820 Geomorphosites Definitions and characteristics

Reynard, E. and, Brilha, J. (eds.). (2018). Geoheritage: Assessment, Protection, and Management. Amsterdam: Elsevier. https://www.elsevier.com/books/geoheritage/reynard/978-0-12-809531-7

Roberts, R., Appleton, P., and Buttler, C. (2016). Root and branch reform for Brymbo fossil. Earth Heritage 45:7-9. http://www. earthheritage.org.uk/wp/wp-content/uploads/2018/03/EH45f.pdf

RPDC [Resource Planning and Development Commission]. (2013). 'Land, Geodiversity and Geoconservation'. In: State of the Environment Report: Tasmania. Hobart, Tasmania, Australia: RSPC.

http://soer.justice.tas.gov.au/2003/lan/2/issue/77/index.php\#zmanagement

Santangelo N., Santo A., Guida D., Lanzara R. and Siervo V. (2005). 'The geosites of the Cilento Vallo di Diano National Park (Campania region, southern Italy)'. II Quaternario 18:103-114. https://www.researchgate.net/publication/258986935 The geosites of the Cilento-Vallo di Diano National Park Campania region southern Italy

Santucci, V.L. (2005). Historical perspectives on biodiversity and geodiversity. The George Wright Forum: 22(3):29-34.

Santucci, V.L. and Hughes, M. (1998). 'Fossil Cycad National Monument: A case of paleontological resource mismanagement'. In: Santucci, V.L. and McClelland, L. (eds.). National Park Service Paleontological Research, 3, pp. 84-89. Technical Report NPS/ NRGRD/GRDTR-9801. Washington, DC: US National Park Service.

https://www.nps.gov/subjects/fossils/upload/NPS 10thconference proceedings.pdf

Santucci, V.L., Kenworthy, J.P. and Mims, A.L. (2009). 'Monitoring in situ paleontological resources'. In: R. Young and L. Norby. (eds.). Geological Monitoring, pp. 189-204. Boulder, CO, USA: Geological Society of America. https://doi.org/10.1130/2009. monitoring(08)

Santucci, V.L. and Koch, A.L. (2003). 'Paleontological resource monitoring strategies for the National Park Service'. Park Science 22:22-25. http://www.npshistory.com/publications/paleontology/paleo-monitoring.pdf

Santucci, V. L., Tweet, J.S. and Kenworthy, J.P. (2012). 'Paleoblitz: Uncovering the fossil record of the national parks'. Park Science 29:29-32.

Scottish Geodiversity Forum. (2013). Scotland's Geodiversity Charter. http://scottishgeodiversityforum.org/charter/

Scottish Natural Heritage. (2008). Scottish Fossil Code. Battleby, UK: Scottish Natural Heritage.

https://www.nature.scot/scottish-fossil-code

Scottish Natural Heritage. (2019). 'Keen of Hamar National Nature Reserve'.

https://www.nature.scot/enjoying-outdoors/snh-nature-reserves/keen-hamar-nature-reserve

Sharples, C. (2002). Concepts and Principles of Geoconservation. Hobart, Tasmania, Australia: Tasmanian Parks \& Wildlife Service. www.dpiw.tas.gov.au/inter.nsf/Attachments/SJON-57W3YM/\$FILE/geoconservation.pdf

Sharples, C. (2011). Potential Climate Change Impacts on Geodiversity in the Tasmanian Wilderness World Heritage Area: A Management Response Position Paper. Nature Conservation Report Series 11/04. Hobart, Tasmania, Australia: Resource Management and Conservation Division, Department of Primary Industries, Parks, Water and Environment.

http://www.dpiw.tas.gov.au/inter.nsf/Attachments/LJEM-8P983Y?open

Smaldone, D. (2003). A Crash Course in Interpretation. Washington, DC: US National Park Service.

https://www.nps.gov/grte/learn/management/upload/interp.pdf

Smith, A.G., Barry, T., Bown, P., Cope, J., Gale, A., Gibbard, P., Gregory, J., Hounslow, M., Kemp, D., Knox, R., Marshall, J., Oates, M., Rawson, P., Powell, J. and Waters, C. (2015). 'GSSPs, global stratigraphy and correlation'. In: D.G. Smith, R.J. Bailey, P.M. Burgess, and A.J. Fraser, A.J. (eds.). Strata and Time: Probing the Gaps in Our Understanding, pp. 37-67. Special Publications No. 404. London: The Geological Society. https://doi.org/10.1144/SP404.8 
Spalding, M.D., Ruffo, S., Lacambra, C., Meliane, I., Hale, L.Z., Shepard, C. and Beck, M.W. (2014). 'The role of ecosystems in coastal protection: Adapting to climate change and coastal hazards'. Ocean \& Coastal Management 90: 50-57.

https://doi.org/10.1016/j.ocecoaman.2013.09.007

Stolton, S., Shadie, P. and Dudley, N. (2013). Guidelines for Applying Protected Area Management Categories: Including IUCN WCPA best practice guidance on recognising protected areas and assigning management categories and governance types. Best Practice Protected Area Guidelines Series No. 21, Gland, Switzerland: IUCN. https://portals.iucn.org/library/node/30018

Tasmanian Government. (Undated). Protecting and Managing Karst. Hobart, Tasmania, Australia: Government of Tasmania. https://dpipwe.tas.gov.au/conservation/geoconservation/karst/protecting-karst

Temmerman, S., Meire, P., Bouma, T.J., Herman, P. M. J., Ysebaert, T. and De Vriend, H.J. (2013). 'Ecosystem-based coastal defence in the face of global change'. Nature 504: 79-83. https://doi.org/10.1038/nature12859

Theobald, D.M., Harrison-Atlas, D., Monahan, W.B. and Albano, C.M. (2015). Ecologically-relevant maps of landforms and physiographic diversity for climate adaptation planning. PLOS ONE 10(12):e0143619. https://doi.org/10.1371/journal.pone.0143619

Tilden, F. (1977). Interpreting Our Heritage. Chapel Hill, NC, USA: University of North Carolina Press. https://uncpress.org/book/9780807858677/interpreting-our-heritage/

Tukiainen, H., Kiuttu, M., Kalliola, R., Alahuhta, J. and Hjort, J. (2019). 'Landforms contribute to plant biodiversity at alpha, beta and gamma levels'. Journal of Biogeography 46:1699-1710. https://doi.org/10.1111/jbi.13569

UNESCO [United Nations Educational, Scientific, and Cultural Organization]. (1972). Criteria for World Heritage Site Selection. Paris: UNESCO World Heritage Centre. https://whc.unesco.org/en/criteria/

US National Park Service. (2013). Yosemite National Park 1997 Flood Recovery Final Report. Washington, USA: US Department of the Interior, National Park Service. https://www.nps.gov/yose/learn/management/1997-flood-recovery.htm

US National Park Service. (2019). 'Transforming the NPS digital experience'. https://www.nps.gov/subjects/digital/index.htm.

Veni, G., DuChene, H., Crawford, N.C., Groves, C.G., Huppert, G.N., Kastning, E.H., Olson, R., and Wheeler, B.J. (2001). Living with Karst: A Fragile Foundation. Environmental Awareness Series No. 4. Alexandria, VA, USA: American Geological Institute. https://www.americangeosciences.org/sites/default/files/karst.pdf.

Vermeulen, J. and Whitten, T. (1999). Biodiversity and Cultural Property in the Management of Limestone Resources: Lessons from East Asia. Washington DC: The World Bank. https://doi.org/10.1596/0-8213-4508-7

Verschuuren, B., Mallarach, J-M., Bernbaum, E., Spoon, E., Brown, S., Borde, R., Brown, J., Calamia, M., Mitchell, N., Infield, M., and Lee, E. (In press). Cultural and spiritual significance of nature: guidance for its role in protected and conserved area governance and management. IUCN WCPA Best Practice Protected Area Guidelines Series No. 32. Gland, Switzerland: IUCN.

Vogel, B., Woo, K.S., Grunewald, R., Crofts, R. and Stolpe, G. (2018) (Eds.) Global Geoheritage: International Significance and Biodiversity Values - Workshop Proceedings. BfN Skripten 500. Leipzig: German Federal Agency for Nature Conservation. https://www.bfn.de/fileadmin/BfN/service/Dokumente/skripten/Skript500.pdf

Waltham, T., Bell, F. and Culshaw, M. (eds.). (2005). Sinkholes and Subsidence. Chichester, UK: Springer-Praxis. https://b-ok.org/book/836594/200a35

Watson, J., Hamilton-Smith, E., Gillieson, D. and Kiernan, K. (eds.). (1997). Guidelines for Cave and Karst Protection. Gland, Switzerland: IUCN. https://portals.iucn.org/library/node/7255

Welch, D. (2004). 'Geoindicators for monitoring Canada's national parks: A proposal'. In: N.W.P. Munro et al. (eds.). Making Ecosystem Based Management Work: Connecting Managers and Researchers. Proceedings of the Fifth International Conference on Science and the Management of Protected Areas, Victoria, British Columbia, 11-16 May, 2003. Wolfville, NS, Canada: Science and Management of Protected Areas Association.

https://epdf.pub/transforming-parks-and-protected-areas-management-and-governance-in-a-changing-w.html

Wellman, J. (2015). 'What does the term rock mean or represent when used in the Bible?' Patheos. http://www.patheos.com/blogs/christiancrier

Werritty, A., Duck, R.W. and Kirkbride, M.P. (1998). Development of a Conceptual and Methodological Framework for Monitoring Site Condition in Geomorphological Systems. Scottish Natural Heritage Research, Survey and Monitoring Report No. 105. Edinburgh: Scottish Natural Heritage. https://discovery. dundee.ac.uk/en/publications/development-of-a-conceptual-andmethodological-framework-for-moni

White, W.B. and Culver, D.C. (2012). Encyclopedia of Caves, 2nd ed. Amsterdam: Elsevier Academic Press. https://www. sciencedirect.com/book/9780123838322/encyclopedia-of-caves 
Wignall, R.M.L. (2019). Scottish Natural Heritage Earth Science Site Condition Monitoring Methodology 1999-2019. Scottish Natural Heritage Research Report No. 1160. Edinburgh: Scottish Natural Heritage.

https://www.nature.scot/snh-research-report-1160-scottish-natural-heritage-earth-science-site-condition-monitoring

Wignall, R.M.L., Gordon, J.E., Brazier, V., MacFadyen, C.C.J. and Everett, N.S. (2018). A Climate Change Risk-Based Assessment for Nationally and Internationally Important Geoheritage Sites in Scotland, Including All Earth Science Features in Sites Of Special Scientific Interest (SSSI). Scottish Natural Heritage Commissioned Report No. 1014. Edinburgh: Scottish Natural Heritage. https://doi.org/10.1016/i.pgeola.2017.11.003

Williams, A.T., Rangel-Buitrago, N., Pranzini, E. and Anfuso, G. (2018). 'The management of coastal erosion'. Ocean \& Coastal Management 156:4-20. https://doi.org/10.1016/j.ocecoaman.2017.03.022

Williams, P. (2008). World Heritage caves and karst: a thematic study. Gland, Switzerland: IUCN. https://portals.iucn.org/library/node/9267

Williams, D. and Edwards, D. (2013). 'Moulding and cast replication of outcrops: A tool in geoconservation'. Proceedings of the Geologists' Association 124:648-652. https://doi.org/10.1016/i.pgeola.2012.08.003

Wimbledon, W.A.P., Barnard, A.F. and Peterken, A.G. (2004). 'Geosite management: A widely applicable, practical approach'. In: Parkes, M.A. (ed.). Natural and Cultural Landscapes: The Geological Foundation. pp. 187-192. Dublin: Royal Irish Academy. https://www.researchgate.net/publication/333546901

Wimbledon, W.A.P. and Smith-Meyer, S. (eds.). (2012). Geoheritage in Europe and its Conservation. Oslo: ProGEO. https:// www.researchgate.net/publication/261917799 Geoheritage in Europe and its Conservation WAPWimbledonSMeyer-Smith ProGEO 2012405 pp Hardback 4000 ISBN 9788242624765

Woo, K.S. and Kim, L. (2018). 'Geoheritage evaluation of caves in Korea: A case study of limestone caves'. In: E. Reynard and J. Brilha (eds.). Geoheritage: Assessment, Protection, and Management, pp. 373-386. Amsterdam, Netherlands: Elsevier. https://doi.org/10.1016/B978-0-12-809531-7.00021-6

Wood, C. (2009). World Heritage Volcanoes: A Thematic Study. A Global Review of Volcanic World Heritage Properties: Present Situation, Future Prospects and Management Requirements. Gland, Switzerland: IUCN. https://portals.iucn.org/library/node/9486

Worboys, G.L., Lockwood, M., Kothari, A., Feary, S. and Pulsford, I. (eds.). (2015). Protected Area Governance and Management. Canberra: Australian National University Press.

https://portals.iucn.org/library/node/45127 https://doi.org/10.22459/PAGM.04.2015

Worboys, G.L. (2015). 'Managing protected areas'. In: G.L. Worboys, M. Lockwood, A. Kothari, S. Feary, and I. Pulsford (eds.). Protected Area Governance and Management, pp. 207-250. Canberra: Australian National University Press.

https://doi.org/10.22459/PAGM.04.2015

Zarnetske, P.L., Read, Q.D., Record, S., Gaddis, K.D., Pau, S., Hobi, M.L., Malone, S.L., Costanza, J., Dahlin, K.M., Latimer, A.M., Wilson, A.M., Grady, J.M., Ollinger, S.V. and Finley, A.O. (2019). 'Towards connecting biodiversity and geodiversity across scales with satellite remote sensing'. Global Ecology and Biogeography 28:548-556. https://doi.org/10.1111/geb.12887 


\section{Biografias dos autores}

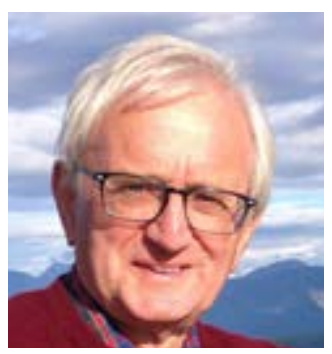

Roger Crofts é geógrafo e especialista em evolução costeira e gestão da natureza em áreas protegidas. Foi Chefe Executivo fundador da Scottish Natural Heritage, a agência governamental para a proteção da natureza e da paisagem, responsável pela implementação do sistema Natura da União Europeia e pela gestão do sistema de áreas protegidas locais na Escócia. Presidiu o Comitê da UICN no Reino Unido, a região europeia da WCPA, o Grupo de Trabalho do Acordo e Plano de Ação de Durban na V Conferência Mundial de Parques e desempenhou um papel de liderança na inserção da "natureza" na definição de áreas protegidas da UICN. Tem várias pesquisas em áreas protegidas e publicações sobre geoconservação. Roger recebeu o Prêmio Fred Packard International Parks em 2016 e muitos outros prêmios na Escócia, Reino Unido e Islândia pelo seu trabalho em gestão ambiental e em áreas protegidas.

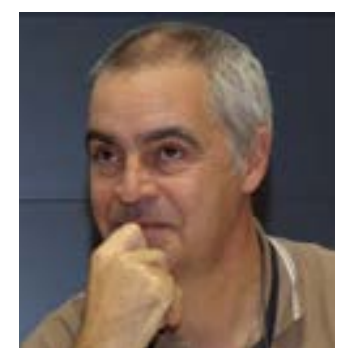

José B.R. Brilha é geólogo e Professor Catedrático do Departamento de Ciências da Terra da Universidade do Minho (Portugal). É membro da Comissão Mundial de Áreas Protegidas e do Grupo de Especialistas em Patrimônio Geológico da UICN e membro da Lista de Avaliadores dos Geoparques Globais da UNESCO. Foi Presidente da ProGEO (Associação Europeia para a Conservação do Patrimônio Geológico), co-fundador e Editor-Chefe da revista científica Geoheritage e membro do Comitê Português para o IGCP e do Fórum Português de Geoparques. Atualmente, desenvolve pesquisas aplicadas em geodiversidade, geoconservação, áreas protegidas e geoparques.

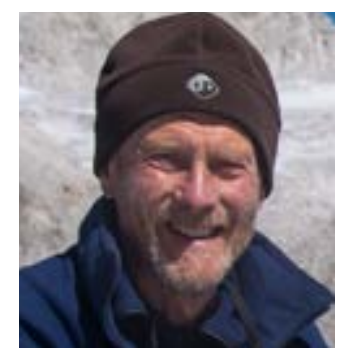

John Gordon trabalhou durante muitos anos com as agências governamentais de conservação da natureza na Grã-Bretanha, como consultor em avaliação, documentação e gestão da conservação do patrimônio geológico em áreas protegidas. É Professor Honorário na Escola de Geografia e Desenvolvimento Sustentável da Universidade de St Andrews, Escócia. É membro do Comitê Diretor e Vice-Presidente do Grupo de Especialistas em Patrimônio Geológico da Comissão Mundial de Áreas Protegidas da UICN, membro do Painel de Especialistas em Patrimônio Geológico da Federação Europeia de Geólogos e membro da ProGEO, a Associação Europeia para a Conservação do Patrimônio Geológico. 


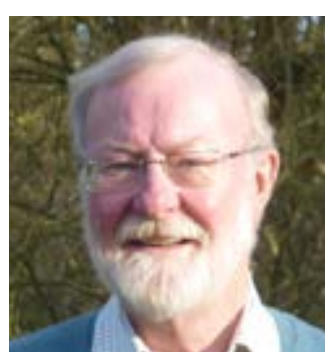

Murray Gray é Professor Honorário da Escola de Geografia da Universidade Queen Mary de Londres, Reino Unido, e Professor Visitante da Escola de Ciências da Terra da Universidade do Minho, Portugal. Tendo iniciado a sua carreira na área da geomorfologia glacial, tornou-se especialista em geodiversidade e suas aplicações, incluindo patrimônio geológico, geoconservação e geoturismo. É autor de duas edições do livro Geodiversity: Valuing and Conserving Abiotic Nature (WileyBlackwell, Chichester, 2004 e 2013). É membro do Grupo de Especialistas em Patrimônio Geológico da WCPA-UICN e do conselho editorial da revista Geoheritage. Tem proferido palestras como convidado sobre geodiversidade nos EUA, Canadá, Brasil, China, Japão, Malásia, África do Sul e em toda a Europa.

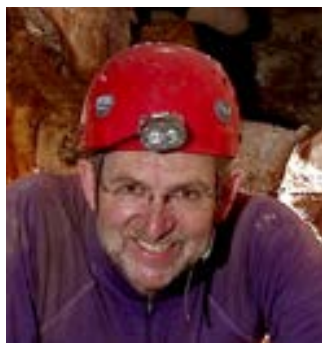

John Gunn (BSc Aberystwyth University; PhD Auckland University) é Professor Honorário na Escola de Geografia, Ciências da Terra e do Ambiente da Universidade de Birmingham. É um cientista multidisciplinar que faz pesquisas sobre uma única rocha - calcário - e sobre os ambientes cársticos associados. John é espeleólogo, ativamente envolvido na exploração de cavernas, com interesse em pesquisas sobre conservação e gestão de patrimônio geológico e recursos associados a cavernas e carste, hidrogeologia do carste, evolução de relevos cársticos e climas de cavernas. É Vice-Presidente do Grupo de Especialistas em Patrimônio Geológico da WCPA da UICN e Presidente do Grupo de Trabalho em Cavernas e Carste.

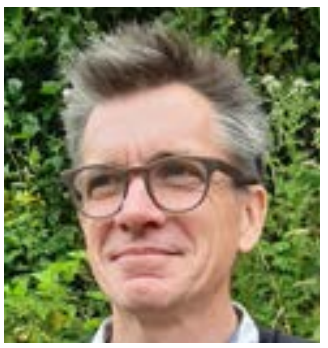

Jonathan Larwood é geólogo pela University College em Londres, com doutorado em micropaleontologia pela University College of Wales, em Aberystwyth, País de Gales. Jonathan direcionou sua carreira para a conservação geológica. Trabalha no órgão governamental Natural England como geólogo e paleontólogo, fornecendo consultoria sobre conservação geológica e paleontológica. Está envolvido em várias iniciativas, incluindo o desenvolvimento de políticas e práticas de coleta e o estabelecimento de planos de ações em geodiversidade no Reino Unido, trabalhando em estreita colaboração com o setor de voluntariado em geologia. Jonathan é atualmente o Arquivista da Associação de Geólogos, conselheiro voluntário do National Trust e curador do Sítio do Patrimônio Mundial da Costa Jurássica. 


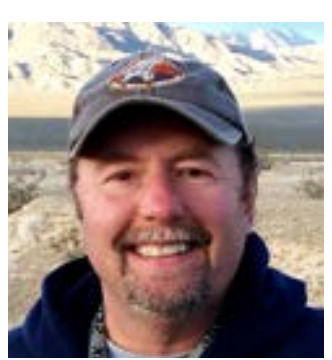

Vincent L. Santucci é Geólogo Sênior e Paleontólogo na Divisão de Recursos Geológicos do Serviço de Parques Nacionais dos EUA. Sua carreira é dedicada às gestão, proteção, interpretação, pesquisa científica e curadoria de fósseis do Sistema de Parques Nacionais dos EUA, identificados em mais de 260 parques nacionais. Uma das suas funções mais importantes é coordenar o planejamento e as atividades ligadas a recursos paleontológicos no Serviço de Parques Nacionais dos EUA e em parceiros acadêmicos, museológicos e educacionais, auxiliando-os no cumprimento de suas missões de gestão de recursos e de educação pública. Um dos aspectos mais gratificantes da sua posição envolve trabalhar com a equipe do Dia Nacional dos Fósseis na promoção de uma maior consciência sobre os valores científicos e educacionais destes elementos.

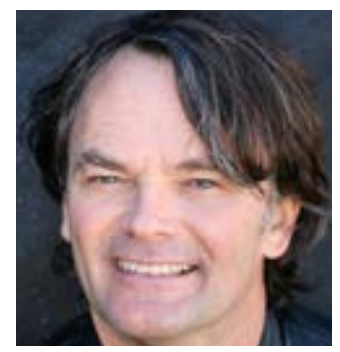

Dan Tormey é Presidente da Catalyst Environmental Solutions, uma empresa de consultoria ambiental. Tem doutorado em Geologia e Geoquímica pelo MIT e bacharelado em Engenharia Civil e Geologia pela Universidade de Stanford. Vem trabalhando com Patrimônio Mundial na UICN desde 2009, com 27 revisões para a Lista do Patrimônio Mundial, uma missão de campo e co-autoria do Estudo Temático em Vulcões da UICN de 2019. Foi nomeado para conselhos consultivos científicos em áreas protegidas pela Academia Nacional de Ciências e pelo Conselho de Ciência e Tecnologia da Califórnia e é um Conferencista Distinto da SPE e ganhador do prêmio de Responsabilidade Ambiental e Social.

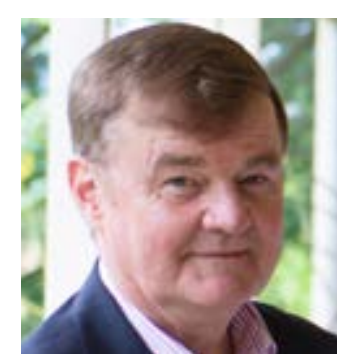

Graeme L. Worboys foi Professor Associado Honorário da Escola Fenner, da Universidade Nacional da Austrália, e conselheiro técnico do Governo da Austrália do Sul no processo de nomeação como Patrimônio Mundial da Cordilheira Flinders (critério viii). Formou-se em geologia, trabalhou em áreas protegidas durante 46 anos e obteve o doutorado com uma tese sobre gestão de áreas protegidas. Foi assessor do Patrimônio Mundial geológico da UICN na África do Sul, Itália, Índia, Vietnã e China. Graeme foi editor principal do Manual de Gestão e Governança de Áreas Protegidas de 2015 da UICN e ganhou, em 2016, o Prêmio Fred M. Packard International Parks da UICN por "serviço notável na promoção dos objetivos das áreas protegidas para a sociedade". Foi agraciado com a Ordem da Austrália (AM) em 2020 pelo seu extraordinário serviço à conservação e à comunidade. Faleceu em setembro de 2020. 



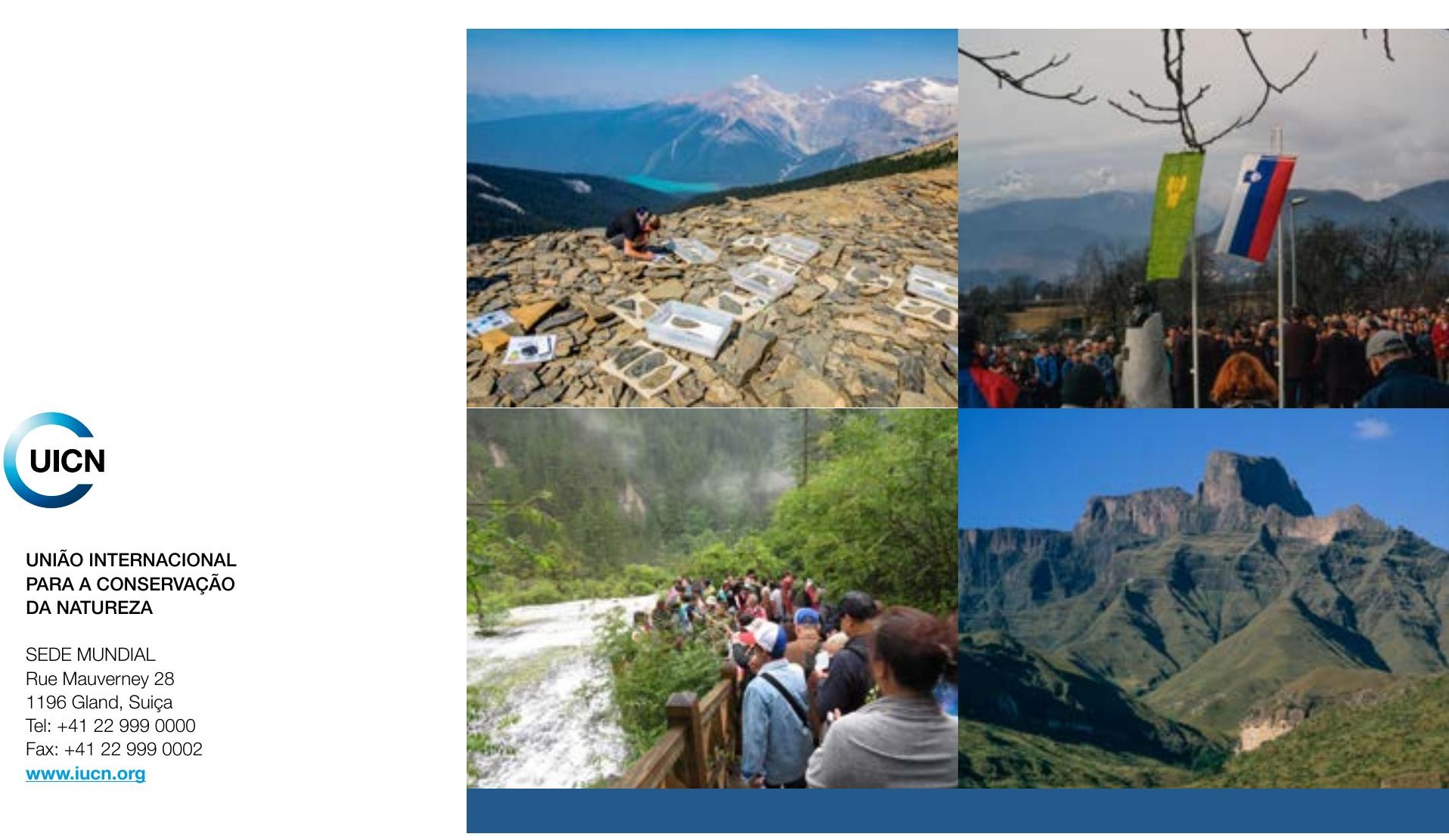

